\title{
EUROPEAN SOCIALIST REGIMES' FATEFUL ENGAGEMENT WITH THE WEST
}

NATIONAL STRATEGIES IN THE LONG 1970 S

\section{Edited by}

Angela Romano and Federico Romero

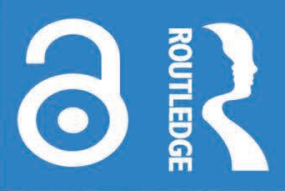




\section{European Socialist Regimes' Fateful Engagement with the West}

This edited volume analyses European socialist countries' strategy of engagement with the West and the European Economic Community in the "long 1970s".

The book focuses on a time when the socialist regimes of Central and Eastern Europe banked their hopes for prosperity and stability on enhanced relations with the West. Crossing the traditional differences among diverse fields of historiography, it assesses the complex influence of European and global processes of transformation on the socialist elites' reading of the international political and economic environment and their consequent decision-making. The volume also explores the debate in each country among and within the elites involved in policymaking as they elaborated this strategic view and coped with shortcomings and unexpected turns. A comparative analysis of national cases shows a shared logic and common patterns, together with national variations and a plurality of views on the desirability of exchanges with their capitalist neighbours and on the ways to promote them. The multinational coverage of seven countries makes this volume a starting point for anyone interested in each socialist state's foreign policy, intra-bloc relations, economic strategy, transformation and collapse, relations with the European Community and access to the EU.

This book will be of much interest to students and researchers of Cold War studies, European history, and international relations.

Angela Romano is Lecturer of International Political Economy, University of Glasgow, UK.

Federico Romero is Professor of Post-War European Cooperation and Integration, and Dean of Research at the European University Institute, Italy. 


\section{Cold War History}

Series Editors: Odd Arne Westad

John F. Kennedy School of Government, USA Michael Cox, London

School of Economics \& Political Science, UK

In the new history of the Cold War that has been forming since 1989, many of the established truths about the international conflict that shaped the latter half of the twentieth century have come up for revision. The present series is an attempt to make available interpretations and materials that will help further the development of this new history, and it will concentrate in particular on publishing expositions of key historical issues and critical surveys of newly available sources.

\section{The Diplomacy of Détente}

Cooperative Security Policies from Helmut Schmidt to George Shultz Stephan Kieninger

\section{America and Romania in the Cold War}

A Differentiated Détente, 1969-80

Paschalis Pechlivanis

\section{The Greek Junta and the International System}

A Case Study of Southern European Dictatorships, 1967-74

Edited by Antonis Klapsis, Constantine Arvanitopoulos, Evanthis

Hatzivassiliou and Effie G. H. Pedaliu

\section{Secrecy, Public Relations and the British Nuclear Debate}

How the UK Government Learned to Talk about the Bomb, 1970-83

Daniel Salisbury

US Foreign Policy and the End of the Cold War in Africa

A Bridge between Global Conflict and the New World Order, 1988-1994

Flavia Gasbarri

\section{European Socialist Regimes' Fateful Engagement with the West}

National Strategies in the Long 1970s

Edited by Angela Romano and Federico Romero

For more information about this series, please visit: www.routledge.com/ Cold-War-History/book-series/SE0220 


\section{European Socialist Regimes' Fateful Engagement with the West \\ National Strategies in the Long 1970s}

\section{Edited by Angela Romano and Federico Romero}


First published 2021

by Routledge

2 Park Square, Milton Park, Abingdon, Oxon OX14 4RN

and by Routledge

52 Vanderbilt Avenue, New York, NY 10017

Routledge is an imprint of the Taylor \& Francis Group, an informa business

(C) 2021 selection and editorial matter, Angela Romano and Federico

Romero; individual chapters, the contributors

The right of Angela Romano and Federico Romero to be identified as the authors of the editorial material, and of the authors for their individual chapters, has been asserted in accordance with sections 77 and 78 of the Copyright, Designs and Patents Act 1988.

The Open Access version of this book, available at www.taylorfrancis.com, has been made available under a Creative Commons Attribution-Non Commercial-No Derivatives 4.0 license.

Trademark notice: Product or corporate names may be trademarks or registered trademarks, and are used only for identification and explanation without intent to infringe.

\section{British Library Cataloguing-in-Publication Data}

A catalogue record for this book is available from the British Library

Library of Congress Cataloging-in-Publication Data

Names: Romano, Angela, 1976- editor. | Romero, Federico, editor.

Title: European socialist regimes' fateful engagement with the

West : national strategies in the long 1970s / edited by Angela

Romano and Frederico Romero.

Description: Abingdon, Oxon ; New York, NY : Routledge, 2021. |

Series: Cold war history | Includes bibliographical references and index.

Identifiers: LCCN 2020023104 (print) | LCCN 2020023105 (ebook) | ISBN 9780367356170 (hardback) | ISBN 9780429340703 (ebook)

Subjects: LCSH: Europe, Eastern-Foreign relations-Europe, Western. | Europe, Western - Foreign relations-Europe, Eastern. | Europe, Eastern-Foreign economic relations-Europe, Western. | Europe, Western-Foreign economic relations-Europe, Eastern. | Communist countries-Foreign relations-Europe, Western. | Communist countries-Foreign economic relations-Europe, Western. | Europe, Eastern - Politics and government-1945-1989. | Europe, EasternEconomic policy-1945-1989.

Classification: LCC DJK45.E85 E95 2021 (print) | LCC DJK45.E85 (ebook) | DDC 327.470409/047—dc23

LC record available at https://lccn.loc.gov/2020023104

LC ebook record available at https://lcen.loc.gov/2020023105

ISBN: 978-0-367-35617-0 (hbk)

ISBN: 978-0-429-34070-3 (ebk)

Typeset in Times New Roman by Apex CoVantage, LLC 


\section{Contents}

List of tables vii

Acknowledgements viii

List of abbreviations $\quad$ ix

List of contributors $\quad$ xi

Introduction 1

ANGELA ROMANO AND FEDERICO ROMERO

1 Socialism Between Détente and Globalisation 11

FEDERICO ROMERO

2 Pan-Europe: A continental space for cooperation(s) 31

ANGELA ROMANO

3 Attraction and Repulsion: Hungary and European integration $\quad 50$ PÁL GERMUSKA

4 From 'Economic Miracle' to the 'Sick Man of the Socialist Camp': Poland and the West in the 1970s

ALEKSANDRA KOMORNICKA

5 Drifting Westward? East Germany and Integrated Europe 107 MAXIMILIAN GRAF

6 Czechoslovakia's Pan-European Relations During the "Long 1970s"

PAVEL SZOBI

7 Balancing Between Socialist Internationalism and Economic Internationalisation: Bulgaria's economic contacts with the EEC 
vi Contents

8 Romania Turns West: National and international rationales

ELENA DRAGOMIR

9 From Liberalism to Underdevelopment: The Yugoslav elites facing Western European economic integration in the "long 1970s"

BENEDETTO ZACCARIA

10 Conclusions

258

Appendix 1: Tables A.1 to A.6

Appendix 2: List of Archival Collections

Index 


\section{Tables}

8.1 The evolution of Romania-EEC commercial exchanges, 1970-1984 (in million US dollars)

8.2 The evolution of Romania's exports to the EEC, 1973-1983 (in million US dollars and percentages)

A.1 Foreign trade of selected countries (in billion US dollars)

A.2 European centrally planned economies' trade with the EEC (without the USSR, in billion US dollars)

A.3 Exports of European centrally planned economies (including the USSR) by regions

A.4 Export structure of European centrally planned economies (including the USSR, in percentages)

A.5 Gross external debts of selected countries (in billion US dollars) 262

A.6 Average annual growth of GDP in selected countries 


\section{Acknowledgements}

Our research has been generously funded by the European Research Council under the European Union's Horizon 2020 research and innovation programme (Grant Agreement no. 669194).

We have been immensely aided and continually supported by the Department of History and Civilization and other parts of the European University Institute, which has hosted us for five years. In particular, we owe immense gratitude to Serena Belligoli, Laura Borgese and Serena Scarselli, whose efficient, effective and most active assistance has made our work both possible and pleasurable.

Many scholars have contributed to our efforts with useful suggestions, sharp criticism and precious advice in the numerous workshops and seminars that year after year have marked the progress of our work. They made us think and rethink what we were doing and kept us on our toes. Our work would have been poorer without their contributions and we want to thank them all most deeply: Melanie Arndt, Péter Balázs, Fritz Bartel, Dorothee Bohle, Laurien Crump, Lukas Dovern, Valentina Fava, Rossitza Guentcheva, Suvi Kansikas, Pavel Kolár, Mikhail Lipkin, Sara Lorenzini, James Mark, Corina Mavrodin, Miklós Mitrovits, Wolfgang Mueller, Gottfried Niedhart, Victor Petrov, Silvio Pons, Svetozar Rajak, Jessica Reinisch, Tobias Rupprecht, Adelina Stefan, André Steiner, Max Trecker, Franek Tyszka, Vladimir Unkovski-Korica, Milica Uvalić and Vladislav Zubok. 


\section{Abbreviations}

BIS Bank for International Settlements (BIS)

BKP Bulgarian Communist Party (Balgarska komunisticheska partiya)

CAP Common Agricultural Policy

CCP Common Commercial Policy

CESTC Commission for Economic and Scientific-Technical Cooperation

CFP Common Fisheries Policy (CFP)

CIER Committee for International Economic Relations

CMEA Council for Mutual Economic Assistance

CPC Communist Party of Czechoslovakia

CPS Communist Party of Slovakia

CPSU Communist Party of the Soviet Union

CSCE Conference on Security and Cooperation in Europe

ECE United Nations Economic Commission for Europe

ECSC European Coal and Steel Community

EEC European Economic Community

EFTA European Free Trade Association

EIB European Investment Bank

EMS European Monetary System

EPC European Political Cooperation

FRG Federal Republic of Germany

GATT General Agreement on Tariffs and Trade

GDR German Democratic Republic

GSP Generalized Scheme of Preferences

HAS Hungarian Academy of Sciences

HSWP Hungarian Socialist Workers' Party

IBRD International Bank for Reconstruction and Development

IMEMO Institute of World Economy and International Relations of the Soviet Academy of Sciences

IMF International Monetary Fund

IPW Institute of International Politics and Economics of the GDR

ISICI Inter-institutional Section on Issues of Capitalist Integration and the GATT

KoKo Bereich Kommerzielle Koordinierung 
KOR Workers Defence Committee

MBFR Mutual and Balanced Force Reduction in Europe

MFA Ministry of Foreign Affairs

MFN most favoured nation

MFT Ministry of Foreign Trade

NATO North Atlantic Treaty Organization

OECD Organisation for Economic Co-operation and Development

OEEC Organisation for European Economic Cooperation

OPEC Organization of Petroleum Exporting Countries

OSCE Organization for Security and Co-operation in Europe

POWP Polish United Workers' Party

RCP Romanian Communist Party

RWP Romanian Workers' Party

SALT Strategic Arms Limitation Talks

SED Socialist Unity Party of Germany

SIV Federal Executive Council (Savezno izvršno veće)

SKJ Communist Party of Yugoslavia (Savez Komunista Jugoslavije)

SPD Social Democratic Party of the Federal Republic of Germany

SSIP Federal Secretariat for Foreign Affairs (Savezni Sekretarijat za Inostrane Poslove)

SSST Federal Secretariat for External Trade (Savezni Sekretarijat za Spoljnu Trgovinu)

StB Czechoslovak State Security agency (Státní bezpečnost)

UNCTAD United Nations Conference on Trade and Development

US United States

USSR Union of Soviet Socialist Republics

VGI Institute for World Economics of the Hungarian Academy of Sciences 


\section{Contributors}

Elena Dragomir is a postdoctoral researcher at Valahia University of Târgoviște, Romania. She has published extensively on Cold War Romania's foreign policy. Her current research focuses on Romania's relations with Western European states and the European Economic Community during the Cold War.

Pál Germuska holds a Doctor of Science degree from the Hungarian Academy of Sciences and is Deputy Director General of the National Archive of Hungary. $\mathrm{He}$ is a historian with interest in military industry, East-West economic relations and industrial and economic policy of the socialist period.

Maximilian Graf is Research Fellow in the ERC-funded project Unlikely Refuge? Refugees and Citizens in East-Central Europe in the 20th Century (MIA, Czech Academy of Sciences). He is a historian of the Cold War and communism. His monograph on Austrian-East German relations in the Cold War (2016) received several prizes.

Aleksandra Komornicka is a $\mathrm{PhD}$ researcher at the European University Institute. Her dissertation deals with Poland's increasing economic and political cooperation with Western Europe in the 1970s. She holds an MA from the London School of Economics and a BA from the University of Warsaw.

Angela Romano is Lecturer of International Political Economy (University of Glasgow). She has published extensively on Cold War and European integration. Her new monograph is The European Community and Eastern Europe in the Long 1970s: Challenging the Cold War order in Europe (Routledge, 2021).

Federico Romero is Professor of Post-War European Cooperation and Integration and Dean of Research at the European University Institute. A specialist on twentieth-century international and transnational history, he worked on various aspects of Cold War and transatlantic relations, post-war European reconstruction, migration and European integration.

Elitza Stanoeva holds a PhD in history (Technical University of Berlin, 2013). She has had postdoctoral research fellowships in Konstanz, Potsdam and Sofia. Author of Sofia: Ideology, urban planning and life under socialism (2016, in Bulgarian) and numerous articles in English, Bulgarian and German. 
Pavel Szobi holds a PhD in world history from Charles University (2013) and is Senior Lecturer in the Department of North American Studies, Institute of International Studies, Charles University in Prague. He specialises in US and European economic history after 1945.

Benedetto Zaccaria is a research grant holder in the Department of Linguistics and Comparative Cultural Studies at the $\mathrm{Ca}$ ' Foscari University of Venice. He is the author of The EEC's Yugoslav Policy in Cold War Europe (1968-1980) (Palgrave Macmillan, 2016). 


\title{
Introduction
}

\author{
Angela Romano and Federico Romero
}

This book offers an unprecedented historical investigation into the strategies, expectations and predicaments of the European socialist regimes in the context of the opening up of a space for pan-European cooperation in the "long 1970s". It is the result of the five-year PanEur1970s research project, which has received funding from the European Research Council under the European Union's Horizon 2020 research and innovation programme (Grant Agreement no. 669194). The project brought together a team of historians with different yet complementary fields of specialisation. Their coordinated research has resulted in a re-conceptualisation of trans-European exchanges and cooperation against a background of Cold War constraints, global economic change and processes of regional integration. It sheds new light on the thinking and agency of the socialist regimes.

Over the last decade, Cold War historiography has revealed a complex pattern of intra-European détente embodied in a deepening web of contacts, interactions, exchanges and mutual obligations across the "Iron Curtain". ${ }^{1}$ Within this context, some historians of European integration have re-examined the emergence of the European Economic Community (EEC) as an influential international actor, particularly through the Conference on Security and Cooperation in Europe, and have appraised the EEC's reach and allure regarding the socialist countries. ${ }^{2}$

It is now evident that from the late 1960s, Europe's Cold War geopolitical and ideological divide cohabited with an emerging continental space for growing exchanges, trade and collaboration, which was often expected to foster convergence and interdependence. On the one hand, these trans-European connections offered the socialist countries much-needed patterns of exchange and potential regional integration. On the other hand, they opened up a less protected and self-enclosed environment that presented significant challenges to the stability, political control and ideological self-legitimisation of the regimes.

We explore these tensions by analysing the changing mindset of the European socialist elites, in particular their assumptions on the international division of labour and cooperation with Western Europe, their attempts at dealing with the commercial giant next door (i.e. the EEC) and the predicaments they faced when these strategies began to unravel. 


\section{State of the art and research questions}

Scholars of Russia and Eastern Europe and/or communism have brought to the fore the economic rationales for the socialist countries' policy of peaceful coexistence and cooperation with the West. By the mid-1960s, the rapid growth of their economies based on planning and intense industrialisation had reached its limits. As their economies could not adjust rapidly enough to the requirements of the unfolding technological revolution, the socialist governments recognised that foreign trade was an important factor in socialist growth and began to follow a long-term policy aimed at extending their trade with the developed market economies. ${ }^{3}$ Improved commercial relations with the West were expected to provide their enterprises with better access to Western technology and their citizens with a diversified range of consumer goods, thus enhancing socialist modernisation. Economic growth had become a conditio sine qua non for political stability in Eastern Europe since the late 1950s, as improving living standards appeared crucial for government legitimacy. Their importance grew even further after the suppression of the Prague Spring in 1968 wiped out the option of profound political reforms.

It is common knowledge that the socialist countries' strategies failed, sometimes in a spectacular way. We know that increased trade with the West did not bring the expected improvement in productivity and that the bloc's overall economic performance fell well short of Western capitalist achievements. Their attempts at opening up and reform turned out to be flawed, mostly amounting to an increasingly ineffective 'muddling through'. ${ }^{4}$ Trade with the global South did not balance increasing deficits with the West. Some tried to bridge the gap with foreign credits and eventually walked into a debt trap: Poland, Hungary, Bulgaria, the GDR. Romania would eventually repay its debts at the expense of depressing its domestic economy to unbearable levels. Czechoslovakia avoided indebtedness and just managed to stagnate. Ultimately, instead of a modernised socialism, these countries received a fatal 'kiss of debt'. 5 Therefore, the socialist governments 'faced two alternatives, either retreat to a conservative stagnation or proceed down the road of gradual capitalist restoration'. ${ }^{6}$ As Valerie Bunce put it, the choice had narrowed to two unpalatable options: liberalise and thereby destroy the system or put off reforms and purchase short-term stability but long-term doom. ${ }^{7}$ The apparent consolidation of the regimes by means of improved consumption turned out to be short-lived, while their public legitimacy was eroded by the unsustainable comparison with Western standards that increased East-West exchanges had put on full display. As the regimes' main claims to legitimacy - safety, full employment and rapid growth - were undermined, even the ruling elites lost their selfconfidence, opening the way for the 1989 collapse. $^{8}$

Our knowledge is now considerably richer than twenty or even ten years ago, yet important gaps still exist. To start with, most of the literature focuses on the domestic determinants of economic reforms, neglecting the impact of external factors, with the exception of those emanating from the Soviet Union. However, from the early 1970s Eastern Europe underwent a series of external economic 
shocks with serious repercussions on its stability. In several countries, this led to a second wave of (cautious) reforms under the pressure of deepening external imbalances. Several scholars have started to investigate the socialist countries' problematic relationship with globalisation and technological change, and their haphazard attempts at deepening relationships with world markets. ${ }^{9}$ Nevertheless, research on exogenous economic influences on transformations in the region is still in its infancy.

Even more glaring is the gap in our knowledge of the changing mindset and outlook of the European socialist elites, particularly their expectations in the evolving rapprochement with Western Europe and their reading of its integration process and its impact. The history of individual socialist countries' relations with the EEC during the Cold War has been largely overlooked or summarily dealt with under the rubric of their post-Cold War "return to Europe" in the context of EU enlargement. ${ }^{10}$ While a few historians have explored the Soviet Union's attitude and policy towards the EEC, studies on the other socialist countries' approaches to it are still scarce. ${ }^{11}$ This lack of historical analysis is startling. By the early 1970s, Yugoslavia was deeply dependent on economic and financial cooperation with the EEC. The EEC had also become the single largest importing and exporting market after the CMEA for the Central and Eastern European socialist countries. Therefore, the EEC's protectionist policies on agricultural products and quantitative restrictions on industrial goods affected the socialist economies to an important and growing extent. The EEC also affected the socialist regimes' attempts at integrating in the world economy, for example by asking them to pay an "admission ticket" to the GATT in commercial rather than political terms. The paucity of historiographical work on these matters is largely the result of the Cold War era legacy of separate studies on Eastern and Western Europe. So far, although historians working on the two sides of what used to be a divided Europe have had considerable contacts, they have usually operated with largely separate agendas and networks. In addition, the historiography on European integration has long developed in self-insulation within the geopolitical, institutional and conceptual boundaries of the Western European communities.

Our research specifically aimed to break down these traditional divides and to bring "Eastern" insights into the wider evolution of the European economies and institutions. It also crosses the traditional demarcations among diverse fields of historiography (namely the Cold War, contemporary Europe, communism, European integration and international economic history). We intertwine international, political and economic history perspectives in order to offer a dynamic portrait of the socialist elites' paradigms, constraints and goals in pursuing policies of cooperation with Western Europe and the EEC.

We assess the complex influence of European and global processes of transformation on the socialist elites' reading of the international political and economic environment and their consequent decisions. We then track the rise, inconsistencies and fall of the national expectations at the basis of their strategies. In so doing, we offer a scholarly analysis of pan-European cooperation that incorporates the 
socialist regimes' concepts and policies and is able to assess the development of the EEC from the (rather unhappy) perspective of these outsiders.

Our research has revolved around four main research questions:

- What were the European socialist regimes' expectations concerning EastWest trade and pan-European cooperation in the 1970s? Their views and analyses shaped the premises on which they assessed the desirability or necessity of opening up to international exchanges and prioritised specific policy goals. This appraisal was not only rooted in economic terms but was also strongly concerned with foreign policy issues. As Europe was morphing into a locus of potential rapprochement, recombination and convergence, most of the socialist countries viewed connections with Western Europe as levers for a cautious but determined reconfiguration of hierarchies within the socialist bloc. Soviet dominance could not be contested but deliberate attempts were made, and many more were conceived, at diluting it within a larger panEuropean web of contacts that enhanced each nation's own agency. In the case of Yugoslavia, closer relations with Western Europe had to be reconciled with the country's non-alignment policy.

- How did European socialist regimes assess the impact of the EEC on their economies and decide how to deal with it? We investigate their debates and policy solutions with specific attention to the complex interplay between national and CMEA options, and to the tensions between socialist integration and growing trans-European interdependence.

- Who in the political and economic elites advocated or opposed higher levels of East-West economic exchange? Party and government officials often had conflicting concerns about opening up to the West. On the one hand, Western technology could stimulate economic growth and Western consumer goods could assuage domestic pressures on the regime. On the other hand, increased economic and financial relations with the West could undermine the regime's stability or constrain its options. In addition, relationships with Moscow had to be factored in, as international economic relations affected each country's degree of dependence on the Soviet Union (for the CMEA member states) or its room for manoeuvre (Yugoslavia). We assume each national elite was a heterogeneous group featuring different opinions ranging from reformist to conservative, and in which positions might well have changed over time.

- Which factors explain the eventual failure of these national strategies? We explore the economic and institutional predicaments the socialist regimes had to face and try to assess the interactions between the domestic constraints of a rigid planning system and the multiple, rapid and often unpredictable transformations in the international context. These transformations changed the rules of the game, and the very playing field, in many ways that were hard to gauge or even imagine at the beginning of the decade, thus altering the whole set of equations at the basis of the socialist strategies. As we progressed in this work, we realised that finding out why the strategies failed also entailed an assessment of the socialist elites' efforts at understanding what was going 
wrong, what (if anything) could be adapted on the go, and what could not be salvaged. In short, a new question arose about when and how it became evident that the strategy was failing.

\section{Methodology}

The basic assumption at the root of our project is that there was an emergence of a space for pan-European cooperation that transcended, yet did not obliterate, the Cold War partition. Therefore, our analysis is not of the socialist bloc as such. On the contrary, we aimed precisely at appraising the individual experiences of the socialist regimes in Europe when they were re-conceptualising and re-negotiating their roles in the changing international and continental scenario, their relationships with the Soviet Union and their national senses of being "European". We considered all the European socialist countries except Albania, devoting a chapter to each: the German Democratic Republic, Poland, Hungary, Czechoslovakia, Romania, Bulgaria and Yugoslavia, which was not a member of the CMEA or the Warsaw Pact. By the same logic, we excluded the Soviet Union as the role, self-perception, predicaments and interests of the superpower were quite different from those of the smaller European socialist regimes. Of course, Soviet views and policies do feature in our analysis as key factors affecting national debates, cooperation strategies with the West and ultimately each country's perception of its room for manoeuvre.

We were also dissatisfied with the narrow view of socialist regimes as party-ruled monolithic entities. We intended to open the socialist regimes' "black box" to reveal the more complex and multi-faceted debates that took place within, between and across the elites most involved in the national analysis and decision-making processes. Therefore, we moved beyond a narrow focus on the communist parties' top political leaderships to also analyse the contributions of state machineries, central and investment banks, trade managers, economic experts and academics. In the government apparatus, we specifically considered the ministries and agencies most concerned with relations with the West, usually the Ministry of Foreign Affairs and the Ministry of Foreign Trade. Within their ranks, the staff dispatched abroad (diplomats, trade attachés, ad hoc advisers) also appeared to be particularly active and relevant in the debate. We also focused on those branches of the state that were more directly responsible for the national economic strategy, such as the Central Planning Commission, the Economic Ministry and the Economic Committee of the Council of Ministers. We considered the managerial elite level to be particularly interesting. The officials at the national central banks and investment banks, which are usually overlooked, had an increasing say in the debate as imports from the West fuelled external debt. On their part, the managers of the socialist foreign trade enterprises had a direct stake in the growth of relations with Western Europe and the EEC. We were interested in investigating and appraising the approaches of these agents who negotiated, organised and staffed most of the trans-European exchanges, and their views on the multiple spaces they tried to connect. Finally, experts associated with research institutes, academies and 
universities were key agents in the circulation of ideas among and within socialist states (and beyond). They often had crucial analytical, cognitive and discursive roles, the differentiated impact of which on political elites deserves full appraisal. Of course, the exact composition and weight of the elites involved in the debate varied from country to country, as the country-specific chapters make clear. These variations are also part of the comparative assessment presented in Chapter 10.

We identified the years between 1969 and the early 1980s as the crucial chronological span due to three interrelated processes that had profound influences on the matter under scrutiny: long-lasting détente in East-West relations, the socialist countries' inclination to cautiously integrate into the world economy, and the EEC's enlargement, deepening and self-assertion as an international actor. Therefore, 1969 is the starting point for all the chapters, due to three fundamental settings that emerged at the time. First, the Warsaw Pact countries' military suppression of the Prague Spring reform (with the sole opposition of Romania) set the limits that the Soviets would tolerate in terms of (political) reforms in any of these countries. The lesson of the invasion would be omnipresent in the considerations of most of the European socialist regimes, including non-aligned Yugoslavia, affecting their policies towards Western Europe and the EEC in various ways. It induced varying degrees of restraint but it also stimulated more autonomous and nationalistic attitudes (most noticeably in Romania) or openly strengthened the urge to reach out to the West (Yugoslavia). Second, in 1969 détente with the East became a mainstream Western policy, as the US under President Richard Nixon and the Federal Republic of Germany led by Chancellor Willy Brandt fully embraced a relaxation of tensions and cooperation with the Soviet Union and its allies. While trade relations had already existed in previous years, West Germany's new Ostpolitik allowed for a systematic development of economic exchanges, opening a wide avenue for the modernisation efforts of the socialist economies. Third, at the 1969 EEC summit at The Hague, the six member states agreed to proceed with the completion and deepening of their integration process and with negotiations for the accession of Ireland, Denmark and, most importantly, the UK. These decisions signalled to the socialist countries that far from being in crisis the EEC was actually growing stronger and larger, taking on an economic role and a weight that could no longer be disregarded.

By contrast, identifying a precise common endpoint year for our national cases would have been artificial. We did not intend to go beyond the mid-1980s, since the arrival of Mikhail Gorbachev with his radical views on international relations heralded the full acceptance of a pan-European space for cooperation and rapidly diminished the political constraints of the USSR on its allies, thus inaugurating profoundly different dynamics. The main benchmark for our research goal was the moment when it became apparent to the socialist regime elites that their strategy of import-led growth and integration in the world economy was failing, and that their agency in shaping relations with the West, the EEC and global markets was very limited. This took place at different moments in the early 1980s, and each chapter details these national specificities. 
Finally, a word about terminology. We refer to the countries under scrutiny as socialist rather than communist. Our guiding principle has been to respect the definition the historical actors themselves adopted at the time according to their Marxist-Leninist lexicon. Communism was conceived as the final stage of the path that these regimes had embarked upon, yet they collapsed way before reaching the promised land. In the 1970s, they described their stages of progress on the path to communism with varying terms: advanced socialism, developing socialism (in the case of Romania) or self-management socialism (in the unique instance of Yugoslavia). In a research project that foregrounds these regimes' agency and self-understanding and which is focused on their economies, the term 'communist' - inevitably also loaded with Western Cold War connotations - is appropriately used when referring to the party and its ideology. We also trust our readers not to be perplexed or misled by the formula 'European socialist countries' since their difference and distance from the social-democratic regimes of Western Europe (like Sweden) is all too apparent.

\section{Organisation of the book}

Our research effort was closely coordinated and collective, and this book tries to achieve coherence and thematic unity by means of shared research questions and a shared format and structure. Two overview chapters explore the overall context, the shared settings and the historiographical debates in which the country-specific analyses are embedded. Chapter 1 provides a critical overview of the international economic transformations and turning points, such as the two 'oil shocks' that altered the trading, financial and conceptual context within which the socialist strategies rose and fell. It contextualises the dynamics of East-West cooperation within the changing paradigms that replaced Keynesian management with global market competition. Chapter 2 focuses on the emerging pan-European space for cooperation. It considers political and economic interactions at the bilateral and multilateral levels (including the CSCE process), the patterns of integration in both the West and the East (EEC and CMEA) together with their interplay, and the impact of the European Economic Community's policies on the socialist countries.

The national case contributions (Chapters 3 to 9) follow a common format in order to allow the single cases to speak to one another effectively and facilitate the identification and discussion of both common patterns and national specificities. Each chapter illustrates and contextualises the origins, development and results of the country's national economic strategy with regard to East-West cooperation and relations with the EEC. More specifically, each chapter presents the country's economic specificities, its international commercial and financial strategy, the goals, assumptions and expectations of its elites, and the latter's assessment of the EEC's impact on the economy. Thus, each chapter brings to the fore the actors and internal dynamics in the decision-making process, with insights into the representation of the strategy to the domestic public. Particular attention is given to the elites' appraisals of the strategies of the other socialist countries, their 
relations with CMEA politics and policies and their perceptions of the country's room for manoeuvre vis-à-vis the Soviet Union. To varying degrees, the chapters examine the implementation of the strategy, its shortcomings and its adjustments in response to domestic and international factors. Each chapter concludes with an overall assessment of the outcomes of the strategy and a brief comparison of the national trajectory with the other socialist experiments.

Chapter 10 presents the overall results of the project in relation to its research questions, outlines the main comparative findings and highlights this study's contribution to a diverse range of historiographical debates.

\section{Notes}

1 Bange and Niedhart, Helsinki 1975 and the transformation of Europe; Romano, From Détente in Europe; Villaume and Westad, Perforating the Iron Curtain; Pons and Romero, "Europe between the superpowers"; Autio-Sarasmo and Miklóssy, Reassessing Cold War Europe.

2 Romano, From Détente in Europe; Zaccaria, The EEC's Yugoslav policy; Romano, "The EC and the socialist world."

3 Steiner, "The decline of Soviet-type economies."

4 Steiner, "The decline of Soviet-type economies," 219.

5 Kotkin, "The kiss of debt."

6 Kopstein, The politics of economic decline, 46.

7 Bunce, Subversive institutions, 37.

8 Berend, "What is Central and Eastern Europe?"; Kotkin and Gross, Uncivil society; Romero, Storia della guerra fredda.

9 Bockman, Markets in the name of socialism; Steiner, "The globalisation process and the Eastern bloc countries"; Sanchez-Sibony, Red globalization; Kansikas, Socialist countries face the European Community; Fürst, Pons and Selden, Endgames?; Pula, Globalization under and after socialism; Mark et al., 1989: a global history of Eastern Europe.

10 Bideleux and Taylor, European integration and disintegration; Berend, From the Soviet bloc to the European Union; Bideleux and Jeffries, A history of Eastern Europe; Guida, L'altra metà del continente; Berend, From the Soviet bloc to the European Union; Ther, Europe since 1989.

11 On the former, see Zubok, "The Soviet Union"; Rey, "Le retour à l'Europe?"; English, "Soviet elites and European integration". On the latter, Jajesniak-Quast, "Reaktionen auf die Westeuropäische"; Obadic, "A troubled relationship."

\section{Bibliography}

Autio-Sarasmo, Sari and Katalin Miklossy, eds. Reassessing Cold War Europe. London: Routledge, 2011.

Bange, Oliver and Gottfried Niedhart, eds. Helsinki 1975 and the transformation of Europe. Oxford: Berghahn Books, 2008.

Berend, Ivan T. "What is Central and Eastern Europe?" European Journal of Social Theory 8:4 (2005): 401-16.

Berend, Ivan T. From the Soviet bloc to the European Union: the economic and social transformation of Central and Eastern Europe since 1973. Cambridge: Cambridge University Press, 2009. 
Bideleux, Robert and Ian Jeffries. A history of Eastern Europe: crisis and change. London and New York: Routledge, 1998.

Bideleux, Robert and Richard Taylor, eds. European integration and disintegration: East and West. London and New York: Routledge, 1996.

Bockman, Johanna. Markets in the name of socialism: the left-wing origins of neoliberalism. Stanford: Stanford University Press, 2011.

Bunce, Valerie. Subversive institutions: the design and destruction of socialism and the state. New York: Cambridge University Press, 1999.

English, Robert. "Soviet elites and European integration: from Stalin to Gorbachev." European Review of History 21:2 (2014): 219-33.

Fürst, Juliane, Silvio Pons and Mark Selden, eds. The Cambridge history of communism, vol. 3, Endgames? Late communism in global perspective, 1968 to the present. Cambridge: Cambridge University Press, 2017.

Guida, Francesco, ed. L'altra metà del continente. L'Europa centro-orientale dalla formazione degli Stati nazionali all'integrazione europea. Padova: Cedam, 2003.

Jajesniak-Quast, Dagmara. "Reaktionen auf die Westeuropäische Wirtschaftsintegration in Ostmitteleuropa: Die Tschechoslowakei und Polen in den fünfziger bis zu den siebziger Jahren.” Journal of European Integration History 13:2 (2007): 69-84.

Kansikas, Suvi. Socialist countries face the European Community: Soviet-bloc controversies over East-West trade. Bruxelles: Peter Lang, 2014.

Kopstein, Jeffrey. The politics of economic decline in East Germany, 1945-1989. Chapel Hill: University of North Carolina Press, 1997.

Kotkin, Stephen. "The kiss of debt." In The shock of the global: the 1970s in perspective, edited by Niall Ferguson, Charles S. Maier, Erez Manela and Daniel Sargent, 80-92. Cambridge, MA: Belknap Press of Harvard University Press, 2010.

Kotkin, Stephen and Jan Tomasz Gross. Uncivil society: 1989 and the implosion of the communist establishment. New York: Modern Library, 2009.

Mark, James, Jacob Bogdan, Tobias Rupprecht and Ljubica Spaskovska. 1989: a global history of Eastern Europe. Cambridge: Cambridge University Press, 2019.

Naimark, Norman, Silvio Pons and Sophie Quinn-Judge, eds. The Cambridge history of communism, vol. 2, The socialist camp and world power 1941-1960s. Cambridge: Cambridge University Press, 2017.

Obadic, Ivan. "A troubled relationship: Yugoslavia and the European Economic Community in détente." European Review of History 21:2 (2014): 329-48.

Pons, Silvio and Federico Romero, eds. "Europe between the superpowers, 1968-1981." In Europe in the international arena during the 1970s: entering a different world, edited by Antonio Varsori and Guia Migani, 85-97. Bruxelles: Peter Lang, 2011.

Pons, Silvio and Stephen A. Smith, eds. The Cambridge history of communism, vol. 1, World revolution and socialist in one country 1917-1941. Cambridge: Cambridge University Press, 2017.

Pula, Besnik. Globalization under and after socialism: the evolution of transnational capital in Central and Eastern Europe. Stanford: Stanford University Press, 2018.

Rey, Marie-Pierre. "Le retour à l'Europe? Les décideurs soviétiques face à l'intégration ouesteuropéenne, 1957-1991.” Journal of European Integration History 11:1 (2005): 7-28.

Romano, Angela. From détente in Europe to European Détente: how the West shaped the Helsinki CSCE. Brussels: Peter Lang, 2009.

Romano, Angela. "The EC and the socialist world: the ascent of a key player in Cold War Europe." In Europe's Cold War relations: the EC towards a global role, edited by 


\section{Angela Romano and Federico Romero}

Ulrich Krotz, Kiran Klaus Patel and Federico Romero, 51-69. New York: Bloomsbury Academic, 2019.

Romero, Federico. Storia della guerra fredda: l'ultimo conflitto per l'Europa. Torino: Einaudi, 2009.

Sanchez-Sibony, Oscar. Red globalization: the political economy of the Soviet Cold War from Stalin to Khrushchev. New York: Cambridge University Press, 2014.

Steiner, André. "The globalisation process and the Eastern bloc countries in the 1970s and 1980s." European Review of History: Revue europeenne d'histoire 21:2 (2014): 165-181.

Steiner, André. "The decline of Soviet-type economies." In The Cambridge history of communism, vol. 3, Endgames? Late communism in global perspective, 1968 to the present, edited by Juliane Fürst, Silvio Pons and Mark Selden, 178-202. Cambridge: Cambridge University Press, 2017.

Ther, Philipp. Europe since 1989: a history. Princeton: Princeton University Press, 2016.

Villaume, Poul and Odd Arne Westad, eds. Perforating the Iron Curtain: European détente, transatlantic relations and the Cold War, 1965-1985. Copenhagen: Museum Tusculanum, 2010.

Zaccaria, Benedetto. The EEC's Yugoslav policy in Cold War Europe, 1968-1980. London: Palgrave Macmillan, 2016.

Zubok, Vladislav. "The Soviet Union and European integration from Stalin to Gorbachev." Journal of European Integration History 2:1 (1996): 85-98. 


\title{
1 Socialism Between Détente and Globalisation
}

\author{
Federico Romero
}

Historians have increasingly connected the demise of Europe's socialist regimes with late twentieth-century global economic transformations. Several interpretations of 1989 focus on the undermining effects globalisation had on the late socialist economies and, more crucially, on its 'ideological erosion' of the regimes' solidity, legitimacy and self-confidence. ${ }^{1}$

After the collapse of the Bretton Woods monetary system and the 1973 oil crisis, growing trade competition and market liberalisation redesigned international commercial and financial flows. Multinational corporations connected by new communication and information technologies reshaped productive and distributive networks. The explosive growth of global finance - with international lending rising more than tenfold between 1970 and 1980 - fuelled these processes and built new dynamics of wealth and power. ${ }^{2}$

With goods and capital moving worldwide in unprecedented amounts and at an increasing pace, the landscape in which socialist economies operated was transformed more quickly and unpredictably than socialist officials could fathom or cope with. Their efforts to make their economies more productive by expanding trade with, and technology transfers from, the West turned sour by the late 1970s, and ever-increasing financial imbalances constrained their options, in a few cases to the point of suffocation. By the 1980s they had fallen victim to 'the kiss of debt', and poor economic performance called into question the very rationale upon which their strategies had been built: 'if socialism was merely aiming at placating consumers just like capitalism, only not as well, was socialism's existence even justified?'3

Of course, economic dynamics were linked to ideological and cultural factors that deepened socialism's predicament, hindering its residual rationale and hollowing out its core meaning. While socialist modernisers were trying to temper the rigidities of planning with limited simulated market mechanisms, the Keynesian consensus was fast unravelling in the West. Rather than the presumed convergence of 'market socialism' and Keynesian mixed economies towards rationally planned industrial societies, the 1970s ushered in a free market ideology that eventually dismantled the societal and economic paradigms underlying post-war recovery. ${ }^{4}$ 
Individual competition rooted in a market concept was hailed as the foundation of freedom and contrasted with the state as the source of authoritarianism. In this starkly binary logic, "freedom of choice" rose from being a consumerist slogan to an overarching paradigm of pervasive influence. ${ }^{5}$ Soon dubbed "neo-liberal", this paradigm of market individualism in a context of deepening global interconnectedness not only sustained a fierce criticism of communism but also struck at the core of any planning and redistributive policy, disabling social-democratic and Keynesian frameworks, which relied primarily on national policy tools. Tighter interdependence and capital mobility forced adjustments at any level - regional and national, between sectors and within firms.

This major systemic transition was deeply upsetting everywhere and the Western economies underwent difficult, often painful changes. However, they adapted better than those of Eastern Europe. After comparable achievements in the two post-war decades, economic performances diverged markedly. Between 1973 and 1989, the planned economies of Eastern Europe grew 0.7\% a year, against $2 \%$ for Western Europe. Per-capita income in socialist economies dropped from $49 \%$ to $37 \%$ of Western European levels. ${ }^{6}$ State socialism proved to be 'a blunt instrument, more suitable for rapid industrialisation ... than for progressing to a sophisticated consumer economy'?

These fast-changing conditions made the national economic strategies analysed in this book far more difficult to implement and ultimately unsuccessful. It was not merely an economic failure to improve productivity and upgrade technology, although this was crucial. The demise of strategies depending on deeper exchanges with the West meant the socialist regimes of central-eastern Europe lost their attempt at overcoming the key long-term dependencies that hampered them and to a large extent defined them.

They were struggling, first, with their historically sedimented condition of "peripheral" economies subordinated to Europe's north-western industrial core. Even though Stalinist industrialisation had transformed their domestic economic agrarian structures, their actual and potential trading relations with the advanced industrialised economies of the West remained disproportionally dependent on exporting primary products and low-tech goods. For Poland, Hungary and Yugoslavia, and even more so for Bulgaria and Romania, catching up with the most advanced economies was a long-term national goal no less than a key imperative of socialist ideology. ${ }^{8}$ Its pursuit might have appeared long and difficult but far from unthinkable in the 1960s and early 1970s, but within a decade it turned out to be an untenable delusion.

Historical "backwardness" was compounded with the relative isolation imposed by the early Cold War partition of Europe in opposite and largely separate camps. Ever since the launch of the Marshall Plan in 1947, Western management of the international economy also aimed to isolate the socialist economies. The institutions, rules and practices of post-war multilateralism ensured they remained fenced in a closed sphere with minimal interchanges with Western capital and advanced technology. No less crucial, of course, was the Stalinist strategy of creating 
an insulated self-blockaded socialist camp - which operated in paradoxical synergy with Western decisions.

Historical scholarship has debunked, or at the very least seriously qualified, the Cold War myth of an impermeable dour socialist autarky. Excluded from the post-war international economy framed by Western multilateralism, the socialist countries strived to build up trade amongst themselves and a planned division of labour through the Council for Mutual Economic Assistance (CMEA). Although this seemingly complemented the bloc's military and ideological cohesion, it neither functioned efficiently for economic integration nor satisfied the participants' key economic ambitions. The Soviet Union gained little economically and soon had to provide its partners with support, while they resisted plans for intra-regional specialisation, strived to maximise their individual shares of Soviet subsidies and usually pursued their own national goals. ${ }^{9}$

This system was not particularly efficient and certainly unsatisfactory, not least for the central-eastern European socialist countries mired in a 'dual dependency' 10 on the region's dominant imperial power and the core economies of the capitalist world, yet it embodied and to a certain extent sustained the post-Stalinist effort to deepen socialism's transnationalism, connect with the world and build networks of global exchange.

Recent studies investigate the multiple deep expanding connections the socialist world built within its own boundaries and with other societies, particularly in post-colonial settings but also in the West. They make a strong case for a far more plural reading of the various internationalist projects and frameworks that not only competed but often overlapped and got intertwined in the complex transformations from the 1960s onwards. ${ }^{11}$ They challenge the teleological view of a single inescapable neo-liberal globalisation and replace it with proper historical questions on the goals, pressures and specific terms under which different states decided to open up their economies. ${ }^{12}$ Above all, they reassess the place and role of socialism in global history, its contribution to a culture of global change in the second half of the twentieth century and its practices to connect with the "third world" in projects of alternative internationalisation. ${ }^{13}$

Of course, assessing socialism's contribution to globalisation, or conceptualising an alternative path to globalisation, is a challenging endeavour, not least because the communists purposely 'wrote themselves out of the story of globalisation' with their language of national independence and antagonistic blocs. ${ }^{14}$ Still, the challenge to global capitalist hegemony inspired socialist views and policies from the mid-1950s onwards, and was sufficiently serious to raise considerable concerns in Western capitals. At least until the mid-1970s, the potential for an emerging compact between socialism and the global South seemed real enough to stoke hopes or fears of an alternative international order..$^{15}$

This did not come to pass. Instead, a compelling market globalisation under Western hegemony came to define the closing decades of the twentieth century. The transition from the former prospect to the latter reality defined the mutable environment in which the socialist economies struggled, illuminating their predicaments. 


\section{Federico Romero}

\section{Socialist transformation or stabilisation?}

The Stalinist model of heavy industrialisation had changed the socialist countries' economies, with intense resource utilisation that fuelled their rapid post-war growth. However, their leaders - and particularly Nikita Khrushchev - looked at Western advanced capitalism as their reference point. The aspiration of catching up with the West oriented their compasses for strategic, ideological and material reasons. It was, of course, a Cold War imperative dictated by the need to sustain the antagonism and possibly surpass and outshine the adversary. Furthermore, it was an ideological tenet rooted in Marxist-Leninist views of class struggle and historical progress. However, by the early 1960s it was also increasingly a thrust grounded in more pragmatic goals and implications.

Under Khrushchev, the Soviet leadership embraced notions of accelerated economic growth premised on a shift towards light industry for increased production of a larger range of consumer goods and on expanded trade within the socialist sphere but also with the new post-colonial nations and the West. Above all, it pinned its hopes on a scientific and technological revolution not only to propel the USSR to the role of global superpower but also to project socialism as an alternative superior form of modernity. This entailed a strong emphasis on technological innovation necessitating not only research but also exchanges between East and West - tasks entrusted to a State Committee of Science and Technology created in 1958. ${ }^{16}$ In 1961, the Communist Party of the USSR published a new programme that associated communism with material abundance and promised socialist consumption policies that betrayed a cultural fascination with Western ideas of societal wellbeing and progress, if not an internalisation of Western superiority. ${ }^{17}$

This shift of emphasis was shared, albeit unevenly, by the other European socialist regimes (but harshly criticised by the Chinese), and there, as in the Soviet Union, it brought both desired transformations and unintended consequences and tensions. Investment priorities were at least partially rearranged. In order to tackle key problems of productivity and incentives, a variety of reform experiments were attempted, usually with 'market mechanisms . . . simulated within the framework of the planned economy without introducing the fundamentals of a market economy'. ${ }^{18}$

However, the reorientation of priorities towards satisfying socio-economic needs, and the introduction of even limited market mechanisms, did not sit smoothly with a planning system that had been created to maximise investment in heavy industry and ensure top-down discipline. Frictions soon emerged both in practical terms, as innovations were stifled and productivity gains seriously limited by the inbuilt strength and inertia of the planning mechanism; and in political terms, as the push for incremental changes raised the spectre of a fundamental reshaping of the socialist model, with the possibility of uncontrolled power struggles and systemic destabilisation. ${ }^{19}$

These tensions played out with different features and timing in the various national contexts, producing multiple threads of Marxist reform thinking and projects that flourished throughout the 1960s. ${ }^{20}$ However, the core issue came to 
an abrupt head in summer 1968 when the Warsaw Pact armies suppressed the Prague Spring, the most ambitious and far-reaching experiment in socialist reform. Driven by the strategic need to preserve the cohesion of the socialist bloc, the Soviet-led intervention made clear, once and for all, that political stability overrode any attempt at reforming the socialist economic model. Therefore, it designed a very narrow perimeter of admissible social and economic change. With reforming or defending socialism now alternative options, radical transformations of the planned economy were ruled out. This had two key consequences. First, socialist reform thinking withered - with its advocates either repressed or withdrawn to the safer sphere of technical advice - and it was eventually eclipsed by criticism centred on civil rights rather than ideas of social and economic transformation. Second, acceptable change was redefined 'exclusively in terms of a gradual improvement of the existing order, as expressed by Leonid Brezhnev's ideology of stabilisation'. ${ }^{21}$

With reform policies and politics forcibly shelved, socialist elites concentrated on strategies for growth that would not engender uncontrolled change and risk instability. Alarmed by popular pressure for economic betterment, particularly evident after the December 1970 strikes in Poland, they came to focus on investment and trade solutions geared to "pacify the workers while securing their own power'. ${ }^{22}$ Public welfare and consumption therefore acquired greater priority, and one of the ways to achieve them came to be seen in increased imports of technology and consumer goods from the West, a strategy shared by the entire bloc (with the exception of Czechoslovakia in the early years of its 'normalisation') and pursued most intensely by the GDR, Hungary and Poland. Socialism would not be reformed but it could be modernised (so the new doctrine predicted) by enhancing its ability to incorporate the technical achievements of the Western economies.

The pursuit of this rationale was facilitated by another transformation that the 1960s had brought to the socialist sphere. The push for accelerated economic growth, technological exchange and increased trade had expanded the role and reach of CMEA. Spurred also by a genuine, albeit apprehensive, interest in the ongoing dynamics of integration among Western economies, the notion that deeper interdependence should be pursued and organised flourished in socialist capitals. CMEA could develop complementarities and strive for deeper integration and specialisation to enhance growth and strengthen the socialist world. At the height of decolonisation, it was also seen as a tool to elaborate a coherent socialist model to offer to some of the newly independent countries of the global South, aiming to shape a larger socialist sphere encompassing both developed and developing countries and affecting the visible growth of global interconnectedness in original alternative ways.

However, initial projects to coordinate national plans and pursue a bloc-wide division of labour were resisted (or openly rejected, in the case of Romania) by the interplay of divergent national ambitions and interests. The intergovernmental nature of CMEA facilitated processes of national identification and limited Moscow's ability to direct and control institutional dynamics, especially at a time when the Sino-Soviet schism made the unity and discipline of the communist 
movement at the party level substantially less solid. As a consequence, diversity rather than homogeneity increased across the Eastern bloc, with each country pushing for competitive advantage, using the bloc's multilateral structures to carve out space for its own trade deals, enhance its national autonomy and pursue key national goals (the GDR and Poland, for instance, thwarted deals with West Germany until their own bilateral issues - recognition and border settlement respectively - had been solved). A similar dynamic also took hold in relations with the global South. Early attempts at coordinated bloc initiatives with strategic relevance were gradually abandoned and replaced with separate national engagements aimed at trade advantages in a logic of national, rather than bloc-wide, economic improvement. ${ }^{23}$

At the beginning of the 1970s, the developmental discourse steeped in antiimperial solidarity remained dominant, but in actual terms it was being superseded by national strategies with a hard-nosed focus on mutual trade benefits. Among these, the supply of raw materials stood out, but equally crucial was the socialist economies' overarching need to gain hard currency via export, in order to sustain their purchases of investment and consumer goods from the West. Rather than an anti-imperial north-south axis, socialist economic strategies were now prioritising an east-west interchange as the key to a more productive, technologically advanced, consumption-oriented socialism.

\section{Opportunities and expectations of détente}

These economic strategies were inextricably intertwined with détente. The two processes were mutually reinforcing, and usually expected - in the East even more widely than in the West - to succeed together. In Warsaw and Budapest, but also in Bucharest and Sofia, the rising tide of East-West détente spelled an unprecedented moment of opportunity and confidence.

The US-Soviet dialogue on strategic arms control, which had brought the 1968 Non-proliferation Treaty and eventually resulted in the 1972 SALT agreement, was meant to diminish the risk of war and stabilise relations between Moscow and Washington but also to buttress their hierarchical control over their respective blocs. However, unintended consequences abounded, as détente opened up a far wider and mutable political space. Within it, several venues of East-West cooperation could now be explored by a variety of protagonists, whose priorities did not always coincide with those of the two hegemons. ${ }^{24}$

Two crucial factors paved the way to a dynamic multi-level multilateral détente between Eastern and Western Europe. Socialist leaders interpreted the armament agreements as a result of Soviet strategic strength. Regulated nuclear parity for them spelled a safer system of mutual deterrence replacing the previous threat inherent in Western superiority and epitomised the rise of socialist world influence. ${ }^{25}$ Even more pivotal, Willy Brandt's Ostpolitik deflated the fear of German "revanchism," inaugurated a language of cooperation that did not threaten socialist stability and indicated the possibility of mutually beneficial exchanges. In particular, his treaties with Moscow and Warsaw (1970) and with the GDR (1972) 
removed the main legal and historical obstacles to cooperation. They designed a new landscape that seemed to consign the Cold War to history while promising a future of peaceful competition between socio-economic systems. ${ }^{26}$

Thus the economic strategies for faster socialist growth based on technological exchanges, credit from the West and an expansion of consumption found their most promising environment in the policies of détente pursued at the diplomatic level. Intensified cooperation would promote trade and partnership deals, thus feeding the ambitious economic goals set in Warsaw or Budapest, while extended exchanges (not only with West Germany, but also with the rest of Western Europe) would in turn provide robust foundations for a durable détente. Socialist leaders saw in this virtuous circle the prospect of self-consolidation with faster economic growth, a possibility for the cautious pursuit of national goals and the best option to 'make detente irreversible'. ${ }^{27}$

These views converged with those of most Western European governments (including the neutral ones), which saw détente not just as an interstate process but rather as a new horizon of cooperative security rooted in growing interdependence among economies, societies and peoples. Increasing trade and exchanges with Eastern Europe could be seen primarily as a political tool, as the US did, with the goal of rewarding and stimulating each government's relative autonomy from Moscow. ${ }^{28}$ However, they could also be imagined as tools for ambitious long-term transformations. This had been one of the original tenets of Ostpolitik and was fast becoming a shared grammar not only within Western European governments and the European Community but also among religious and civic associations, political parties, transnational activists and even business circles. If intensified trade, credit and technological cooperation could go together with increased contacts, ease of travel and tourism, and societal and cultural exchanges, the ensuing interdependence would foster mutual confidence, shared interests and (possibly) an easing of the East-West divide. Confident in their superior economic strength and democratic legitimacy, Western European actors trusted the attractiveness of their social model to gradually open up socialist societies, temper their rigidities and perhaps in the long run erode their regimes' authoritarian nature and hostile postures. ${ }^{29}$

The main overarching venue in which these strategies and expectations converged was the Conference for Security and Cooperation in Europe (CSCE), which in Helsinki in 1975 produced a broad accord on East-West relations, contacts and exchanges. It enshrined the twin pillars of intra-European détente, the double notion that states would respect each other's sovereignty and borders but would also facilitate mutual trade, travel and transnational societal interactions. ${ }^{30}$ This was the high point of détente and was seen in the socialist sphere as the crowning of its effort to obtain international legitimacy and stability. At the same time, it opened up new areas of competition and potential tensions, particularly on human rights, that would eventually challenge the socialist regimes' domestic discipline and control. ${ }^{31}$

Among socialist officials, concerns about capitalist encroachments, dependence on the West's superior economic power and the corrupting effects that consumer 
culture could have on social discipline and cohesion were far from absent. Such fears were outweighed, though, by new expectations of safety, stability and prosperity. These hypothetical risks - including those related to human rights appeared manageable and seemed more than balanced by Helsinki's substantial results and promises. ${ }^{32}$ Stable and durable détente was the key strategic prospect for peace and stability. Moreover, as economic strategies were pivoted on expanded trade and cooperation with the West, multilateral détente offered important opportunities for national improvement and even some degree of autonomy. In the mid-1970s, socialist governments could still look at their prospects and predicaments with considerable confidence, not least because the West was not faring very well as it was mired in its major post-war crisis.

The demise of the Bretton Woods monetary system had brought instability and uncertainty coupled with transatlantic frictions and mutual recriminations. Foreign policy divergences - first on Vietnam, then on the management of détente and finally on the Middle East - intersected with economic issues, opening up a considerable gap between Washington and its European allies. The European Community was openly searching for a foreign policy role of its own and trying to assert its economic power. Socialist leaders resurrected the notion of an impending crisis of capitalism and mused on Western Europe's potential emancipation from US hegemony. There was, of course, an element of wishful thinking in all this, but they were neither alone nor daydreaming, as many in the West also looked with trepidation at the implications of trans-Atlantic frictions and rivalry. ${ }^{33}$

Then the oil crisis added a shocking existential dimension to the sense of impending crisis. The rise in oil prices signalled to Western societies that their long post-war boom was over and that their dominance of the international terms of trade was challenged, by OPEC in a direct way and more broadly by a large coalition of developing countries that demanded a new, more equitable international economic order. ${ }^{34}$

With the ensuing recession, unemployment resurfaced in the West and inflation took off. The post-war winning combination of growth and democratic stability suddenly appeared shaky. Economic policymaking and business plans had to be rearranged in a fractious landscape that exasperated national and trans-Atlantic divergences. Preserving the West's multilateral system required new tools and institutions for the management of interdependence..$^{35}$ As a result of this crisis, a complex multi-level reshaping of the world economy got under way. Under new paradigms of market competition and financial liberalisation, Keynesian demand management was replaced with policies of privatisation, deregulation and fiscal austerity, ushering in the dynamics and concept of globalisation that would eventually triumph after $1989 .{ }^{36}$

At first, though, no one anticipated this deep successful restructuring of Western dominance. The crisis was so multi-dimensional and severe (at least between 1973 and 1976) that it evoked spectres of Western decline. For a short moment, predictions of a crisis of capitalism appeared no more fanciful than expectations of its global resurgence. 
Therefore, socialist leaders saw far more opportunity than risk. The oil crisis raised demand for (and returns on) Soviet oil, coal and other raw materials. Western European corporations were eager to find new export markets. Multinationals were reorganising production networks worldwide. The spectacular rise of Japan's industrial and trading power appeared as an enticing example of catchingup achieved through integration in the international market. Even more crucially, the recycling of OPEC oil revenue provided Western banks with abundant capital for loans that inflation would make cheaper to repay. Thus, socialist planners with a modernising attitude 'saw . . . a unique set of opportunities for upgrading the path of socialist economic development' ${ }^{37}$ It seemed a favourable moment to engage economically with the West.

\section{Systemic inadequacy and external constraints}

National strategies based on imports and credit from the West initially achieved remarkable results. Between 1971 and 1975, economic growth was intense, exceptionally so in Poland and Romania. Consumption rose to unprecedented levels, as it did in the GDR. Exports to OECD countries also grew. Hungary launched many cooperation agreements in light industry, as did Romania and Yugoslavia with several joint ventures.

However, this opening of (relatively) closed economies made the socialist countries vulnerable to the shocks and tensions of a globalising world economy and exposed their planning systems to strains and competitive pressures. In a few years, problems piled up, uncovering serious shortcomings and vulnerabilities, and key indicators became almost unsustainable. The trade deficit of the six central-eastern European countries grew from 1.2 billion US dollars in 1972 to 6.6 billion US dollars in 1978, and their debt to the West from 4.9 billion US dollars in 1971 to 48.5 billion US dollars in 1979 (almost half of which was Poland's). ${ }^{38}$

There were several intertwined root causes of this cycle. As the chapters in this book demonstrate, the elements of flexibility introduced in the system to make it more responsive to international trade were far from sufficient. Even though there were large variations among countries, firms and enterprise associations were usually given more autonomy and foreign trade authority was partially decentralised. However, the inherent inefficiencies of the planning system remained entrenched and they hampered the overall effort for a technological and productivity upgrade. Even the firms more directly affected by new equipment imported from the West and those involved in the export drive to gain hard currency were often held back by bottlenecks and poor quality suppliers. This limited their efficiency gains, their output of new products and their export opportunities. The impact of new technologies and processes was also constrained by the nature of socialist enterprises, which could not restructure - in particular, replace workers with machines - with the rapidity and suppleness of capitalist firms. Additionally, much new investment went to traditional heavy-industry sectors like steel, coal and refineries due to their superior lobbying power entrenched within the party-state apparatus and the prevailing economic and administrative culture in the planning system. In 
broad terms, a planning structure designed for mass production of standardised goods fared poorly when confronted with the needs to become flexible and innovative, to diversify its products and to adapt to the increasing relevance of services. Therefore, even though some productivity gains were achieved - especially in Poland, Hungary and the GDR - systemic inefficiencies reduced the potential impact and expected benefits of the new strategies.

A second set of difficulties concerned export opportunities, which turned out to be less ample than expected. Low-end sectors in which the Eastern European economies could be competitive, like textile and agricultural goods, were often protected in Western markets, and particularly so in the most crucial neighbouring EEC. In the mid-level technology range, industrial products - even the new ones that were being developed with imported Western equipment and licenses - had to compete not only with Western rivals but with the rising prowess of the East Asian industrialising economies, which pursued coherent export drives and were rapidly conquering markets worldwide. As a result, inefficiencies and poor reliability on the domestic side interacted with increasingly competitive dynamics abroad to make socialist exports too often costly, unappealing or simply outperformed by their Western and Asian rivals. Several socialist governments even tried to use international institutions to position themselves as developing economies (in marked contrast with socialism's own self-representation) so as to obtain preferential access to the richer markets, particularly the EEC. In this endeavour, they emulated Yugoslavia's established policy and stance. However, unlike Yugoslavia, they obtained scarce results. ${ }^{39}$ Gaining substantial permanent export shares in the West and the developing economies of the global South proved to be quite difficult. Even though international trade as a proportion of global GDP rose spectacularly throughout the 1970 s, the socialist economies intercepted only a small quota of it. Too small, that is, to balance the growing volume of imports that they had to pay for with hard currency. Thus the productivity gains and welfare improvements that the new economic strategies initially achieved soon ran against increasing external constraints..$^{40}$

The key measure of these growing difficulties - and the noose that would eventually doom the new strategies - was the fast-expanding foreign debt with Western banks and governments. Several factors contributed to its rapid growth. The prediction that rising energy prices would help the socialist economies soon went into reverse. Oil sales brought more revenue to the Soviet Union but a new CMEA price formula - designed to reduce the differential with world prices - meant that energy costs for the central-eastern European countries started to rise from 1975. The prices of other raw materials and intermediate goods that sustained the new productions also rose. Thus, foreign expenditure grew faster than revenue from exports. Moreover, no small amount of foreign credit was used to finance consumption (in accordance with the new policy's welfare rationale) rather than productivity-enhancing investment.

Rising foreign debt was initially seen as temporary, and therefore inherently manageable. As exports were expected to grow and bring hard currency, the rationale for a debt-fuelled investment spurt appeared sound. However, the 
mechanism never came close to its anticipated balance. Even when good, export performances were not sufficient to offset the growing trade and finance imbalance. Several new investments turned out to require constant additional imports of raw and intermediate materials, thus further stretching debt creation into the future. The devolution of authority reduced the planning system's internal consistency and empowered regional, sectoral and company managers to lobby for their own interests, over-invest and increase the debt's growth. There were other domestic imbalances. In the most extreme case of Poland, real wages grew faster than productivity, sucking in more imports. In 1976 the government intervened with a highly unpopular food price rise and diversion of exportable goods to the domestic market, making the debt problem even less manageable and stimulating radical opposition. ${ }^{41}$

However, for a while the lenders were not seriously concerned. Western states and businesses heavily invested in deepening détente and expanding East-West exchanges. Even though some Western banks and government officials already began to feel concerned in 1977, the overall assumption was that the socialist states (and ultimately the USSR) could guarantee repayment. Maintaining a high (and possibly growing) level of East-West trade remained a paramount goal for both political and commercial reasons. ${ }^{42}$

Therefore, credits were extended and renewed until the moment of reckoning, which came in 1979 when the US Federal Reserve reacted to growing inflation and a new oil price rise with a restrictive monetary policy. The sharp increases in the cost of energy and interest rates radically altered the international financial landscape. Debt servicing became far more expensive, and the ensuing recession further reduced the debtors' ability to export. Highly indebted countries - both in Eastern Europe and Latin America - entered an era of severe economic hardship. ${ }^{43}$

The already apparent flaws in the socialists' strategies based on Western imports and credits became serious vulnerabilities, as the very interconnectedness with world markets that they had pursued (as a path to prosperity and stabilisation) now turned into a suffocating constraint. The debts grew more expensive. Oil and many raw material prices rose. Exports declined as a result of the global recessionary trend and collapsed towards "third world" countries whose own debt burden was fast becoming untenable. ${ }^{44}$

With a debt trap looming large (see Appendix, Table A.5), the classical response would have been domestic deflation to cut imports and eventually restore equilibrium. However, this went against the grain of the strategy pursued thus far and belied the rhetoric of prosperous modernising socialism. Above all, it carried considerable dangers. When in July 1980 the Polish government announced hefty food-price increases, workers' strikes swept the country with such strength that they forced the recognition of an independent trade union, Solidarnosc, which soon became the backbone of a massive opposition movement. ${ }^{45}$ With Poland entering a profound crisis that threatened the regime's survival (and depressed exports even further), policies decreasing consumption appeared too dangerous across the socialist bloc. Instead, import reduction was primarily pursued with cuts in investment, a stopgap measure that further reduced growth and export capacity. 
As a result, the debt crisis rapidly intensified. In 1981, Poland negotiated rescheduling agreements but its financial position deteriorated even further after the imposition of martial law, which brought US sanctions and a tightening of Western credit. In rapid succession, all the indebted countries of the socialist bloc and Yugoslavia had to adopt emergency measures. Hungary decided to stabilise its finances by applying to the International Monetary Fund, and it was admitted in 1982 (Poland also applied, but its entry, which only took place in 1986, was made conditional on ending martial law). The GDR turned to West Germany, whose massive credit allowed it to restructure its debt in 1983. Romania prioritised repayment of foreign debt and so imposed draconian domestic austerity. ${ }^{46}$

Within a few years external liabilities were lessened, but the socialist economies suffered badly with reduced capacity, anaemic growth, lower levels of income and consumption, and an even larger productivity gap vis-à-vis the West. East-West exchanges were reduced, but there was no going back to semi-autarky. Despite substantial national variations, dependence on Western finance and technology had become ingrained. The West itself did not cut economic ties in the years of renewed bipolar tensions that followed the Soviet invasion of Afghanistan and martial law in Poland. The US adopted a punitive strategy of sanctions and a trade embargo, but Western Europe resisted this approach and strove (rather successfully) to preserve the key elements of European détente. As Helmut Schmidt stated at the Venice G-7 summit in 1980, economic exchanges were not simply 'a mere matter of trade' but 'a moral and historical necessity to reach a better understanding with the East, and especially Poland' ${ }^{47}$ Thus crucial East-West commercial and financial links were maintained throughout the 1980s, the US hard-line strategy proved ineffective and was eventually forsaken, and Western European financial clout came increasingly to be used to negotiate political goals too (like the mellowing and ending of martial law in Poland or support for reforms in Hungary). ${ }^{48}$

However, the 1970s import-based socialist strategies were in tatters, and the sharp contrast between failed promises and renewed hardship undermined the regimes' residual domestic authority, credibility and solidity. By the mid-1980s, Western capitalism was triumphantly redefining itself in neo-liberal terms and China was embracing a capitalist economy. The future of socialism in a rapidly globalising world economy appeared unfathomable. Even the socialist elite seemed to have lost confidence and any vision for the future. When the 1989 revolutions brought down their regimes, the leaders and technocrats were confusedly exploring ways to transition to a market economy.

\section{Conclusion}

The import-led socialist strategies of engagement with the market economies were inaugurated under seemingly favourable conditions in the early 1970s. Détente and Ostpolitik offered a reassuring enticing context. With the Keynesian framework still prevalent, the mixed economies of the West appeared steeped in capital controls and regulated trade that channelled or contained market dynamics. The 
notion of East-West convergence might have been far-fetched, but the expectations of mutual advantages deriving from state-regulated exchanges were not.

Some of these conditions, though, started to shift by the middle of the decade, with large capital movements nurturing a more competitive environment of increasingly global scope. The spread of post-Fordist practices, based on more flexible technologies and procedures, amplified the relevance of market dynamics and the consumerist ethos, moving the goalposts towards a harsher all-encompassing market environment. This magnified the 'structural dilemma' of the socialist economies, which 'required more imports and thus more borrowing' but 'were not able to sell their products on the Western markets to a sufficient degree'. ${ }^{49}$ Some of them soon became hostage to a deepening debt trap. However, the different case of Czechoslovakia - which followed a more cautious path of financial prudence and limited exposure to the global economy - shows that their comparative disadvantage ran very deep, and their impediments were rooted in the structure of planned economies. ${ }^{50}$ Where reforms were introduced to adapt to the new demands emanating from the harsh confrontation with capitalist markets, they proved ineffectual or insufficient and fostered a 'relatively slow ... disintegration of the planning regime'. ${ }^{51}$

Thus strategies meant to harness market mechanisms to the prosperity and stability of socialist regimes brought unintended - and largely opposite - consequences. Rather than a more confident socialism on an upward trajectory of modernisation, the heightened confrontation with globalising markets delivered uneven, deteriorating and ultimately unsustainable economic performances. Dependence on the West grew deeper in material terms and inescapable in its symbolic meanings. Not only was the world not going the socialist way, but socialism grew increasingly mired in the uncomfortable role (and image) of a subaltern system whose degree of autonomy and self-determination was rapidly dwindling..$^{52}$ The bloc itself grew more dissimilar and fractious as trade intensification with the West exasperated divergencies among national paths and policy options, fostered a search for separate deals and solutions, and made the bloc's cohesion not only more difficult to manage - as Moscow could not take on the burden of its allies' debt - but also less valuable as a shared resource. ${ }^{53}$

The 1970s promise of increasing welfare and consumption might have stabilised the regimes in the short term, but it also shifted the ground of their domestic legitimisation towards capitalist values of individualised consumption in the private sphere. It was a metric that socialism could not successfully sustain since it was outcompeted in terms of productivity, quality and variety, and that fostered processes of identification with Western notions of personal freedom and wellbeing. ${ }^{54}$ Intertwined with the emerging politics of human rights and the financial dependence on Western credit, the rise in consumerist expectations brought the West deep within. The possibilities for the regimes to shield their societies from their adversary's influence and allure were ever more limited. ${ }^{55}$

Therefore, interpretations of 1989 centred on security and geopolitical factors, and particularly on Gorbachev's withdrawal of the Soviet guarantee to the socialist regimes of central-eastern Europe,${ }^{56}$ need to be qualified and contextualised. 
Gorbachev's choices were obviously crucial in dispelling notions (already quite fanciful at that point) that help for the regimes could come from Moscow. However, these interpretations do not account for too many key factors: the regimes' long forsaken economic dynamism; their all too manifest failure in the sociocultural competition with the West; the long-term unravelling of their viability and coherence; their citizenry's deep and widespread alienation, well beyond the perimeter of structured opposition; and the vanishing of any confidence that socialism had a promising future. Without these factors, one cannot explain the 'elites' sense of exhaustion with their own project', ${ }^{57}$ the crucial loss of will and confidence that eventually gripped officialdom all the way up. This was the most decisive feature in 1989.

Two decades of deepening East-West interaction, with increasing exposure to the material pressures and socio-cultural influences of market globalisation, had made the regimes more brittle and ineffective. They had exposed their structural weaknesses, magnified their inbuilt dependencies, blown their residual rationale and, ultimately, emptied socialism out. The extended processes that this book explores and compares in their national settings were key determinants of the protracted demise and then sudden collapse of socialism. At the same time, they set some of the foundations on which the transition would take place, with legacies of trans-nationalisation that would mould the new democratic republics' paths to their turn-of-the-century Europeanisation and globalisation. ${ }^{58}$

\section{Notes}

1 Maier, "Thirty years after," 604. An analogous reading is also in Berend, From the Soviet bloc; Romero, Storia della guerra fredda; Pons, The global revolution; Westad, The Cold War.

2 See Frieden, Global capitalism, 351-97.

3 Kotkin, "The kiss of debt," 91. See also Kotkin and Gross, Uncivil society.

4 For a recent scholarly overview of planning cultures and actors which highlights comparability and transnational East-West interaction, see Christian, Kott and Matejka, Planning in Cold War Europe.

5 Rodgers, Age of fracture. On the relevance of market ideas across socialist Europe and their contribution to neo-liberal culture, see Bockman, Markets in the name of socialism.

6 Berend, From the Soviet bloc, 35.

7 Maier, "Thirty years after," 608.

8 See the overview by Harrison, "Communism and Economic Modernization," 388-404, and Kott, "The social engineering project," 195-222.

9 See Sanchez-Sibony, Red globalization; Stone, Satellites and commissars; Bergson, Planning and performance; Marrese and Vaňous, Soviet subsidization of trade.

10 Staniszkis, "Patterns of change in Eastern Europe," 77-97.

11 Kott, "Cold War internationalism," 340-62.

12 Pula, Globalization under and after socialism.

13 See Mark and Rupprecht, "The socialist world in global history," 81-114.

14 Mark and Rupprecht, "The socialist world in global history," 84. On this fundamental unresolved tension, see the discussion by Pons, The Global Revolution.

15 See Lorenzini, Global development; special issue on the "New International Economic Order," in Humanity 6:1 (2015); Hilger, "Communism, de-colonization, and the third world," 317-40. 
16 Smith and Ilic, Khrushchev in the Kremlin); Autio-Sarasmo, "Stagnation or not?," 87-103.

17 Fürst and Bittner, "The aging pioneer," 281-306.

18 Steiner, "The decline of Soviet-type economies," 203-4.

19 Hanson, The rise and fall of the Soviet economy; Feygin, Building a ruin.

20 On reformist Marxism until 1968, see Trencsényi et al., Negotiating modernity.

21 Kolar, "Post-Stalinist reformism," 170. On the retreat from socialist reform thinking by experts and intellectuals after 1968, see Zubok, Zhivago's children, ch. 8.

22 Steiner, "The decline of Soviet-type economies," 206.

23 Godard, "The Council for Mutual Economic Assistance," 287-323; Lorenzini, "The socialist camp," 341-63; Kansikas, Socialist countries face the European Community; Crump, The Warsaw Pact reconsidered; Muehlenbeck and Telepneva, Warsaw Pact intervention.

24 On the multiple, even contrasting goals, dimensions and results of détente, see the specialissue debate on "Détente and Its Legacy," in Cold War History 8:4 (November 2008).

25 Zubok, A failed empire, 209-25; Hanhimäki, The rise and fall of détente; Kieninger, Dynamic détente.

26 Loth and Soutou, The making of détente; Sarotte, Dealing with the devil.

27 Archiwum Akt Nowyth (AAN - Central Archives of Modern Records), KC PZPR 1354, v/120, "Węzłowe kierunki i zadania politiki zagranicznej PRL w 1974" (Ministry of Foreign Affairs guidelines for 1974), 15 January 1974, 3, quoted in Chapter 4 by Aleksandra Komornicka in this book.

28 See "Response to NSSM 163 Prepared by the Ad Hoc Group on Economic Policies Toward Eastern Europe," Washington, 1 February 1973, in Miller, Selvage and Van Hook, FRUS, Document 26.

29 Bange and Villaume, The long détente; Kieninger, The diplomacy of détente; Villaume and Westad, Perforating the Iron Curtain.

30 Romano, Détente in Europe to European détente; Ludlow, Ostpolitik-Westpolitik, 1965-1973.

31 Villaume, Mariager and Porsdam, The 'long 1970s'; Snyder, Human rights activism; Blumenau, Hanhimäki and Zanchetta, Unexpected transformations?

32 Jarzabek, "Polish reactions to the West German Ostpolitik," 35-55, and Bange, "The GDR in the era of détente," 57-77.

33 Möckli, European foreign policy; Schulz and Schwartz, The strained alliance; Gfeller, Building a European identity.

34 Garavini, After empires; Bini, Garavini and Romero, Oil shock; Dietrich, Oil revolution.

35 Mourlon-Druol and Romero, International summitry and global governance; Sargent, A superpower transformed.

36 Chassaigne, Les Années 1970; Ferguson et al., The Shock of the Global.

37 Pula, Globalization under and after socialism, 23.

38 See Table A.1 in the Appendix and Zloch-Christy, Debt problems of Eastern Europe, $31-4$.

39 See the chapters in this book about Bulgaria, Romania, Yugoslavia and even Czechoslovakia.

40 Steiner, The plans that failed, 141-93.

41 Poznański, Poland's protracted transition and Chapter 4 by Aleksandra Komornicka in this book.

42 See, for instance, The UK National Archives (TNA), CAB133/467, "Economic Summit Meeting 27-28 June 1976: Steering Brief by FCO," 23 June 1976; Historical Archives of the European Union (HAEU), EN 1569, "Relations between the Community and eastern Europe, 1 April 1977"; Romano, "G-7s, European Councils and East-West Economic Relations," 198-222.

43 Axilrod, Inside the Fed; Frieden, Global capitalism, 372-400.

44 Trecker, "Circle of debt." 
45 Paczkowski and Byrne, From Solidarity to martial law.

46 Graf, "Before Strauß”; Köves, The CMEA countries.

47 TNA, PREM19/189, "Second Session of Economic Summit on 22 June 1980 at 1515 hours: discussion of political matters." See also TNA, PREM19/188, Michael Palliser to M. Alexander, "Political Discussion at the Venice Summit," 6 June 1980.

48 See Esno, "Reagan's economic war," 281-304; Bátonyi, "“Creative ferment in Eastern Europe," 638-66; Bartel, "The power of omission," 200-20.

49 Steiner, "The Decline of Soviet-Type Economies," 214.

50 See Chapter 6 by Pavel Szobi in this book.

51 Poznański, Poland's protracted transition, xi.

52 See the discussion in Mark and Rupprecht, "Europe's '1989' in global context," 224-49.

53 Godard and Crump, "Reassessing communist international organisations," 85-109; Lüthi, "Drifting apart."

54 Bartha, "Welfare dictatorships," 63-82; Péteri, Imagining the West in Eastern Europe; Lovell, "Communist propaganda and media," 354-75.

55 Badalassi and Snyder, The CSCE and the end of the Cold War.

56 Kramer, "The demise of the Soviet Bloc," 7-62; Zubok, "The collapse of the Soviet Union," 250-77.

57 Mark et al., 1989: a global history of Eastern Europe, 43.

58 See Ther, Europe since 1989; Jarausch, Out of ashes.

\section{Bibliography}

\section{Published primary sources}

James E. Miller, Douglas E. Selvage, Laurie Van Hook, eds. Foreign Relations of the United States (FRUS) 1969-1976, Volume XXIX, Eastern Europe; Eastern Mediterranean, 19691972. Washington, DC: United States Government Printing Office, 2005.

\section{Secondary sources}

Autio-Sarasmo, Sari. "Stagnation or not? The Brezhnev leadership and East-West interaction." In Reconsidering stagnation in the Brezhnev Era: ideology and exchange, edited by Dina Fainberg and Artemy M. Kalinovsky, 87-103. Lanham: Lexington Books, 2016.

Axilrod, Stephen. Inside the Fed: monetary policy and its management, Martin through Greenspan to Bernanke. Cambridge, MA: MIT Press, 2009.

Badalassi, Nicolas and Sarah B. Snyder, eds. The CSCE and the end of the Cold War: diplomacy, societies and human rights, 1972-1990. New York: Berghahn Books, 2019.

Bange, Oliver. "The GDR in the era of détente." In Perforating the Iron Curtain: European détente, transatlantic relations, and the Cold War, 1965-1985, edited by Poul Villaume and Odd Arne Westad, 57-77. Copenhagen: Museum Tusculanum, 2010.

Bange, Oliver and Poul Villaume, eds. The long détente: changing concepts of security and cooperation in Europe, 1950s-1980s. Budapest: Central European University Press, 2017.

Bartel, Fritz. "The power of omission. The IMF and the democratic transitions in Poland and Hungary." In New perspectives on the end of the Cold War: unexpected transformations?, edited by Bernhard Blumenau, Jussi M. Hanhimäki and Barbara Zanchetta, 200-20. London: Routledge, 2018.

Bartha, Eszter. "Welfare dictatorships, the working class and the change of regimes in East Germany and Hungary." In Reflections on 1989 in Eastern Europe, edited by Terry Cox, 63-82. London: Routledge, 2013. 
Bátonyi, Gábor. “'Creative ferment in Eastern Europe': Thatcher's diplomacy and the transformation of Hungary in the mid-1980s." Diplomacy \& Statecraft 29:4 (2018): 638-66.

Berend, Iván T. From the Soviet bloc to the European Union: the economic and social transformation of Central and Eastern Europe since 1973. New York: Cambridge University Press, 2009.

Bergson, Abram. Planning and performance in socialist economies: the USSR and Eastern Europe. Boston: Unwin Hyman, 1989.

Bini, Elisabetta, Giuliano Garavini and Federico Romero, eds. Oil shock: the 1973 crisis and its economic legacy. London: I.B. Tauris, 2016.

Blumenau, Bernhard, Jussi M. Hanhimäki and Barbara Zanchetta, eds. New perspectives on the end of the Cold War: unexpected transformations? New York: Routledge, 2018.

Bockman, Johanna. Markets in the name of socialism: the left-wing origins of neoliberalism. Stanford: Stanford University Press, 2011.

Chassaigne, Philippe. Les Années 1970: fin d'un monde et origine de notre modernité. Paris: Armand Colin, 2008.

Christian, Michel, Sandrine Kott and Ondreij Matejka, eds. Planning in Cold War Europe: competition, cooperation, circulation (1950s-1970s). Berlin: De Gruyter, 2018.

Cox, Terry, ed. Reflections on 1989 in Eastern Europe. London: Routledge, 2013.

Crump, Laurien. The Warsaw Pact reconsidered: international relations in Eastern Europe, 1955-1969. London: Routledge, 2015.

Dietrich, Christopher. Oil revolution: anticolonial elites, sovereign rights, and the economic culture of decolonization. Cambridge: Cambridge University Press, 2017.

Esno, Tyler. "Reagan's economic war on the Soviet Union." Diplomatic History 42:2 (April 2018): 281-304.

Feygin, Yakov. Building a ruin: the international politics of Soviet economic reform 19561992. Cambridge, MA: Harvard University Press, forthcoming.

Frieden, Jeffry A. Global capitalism: its fall and rise in the twentieth century. New York: W.W. Norton, 2006.

Fürst, Juliane and Stephen V. Bittner. "The aging pioneer: late Soviet socialist society, its challenges and challengers." In The Cambridge history of communism, vol. 3, Endgames? Late communism in global perspective, 1968 to the present, edited by Juliane Fürst, Silvio Pons and Mark Selden, 281-306. Cambridge: Cambridge University Press, 2017.

Fürst, Juliane, Silvio Pons, Mark Selden, eds. The Cambridge history of communism, vol. 3, Endgames? Late communism in global perspective, 1968 to the present. Cambridge: Cambridge University Press, 2017.

Garavini, Giuliano. After empires: European integration, decolonization, and the challenge from the global South, 1957-1985. Oxford: Oxford University Press, 2012.

Gfeller, Aurélie Elisa. Building a European identity: France, the United States, and the oil shock, 1973-1974. New York: Berghahn Books, 2012.

Godard, Simon. "The Council for Mutual Economic Assistance and the failed coordination of planning in the socialist bloc in the 1960s." In Planning in Cold War Europe: competition, cooperation, circulation (1950s-1970s), edited by Michel Christian, Sandrine Kott and Ondreij Matejka, 287-323. Berlin: De Gruyter, 2018.

Godard, Simon and Laurien Crump. "Reassessing communist international organisations: a comparative analysis of COMECON and the Warsaw Pact in relation to their Western competitors." Contemporary European History 27:1 (2018): 85-109.

Graf, Maximilian. "Before Strauß: the East German struggle to avoid bankruptcy during the debt crisis revisited." International History Review (2019): 1-18. Accessed 12 March 2020. https://doi.org/10.1080/07075332.2019.1641542. 
Hanhimäki, Jussi M. The rise and fall of détente: American foreign policy and the transformation of the Cold War. Washington, DC: Potomac Books, 2013.

Hanson, Philip. The rise and fall of the Soviet economy: an economic history of the USSR from 1945. London: Longman, 2003.

Hilger, Andreas. "Communism, de-colonization, and the third world." In The Cambridge history of communism, vol. 2, The socialist camp and world power 1941-1960s, edited by Norman Naimark, Silvio Pons and Sophie Quinn-Judge, 317-40. Cambridge: Cambridge University Press, 2017.

Jarausch, Konrad Hugo. Out of ashes: a new history of Europe in the twentieth century. Princeton: Princeton University Press, 2015.

Jarzabek, Wanda. "Polish reactions to the West German Ostpolitik and East-West detente, 1966-78." In Perforating the Iron Curtain: European détente, transatlantic relations, and the Cold War, 1965-1985, edited by Poul Villaume and Odd Arne Westad, 35-55. Copenhagen: Museum Tusculanum Press, 2010.

Kansikas, Suvi. Socialist countries face the European Community: Soviet-bloc controversies over East-West trade. Frankfurt: Peter Lang, 2014.

Kieninger, Stephan. Dynamic détente: the United States and Europe, 1964-1975. Lanham: Lexington Books, 2016.

Kieninger, Stephan. The diplomacy of détente: cooperative security policies from Helmut Schmidt to George Shultz. London: Routledge, 2018.

Kolar, Pavel. "Post-Stalinist reformism and the Prague Spring." In The Cambridge history of communism, vol. 2, The socialist camp and world power 1941-1960s, edited by Norman Naimark, Silvio Pons and Sophie Quinn-Judge, 170-95. Cambridge: Cambridge University Press, 2017.

Kotkin, Stephen. "The kiss of debt." In The shock of the global: the 1970s in perspective, edited by Niall Ferguson, Charles S. Maier, Erez Manela and Daniel Sargent, 80-92. Cambridge, MA: Belknap Press of Harvard University Press, 2010.

Kotkin, Stephen and Jan Tomasz Gross. Uncivil society: 1989 and the implosion of the communist establishment. New York: Modern Library, 2009.

Kott, Sandrine. "Cold War internationalism." In Internationalisms: a twentieth-century history, edited by Glenda Sluga and Patricia Clavin, 340-62. Cambridge: Cambridge University Press, 2017.

Kott, Sandrine. "The social engineering project. Exportation of capitalist management culture to Eastern Europe (1950-1980)." In Planning in Cold War Europe: competition, cooperation, circulation (1950s-1970s), edited by Michel Christian, Sandrine Kott and Ondreij Matejka, 192-222. Berlin: De Gruyter, 2018.

Köves, András. The CMEA countries in the world economy: turning inwards or turning outwards. Budapest: Akadémiai Kiadó, 1985.

Kramer, Mark. "The demise of the Soviet bloc." In Reflections on 1989 in Eastern Europe, edited by Terry Cox, 7-62. London: Routledge, 2013.

Lorenzini, Sara. "The socialist camp and the challenge of economic modernization in the third world." In The Cambridge history of communism, vol. 2, The socialist camp and world power 1941-1960s, edited by Norman Naimark, Silvio Pons and Sophie QuinnJudge, 341-63. Cambridge: Cambridge University Press, 2017.

Lorenzini, Sara. Global development: a Cold War history. Princeton: Princeton University Press, 2019.

Loth, Wilfried and Georges-Henri Soutou, eds. The making of détente: Eastern and Western Europe in the Cold War, 1965-75. London: Routledge, 2008.

Lovell, Stephen. "Communist propaganda and media in the era of the Cold War." In The Cambridge history of communism, vol. 3, Endgames? Late communism in global 
perspective, 1968 to the present, edited Juliane Fürst, Silvio Pons, Mark Selden, 354-75. Cambridge: Cambridge University Press, 2017.

Ludlow, Piers N., ed. European integration and the Cold War: Ostpolitik-Westpolitik, 1965-1973. London: Routledge, 2007.

Lüthi, Lorenz M. "Drifting apart: Soviet energy and the cohesion of the communist bloc in the 1970s and 1980s." In Cold War energy: a transnational history of Soviet oil and gas, edited by Jeronim Perović, 371-400. Basingstoke: Palgrave Macmillan, 2017.

Maier, Charles S. "Thirty years after: the end of European communism in historical perspective." In The Cambridge history of communism, vol. 3, Endgames? Late communism in global perspective, 1968 to the present edited by Juliane Fürst, Silvio Pons, Mark Selden, 600-21. Cambridge: Cambridge University Press, 2017.

Mark, James, Bogdan Jacob, Tobias Rupprecht and Ljubica Spaskovska. 1989: a global history of Eastern Europe. Cambridge: Cambridge University Press, 2019.

Mark, James and Tobias Rupprecht. "Europe's '1989' in global context." In The Cambridge history of communism, vol. 3, Endgames? Late communism in global perspective, 1968 to the present, edited by Juliane Fürst, Silvio Pons, Mark Selden, 224-49. Cambridge: Cambridge University Press, 2017.

Mark, James and Tobias Rupprecht. "The socialist world in global history. From absentee to victim to co-producer." In The practice of global history: European perspectives, edited by Matthias Middell, 81-113. London: Bloomsbury, 2019.

Marrese, Michael and Jan Vaňous. Soviet subsidization of trade with Eastern Europe: a Soviet perspective. Berkeley: University of California, 1983.

Möckli, Daniel. European foreign policy during the Cold War. London: Tauris, 2009.

Mourlon-Druol, Emmanueland Federico Romero, eds. International summitry and global governance: the rise of the G7 and the European Council, 1974-1991. London: Taylor \& Francis, 2014.

Muehlenbeck Philip E. and Natalia Telepneva, eds. Warsaw Pact intervention in the third world: aid and influence in the Cold War. London: I.B. Tauris, 2018.

Naimark, Norman, Silvio Pons and Sophie Quinn-Judge, eds. The Cambridge history of communism, vol. 2. The socialist camp and world power 1941-1960s. Cambridge: Cambridge University Press, 2017.

Paczkowski, Andrzej and Malcolm Byrne. From Solidarity to martial law: the Polish Crisis of 1980-1981. Budapest: Central European University Press, 2007.

Péteri, György, ed. Imagining the West in Eastern Europe and the Soviet Union. Pittsburgh: University of Pittsburgh Press, 2010.

Pons, Silvio. The global revolution: a history of international communism 1917-1991. Oxford: Oxford University Press, 2014.

Poznański, Kazimierz. Poland's protracted transition: institutional change and economic growth 1970-1994. Cambridge: Cambridge University Press, 1996.

Pula, Besnik. Globalization under and after socialism: the evolution of transnational capital in Central and Eastern Europe. Stanford: Stanford University Press, 2018.

Rodgers, Daniel. Age of fracture. Cambridge, MA: Belknap Press of Harvard University Press, 2011.

Romano, Angela. From détente in Europe to European détente: how the West shaped the Helsinki CSCE. Bruxelles: Lang, 2009.

Romano, Angela. "G-7s, European Councils and East-West economic relations, 19751982." In International summitry and global governance: the rise of the $G 7$ and the European Council, 1974-1991, edited by Emmanuel Mourlon-Druol and Federico Romero, 198-222. London: Taylor \& Francis, 2014.

Romero, Federico. Storia della guerra fredda. Torino: Einaudi, 2009. 
Sanchez-Sibony, Oscar. Red globalization: the political economy of the Soviet Cold War from Stalin to Khrushchev. New York: Cambridge University Press, 2014.

Sargent, Daniel J. A superpower transformed: the remaking of American foreign relations in the 1970s. Oxford: Oxford University Press, 2015.

Sarotte, Mary E. Dealing with the devil: East Germany, détente, and Ostpolitik, 19691973. Chapel Hill: University of North Carolina Press, 2001.

Schulz, Matthias and Thomas Alan Schwartz, eds. The strained alliance: US-European relations from Nixon to Carter. New York: Cambridge University Press, 2009.

Smith, Jeremy and Melanie Ilic, eds. Khrushchev in the Kremlin: policy and government in the Soviet Union, 1953-1964. London: Routledge, 2011.

Smith, Stephen A., ed. The Oxford handbook of the history of communism. Oxford: Oxford University Press, 2014.

Snyder, Sarah B. Human rights activism and the end of the Cold War: a transnational history of the Helsinki Network. New York: Cambridge University Press, 2011.

Staniszkis, Jadwiga. "Patterns of change in Eastern Europe." East European Politics and Society 4:1 (1989): 77-97.

Steiner, André. The plans that failed: an economic history of the GDR. New York: Berghahn Books, 2010.

Steiner, André. "The decline of Soviet-type economies." In The Cambridge history of communism, vol. 3, Endgames? Late communism in global perspective, 1968 to the Present, edited by Juliane Fürst, Silvio Pons and Mark Selden, 203-23. Cambridge: Cambridge University Press, 2017.

Stone, Randall. Satellites and commissars: strategy and conflict in the politics of Sovietbloc trade. Princeton: Princeton University Press, 1996.

Ther, Philipp. Europe since 1989: a history. Princeton: Princeton University Press, 2016.

Trecker, Max. "Circle of debt: how the crisis of the global South in the 1980s affected the socialist East." Cold War History 20:1 (2020): 1-19.

Trencsényi, Balázs, Michal Kopeček, Luka Lisjak Gabrijelčič, Maria Falina, Mónika Baár and Maciej Janowski. A history of modern political thought in East Central Europe. Volume II: negotiating modernity in the 'short twentieth century' and beyond, part I: 1918 1968. Oxford: Oxford Scholarship Online, 2018. Accessed 12 March 2020. https://doi. org/10.1093/oso/9780198737155.001.0001.

Villaume, Poul, Rasmus Mariager and Helle Porsdam, eds. The 'long 1970s': human rights, East-West détente and transnational relations. London: Routledge, 2016.

Villaume, Poul and Odd Arne Westad, eds. Perforating the Iron Curtain: European détente, transatlantic relations, and the Cold War, 1965-1985. Copenhagen: Museum Tusculanum Press, 2010.

Westad, Odd Arne. The Cold War: a world history. New York: Basic Books, 2017.

Zloch-Christy, Iliana. Debt problems of Eastern Europe. Cambridge: Cambridge University Press, 1987.

Zubok, Vladislav. A failed empire: the Soviet Union in the Cold War from Stalin to Gorbachev. Chapel Hill: University of North Carolina Press, 2007.

Zubok, Vladislav. Zhivago's children: the last Russian intelligentsia. Cambridge, MA: Belknap Press of Harvard University Press, 2009.

Zubok, Vladislav. "The collapse of the Soviet Union." In The Cambridge history of communism, vol. 3, Endgames? Late communism in global perspective, 1968 to the present, edited by Juliane Fürst, Silvio Pons and Mark Selden, 250-77. Cambridge: Cambridge University Press, 2017. 


\title{
2 Pan-Europe \\ A continental space for cooperation(s)
}

\author{
Angela Romano
}

With its military, economic and cultural blocs, Europe was the epitome of Cold War systemic antagonism, ideological confrontation and society separation. The fact that the historiography of post-Cold War Central and Eastern Europe offers a narrative of these countries" "return to Europe" and considers the forty-year socialist experience an interlude in an otherwise all-European or pan-European history only strengthens the image of a divided Cold War Europe. In the past decade, however, a flourishing historiography focusing on Europeans' agency is deeply changing our understanding of the continent as a realm of confrontation and separation.

In particular, studies on détente have revealed that European governments on the one hand and the superpowers on the other held different views on its meaning, scope and aim. The US-Soviet détente was a decade-long period of bilateral agreements aiming to consolidate bipolarity and lower the costs (and risks) of military confrontation. In contrast, 'European détente' had a transformative intent, as it aimed to overcome the Cold War partition of the continent through a gradual process of expanding contacts and interdependence between Western and Eastern Europe. ${ }^{1}$

Several historians have also shown that European détente, with its multi-layered patterns, became a key feature of the continent from the mid-1960s until the end of the Cold War, thanks to the efforts of European countries, including the neutral ones, as opposed to the US, to preserve cooperation. By the mid-1970s, European states and citizens were connected through an expanding web of political, economic and cultural exchanges. This area of pan-European cooperation, which coexisted with Cold War military alliances, border fences and the Berlin Wall, nourished interdependence between the capitalist (which includes neutral) and socialist European countries. Historians Oliver Bange and Poul Villaume have recently defined this long détente as 'antagonistic cooperation' with strong elements of a 'trans-bloc, trans-societal and trans-ideological framework' and with European actors at its centre. ${ }^{2}$

It is now evident that European détente also enhanced continental multilateral cooperation. This was epitomised by the Helsinki Conference on Security and Cooperation in Europe (CSCE) and its ensuing process, which historiography 
now recognises as having favoured a more autonomous role for the European states, be they Western, Eastern or neutral and non-aligned. ${ }^{3}$

This opening pan-European space also prompted the action of actors that were previously passive, such as the European Economic Community (EEC). Ludlow has debunked the myth of a Community insulated from Cold War dynamics in the 1960s, while research on the 1970s has identified the emergence of the EEC as an influential actor in the CSCE context, and its transformative influence on the Soviet Union and its allies and on Yugoslavia. ${ }^{4}$ It is becoming clear that from the early 1970s onwards the enlarged, strengthened and politically active EEC had a leading role in the promotion of new European relations.

To reveal the complexity and interconnectedness of this emerging pan-European space for cooperation, this chapter considers political and economic interactions at the bilateral and multilateral levels, the main forms of integration between East and West and the impact of EEC policies on the socialist countries, including the question of recognition.

\section{Bilateral détente and cooperation}

With the onset of the Cold War, the West's containment and embargo policies and the creation of separate economic organisations severely reduced trade across the continent. Already after Stalin's death in 1953, however, most Western European governments saw the possibility of beginning to normalise exchanges. Denmark and the UK were pioneers in the field. In the 1950s, Danish politicians, civil servants and business milieus perceived the economic importance of trade with the Soviet Union and Eastern Europe and engaged in its development. ${ }^{5}$ In the UK, Winston Churchill intended to renew politico-diplomatic contacts and promote as many commercial, social and cultural contacts as possible across the Iron Curtain. ${ }^{6}$ As socialist regimes broke away from autarchy and Western countries granted long-term credits (1957) and liberalising measures (1963), East-West trade increased.

It was between the mid-1960s and the early 1970s, however, that these attitudes became mainstream. Most Western European governments deliberately used trade, economic, financial and cultural cooperation to foster dialogue with socialist bloc countries, with the political aim of overcoming the continental divide in the long term. ${ }^{7}$ The first articulated vision of this kind was expressed by French President Charles de Gaulle, who in 1965 launched a policy of 'détente, entente and cooperation' with the Soviet Union and its allies. In his opinion, this was the only road to peace in Europe and to the solution of its main problem, the German question. France signed a relevant commercial treaty with the USSR, and economic and cultural cooperation agreements with the other socialist countries. ${ }^{8}$ Italy too was very active in the mid-1960s, increasing its trade with the CMEA area and securing one of the biggest slices of the Soviet market for industrial orders. ${ }^{9}$ Among the smaller states, Belgium was particularly dynamic. In 1966, Foreign Minister Pierre Harmel started a lively policy of contacts with the East in the conviction that the existence of different regimes was not an insuperable 
obstacle to common initiatives and that economic détente was the road to and the pre-condition for political détente. ${ }^{10}$ In the Federal Republic of Germany (FRG), businessmen started to penetrate socialist markets ahead of diplomatic improvements. ${ }^{11}$ Then, between 1966 and 1969 the Grosse Koalition government revoked the Hallstein Doctrine, according to which no relations should exist with the GDR and those states that had recognised it (with the exception of the Soviet Union). When Willy Brandt became chancellor in 1969, the FRG moved to fully implementing the Neue Ostpolitik, which was based on the concept that change (and eventually reunification) would only come after recognition of the existing realities and rapprochement with the East. ${ }^{12}$ Thanks to re-established diplomatic relations and fundamental treaties signed with the Soviet Union (1970), Poland (1970) and Czechoslovakia (1973) and agreements with the GDR (1972), the FRG shortly became the most important Western economic partner for all the socialist countries. The economic prosperity that Western Europe had achieved by the mid-1960s was 'the foundation for the self-confidence required to pursue a policy of open borders and open competition'. ${ }^{13}$ Likewise, European neutral countries enhanced trade and cooperation with the socialist economies. ${ }^{14}$

Nevertheless, the détente policies of Western and neutral European states would have not gone far had they not met a new attitude on the part of the socialist regimes. Nikita Khrushchev, secretary-general of the Soviet Communist Party from 1956, promoted a policy of peaceful coexistence which called for a cooperative/competitive relationship with the West. ${ }^{15}$ Besides strategic considerations, economic reasons gave impetus to expanding relations with developed market economies in the mid-1960s. As the socialist economies could not adjust rapidly enough to the unfolding technological revolution, the ruling parties ideologically recognised foreign trade as an important factor in socialist development and modernisation with an eye to improving living standards, which had become crucial for the regimes' political stability. ${ }^{16}$

Economic and financial relations markedly increased between the two halves of Europe, unhalted even by the repression of the Prague Spring in August 1968. The most important relations developed bilaterally at the state-to-state level in the field of trade and financial loans, followed by industrial cooperation. However, the Western governments often used trade agreements to allow or regulate relations initiated and conducted by private enterprises. On their side, the socialist regimes in the 1960s introduced decentralisation and increased the capacity of enterprises to develop relations with foreign operators, provided they acted within the context of the economic plan. ${ }^{17}$ Bilateral cooperation thus also developed at the firm-to-firm level, adding multiple threads to the web of trans-European relations. ${ }^{18}$ These were not confined to economic relations; cultural exchanges and tourism were also important, and a diversified range of non-governmental actors was key in effecting trans-European contacts. ${ }^{19}$ The Iron Curtain that parted Europe was becoming increasingly porous.

This European détente did not grind to a halt in the late 1970s and early 1980s, a period that some scholars focusing on the superpowers still label the "second Cold War". Although all the governments of the West denounced the Soviet invasion of 
Afghanistan in 1979 and the imposition of martial law in Poland in 1981, actions across the Atlantic differed. US policy shifted first to sanctions under Jimmy Carter, and then to economic warfare with Moscow during Ronald Reagan's first mandate. In contrast, the Western European governments continued to pursue détente. ${ }^{20}$ In addition to confrontation, Cold War Europe experienced growing East-West interdependence nourished by a multi-layered and lasting network of exchanges and treaty obligations.

\section{The multilateralisation of détente}

Another peculiarity of European détente was that it had an additional multilateral component. Already in 1966, the UK government tabled a proposal to NATO for a code of good behaviour in East-West relations in Europe that would expand bilateral and collective cooperation in several fields. ${ }^{21}$ Although the proposal did not spur a NATO initiative, the Western Europeans' penchant for a more constructive approach towards the socialist bloc entered the 'Report on the Future Tasks of the Alliance' (Harmel Report), which was approved in 1967 and which assigned NATO the double aim of guaranteeing deterrence while promoting détente. ${ }^{22}$ The first step in this new pattern was the 1968 NATO appeal to the Warsaw Pact for negotiations on Mutual and Balanced Force Reduction in Europe (MBFR). ${ }^{23}$ The proposal only entered the diplomatic scene in connection with the CSCE.

On 17 March 1969, the Warsaw Pact issued the Budapest appeal, which re-launched an old proposal for a pan-European security conference enriched with an economic cooperation component. It soon became evident that in the Western camp European governments favoured the proposal to various degrees, while the lukewarm US administration only agreed in order to preserve bloc unity. ${ }^{24}$ In December 1969 the NATO Council declared the conference a feasible option within the general East-West dialogue but conditioned acceptance on a successful outcome of negotiations on Ostpolitik treaties, Berlin and German-German relations, as well as the opening of the MBFR talks. ${ }^{25}$

These talks started in Vienna in October 1973, and continued intermittently with little progress until early 1990, when the forum was replaced with talks on conventional forces in Europe. The CSCE, by contrast, became a permanent feature of European life, turning into a proper organisation in the post-Cold War era: OSCE (Organization for Security and Co-operation in Europe). Its success is likely to have been due to its being a pan-European forum for discussion of a wide range of matters rather than a bloc-to-bloc negotiation, where conflict was the default setting.

From 22 November 1972 to 8 June 1973 the diplomatic delegations of thirty-five countries - the US, Canada, the Soviet Union and all the European states except Albania - gathered in Helsinki to set the rules, format and agenda for the CSCE negotiations. The negotiations started on 18 September 1973 and concluded twenty-two months later. The CSCE produced the Final Act, a non-legally binding document solemnly signed at a summit in Helsinki from 30 July to 1 August 1975 . 
The Final Act called for balanced progress in three subject areas, informally called "baskets": questions of security in Europe, including principles guiding relations among participating states and confidence-building measures (Basket I); cooperation in the fields of economics, science, technology and the environment (Basket II); and cooperation in humanitarian and other fields (Basket III). Rather than permanently selling off Eastern Europe to the Soviets in exchange for empty declarations of goodwill, as vocal detractors of the CSCE decried at the time, the Final Act established a pattern of changing the status quo. ${ }^{26}$ First, while recognising existing frontiers, it explicitly admitted their peaceful change according to international agreements, thus legitimising the possibility of future German reunification. Second, the wording of the Final Act clearly rejected the Brezhnev doctrine and upheld the rights inherent in sovereignty irrespective of a country's belonging to a group or alliance. Finally, it endorsed the liberal concepts of human rights and the centrality of individuals, giving Western governments and Eastern European dissidents the locus standi to legitimately request the modification of certain rules and practices in the socialist regimes. ${ }^{27}$

The nature of the CSCE constituted per se a step towards overcoming the Cold War blocs, for its procedures guaranteed all countries the right to table and debate proposals on an equal basis. This gave neutral and non-aligned states an unprecedented room for manoeuvre and also made it more difficult for the Soviets to force alignment on its allies. ${ }^{28}$ All accounts of the CSCE report that the delegations teamed up in three major caucuses - NATO, the Warsaw Pact and the neutrals and non-aligned group. However, recent historiography reveals a much more complex reality: the actual CSCE dichotomy was between countries interested in stabilising the situation in Europe - the superpowers, and the GDR to a great extent - and states promoting its overcoming. Among the latter, the true makers of the Final Act were the nine states of the EEC speaking as one, the neutral and non-aligned countries and Romania. The EEC Nine introduced Basket III and shaped most of the Final Act according to their shared vision of détente as a transformative process prioritising citizens' rights and conditions. The neutral and non-aligned countries were key in securing the rule that all states would participate on an equal basis and in effecting the agreement on the follow-up to the Helsinki conference. Excluded from East-West negotiations on crucial security issues, they were determined to guarantee the continuity of the CSCE, where they could have a say on these matters. Although it was a member of the Warsaw Pact, Romania fully shared this view that security should be debated by all states outside of the blocs, and even called for a collective security system substituting the existing military alliances. Moreover, the Romanian delegation constantly stressed the relevance of principles that openly denied legitimacy to the Brezhnev doctrine, which the Bucharest authorities had always opposed. ${ }^{29}$

The Final Act of the CSCE prefigured a general shift to a new system that would supersede the bipolar order and create a pan-European space for bilateral and multilateral cooperation. This was confirmed by the CSCE becoming a process through follow-up conferences in Belgrade (1977-78), Madrid (1980-83) and Vienna (1985-89). These meetings further highlighted the European nature 
of the CSCE. Whereas the superpowers used meetings as a battlefield for their renewed confrontation, the European participants preserved the CSCE as a forum for cooperation. ${ }^{30}$ However, the CSCE provisions, in particular those in Basket III, also represented a formidable challenge to the stability and legitimacy of the socialist regimes. ${ }^{31}$ Opening up to the West entailed perils, which the European socialist regimes assessed and addressed in various manners, as the chapters in this book illustrate.

The CSCE also promoted multilateralism through a revival of the United Nations Economic Commission for Europe (ECE). This organisation was established in 1947 in Geneva to help with post-war reconstruction, but its activity had slowed down during the height of the Cold War. After Stalin's death, cooperation restarted in the fields of statistics, trade, agriculture, science and technology. ${ }^{32}$ From the early 1960s onwards, the ECE Secretariat established informal relations with the OECD, the Council of Europe, CMEA and the EEC. The year 1967 saw an important political declaration re-launching the role of the ECE, which was issued at the special ministerial meeting celebrating the twentieth anniversary of the organisation. The declaration recognised the ECE as the most important framework for East-West dialogue on all-European economic and technological cooperation. In 1969, the ECE agreed on four priority areas for future cooperation: trade development; scientific and technological cooperation; long-term economic projections and planning; and environmental problems. ${ }^{33}$ Light structures, a pragmatic approach and consensus decision-making made the ECE the only organisation to which the CSCE Final Act assigned a role in the implementation of its provisions. The ECE Executive Secretary and his staff immediately started to prepare proposals linked to the Final Act mandate with a view to presenting some results to the first CSCE follow-up meeting in Belgrade in $1977 .{ }^{34}$

\section{Integration processes and their interrelations}

The image of a Cold War Europe divided in two opposing blocs is also due to the existence of two major economic organisations East and West (the Council for Mutual Economic Assistance [CMEA] and the EEC), which had no official relations until 1988 and to the persistence of the socialist official policy of non-recognition of the EEC until the same date. This situation would seem to be in sharp contrast with the emergence of the pan-European cooperation space described previously. However, close scrutiny of developments behind official policies reveals actual connections and exchanges.

Western Europe's integration process developed in the cocoon of stability and security that US post-war policy had established, including the Bretton Woods international monetary system and NATO's military umbrella. France, Italy, the FRG, Belgium, the Netherlands and Luxembourg first agreed to create the European Coal and Steel Community (1951), and then they moved on to the bolder step of establishing, through the Treaties of Rome signed on 25 March 1957, Euratom and the EEC. Common to the three communities was the choice to transfer competence in specific sectors from the state level to newly created supranational 
institutions. The EEC Treaty called for the creation of a customs union, a common market and common policies. In its first decade, the integration process proved very effective, thanks to the fact that it was based on the harmonisation of economies that had been closely interdependent in the past, free from the presence of a hegemon within and unencumbered by Cold War concerns, which were dealt with within the Atlantic Alliance. ${ }^{35}$ Because of the latter, EEC institutions did not really pay attention to the East in the first decade.

By contrast, the East followed Western Europe's economic integration closely. To begin with, the CMEA was born in reaction to the Marshall Plan and the formation of Western institutions that organised economic and financial relations among the capitalist countries while openly excluding socialist states. ${ }^{36}$ Cold War concerns and the ideological mindset also informed the view that the socialist regimes held of the European communities since their inception. Stalin's capitalist encirclement phobia led to identifying the ECSC as a mere means to revitalise German industrial power in favour of the anti-Soviet policy of the imperialist West. Constrained by ideology, expert analyses confirmed the forecast of an inevitable conflict among capitalist economies rather than appreciating the novelty of supranational integration. ${ }^{37}$ Reality soon falsified this dogmatic interpretation. The ECSC proved a major success by contributing to the economic resurrection of West Germany and linking it to the other Western European economies. The creation of the EEC and then the achievements of the customs union and the Common Agricultural Policy (CAP) further proved that capitalism could organise in positive-sum interactions.

In order to compete with the West, Khrushchev reformed the relations with the Soviet allies in a more economically rational and fair way and launched the first attempt at socialist integration. In 1959, the CMEA, which until then only existed on paper, acquired a structure and a statute. ${ }^{38}$ New economic theories supported specialisation across the socialist world. In 1961, the CMEA Council approved the fundamental principles of the socialist division of labour, according to which socialist economies would gradually integrate through the coordination of national plans. ${ }^{39}$ Moreover, in 1964 the International Bank for Economic Cooperation was established to ease and regulate intra-CMEA payments by means of the 'convertible rouble'.

Socialist propaganda continued to depict the EEC as a Cold War economic instrument, a means to strengthen revanchist Germany, a despicable imperialist tool and a source of discrimination in international trade. ${ }^{40}$ However, socialist economic experts started to elaborate a more sophisticated analysis. In 1962, the Institute for International Economy and Politics in Prague convened the first international conference on the problems of Western European integration. ${ }^{41}$ The successful development of the EEC and the remarkable growth of its members' economies led experts to acknowledge the unprecedented features of the EEC experiment. Soviet intellectual evolution was first visible in August 1962, when the Academy of Sciences' Institute of World Economy and International Relations (IMEMO) published its thirty-two theses 'On the imperialist integration in Western Europe' and acknowledged the original and positive experiment of capitalist 
integration. ${ }^{42}$ In December 1962, Khrushchev recognised the capacity of Western European capitalist states to overcome their natural antagonism and forge some positive alliances. ${ }^{43}$

By contrast, the division of labour in the socialist community met with the resistance of several member states, most vocally Romania, whose political authorities refused to see the country relegated to the role of agricultural provider. Many economists in Eastern Europe considered that the coordination of national plans at the CMEA level would reproduce and even amplify most of the national malfunctioning and rigidities, and that the needs of the colossal Soviet economy would inevitably prevail over those of the smaller European economies. ${ }^{44}$ As foreign trade (outside the CMEA) was acknowledged as a major factor in economic growth in the mid-1960s, Hungary was the first CMEA member to recognise the 'objective reality' of the EEC and the necessity to adopt a correspondingly realistic attitude to the matter of developing contacts with it. ${ }^{45}$

The EEC's Hague Summit in December 1969 decisively attracted the attention of socialist analysts. The EEC member states agreed to complete the Common Market, to deepen integration via the adoption of other common policies and to open the negotiations for the accession of the UK, Denmark, Ireland and Norway. Moreover, they posited that the enlarged EEC should have a prominent international political role, and hence called for a mechanism for political coordination. The first meeting of the brand-new European Political Cooperation took place less than a year later, on 19 November 1970. The EEC member states lively discussed East-West relations, especially the socialist proposal for a pan-European conference, and decided to elaborate a collective approach to the CSCE distinct from NATO coordination.

The bold steps taken by the EEC gave a new impulse to socialist debate on integration, which had been hitherto described as a capitalist feature and hence rejected as an option for the socialist states. Now, prompted by the scientifictechnological revolution and the deep changes in the way production and the division of labour were organised, integration was recognised as a global trend of an objective nature. ${ }^{46}$ Therefore, between 1969 and 1971 the CMEA members discussed how to promote socialist integration. According to Soviet proposals, the gradual integration of the socialist economies should be achieved through joint planning at the CMEA level, coordination of national economic policies, the creation of supranational institutions and the elaboration of a coordinated foreign trade policy towards non-socialist countries. The Soviet attempt at organising a supranational CMEA was driven by the political rationale of preserving bloc cohesion - what has been described as the economic component of the Brezhnev doctrine. ${ }^{47}$ However, the CMEA European members had a say on how integration should be organised and they obstructed any step towards supranationality, which would have severely limited their autonomy and given Moscow maximum leverage. ${ }^{48}$ For all the ruling elites, autonomy over national economic planning was key to preserving their legitimacy and power. However, it was the Romanian leadership that took the responsibility to kill supranational initiatives. The Romanian representatives argued that CMEA resolutions should respect member 
states' sovereignty, which entailed the right to formulate national economic policy according to national interests and socio-economic conditions. Accordingly, each country was also free to conduct trade relations with third countries without the constraints of a CMEA policy. ${ }^{49}$ Thanks to the unfaltering stance of the Romanians, the 'Comprehensive Programme for the further deepening and perfection of the collaboration and developing of the socialist economic integration of the CMEA member states' approved in 1971 contained no supranational features and, more importantly, no common foreign trade policy. ${ }^{50}$

Socialist academic experts animatedly discussed the scope and consequences of Western European integration. The EEC was increasingly seen as a specific centre of power within the capitalist world, able to successfully compete with the economies of Japan and the US. ${ }^{51}$ Socialist experts interpreted the creation of the monetary 'snake' and then of the European Monetary System as a defence against the end of the Bretton Woods system and the now free-floating US dollar. ${ }^{52}$ In the eyes of the socialists, Western Europe was coming out of the American cocoon to become an independent entity. At the beginning of 1972, a series of articles in the Soviet newspaper Pravda highlighted the polycentrism of the capitalist system and the importance of Western Europe as a third pole between Washington and Moscow in positive tones. ${ }^{53}$ From the economic point of view, the idea gained acceptance that the EEC was a reality to reckon with. Nevertheless, how exactly to do so proved a less straightforward question.

A major discussion started within the CMEA, where the GDR and the Soviet Union demanded a bloc response to the "EEC question". The Soviets did not lose time to indicate the road. In December 1972, a Brezhnev public speech explicitly called for EEC-CMEA negotiations. In 1974, in a clear move to re-establish Soviet leadership of the bloc, Brezhnev informed the CMEA partners that he had decided to open such negotiations. ${ }^{54}$

The two organisations established contact and then opened negotiations in the spring of 1978. Talks dragged on, broke off in 1980, resumed in 1984 and only ended up successfully in 1988. From the mid-1970s to the mid-1980s, many experts on both sides of Europe discussed possible mechanisms for collaboration between the two organisations. ${ }^{55}$ The main problem with EEC-CMEA relations lay in the nature of the socialist organisation which, unlike the EEC, had no competence to sign trade agreements on behalf of its member states. This point was constantly reiterated by the EEC representatives, who proposed cooperation on subjects such as statistics and research in science and technology. Besides legal and technical concerns, however, there was a strong political rationale. In 1973, the EEC members had formally agreed not to treat the socialist countries as a bloc, their priority goal being to establish bilateral contacts between the EEC and each socialist country.

\section{The EEC's impact on the socialist countries and the question of recognition}

If the EEC experience influenced the socialist countries' attempts at integrating, certainly the impact it had on their economies was a far more important matter 
for discussion and strategy definition at the CMEA and national levels alike. The policy of non-recognition, although still in place, lost substance as one by one all the socialist regimes developed relations with the EEC.

The first framework in which the socialist countries de facto acknowledged the existence and competence of the EEC was that of the international fora in which it participated. The General Agreement on Tariffs and Trade (GATT) was the first case in point. Czechoslovakia was a founding member (although not actively participating); Poland was admitted in 1967, Romania in 1971 and Hungary in 1973. The EEC had competence to negotiate in the GATT and had a say in the admission of new members. In this multilateral context, the attitude of the socialist countries was pragmatically similar to that of other GATT members that had officially recognised the EEC. ${ }^{56}$

The CSCE was the other multilateral forum in which socialist countries, including the Soviet Union, were eventually compelled to de facto recognise the EEC. In this case, the result came out of assertive action orchestrated on purpose by the EEC Commission and the member states. While the EEC was a pillar of the GATT when a few socialist states joined, the CSCE was a diplomatic gathering convened among states and springing from an initiative of the socialist bloc. One of the fundamental rationales behind their proposition to discuss economic cooperation at the multilateral level was precisely to eliminate discriminatory practices in continental trade. Quite evident between the lines was reference to the EEC, the protectionist policies of which the socialist regimes had long denounced. Convinced that the Soviets intended to use the CSCE to hamper the progress of Western integration and dilute the EEC into a pan-European system, the EEC member states collectively prepared for a hard fight. They agreed that the best way to preserve the EEC was to make it take part in the CSCE negotiations. The tactic was simple: as states had the right to compose their delegations as they saw fit, Commission representatives joined the CSCE delegation of the member state holding the EEC presidency and, more importantly, intervened in the negotiations by officially expressing the viewpoint of the Community to the extent required by its competence. Initially, the socialist delegates uttered some protests. After a while, as the negotiations proceeded quite smoothly in Basket II, the socialist delegates showed acquiescence and a business-like attitude. The most significant step, however, was adding the EEC to the signatories of the Final Act, which the EEC member states had categorically established as a non-negotiable condition for their assent to closing the CSCE at the summit level. The Soviets gave in because Brezhnev had linked his name to the CSCE initiative and could not risk its failure. Hence, Italian Prime Minister Aldo Moro signed the Final Act in his capacity as president of the EEC Council and declared that the phrasing 'participating States' would apply to the EEC in accordance with its competence and rules. That signature engaged the EEC in the CSCE process just like the participating states. ${ }^{57}$

However, the socialist regimes' acquiescence in multilateral fora neither meant revoking the non-recognition policy nor did it entail the development of bilateral relations with the Community. The contacts with it were induced by the 
consequences that the actual and potential deepening and enlargement of the EEC had for the socialist economies. ${ }^{58}$ The first time that progress in Western European integration compelled the socialist economies to deviate from the strict non-recognition policy was in the mid-1960s, when the development of the CAP entailed heavily preferential measures in favour of EEC agriculture produce against that coming from third countries. The protectionist CAP had a severe impact on the exports of the socialist European economies. Between 1964 and 1968, the governments of Poland, Czechoslovakia, Hungary and Romania informally approached the EEC Commission and negotiated specific deals that could mitigate the charges and quotas imposed on agricultural imports by the EEC. The CAP spurred Yugoslavia's first official exploratory talks with the EEC Commission in 1965, which were followed by an official request for the conclusion of a trade agreement with the Community. ${ }^{59}$ The neat growth in trade flows across the Iron Curtain between the mid-1960s and early 1970s inevitably aggravated the exposure of the CMEA socialist economies to the consequences of EEC evolution. The prospect of the EEC enlarging to the UK, Ireland, Denmark and Norway ${ }^{60}$ constituted a major threat. These new members' production could replace some goods imported from Eastern Europe, and more importantly their imports from socialist countries would drop significantly when they began operating according to the internal rules of the Common Market. An additional EEC development that worsened the prospects of socialist exports was the imminent adoption of the Common Commercial Policy (CCP), according to which the member states surrendered their right to negotiate and sign trade agreements with third countries to the EEC Commission, which would negotiate for the whole Community. The bilateral trade agreements between EEC member states and socialist countries would remain in force until their expiry, which was 1975 at the latest.

The combination of the CCP and the EEC's forthcoming enlargement spurred the CMEA debate on recognition. Moscow maintained that relations with Western Europe should continue bilaterally between states and be accompanied by relations between the two economic organisations, which would negotiate overall trade agreements. The Soviet leadership opposed the establishment of relations between the EEC and individual CMEA countries, which would obviously loosen the cohesion of the socialist bloc and ease Western influence in Eastern Europe. Most of the Eastern European countries were not fully averse to establishing EECCMEA relations, as they acknowledged that negotiating as a group could enhance their chances of striking a good deal with the largest trade power in the world. In this vein, Hungary initially supported the idea of relations with the EEC within a CMEA common approach. ${ }^{61}$ By contrast, Romania remained adamant that a CMEA-EEC agreement could not prevent the member states from having relations on their own with the EEC and pursuing their specific commercial interests. ${ }^{62}$ Overall, export-oriented economies like Poland, Hungary and Czechoslovakia were more interested in direct contacts with the EEC. Due to their adopted strategies of import-led growth, they needed to increase exports to the West in order to be able to pay for imports and loans. The USSR had the luxury of not needing concessions from the EEC. Up to nine-tenths of its exports to the Common Market 
consisted of oil, natural gas and other raw materials, to which the EEC applied no tariffs or quotas. ${ }^{63}$ By contrast, the exports of the CMEA European countries to the EEC market consisted of foodstuffs for a quarter, materials for another quarter, and manufactured goods for the remaining half. Agricultural products, textiles, footwear, chinaware and steel faced the EEC's highest protectionist measures, for these economic sectors were struggling the most at the time. Moreover, the socialist European regimes could hardly reduce their imports from the EEC states because a large amount of them went to those industries meant to push economic growth. In deciding their approach, the Eastern European regimes also probably considered the example of Yugoslavia, which had recognised the EEC in 1968 and signed its first trade agreement with it on 19 March 1970. The accord had met many Yugoslav requests, particularly in the agricultural field, and set up a joint commission that would allow Yugoslav interests to be appraised over time. ${ }^{64}$ The Romanian government, which opposed the CMEA attempts at elaborating a common policy towards the EEC, formally applied for beneficiary status in the Community's Generalized Scheme of Preferences (GSP) on 31 January 1972 and obtained it as of 1 January 1974. In August 1974, with the implementation of the CCP towards the socialist country due in six months, Polish representatives approached the EEC Commission to explore the possibility of trade talks.

The EEC and its member states had on many occasions made clear that there was no interest in an EEC-CMEA trade agreement, and that their priority was the establishment of relations between the Community and each socialist country. To make things adamantly clear and to press the case for recognition, in November 1974 the EEC Commission sent all the socialist governments a letter explaining that as of 1 January member states would no longer sign or renew bilateral trade agreements, and competence would pass to the Commission. Contextually, the Commission invited the recipients to open all-areas negotiations, for which it attached a draft agreement. The draft addressed most of the concerns of the socialist economies, namely import quotas, most favoured nation treatment, safeguard mechanisms and payment problems. Pending the replies, the EEC Council adopted unilateral import arrangements, which it would revise unilaterally every year. The letter was sent to all the socialist countries that had not yet recognised the EEC, including the People's Republic of China. China was the only one to reply, and positively so. Within three years it recognised the EEC and signed a major trade and cooperation agreement with it. ${ }^{65}$ In the subsequent years, the EEC's expanding competence affected the socialist economies sector by sector. In January 1977 the Common Fisheries Policy entered into effect, and the governments of Poland, the GDR and the Soviet Union each received an EEC letter requesting that they either negotiate fishing quotas with the Commission or withdraw their fleets from EEC common waters. The three governments agreed to enter talks (which eventually broke off) in order to protect their economic and strategic interests. In December 1977, the EEC Council decided to apply the CCP to textile and steel imports from state-trading countries. To avoid severe reductions in their exports, Poland and Hungary negotiated five-year textile agreements with the Commission in 1978, and Bulgaria signed a four-year agreement in April 1979. 
Czechoslovakia was the first CMEA country to conclude a steel arrangement with the Community in mid-1978, and was imitated by Hungary, Romania and Poland shortly afterwards, and by Bulgaria in January 1979. The previous year, Sofia had applied to join the Community's GSP, partly due to concerns over negative repercussions of Greece's entry in the EEC, which was then under negotiation. ${ }^{66}$ Overall, facing the severe economic impact of actual and potential EEC policies, and confronted with a politically assertive EEC, most of the socialist regimes decided (or resigned themselves) to have direct relations with the Community, irrespective of the formal non-recognition policy and the stalling EEC-CMEA talks. The national case studies presented in the following chapters offer detailed analyses of their policymaking and actions.

\section{Conclusions}

Since the early 2000s, several historians have successfully challenged and qualified the long-lived understanding of Cold War Europe as a space of confrontation and separation. This historiography focused on European actors and relations has revealed the emergence and consolidation of a multi-layered space for cooperation which coexisted with opposing military blocs, separated economic organisations and ideological competition.

While the first signs were already visible in the aftermath of Stalin's death, it was from the mid-1960s that European actions to challenge the Cold War divide rapidly multiplied. Cooperation developed in a multitude of exchanges at the governmental and society levels in diverse fields and carried on through bilateral and multilateral relations and accords. Multilateralism became a visible aspect of continental relations from the 1970 s onwards, particularly thanks to the CSCE and its ensuing process, which greatly contributed to forging true pan-European thinking.

However, for the socialist regimes this web of cooperative threads also entailed perils and challenges. To start with, most of the Western European détente policies aimed in the long run to not only overcome the Cold War but also to favour the liberalisation of the socialist regimes, and hence posed an existential threat to them. The same applied to the CSCE, which adopted the Western Europeans' view of détente and their intention to give more room for manoeuvre to citizens. Second, their adopted import-led growth strategy made the socialist economies more exposed to European capitalist countries' fortunes and actions. In particular, the development of the Western European integration process, and notably the EEC's enlargements and common policies, had direct negative impacts on the socialist economies and socialist bloc integration. The questions of recognition of and relations with the Community deepened existing fractures in the CMEA. Likewise, the search for deals with the EEC that would mitigate the impact of its protectionist policies worsened the competition between the socialist countries. Within the socialist regimes, the debate on the "EEC question" exposed different views among the ruling elites and factions within them. Beyond its economic impact, or through it, the EEC posed an existential challenge to the socialist regimes, adding to the intrinsic risks of pan-European cooperation. 
The following chapters of this book reveal the internal debates and bargaining that the socialist ruling elites went through in order to elaborate a strategy that would allow them to address national economic needs while facing the impact of Western Europe's deepening integration, comply with CMEA solidarity and handle Soviet pressures for bloc discipline.

\section{Notes}

1 Loth, Overcoming the Cold War; Romano, From détente in Europe; Villaume and Westad, Perforating the Iron Curtain; Hanhimäki, "Détente in Europe, 1969-1975"; Bozo, Rey, Ludlow and Rother, Overcoming the Iron Curtain.

2 Bange and Villaume, The long détente, 1-15.

3 See the discussion below.

4 Ludlow, "An insulated community?"; Romano, From détente in Europe; Romano, "Untying Cold War knots"; Zaccaria, The EEC's Yugoslav policy.

5 Boje, Rostgaard and Rüdiger, Handelspolitikken som kampplads under Den Kolde Krig.

6 Woolcock, "Great Britain," 143.

7 For instance, Loth and Soutou, The making of détente.

8 Rey, La tentation du rapprochement; Vaïsse, La Grandeur; Badalassi, En finir avec la guerre froide.

9 Bagnato, Prove di Ostpolitik; Fava, "Between business interests and ideological marketing."

10 Dujardin, "Go-between: Belgium and Détente."

11 Rudolph, Wirtschaftsdiplomatie im Kalten Krieg.

12 For instance, Hofmann, The emergence of détente in Europe; Niedhart, "Ostpolitik."

13 Loth, "The Cold War and the social and economic history of the twentieth century," 520.

14 For instance, Enderle-Burcel, Gaps in the Iron Curtain.

15 Mueller, A good example of peaceful coexistence?, 16-20.

16 Andras Inotai, "CMEA integration and national economic policies," 81; Wallace and Clarke, Comecon, trade and the West,102-3; Berend, "What is Central and Eastern Europe?," 413; Cutler, "Harmonizing EEC-CMEA relations," 259.

17 Cutler, "Harmonizing EEC-CMEA," 259-60.

18 Several scholars have analysed East-West business interaction and financial flows, often with the aim of offering policy advice to governments, for instance, Paliwoda, Joint EastWest marketing; Saunders, East-West cooperation in business; Hill, East-West trade; Fallenbuchl, "East-West trade in capital goods since 1970." More recently, Tiusanen, Western direct investments; Eloranta and Ojala, East-West Trade and the Cold War.

19 Mikkonen and Koivunen, Beyond the divide; Villaume, Mariager and Porsdam, The 'long 1970s'; Mikkonen, Jari Parkkinen and Scott-Smith, Entangled East and West; Bechmann, Pedersen and Noack, Tourism and travel during the Cold War.

20 For instance, Sjursen, The United States, Western Europe and the Polish Crisis; Chiampan, "Those European chicken littles"; Bange and Villaume, The long détente.

21 Romano, "The UK policy towards socialist countries," 467.

22 Wenger, "NATO's transformation in the 1960s."

23 "Declaration on Mutual and Balanced Force Reduction, Statement of NATO Ministerial Meeting," Reykjavik, 24 and 25 June 1968, accessed 13 March 2020, www.nato. int/docu/comm/49-95/c680624b.htm.

24 Crump and Romano, "Challenging the superpower straitjacket."

25 "NATO Declaration on European Security," Brussels, 5 December 1969, paras. 14 and 15, accessed 13 March 2020, www.nato.int/docu/comm/49-95/c691204b.htm.

26 See Bange and Niedhart, Helsinki 1975 and the transformation of Europe.

27 On the consequences of this approach, Thomas, "Human rights ideas"; Snyder, Human rights activism.

28 For instance, Jarzabek, "Hope and reality"; Fisher, Neutral power in the CSCE; Makko, Ambassadors of realpolitik. 
29 Romano, "The Conference on Security and Cooperation in Europe: a reappraisal."

30 Bilandzic, Dahlmann and Kosanovic, From Helsinki to Belgrade; Selvage, "The superpowers and the Conference on Security and Cooperation in Europe"; Romano, "More cohesive, still divergent."

31 Selvage and Süß, Staatssicherheit und KSZE-Prozess.

32 Stinsky, International cooperation in Cold War Europe.

33 Chossudovsky, East-West diplomacy, 14.

34 Chossudovsky, East-West diplomacy, 21.

35 Ludlow, "European integration and the Cold War," 191-2.

36 Brabant, Economic integration in Eastern Europe, 8-12.

37 Zubok, "The Soviet Union and European integration," 85.

38 Brabant, Economic integration in Eastern Europe, 46-7 and 52-54.

39 Wallace and Clarke, Comecon, trade and the West, 5-6.

40 Rey, "Le retour à l'Europe?," 8-10.

41 Ham, The EC, Eastern Europe, 64.

42 Grachev, "The Soviet leadership's view," 40.

43 Rey, "Le retour à l'Europe," 13.

44 Bideleux, "The Comecon experiment," 186.

45 See Chapter 3 by Pàl Germuska in this book.

46 Bideleux, "The Comecon experiment," 187-8.

47 Kansikas, "Room to manoeuvre?," 197.

48 Brabant, Economic Integration in Eastern Europe, 85-89. Also, Stone, Satellites and commissars.

49 Dragomir, "Breaking the CMEA hold."

50 Kansikas, Socialist countries face the European Community, 59.

51 Zaslavsky, "L'atteggiamento sovietico," 63.

52 Cutler, "Harmonizing EEC-CMEA," 261-3.

53 Rey, "Le retour à l'Europe," 18.

54 Kansikas, Socialist countries face the European community.

55 Pinder, "Economic integration"; Lebahn, "Alternatives in EC/CMEA relations"; Chapman, "The economic relations between the EEC and the CMEA"; Cutler, "Harmonizing EEC-CMEA."

56 For details, see the specific chapters in this book.

57 Romano, From détente in Europe.

58 When not otherwise stated, the following part draws from Romano, "Untying Cold War knots."

59 See Chapter 9 by Benedetto Zaccaria in this book.

60 Norway rejected membership in a referendum in September 1972; the others joined the EEC on 1 January 1973.

61 See Chapter 3 by Pàl Germuska in this book.

62 See Chapter 8 by Elena Dragomir in this book.

63 Pinder, The European Community, 14.

64 Zaccaria, The EEC's Yugoslav policy, 30-45.

65 Chenard, "Seeking détente."

66 See Chapter 7 by Elitza Stanoeva in this book.

\section{Bibliography}

Badalassi, Nicolas. En finir avec la guerre froide: La France, l'Europe et le processus d'Helsinki, 1965-1975. Rennes: Presses Universitaires de Rennes, 2014.

Bagnato, Bruna. Prove di Ostpolitik. Politica e economia nella strategia italiana verso l'Unione Sovietica 1958-1963. Firenze: Olschki, 2003.

Bange, Oliver and Gottfried Niedhart, eds. Helsinki 1975 and the transformation of Europe. Oxford: Berghahn Books, 2008. 
Bange, Oliver and Poul Villaume, eds. The long détente: changing concepts of security and cooperation in Europe, 1950s-1980s. Budapest: Central University Press, 2017.

Bechmann Pedersen, Sune and Christian Noack, eds. Tourism and travel during the Cold War: negotiating tourist experiences across the Iron Curtain. London: Routledge, 2019.

Berend, Iván T. "What is Central and Eastern Europe?" European Journal of Social Theory 8:4 (2005): 401-16.

Bideleux, Robert. "The Comecon experiment." In European integration and disintegration: East and West, edited by Robert Bideleux and Richard Taylor, 174-204. London: Routledge, 1996.

Bilandzic, Vladimir, Dittmar Dahlmann and Milan Kosanovic, eds. From Helsinki to Belgrade: the first CSCE follow-up meeting and the crisis of détente. Göttingen: Vandenhoeck \& Ruprecht, 2012.

Boje, Per, Marianne Rostgaard and Mogens Rüdiger. Handelspolitikken som kampplads under Den Kolde Krig. Aalborg: Aalborg Universitetsforlag, 2012.

Bozo, Frédéric, Marie-Pierre Rey, N. Piers Ludlow and Bernd Rother, eds. Overcoming the Iron Curtain: visions of the end of the Cold War in Europe, 1945-1990. Oxford: Berghahn Books, 2012.

Brabant, Jozef van. Economic integration in Eastern Europe: a handbook. New York: Routledge, 1989.

Chapman, Sheila A. "The economic relations between the EEC and the CMEA: a survey of problems and prospects." La comunità internazionale 40:3 (1985): 421-49.

Chenard, Marie Julie. "Seeking détente and driving integration: the European Community's opening towards the People's Republic of China, 1975-1978." Journal of European Integration History 18:1 (2012): 25-38.

Chiampan, Andrea. "Those European chicken littles: Reagan, NATO and the Polish Crisis, 1981-2." International History Review 37:4 (2015): 682-99.

Chossudovsky, Evgeny. East-West diplomacy for environment in the United Nations. New York: UNITAR, 1988.

Crump, Laurien and Angela Romano. "Challenging the superpower straitjacket (19651975): multilateralism as an instrument of smaller powers." In Margins for manoeuvre: the influence of smaller powers in the Cold War era, edited by Laurien Crump and Susanna Erlandsson, 13-31. London: Routledge, 2019.

Cutler, Robert. "Harmonizing EEC-CMEA relations: never the twain shall meet?" International Affairs 63:2 (1987): 259-70.

Dragomir, Elena. "Breaking the CMEA hold: Romania in search of a 'strategy' towards the European Economic Community, 1958-1974." European Review of History (2019): 1-33. Accessed 15 February 2020. https://doi.org/10.1080/13507486.2019.1694492.

Dujardin, Vincent. “Go-between: Belgium and Détente, 1961-73.” Cold War History 7:1 (2007) 95-116.

Eloranta, Jari and Jari Ojala, eds. East-West trade and the Cold War. Jyväskylä: University of Jyväskylä, 2005.

Enderle-Burcel, Gertrude, ed. Gaps in the Iron Curtain: economic relations between neutral and socialist countries in Cold War Europe. Crakow: Jagiellonian University Press, 2009.

Fallenbuchl, Zbigniew M. "East-West trade in capital goods since 1970." Studies in Comparative Communism 19:2 (1986): 129-47.

Fava, Valentina. "Between business interests and ideological marketing: the USSR and the Cold War in Fiat corporate strategy, 1957-1972." Journal of Cold War Studies 20:4 (Fall 2018): 26-64. 
Fisher, Thomas. Neutral power in the CSCE: the N+N States and the making of the Helsinki Accords 1975. Baden-Baden: Nomos, 2009.

Grachev, Andrei. "The Soviet leadership's view of Western European integration in the 1950s and 1960s." In Widening, deepening and acceleration: the European Economic Community, 1957-1963, edited by Anne Deighton and Alan Milward, 31-40. BadenBaden: Nomos, 1999.

Ham, Peter van. The EC, Eastern Europe and European unity. London: Pinter, 1993.

Hanhimäki, Jussi M. "Détente in Europe, 1969-1975." In The Cambridge history of the Cold War, vol. 2, Crises and détente, edited by Melvyn Leffler and Odd Arne Westad, 198-218. Cambridge: Cambridge University Press, 2010.

Hill, Malcolm. East-West trade, industrial co-operation and technology transfers: the British experience. Aldershot: Gower, 1983.

Hofmann, Arne. The emergence of détente in Europe: Brandt, Kennedy and the formation of Ostpolitik. London: Routledge, 2007.

Inotai, Andras. "CMEA integration and national economic policies: adjustment to the changed world economic environment." In Regional integration in East and West, edited by Christopher T. Saunders, 81-94. Vienna: Springer-Verlag, 1983.

Jarzabek, Wanda. "Hope and reality: Poland and the Conference on Security and Cooperation in Europe, 1964-1989." Cold War International History Project Working Paper no. 56, 2008.

Kansikas, Suvi. "Room to manoeuvre? National interests and coalition-building in the CMEA, 1969-74." In Reassessing Cold War Europe, edited by Sari Autio-Sarasmo and Katalin Miklossy, 193-209. London: Routledge, 2011.

Kansikas, Suvi. Socialist countries face the European Community: Soviet-bloc controversies over East-West trade. New York: Peter Lang, 2014.

Lebahn, Alex. "Alternatives in EC/CMEA relations." Aussenpolitik 31:2 (1980): 147-66.

Loth, Wilfried. Overcoming the Cold War: a history of Détente, 1950-1991. London: Palgrave, 2002.

Loth, Wilfried. "The Cold War and the social and economic history of the twentieth century." In The Cambridge history of the Cold War, vol. 2, Crises and Détente, edited by Melvyn Leffler and Odd Arne Westad, 503-23. Cambridge: Cambridge University Press, 2010.

Loth, Wilfried and George-Henri Soutou, eds. The making of détente: Eastern and Western Europe in the Cold War, 1965-75. London: Routledge, 2008.

Ludlow, Piers N. "An insulated Community? The Community institutions and the Cold War, 1965 to 1970." In European integration and the Cold War: Ostpolitik-Westpolitik, 1965-1973, edited by N. Piers Ludlow, 137-51. London: Routledge, 2007.

Ludlow, Piers N. "European integration and the Cold War." In The Cambridge history of the Cold War, vol. 2, Crises and détente, edited by Melvin Leffler and Odd Arne Westad, 179-97. Cambridge: Cambridge University Press, 2010.

Makko, Aryo. Ambassadors of realpolitik: Sweden, the CSCE and the Cold War. New York, Oxford: Berghahn Books, 2017.

Mikkonen, Simo and Pia Koivunen, eds. Beyond the divide: entangled histories of Cold War Europe. New York: Berghahn Books, 2015.

Mikkonen, Simo, Jari Parkkinen and Giles Scott-Smith, eds. Entangled East and West: cultural diplomacy and artistic interaction during the Cold War. München: De Gruyter Oldenbourg, 2018.

Mueller, Wolfgang. A good example of peaceful coexistence? The Soviet Union, Austria and neutrality 1955-1991. Vienna: Verlag des Österreichischen Akademia der Wissenschaften, 2011. 
Niedhart, Gottfried. "Ostpolitik: transformation through communication and the quest for peaceful change.” Journal of Cold War Studies 18:3 (2016): 3-13.

Paliwoda, Stanley J. Joint East-West marketing and production ventures. Aldershot: Gower, 1976.

Pinder, John. "Economic integration and East-West trade: conflict of interests or comedy of errors?" Journal of Common Market Studies 16:1 (1977): 1-21.

Pinder, John. The European Community and Eastern Europe. London: Pinter, 1991.

Rey, Marie-Pierre. La tentation du rapprochement: France et URSS à l'heure de la détente (1964-1974). Paris: Publications de la Sorbonne, 1991.

Rey, Marie-Pierre. "Le retour à l'Europe? Les décideurs soviétiques face à l'intégration ousteuropéenne, 1957-1991.” Journal of European Integration History 11:1 (2005): 7-28.

Romano, Angela. From détente in Europe to European détente: how the West shaped the Helsinki CSCE. Brussels: Peter Lang, 2009.

Romano, Angela. "More cohesive, still divergent: Western Europe, the US and the Madrid CSCE follow-up meeting." In European Integration and the Atlantic Community in the 1980s, edited by Kiran K. Patel and Ken Weisbrode, 39-58. Cambridge: Cambridge University Press, 2013.

Romano, Angela. "The Conference on Security and Cooperation in Europe: a reappraisal." In The Routledge handbook of the Cold War, edited by Artemy M. Kalinovsky and Craig Daigle, 223-34. London: Routledge, 2014.

Romano, Angela. "Untying Cold War knots: the EEC and Eastern Europe in the long 1970s." Cold War History 14:2 (2014): 153-73.

Romano, Angela. "The UK policy towards socialist countries in the 1970s: trade as a cornerstone of détente." In The Foreign Office, commerce and foreign policy in the twentieth century, vol. 2, edited by Effie Pedaliu, John Fisher and Richard Smith, 465-85. London: Palgrave, 2016.

Rudolph, Karsten. Wirtschaftsdiplomatie im Kalten Krieg: Die Ostpolitik der westdeutschen Großindustrie 1945-1991. Frankfurt: Campus Verlag, 2004.

Saunders, Thomas, ed. East-West cooperation in business: inter-firm studies. Vienna: Springer-Verlag, 1977.

Selvage, Douglas. "The superpowers and the Conference on Security and Cooperation in Europe, 1977-1983." In Die KSZE im Ost-West-Konflikt: Internationale Politik und gesellschaftliche Transformation 1975-1990, edited by Matthias Peter and Hermann Wentker, 15-58. München: Oldenbourg, 2012.

Selvage, Douglas and Walter Süß. Staatssicherheit und KSZE-Prozess: MfS zwischen SED und KGB (1972-1989). Göttingen: Vandenhoeck \& Ruprecht, 2019.

Sjursen, Helene. The United States, Western Europe and the Polish Crisis: international relations in the Second Cold War. Basingstoke: Palgrave Macmillan, 2003.

Snyder, Sarah B. Human rights activism and the end of the Cold War: a transnational history of the Helsinki network. New York: Cambridge University Press, 2011.

Stinsky, Daniel. International cooperation in Cold War Europe: the United Nations Economic Commission for Europe (UNECE), 1947-64. Bloomsbury, forthcoming.

Stone, Randall W. Satellites and commissars. Princeton: Princeton University Press, 1996.

Thomas, Daniel. "Human rights ideas, the demise of communism and the end of the Cold War." Journal of Cold War Studies 7:2 (2005): 110-41.

Tiusanen, Tauno. Western direct investments in European CMEA countries in the 1970s and 1980s. Helsinki: Finnish Institute for International Trade, 1990.

Vaïsse, Maurice. La Grandeur. Politique étrangère du Général de Gaulle, 1958-1969. Paris: Fayard, 1998. 
Villaume, Poul, Rasmus Mariager and Helle Porsdam, eds. The 'long 1970s': human rights, East-West détente and transnational relations. London: Routledge, 2016.

Villaume, Poul and Odd Arne Westad, eds. Perforating the Iron Curtain: European détente, transatlantic relations and the Cold War, 1965-1985. Copenhagen: Museum Tusculanum, 2010.

Wallace, William V. and Roger A. Clarke. Comecon, trade and the West. London: Frances Pinter, 1986.

Wenger, Andreas. "NATO's transformation in the 1960s and the ensuing political order in Europe." In Transforming NATO in the Cold War: challenges beyond deterrence in the 1960s, edited by Andreas Wenger, Christian Nuenlist and Anna Locher, 221-42. London: Routledge, 2007.

Woolcock, Stephen. "Great Britain." In Economic warfare or détente: an assessment of East-West relations in the 1980s, edited by Reinhard Rode and Hanns-Dieter Jacobsen, 141-56. Boulder, CO: Westview Press, 1985.

Zaccaria, Benedetto. The EEC's Yugoslav policy in Cold War Europe, 1968-1980. London: Palgrave Macmillan, 2016.

Zaslavsky, Victor. "L'atteggiamento sovietico verso l'integrazione europea." In Atlantismo ed europeismo, edited by Piero Craveri and Gaetano Quagliariello, 51-70. Soveria Mannelli: Rubbettino, 2003.

Zubok, Vladislav. "The Soviet Union and European integration from Stalin to Gorbachev." Journal of European Integration History 2:1 (1996): 85-98. 


\title{
3 Attraction and Repulsion \\ Hungary and European integration
}

\author{
Pál Germuska
}

Amid easing international tensions, Hungary approached the West from the mid1960s onwards because it desired more intensive economic, cultural and technological cooperation with the developed market economies of Western Europe. However, Budapest repeatedly retreated from Brussels in the belief that it risked the benevolence of Moscow if it recognised the European Economic Community (EEC or Common Market). Before Mikhail Gorbachev's root-and-branch reforms, the Hungarian elite did not dare to cross the Rubicon and conclude an agreement with the country's most important Western economic partner. Although the Soviet Union was unable to provide financial resources to stabilise Hungary from the early 1980s, ${ }^{1}$ energy safety (secure supplies of crude oil and natural gas) remained a core issue for Hungarian decision-makers. A second crucial factor in this careful policy was the idée fixe of First Secretary János Kádár and his older generation comrades that Hungary was such a small and negligible country that any vacillation in their loyalty towards Moscow might result in a Soviet political intervention and provoke a U-turn in Soviet foreign economic policy towards Hungary.

The issue of obtaining access to the Common Market provoked sharp debates within Hungarian elite groups from the mid-1960s, and this chapter analyses Hungary's internal discussions on European integration and its envisaged role in pan-European cooperation. Although the Hungarian leadership adopted a negative Soviet stance on the Common Market and refused to diplomatically recognise the EEC (as did the other Soviet satellite states), this standpoint was questioned in confidential documents in the early 1960s. Faced with deepening Western European integration and evolving EEC protectionism, Budapest attempted to manage a rapprochement with Brussels. Hungary moved through two different channels: the Council for Mutual Economic Assistance (CMEA), hoping to unify the efforts of socialist countries to conclude a general agreement with Brussels; and the General Agreement on Tariffs and Trade (GATT), trusting that the organisation would be able to persuade the European Community to abolish its protectionist measures. However, by the end of the 1970 s both paths proved to be dead ends: CMEA-EEC negotiations manifestly reached stalemate, and GATT membership did not gain Hungary better access to the Common Market. When in 1980 Romania signed a separate agreement with the EEC, a small but loud-mouthed group of trade politicians still argued against preparing a similar document, continually 
reiterating that Brussels should guarantee Hungary's commercial rights on the ground of its GATT membership. As we will see, younger generation elite groups recognised the signs of the times that such an agreement with the EEC would have political importance (instead of economic) and it would demonstrate Hungary's willingness to open its markets and recruit investors to modernise its economy. At the same time, this was precisely the situation that Moscow, and therefore Kádár himself, intended to avoid: turning a commercial problem into a political matter.

The policy conducted towards the EEC was embedded in Hungary's four main foreign policy directions: the principal direction was the Soviet Union; the second was the Soviet bloc and the entire socialist community; the third circle of relations covered the West, including developed market economies and the EEC; and the fourth and newest direction was the "third world" with its developing countries. ${ }^{2}$ For understandable reasons of trade and foreign policy, the focus shifted from the socialist world towards market economies during the "long 1970s", and the importance of the four pillars mentioned changed. It is undisputed that the Soviet Union maintained its first place as the leading force in the communist movement, the largest buyer of Hungarian goods and the vital supplier of energy. However, the importance of the European CMEA countries gradually decreased since the partner states were not able to intensify their cooperation. On the other side, as Eastern cooperation weakened, Western relations were appreciated more. According to Ervin Csizmadia, after its initial phase the Kádár regime aimed to broaden its international relations and during the 1970s the idea of socialist integration was supplemented with rapprochement to the West and Western integration. Therefore, the idea of 'openness' and an 'open economy' became a positive approach and the perception of the West in those years was re-constituted among the Hungarian elite. Moreover, Hungary was characterised by a dual dependency: it depended on the Soviet empire but also on the Western world's economy. ${ }^{3}$

The fourth foreign policy circle manifested the new challenges of the 1970s: how could Hungary cope with the radically changing world economy and how could it profit from the expanding globalisation? A new party foreign economic policy decree of 1977 synthesised this issue at the conceptual level. It stated that Hungary and the socialist economies were an integral part of the world economy and Hungary had to open towards non-European markets too. To a certain extent, the Hungarian Socialist Workers' Party (HSWP) subsequently just approved the current situation, especially because the country multiplied its commerce with the global South in the early 1970s and extended its political, cultural and technical cooperation with the developing world. ${ }^{4}$ An additional consideration is the fact that the socialist states (re)joined several international organisations and enhanced their activities in these arenas. ${ }^{5}$ On the other hand, these organisations - where the socialist states were a minority - played an increasingly important role in the economic life of the socialist bloc. As Fritz Bartel has recently argued, the involvement of the International Monetary Fund (IMF) as the lender of last resort during the Eastern European debt crisis offered the Western states an indirect pressure possibility. ${ }^{6}$ Overall, Hungary irrevocably became part of the indivisible global economy. 
It is also important to remember that economic motivation was a core element in Hungary's opening up policy: détente was not a foreign policy goal per se but rather an advantageous environment in which to do business. From 1963 to 1964 the Hungarian leadership intended to normalise its relations with the Western powers, especially the US, aiming to return to the international financial markets to acquire loans for the modernisation of the economy. As the first ideas of an economic reform emerged, it was indisputably clear that it could not roll out without a foreign policy opening towards the West. ${ }^{7}$ Therefore, reform and opening progressed hand in hand in Hungary.

The unfolding liberalisation offered more room for manoeuvre to large enterprises which were interested in the acquisition of modern technologies to win new markets. State-owned enterprises established joint ventures in Western Europe to facilitate market access, circumvent EEC regulations and sometimes smuggle embargoed products, parts or technologies. By 1970, forty companies with Hungarian shareholding operated in Western Europe. From 1972 a Ministry of Finance decree provided new possibilities for Hungarian enterprises to set up joint ventures abroad. At the same time, this decree also enabled foreign owners to buy a share in newly established companies in Hungary. ${ }^{8}$ Established international companies introduced new technologies and know-how, institutionalised Western production culture, and standardised higher quality requirements in Hungary. The joint ventures made the Iron Curtain permeable in both directions.

Hungary's import-led modernisation strategy had its downside: a permanent foreign trade deficit (see Appendix, Table A.1). The two oil shocks of 1973 and 1979 dramatically deteriorated the balance of exports and imports. Between 1974 and 1980 the cumulated trade deficit exceeded 5.7 billion US dollars. Ministerial plans were elaborated from the turn of 1973-74 to re-shape the Hungarian export structure and to adjust the entire economy to the changed conditions, but competitiveness adaptation progressed slowly. ${ }^{9}$ Even though the export expansion had a strategic rationale, hardly any change occurred within a decade. Agricultural products still had considerably more weight in Hungarian exports to Western Europe than industrial ones. According to Michael Marrese, in the period between 1974 and 1986, animals, cereals, raw food materials, additional foods and food products, beverages and tobacco constituted $25 \%$ of the Hungarian products that were exported to European market economies, while machinery, equipment and industrial consumer goods represented only $29 \% .{ }^{10}$ In more detail, nearly a quarter of Hungarian agricultural exports (22\% in 1981 and $24 \%$ in 1984) went to the Common Market. Additionally, in the first half of the 1980s the foodstuff sector was a net exporting branch of the Hungarian economy, contributing a notable surplus to the national foreign trade balance. ${ }^{11}$ This is why agricultural tariffs and quotas remained permanently at the forefront of Hungarian (economic) diplomacy. In the absence of marketable industrial goods, grain, beef cattle and fresh fruit had to offset the sizeable Western imports. As will be shown, the unchanged internal economic structure constituted a hard constraint on foreign trade and policy towards the European Community.

This chapter proceeds in five steps in thematic order. The first section sketches how Hungary-EEC relations were interpreted for the wider public. The second 
depicts the formulation of new trade policy directives, while the third presents foreign-policy initiatives to improve pan-European cooperation. The fourth section examines discourse among the expert and academic communities during the 1970s and shows the role of bankers in the economic policy turnaround at the end of the decade. The final section reveals non-public discourse regarding HungaryEEC relations when the young party elite sought to shift from the outdated standpoint but clashed with the taboo of going against the Soviets. Using records from the Ministry of Foreign Trade, the Hungarian National Bank and inter-ministerial bodies (like the Committee for International Economic Relations), the chapter demonstrates that in certain fields the Ministry of Foreign Trade was an active and independent agent while colourful - and sometimes contradictory - ideas flourished in internal debates. Since creating access to the Common Market was envisioned primarily as a tariff and commercial issue during the 1960s and 1970s, the trade apparatus mainly managed the internal and external coordination of Hungary's policy towards the EEC. As Gábor Szilágyi highlights, the HSWP ignored the issue for a long time and new initiatives were mostly launched by the state bureaucracy. ${ }^{12}$ This study challenges his interpretation on one crucial point: it argues that from the early 1980s the genuine initiator of a foreign trade policy shift was the reform wing of the party, while the foreign trade apparatus remained steadfast on non-recognition. The chapter sheds new light on the intersection between the different Hungarian foreign policy circles, where national interest confronted ideological doctrine. Exploration of these internal debates contributes to a better understanding of the Hungarian elite's motivations and reveals the frontlines between the elite groups.

\section{Public interpretation of Hungary's relations with the Common Market}

The 1957 treaty that created the EEC was a side issue in Hungary. The official newspaper of the Hungarian Socialist Workers' Party, Népszabadság (Peoples' Freedom), relegated news of the event to page 7. In the years that followed, the HSWP supported the Soviet stance on the Common Market and the official press regularly echoed this attitude. Indeed, the issue of collaborating with the Common Market was never discussed publicly due to the severity of the problem. A small circle of diplomats and commercial experts worked on new solutions in the background while the Ministry of Foreign Affairs promoted well-known clichés about the EEC in newspaper articles and diplomatic conferences.

For example, Foreign Minister János Péter explained Hungary's principal goals at an ambassadors' conference from 30 July to 4 August 1962. (These so-called ambassadors' conferences were held at random intervals and the three- to fourday meetings aimed to summarise Hungarian foreign policy targets for the country's diplomats.) He justified building new links with the Western countries on the grounds of peaceful coexistence; working in the interest of the worldwide victory of socialism; improving Hungary's place among the socialist countries; and establishing Hungary's reputation in the international arena. He also underlined that 
Hungary should weaken the Western European integration efforts and prevent the accession of Austria to the EEC. ${ }^{13}$

By the mid-1960s, the peaceful coexistence of different political systems in Europe emerged as a favoured topic in public communication. Budapest insisted that Western countries should take the first steps to abolish obstacles to inter-bloc trade. On 11 February 1965, János Kádár told Parliament: 'If the capitalist countries are going to develop commercial ties in reality, then these obstacles should be discontinued and most-favoured-nation [status] should be granted to the socialist countries'. ${ }^{14}$ Also in the following years, the Hungarian press paid close attention to key events in the Community, always informing its readers about harsh debates and contrasts between the six member states (the Six).

On the occasion of a 1969 ambassadors' conference, Deputy Foreign Trade Minister Béla Szalai explained the three main targets of Hungary's trade policy: enlarging the circle of liberalised products; expanding trade quotas; and initiating industrial cooperation and joint ventures. He reminded the ambassadors that the next aim on the commercial agenda was to conclude agreements with the EEC and the European Free Trade Association (EFTA). He emphasised that although diplomatic recognition of the EEC should not be taken into consideration, a continuation of technical talks was desired. The Economic Secretary of the HSWP, Rezső Nyers, also argued for further negotiations with the Common Market as the organisation was gradually formulating its common trade policy. ${ }^{15}$ In August 1969, Pál Gulyás condemned the launch of this policy. The columnist reminded the readers of the Népszabadság that the planned EEC regulation would hurt the export interests of all the socialist countries and stressed that expanding international trade was a winning proposition, while those who hindered it with discrimination would be the losers. ${ }^{16}$

In the first half of the 1970s, cooperation difficulties among the Six were continually highlighted, and discrimination by the Common Market remained a regular headline topic. For example, in February 1970 Hungarian radio pointed out that establishing a common monetary policy within the Common Market would be a 'difficult and lengthy process'. It also touched on the common trade policy and envisaged that 'small Hungary' would confront the 'giant monster of an economic association'. At the same time, it expressed its hopes that the Western countries also intended to avoid unmanageable situations and that the liberalisation of product lists would be enlarged by $1972 .{ }^{17}$

Hungary's sharp criticism of Common Market practices was also demonstrated in the party daily. In April 1972, Népszabadság reported Foreign Trade Minister József Bíró's attack on the EEC at the United Nations Conference on Trade and Development (UNCTAD) in Santiago de Chile. He condemned discriminatory restrictions which seriously affected the socialist states and indicted the Community for refusing to grant them most favoured nation status for 'political reasons'. The common agricultural policy was deemed 'one heavy burden' on international trade. ${ }^{18}$ Budapest also enhanced its protests when the Community ordered an import ban on beef cattle in the summer of 1974. Hungary demanded the withdrawal of this decision and criticised the 'irresponsible and outrageous behaviour' of EEC politicians. ${ }^{19}$ 
On the other hand, a more friendly tone was used regarding the EEC when general pan-European cooperation issues were on the table. In September 1973, János Kádár welcomed a meeting between representatives of the Common Market and the CMEA. He expressed Hungary's desires in an interview on Finnish radio and TV: 'What we require from the contacts between the two organisations is that they offer their member countries the opportunity to take a serious step forward along the road toward amplifying their economic links and their co-operation and facilitating contacts'. ${ }^{20}$

The first secretary was also a keynote speaker at the next ambassadors' conference in July 1975. Kádár reminded his audience that peaceful coexistence was not a tactical usage in Hungarian foreign policy but a 'communist policy for a historical epoch' which would indirectly assist the world revolution. He warned the diplomats that they should not be 'more Catholic than the Holy Father in Rome, redder than Moscow and more leftist than the Central Committee and the Government'. Namely, the Hungarian diplomatic corps should follow the intentions of the party exactly instead of formulating alternative pathways. ${ }^{21}$

Minister of Foreign Affairs Frigyes Puja explained the concept more concretely to department leaders in November 1976. He stressed that the capitalist states were the second most important country group to deal with, as he noted 'we can purchase modern technologies there, we can acquire loans there, we can sell our goods there'. He mentioned bilateral relations with Western states as a tool to improve the international climate and resolve international debates. He complained that the EEC subjugated its relations with the CMEA to its 'fight against' the Soviet Union. He supposed that the Community did not wish for an inter-bloc agreement since then the room for manoeuvre for the smaller socialist states (like Romania) would be eliminated while Brussels would gain from division among the socialist countries. ${ }^{22}$

At a 1978 ambassadors' conference János Kádár was again the keynote speaker. He stressed the openness of Hungarian foreign policy and explained the equal importance of the three main directions: the socialist ally system, the developing world and the Western capitalist countries. On this occasion, the Common Market was only mentioned in an expert report, which pointed out that the Hungarian embassies did not maintain appropriate contacts with the representatives of NATO, the EEC and the European Parliament. ${ }^{23}$

The next ambassadors' meeting in 1980 was the first occasion when BudapestBrussels relations received specific attention. Foreign Minister Puja reminded Hungary's representatives about the worldwide economic recession, the heating of international tensions and the unfolding conflict of interests between the US and the EEC. The Community was depicted as the main hindrance to Hungarian export expansion since Brussels had not only intensified its protectionist measures but also undermined Hungary's rights under the GATT Agreement. Puja stated that criticising trade discrimination was a constant cornerstone of Hungary's foreign policy and encouraged further negotiations on trade and a contractual relationship between the CMEA and the Common Market. ${ }^{24}$

Noteworthily, in the following years the official press regularly repeated wellknown clichés concerning the EEC (harsh debates between the member states, 
failures of summits, etc.) but never mentioned the exploratory discussions between Budapest and Brussels. Meanwhile Hungary was seeking new paths behind the façade of socialist unity.

\section{Challenging the socialist non-recognition policy - the foreign traders}

During the preparation for the economic reform, the Ministry of Foreign Trade proposed to seek Hungary's entry into the GATT with the purpose of improving access to the Common Market. On 31 May 1966, the Committee for International Economic Relations (CIER) gave Hungary permission to submit an application for GATT observer status, which was conceived as a first step towards full membership. ${ }^{25}$ The top party leadership also consented. In October 1966, the HSWP Political Committee (PC) requested new policy papers with different options on how to launch talks with the EEC and called on the Ministries of Foreign Trade and of Foreign Affairs to effectively represent Hungarian interests in tariff and discrimination issues abroad. ${ }^{26}$

In April 1968, Deputy Minister Béla Szalai submitted a report to the Ministerial Board with fresh ideas and evaluations regarding the Common Market. The report's point of departure was the agricultural issue, since agriculture and food products represented $60 \%$ of Hungary's exports to the Common Market. Before 1968, exports of agricultural goods (especially eggs, poultry, pigs and pork) had dynamically expanded, and the EEC regulations on beef cattle were of crucial importance since this product alone amounted to $35 \%$ of Hungary's agricultural exports. The ministry warned that Hungary would soon face new challenges due to the EEC's decision to abolish its internal customs tariffs by 1 July 1968. Nearly half of Hungary's Western trade involved EEC countries, and this was 13\% of its total trade. In addition, West Germany and Italy were the primary suppliers of modern technologies to Hungary. It was therefore essential for Budapest to negotiate with the Common Market. The ministry called the CMEA position an outdated perspective and stated that CMEA member states should consider official diplomatic recognition of the Common Market. In his conclusion, Szalai called on the government to reconsider its non-recognition policy at forthcoming CMEA meetings. In the meantime, he suggested the continuation of informal HungaryEEC bilateral talks to resolve technical questions. ${ }^{27}$

A finalised version of this proposal was circulated and commented on by the top leadership. Prime Minister Jenő Fock supported Hungary's accession to the GATT and continuation of technical negotiations with the Community. He added that concluding multi-annual agreements with EEC member states on joint ventures and technical cooperation would be desirable. Vice Prime Minister Antal Apró's secretariat also agreed on the key points. Their note asserted that the former arguments against the EEC (that it was an economic arm of NATO, a tool of West-German revanchism, and a supranational power which would soon fall apart) had been proven wrong. Apró's secretariat agreed with Fock's comments that it would be too early to grant the EEC 'political recognition', but the CMEA 
should reconsider its standpoint soon. In the meantime, Hungary might gain more advantages through accession to the GATT as an associate member. ${ }^{28}$ On 10 May 1968, the CIER debated the April proposal on the Common Market and passed a resolution requiring Hungary to initiate a re-evaluation and better coordination regarding CMEA-EEC relations within the CMEA. ${ }^{29}$

Just a month later, on 10 June 1968, the Ministry of Foreign Trade suggested revising the internal customs tariff system to prepare for Hungarian accession to the GATT. It argued that full membership would result in further gains for Hungary since the GATT, as a multilateral foreign trade coordination forum, played an increasingly significant role in discussing trade discrimination and barriers. The second most important argument for accession was: 'It would be an advantage if in the framework of the GATT - we could directly negotiate with the Common Market in earnest without diplomatically recognising it' ${ }^{30}$ This sentence reveals the true intentions behind the accession request: to make a new deal with the EEC without openly breaking socialist unity.

On 21 June, the CIER supported the action plan and ordered the Ministry of Foreign Trade to elaborate a proposal to improve the tariff system and to draft a decree on GATT accession. ${ }^{31}$ One year later on 9 July 1969, the Hungarian government submitted its application for full membership to GATT in accordance with Article XXXIII of the General Agreement. ${ }^{32}$

Already Hungary's observer status fulfilled its expectations in the sense that it facilitated informal networking efforts with the EEC. In September 1969, János Nyerges, the Hungarian representative delegated to international economic organisations, was welcomed in Brussels by Wolfgang Ernst, the deputy head of the Directorate General External Trade (DG XI) of the European Commission, and Commissioner Jean-François Deniau, head of DG XI. Although the Hungarian economic diplomat considered their meeting to be part of the general GATT talks, he consistently dealt with Budapest-Brussels relations. He argued for a flexible liberalisation of Common Market regulations, especially in the field of agricultural trade. On the contrary, Deniau and Ernst suggested discussing general trade policy issues in the framework of the GATT. Foodstuff exports were again the core issue at a business lunch, but Edmund Wellenstein, director general of DG XI, declared that the Community could not offer any positive prospects for Hungarian agricultural exports since a decided intent of the EEC was to be selfsufficient in terms of food. Therefore, Hungary should seek to change its export structure. Conversely, Nyerges insisted that, for economic and historical reasons, Hungary was not able to cease its agricultural exports and demanded a guarantee from Brussels that it would not change its trade regime in the future. ${ }^{33}$

These non-official meetings continued in the following year, since Budapest intended to ensure a better position for its exports. In August 1970, the head of Jean-François Deniau's cabinet, Pierre Duchâteau, visited János Nyerges at the ministry during a holiday in Hungary. They discussed the kind of treatment of the socialist states that would be desirable in a new Common Market Eastern policy. Nyerges argued again for a new EEC policy regarding agricultural trade which would open its market for Eastern foodstuff supplies at good prices and in large 
volumes. He stated that Hungary 'was fighting for' normalisation of international commerce in the framework of the GATT talks and pointed out that trade liberalisation would not risk the Common Market states' interests. ${ }^{34}$

Presumably, additional informal meetings were held even though technical issues were being increasingly addressed as the GATT negotiations proceeded. After four years of intensive negotiations, the GATT working party finalised its evaluation of the Hungarian application in July 1973 and submitted its recommendations, including a draft protocol. ${ }^{35}$ On 10 August 1973, the Hungarian government finally signed the Accession Protocol. The Hungarian economic leadership pinned all its hopes on getting better access to the Common Market because the Protocol envisaged the elimination of trade barriers. Nevertheless, these Hungarian expectations were not realised since the EEC member states maintained most of the quantitative restrictions related to Hungarian exports. ${ }^{36}$

\section{A CMEA reform attempt and initiatives on pan-European cooperation - diplomats at the forefront}

A second strand in Hungary's strategy regarded the socialist bloc. To create a solid background to its economic reform and to expand commercial opportunities, Budapest elaborated far-reaching reforms to improve the CMEA. A proposal in May 1968 aimed to foster CMEA integration with advanced financial conditions, monetise commercial relations between partner states, promote direct inter-firm links and provide non-socialist countries with opportunities to join the CMEA. ${ }^{37}$

It soon became evident that Hungarian aspirations to find supporting partners within the CMEA would at most only be partially fulfilled. In January 1969, the Executive Committee passed a resolution on EEC relations declaring that each CMEA member state could have 'links with EEC organs to defend their economic interests' and calling on the member states to readily exchange information. Although the Hungarian Ministry of Foreign Trade later interpreted this declaration as advantageous (the Executive Committee did not explicitly prohibit building contacts with the Common Market), the decision also clearly dictated that the member states should abstain from granting diplomatic recognition to the EEC. ${ }^{38}$

The Hungarian state apparatus regularly re-assessed recent developments in the Common Market - the planned enlargement of the Community and the decision to implement a Common Commercial Policy and so forth. In December 1970, the Foreign Trade Ministry summarised new tasks in Hungarian policy towards the EEC. A report by the Inter-state Department of European Non-socialist Countries analysed the EEC regulations concerning the most important Hungarian export products (beef, cheese, wine, etc.) in detail together with relations between the other CMEA members and the Common Market. Although it made clear that the EEC's Common Commercial Policy was not completely implemented, the department proposed - and the Ministerial Advisory Board accepted - the following guidelines: Hungary should conclude agreements on certain products, initiate negotiations with EEC candidate countries and attempt to sign long-term trade agreements with the actual member states before 1974. Assuming that Western 
European integration would progress in the forthcoming years, the report considered it necessary to revise the CMEA's approach. ${ }^{39}$

Facing firm Soviet resistance to the adoption of a new line, Hungarian diplomacy attempted to avoid the issue of diplomatic recognition by proposing ways to make direct ties between the CMEA and the EEC. In February 1972, for example, a Hungarian proposal offered the following options: a CMEA declaration that the Eastern side was ready to establish contacts with the EEC; preliminary informative links between the CMEA and the EEC on possible forms of contact; principle agreements on certain economic and trade policy issues; and treaties or agreements on selected sectoral issues (coordination or mutual acknowledgement of quality specifications and standards, environmental protection, transport, energy). ${ }^{40}$ The Ministry of Foreign Affairs also agreed that expanding economic relations with the EEC would be crucial for Hungary since Hungarian raw material exports offset the imports of high-quality complex technologies, licences and industrial equipment. However, in accordance with the official CMEA policy, the Economic Policy Group of the ministry did not intend to build new ties with the supranational organs of the Common Market. ${ }^{41}$

Hungary also presented remarkable new initiatives to encourage wider panEuropean cooperation only half a year after the Budapest Declaration of the Warsaw Pact Political Consultative Committee. In October 1969, the Ministry of Foreign Affairs elaborated a detailed memorandum which suggested adding economic topics that went beyond questions of security to the Conference on Security and Co-operation in Europe (CSCE) agenda: cooperation in various economic sectors, including industry, supply infrastructure, and telecommunications and transport networks. Moreover, the ministry proposed to establish a new 'Committee for European Economic Cooperation' to re-shape the role of the United Nations Economic Commission for Europe. ${ }^{42}$ Before the commencement of CSCE talks in Helsinki, the Hungarian leadership once again voiced its interest in moving beyond common security issues regarding the bloc countries. In June 1973, when the HSWP Political Committee discussed an upcoming speech by Foreign Minister János Péter to the CSCE, it placed more emphasis on cultural and economic cooperation, requesting the elimination of discriminatory trade barriers and highlighting the importance of pan-European collaboration to improve the wellbeing of European citizens. It also pointed out that economic cooperation between the opposing political systems would provide increased security across the continent. ${ }^{43}$

From the Hungarian viewpoint, it was a crucial result that the Helsinki Final Act declared in the first chapter (Commercial Exchanges) of Basket II that the participating states 'will endeavour to reduce or progressively eliminate all kinds of obstacles to the development of trade' ${ }^{44}$ Budapest had a legitimate expectation that the Act could give a new impetus to unhindered trade. ${ }^{45}$ Shortly after the signing of the Helsinki Accords in September 1975, the secretariat of the Committee for International Economic Relations analysed the economic consequences of the CSCE in detail. János Szita, secretary of the CIER, recalled in this report that neither the socialist nor the capitalist countries intended confrontation regarding 
Basket II. He drew attention to the fact that with its signing of the Act the EEC became not only a de facto but also a de jure actor in international politics. Moreover, he suggested that Brussels intended to give more expression to its role. The report assessed the tasks concerning the implementation of the Final Accord and the preparation for the follow-up Belgrade conference planned for 1977. ${ }^{46}$

As a direct consequence of the Accords, in December 1976 Budapest proposed talks with nineteen Western countries in order to develop bilateral political, economic and cultural relations. These proposals were highly 'personalised' since they varied from country to country. In the case of West Germany, for example, the Hungarian Ministry of Foreign Affairs suggested initiating talks that would balance bilateral trade and abolish trade discrimination against Hungarian exports. In addition, Budapest questioned whether the interlocutors would speak up for the establishment of official relations between the CMEA and the EEC after a Hungarian-West German summit. ${ }^{47}$

Maintaining détente also remained one of the main goals of Hungary's foreign policy after the Belgrade Conference, which ended in the late winter of 1978 with limited results. Budapest wished to continue the inter-bloc dialogue not only in the field of arms reduction and disarmament but also with more attention to economic and trade issues. As the Ministry of Foreign Affairs pointed out in its October 1978 proposal, Hungary prioritised Basket II (economic and trade cooperation) rather than the Warsaw Pact plans to organise a pan-European conference on environment protection and energy. Budapest treated Basket III with contradictory feelings: on the one hand it was considered a potential threat to the expanding unofficial contacts, but on the other hand cultural exchange was envisaged as a tool to correct the image of the socialist countries in Western states. ${ }^{48}$ Hungarian diplomacy kept trade issues at the forefront in the following years too, for example during the Madrid conference (see below).

\section{Forcing an economic policy turnaround - experts and bankers}

By the early 1970s, a structured network of background research institutes was supporting policymaking in Hungary. These institutions played a crucial role in re-formulating attitudes towards the West: the Institute for World Economics (VGI) of the Hungarian Academy of Sciences (HAS), the Economic Research Institute of the Central Statistical Office and the Institute for Economic and Market Research shaped thoughts on the international economy while the Hungarian Institute for Foreign Affairs (re)fashioned the foreign-policy mindset. ${ }^{49}$

In 1973, the newly established Külpolitika (Foreign Policy; journal of the Institute for Foreign Affairs) proclaimed the official standpoint in an article by János Szita, the secretary of the Committee for International Economic Relations. He examined the differences between the CMEA and the Common Market and also the possibilities for cooperation. He argued that the CMEA countries' policy did not lead to isolation from other parts of the world economy but the discriminatory policies of the Common Market towards non-affiliated countries seemed to slow down pan-European cooperation in the coming years. ${ }^{50}$ In 1974, Ferenc Kozma 
attempted to predict the 'realistic possibilities' for the future relationship between the two European integration organisations in the pages of Külpolitika. He stated that the essential condition for developing inter-bloc cooperation was a revision of the EEC's disadvantageous business policies and granting the most preferential terms to the socialist countries. ${ }^{51}$ Two years later, in his book on economic integration, Kozma suggested that the CMEA should learn from the experiences of the Common Market instead of copying the Western model. ${ }^{52}$

A leading Hungarian economics monthly, Közgazdasági Szemle (Review of Economics; journal of the HAS Institute of Economics) paid special attention to advances in the EEC's enlargement (with the UK, Ireland and Denmark). However, its author, Gabriella Ízikné Hedri, stressed that Brussels had no concept of how to cooperate with socialist countries. After 1976, the perception among economists of Western integration was more positive: the encouragement of inner mobility, the development of depressed areas and technological and structural regeneration were depicted as features of a successful adaptation model through the deepening integration. ${ }^{53}$

Experts from these research institutes were also invited to participate in preparing a new foreign economic policy concept, which was ordered by the HSWP Political Committee in July 1975. This party resolution aimed for a thorough analysis of global changes and their consequences for the Hungarian economy, and the Economic Policy Department of the HSWP Central Committee (CC) organised six working groups to elaborate guidelines. In January 1976, the Fifth Working Group - dealing with foreign economy strategy (as the fifth chapter of the planned document) - gathered key figures in the field: representatives of ministries, the national bank, researchers, the party centre and the Hungarian Chamber of Commerce. In this way the academic sphere had the opportunity to give direct feedback to the decision-makers and encourage them to adopt a more active and open economic policy.

One can follow the entire elaboration process of the concept from the first drafts to the finalised chapter in the personal files of János Nyerges. In March 1976, Nyerges personally wrote the first sketch on 'capitalist integrations', in particular on the desired policy towards the Common Market. Since it was an internal preparatory outline, he formulated his ideas more frankly. He bitterly recalled that Hungary depended highly on the EEC and noted, 'There is no real choice in the field of relations with the Common Market. The situation is that the Common Market keeps almost all our capitalist exports in its hands as an entail without a real effort or compelling competitive pressure'. ${ }^{54}$

Nyerges stressed that Hungary only had legal and political instruments against the Community since the country had no power to use any economic pressure. He considered the launch of CMEA-EEC talks a very hopeful sign, but in the long run there were no high hopes of concluding an agreement. Instead, other trade policy measures were deemed necessary like reaping the benefits from rivalries between the EEC and other third parties: improving Hungarian-US trade relations and negotiating with the EFTA member states. Last but not least, the GATT rounds also offered room for manoeuvre to reach equal treatment by the Common Market. ${ }^{55}$ 
In June 1976, the Fifth Working Group compiled a 'Summary and Conclusions' which tackled the EEC in five pages. This part of the document followed Nyerges' argumentation but formulated measures more softly. The summary designated the Common Market as an organisation that gathered Hungary's most important nonsocialist commercial partners. Therefore, this direction was crucial. It expressed the hope that a CMEA-EEC framework agreement could be concluded within two to three years if the socialist states could offer profitable economic opportunities to the Common Market. The working group proposed to reject any effort by Brussels to sign a bilateral agreement with Budapest and stated that only the GATT Agreement should be the principle framework for any talks with the Community. It also suggested substituting the commercially dominant EEC with an alternative market orientation (the US, non-EEC member European states, developing countries) since suppliers faced difficult competitive conditions. Overall, they argued that Hungary should develop its relations with EFTA members and build new ties with the "third world". 56

The Economic Policy Department of the HSWP CC and the Committee for International Economic Relations drew up a final proposal from the working group reports submitted. The finalised document, titled 'Guidelines for LongTerm Foreign Economic Policy', paid less attention to the EEC than the previous drafts since the new approach was to diversify Hungary's relations. However, for the first time this report intertwined the three main tasks in Hungarian economic policy: handling the aftermath of the oil crisis, adjusting economic structure and opening towards the non-CMEA world. Détente - the easing of tensions in international relations - was favourable to expanding East-West cooperation. Therefore, the proposal aimed to intensify more dynamic business links with the world economy. It stated clearly that deepening foreign economic relations brought risks, but this was a 'smaller [hazard] than the economic and political outcomes of isolation'. ${ }^{57}$ The guidelines proposed building international economic relations with socialist and non-socialist states on a solid basis. However, it ranked relations according to a political criterion: cooperation with the Soviet Union came first, cooperation with the socialist states followed closely and last came cooperation with capitalist states. Relations with the developed Western countries were presented as an important national interest and as an inherent part of a policy intended to foster peaceful cooperation between the two economic systems. The rapporteurs stated that Hungary should urge for negotiations between the CMEA and the EEC and also aim to improve the Hungarian trade policy position. At the same time, they stated that the basic rule in Hungarian trade policy was the most favoured nation principle, and on the contractual legal basis of the GATT Budapest should act against the defaulting Common Market practices. ${ }^{58}$ The HSWP Political Committee accepted this document as a resolution in April 1977, and in the following year it became the guideline for further state measures.

Although official attention was more devoted to non-European markets, new research projects were also launched to explore the current situation of the core Western European economies. Between autumn 1977 and spring 1978, an ad hoc research group in the HAS Institute for World Economics worked to investigate 
several different aspects of the EEC, among them the industrial structure and industrial policies in the Community; its relations with the EFTA states, Canada, Japan and China; developments in EEC-US relations; and the CMEA and EastWest trade. In his concluding study, principal investigator András Inotai identified an asymmetry of interests between the CMEA and the EEC. The Common Market had a much more important role in the realisation of the socialist states' economic policy targets than vice versa. The EEC represented the larger part of the CMEA states' trade with capitalist countries while the CMEA had only a $4 \%-5 \%$ share in the EEC Nine's imports and exports (excluding intra-German trade). Inotai also recalled that the CMEA members were attempting to expand their exports to the Nine in the sectors where the highest tariffs and quotas were levied (e.g. clothing products). Consequently, the socialist states should reshape their development policies and adjust their export patterns to forecast market demands. In his conclusion, Inotai warned that countries which had not yet established a contractual relationship with the EEC would be forced to act, and not Brussels. Therefore Inotai - and to a certain degree the expert community - argued for reaching an agreement as soon as possible: 'Any problems involved in this step [of concluding an agreement], which is an imperative necessity, should thus be considered as the price for ensuring more favourable conditions for future and longer-term development'. In his closing remarks, Inotai not only reflected on but also disproved the key point in the 1977 party resolution, stating that there was no real alternative market that could substitute socialist exports to the EEC. ${ }^{59}$

At the end of the 1970s, another important expert community, bankers, also formulated criticism - at least in non-public documents. The central bank was the hub of Western business ties since Western European, North American and Middle Eastern banks were all among the country's creditors. Between 1973 and 1979, Hungary borrowed 8 billion US dollars to stabilise its state budget, to finance its trade deficit and to restructure its industry (see Appendix, Table A.5). In fact, this 'planned indebtedness' strategy was not supported and accepted uniformly. For example, the reformist president of the Hungarian National Bank (HNB), Andor László, expressed his disagreement, which caused his early retirement in 1975 at the age of 61 . His successor, Mátyás Tímár (previously vice president of the Executive Council), managed the central bank more smoothly. The HNB secured the required external funding for the national economy. However, several times it reported doubts. ${ }^{60}$

Although the central bank was publicly rather passive concerning the issue of foreign trade policy, behind the scenes the HNB was the genuine engine of economic policy turnaround. From the perspective of the HNB, the 'unresolved' relation with the EEC was a serious obstacle that hindered Hungarian exports and negatively affected the entire financial balance. In September 1978, reviewing a CIER proposal, the foreign currency department of the central bank remarked that due to its organisational structure and its outstanding internal problems, the CMEA was not capable of managing inter-bloc talks. Therefore, dialogue should be continued but it was worth formulating the Hungarian standpoint to initiate bilateral negotiations with the Common Market. The department also warned that 
Hungary itself had to take the first step to avoid sizeable losses in trade, since the country's financial balance did not permit any postponement of talks with the Community. ${ }^{61}$ In July 1979, analysing another proposal by the Foreign Trade Ministry, the same department of the HNB pointed out the lack of concrete suggestions on how to handle the ineffectiveness of the CMEA-EEC negotiations and called for a clear declaration that in the absence of a CMEA solution Hungary should negotiate with the Common Market itself. ${ }^{62}$

\section{A political deal with the EEC? - State 'hawks' and party 'doves'}

The crucial moment came in a year and a half. The CMEA-EEC negotiations reached stalemate in October 1980 and there was no hope of reviving them in the short term. The Hungarian leadership was disappointed and attempted to find a narrow path to avoid confrontation with the Soviets while at the same time trying to improve its relations with core Western European countries. It is noteworthy that in this delicate situation certain circles in Budapest envisaged the possibility of concluding a free trade agreement with Brussels. However, the idea was deemed 'economic naivety' by foreign traders since the Hungarian economy was only a reformed planned economy and not a genuine market economy. ${ }^{63}$ Presumably, given international commercial legislation the trade apparatus considered it illusory to draw up a contract with the EEC, while reformers desired a shift from the outdated standpoint. The general international climate was contradictory at the beginning of 1981 . The Polish crisis overshadowed the prospects for any new reform in socialist states and the next CSCE follow-up conference in Madrid continued with endless disputes. Only economic cooperation seemed to be a promising neutral terrain at the conference. Regarding Basket II, Hungarian proposals on the exchange of market information, on industrial cooperation and on eliminating trade obstacles received positive echoes. ${ }^{64}$

In these circumstances, the reformist younger generation within the party elite initiated action. In March 1981, the Department for Economic Policy of the HSWP CC elaborated a top-secret report on relations with the Common Market. In its memo, which was addressed to Ferenc Havasi, the economic secretary of the $\mathrm{CC}$, it proposed concluding an all-embracing agreement with the Community to arrange economic and commercial issues simultaneously. The document stressed that such an agreement could improve the Hungarian economic position or at least would help to avoid major losses. The department assumed that Budapest might be able to bargain better conditions with Brussels like Romania or even Yugoslavia. The rapporteurs underlined that the Romanian and Yugoslavian cases clearly demonstrated that an economic-commercial agreement with the EEC did not cause 'political storms'. ${ }^{65}$ According to István Horváth's (the subsequent Hungarian ambassador in Bonn) memoirs, Havasi embraced the idea and consulted on this initiative with János Kádár, who informed the Soviet leadership during his summer holiday in Crimea. ${ }^{66}$

Following preparatory talks with the West German Sozialdemokratische Partei Deutschlands (SPD), Ferenc Havasi had the chance to express the HSWP approach 
in November 1981. He stressed in Bonn that Hungary aimed to develop equally bilateral (Budapest-Brussels) and CMEA-EEC relations. ${ }^{67}$ In his memoirs, Havasi affirmed that West German Chancellor Helmut Schmidt promised discrete support in negotiations on a Budapest-Brussels cooperation agreement. ${ }^{68}$ Despite the promising start, a month later Budapest received an unexpected warning from the chancellor. In an 18 December letter addressed to Kádár, Schmidt stated that the political risks of Hungary's stronger attachment to the European Community were evident. As he argued, since Hungary was an important member and partner in the CMEA, any attempt to establish closer links with the EEC would have far-reaching implications of high political importance. He expressed his considerable doubts that the EEC could present an attractive offer in the economic field for Hungary. He concluded that the Hungarian leadership should assess whether the potential benefits of building a closer relationship with the EEC could outweigh the immediate political risks. ${ }^{69}$

The issue of a rapprochement was raised again in April 1982 in the last moments of a Kádár-Schmidt summit in Bonn. The West German chancellor stated that it was still unclear to Brussels what the exact content of an EEC-Hungary agreement would be. Additionally, he repeated his concerns about Moscow since such negotiations might cause a serious conflict for Budapest. Finally, Schmidt explicitly advised the Hungarians to take the matter off the table. Gyula Horn (at the time deputy leader of the Department for Foreign Affairs in the HSWP CC) asked the chancellor why it was he, rather than the Hungarians, who were worried about the Soviets. Schmidt replied that it might be unpleasant for the Federal Republic of Germany if the Soviets found out that Bonn had helped to draw up a BudapestBrussels agreement. ${ }^{70}$ Following his visit in Bonn, Kádár also expressed criticism of Havasi and the $\mathrm{CC}$ departments for having suggested an agreement with the EEC which was not in accordance with reality. ${ }^{71}$ Kádár seemed to be so disappointed at Schmidt's refusal that he never supported any similar action again.

During the spring of 1982, the Ministry of Foreign Trade elaborated a new proposal on Hungary's relations with the EEC. The ministry pointed out that even if they were successful the CMEA-EEC talks would not be able to improve Hungary's commercial position. Therefore, Budapest should continue its negotiations with Brussels and conclude agreements that would adequately satisfy its economic interests. The report examined three main topics: tariffs, quantitative quotas and the Common Market's agricultural policy. Concerning tariffs, the ministry underlined that there was no chance of signing a free trade agreement under the current circumstances. The report also self-critically emphasised the low level of competitiveness of Hungarian suppliers, which was a greater hindrance to export expansion than Common Market customs tariffs. According to the report, agriculture was a crucial area of dispute because this sector absorbed the heaviest losses from EEC protectionism. The trade ministry urged the Hungarian leadership to conclude a bilateral arrangement with the Community as soon as possible, even at the expense of Hungary bartering Western market opening with increasing foodstuff imports from the Community. The concluding part of the report emphasised that appointing Hungarian diplomatic representatives in Brussels would be an 
important political gesture and pointed out that diplomatic recognition was inevitable sooner or later. ${ }^{72}$ However, the finalised version of the proposal, which was signed by Minister of Foreign Trade Péter Veress on 7 June, clearly demonstrated that the time had not yet come to shift towards a new approach. The crucial last sentence of the proposal was changed to state that recognition was 'no longer relevant'. ${ }^{73}$

It is not hard to discover the coincidence between the parallel events. Indeed, Hungary was on the verge of total financial collapse by the beginning of summer 1982. Although the IMF accepted the Hungarian request for accession in November 1981, turbulence in the international debt crisis resulted in panic reactions several hundreds of millions in US dollar deposits were withdrawn from the Hungarian National Bank. In February 1982, the financial situation deteriorated dramatically. János Fekete, HNB vice president, forecast that without new external credits the country's savings would only stretch to the next month. On 6 May, József Marjai, vice prime minister, and Fekete signed the IMF accession document at a lavish ceremony in Washington, but this membership did not in itself mean an immediate capital injection. Therefore, hard bargaining was launched with the Bank for International Settlements (BIS) and private banks to provide the country with fresh credit. At a Budapest meeting on 9 July, János Fekete hoped to convince Jacques de Larosière, the managing director of the IMF, that it was a primary interest of the West to support the 'unique, firmly independent and difficult' Kadarian path, since its failure would certainly delay opening up. ${ }^{74}$

On the other hand, from time to time the Hungarians had to reassure the Soviets that the country did not depend on the West at all. For example, on 9 June 1982 Prime Minister György Lázár affirmed to Nikolai Aleksandrovich Tikhonov, the Soviet chairman of the Council of Ministers, that Hungary was firmly committed to Soviet and socialist shipments. Lázár cited at length commercial data to demonstrate that Hungarian exports had expanded more intensively to the partner states than to the capitalist states, and he rejected a statement that Hungarian trade enterprises were exclusively interested in trading with market economies. He emphasised that Hungary purchased goods from developed capitalist countries only when it was impossible to acquire them from socialist or developing states. ${ }^{75}$

Obviously, the Hungarian leadership was dancing on a razor blade. Budapest had to satisfy the requirements of the IMF in exchange for loans but did not want to incite Moscow's anger with an additional Western deal. Therefore, when the economic cabinet of the Council of Ministers, presided by Marjai, accepted the Foreign Trade Ministry's proposal at its 1 September 1982 meeting, it gave permission for talks with the EEC to be launched and a comprehensive agricultural agreement to be negotiated, but explicitly stated that these negotiations would be solely an exchange of views of a technical nature. ${ }^{76}$ However, in November 1982 on the occasion of a GATT ministerial meeting in Geneva, the Hungarian trade delegation suggested to the EEC representatives on a confidential basis that they should examine the possibility of concluding a comprehensive bilateral agreement. In his 2016 book, Péter Balázs, at the time the commercial counsellor in Brussels, called this initiative a 'bold and ambitious' proposal which ran counter 
to the common CMEA standpoint. ${ }^{77}$ Indeed, the idea of a bilateral agreement between Budapest and Brussels was undeniably a courageous measure. Nevertheless, the archival evidence reveals that it was part of a tactical game. The Ministry of Foreign Trade and the close circle of Vice Prime Minister Marjai confidentially showed a positive attitude towards the Common Market while they kept a watchful eye on Moscow's reactions, and in fact intended to avoid a compromise with the EEC.

Publicly, Hungarian representatives repeatedly condemned EEC trade practices, as did Foreign Trade Minister Péter Veress at the thirty-eighth GATT ministerial meeting on 24-29 November $1982 .{ }^{78}$ However, at the expert level signs of dissatisfaction were observable, think tank institutions - hand in hand with certain HSWP CC departments - sought newer points to break out. A prime example of these pathfinding attempts was a January $1983 \mathrm{draft}$ proposal by the Institute for Foreign Affairs titled 'The Eighties and Hungarian Foreign Policy'. Gyula Gyovai, director of the institute, highlighted new opportunities for Hungarian foreign policy, since the room for manoeuvre for small countries had considerably expanded by the 1980s. The authors emphasised that the more trust and cooperation with the Soviet Union was built, the better Hungary could operate flexibly both inside the country and outside in the international arena. Moreover, it stated that in the current situation Budapest should narrow its confrontation with Moscow to the minimum and concentrate on the most important issues (like IMF membership). Regarding the capitalist world, the document stated that market economies would be 'one of the strongest' players in world politics, and in East-West relations the escalation of conflicts would change into an alternation between détente and tensions by the second half of the 1980s. What is quite astounding in the draft is the idea of joining another trade association. It supposed that Budapest would have real a chance during the 1980s to prepare a proper framework agreement with the EEC. Moreover, it stated that '[Hungarian foreign policy] - following an adequate preparation and not demonstratively - could prepare the ground for Hungary's accession to EFTA. In order to ensure the modernisation and effective functioning of the Hungarian socialist economy, these steps will be necessary.' The authors trusted that Budapest would have the opportunity to realise this plan, even though political criticism and protest was expected from both East and West. ${ }^{79}$

The Institute for Foreign Affairs submitted this proposal to the Department for Foreign Affairs of the HSWP CC, where its deputy head, Gyula Horn, reviewed it. He considered the document a collection of embryonic and fragile ideas which could not offer a coherent blueprint for Hungarian foreign policy. Although he criticised several points in the proposal in detail, he did not officially comment on the plan of joining EFTA or concluding an agreement with the EEC. However, in the margin of the document he remarked in pencil, 'these things cannot be done under the table, nor are the others entirely stupid' ${ }^{80}$ This comment may allow a presumption that Horn agreed with the ideas but that he deemed them unrealistic.

This January 1983 plan and its perception unequivocally demonstrate the front lines between the state's "hawks" and the party's "doves". Marjai's circle, the Ministry of Foreign Trade and the top leadership in the Ministry of Foreign 
Affairs preferred to only conclude a commercial agreement with the EEC - with certain prerequisites. Meanwhile the reformist wing of the HSWP, in particular two departments in the Party Centre, intended to conclude a general, demonstrative political agreement with the Common Market to prove Hungary's goodwill and commitment to its most important European commercial partners. ${ }^{81}$ The former grouping still wished to avoid any confrontation with the Soviet Union and the CMEA partner states, while the latter desired to find Western supporters to advance the internal reform process. For a year and a half, the hawks' approach prevailed over that of the doves.

Bilateral negotiations with the EEC developed slowly and hesitantly, maybe due to the absence of a sincere Hungarian intention to compromise. After preliminary soundings in which the Hungarian side tried to spur the Commission to declare an economic offer, Foreign Trade Minister Péter Veress met Commission Vice President Haferkamp on 17 January 1984. Haferkamp expressed the unequivocal political will of the member states to manage a rapprochement with Hungary. Conversely, Veress declared that Budapest would examine different options, including a comprehensive agreement, but was also interested in concluding additional arrangements on agriculture, tariffs and so forth. ${ }^{82}$

Nearly a month later, Trade Minister Veress summarised the aims for the further negotiations. In a 13 February memorandum to Vice Prime Minister Marjai, he paid special attention to the fact that for political reasons the Soviet Union was greatly inconvenienced by (potential) agreements between certain socialist countries and the Common Market apart from sectoral and technical arrangements. He stated that Moscow saw these agreements as a threat to the unity of the CMEA and to the chances of a politically desirable CMEA-EEC general agreement. Veress suggested continuing the talks with Brussels but intended to only submit the issue to the top leadership at the last moment, when an agreement would be close to conclusion. ${ }^{83}$

There is no archival record reporting that any government body discussed Veress' proposal. Marjai himself probably decided that Budapest should show firmness towards Brussels. Presumably, talks the vice prime minister had in Moscow urged him in this direction. During a meeting in the Soviet capital on 23 January 1984, Marjai informed Nikolai Talyzin, Soviet deputy chairman of the Council of Ministers, about the Hungary-EEC negotiations. Talyzin declared that the Romanian agreement with the Common Market opened not only a crack but also a gate in the bloc's principles regarding the EEC. He commended and thanked Hungary for continual information on Budapest's talks with Brussels. Talyzin reminded Marjai that in the current political situation a common action would be the most important goal, and all separate negotiation attempts would weaken these efforts. The Hungarian vice prime minister replied that Hungary would only conclude an agreement if it corresponded with common principles and resulted in relevant gains. ${ }^{84}$

Additionally, the Soviet economic factor was still a hard constraint in the background. It was not possible to disregard the issues of energy supply, the USSR's sizeable market and privileged loans. According to an annual evaluation report 
by the Ministry of Foreign Affairs, in 1983 the Soviet Union had a 34\% share of total Hungarian foreign trade and $17 \%$ of national income was realised in trade with the Soviets. The USSR delivered $90 \%$ of Hungary's crude oil and $95 \%$ of its natural gas and timber imports, and the large Eastern neighbour purchased $50 \%$ of total Hungarian machinery exports and $30 \%$ of its agricultural supplies. Moreover, at a 1983 annual summit Budapest requested the prolongation of a loan of one billion roubles (re-scheduling it from the 1986-90 plan period to the following post-1990 period), but Moscow still floated the issue during spring $1984 .{ }^{85}$ To sum up, the Soviets possessed strong trump cards in their hands to handle the intractable Hungarians. They did not explicitly express their reservations. Instead, they temporarily blocked a shipment or postponed an important meeting at the appropriate moment. Therefore, the Hungarians had to read between the lines to decode Moscow's intentions.

In any case, at the end of February 1984 the Foreign Trade Ministry ordered the commercial counsellor at the Hungarian embassy in Brussels, Péter Balázs, to present a so-called non-paper paper to Haferkamp. This written memo aimed to underscore Hungary's key conditions for any agreement. Budapest reconfirmed that it could not accept any discriminatory measures and asked the EEC to eliminate all 'quantitative restrictions inconsistent with Article XIII of the GATT'. The document also stated that the idea of effective reciprocity was not acceptable. Additionally, the non-paper claimed that a desirable agreement should result in a substantial improvement in export conditions for Hungarian goods. ${ }^{86}$ Some Western partners were shocked by these firm Hungarian demands. As the West German ambassador in Budapest, Norman Dencker, pointed out, Bonn got the impression that the Hungarian government came to a sudden stop in its progress. On 12 March, Dencker reminded Deputy Trade Minister Tibor Melega that a possible agreement between Hungary and the EEC would have political significance. ${ }^{87}$

Despite the disappointment in Brussels, on 23 March Louis Kawan presented the Commission's official proposal to continue the expert negotiations. When Melega reported on these latest developments, he highlighted that Brussels expected an unconditional approach, namely that Budapest should abandon its principles declared in its February non-paper. The deputy minister warned that acceptance of such a condition could discredit Hungary in the eyes of the Soviets: such an appearance may confirm the suspicion that Hungary was in fact not driven by economic but by political motivations. He suggested the following tactic to Marjai: Hungary would send its representatives to the expert-level negotiations but maintain its positions concerning discontinuation of discrimination, rejection of effective reciprocity and so forth. ${ }^{88}$

It is no wonder that the next expert meeting in Brussels on 15-17 May 1984 adjourned without any concrete result. ${ }^{89}$ The Belgian daily Le Soir reporting on these talks characterised the situation perfectly in its headline on 24 May: 'Hungary Approaches the Ten then Retreats: Attraction-Repulsion'.

The HSWP Political Committee's decision on 3 July 1984 in one sense closed an epoch. The committee embraced the statement that Hungary should not initiate 
any further step towards the Community until Brussels suspended its discriminatory and protectionist regulations. However, a loophole was hidden in the voted proposal: the Department for Economic Policy pointed out that a disagreement had emerged between the EEC member states regarding Hungary and suggested that any shift in the Community's standpoint could only be initiated by the largest, most respected countries. ${ }^{90}$ Thus Budapest retreated again but did not burn its bridges with Brussels.

\section{Conclusions}

On 25 July 1985, Foreign Trade Minister Péter Veress retrospectively evaluated the Hungary-EEC unofficial negotiations over the previous two years. First, he prided himself on having continually informed the CMEA states and especially the Soviet Union about these talks. He presented this as evidence of Hungary's fidelity to its allies. Second, he blamed Brussels for its unwillingness to negotiate on the grounds of the GATT agreement. The EEC did not offer special treatment to Hungary and deemed Hungarian demands 'excessively maximalist'. According to Veress, the real reason for the failure of the talks was Brussels' fear that if the Common Market granted concessions to Hungary it would have to grant the same to all the socialist countries, including stronger exporters such as the GDR and Czechoslovakia. ${ }^{91}$

The trade minister's speech showed that in certain cases ideological doctrine still overrode the national interest; political loyalty towards Moscow remained a stronger factor than the expected economic gains of concluding a compromise with the second most important economic partner, the EEC. This notion brings an additional perspective to the general evaluation of the then Hungarian foreign policy. In a broader sense, according to Csaba Békés, Hungary's Western relations dynamically developed during the first half of the 1980s. Indeed, Budapest presented an innovative and initiating foreign policy even in the coolest moments of the period. ${ }^{92}$ László Borhi also emphasises that despite the deterioration in the superpower relations, Hungary was able to preserve the gains achieved in its relationship with the US in $1983-84 .{ }^{93}$ However, it is obvious that a significant discrepancy arose between Hungary's foreign and commercial policies. Békés argues correctly in general terms when he states that the foreign policy was based on a relative independence from the end of the 1970s, with the slogan 'that which is not forbidden may be free' ${ }^{94}$ However, in fact Budapest showed a self-restraining character in its relations with the Common Market, and so its foreign economic policy remained ambiguous and ineffective in this direction.

In comparison with the CMEA partner states, Hungary walked along its own individual path, especially because it remained alone in its radical reforms following the repression of the Prague Spring. The former Polish-Hungarian-Czechoslovak axis no longer worked and divergent interests of the CMEA states prevented the formation of a 'united front' against the Western 'giant monster', the EEC. Instead of coordinated cooperation, the bloc countries essentially became competitors in Western markets. Although Hungarian diplomacy continually closely 
followed the meetings between the Community and the socialist states, Yugoslavia and Romania served as a reference point for Budapest: Belgrade positively and Bucharest negatively. According to the interpretation at the time, the Yugoslavs had the chance to act more independently without additional risks while the Romanians behaved obstinately and impeded any common action. (The latter perception became somewhat softened after the 1980 EEC-Romania agreement.) If one examines the macro-financial vulnerability of Hungary, it belonged to the heavily indebted group within the bloc, together with Poland and the German Democratic Republic. Hungarian bankers did not follow the conservative Czechoslovak borrowing pattern. Therefore, management of the debt crisis to a great extent determined the foreign economic policy targets.

As far as the role of the 'Soviet factor' is concerned, it was at least as important in the Hungarian case as in the East German one, not simply because of Hungary's economic dependence on the Soviet Union but additionally for moral and emotional reasons (predominantly due to 1956). Certainly, what Helmut Schmidt wrote proved to be true: the Hungarian politicians carefully examined the short-term pecuniary advantages of a rapprochement and the long-term hazard of confronting the Soviets, and finally they deemed it safer to stand in line. The previously mentioned dual dependency of the Hungarian economy (Eastern fuels and raw material, Western loans and technologies) required a prudent economic policy after the end of the 1970 s to maintain solvency and internal social stability. Presumably, the Hungarian leadership did not wish to lose Soviet support in exchange for an EEC trade agreement which might generate negligible commercial profit. It is a hypothetical question whether the Hungarian leadership had a real chance of conducting a bolder foreign (economic) policy before Gorbachev. Perhaps not. Maybe the foreign traders had a realistic view. However, party reformers paved the way for later changes.

This chapter has shown that attitudes towards European integration underwent a radical transformation over time. Initially the EEC was depicted as the "economic flank" of NATO, then it was designated as the main obstacle to Hungary's export expansion in the West, and finally it was considered a prospective supporting partner. As has been seen, radically new approaches emerged from the middlelevel expert community in two waves: first, when the trade apparatus identified the problem of improving market access, which led to the GATT accession, and a second time when the younger party apparatchiks recognised the change of context and envisioned a political solution to cut the Gordian knot. The issue of an agreement with the EEC also became a home-front battlefield between the "hawks" and "doves" in the political leadership at the end of the 1970s. Although the reform wing of the HSWP lost this battle in 1983-84, the socialist unity idea irreversibly eroded.

As an indirect consequence of these political discussions, in the mid-1980s a new public discourse was generated regarding terms like "Europe", "Europeanisation", "re-Europeanisation" and the "paradigm of Europe". Hungary's historical roots and geographical place (Central Europe? East-Central Europe? Central Eastern Europe?) were discussed alongside perceptions of the West and the 
emancipation of Eastern Europe. Some experts argued that 'the comprehensive institutional reform of the relations between Hungary and the European Community fit[ted] in the process of the restoration of a geographically and historically determined system of relations' ${ }^{95}$ From 1986 Budapest attempted to manage the disadvantageous consequences of a three-decade-long confrontation with the EEC. By 1989, Common Market membership was still an unreality for Hungary since the country was a member of another alliance system. However, according to Deputy Trade Minister Tibor Melega, a rapprochement towards the European economic development centre was strongly required in order to increase the efficiency of the Hungarian economy. ${ }^{96}$ During the political transformation process in 1989-90, the European Community became the symbol of Europeanism, it embodied peace and prosperity, and it emerged as a target to be achieved which would fulfil the desire of thousands of Hungarians to return to Europe.

\section{Acknowledgements}

I would like to thank Angela Romano, Federico Romero, Suvi Kansikas, Márkus Keller and the entire PanEur1970s project research team for their comments and remarks.

\section{Notes}

1 Lorenz Lüthi considers Hungary's accession to the International Monetary Fund to be a testimony to the Soviet Union's weakness. Lüthi, "Drifting apart," 386.

2 Csaba Békés argues for a 'tripartite determination' that constituted Hungarian foreign policy: the Soviet Union, the West and the 'Eastern European lobby fights'. For details, see Békés, Enyhülés és emancipáció, 192-3. My interpretation also incorporates the global South into the 'determinations' since the unfolding globalisation re-shaped Hungarian foreign policy preferences.

3 Csizmadia, Diskurzus és diktatúra, 24.

4 On Hungary's internationalist missions, see the details in Mark and Apor, "Socialism goes global," 852-91.

5 Mark and Rupprecht, "The socialist world in global history," 91-2.

6 Bartel, "The power of omission," 200-21.

7 Borhi, Dealing with dictators, 193 and 195.

8 Borvendég, Az "impexek" kora, 52-8; Pogány, "Cooperation through the Iron Curtain," 151-9.

9 For details, see Germuska, "Failed Eastern integration," 271-91.

10 Marrese, "Hungarian foreign trade," 36.

11 Győri, "Az EGK-ba," 45-6.

12 Szilágyi, "From ignorance to a (delayed) strategy," 84-105.

13 Garadnai, "A magyar-francia kapcsolatok története De Gaulle," 158-9.

14 Az Országgyülés 15. ülése 1965. február 11-én, csütörtökön. in Az 1963. évi március hó 21-ére összehívott Országgyülés naplója. Vol. I. 1963. III. 21. - 1965. II. 12. (Budapest: 1974), 1065-6.

15 National Archives of Hungary (MNL OL), XIX-J-1-j 1969 2. d. 001628/1969. 174175, 258, "Követi konferencia, 1969. augusztus 25. - szeptember 4."

16 Népszabadság, "Kik akadályozzák a fejlődést? Megjegyzések a közös piaci javaslatokhoz," 29 August 1969, 4. 
17 Records of Radio Free Europe/Radio Liberty Research Institute: Publications Department: Situation Reports; Open Society Archives at Central European University, Budapest (RFE-OSA), HU OSA 300-8-47-101-8, "Situation Report: Hungary," 24 February 1970, 18, accessed 10 February 2020, http://hdl.handle.net/10891/ osa:1fdca935-d0b3-4cec-b895-b05b1a3cc145.

18 RFE-OSA, HU OSA 300-8-47-103-16, "Situation Report: Hungary," 25 April 1972, 6-7, accessed 10 February 2020, http://hdl.handle.net/10891/osa:17fe8ab5-ab6c-493cad13-787968e68b92.

19 RFE-OSA, HU OSA 300-8-47-106-3, "Situation Report: Hungary," 21 January 1975, 6, accessed 10 February 2020, http://hdl.handle.net/10891/osa:e315d209-4d43-4e04$8 \mathrm{e} 95-76 \mathrm{a} 3216 \mathrm{f} 8 \mathrm{a} 83$.

20 RFE-OSA, HU OSA 300-8-47-104-35, "Situation Report: Hungary," 9 October 1973, 11-12, accessed 10 February 2020, http://hdl.handle.net/10891/osa:50409212-176f4c43-a7cf-345e686bf693

21 MNL OL, XIX-J-1-j 1975. 2. d. 00929/27/1975. 178-179, “Jegyzőkönyv a követi konferenciáról. 1975. július 21-24."

22 MNL OL, XIX-J-1-j 1976. 2. d. 005712/1976. 6, 8, “Az 1976. november 23-án megtartott főosztályvezetöi értekezlet jegyzőkönyve."

23 MNL OL, XIX-J-1-j 1978. 2. d. 001660/14/1978, "Kádár János elvtárs beszéde a nagyköveti értekezleten. 1978 július 24"; "Külképviseleteink hivatalos és társadalmi kapcsolatainak helyzete. 1978 július 25" (situation of official and non-official relations of our embassies).

24 MNL OL, XIX-J-1-j 1980. 1. d. 002490/6/1980, “Jegyzőkönyv a követi konferenciáról. 1980. július 28. - augusztus 1."

25 MNL OL, XIX-A-90-c 165. d. . 2-006/26/1968, “Akcióprogram a GATT-tal kapcsolatos további lépésekre. 1968. június 10."

26 MNL OL, M-KS 288. f. 5/407. ő. e. 28, “Jegyzőkönyv a Politikai Bizottság 1966. október 18-án tartott üléséröl."

27 MNL OL, XIX-A-90-c 165. d. 2-002/19/1968, “Kapcsolataink a Közös Piaccal. 1968. április 25."

28 MNL OL, XIX-A-2-gg 249. d., "Feljegyzés a Közös Piacról szóló előterjesztéshez. 1968. május 10."

29 MNL OL, XIX-A-90-c 165. d. 00259/NGKT/68, "Kivonat az NGKB 1968. május 10-i üléséről készült tájékoztatóból"; MNL OL XIX-A-90-a 83. d., "A NGKB 20 022/1968/V.10 sz. határozata. 1968. május 10."

30 MNL OL, XIX-A-90-c 165. d. 2-006/26/1968. Citation 2.

31 MNL OL, XIX-A-90-a 83. d., “A NGKB 20033/1968/VI.21. sz. határozata. 1968. június 21."

32 Historical Archives of the European Union (HAEU), Conseil des Communautés européennes, CM2/1973-2015, "Statement by Mr. Janos Nyerges, Special Representative of the Hungarian Government to International Economic Organisations, at the [GATT] Council Meeting on 23 July 1969." Otherwise, Nyerges was head of the Department for Customs Policy and International Organisations in Ministry of Foreign Trade between 1967 and 1984.

33 MNL OL, XIX-G-3-n 11. d. 1-0010/31/1969, "Beszélgetés Deniau úrral, a Közös Piac Bizottsága külső gazdasági kapcsolatok főigazgatóságának vezetőjével. 1969. szeptember 26."

34 MNL OL, XIX-G-3-n 12. d. 1-0014/54/1970, "Tárgyalásjelentés a du Chateau-val [sic] folytatott beszélgetésröl. 1970. augusztus 13.” In his oral history interview, Duchâteau reported on a meeting with 'director Niergesch' in which they discussed inter-bloc relations. See HAEU, EUI Interview collection, No. 710, Entretien avec Pierre Duchâteau par Yves Conrad et Anaïs Legendre à Bruxelles le 22 décembre 2003, 21.

35 Kostecki, "Hungary and GATT," 402.

36 Martonyi, "Eastern European countries and the GATT," 278. 


\section{Pál Germuska}

37 Földes, Kádár János külpolitikája, vol. 1, 90.

38 MNL OL, XIX-A-90-c 166. d. 2-004/35/1970, "Közös Piac szerveivel kialakított kapcsolataink helyzete és a további feladatok" (Our links with the organs of the Common Market), 7 December 1970.

39 MNL OL, "Közös Piac szerveivel kialakított kapcsolataink helyzete és a további feladatok." For details on these CMEA debates, see Kansikas, Socialist countries face the European Community, 59-81.

40 MNL OL, XIX-A-90-c 166. d. 00217/NGKT/72, "Magyar elgondolások a KGST és a Közös Piac közti kapcsolatok létesítésének kérdéseiről. 1972. február 18."

41 MNL OL, XIX-J-1-j 1972 132. d. 00669/1972, “Magyarország és a Közös Piac. 1972. június 26."

42 Békés, "Hungary, the Soviet Bloc," 109-10.

43 Békés, "Hungary, the Soviet Bloc," 136. For details on the CSCE, see Chapter 2 by Angela Romano in this book.

44 CSCE Final Act, Helsinki 1975, 15, accessed 10 February 2020, www.osce.org/ helsinki-final-act?download=true.

45 Balázs, Az Európai Unió külpolitikája, 413.

46 MNL OL, XIX-A-90-c 166. d. 001217/NKGT/75, “Az Európai Biztonsági és Együttmüködési Konferencia gazdasági kérdései. 1975. szeptember 16.”

47 Földes, Kádár János külpolitikája, vol. 1, 212-13.

48 Takács, "Hungarian foreign policy," 82-4.

49 Csizmadia, Diskurzus és diktatúra, 15.

50 Szita, "A kelet-nyugati kapcsolatok," 34-47.

51 Kozma, "Integráció és gazdasági," 3-12.

52 Kozma, Gazdasági integráció.

53 Csizmadia, Diskurzus és diktatúra, 53 and 62-4.

54 Budapest City Archives (BFL) XIV.43 22. d., "Külgazdasági távlati koncepció - tőkés integrációk." Presumably March 1976. Entail or fee tail: a special form of trust when the founder restricts the sale of real property to keep the estate intact.

55 BFL, "Külgazdasági távlati koncepció - tőkés integrációk."

56 BFL XIV.43 22. d., "Összefoglaló, következtetések.” May 1976.

57 MNL OL, M-KS 288. f. 5/715. ő. e. 29-112, “Előterjesztés a PB-hez a hosszú távú külgazdasági politika irányelveire,1977. március," citation 37.

58 MNL OL, "Előterjesztés a PB-hez a hosszú távú külgazdasági politika irányelveire."

59 Inotai, The EEC at the end of the seventies, 95.

60 Mong, Kádár hitele, 152-9.

61 MNL OL, XXIX-L-1-e 492. d. 411/1978, "Észrevételek a az NGKB részére a KKM által készített előterjesztéshez. 1978. szeptember 2."

62 MNL OL, XXIX-L-1-e 531. d. 247/79, "Megjegyzések a KKM 4-0013/46/1979 sz. NGKB előterjesztéséhez. 1979. július 2."

63 Balázs, Az Európai Unió külpolitikája, 416.

64 Takács, "Hungarian foreign policy," 99-100.

65 "Kereskedelempolitikánk az EGK országokkal az új világgazdasági viszonyok között. 1981. március," in Horváth and Heltai, A magyar-német játszma, 103-12. Yugoslavia signed its first agreement with the EEC in 1970, and Romania in July 1980. For details, see Chapter 9 by Benedetto Zaccaria and Chapter 8 by Elena Dragomir in this book.

66 Horváth and Heltai, A magyar-német játszma, 20.

67 Földes, Kádár János külpoliti, vol. 1, 339.

68 Koltay and Bródy, "Érdemei elismerése mellett . . .," 90.

69 MNL OL, M-KS 288. f. 47. cs. 765. ö. e., "Engere Zusammenarbeit zwischen Ungarn und den Europäische Gemeinschaften. 18. Dezember 1981" (letter from Helmut Schmidt to János Kádár), 210-14.

70 Horn, Cölöpök, 142.

71 Horváth and Németh, ... és a falak leomlanak, 176. 
72 MNL OL, XIX-A-2-af 40. d. Ma-004/94/82, “Gazdaság- és kereskedelempolitikánk a Közös Piac irányában, továbbfejlesztésének lehetőségei. 1982. április."

73 MNL OL, XIX-A-39-b 37. d. 00941/45/1982, "Gazdaság- és kereskedelempolitikánk a Közös Piac irányában, továbbfejlesztésének lehetőségei. 1982. június 7.”

74 Mong, Kádár hitele, 187-211. Hungary received the much-desired stand-by credit in December 1982. Mong, Kádár hitele, 214.

75 MNL OL, XIX-J-1-j 1983 117. d. 004569/1982, "Lázár és Tyihonov elvtársak megbeszélése 1982. június 9-én."

76 MNL OL, XIX-A-39-b 25. d., "A Gazdasági Bizottság 10129/1982. sz. határozata. 1982. szeptember 1."

77 Balázs, Az Európai Unió külpolitikája, 417. The protocols of the GATT Thirty-Eighth Session Ministerial Meeting on 24-29 November 1982 do not mention such an initiative, accessed 10 February 2020, https://docs.wto.org/gattdocs/q/1981_85.htm.

78 See the statement by H.E. Mr. Peter Veress, Minister of Foreign Trade of Hungary, accessed 10 February 2020, https://docs.wto.org/gattdocs/q/GG/SPEC/82-120.pdf.

79 MNL OL, M-KS 288. f. 32/b cs. 105. ö. e. 66-83, "A nyolcvanas évek és a magyar külpolitika. 1983. január 7," citation 79.

80 MNL OL, M-KS 288. f. 32/b cs. 105. ö. e. 84-87. "Vélemény A magyar külpolitika a 80-as években címü anyagról. 1983. február 24." Citation, MNL OL, M-KS 288. f. 32/ b cs. 105. ö. e. 79 .

81 This standpoint is articulated particularly in memoirs by the HSWP's reformists, for example Gyula Horn. See Horn, Cölöpök, 139-43; István Horváth, see Horváth and Németh, ... és a falak leomlanak, 176-86.

82 MNL OL, XIX-A-2-af 187. d., "Tárgyalás Wilhelm Haferkamppal, a Közös Piac Bizottságának alelnökével. 1984. január 19."

83 MNL OL, XIX-A-2-af 187. d., "Elgondolások az EGK-val folytatandó tárgyalásokhoz. 1984. február 15."

84 MNL OL, XIX-A-2-af 187. d., "Rövidített jelentés Marjai és Talizin elvtársak között [1984.] január 23-án folytatott megbeszélésről."

85 MNL OL, XIX-J-1-j 1984 133. d. 002096/1/1984, "Magyar-szovjet kapcsolatok. 1984. április."

86 MNL OL, XIX-A-2-af 187. d. 185/Ap., "Válasz Haferkamp alelnöknek. 1984. február 22."

87 MNL OL, XIX-A-2-af 187. d. M-296/2-17/984, "Emlékeztető Norman Dencker nyugatnémet nagykövettel 1984. március 12-én folytatott megbeszélésemröl."

88 MNL OL, XIX-A-2-af 187. d. 820/Me., "Újabb fejlemények az EGK-val való kapcsolatokban. 1984. március 29."

89 Balázs, "Trade relations between Hungary and the European Community," 65 and 73.

90 MNL OL, M-KS 288. f. 5/915. ő. e. 4, 48-54, "Jegyzőkönyv a Politikai Bizottság 1984. július 3-án megtartott üléséről."

91 MNL OL, XIX-J-1-j 1985. 2. d. 001700/5/1985. 57-59, “Jegyzőkönyv a követi konferenciáról. 1985. július 25-26."

92 Békés, Enyhülés és emancipáció, 306-7.

93 Borhi, Dealing with dictators, 330.

94 Békés, Enyhülés és emancipáció, 332.

95 Wéber, "Europe as conceptualised by the Hungarian elite," 314.

96 Melega, "Hogyan tovább?," 24.

\section{Bibliography}

\section{Published primary sources}

Az 1963. évi március hó 21-ére összehívott Országgyülés naplója. Vol. I. 1963. III. 21. 1965. II. 12. Budapest, 1974. 


\section{Secondary sources}

Balázs, Péter. "Trade Relations between Hungary and the European Community." In The political and legal framework of trade relations between the European Community and Eastern Europe, edited by Marc Maresceau, 55-74. London: Martinus Nijhoff, 1989.

Balázs, Péter. Az Európai Unió külpolitikája. Budapest: Wolters Kluwer, 2016.

Bartel, Fritz. "The power of omission. The IMF and the democratic transitions in Poland and Hungary." In New perspectives on the end of the Cold War: unexpected transformations?, edited by Bernhard Blumenau, Jussi M. Hanhimäki and Barbara Zanchetta, 200-21. London: Routledge, 2018.

Békés, Csaba. "Hungary, the Soviet Bloc, the German Question and the CSCE Process, 1965-1975." Journal of Cold War Studies 18:3 (2016): 95-138.

Békés, Csaba. Enyhülés és emancipáció. Magyarország, a szovjet blokk és a nemzetközi politika 1944-1991. Budapest: Osiris, 2019.

Borhi, László. Dealing with dictators: The United States, Hungary, and East Central Europe, 1942-1989. Bloomington: Indiana University Press, 2016.

Borvendég, Zsuzsanna. Az “impexek” kora. Budapest: Nemzeti Emlékezet Bizottsága, 2017.

Csizmadia, Ervin. Diskurzus és diktatúra. A magyar értelmiség vitái Nyugat-Európáról a késői Kádár-rendszerben. Budapest: Századvég, 2001.

Földes, György. Kádár János külpolitikája és nemzetközi tárgyalásai 1956-1988. Budapest: Napvilág, 2015.

Garadnai, Zoltán. "A magyar-francia kapcsolatok története De Gaulle tábornok elnöksége alatt, 1958-1969.” Külügyi Szemle 10:4 (2011): 157-72.

Germuska, Pál. "Failed Eastern integration and a partly successful opening up to the West: the economic re-orientation of Hungary during the 1970s." European Review of History 21:2 (2014): 271-91.

Győri, Borbála. “Az EGK-ba irányuló élelmiszergazdasági exportunkról.” Bankszemle 30:1 (1986): 45-9.

Horn, Gyula. Cölöpök. Budapest: Móra, 1991.

Horváth, István and András Heltai. A magyar-német játszma. Emlékezés és dokumentumok. Budapest: Corvina, 2015.

Horváth, István and István Németh. . . és a falak leomlanak: Magyarország és a német egység, 1945-1990. Legenda és valóság. Budapest: Magvetö, 1999.

Inotai, András. The EEC at the end of the seventies: Western European integration in the new world economic environment. Budapest: Magyar Tudományos Akadémia Világgazdasági Intézet, 1979.

Kansikas, Suvi. Socialist countries face the European Community: Soviet-bloc controversies over East-West trade. New York: Peter Lang, 2014.

Koltay, Gábor and Péter Bródy. “Érdemei elismerése mellett . . .” Beszélgetések Havasi Ferenccel. Budapest: Szabad Tér, 1989.

Kostecki, Maciej. "Hungary and GATT.” Journal of World Trade Law 8:4 (1974): 401-19.

Kozma, Ferenc. "Integráció és gazdasági együttmüködés Európában." Külpolitika 2:3 (1974): 3-12.

Kozma, Ferenc. Gazdasági integráció és gazdasági stratégia. Budapest: Közgazdasági és Jogi Könyvkiadó, 1976.

Lüthi, Lorenz M. "Drifting apart: Soviet energy and the cohesion of the communist bloc in the 1970s and 1980s." In Cold War energy: a transnational history of Soviet oil and gas, edited by Jeronim Perović, 371-400. London: Palgrave Macmillan, 2017. 
Mark, James and Péter Apor. "Socialism goes global: decolonization and the making of a new culture of internationalism in Socialist Hungary, 1956-1989." Journal of Modern History 87:4 (2015): 852-91.

Mark, James and Tobias Rupprecht. "The socialist world in global history. From absentee to victim to co-producer." In The practice of global history: European perspectives, edited by Matthias Middell, 81-113. London: Bloomsbury, 2019.

Marrese, Michael. "Hungarian foreign trade: failure to reform." In The challenge of simultaneous economic relations with East and West, edited by Michael Marrese and Sándor Richter, 23-57. Basingstoke: Macmillan, 1990.

Martonyi, János. "Eastern European countries and the GATT." In The political and legal framework of trade relations between the European Community and Eastern Europe, edited by Marc Maresceau, 269-83. Dordrecht: Martinus Nijhoff, 1989.

Melega, Tibor. "Hogyan tovább? Gondolatok az Európai Közösséghez füződő kapcsolatainkról." Külpolitika 16:3 (1989): 24-32.

Mong, Attila. Kádár hitele. A magyar államadósság története 1956-1990. Budapest: Libri, 2012.

Pogány, Ágnes. "Cooperation through the Iron Curtain: economic relations between Austria and Hungary after the Second World War." In Gaps in the Iron Curtain: economic Relations between Neutral and Socialist Countries in Cold War Europe, edited by Gertrude Enderle-Burcel, Piotr Franaszek, Dieter Stiefel and Alice Teichova, 142-62. Krakow: Jagiellonian University Press, 2009.

Szilágyi, Gábor. "From ignorance to a (delayed) strategy: Hungarian communists and European Integration, 1957-1989." In Kommunismus und Europa: Europapolitik und vorstellungen europäischer kommunistischer Parteien im Kalten Krieg, edited by Francesco Di Palma and Wolfgang Mueller, 84-105. Paderborn: Schöningh, 2016.

Szita, János. "A kelet-nyugati kapcsolatok és az integrációs folyamatok gazdasági és politikai összefüggései Európában.” Külpolitika 1:1 (1973): 34-47.

Takács, Róbert. "Hungarian foreign policy and Basket III in the Cold War confrontation from Helsinki to Madrid." Múltunk 64, Special Issue (2019): 59-106.

Wéber, Attila. "Europe as conceptualised by the Hungarian elite in the late 1980s." In Influences, pressures pro and con, and opportunities: studies on political interactions in and involving Hungary in the twentieth century, edited by Zoltán Ripp, 305-37. Budapest: Napvilág, 2014. 


\title{
4 From 'Economic Miracle' to the 'Sick Man of the Socialist Camp' \\ Poland and the West in the 1970s
}

\author{
Aleksandra Komornicka
}

The 1970s were a particular decade in Polish history. In December 1970, an economic and political crisis resulting from price increases led to the dismissal of Władysław Gomułka as head of the Polish United Workers' Party (PUWP) and the appointment of a new leadership. Edward Gierek's takeover of power symbolised a new beginning and hope for constructive reforms in Poland. Nevertheless, ten years later in August 1980, Gierek and his political agenda were also dismissed in a context of economic and political crisis. However, despite some similarities, Poland's situation in the summer of 1980 was very different to that before Christmas in 1970. Strikes were no longer spontaneous worker demonstrations but instead a coordinated cross-country movement supported by powerful dissident organisations. Moreover, this time the protesters demanded not only an improvement in economic and labour conditions but also human rights, such as freedom of speech, which the socialist regimes had committed to respecting in the Final Act of the CSCE, signed in August 1975. The economic situation which underlaid the political upheaval was additionally complicated by $\$ 22$ billion in debts owed to Western creditors which had accumulated over the previous ten years. Unlike in 1970, the crisis could hardly be explained without considering Western influence or be handled independently of Western actors. The ties between socialist Poland and the capitalist world were the most irreversible outcome of Gierek's decade.

Despite the paramount impact which the unprecedented opening up towards the West had on the situation of the Polish socialist regime, it has rarely been studied as an independent phenomenon. ${ }^{1}$ Instead, the historiography of the 1970 s deals predominantly with the two crises, their origins and consequences. ${ }^{2}$ The emphasis on revolts against the regime, however, results in a perception of political decisions, including those concerning economic and foreign policy, being solely responses to pressure from society. The strategy of the Polish socialist elite is therefore usually regarded as a constant balancing of claims by the population on the one hand and commands arriving from the Soviet Union on the other. However, looking at the socialist regimes from a comparative perspective allows the differences between national strategies to be highlighted and therefore the socialist elites to be rediscovered with their convictions, interpretations and goals as agents of the diversified trajectories of the Eastern European states in the 1970s. 
This study contributes to this task by reconstructing the strategy of the Polish socialist elite and its dynamics between the 1970 and 1980 crises, a period marked by international détente and accelerating globalisation. While in these circumstances all the European socialist regimes increased their cooperation with the capitalist countries, aiming to improve their international and economic situations, Poland was not only the frontrunner in exchanges with the actors on the other side of the Iron Curtain but also was the country which ended the decade with the most spectacular economic and political crisis. As a consequence, in the Polish case, alongside scrutinising the motivations and expectations behind the policy of opening up, the question also arises concerning the exaggerated scale of this phenomenon.

This chapter argues that the opening towards the West was an outcome of the socialist elite's ambition. This sentiment, which was driven by the traditional Polish aspiration for international grandeur, was reinforced in the 1970 s by confidence that the socialist state, even though unreformed, could experience an economic revival and that détente would remain a permanent feature of international relations. However, as problems accumulated, the groups of policymakers who shared these assumptions became increasingly small. The history of Poland in the 1970 s is therefore not only a history of the escalating influence of Western actors on the domestic situation but also a history of internal decomposition caused by declining confidence and unity among the socialist elite.

\section{Towards détente, the late 1960s}

Poland was one of the socialist regimes most politically, economically and culturally linked with Western Europe before the Second World War. While during the Stalinist years these economic exchanges almost disappeared, unofficial ties persisted. Polish emigration, on a scale and with an influence unseen in the cases of the other socialist regimes, played an essential role in maintaining private and cultural connections with the other side of the Iron Curtain. In this sense, Polish society exerted persistent pressure on the leadership to open up and positively welcomed any sign of rapprochement between the two parts of the continent.

At the official level, a major revival of Polish cooperation with capitalist countries took place after 1953 thanks to the process of de-Stalinisation. The idea of a national way to socialism, which triumphed in 1956 with the takeover of power by Gomułka, who had been imprisoned between 1951 and 1954 under allegations of national deviation, allowed Poland to loosen its dependence on Moscow and enhance its activity in the international arena. ${ }^{3}$ Relying on his initial massive domestic support, the new first secretary of the PUWP openly rejected Soviet pressure concerning, for instance, collectivisation, which eventually failed to cover more than $11 \%$ of the land overall. ${ }^{4}$ His insubordinate position, however, often drove him into conflict with the Soviet Union, which did not hesitate to threaten Poland economically with cuts in the supply of resources. ${ }^{5}$

In this context, the idea of expanding relations with the capitalist countries emerged as a means of counterbalancing Poland's risky economic reliance on 
Moscow. Aiming to secure room for independent manoeuvre through hardcurrency income, Poland increased its exports of agricultural products and raw materials to the West. Gomułka considered the mining industry to be particularly important in guaranteeing Poland's international position. The focus on industrialisation but overlooking both innovation and domestic consumption, however, already in the mid-1960s resulted in economic stagnation. In this period, the Western countries appeared not only as recipients of Polish exports but also as an important source of new technology, and in some cases consumer products, which were repeatedly lacking in the domestic market. In order to facilitate these imports and the access of Polish goods to Western markets, in 1967 Poland joined the General Agreement on Tariffs and Trade (GATT), becoming the second socialist state in the organisation after Czechoslovakia. Similarly, in the late 1960s it reached bilateral trade agreements with France and the UK. In total, between 1966 and 1970, the level of economic exchange with the capitalist countries rose by around one third. ${ }^{6}$

Gomułka's opening up was, however, limited. Despite developing foreign trade, the level of exchange with capitalist countries was never intended to come close to that with the CMEA members, which were envisaged by the leadership as the main receivers of Polish exports and the main pillar of Polish economic development. ${ }^{7}$ During the late 1960s, Poland, alongside Hungary, became a main advocate for a reform of the organisation and further economic integration between the socialist states. ${ }^{8}$ The aversion of Gomułka's leadership towards engaging closer with Western countries was especially apparent in the case of foreign loans. In the late 1960s Polish indebtedness was among the lowest in Europe. During a meeting devoted to the difficult economic situation in early 1970, Gomułka and his closest collaborators fiercely rejected the possibility of taking Western credit, motivating this position with the risk of entering a trap of indebtedness or even 'walking on the leash of capitalism'. ${ }^{9}$ Instead, the leadership aimed to improve the economic situation through balanced economic exchanges and increasingly severe austerity measures.

The reluctance to expand cooperation with capitalist countries was largely determined by unregulated political relations with the Federal Republic of Germany (FRG). The lack of recognition of Poland's western border on the OderNyssen line together with tragic memories of the Nazi occupation of Poland which were shared not only by the leadership but also the population fuelled the official antagonism towards West Germany and consequently Western Europe as a whole. Despite the establishment of a trade representation in Cologne in 1963, in this period Poland aimed to limit political rapprochement between the socialist countries and the FRG. ${ }^{10}$ Instead, Gomułka lobbied for a security conference which would confirm the territorial status quo in Europe and which he considered a preliminary condition for European détente. ${ }^{11}$

Alongside the unresolved problem of the German border, the hesitance of the 1960s leadership concerning further expanding East-West cooperation is often associated with the first secretary himself, or more broadly with his generation, which then dominated the political structure. As is widely recognised, Gomułka's 
leadership in the late 1960s was marked by authoritarian methods, a limited inflow of challenges to the line he imposed and a concentration of policymaking in the small circle of politburo members. ${ }^{12}$ Furthermore, this group consisted primarily of communists who had been politically trained in the interwar period and who were shaped by both the experience of the Second Polish Republic, a state economically dependent on the West and classical Marxist thought in which economic accumulation was a necessary condition for political independence. They therefore remained reluctant to expand contacts with capitalist countries.

A generational change and a gradual inflow of younger politicians, whose political views already originated in socialist Poland, challenged the older communists' monopoly of power. The events of March 1968, when the anti-Zionist narrative of the socialist states related to the Arab-Israeli war was used as a tool for party purges, played a major role in this respect. ${ }^{13}$ The anti-Semitic campaign aimed at older communists of Jewish origin led to the removal of around a third of the party and government elite. ${ }^{14}$

Moreover, the events of 1968 significantly damaged Gomułka's authority and allowed the rise of alternative factions within the party. The first of these, labelled 'partisans' and defending extreme national views such as strong hostility to West Germany, predominantly included party members linked with the secret services, most notably Mieczysław Moczar, a former minister of internal affairs. The other 'Silesians' gathered around Gierek, a politburo member widely known for a modernisation programme he executed as the regional party leader in Silesia. Unlike the majority of the socialist elite at the time, Gierek experienced his political formation in the communist parties of France and Belgium, where he grew up and worked as a miner ${ }^{15}$ His faction mostly attracted the regional PUWP apparatuses and the managerial elite.

The negative attitude of Gierek's supporters to the leadership in place had its source in Gomułka and his closest co-operators' strategy of 'selective development' of the late 1960s for the new five-year plan for 1971-75. This policy attempted to focus exclusively on a few branches of economic production and marginalised others, which naturally resulted in opposition coming from the unprivileged sectors. Among other losses, the groups related to these industries were supposed to have limited access to new Western technologies, which they traditionally demanded. ${ }^{16}$ Tadeusz Wrzaszczyk, an engineer and the head of the Polish automobile industry association 'Polmo' in the late 1960s, was the most influential representative of these circles and became well known for his lobbying for the motorisation of Poland. Gomułka considered cars an unnecessary luxury good, contradictory to the very idea of socialism. ${ }^{17}$ On the contrary, already in the late 1960s Gierek openly supported Wrzaszczyk's proposals. ${ }^{18}$

The question of motorisation became an emblematic battle over visions of the regime's future, attracting not only industrial managers and politicians but also experts in the state apparatus, above all in the Planning Commission, and in academic institutions such as the Main School of Planning and Statistics. Within these groups, the most open supporting voice arrived from Józef Pajestka, professor of economics and deputy chief of the Planning Commission since 1968. ${ }^{19}$ 
Not only did he advocate mass motorisation and point out its numerous strengths for the economy, but he also triggered a debate about the 'socialist model of consumption'. ${ }^{20}$ This long-lasting discussion between party-related and more independent experts and also professional journalists increasingly revealed growing discontent with the economic austerity implemented in the late 1960s, pointing to shortages, low quality and the limited offer of accessible supplies. ${ }^{21}$ Many of the economic experts participating in the debate, including Pajestka himself, advocated a policy of intensification of economic growth and technological modernisation which would move Poland towards a second phase of industrialisation in which the quality and modernity of production was expected to replace its quantity. ${ }^{22}$ The Japanese model of fast modernisation through technology transfers was considered a possible example for Poland. ${ }^{23}$ Postulates concerning modernisation, foreign technology and consumption often appeared on the pages of two weeklies: Polityka (Politics), edited since 1958 by Mieczysław Rakowski; and Życie i Nowoczesność (Life and Modernity), established in early 1970 and edited by Stefan Bratkowski. While both editors-in-chief were PUWP members and subject to censorship, their newspapers represented liberal and reformist outlets of the socialist elite.

Gomułka's policy was finally challenged by the détente agenda in Western Europe. In March 1969, several Western European leaders positively welcomed the Budapest Appeal for a European Security Conference issued by the socialist states. In September, the results of elections in the FRG brought the Social Democratic Party of Germany (SPD) to power. The new chancellor, Willy Brandt, advocated a policy of bringing the two parts of the continent closer and among other things started negotiations with the Polish leadership on a bilateral treaty. This period witnessed a substantial change in attitudes to the FRG, and as a consequence to Western Europe as a whole, which found reflection in the party's theoretical monthly Nowe Drogi (New Paths). In late 1968 and early 1969, the journal still emphasised links between the US and the FRG and evidenced their 'imperial' and 'Cold War' aims. ${ }^{24}$ By September 1970 Brandt's policy was classified as a force for peaceful coexistence. ${ }^{25}$ Although the visible change in the official narrative might be interpreted as an effort to rationalise the ongoing negotiations with West Germany, it still signalled a major shift in the ideological framework of the Polish socialist regime, which traditionally legitimised itself with the threat of German revisionism. In this context, the treaty of 7 December 1970 in which FRG accepted Poland's western border on the Oder-Neisse line was widely recognised as a historical breakthrough. ${ }^{26}$

Gomułka and his closest collaborators expected this diplomatic success to improve their popularity and facilitate the austerity measures they planned to introduce a few days later. ${ }^{27}$ On 12 December, the leadership increased the prices of basic alimentary products, most notably of meat. The decision led to social upheavals on a scale previously unseen in Poland's socialist history. Brutal suppression of workers' demonstrations in the coastal region executed by the army resulted in the dismissal of Gomułka and the appointment of Gierek as PUWP first secretary. This course of events, however, remains an object of historical debate. Views vary from opinions that Gierek did not expect to become first secretary 
to opinions that he himself triggered the political crisis or that his victory was planned in advance in Moscow. ${ }^{28}$ In any case, the dismissal of Gomułka and the arrival of Gierek might be seen as a reflection not only of political manoeuvring but also of ideas present in the party. The choice of him was a victory over other agendas popular among the socialist elite, in particular those represented by the nationalist "partisan" faction.

Despite developing foreign trade, Gomułka's leadership had remained hesitant about engaging more closely with capitalist states until the very end. However, the last years of the decade brought increasing challenges to the official policy arriving from the evolving international situation and from different groups among the socialist elite. Many arguments raised during that period signalled the direction of upcoming changes in the early 1970s.

\section{A new ambitious strategy, 1971-72}

In addition to the new first secretary, replacements of personnel in the party and the government took place which continued the generational change in the leadership initiated in 1968. In total, in 1971 ten of the sixteen members of the politburo lost their positions, as did half of the ministers and presidents of commissions in the government, in what has been labelled a 'revolutionary' reshuffle. ${ }^{29}$

However, while the manner and speed of personnel replacements might have had a revolutionary character, they did not foreshadow a revolutionary change in the political line. Despite the removal of Gomułka and his closest collaborators, still around half of the leadership, including Gierek, had been part of the previous cohort. This was also the case of the new prime minister, Piotr Jaroszewicz, who held this position throughout the 1970s. As vice prime minister and Polish representative to the CMEA for many years, Jaroszewicz was definitely not new to the socialist leadership. Similarly, Stefan Jędrychowski, a member of the government since 1945 and of the politburo since 1954, kept his position in the main decisionmaking bodies, first as minister of foreign affairs and after 1972 as minister of finance, as did Wojciech Jaruzelski, who had been active in the Polish army since the Second World War and became its general in 1956 and was minister of national defence and a member of the politburo throughout the 1970s. Although in 1971 Gierek marginalised Moczar within the leadership, many of his associates remained in place and acquired new positions. For instance, Franciszek Szlachcic, who was very influential in secret-service circles, joined the new politburo while Stefan Olszowski took over the Ministry of Foreign Affairs in late 1971. The common characteristic of the majority of the newly promoted party and government members, including both those mentioned earlier, was their political training in the Union of Polish Youth, a formation inspired by the Soviet Komsomol which existed in the Stalinist period. Resulting from this education, younger members of the leadership often presented highly ideological attitudes.

Nonetheless, Western governments and media quickly labelled the new Polish leadership 'technocratic'.${ }^{30}$ Indeed, the renewed composition of the key political bodies brought to power engineers, academics and professionals in their fields. 
Among others, this was the case of Wrzaszczyk, the new minister of machinery industry; Tadeusz Olechowski, who became minister of foreign trade after over twenty years of a professional career in foreign trade ventures and trade representations; Henryk Kisiel, who after serving at the National Bank for over twentyfive years first led the Trade Bank and then became minister of finance in the 1970s; and Pajestka, who had a position in the Planning Commission.

The professionalisation of the leadership was accompanied by institutional change. Already in January 1971, the politburo issued a document regarding a need for increased parliamentary activity. ${ }^{31}$ This very early decision laid the ground for a rise in the government's influence, especially over economic matters, eventually marginalising the party apparatus in this respect. Given the overlap between the politburo and government members, at first glance this change might not appear relevant. Indeed, throughout the decade over a half of the politburo members also held ministerial positions. The leading role of the government, however, allowed the rise of people who had never pursued careers in the party structures, like Wrzaszczyk. The increase in government influence also meant a growth in the independence of particular ministries. Already in the first years of the 1970s, many of them officially widened their competences and therefore secured broader autonomy from the centre. ${ }^{32}$

Apart from improving existing institutions, the leadership aimed to establish new ones. In February 1971, the politburo decided to create a Commission for the Modernisation of the Economy and State Functioning - Szydlak's Commission, named after its supervisor, Jan Szydlak, one of Gierek's closest co-operators from Silesia. Over two hundred politicians, experts and professionals were gathered in ten different sections of the body to provide the party and government with effective solutions to tackle the most pressing problems. Also in 1971, for the first time in Polish socialist history the first secretary named a personal advisor. Zdzisław Rurarz was a graduate from the Main School of Planning and Statistics and a former employee of the Ministry of Foreign Trade with impressive international experience, including a career in Polish representation at Geneva dealing with the GATT and the United Nations Conference on Trade and Development (UNCTAD).

As is often stressed in testimonies from the decade, the new first secretary did not bring any ready-made programme but worked out a plan during his first year in power. ${ }^{33}$ In this context, the increasing involvement of broader groups of the socialist elite became critical for the new agenda. Nevertheless, Polish histography often dismisses the technocratic character of policymaking in the 1970s. ${ }^{34}$ However, when compared with other socialist states such as Bulgaria and Hungary, where power was still concentrated in the hands of older generation communists, the new leadership and its governing methods stand out as unique. ${ }^{35}$ The new management model was expected to improve the domestic situation and enable the successful implementation of a new agenda despite the principal ideological and personal continuities.

Already on 19 December, Gierek communicated a shift in economic strategy to the public by promising in a TV appearance to improve the quality of life. The 
following day, the politburo decided to increase salaries and social benefits. These immediate actions were followed in January by a price freeze to the same level as before the 1970 rise. Further development of this agenda took place over the following year and resulted in a radical revision of the five-year plan for 197175 prepared by the previous leadership. Doubling the figures in the previous version, the new plan envisaged a rise in salaries of $18 \%$ and a $40 \%$ growth in consumption. ${ }^{36}$

Scholars usually see these decisions as an immediate response to the crisis and a means of securing social stability. ${ }^{37}$ While this logic undoubtedly drove the immediate reactions and above all the cancellation of the price rise, it fails to explain the model of consumption proposed by the new leadership. Rather than efficiently improving the accessibility of foodstuff, as the protesters demanded in December 1970, the new five-year plan focused on enriching the supply of more sophisticated consumer goods, including electronics and machinery, thus responding to the postulates raised by experts in the late 1960s. Already in February 1971, the leadership started to explore the possibility of purchasing a licence to produce a widely accessible personal car, which materialised in a deal with Italian Fiat signed later in the year. Purchases of licences for many other consumer products including tape recorders, buses and colour TV sets followed. Given that the country was slowly emerging from economic turmoil, the decisions to initiate complex production and increase imports of machinery appear bold rather than necessary.

Moreover, the new model of consumption went further than improving the accessibility of goods. For example, the renewed five-year plan proposed a 17\% rise in expenditure on tourism, leisure and sport. ${ }^{38}$ Already in 1972, the leadership introduced the first free Saturdays and the annual number of them rose systematically through the decade. ${ }^{39}$ The proposed model of life based on leisure, free time and the widespread accessibility of consumer products differed from that of the 1960s. As Rurarz recalls, he suggested to Gierek that he should call this programme a new official socialist doctrine of 'mass consumption'. The first secretary, however, objected to the proposal for ideological reasons ${ }^{40}$ Although since the 24th Congress of the CPSU the Soviet leadership had also aimed to improve the quality of life, it still regarded the concept of consumption as a capitalist state perversion. According to Rurarz, an article he wrote for Nowe Drogi, in which he praised the new consumption model, caused significant controversy among Soviet officials, who became sceptical about his advisory role to the first secretary. ${ }^{41}$ In the article, he stated among other things that "cars and comfortable apartments will become accessible for everyone... To the mass tourism of those [Western] societies we will reply with our mass tourism' ${ }^{42}$

Alongside improving the quality of life, the new leadership aimed to intensify economic growth and thus fulfil the ideological requirements of the socialist regimes concerning continual industrialisation. The revised five-year plan increased the envisaged $6 \%$ annual growth to $9 \% .{ }^{43}$ The document also dismissed the proposal for 'selective development' from the 1960s, instead introducing balanced growth in all sectors. Alongside the advancement of industries producing consumer goods, 
the leadership initiated new investments in heavy industry. The most spectacular ones were in the Katowice Steelworks and the Gdańsk Refinery, both launched in 1971. Moreover, the government encouraged both new and more traditional industries to look for modern technology abroad. ${ }^{44}$ The five-year plan named imports of Western technology one of the principal pillars of the new programme and recommended using licences to establish more long-term cooperation agreements with Western companies. The document assessed that the lack of ties with foreign industries had often limited Poland's production ability and recommended doubling expenditure on this kind of agreements. ${ }^{45}$ The impetus of the modernisation programme of the early 1970 s stimulated comparisons with the demanding first six-year plan implemented after the Second World War. ${ }^{46}$ Moreover, the Japanese development model based on technology imports and intensified economic growth, which was praised by experts already in the late Gomułka period, explicitly resonated in official documents from the early 1970s. ${ }^{47}$

While the new leadership responded to pressures from regional PUWP apparatuses and the managerial elite securing the internal cohesion of the party, its proposals concerning intensified economic growth carried many risks. Combining intensified economic growth with a similarly ambitious rise in consumption violated the assumptions of the socialist economy, which regarded the simultaneous development of both as exclusive. Moreover, the experience of the previous decades spoke against exaggerated economic goals. The new plan also openly encouraged closer links with companies in the capitalist countries, disregarding the possibility of dependency on Western industries. Finally, in the post-crisis reality Polish accumulated capital was not sufficient to achieve these ambitious aims. From early 1971 onwards, it was clear that the new strategy critically depended on foreign loans.

The politburo explored Western credit opportunities immediately. ${ }^{48}$ The new economic plan for 1971-75 was initially expected to allow Poland to extend its debt to 9 billion exchange złotys - over twice as much as was proposed in the late 1960s. A strong preference was given to investment credits, but consumption credits were also acceptable from 1971 onwards. ${ }^{49}$ This policy encountered an especially strong backlash from the highly positioned members of the previous leadership, including Gomułka himself, who in an emotional letter to the PUWP Central Committee blamed the new leadership for 'eating from someone else's plate'. ${ }^{50}$ On the other hand, according to testimony from Piotr Kostikow, head of the Polish department in the Central Committee of the CPSU, Moscow not only allowed but recommended the Polish leadership to look for credit opportunities in the West. ${ }^{51}$ Undoubtedly, in the early years of the decade the Polish leadership informed Moscow about its economic plans concerning credits and regularly consulted on its political choices. ${ }^{52}$

Given the scale of the envisaged debt, long-term repayment schedules and the launch of costly new investments, the success of the new economic agenda was conditioned on efficient trade with the capitalist countries. The new five-year plan forecast a $57 \%$ increase in foreign trade volume, including $55 \%$ in exports. ${ }^{53}$ These goals were not only already higher than those assumed in the late 1960s, 
but also surprising given the experience of unfulfilled export promises in previous economic plans. ${ }^{54}$

While expecting an improvement in economic performance, the new agenda did not entail significant systemic reforms. As already mentioned, the newly established Commission for the Modernisation of the Economy and State Functioning was expected to propose more general changes in this respect. Its activity was, however, ideologically limited. As Szydlak, the head of the Commission, stated during a meeting, 'First of all, we will not be making any noise, any propaganda noise. As you all well know, comrades, we are under constant fire, both from within the country and from the outside, so we will not make any noise. Economic reforms are the least suited to propaganda noise' ${ }^{55}$ According to testimonies from the decade, ideological concerns constrained implementing proposals from the Commission. ${ }^{56}$ Similarly, the idea of fashioning the Polish economic system on the Hungarian or Yugoslavian models, which had supporters among the socialist elite, remained at the level of unofficial debates. ${ }^{57}$ In the aftermath of the suppression of the Prague Spring and the rise of the Brezhnev doctrine, reform of the system became a taboo for the Warsaw Pact members. ${ }^{58}$

Members of the leadership were well aware of the bold character of the new agenda. As Jaroszewicz framed it when referring to the new economic plan: 'We have to conclude that the plan is not smooth and easy. It is bold and ambitious and contains many difficulties and risks' ${ }^{59}$ During discussion on how to present the new agenda to society, Stanisław Trepczyński, a diplomat, highlighted that 'a big novelty is the vision of our industrial modernisation on a scale unseen before. This includes the question of foreign debt and licenses and other things which used to be a deadly sin to think of, and we are not afraid of them'.${ }^{60}$ Interestingly, the ambition and confidence underlying the new economic strategy were also expected to serve as a means of mobilising society and improving the popularity of the socialist elite. This logic stood behind famous propaganda slogans, such as 'Poland, the 10th global industrial power' and 'We are building a second Poland', which originated in that period. ${ }^{61}$

A bold international agenda accompanied the new five-year plan. The new guidelines for foreign policy expected Poland to become the most influential socialist state in Europe after the Soviet Union. The document considered Europe as a primary field of Polish diplomatic activity, identified the EEC as an important new actor in European politics and recommended expanding contacts with the body as well as improving the institutional apparatus working on integration processes. It also envisaged Poland having a critical role in shaping the CSCE. ${ }^{62}$ The list of the first secretary's planned travels and visits by politicians to Poland reflected the launch of a new diplomatic offensive. ${ }^{63}$ Apart from traditional channels, documents from the Ministry of Foreign Affairs conceptualised economic relations as an integral part of foreign policy, describing them as a means of 'making détente irreversible' ${ }^{64}$

In view of the traditional hostility between socialist and capitalist countries, the choices in the early years of the decade not only signalled the boldness of the leadership but also reflected the evolving perception of the international situation. Following the signing of a treaty with the FRG in December 1970, and especially 
after its ratification by the Bundestag in May 1972, antagonism towards West Germany gradually disappeared from propaganda and foreign policy. ${ }^{65}$ Moreover, official documents and academic publications associated Western European integration with a trend towards European 'emancipation from American hegemony'. ${ }^{66}$ The ongoing talks preceding the CSCE, together with the increasing role of social democratic parties in Western European states, further fuelled the positive perception of the region as opposed to the US. ${ }^{67}$ In this context, from the early 1970s not only the popular press and PUWP journals but also some official documents of the Ministry of Foreign Affairs started to refer to the Cold War as a phenomenon of the past, proclaiming a new era of peaceful coexistence whereby the superiority of one system over the other would be decided by its attractiveness. ${ }^{68}$ Similarly, in academic party-related writings, the period between the end of the Second World War and the Polish-FRG treaty was depicted and historicised as a 'Cold War' ${ }^{69}$ In an interview with Gierek published in 1990, the first secretary himself confirmed that at the time he 'bet on the end of the Cold War'. ${ }^{70}$

The strong confidence in the attractiveness and success of the renewed domestic economic agenda and of the durability of détente in Europe allowed the leadership to introduce significant cultural liberalisation in the early 1970s. An immediate improvement in the traditionally problematic relationship between the PUWP and the Catholic Church became emblematic of the new approach. ${ }^{71}$ Moreover, already in the first years of the decade, authors and artists banned from presenting their work publicly by the censorship received rehabilitation. An inflow of Western culture followed, including publications, films, arts and music. Also, the leadership substantially liberalised the passport policy and created a fund allowing Polish citizens to exchange a limited amount of domestic currency against foreign currencies at the official beneficial rate. This decision opened the door to an unprecedented number of visits to Western countries, which tripled within five years compared to $1971 .^{72}$ Except for Yugoslavia, which was known for its openness and broader individual freedoms, no socialist regime experienced such a cultural liberalisation in the détente period. The decisions enabling the inflow of Western culture and visits to the West are evidence not only of the belief that the system could stand up to domestic challenges but also that it could successfully sustain comparison with capitalism.

The Gierek leadership's first plan largely responded to the questions raised by different groups in the socialist elite already in the late 1960s. The new leadership took into consideration the demands of regional party apparatuses, the managerial elite and experts and lastingly increased the influence of these groups in policymaking, securing a unity of the socialist elite in a period of a shift in national strategy. The new technocratic approach and détente, which was assumed to be the permanent condition of international relations, drove the ambition underlying the new agenda for complex cooperation with the West.

\section{External and domestic challenges, 1973-76}

The 1970s are often referred to as a belle époque in socialist Poland's history. ${ }^{73}$ This picture emerges predominantly from the first half of the decade, which 
witnessed consistently rising wages and a substantial increase in consumption, which contributed to securing domestic stability. The policy of large investments also allowed accommodation of the children of the post-war demographic boom, who entered the job market during this period. Moreover, in 1975 the volume of foreign trade with capitalist countries tripled compared to 1970, fulfilling leadership's expectations from the beginning of the decade. ${ }^{74}$ However, it quickly became apparent that while imports rose, exports remained quite modest, which made the repayment of loans more and more burdensome. Polish indebtedness in 1975 is estimated at around $\$ 11$ billion. At the same time, however, the economic plan drawn up in 1971 foresaw that the 'investment harvest' would only come in the second half of the decade when all the new factories would start producing. ${ }^{75}$

The honeymoon in political relations with Western Europe accompanied promising results in the domestic economy. Gierek's command of French and German soon enabled him to establish personal relations with Western leaders and, alongside Nicolae Ceaușescu, pursue a 'policy of prestige'. ${ }^{76}$ The diplomatic renewal was marked by numerous visits, such as trips by the first secretary to Paris in 1972, Brussels in 1973 and Bonn in 1975. Likewise, Western leaders including Richard Nixon, Valéry Giscard d'Estaing and others visited Poland during that period. Preparation for the CSCE additionally drove the explosion of contacts with Western politicians. The first secretary's international activity brought an unprecedented quality change in official relations with Western partners and improved his domestic image. ${ }^{77}$ The press widely described Gierek's international travels, portraying him as an influential global leader. ${ }^{78}$

These results in economic and foreign relations fuelled confidence in the early 1970s. As is pointed out in testimonies from the decade, the leadership was overwhelmed and surprised by its own success. ${ }^{79}$ Positive assessment of the new policy also found reflection in support from the PUWP, which between 1970 and 1980 acquired 700,000 new members, reaching its maximum size, involving around $12 \%$ of the Polish population. This perception was also shared by both Eastern and Western observers. As Kostikow recalled, more and more people talked about a Polish 'economic miracle'. ${ }^{80}$ Similarly, Western states competed for lucrative business opportunities in Poland, debating whether Gierek had found a 'magic key which unlocked the door to efficiency' ${ }^{81}$ In the circumstances of internal and external enthusiasm, the leadership did not perceive a revision of its strategy to be necessary.

At the same time, international developments in the 1970s accelerated Polish cooperation with the West. While Poland praised the Western European states for increasing their independence from the US, their proceeding integration posed a significant economic challenge for Poland. Unlike exporters of natural resources such as the Soviet Union and Romania, Polish exports to Western Europe consisted above all of agricultural products, the access of which to the EEC market was already limited in the 1960s with the introduction of the Common Agricultural Policy (CAP). The enlargement of the Community to the UK, Poland's second biggest trading partner in the West, challenged Poland's export ability in 1973. The most important threat, however, concerned the Common Commercial Policy (CCP) envisaged for introduction in 1975, according to which trade agreements 
could no longer be negotiated and signed with Western European states but had to be agreed with the European Commission instead. The EEC's intensified integration process clashed with Polish plans in the early 1970s based on large-scale exchanges and a vision of Pan-European cooperation.

In these circumstances, the Ministry of Foreign Affairs and the Ministry of Foreign Trade, two institutions primarily concerned with the EEC, responded by expanding the institutional apparatus monitoring developments in Western Europe, for instance by establishing a special unit in the Polish embassy in Brussels. ${ }^{82}$ The general CMEA policy of non-recognition of the EEC, however, limited the actions of such institutions. In the period of increasing Western European integration, the Ministry of Foreign Affairs, the Ministry of Foreign Trade and associated experts became a source of pressure on the politburo and the government to regulate the relationship with the Community. ${ }^{83}$

Unwilling to depart from the unified socialist front, while lobbying alongside Hungary in Moscow for recognition of the EEC, the Polish leadership aimed instead at means to overcome the challenges posed by EEC integration, particularly before the introduction of the CCP in $1975 .{ }^{84}$ As a consequence, the guidelines for Polish foreign policy assumed: 'Our goal is to maintain, as long as possible, bilateral relations with the EEC states, not allowing any interference by the Commission. In the short term, we should take advantage of these relations to mitigate harmful restrictive and discriminatory practices. ${ }^{95}$ Following this direction, Poland concluded economic agreements with eight out of nine members of the EEC before 1975, some for the first time since the Second World War. Moreover, looking for an alternative to the regional integration in Western Europe and for a space for interaction with the representatives of the officially unrecognised European Commission, Poland intensified its activity in international organisations, above all in the GATT and the United Nations Economic Commission for Europe (ECE). The Polish leadership aimed for as many economic gains as possible before the further closure of the EEC markets. Although the EEC never planned to unify the terms of credits, reports from the Ministry of Foreign Trade suggested: 'We should expect that the EEC will aim to unify the terms of investment credits for socialist states, especially after 1974 . We should take advantage of the time separating us from this moment to get indebted as much as possible with the EEC member states. ${ }^{96}$ A similar recommendation concerned establishing as many long-term cooperation agreements as possible, which if signed before the introduction of the CCP could still function on the terms in the original contracts. ${ }^{87}$ This strategy of bypassing the EEC, however, often reached a dead end and direct unofficial contacts with representatives of the European Commission became inevitable. In the first half of the 1970s, alongside Hungary and Romania, Poland became a frontrunner in such practices among the CMEA members. ${ }^{88}$

Inflation in capitalist countries in the early 1970s, fuelled by the collapse of the Bretton Woods system and a stock market crash resulting from the oil embargo proclaimed by Arab petroleum countries in 1973, similarly accelerated Poland's engagement with the West. The leadership welcomed the difficulties of the capitalist states, quickly recognising the attractive financing conditions in which 'the 
real prices of instalments are lower than initially assumed', and pushed for as many loans as possible. ${ }^{89}$ Poland's position as a coal exporter only encouraged its confidence in its ability to take advantage of the turmoil in global resources..$^{90}$

At the same time, the problem of energy supplies put Poland in a disadvantageous position with regard to the other socialist states. As the key producer of coal, it was obliged to sell more to the CMEA countries at set unfavourable prices. ${ }^{91}$ This concern caused increasing scepticism over socialist economic integration, which in that period was also emerging over the unreformed model of economic exchanges still based on transferable roubles, which meant that Polish goods, which were often based on expensive foreign technology and contained parts imported from the West using hard currency, were sold for prices not corresponding to the production costs. This situation naturally led to privileging the West as a trading partner.

However, the oil crisis had another effect on Polish national strategy in the 1970s. Reports from the Planning Commission assumed the difficulties of the capitalist countries to be the reason behind insufficient Polish export revenues. ${ }^{92}$ This argument was often used by Jaroszewicz when justifying his commitment to the economic agenda of the early 1970s. According to this logic, the moment the international economic situation improved, Polish trade exchanges would bring the expected results. ${ }^{93}$ In this sense, the oil crisis not only speeded up Poland's opening towards the West but also blurred the picture of the domestic economic situation.

Not everyone in the new leadership, however, shared the mainstream interpretation of 'beneficial momentum' with regard to the first half of the 1970s. Reports produced by Minister of National Defence Jaruzelski warned against a positive assessment of Western Europe and the building of economic ties with the EEC states, recalling the continued existence of security dangers. ${ }^{94}$ Similarly, some reports from the Planning Commission in 1974 advised a cut in expenditure and an economising of resources given the prospect of economic slowdown in global markets as a consequence of the oil crisis. ${ }^{95}$ Minister of Finance Jędrychowski also insisted on a reversal of the economic strategy, which drove him into conflict with Jaroszewicz and resulted in his dismissal from the government in 1974. ${ }^{96}$ The same trajectory was followed by Szlachcic, who openly warned the politburo against 'idealising credits' and 'slithering towards the West' ${ }^{97}$ He lost his influence soon afterwards and was removed from the leadership in $1975 .{ }^{98}$

Criticism of the official policy was also the reason behind the removal in 1973 of the original editorial board of the weekly Life and Modernity, which since early 1970 had consisted of members of the liberal side of the socialist elite and economic experts advocating reforms and modernisation. Moreover, already in late 1972, Rurarz, Gierek's personal advisor, resigned from his position and transferred back to the Ministry of Foreign Affairs. In his own assessment, this change was motivated by profound disagreement over the economic choices made by the leadership..$^{99} \mathrm{He}$ was quickly replaced with Paweł Bożyk, a professor at the Main School of Planning and Statistics and, like his predecessor, a specialist in foreign trade and international economics. 
The mid-1970s also witnessed a decline of the Commission for the Modernisation of the Economy and State Functioning. While the majority of the proposals prepared by this institution remained unimplemented, the government established Huge Economic Units (WOG) in 1973 following a recommendation by the Commission. The new entities enjoyed unprecedently wide prerogatives. Not only were they exempt from the obligation to follow the central plan closely, but they could also decide on foreign trade deals and in some cases on the prices of goods produced. ${ }^{100}$ The reform contributed to the general trend of widening the competences of specific ministries and industries initiated after Gierek's arrival in power, which made the coordination ability of the central institutions looser. Moreover, each industry and ministry behind it was primarily concerned with its own interests and constantly sought funding for new investments. The activity of Wrzaszczyk, the highly influential minister of machinery industry, best illustrates these practices, which were labelled 'investment pressure'. ${ }^{101}$ Even though many of the newly initiated productions, such as the Fiat, turned out to be much costlier than initially assumed, he always successfully persuaded the rest of the leadership to provide more funds and launch further investments. ${ }^{102}$

Already before his removal, Szlachcic drew attention to the loss of coordination over the rising economic engagement with the West, above all credit-taking. ${ }^{103}$ Ensuing efforts to increase party and government control over the matter, however, did not prevent a growing concern in the Soviet Union over the economic situation in Poland. ${ }^{104}$ Signs of the Soviet preoccupation are often recalled in memoirs by the policymakers of the decade. ${ }^{105}$ They also find illustration in the leadership's actions aiming to obscure the cooperation with the West, for instance by covering up official statistics which indicated that the level of economic exchange with capitalist countries already overtook that with the CMEA around 1975. ${ }^{106}$ The Soviet Union's growing concern explains Gierek's symbolical gestures of subordination, which multiplied in that period. In 1974 the first secretary honoured Leonid Brezhnev with the Virtuti Militari, the highest Polish military award. Moreover, a year later he announced plans to incorporate into the constitution a new article proclaiming a timeless alliance with the Soviet Union.

These actions triggered the unification of the opposition-minded intellectuals, who in early 1976 issued a 'Letter of 59' protesting against changes in the constitution and calling for respect for citizens' rights. The signatories directly referred to the Final Act of the CSCE signed in Helsinki in August 1975, which acknowledged these prerogatives. The leadership strongly condemned the protest and accordingly proceeded with its initial plans despite the objections raised.

In late 1975, alongside revising the constitution the government launched work on the new economic plan for 1976-80. Driven by Poland's positive achievements and regardless of the increasing domestic scepticism and worrying external developments, the document predicted a boom in exports and modern high-quality production and therefore established intensified growth and improvement in the quality of life as the main economic goals for the following five years. ${ }^{107}$ Similarly, with the peak of European détente marked by the CSCE Final Act, the leadership did not anticipate a reversal of the positive international trends. As in the case 
of economic policy, the guidelines for foreign policy for 1976 remained largely untouched. ${ }^{108}$

\section{Securing the status quo, 1976-80}

The second half of the 1970s brought to the fore the previously marginalised negative outcomes of Gierek's policy. The existing price freeze combined with rising wages, which in 1976 were double those of 1970, resulted in repeated shortages and often made it necessary to import basic agricultural products from the West. Aiming to restore equilibrium, in June 1976 Jaroszewicz announced price rises. Gierek is reported to have expected that the population would support the leadership and its agenda and understand the necessity of the decision. ${ }^{109}$ Instead, the new prices triggered mass protests, especially in Radom and Ursus, where the police brutally intervened, injuring some of the participants. This negative reaction resulted in an immediate cancellation of the decision. ${ }^{110}$ Social stability had been one of the key features of the early 1970s, and the leadership wanted to secure it at any price.

An alarming report issued after these events by the Planning Commission in cooperation with Bożyk exposed the state of the Polish economy. It revealed expenditure was around $20 \%$ higher than income and that the debts accumulated over the previous years already consumed $44 \%$ of export revenue, a figure that would probably rise to more than $60 \%$ in the next two years. It stated that exports were often rejected due to their disappointing quality and were growing insufficiently, while imports, which were necessary for continuing production in many sectors, were rising rapidly. The authors firmly recommended drastically cutting the number of new investments, improving centralised control and accelerating exports. ${ }^{111}$ These recommendations laid the ground for a revision of the draft five-year plan prepared in 1975, which was labelled an 'economic manoeuvre'. By slowing down the negative trends, the leadership aimed to put the original agenda on hold rather than drastically reversing it. This strategy, based on the hope of a sudden improvement in Polish performance, continued until the end of the decade.

However, even the limited changes in economic policy quickly proved difficult to implement in practice. The 'open plan' idea aiming to improve the leadership's flexibility in reality only facilitated unforeseen expenditure. Moreover, a partial cancellation of the WOG reform in 1976, which was part of the programme to reinforce central control, did not put an end to 'investment pressure'. Representatives of the managerial elite still often managed to successfully persuade the leadership to grant more funds. ${ }^{112}$ Preserving the unity of the socialist elite by avoiding discontentment among these groups became another feature of the policy to maintain the status quo.

The continuation of exchanges with the West was critical to maintain the favourable situation of the early 1970s, and the leadership interpreted international developments as not foreshadowing any change. Elections in the FRG in October 1976 confirmed the SDP in power, thus removing concerns about a 
reversal of Ostpolitik. Moreover, despite increasing awareness among the Western states and banks about the real state of the Polish economy after the 1976 crisis, foreign loans continued to flow in to Poland. ${ }^{113}$ These developments confirming the durability of détente enabled and encouraged the Polish leadership's passive policy in the second half of the 1970s.

At the same time, however, its actions following the price rises contributed to a deterioration in East-West relations. Despite the fact that the scale of repression in 1976 was much less severe than in 1970, it substantially undermined the peaceful image of the leadership. The persecution of demonstration participants, which included lay-offs and imprisonment, raised the attention of the oppositionminded intellectuals who had already been active on the occasion of the 'Letter of 59'. A Workers Defence Committee (KOR) was officially established in September 1976 with the aim of supporting the families harmed by the repression both financially and legally. This continually growing group and others that originated in that period became permanent actors on the political landscape in the second half of the 1970s. ${ }^{114}$ Although only the US officially linked the stream of loans with respect for human rights, Western European politicians also regularly inquired about the KOR and the situation of dissidents. ${ }^{115}$ Fearing an end of détente and economic exchanges with the West, policymakers tolerated the dissident activity. ${ }^{116}$ As Rakowski stated in his memoirs, 'A few words from Giscard d'Estaing . . . would be enough to let everyone out of prison'. ${ }^{117}$

The events of 1976 and the following rise of the dissident movement triggered concerns not only in the West but also in the East. As memoirs of the decade recall, the Soviet Union frequently urged the Polish leadership to regulate the domestic economic and political situation. ${ }^{118}$ In addition, the other socialist states became anxious about possible contagion by the Polish situation and annoyed about often unfulfilled export promises. ${ }^{119}$ As a result, from 1976 the Soviet Union increased its scrutiny of the socialist regimes. ${ }^{120}$ The rising concern and involvement of Western and Eastern actors limited the independence of the Polish leadership, confirming its passivity.

The external developments further harmed Poland's economic situation. After the implementation of the CCP, the EEC introduced new regulations negatively impacting Poland's steel exports and its access to fisheries in the Baltic Sea. ${ }^{121}$ In addition, the continuing slowdown of the international economy caused by the oil crisis limited the access of Polish exports to Western markets. Against the expectations of the mid-1970s, the cost of servicing foreign debt increased as a result of Western countries defending their currencies with high interest rates. ${ }^{122}$ Moreover, many energy-intensive Polish industries experienced unforeseen costs as a consequence of energy price rises, especially after the oil crisis in 1979 caused by the Iranian revolution. If that was not enough, in the second half of the decade Poland suffered adverse meteorological conditions. In particular in 1979, a "winter of the century" and a devastating drought during the summer resulted in agricultural difficulties and unexpected energy consumption.

These developments and the lack of decisive action by the Polish leadership accelerated the negative trends. Apart from the constantly worsening quality of 
everyday life and burdensome shortages, the suspension of many investments resulted in massive depreciation. Meanwhile the debts kept rising and reached over $\$ 20$ billion in 1979, which made Poland the most indebted socialist state in Europe. In these circumstances, Polish economic problems were 'on the lips of all the [PUWP] members' ${ }^{123}$ A rise in Cold War tensions due to the Soviet invasion of Afghanistan in December 1979 fuelled and polarised internal debates.

On the one hand, the economic crisis pushed Poland closer to the Soviet Union, which to some members of the socialist elite appeared as the only remedy to the situation. This group included the former minister of foreign affairs, Olszowski, who according to Rakowski's journals already stated in 1976 that 'in order to leave the crisis we need to rely on Moscow. There is no other choice'. ${ }^{124}$ Jaruzelski and Stanisław Kania, the politburo member responsible for the security services, also shared this view. Together with Olszowski, they became the strongest opponents of Gierek's policy and the most prominent candidates to replace him. ${ }^{125}$ However, Moscow signalled to Polish interlocutors that the idea of a 'Soviet umbrella' over the Polish economy was misplaced. ${ }^{126}$ Soviet engagement in Afghanistan only lowered the chance of it providing economic support.

Meanwhile, expert bodies suggested a more profound reform of the system, an improvement of export capacity and an easing of the increasingly burdensome loan instalments through cooperation with Western institutions. Reports issued by the team of experts gathered by Bożyk unequivocally insisted on joining the IMF and the World Bank. ${ }^{127}$ Similarly, bankers and representatives of the Ministry of Finance, who in this period acquired unprecedented importance as they were at the forefront of securing Polish economic stability, advocated the solution of negotiations with creditors and participation in Western economic institutions. ${ }^{128}$ Experts from the Ministry of Foreign Affairs, including Rurarz, who since the early 1970s had called for regulation of the relationship with the EEC, in this period explicitly emphasised the positive economic and political consequences that could flow from recognition of the organisation. ${ }^{129}$ Despite these recommendations, both joining the IMF and the World Bank and establishing official relations with the EEC remained impossible due to the position of Moscow. ${ }^{130}$

Despite the pressure, the leadership, which was increasingly concentrated in small group around the first secretary, still hoped to continue balancing between the West and the East and to handle the crisis independently. While a meeting between Giscard d'Estaing and Brezhnev in Warsaw in May 1980 aimed to preserve the favourable international circumstances, a rise in the prices of basic alimentary products in June was the last attempt to cure the Polish economy.

The decision triggered massive strikes, especially in the coastal region, which eventually led to the creation of the independent self-governing labour union Solidarity and an unprecedented rise of civil society. While the price rise was the spark for the protest, historiography concerning the origins of the phenomenon shows longer structural developments. Despite the daily worsening of the economic situation, propaganda continually proclaimed spectacular successes, which contributed to the frustration in society. ${ }^{131}$ Moreover, in 1978 Polish Cardinal Karol Wojtyła was elected pope of the Catholic Church. Pope John Paul II 
became a symbol of the strength of the Polish church and an important counter authority to the socialist leadership. His official visit to Poland in 1979 played a major role in the mass mobilisation. ${ }^{132}$ Finally, scholars studying Solidarity also agree on the paramount importance of the economic agenda established in the early 1970s. The new consumption model elevated social expectations which were still unfulfilled in the late 1970s, more prevalent visits to the West brought frustration with domestic living standards and liberalisation created space for the rise of alternative culture centres and organisations; all jointly paved the way for the rise of civil society. ${ }^{133}$

The 1970s ended with a consolidation of workers, the church and the opposition, and the PUWP experienced a profound crisis. Already in early 1980, Jaroszewicz lost his position, being blamed for the economic decline. Facing mass protests in the summer of the same year, the vulnerable leadership agreed to twenty-one demands formulated by Solidarity, thereby confirming its legal existence. The event triggered the replacement of Gierek and his closest collaborators such as Wrzaszczyk and Szydlak. Kania acquired the first secretary position, acting (as is often stressed) under the influence of Jaruzelski, who took over the prime minister's office in early 1981 and after a few months became head of the PUWP. After a party convention in July 1981, only four previous members remained in the politburo and none of the ministers from Jaroszewicz's government secured their positions. The critical economic situation also affected the regional party apparatuses and the managerial elite, preventing these groups from initiating new investments or even modernising and completing old ones. Similarly, widely marginalised leading experts retreated from political life to academia, as in the case of Pajestka; emigrated to the West, as in the case of Rurarz; or joined the opposition, as in the case of Bratkowski. Between 1980 and 1981, a period described as the "carnival of Solidarity", over 300,000 members officially left the PUWP.

The events in Poland in 1980 caused not only an internal crisis among the socialist elite but also a deterioration in Polish relations with both the East and the West. On the one hand, since the rise of Solidarity a threat of a Warsaw Pact intervention in Poland hung over the PUWP leadership. On the other hand, from the Western European perspective, the consolidation of the opposition challenged the policy of close cooperation with the socialist leadership. From the summer of 1980, Western states maintained relations with both the official Polish representatives and the opposition, regarding Poland as the 'sick man of the socialist bloc' which could be used to undermine socialist unity. ${ }^{134}$ The tragic financial situation resulted in the launch of multilateral talks concerning rescheduling Polish debts in Paris and London clubs gathering the creditors. Facing these institutions in March 1981, Polish representatives declared that the country was insolvent. ${ }^{135}$

The new circumstances terminated the peaceful coexistence as envisaged by the Polish leadership in the early 1970s and put a radically polarised choice in front of Poland. The introduction of martial law in 1981 epitomised a short turn towards the East, which hardly helped the domestic situation. Economic support from Moscow was limited, and the suspension of foreign debt repayments further aggravated the economic situation. The socialist elite was left in no doubt that the remedy to Poland's problems lay in the West. 


\section{Conclusions}

The ambition of the leadership in the early years of the 1970s plays a paramount role in understanding of the subsequent developments in socialist Poland. In fact, the scale of the confidence underlying the agenda at the beginning of the decade was in proportion to the scale of the crisis which ended it. In the early 1980s, unlike in the late 1960s, the accelerating problems could hardly be resolved with personnel replacements in the party and the government. Poland's dependence on both the West and the East and the rise of civil society permanently limited leadership's room for independent manoeuvre. Moreover, the socialist elite never recovered from internal decomposition caused not only by the bankruptcy of the regime and the rise of alternative authorities but also by increasingly diversified views and declining confidence. Frequent personnel reshufflings characterised the leadership in the 1980s. Moreover, socialist Poland never pursued such an ambitious economic and foreign strategy again. Gierek's leadership was the last one to believe that the system could experience revival without profound economic reforms implying marketisation and moving further away from the Soviet model.

In comparison with the other socialist regimes, the Polish strategy in the 1970s had some important particularities. The significant cultural liberalisation and the tolerance of dissident activity in the second half of the decade had no equivalent in the other socialist countries. At the same time, the Polish trajectory in the 1970s shares some important similarities with the GDR and Hungary, where the ruling elites also focused on rising living standards and consumption. All three - Hungary with its special economic system and unreformed Poland and the GDR - found themselves on the edge of economic collapse at the end of the 1970s. With debts exceeding \$22 billion in 1980 - more than Hungary's and the GDR's debts combined - and with Solidarity disqualifying the possibility of introducing austerity measures as in Romania, Poland was the only socialist state to default. ${ }^{136}$

Assessments of Polish policy in the 1970s vary between two positions. According to most contemporary Polish historians, the agenda was misplaced and rooted in the incompetence and short-term thinking of the Polish socialist elite. In contrast, the participants in the events, including politicians and experts, instead blame external factors and the lack of central coordination of economic matters. The answer to this dilemma lies in the middle. On the one hand, the Polish leadership successfully tackled some challenges of the 1970s such as the demographic boom, modernised Poland's industry on a scale incomparable with the 1960s and 1980s and effectively participated in easing Cold War tensions. Moreover, Gierek's policy mirrored the modernisation efforts and credit practices not only of other socialist states but also of other peripheral countries around the world. In the case of Poland, however, the strategy was characterised by overconfidence and misinterpretation. Assumptions regarding the termination of the Cold War underlying the ambitious planning of the early 1970s and expectations concerning the consequences of the oil crisis and Western European integration accelerated the negative outcomes of the decade. As the leadership nevertheless continued the policy of the early 1970s, the external factors were not the only ones to blame for the regime's evident decline in the early 1980s and fall at the end of the decade. 


\section{Notes}

1 For general studies on Poland's history in the 1970s, see Kemp-Welch, Poland under communism, 180-236; Paczkowski, The spring will be ours, 351-410; Eisler, Czterdzieści pięć lat, 287-352.

2 E.g. Paczkowski, Revolution and counterrevolution in Poland; Friszke, Rewolucja Solidarności 1980-1981; Eisler, Grudzień 1970. On critiques of this approach and the cultural turn in Polish historiography, see Fidelis, "Pleasures and perils of socialist modernity," 1-12; Zaremba and Brzostek, "Polska 1956-1976," 25-37.

3 On Gomułka, see Prażmowska, Władysław Gomulka; Eisler, Siedmiu Wspaniałych, 167-252. On Poland in 1956, see Machcewicz, Rebelious satelite; Skrzypek, Dyplomatyczne dzieje PRL, 15-97.

4 Jarosz, "The collectivization of agriculture in Poland," 113.

5 Skrzypek, Mechanizmy autonomii, 65-312.

6 Jasiński, Bliżej centrum czy na peryferiach?, 231.

7 Archiwum Akt Nowyth (AAN - Central Archives of Modern Records), KC PZPR 1354, III/51, "Stenogram XI plenarnego posiedzenia KC PZPR" (Minutes of the 11th PUWP Plenary Session), 27-28 February 1968, 304.

8 Kansikas, Socialist countries face the European Community, 59-92; See Chapter 3 by Pál Germuska in this book.

9 AAN, KC PZPR 1354, XI/186, "Stenogram narady członków BP i sekretariatu KC z I sekretarzami KW i kierownikami wydzałów KC oraz członków Rady Ministrów i Prezydium Komisji Planowania" (Minutes of the PUWP and government meeting), 16 April 1970, 256.

10 On Poland and FRG, see Stokłosa, Polen und die deutsche Ostpolitik; Jarząbek, Polska Rzeczpospolita Ludowa.

11 Jarząbek, "Hope and reality," 6.

12 Namiotkiewicz, Bytem sekretarzem Gomułki, 80; Tejchma, Pożegnanie z władza, 81 and 89; Bobrowski, "Na to nas nie stać ...," 190-1.

13 On 1968 in Poland, see Eisler, "March 1968 in Poland," 237-52; Stola, Kampania antysyjonistyczna $w$ Polsce 1967-1968.

14 Szumiło, "Pomarcowa wymiana kadr-elita PZPR w latach 1968-1970," 528.

15 On Gierek, see Eisler, Siedmiu Wspaniatych, 253-312.

16 Dwilewicz, "Reformy Bolesława Jaszczuka,"107.

17 Rakowski, Dzienniki 1958-1962, 124; Rakowski, Dzienniki 1969-1971, 266; Rurarz, Bytem doradca Gierka, 113.

18 Rakowski, Dzienniki 1969-1971, 52.

19 Józef Pajestka, “O społeczno-kulturową koncepcję motoryzacji,” Polityka 2 (1969): 3.

20 Józef Pajestka, "Problemy polityki strukturalnej konsumpcji na obecnym etapie rozwoju," Nowe Drogi 10:245 (1969): 12-29; Józef Pajestka, "Smalec czy garsonka?," Polityka 38 (1969): 1 and 5.

21 See the summary of the debate: "Kierunki kształtowania struktury konsumpcji," Życie Gospodarcze 10-11:964-5 (1970): 2-4.

22 E.g. Józef Pajestka, "Na nowym etapie postępu," Życie gospodarcze 22:872 (1968).

23 Włodzimierz Wowczuk, 'Japonia. Kulisy dynamicznego rozwoju', Życie Gospodarcze 14:864 (1968): 11.

24 Marian Naszkowski, "Na widowni międzynarodowej," Nowe Drogi 10:233 (1968): 114; Marian Naszkowski, "Na widowni międzynarodowej," Nowe Drogi 3:238 (1969): 40; Marian Naszkowski, "Na widowni międzynarodowej," Nowe Drogi 4:239 (1969): 65.

25 Marian Naszkowski, "Na widowni międzynarodowej," 9:256 (1970): 74.

26 Westad, "Beginnings of the end," 68-81.

27 Eisler, Grudzień 1970, 59.

28 For debates on Gierek's arrival in power, see Szumiło, "Rozmowy Edwarda Gierka," 315-36; Eisler, Grudzień 1970, 282-93. 
29 Szumiło, "Kierownictwo PZPR w latach 1971-1980," 32.

30 E.g. "Poland's new leader," New York Times, 21 December 1970, 15; Adam Bromke, "Beyond the Gomulka era," Foreign Affairs 49:3 (1971): 480-90; Adam Bromke, "Poland under Gierek. A new political style," Problems of Communism 21:5 (1972): 1-19.

31 AAN, KC PZPR 1354, V/91, "Wnioski w sprawie aktywizacji funkcji Sejmu" (calls for increase in parliamentary activity), 25 January 1971.

32 E.g. AAN, URM 290, 5.4/22, "Projekt rozporządzenia Rady Ministrów w sprawie zakresu działania Ministra Handlu Zagranicznego i jego uprawnień w dziedzinie koordynacji stosunków gospodarczych z zagranicą" (draft decision concerning competences of the Minister of Foreign Trade), 9 July 1971.

33 Bożyk, Apokalipsa wedtug Pawła, 34; Waszczuk, Biografia niezlustrowana, 33.

34 Dwilewicz, "Rola ekspertów," 7-46.

35 See Chapter 7 by Elitza Stanoeva and Chapter 3 by Pál Germuska in this book.

36 AAN, KC PZPR 1354, V/100, "Główne propozycje, zadania i problem projektu planu 5-letniego na lata 1971-1975-plan podstawowy" (main tasks of five-year plan), Planning Commission, accepted by the politburo, 15 February 1972, 4.

37 E.g. Dwilewicz, "Polityka gospodarcza," 333-53; Jarząbek, "Polish economic policy," 298.

38 "Główne propozycje," 14.

39 Council of State decision no. 203, 20 July 1972, accessed February 2020, http:// prawo.sejm.gov.pl/isap.nsf/download.xsp/WDU19720290203/O/D19720203.pdf.

40 Rurarz, Bytem doradca, 157.

41 Rurarz, Bytem doradca, 162-3.

42 Zdzisław Rurarz, "Przesłanki przyspieszonego rozwoju kraju," Nowe Drogi 10:281 (1972): 137.

43 "Główne propozycje," 3.

44 AAN, URM 290, 5.4/20, “Zamierzenia w zakresie polityki licencyjnej w latach 1971-1975 na tle dotychczasowych wyników wykorzystania zakupów licencyjnych w krajach kapitalistycznych" (plans concerning license policy), Committee of Science and Technology, accepted by the government, 14 May 1971.

45 "Główne propozycje," 17.

46 Eisler, Czterdzieści pięć lat, 293.

47 AAN, KC PZPR 1354, XIA/1172, “Koncepcje Rozwoju Gospodarczego Polski w latach 1971-1995" (concepts of Poland's economic development), Rurarz's report for Gierek, 24.

48 AAN, KC PZPR 1354, V/90, "Protokół nr 24 posiedzenia Biura Politycznego" (Protocol from the politburo meeting), 29 December 1970, 3.

49 AAN, KC PZPR 1354, V/92, "Notatka w sprawie kierunkowych założeń rozwoju gospodarki narodowej w latach 1971-1975" (memo on the direction of Poland's economic development), Planning Commission, accepted by the politburo, 16 April 1971, 9.

50 AAN, KC PZPR 1354, V/93, Gomułka's letter to PUWP Central Committee, 27 March 1971, 25.

51 Kostikow and Roliński, Widziane z Kremla, 152.

52 On Poland and the Soviet Union in the 1970s, see Szumski, "Leonid Brezhnev and Edward Gierek," 253-86; Borodziej, "Polskie peryferie polityki," 51-72; Skrzypek, Mechanizmy klientelizmu, 119-221.

53 "Notatka w sprawie kierunkowych," 8.

54 AAN, KC PZPR 1354, V/90, "Podstawowe założenia projektu Narodowego Planu Gospodarczego na 1971" (economic plan proposal), Planning Commission, accepted by the politburo, 30 October 1970, 3 .

55 AAN, KC PZPR 1354, XIA/415, "Dyskusja na posiedzeniu Komisji PartyjnoRządowej d/s usprawnienia gospodarki narodowej" (Minutes from the Commission for the Modernisation of the Economy and State Functioning meeting), 12 June 1972, 289. 
56 Rurarz, Bytem doradca, 82-4.

57 Bożyk, Marzenia i rzeczywistość, 221; Rurarz, Byłem doradca, 83.

58 Kramer, "The Czechoslovak crisis and the Brezhnev Doctrine," 169.

59 AAN, KC PZPR 1354, V/100, "Protokół nr 11 z posiedzenia Biura Politycznego" (Protocol from the politburo meeting), 28 February 1972, 2.

60 AAN, KC PZPR 1354, XIA/337, 'Stenogram z posiedzenia komisji zjazdowej" (Minutes from Congress Commission meeting), 23 July 1971, 51.

61 On propaganda in the 1970s, see Zaremba, "Propaganda sukcesu," 22-32.

62 AAN, KC PZPR 1354, V/92, "Kierunki działania Ministerstwa Spraw Zagranicznych na rok 1971" (Ministry of Foreign Affairs guidelines for 1971), accepted by the politburo, 11 May 1971, 12-21 and 25-7.

63 AAN, KC PZPR 1354, V/91, "Pilna notatka" (Memo on diplomatic visits), Ministry of Foreign Affairs, accepted by the politburo, 2 March 1971.

64 AAN, KC PZPR 1354, V/120, "Węzłowe kierunki i zadania polityki zagranicznej PRL w 1974" (Ministry of Foreign Affairs guidelines for 1974), accepted by the politburo, 15 January 1974, 3.

65 Mazur, Propagandowy obraz świata, 179-80.

66 E.g. Archiwum Ministerstwa Spraw Zagranicznych (AMWZ - Archive of the Ministry of Foreign Affairs), Dep. IV, 27/77, w.10, "Program pracy na 1971" (work plan for 1971), March 1971, 3; Jerzy Sułek, "Prognoza rozwoju Europy w latach siedemdziesiątych," Sprawy Międzynarodowe, 3:250 (1973): 104-10.

67 E.g. Janusz Gołębiowski, "Socjaldemokracja a problemy współczesności," Nowe Drogi, 12:283 (1972): 76-85.

68 Jan Główczyk, "Przesłanki europejskiej współpracy gospodarczej," Polska Prasa, 10 (1972): 9; Mieczysław Rakowski, "Szanse na wielki pokój," Nowe Drogi, 11:282 (1972): 69; AMSZ, Dep. IV, 27/77, w.10, "Perspektywiczny plan działania w stosunku do krajów Europy Zachodniej” (prospective plan concerning Western Europe), 9 July 1971, 1.

69 Frelek, Historia zimnej wojny, 24.

70 Gierek and Rolicki, Przerwana dekada, 105.

71 On relations between the PUWP and the church in the 1970s, see Pawlicka, Polityka władz wobec kościoła katolickiego; Dudek and Gruz, Komuniści i Kościót, 277-350.

72 Stola, Kraj bez wyjścia?, 486-7.

73 Paczkowski, The spring will be ours, 351.

74 "Tabela obrotów handlu zagranicznego" in Rocznik statystyczny 1976, 333.

75 Bożyk, Marzenia i rzeczywistość, 101.

76 Machcewicz, "Materiały: Polityka Zagraniczna PRL w roku 1975," 120.

77 On bilateral relations with Western European states see, e.g., Jarosz and Pasztor, Polska-Francja, 1970-1980. Relacje wyjatkowe?; Tavani, "Muddling through the European bloc system," 147-68; On FRG and Poland, see Stokłosa, Polen und die deutsche Ostpolitik; Jarząbek, Polska Rzeczpospolita Ludowa. On Polish foreign policy in specific years, see the introductions to volumes Polskie Dokumenty Dyplomatyczne (Polish Diplomatic Documents) published by Polski Instytut Spraw Międzynarodowych (Polish Institute of International Affairs); On diplomacy in the 1970s in general, see Skrzypek, Dyplomatyczne dzieje PRL, 188-302.

78 E.g. Życie Warszawy, 3 October 1972, 2.

79 Bożyk, Marzenia i rzeczywistość, 35 and 46; Pajestka, Polski kryzys, 52; Rurarz, Bytem doradca, 63.

80 Kostikow and Roliński, Widziane z Kremla, 171.

81 The UK National Archives (TNA), FCO 28/1931, “The Polish economy," Fretwell's report from Warsaw, 27 September 1972, 6.

82 AMSZ, Dep. IV, 27/77, w.11, Staniszewski to Paszek, 29 June 1971.

83 E.g. AMSZ, Dep. IV, 27/77, w.11, Olszowski to Jaroszewicz, 7 August 1971. 
84 Kansikas, "Room to manoeuvre?," 200-2; See Chapter 3 by Pál Germuska in this book.

85 "Kierunki działania," 20-1.

86 AAN, URM 290, KT 75/8, "Notatka w sprawie kredytów na import z krajów kapitalistycznych rozwiniętych w okresie 1972-1975" (memo on credits from capitalist states), Ministry of Foreign Trade, February 1972, 10.

87 AAN, KC PZPR 1354, V/101, "Wstępne poglądy strony polskiej w sprawie stosunków pomiędzy RWPG i krajami EWG" (on attitudes towards EEC-CMEA relations), Ministry of Foreign Trade, accepted by the politburo, 14 March 1972, 12.

88 Romano, "Untying Cold War knots," 153-73.

89 AAN, KC PZPR 1354, V/93, "Zasady polityki kredytowej w zakresie obrotów płatniczych z zagranicą w latach 1971-1975" (report on credit policy), Planning Commission, accepted by the politburo and government, July 1971, 8 .

90 AMSZ, Dep. IV, 20/79, w.11, "Plan pracy na 1974" (work plan for 1974), December $1973,3$.

91 AAN, URM 290, 5.4/71, "Podstawowe zasady koordynacji planów z krajami RWPG na lata 1976-1980" (report on coordination of planning between CMEA countries), Planning Commission, accepted by the government, January 1974, 1.

92 AAN, URM 290, 5.4/71, "Informacja w sprawie podstawowych problemów realizacji NPSG w 1974 roku" (report on problems with fulfilling five-year plan), Planning Commission, accepted by the government, 5 February 1974, 9.

93 E.g. AAN, URM 290, 5.4/71, "Zapis przebiegu obrad posiedzenia Prezydium Rządu" (minutes from government meeting,) 8 February 1974, 86-106.

94 AMSZ, Dep. IV, 46/77, w.10, "Pilna notatka dotycząca militarnych aspketów funkcjonowania EWG" (memo on military aspects of the EEC), Jaruzelski, 2 April 1972.

95 "Informacja w sprawie," 9-10.

96 Bień, Jak doszło do zadłużenia Polski, 18-24; Rurarz, Byłem doradca, 75.

97 AAN, KC PZPR 1354, V/110, "Skrót wypowiedzi F. Szlachcica na posiedzeniu Biura Politycznego" (Szlachci's speech during the politburo meeting,) 11 December 1972, 2-3.

98 Barcikowski, U szczytów władzy, 65; Gierek and Rolicki, Przerwana dekada, 162; Tejchma, Kulisy dymisji, 132.

99 Rurarz, Bytem doradca, 131-71.

100 On WOG, see Slay, The Polish economy, 36-42.

101 Kotowicz-Jawor, Presja inwestycyjna. For other authors describing the phenomenon, see Balcerowicz, Przetarg planistyczny; Kuczyński, Po wielkim skoku.

102 E.g. AAN, URM 290, 5.4/72, "Zapis przebiegu obrad posiedzenia Prezydium Rządu" (minutes from the government meeting), 1 March 1974, 41-52.

103 "Skrót wypowiedzi," 11 December 1972, 3.

104 AAN, KC PZPR 1354, V/110, "Uchwała Biura Politycznego KC PZPR o zasadach koordynacji i organizacji stosunków PRL z zagranicą" (decision concerning the coordination of foreign relations), December 1972.

105 Rakowski, Dzienniki, 1972-1975, 163; Tejchma, Odszedt Gomułka, 133; Waszczuk, Biografia niezlustrowana, 64.

106 Gierek and Rolicki, Przerwana dekada, 84; Rakowski, Dzienniki, 1979-1981, 30.

107 AAN, KC PZPR 1354, V/131, "Podstawowe założenia społeczno-gospodarczego rozwoju kraju 1976-1980" (five-year plan proposal), Planning Commission, accepted by the politburo and government, 6 June 1975.

108 AAN, KC PZPR 1354, V/134, "Węzłowe kierunki i zadania polityki zagranicznej w 1976 r." (Ministry of Foreign Affairs guidelines for 1976), accepted by the politburo, January 1976.

109 Tejchma, Kulisy dymisji, 221. 
110 On the events of 1976, see Kemp-Welch, Poland under communism, 206-36; Zaremba, "Upalny czerwiec 1976," 106-19.

111 AAN, KC PZPR 1354, XIA/486, "Możliwości i warunki kontynuacji strategii dynamicznego rozwoju Polski w latach 1977-1980" (report on strategy of dynamic development), Planning Commission and Bożyk's team for Gierek, 20 October 1976.

112 E.g. AAN, URM 290, 5.4/135, "Zapis przebiegu obrad posiedzenia Prezydium Rządu" (minutes from the government meeting), 18 February 1977, 22-78.

113 E.g. Das Politische Archiv des Auswärtigen Amts (PA/AA), BA63/122531, "Verschuldungssituation Polens," 21 August 1978; Centre des Archives diplomatiques de la Courneuve (CADC) 1929/4594, "Relations économique franco-polonaises, Ministre de l'Economie," 14 September 1978; Mourlon-Druol, "The role of a creditor in the making of a debt crisis."

114 Lipski, KOR; Skórzyński, Siła bezsilnych.

115 E.g. AAN, KC PZPR 1354, V/139, "Pilna notatka dotycząca rezultatów oficjalnej wizyty w W. Brytanii Prezesa Rady Ministrów Piotra Jaroszewicza" (memo on Jaroszewicz's visit to the UK), 18 December 1976, 4; AAN, KC PZPR 1354, XIA/662, "Pilna Notatka z oficjalnej wizyty we Francji I Sekretarza Komitetu Centralnego PZPR, Tow. Edwarda Gierka" (memo of Gierek’s visit to France), 17 September 1977, 19.

116 Jarząbek, "A trap and a chance," 150-60.

117 Rakowski, Dzienniki, 1976-1978, 220.

118 Rakowski, Dzienniki 1976-1978, 199, 301 and 440; Rakowski, Dzienniki, 1979$1981,21,42$ and 46.

119 Lüthi, "Drifting apart," 382.

120 Majewski, "Polityka zagraniczna PRL w roku 1977," 115-17.

121 Romano, "Untying Cold War knots," 15-7.

122 See Chapter 1 by Federico Romero in this book.

123 Rakowski, Dzienniki 1976-1978, 416.

124 Rakowski, Dzienniki 1976-1978, 398.

125 Pawłow, Generat Pawłow, 84-5; Rakowski, Dzienniki 1976-1978, 292-3.

126 Rakowski, Dzienniki, 1979-1981, 141.

127 Kozłowski, Raporty dla Edwarda Gierka, 192.

128 Bień, Jak doszło do zadlużenia Polski, 80-1; Karcz, Zadlużenie zagraniczne Polski, 29 and $57-8$.

129 AMSZ, Dep. IV, 1/83, w.17, "Stanowisko Polski wobec projektu porozumienia RWPGEWG" (Polish attitude to EEC-CMEA agreement), Rurarz, 14 November 1977.

130 AMSZ, ZD, 24/79, w.11, Olszowski to Gierek, 17 March 1977 in Majewski, Polskie dokumenty dyplomatyczne 1977, 234-6.

131 Kubik, The power of symbols, 31-74.

132 Kubik, The power of symbols, 129-52; Zaremba, "Karol Wojtyła," 317-36.

133 E.g. Ash, The Polish Revolution, 13-34. Staniszkis, Poland's self-limiting, 150-88.

134 Rakowski, Dzienniki, 1979-1981, 130.

135 Although Poland declared default, the creditors did not proclaim it officially insolvent. See Bartel, "Fugitive leverage."

136 See Chapter 5 by Maximilian Graf and Chapter 3 by Pál Germuska in this book.

\section{Bibliography}

\section{Published primary sources}

Polskie dokumenty dyplomatyczne 1977, edited by Piotr M. Majewski, Warszawa: Polski Instytut Spraw Międzynarodowych, 2009.

Raporty dla Edwarda Gierka, edited by Krzysztof Kozłowski, Warszawa: Polskie Wydawnictwo Ekonomiczne, 1988. 


\section{Secondary sources}

Ash, Timothy Garton. The Polish Revolution: Solidarity. London: Jonathan Cape, 1983.

Balcerowicz, Ewa. Przetarg planistyczny: mechanizmy i skutki spoteczno-gospodarcze. Warszawa: Państwowe Wydawnictwo Ekonomiczne, 1990.

Barcikowski, Kazimierz. U szczytów władzy. Warszawa: Projekt, 1998.

Bartel, Fritz. "Fugitive leverage: commercial banks, sovereign debt, and Cold War crisis in Poland, 1980-1982.” Enterprise \& Society 18:1 (2017): 72-107.

Bień, Witold. Jak doszło do zadtużenia Polski za granica w latach 1970-1985. Wspomnienia uczestnika wydarzeń. Warszawa: Difin, 2017.

Bobrowski, Czesław. "Na to nas nie stać. ...” In Władysław Gomułka we wspomnieniach, edited by Bronisław Syzdek, 184-96. Lublin: Wydawnictwo Lubelskie, 1989.

Borodziej, Włodzimierz. "Polskie peryferie polityki zagranicznej Związku Radzieckiegolata siedemdziesiąte.” In Modernizacja. Centrum. Peryferie. Księga jubileuszowa z okazji 70. Rocznicy urodzin Profesora Ryszarda Stemplowskiego, edited by Włodzimierz Borodziej and Sławomir Dębski, 51-72. Warszawa: Polski Instytut Spraw Międzynarodowych, 2009.

Bożyk, Paweł. Marzenia i rzeczywistość, czyli anatomia polskiego kryzysu. Warszawa: Państwowy Instytut Wydawniczy, 1983.

Bożyk, Paweł. Apokalipsa wedlug Pawła. Jak zniszczono nasz kraj? Wrocław: Wektory, 2015.

Dudek, Antoni and Ryszard Gruz. Komuniści i Kościól w Polsce 1945-1989. Kraków: Znak, 2003.

Dwilewicz, Łukasz. "Polityka gospodarcza, a spokój społeczny. Posunięcia władz partyjnych i państwowych od grudnia $1970 \mathrm{r}$ do grudnia 1971." In Gospodarka i spoleczeństwo w czasach PRL-u, edited by Elżbieta Kościk and Tomasz Głowiński, 333-53. Wrocław: Gajt, 2007.

Dwilewicz, Łukasz. "Rola ekspertów w zarządzaniu gospodarką PRL w latach siedemdziesiątych." Studia Polityczne 24 (2009): 7-46.

Dwilewicz, Łukasz. "Reformy Bolesława Jaszczuka i polityka gospodarcza ekipy gierkowskiej- zwrot i ciągłość." In Dekada Gierka. Wnioski dla obecnego okresu modernizacji Polski, edited by Krzysztof Rybiński, 73-120. Warszawa: Wyższa Szkoła Ekonomiczno-Informatyczna, 2011.

Eisler, Jerzy. Grudzień 1970. Geneza, przebieg, konsekwencje. Warszawa: Sensacje XX wieku, 2000.

Eisler, Jerzy. "March 1968 in Poland." In 1968: the world transformed, edited by Carole Fink, Philipp Gassert and Detlef Junker, 237-52. Cambridge: Cambridge University Press, 2013.

Eisler, Jerzy. Siedmiu wspaniatych. Poczet pierwszych sekretarzy KC PZPR. Warszawa: Czerwone i Czarne, 2014.

Eisler, Jerzy. Czterdzieści pięć lat, które wstrząsnęło Polska. Historia polityczna PRL. Warszawa: Czerwone i Czarne, 2018.

Fidelis, Małgorzata. "Pleasures and perils of socialist modernity: new scholarship on postwar Eastern Europe.” Contemporary European History 25:4 (2016): 1-12.

Friszke, Andrzej. Rewolucja Solidarności 1980-1981. Kraków: Znak, 2014.

Gierek, Edward and Bohdan Rolicki. Przerwana dekada. Warszawa: Fakt, 1990.

Jarosz, Dariusz. "The collectivization of agriculture in Poland: causes of defeat." In The collectivisation of agriculture in communist Eastern Europe, edited by Constantin Iordachi and Arnd Bauerkämper, 113-46. Budapest: Central European University Press, 2014.

Jarosz, Dariusz and Maria Pasztor. Polska-Francja, 1970-1980. Relacje wyjątkowe? Warszawa: Aspra, 2006. 


\section{4}

Jarząbek, Wanda. "Hope and reality: Poland and the Conference on Security and Cooperation in Europe, 1964-1989." Working Paper No. 56. Washington, DC: Woodrow Wilson International Centre for Scholars, 2008.

Jarząbek, Wanda. Polska Rzeczpospolita Ludowa wobec polityki wschodniej Republiki Federalnej Niemiec $w$ latach 1966-1976: wymiar dwustronny i międzynarodowy. Warszawa: Instytut Studiów Politycznych Polskiej Akademii Nauk, 2011.

Jarząbek, Wanda. "Polish economic policy at the time of détente." European Review of History 21:2 (2014): 293-309.

Jarząbek, Wanda. "A trap and a chance: Basket III, dissidents and state authorities in Communist Poland." In Human Rights in Europe during the Cold War, edited by Rasmus Mariagerm Karl Molin and Kjersti Brathagen, 150-60. Abingdon: Routledge, 2014.

Jasiński, Leszek. Blizej centrum czy na peryferiach? Polskie kontakty gospodarcze z zagranica wXX wieku. Warszawa: Trio, 2011.

Kansikas, Suvi. "Room to manoeuvre? National interests and coalition-building in the CMEA, 1969-75." In Reassessing Cold War Europe, edited by Sari Autio-Sarasmo and Katalin Miklóssy, 193-209. Abingdon, Routledge, 2011.

Kansikas, Suvi. Socialist countries face the European Community: Soviet-bloc controversies over East-West trade. New York: Peter Lang, 2014.

Karcz, Zbigniew. Zadtużenia zagraniczne Polski. Gra o miliardy. Kiedy do Euro? Warszawa: Difin, 2006.

Kemp-Welch, Anthony. Poland under communism: a Cold War history. Cambridge: Cambridge University Press, 2008.

Kramer, Mark. "The Czechoslovak crisis and the Brezhnev Doctrine." In 1968: the world transformed, edited by Carole Fink, Philipp Gassert and Detlef Junker, 111-71. Cambridge: Cambridge University Press, 1998.

Kostikow, Piotr and Bohdan Roliński. Widziane z Kremla, Moskwa-Warszawa. Gra o Polske. Warszawa: Oficyna Wydawnicza BGW, 1992.

Kotowicz-Jawor, Joanna. Presja inwestycyjna $w$ latach siedemdziesiatych. Warszawa: Państwowe Wydawnictwo Naukowe, 1983.

Kubik, Jan. The power of symbols against the symbols of power: the rise of Solidarity and the fall of state socialism in Poland. University Park: Pennsylvania University Press, 1994.

Kuczyński, Waldemar. Po wielkim skoku. Warszawa: NOWA, 1979.

Lipski, Jan Józef. KOR: a history of the Workers Defense Committee in Poland, 19761981. Berkeley: University of California Press, 1985.

Lüthi, Lorenz M. "Drifting apart: Soviet energy and the cohesion of the communist bloc in the 1970s and 1980s." In Cold War energy: a transnational history of Soviet oil and gas, edited by Jeronim Perović, 371-400. London: Palgrave Macmillan, 2017.

Machcewicz, Paweł. Rebelious satelite: Poland 1956. Translated by Maya Latynski. Washington, DC: Woodrow Wilson Centre Press, 2009.

Machcewicz, Paweł. "Materiały: Polityka Zagraniczna PRL w roku 1975." Polski Przeglad Dyplomatyczny 4:62 (2011): 119-52.

Majewski, Piotr. "Polityka zagraniczna PRL w roku 1977." Polski Przegląd Dyplomatyczny 52:6 (2010): 108-38.

Mazur, Mariusz. Propagandowy obraz świata. Polityczne kampanie prasowe w PRL 19561980. Warszawa: Trio, 2003.

Mourlon-Druol, Emmanuel. "The role of a creditor in the making of a debt crisis: the French government's financial support to Poland, between Cold War interests and economic 
constraints, 1958-1971." Financial History Review (2020): 1-22. Accessed 18 March 2020. https://doi.org/10.1017/S0968565019000222.

Namiotkiewicz, Walery. Bytem sekretarzem Gomutki. Warszawa: Comandor, 2002.

Paczkowski, Andrzej. The spring will Be ours: Poland and the Poles from occupation to freedom. Translated by Jane Cave. University Park: Pennsylvania State University Press, 2003.

Paczkowski, Andrzej. Revolution and counterrevolution in Poland 1980-1989: Solidarity, martial law, and the end of communism in Europe. Translated by Christina Manetti. Rochester: University of Rochester Press, 2015.

Pajestka, Józef. Polski kryzys, 1980-1981. Jak to do niego doszło i co rokuje? Warszawa: Książka i Wiedza, 1981.

Pawlicka, Katarzyna. Polityka władz wobec kościoła katolickiego: grudzień 1970październik 1978. Warszawa: Trio, 2004.

Pawłow, Witalij. Generat Pawłow: byłem rezydentem KGB w Polsce. Warszawa: Oficyna Wydawnicza BGW, 1994.

Prażmowska, Anita. Władysław Gomułka a biography. London: I.B. Tauris, 2015.

Rakowski, Mieczysław. Dzienniki polityczne 1958-1962. Warszawa: Iskry, 1998.

Rakowski, Mieczysław. Dzienniki polityczne 1969-1971. Warszawa: Iskry, 2001.

Rakowski, Mieczysław. Dzienniki polityczne, 1972-1975. Warszawa: Iskry, 2002.

Rakowski, Mieczysław, Dzienniki polityczne, 1976-1978. Warszawa: Iskry, 2002.

Romano, Angela. "Untying Cold War knots: the European Community and Eastern Europe in the long 1970s." Cold War History 14:2 (2014): 153-73.

Rurarz, Zdzisław. Bytem doradca Gierka. Chicago: Andy Grafik, 1990.

Skórzyński, Jan. Siła bezsilnych. Historia Komitetu Obrony Robotników. Warszawa: Świat Książki, 2012.

Skrzypek, Andrzej. Mechanizmy autonomii: stosunki polsko-radzieckie 1956-65. Pułtusk: Akademia Humanistyczna im. A. Gieysztora, 2008.

Skrzypek, Andrzej. Mechanizmy klientelizmu. Stosunki polsko-radzieckie 1964-1989. Pułtusk: Akademia Humanistyczna im. A. Gieysztora, 2008.

Skrzypek, Andrzej. Dyplomatyczne dzieje PRL w latach 1956-1989. Pułtusk: Akademia Humanistyczna im. A. Gieysztora, 2010.

Slay, Ben. The Polish economy: crisis, reform, and transformation. Princeton: Princeton University Press, 1994.

Staniszkis, Jadwiga. Poland's self-limiting revolution. Princeton: Princeton University Press, 1984.

Stokłosa, Katarzyna. Polen und die deutsche Ostpolitik 1945-1990. Göttingen: Vandenhoeck \& Ruprecht, 2011.

Stola, Dariusz. Kampania antysyjonistyczna w Polsce 1967-1968. Warszawa: Instytut Studiów Politycznych Polskiej Akademii Nauk, 2000.

Stola, Dariusz. Kraj bez wyjścia? Migracje z Polski 1949-1989. Warszawa: Instytut Pamięci Narodowej, 2010.

Szumiło, Mirosław. "Rozmowy Edwarda Gierka z dyplomatami sowieckimi w latach 1963-1965 (dokumenty odnalezione w RGASPI).” Komunizm: system, ludzie, dokumentacja 2 (2013): 315-36.

Szumiło, Mirosław. "Kierownictwo PZPR w latach 1971-1980." In PRL na pochylni (1975-1980), edited by Marcin Bukała and Dariusz Iwaneczko, 30-59. Rzeszów: Instytut Pamięci Narodowej, 2017.

Szumiło, Mirosław. "Pomarcowa wymiana kadr-elita PZPR w latach 1968-1970." In Yesterday. Studia z historii najnowszej. Księga dedykowana prof. Jerzemu Eislerowi w 


\section{6}

65 rocznicę urodzin, edited by Jan Olaszek, Antoni Dudek, Łukasz Kamiński, Krzysztof Kosiński, Michał Przeperski, Konrad Rokicki, Paweł Sasanka, Robert Spałek and Sławomir Stępień, 514-28. Warszawa: Instytut Pamięci Narodowej, 2017.

Szumski, Jakub. "Leonid Brezhnev and Edward Gierek: The making and breaking of an uneven friendship." Soviet and Post-Soviet Review 45:3 (2018): 253-86.

Tavani, Sara. "Muddling through the European bloc system: the evolution of Italian-Polish relations over the 1970s and 1980s." In Disintegration and integration in East-Central Europe: 1919-post-1989, edited by Wilfried Loth and Nicolae Pãun, 147-68. BadenBaden: Nomos Verlag, 2014.

Tejchma, Józef. Kulisy dymisji. Z dzienników ministra kultury. Kraków: Oficyna Cracovia, 1991.

Tejchma, Józef. Pożegnanie z władza. Warszawa: Projekt, 1998.

Tejchma, Józef. Odszedt Gomutka przyszedt Gierek. Toruń: Adam Marszałek, 2006.

Waszczuk, Jerzy. Biografia niezlustrowana: zapamiętywanie czasu nieutraconego. Warszawa: Studio Emka, 2007.

Westad, Odd Arne. "Beginnings of the end: how the Cold War crumbled." In Reinterpreting the end of the Cold War: issues, interpretations, periodizations, edited by Silvio Pons and Federico Romero, 68-81. London: Frank Cass, 2011.

Zaremba, Marcin. “Upalny czerwiec 1976.” Więź 6:512 (2001): 106-19.

Zaremba, Marcin. "Propaganda sukcesu. Dekada Gierka." In Propaganda w PRL, edited by Piotr Semków, 22-32. Gdańsk: Instytut Pamięci Narodowej, 2004.

Zaremba, Marcin. "Karol Wojtyła the pope: complications for comrades of the Polish United Workers' Party." Cold War History 5:3 (2005): 317-36.

Zaremba, Marcin and Błażej Brzostek. "Polska 1956-1976: w poszukiwaniu paradygmatu." Pamięć i Sprawiedliwość 5:2 (2006): 25-37. 


\title{
5 Drifting Westward? East Germany and Integrated Europe
}

\author{
Maximilian Graf
}

In spring 1983, when the German Democratic Republic (GDR) faced acute danger of bankruptcy, Erich Honecker's critics in the East German leadership reported to Moscow that the general secretary of the Socialist Unity Party of Germany (Sozialistische Einheitspartei Deutschlands [SED]) considered the 'European Community to be way ahead of the CMEA'. In their view, his position was 'anti-communist, false, slanderous and has to be appropriately shattered through a proper appraisal of the history of the CMEA and a thorough exposure of the imperialist EC'. ${ }^{1}$ But this was only the tip of the iceberg. For some years they had complained about Honecker's economic policy, the growing dependence on the West and West Germany and, in their view, an increasingly ambivalent attitude towards the Soviet Union. Next to Honecker, the almost almighty SED secretary of economics, Günter Mittag, was the main target of their criticism. They even demanded his removal. Seeing no way of changing the course within the politburo, Honecker's critics hoped for action by the Communist Party of the Soviet Union (CPSU). ${ }^{2}$ Among them were politburo members Werner Krolikowski, Prime Minister Willi Stoph and, though to a varying degree, Minister of State Security Erich Mielke, who in the years of economic and financial crisis often backed Honecker's policy in Moscow. ${ }^{3}$ Within the GDR's ruling circles these back-channel critics stayed surprisingly silent and hardly ever openly opposed the political course. Regarding economics, opposition was instead voiced by experts. However, their criticism fell on deaf ears and economic policy was not changed throughout the Honecker era.

In comparison to other CMEA countries, the economic history of the GDR is especially well researched. It is well known who the economic decision-makers were, and internal conflicts have been studied in detail. At the macro level, economic decision-making was dominated by Honecker's 'small circle'. This consisted of the politburo members responsible for economic policy and the head of the State Planning Commission, Gerhard Schürer, whose influence declined in the Honecker era. Although officially out of office from 1973 to 1976, the most remarkable figure in this circle was Mittag, who also presided over the politburo's FRG Working Group. ${ }^{4}$ Foreign policy decision-making was centralised to, and at times even monopolised by, the secretary general and his closest advisors. Nevertheless, regarding dependence on the West and relations with the Federal Republic 
of Germany (FRG), it remains questionable whether Honecker's critics were right in accusing him of a westward drift or if this policy was more a result of the unresolvable paradoxes of the existence of the GDR.

Among the European socialist states, East Germany was a special case characterised by several particularities. Many of these were direct consequences of the division of Germany. While the more prosperous FRG became a permanent magnet for the East German population, the Soviet Union was the most important political and economic partner and controller when it came to the GDR's relations with the West. Therefore, Moscow and Bonn were the points of reference for the most exposed Warsaw Pact country. Historiography has established solid knowledge of the GDR's foreign relations, ${ }^{5}$ but a thorough analysis of East Germany's perceptions of the West and its dealings with it in the "long 1970s" is lacking. By combining often separated narratives on foreign policy and foreign trade, this chapter aims to broaden our understanding of the East German regime's rationale and actions by widening the perspective to a pan-European view.

The early 1970s brought not only a normalisation of German-German relations but also long-desired diplomatic recognition by the West and a sudden multiplication of international relations. Notwithstanding the centrality of the FRG in the East German concept of the West, this led to a far more pan-European approach than the common narrative centred on Bonn and Moscow suggests. Even though publicised SED policy documents only ranked the priority of the West after the socialist world and developing countries, the GDR devoted much energy to improving relations with it, especially with a view to reducing its dependency on the FRG. ${ }^{6}$ Although the GDR's pan-European policy extended to most countries on the continent, this chapter focuses on its foreign and economic policy towards the European Economic Community (EEC) and its member states. Apart from the FRG, France, Italy and the UK became preferred partners, though the smaller countries mattered as well. ${ }^{7}$ Although the GDR pursued a strictly bilateral approach in its relations with the West, it had to cope with the progress of European integration. While existing scholarship on the East German attitude to the EEC is mostly limited to perceptions of the integration process, ${ }^{8}$ this chapter investigates how the GDR dealt with the economic policies of the EEC and their repercussions on trade. The analysis is embedded in a broader account of how the East German elites perceived the role of Western Europe and the EEC in times of incipient globalisation, economic turbulence and détente.

What strategies did the East German regime develop to secure its goals against the challenge presented by the fact that long-desired international recognition and growing economic cooperation also resulted in dependencies and required at least some opening up? How did they change when the GDR faced growing economic problems towards the end of the decade? We know that many East German policies constituted little more than wishful thinking, but their intent was to make the existence of the GDR under SED rule permanent. Hence, the leadership aimed at demarcation, far more regarding West Germany than the rest of the West. The seemingly westward drift of the GDR in the Honecker era must be placed in its proper historical context by stressing continuities originating in the 1960s. Therefore, this chapter will first offer a summary of the European and German-German 
background. It will then examine the first half of the 1970s, a period of selfperceived success and confidence in which foreign and domestic political considerations shaped East German politics most. The third section will analyse the second half of the decade, when economic problems became more pressing and finally led to the debt crisis of the early 1980s. The conclusion emphasises how the East German way of surviving a severe economic crisis without fundamentally changing the failed economic policy was successful in the short term but contributed to the collapse of the regime in 1989.

\section{European and German-German background}

The East German long 1970s were decisively shaped by earlier developments, not only by the division of Germany but also the economic path(s) chosen. The industrialised East German territory was cut off from the broader economic area it belonged to until 1945 and lacked supplies of raw materials and the sales markets in which it was formerly embedded. Instead, it became a centrally planned economy integrated in the socialist bloc. The founding of two German states in 1949 was a result of the Cold War's division of Europe and was followed by two decades of mutual non-recognition. However, in the economic field, strong and beneficial bonds persisted. Intra-German trade became a unique specialty that developed out of exchanges between the occupation zones. It was regulated in 1951 through the indefinite Berlin agreement on trade between the currency zones of East and West Germany, which (with modifications) remained in force until German unification. The intentionally balanced exchange of goods was deducted in clearing units (Verrechnungseinheiten [VE]), with one VE equalling one deutsche mark (DM) and one GDR mark. Due to its nature, intra-German trade meant considerable economic advantages for the GDR, while the FRG pursued primarily, although not exclusively, political interests. There were tax benefits and no customs, and West Germany provided an interest-free technical loan covering the (anything but temporary) imbalances in the clearing account, the so-called swing. ${ }^{9}$

The founding of the EEC did not affect intra-German trade. In a protocol annexed to the Rome Treaties of 1957, the member states accepted the FRG's stance that trade between the two Germanies was domestic trade and did not require certificates of origin and was not subject to customs. Privileged access to the West German market made the GDR's economic relations with the West unique. While the other socialist states lacked this advantage and complained about it, the GDR defended it regardless of broader political goals. After an initial decline in the first half of the 1960s, due to the Störfreimachung policy aiming at a reduction of economic dependence on the FRG, the trade volume increased towards the end of the decade. This development was facilitated by easings that Bonn offered on investment loans and a more generous "swing". ${ }^{10}$

None of the Western countries recognised the GDR until the settling of GermanGerman relations with the Basic Treaty of 1972. Despite the absence of diplomatic relations, economic exchanges between East Germany and the West had never ceased, and they re-intensified in the mid-1960s. East Berlin's political elite regarded the improvement of economic relations as an instrument for achieving 
recognition. The first loan-financed investment deals with Western companies were intended to serve this purpose. In 1970, a large railway rolling stock order amounting to 800 million francs was placed in France. Paris enabled this deal by violating the EEC credit guidelines, which were changed a little later on French request. The next year, Mittag was invited to the French capital. East Berlin celebrated this as a major success, although it did not lead to any progress regarding recognition. ${ }^{11}$

The share of East German exports to the CMEA countries declined from $66.4 \%$ in 1965 to $59.5 \%$ in 1971 and the share of imports from $63.3 \%$ to $58.3 \%$. However, the impact of economic decisions taken for political purposes should not be overestimated. In fact, the West's increasing share in the GDR's foreign trade had basic economic reasons. The USSR and the other CMEA members were not willing or able to provide everything the industrialised East German economy needed to promote its competitiveness. For example, the production of machinery required new (Western) technology, and components needed to export to the socialist states had to be bought in the West. The CMEA Comprehensive Programme of 1971 did not facilitate the situation, as catching-up specialisation by the less developed member states reduced the sales markets in the East. In the West, East German products became less and less marketable. Terms of trade worsened both in the East and West, and increased exchanges with the West boosting the technology level of the East German economy seemed the only way out of this downward spiral. Nevertheless, the GDR was well integrated in the CMEA market, and modernisation through economic cooperation with the West always aimed to reduce dependence on the West and especially West Germany in the long run. As Ralf Ahrens states, 'Trade with capitalist countries was always a necessary evil to compensate the shortcomings of intra-COMECON trade and Eastern bloc economic coordination'. ${ }^{12}$

André Steiner has demonstrated that the New Economic System reform of the 1960s (which included some market elements, a very limited short-lived liberalisation of the foreign trade regime and a strategy of import-led growth labelled as a technology offensive) had remained within the concept of a centrally planned economy. It failed and was finally abandoned in 1970-71. The escalating number of large-scale investments exceeded the economic means of the GDR. One of the reasons why this was paralleled by a change of party leader in 1971 was internal and Soviet disagreement over the reforms and growing dependency (in the form of debts) on the West and West Germany. ${ }^{13}$

\section{The hopeful years: recognition, cooperation and welfare without opening}

In May 1971, the politburo ousted First Secretary Walter Ulbricht from power, elected Honecker as his successor, abolished the economic reforms and returned to strict central planning. Following the example of the CPSU, the eighth Party Congress of the SED later that year adopted the so-called Main Task, a socialist welfare policy concept that was later labelled Unity of Economic and Social Policy. This policy was expensive as it included subsidised prices, a housing programme 
and imports of consumer goods. The East German economy was never able to cover the costs. The State Planning Commission (headed by Schürer), central and foreign trade bankers (Grete Wittkowski, Horst Kaminsky, Helmut Dietrich, Werner Polze), Minister of Finance Siegfried Böhm and experts from academia (Helmut Koziolek, Otto Reinhold) immediately warned about the potential consequences of increasing debts. In later years their chorus was joined by the Ministry of State Security. Apart from the issue of debt, the agency of these economic elites is less visible than in other CMEA countries. Economic decisions were taken in Honecker's party-state small circle, and his rationale was to keep people satisfied (to the greatest possible extent). Hence, the policy remained unchanged even when the situation dramatically worsened from the mid-1970s onwards. ${ }^{14}$

Why did criticism fall on deaf ears for so many years? Against the background of the Polish workers' uprising in 1970 and incipient détente, the East German leadership truly believed that any worsening of living conditions was likely to destabilise the regime. Among the reasons for this are the socialisation of politicians in the interwar period, or more precisely Honecker's distrust of his own people, ${ }^{15}$ as well as the spectre of another people's uprising haunting the SED leadership since 1953. At least in retrospect, the belief that better living conditions would automatically lead to improved economic performance was wishful thinking. ${ }^{16}$ Although the policy was unaffordable in the long term, even the critical chief planner Schürer admitted in his memoirs that the loan-financed economic and social policy created a hopeful and more satisfied atmosphere in the first half of the 1970s, until it became clear that servicing the debts had turned into a serious problem. ${ }^{17}$

The rise of the Commercial Coordination division (Bereich Kommerzielle Koordinierung [KoKo]) operating outside the plan is proof of the leadership's acknowledgement that the economic policy did not work. Founded in 1966, KoKo was formally part of the Ministry of Foreign Trade, but in fact it was closely connected to the Ministry of State Security and under the control of the party's leading economic officials. The purposes of this institution, headed by Alexander Schalck-Golodkowski, were to earn convertible currency, make Western trade more flexible and solve financial crises. It gained importance throughout the $1970 \mathrm{~s}$, and in the 1980s KoKo organised Western and intra-German trade, reaching a share of more than $40 \%$. Nevertheless, it acted within the economic policy decreed by the SED, which was not put into question. ${ }^{18}$

Already in August 1971, the Council of Ministers regarded the balance of payments as a major problem. However, there was no easy way out. The need for further imports clashed with a level of debt that was regarded as unreasonable. The aim of increasing exports to the West clashed with export obligations to the CMEA countries, which secured the necessary supply of raw materials. ${ }^{19}$ Was there a real economic strategy, or did the preservation of power shape policy the most? The consumerist turn in the early Honecker era points in the latter direction and reduced the available funds for innovation and the technology offensive of the late Ulbricht years. However, soon after this policy shift, investments in the East German economy continued to serve foreign trade purposes. Modernisation through imports based on loans was initially regarded a temporary necessity but 


\section{Maximilian Graf}

developed into a permanent strategy. As it turned out, subsequent import substitution did not work. Investments in other sectors were too small and never paid back sufficiently. In a meeting of the State Planning Commission in 1972, Deputy Chairman Heinz Klopfer recalled that the investments were intended to increase exports and stated, 'The opposite is the case. The stream of imports has more and more increased. In my view, this is the main reason for our current situation' ${ }^{20}$ Although the debt was small in comparison with later years, the ratio of liabilities to annual export revenue was already alarming. However, in the age of easy access to cheap money the downside of this economic policy seemed negligible, or at least far away. When criticised for increasing debts in 1972, Honecker remarked that he 'did not intend to pay back the GDR's debts within two years'. ${ }^{21}$

In the first half of the 1970s it seemed that global economic and financial developments might work in favour of socialism. The monetary crisis following the end of the Bretton Woods system, and the first oil shock of 1973 troubled the Western economies. Initially, the crisis was interpreted in classical ideological terms by academics and the party alike. The dictum of the "chronic contradictions of the imperialist system' was in vogue again. ${ }^{22}$ Although to the foreign trade ministry it was clear that economic turbulence would limit the sales markets for exports and worsen conditions for financing imports, ${ }^{23}$ the effects that global economic changes would have on the GDR were hardly predicted and did not lead to policy changes. The oil shock can be seen in this regard. In the long run it resulted in high costs and massively influenced the domestic energy strategy, ${ }^{24}$ but initially and throughout the 1970s the GDR profited from rising world market prices. The export of refinery products made from cheap Soviet crude oil increased and has been interpreted as a logical answer to the need to earn more hard currency. ${ }^{25}$ Indeed, the export of processed oil products to West Berlin was lucrative, and profits increased with the second oil shock in 1979. ${ }^{26}$

However, even before the first shock, it had become clear that there would be no endless raw material supply from the USSR. ${ }^{27}$ In May 1973, chief planner Nikolai Baibakov informed the East Germans that the Soviet Union 'had overextended itself' with promises of deliveries. ${ }^{28}$ With regard to oil and rolled steel, this was a massive blow to the GDR's long-term export planning. East Berlin's acknowledgment that this would further increase imports from the West did not change the Soviet position even though the Kremlin worried about East German indebtedness. In August 1973, Prime Ministers Stoph and Aleksei Kosygin discussed the figures in detail. Annual payment obligations started to exceed the annual export earnings. This was considered the absolute maximum. Nevertheless, Stoph expected debt to rise further and told Kosygin that any forecast up to 1980 depended on the raw materials supplied by the Soviet Union and the other CMEA countries. In a nutshell, the GDR openly admitted that without growing quantities of cheap raw material from the USSR, indebtedness would continue to rise. Only increased production with this support could counteract this development. Kosygin remarked that the socialist countries must capitalise on the economic chaos in the West but conceded that Moscow had no idea how this could be done. ${ }^{29}$ Neither had the GDR. In the age of détente, East German dealings with the West focused on other things: politics dominated over economics. 
After twenty years of international isolation, by the early 1970s diplomatic recognition of the GDR in the West was under way due to the West German Neue Ostpolitik and the Soviet Union pushing through its own détente goals. The conclusion of the Basic Treaty in 1972 was a political bargain in which the GDR had to concede increasing contacts with the FRG and received economic benefits in return. ${ }^{30}$ Serving 'the economic interests of the GDR', as the politburo stated, intra-German trade remained unchanged. ${ }^{31}$ Entirely different assessments existed about its future development. In 1970, the Ministry of Foreign Trade expected a change in global economic developments in favour of the socialist world and anticipated a decreasing dependence on the FRG as a result of growing diversification of trade with the West. ${ }^{32}$ In contrast, in 1973 the State Planning Commission warned that the danger of economic dependency on the FRG was still underestimated. ${ }^{33}$ However, a turnaround was not in sight. The FRG was by far the most important Western trading partner and overall second only to the Soviet Union. While intra-German trade doubled in nominal value during the 1970s, in other fields the GDR aimed at a demarcation from the FRG. East Berlin refused to make any change to the border regime and doubled the minimum exchange rate of DM for West German visitors in 1973. Only economic pressure undermined this strategy. In 1974, after lengthy negotiations, East Berlin accepted some easing of the travel regime in exchange for a prolongation of the "swing". ${ }^{34}$ Concessions to maintain favourable economic ties were unavoidable but no formal linkage was accepted. East Berlin's attitude to the FRG remained ambivalent. It 'oscillated between cooperation and demarcation', and sometime these antipodes could also coexist. ${ }^{35}$ In 1975, cooperation agreements with the West German companies Krupp and Hoechst were concluded (enabling loan-financed imports of steel and chemical plants). ${ }^{36}$ Political dialogue continued, based on the assumption that the division of Germany was permanent, ${ }^{37}$ but even in the heyday of détente, increasing contacts across the border were not on the agenda.

After the Basic Treaty, the EEC member states recognised East Germany and it was admitted to the United Nations. International recognition increased the GDR's prestige, contributed to the legitimacy of its leadership and was another source of optimism. The GDR participated in the CSCE from the very beginning and the SED leaders celebrated the signing of the Final Act as the endpoint of achieving international recognition. Although the ministerial bureaucracy anticipated several potential consequences, in the mid-1970s the regime felt secure and the population seemed more satisfied, not least due to social and consumerist improvements. Dissidence was repressed and Western influence kept out to the best possible extent. However, the rising number of people requesting to permanently leave East Germany had been underestimated, even by the Ministry of State Security. In the long term, this seriously harmed the legitimacy of the SED regime. ${ }^{38}$ On the one hand, demarcation from the West increased. On the other, political and economic relations were about to be further developed. When the economic situation worsened, the GDR's approach to East-West relations came under pressure, but it was formally, though not consistently, upheld throughout the "long 1970s".

Apart from international recognition, the first half of the 1970s brought only limited political success regarding relations with the West. Only a few treaties 


\section{Maximilian Graf}

were signed, and state visits remained scarce. ${ }^{39}$ As always in East-West relations, economics came first. Given that intra-German trade represented the largest share of the GDR's Western trade (more than 30\%, and at times up to $40 \%$ and beyond), ${ }^{40}$ the relevance of other Western states had its limits. Aiming to create a counterbalance to its dependence on the FRG, the GDR tried to exploit the rest of the West. Those who agreed to visibly improve political relations became preferred economic partners. After recognition, some of the European neutral states took the lead. ${ }^{41}$ Among the EEC members, France, Italy and the UK were of most interest, ${ }^{42}$ but the development of economic relations was immediately influenced by the progress of European integration.

In the first two post-war decades, the GDR denounced every form of Western European integration as directed against the socialist camp and consistently argued that the project would fail due to the 'contradictions of imperialism'. From the mid-1960s onwards, a more nuanced approach evolved in the state and party apparatus. ${ }^{43}$ In the late 1960 s, the SED top level had come to terms with the EEC as a reality but refused to recognise it as a political entity. The Community's economic efficiency and political attractiveness were acknowledged internally, ${ }^{44}$ although traditional ideological patterns of capitalism analysis prevailed. In 1972 the politburo did not doubt the further progress of integration, but it expected enlargement in 1973 to cause conflicts among the main 'capitalist powers', which would be exacerbated by 'cyclical crises of capitalism'. ${ }^{45}$

Since the second half of the 1960s, the CMEA's EEC policy had become a major issue in intra-bloc discussions. Facing protectionism, Romania, Hungary, Poland and Bulgaria had hardly any other option than to deal with the Community to maintain the quantity of their exports. Hence, these countries aimed at a more flexible policy, while the Soviet Union and the GDR advocated strict non-recognition of the EEC. ${ }^{46}$ The East German leadership was conscious of the socialist states' need for Western technology, which had to be paid for by exports, but it did not expect any easing from Brussels. Despite the meagre results of the Comprehensive Programme, the GDR demanded deeper integration of the CMEA and a coordinated policy towards the EEC, ${ }^{47}$ a stance that sometimes brought it to the 'brink of isolation' within the socialist camp. ${ }^{48}$

Due to its special situation, the progress of Western integration initially affected the GDR less than other countries. The status quo of intra-German trade remained in place; for the other member states the newly recognised GDR became a third country. ${ }^{49}$ Since the GDR had never stipulated a trade agreement with any of them, the changes resulting from the EEC's Common Commercial Policy (CCP) seemed to be limited. On the contrary, the recently concluded cooperation agreements with almost all the Western countries were regarded as progress. However, none of them was ready to violate the CCP. ${ }^{50}$

Nevertheless, the GDR opted for bilateralism when dealing with the EEC members until it recognised that ignoring the Community had repercussions on trade. When additional charges caused losses to the export of pigs and pork to Italy and France in 1975, the Ministry of Foreign Trade recommended commencing technical contacts. ${ }^{51}$ The GDR gathered detailed information about the EEC modus 
operandi from Hungary. After consultation with the responsible party units, the politburo regretfully concluded that a concerted action by the CMEA was no longer possible and the GDR could only follow the path of the other member states. The SED accepted the advice from the state bureaucracy and approved the establishment of 'technical contacts of companies and institutions of the GDR with the EEC organs'. ${ }^{52}$ While acknowledging that the GDR, like the other socialist states, could solve all economic questions directly with the EEC, in 1977 the Ministry of Foreign Trade stressed the political importance of a desired agreement between CMEA and EEC. ${ }^{53}$ In an internal note, academic Hermann von Berg asked whether a framework agreement with the EC would not be the best solution and questioned if the GDR had a strategy at all. In his view, relations with the EEC were primarily shaped by the FRG's stance within the Community and it was in the GDR's interest that no questions regarding intra-German trade were raised during the CMEA-EEC negotiations. Furthermore, he wondered why the GDR was still so reluctant to conduct technical contacts and accepted the economic disadvantages. ${ }^{54}$

In 1977, the implementation of the EEC's common fisheries policy induced Poland, the USSR and the GDR to open direct negotiations. ${ }^{55}$ Since a substantial economic interest was impaired, the politburo agreed to talk to the Commission but insisted that this would not imply recognition of the EEC. ${ }^{56}$ The negotiations finally failed due to the question of the inclusion of the Berlin clause. Honecker personally authorised every step during the negotiations and interfered in the formulations regarding Berlin. ${ }^{57}$ The Common Market's increasing protectionism made the GDR's economic relations with the West no easier. However, the already inconsistent policy of non-recognition did not change, and bilateralism in relations with the West prevailed.

\section{The fateful years: prestige, dependence and the debt crisis}

In the second half of the 1970s, political relations with the West intensified, yet East German efforts achieved only limited results. From 1975 to 1978, first visits at the foreign minister level took place. Foreign Minister Oskar Fischer travelled to all the EEC capitals except Bonn and Dublin (since Ireland abstained from recognising the GDR until 1980). Several Western foreign ministers paid return visits to East Berlin, but only towards the end of the decade did high-level diplomatic encounters intensify. Visits by the heads of government or state only followed in the 1980s. To the public, all the visits and agreements were sold as proof of the international reputation the GDR had achieved. Regularly dominating the headlines of East German media, they were portrayed as the GDR's contribution to détente and economic cooperation in Europe (after 1975, always with reference to the CSCE). Naturally the public was not informed about the consequences of increasing economic exchanges with the West. ${ }^{58}$

Internally, the dilemma of import needs and growing indebtedness was omnipresent. The establishment of crisis management bodies like the Economic Commission and the Balance of Payments Working Group in 1976, together with the increasing relevance of KoKo, are proof of this. A permanent issue on the agendas 


\section{Maximilian Graf}

of all the economic bodies was reducing imports from the West, but sometimes the only path to reach this goal was further investment in industrial sectors that still demanded imports to fully function. The top-down implementation of import reduction through the plan failed due to the needs and obstinacy of various industrial sectors which had to keep buying from the West. ${ }^{59}$ With debt on the rise, the GDR's ability to meet its financial obligations was endangered. ${ }^{60}$ The outlook for the 1976-80 planning period was bleak, and avoiding bankruptcy seemed to be the real Main Task. ${ }^{61}$

The internal discussions reveal a strange dualism of realism and delusion. In a meeting of the small circle in November 1976, Schürer stated, 'The gap between imports and exports has widened further but it has to be closed by all means. That is a fateful question for the GDR'. Some considered rigorous import cuts; others reasoned about the causes within the CMEA and a re-prioritisation of investments. Stoph argued that major insecurity resulted from the development of the capitalist economy. Mittag endorsed this view by pointing to the difficulties in selling on Western markets. However, he also mentioned examples of favourable trade relations, such as with Greece, where the GDR had a high market share in machinery and imported agricultural products. Additionally, he highlighted the growing Western acceptance of countertrades. Contracts with France and Japan resulted in increasing trade volumes and constituted the best positions in the balance of payments. Mittag wanted to continue along this path. Honecker concluded that the 1976-80 plan was shaped by enforcement of the Unity of Economic and Social Policy. He stated: 'We can only walk our socialist path. The capitalists are currently cutting everything that serves social policy.... We shall not and cannot limit this side'. Whether a delusion or belief, Honecker remarked further:

The GDR is admired by many. Capitalism has taken the path of deflation or inflation. We are not taking those roads. We tread the path of planned and proportional development of our economy on an ever-higher level. . . We have to keep that course. All this must not be achieved at the expense of the worker's bones.

Regarding foreign trade, he said, 'We have to master the new problems due to the pressure external commerce exerts on our republic'. Honecker did not expect any progress in CMEA integration, expressed his worries about the balance of payments, and advocated increasing exports to the West and developing countries as well as cooperation in third markets if they earned hard currency. Like Mittag, he saw potential in trade with the West. He mentioned Greece and Sweden, countertrades with France and Japan, and similar possibilities with Italy and the US that would enable East German production to expand. ${ }^{62}$

In summer 1976, Honecker told Leonid Brezhnev that the GDR possessed a 'special plan to become independent from the West', but he did not detail it. ${ }^{63}$ The archival documents do not reveal any such plan, but it is very likely that modernisation through countertrades resulting in increased exports to the West was his core idea and hope. The most convenient solution would have been to solve the 
hard-currency deficit by making use of the differences between CMEA and world market prices for Soviet raw materials. However, these hopes were shattered by Kosygin in a conversation with Stoph at the end of 1976 when he stated that increased imports of such valuable resources would have to be paid for in hard currency. In March 1977, the balance of payments had worsened to such an extent that Schürer and Mittag for once joined forces and reported to Honecker, 'For the first time, we are in acute financial difficulties'. When confronted with their call to immediately change trade policy, Honecker reacted furiously. He regarded their step as an all-out attack on him and his economic policy. In the end, Mittag and Schürer backed down. ${ }^{64}$ In the next meeting of the small circle, the general secretary proposed to solve the acute problems by making use of existing secret reserves (like West German subsidies, which were under his exclusive control and probably contributed to his rather relaxed attitude). However, he regarded this as a last resort. ${ }^{65}$

In 1977, East Germany's export earnings did not suffice to service its debts. At the end of 1978 the balance of payments showed a deficit of 17.8 billion Valutamark (VM $)^{66}$ in convertible currencies. Ninety percent of the imports from the West were loan-financed. Interest payments and amortisations required new loans. As always, the East German leadership intended to solve this problem by reducing imports, increasing exports and adopting other measures that throughout the 1970s constantly failed to materialise. Nevertheless, not everything was a direct result of the state planning system's failure. Global developments were beyond the SED's control. According to East German estimates, the 1971-78 rise in world market prices had increased the deficit by 3.1 billion VM and unplanned imports of grain (due to crop shortfalls in the GDR and the USSR) added another 3.8 billion VM. The overall outlook was bleak. Since the annual hard-currency spending on interest payments and amortisations exceeded export earnings, the deficit was growing year after year. An analysis of the GDR's balance of payments in 1978 by Schürer, Böhm, Kaminsky and Polze stated the obvious: 'This spiral cannot be prolonged'. It was entirely clear that 'without the willingness of foreign, and especially capitalist, banks to provide further loans of the amount needed, the planned imports and the due payment obligations cannot be realised'. Without a fundamental turnaround in the GDR's trade balance with the West, debt was expected to skyrocket until the mid-1980s. ${ }^{67}$ In November 1980, the economic experts of the Ministry of State Security advocated a complete stop to all imports from the West that were not indispensable to keep production afloat. ${ }^{68}$

Nevertheless, the GDR's assessment of the economic situation in Western Europe seems to have encouraged its economic elite to pursue the path of loanfinanced imports and countertrades further - there seemed to be no alternative ${ }^{69}$ In Italy, GDR foreign traders registered a growing interest in developing economic relations and aimed to treble the trade volume until $1980 .{ }^{70}$ In the case of France, the economic situation of the country was seen as an incentive for more intense economic relations with the GDR..$^{71}$ One of the preferred strategies was loan-financed countertrades - a business model that made the development of exports a bit more plannable and secured at least some revenue. Usually, these 


\section{Maximilian Graf}

deals had a credit period of up to eight years and favourable credit conditions. Additionally, the compensation principle guaranteed certain exports in return (up to $100 \%$, but generally way below $50 \%)^{72}$

Internal plans for loan-financed countertrades reveal how debt-driven this business had become. In 1978, State Secretary Gerhard Beil, who was in charge of day-to-day business in trade relations with the West, prepared a detailed list of the sums available for export funding and loans in various Western countries that would not impair the credit volumes of the East German Foreign Trade Bank. The overall volume amounted to 7.9 billion VM. ${ }^{73}$ In 1979 the GDR planned to conclude countertrades worth more than 15 billion VM. ${ }^{74}$ Despite the year-long failure to reach a balanced trade with the West, Honecker objected to any negative views on compensation within the state and party economic elite: 'This is nonsense. It is of great value for us. We import to export in the future' ${ }^{75}$ In the view of his opponents, the general secretary and Mittag had entered an economically unjustifiable 'technological alliance with capitalism' camouflaged as countertrades to keep their 'consumer socialism' afloat. ${ }^{76}$

Metallurgy products played an important role in many of these countertrades. In this regard, EEC policies on imports made the life of the East German foreign traders more difficult. Against the backdrop of a crisis in the European steel sector, in December 1977 the European Council 'decided that all countries exporting steel to the EEC' had to conclude bilateral agreements so that the EEC 'could impose price discipline'. ${ }^{77}$ Varying from country to country, up to $100 \%$ of the exports seemed endangered. While in 1975 the Ministry of Foreign Trade had promoted technical contacts with the EEC, in 1978 it warned that sectoral agreements on quotas and minimum prices would go beyond technical contacts. ${ }^{78}$ Again, East Berlin hoped for concerted action by the CMEA members. At the next meeting of the CMEA Executive Committee's Standing Commission on Foreign Trade, Foreign Trade Minister Horst Sölle proposed considering if a threat or actual shifting of the CMEA's steel imports from the Common Market to other suppliers could be used as a means of commercial policy. ${ }^{79}$ While East Germany considered counteraction potentially more effective than negotiations with the Commission, most of the other CMEA countries thought differently. ${ }^{80}$

Within four months, Czechoslovakia concluded an agreement with Brussels and was soon followed by Hungary, Romania and Poland. The GDR and the USSR refused to enter negotiations and faced the consequences. Several EEC countries announced restrictions on East German steel exports. The UK imposed an import contingent, reducing planned exports by $15 \% .{ }^{81}$ Furthermore, many of the loanfinanced steel plants and other industrial complexes predominantly had to be refinanced by metallurgy exports. The GDR had to rely on the good will of its partners. By successfully negotiating with Italy, Beil secured refinancing exports and there was hope that similar results could be reached with other countries. ${ }^{82}$

According to the commercial department of the GDR's embassy in Brussels, the 1977 Davignon Plan for Europe's Steel had led to the establishment of permanent 'working contacts' with other CMEA member embassies in the EEC that aimed to 'secure individual economic interests'. Despite intensive cooperation among the diplomats of the CMEA states, for the East Germans 'their knowledge was only of 
limited use'. Even appealing incentives, like Belgian interlocutors stating that the GDR would be in 'a far better position, if it were willing to negotiate with the EEC', did not change the East German stance. ${ }^{83}$ Instead, the GDR faced several antidumping measures. ${ }^{84}$ To 'prevent economic losses', the Ministry of Foreign Trade decided that foreign trade companies should establish short-term technical contacts with the Commission, which they did in five out of ten cases until mid-1980. ${ }^{85}$

Despite the problems in day-to-day business, no initiative to change policy towards the EEC came from the ministries or foreign trade companies. It was the CMEA Working Group of the SED, headed by Horst Tschanter, that became frustrated about the CMEA's inability to negotiate a treaty with the EEC and in 1979 recommended that the GDR also made its own agreements with the Common Market. ${ }^{86}$ Only in 1981 did the commercial department of the embassy in Brussels argue that an engagement with the EEC regarding certain commodity groups would positively influence exports to the Common Market. ${ }^{87}$ In the end, none of these recommendations led to a policy change. Against all odds, bilateralism continued. At the end of the 1970s, the GDR aimed at a breakthrough in political and economic relations with France. Top-level visits were accompanied by the placing of large-scale orders, and cooperation agreements were concluded. However, even though the trade volume increased significantly in the early 1980s, it hardly ever exceeded $10 \%$ of the volume of intra-German trade. ${ }^{88}$ In 1980, Soviet Minister of Foreign Trade Nikolai Patolichev told the East Germans, 'As soon as France breaks out of the EEC bloc regarding cooperation with the Soviet Union, the EEC measures will be more or less without effect' ${ }^{89}$ The East German economic elite perceived it as characteristic of the French attitude to accept proposals violating certain EEC provisions as long as they did not appear in the official text of the treaty subject to review by the Commission. ${ }^{90}$ East Berlin was in line with Moscow and, indeed, the EEC was definitely not a field on which the SED leaders intended to quarrel with the already suspicious Soviets. Even though attempts to diversify trade continued, West Germany remained by far the most important economic partner in the West. In August 1980, Soviet criticism escalated. At a meeting in Crimea, Brezhnev attacked Honecker's economic policy, the GDR's Western orientation and especially its relations with the FRG..$^{91}$ The Soviet leader was furious about the resulting dependence and repercussions on trade with the USSR. According to Schürer, the 'distinctness and harshness' of his criticism was new in form and scale. Mittag and Honecker engaged in appeasing but countered Brezhnev by blaming Moscow for not satisfying the GDR's raw material needs and defending the resulting increased exchanges with the West as unavoidable. ${ }^{92}$

In fact, because of the Soviet stance and for its very own reasons, in the second half of the 1970s political relations with the FRG stagnated, while economic and financial reasons commanded continued cooperation. ${ }^{93}$ Altogether, the annual lump sums for transit and communication and the money earned from trading political prisoners ${ }^{94}$ increased from 600 million DM in 1975 to 1.556 billion DM in $1979 .{ }^{95}$ In return for benefits beyond this already high level, Bonn demanded concessions in other fields. Additionally, the GDR feared a spillover of EEC protectionism to intra-German trade. ${ }^{96}$ Securing economic exchanges on the best plannable basis made long-term agreements on economic cooperation appealing, 
and in early 1979 the idea of such an accord between the two German states surfaced. ${ }^{97}$ Obviously the Soviet-West German agreement of 1978 served as an incentive, and a first draft was agreed with the USSR. ${ }^{98}$ According to West German sources, Honecker was even willing to give up the benefits of intra-German trade. ${ }^{99}$ The East German sources reveal no such intention, and for the FRG only an agreement not affecting the principles of intra-German trade was conceivable. In the end, no agreement was concluded, most probably because of West German considerations regarding the EEC. ${ }^{100}$

In August 1980, Helmut Schmidt cancelled a visit to the GDR on short notice and Honecker was relieved, despite publicly regretting the cancellation. Like the West German chancellor, he feared potential repercussions of the situation in Poland, with Solidarity turning from a strike committee into a political force. In part a result of Soviet criticism and in part due to the Polish crisis, in autumn 1980 the climate in German-German relations worsened. Honecker issued his Gera demands aiming at basic political concessions (i.e. West German recognition of East German citizenship) and increased the minimum exchange rates for Western visitors to the GDR. Bonn regarded this step as a moral breach of the 1974 compromise, and the expiry of the "swing" agreement at the end of 1981 gave it a lever over the economically ailing GDR. During a visit to the GDR in December 1981, Schmidt granted an interim six-month prolongation of the "swing", pointing out that a future agreement would be psychologically linked to the minimum exchange rates. ${ }^{101}$ Nevertheless, East Germany upheld its dogma that negotiations on economic questions must not be linked with other bilateral issues. ${ }^{102}$ In April 1982, Schalck-Golodkowski, who had a prominent role in developing relations with the FRG, warned that a reduction of the "swing" would strengthen those in the leadership who already advocated economic isolation and closed borders. ${ }^{103} \mathrm{~A}$ compromise was reached in June and constituted a relief during the GDR's debt crisis, which had worsened since the turn of the year.

Apart from the uncertainty about the future of the "swing", the year 1981 had dramatically complicated the economic situation. In the summer, the USSR announced a reduction in crude oil deliveries to the GDR by 2 million tons. This was a massive blow, because the refined oil was sold for hard currency on the world market. According to Krolikowski, Honecker reacted with an 'enforced drift westward'. He wanted to keep the GDR stable with a more 'elastic' approach to the West and the FRG. In November, behind closed doors, central banker Kaminsky confirmed Stoph's assessment of the financial situation: 'If I got it right, without a miracle, we will go bankrupt in 1982 ' ${ }^{104}$ Things became much worse, with a Western 'credit boycott' after the imposition of martial law in Poland on 13 December. The GDR's practice of servicing debts by taking out new loans immediately brought it to the verge of bankruptcy. To the discomfort of most of the economic elite, the politburo opted for a going-out-of-business sale during which everything possible was sold. Even though an active trade balance was achieved, the effort was not enough to prevent insolvency. In spring 1982, debt conversion or bankruptcy seemed unavoidable to many of the GDR's experts, but the leadership determinedly opted to stay solvent. All the secret funds were used, and 
expensive trade operations by KoKo created liquidity. ${ }^{105}$ According to a report by the economic division of the Ministry of State Security, Günter Ehrensperger, the head of the SED's department for Planning and Finance, remarked, 'Mittag has to save his face and to postpone insolvency of the GDR as long as possible'. He 'is fighting for his political existence'. Others even held the revealing view that the future existence of the GDR 'depended solely on the West'. ${ }^{106}$

However, unlike other socialist countries, the GDR did not aim at joining the International Monetary Fund or the World Bank. ${ }^{107}$ The economic elite had toyed with several options. A bailout by the Soviets was favoured by many but was unlikely, yet the USSR helped by selling additional quantities of crude oil for world market prices with favourable credit periods. In return, the GDR exported consumer goods purchased in the West. The immediate conversion of Western export loans and clearing units from intra-German trade into hard currency and large-scale oil deals with the Soviet Union - and interestingly, also Austria - finally secured solvency in 1982-83. Indeed, the USSR contributed much to this, but ironically, it was still Western money that saved the GDR from bankruptcy. The Western vendors providing export loans to boost their own economies became the real creditors. Since these trade operations were extremely expensive, the search for new loans continued. In the early stages of the 'credit boycott', the option of a West German loan following the principle of 'freer movement in return for cash' (the so-called Zurich model) was seriously considered by the GDR. However, a loan of up to 5 billion DM would have required substantial concessions in return, which the SED leadership intended to avoid. Until the government change in Bonn in October 1982 (when Schmidt tumbled in a no-confidence vote and Helmut Kohl became chancellor), no loan was provided. ${ }^{108}$ Finally, two loans of 1 billion DM contrived by the Bavarian Prime Minister Franz-Josef Strauß in 1983 and 1984 released the GDR from its acute debt crisis, not least because they re-established the country's creditability in the international financial markets. ${ }^{109}$ However, they did not solve all the problems and, indeed, allowed the leadership to avoid changes in economic policy.

In a meeting of the small circle after the first Strauß loan held in August 1983, Honecker remarked, 'The Milliardenkredit is not here to bridge gaps in the plan. No minister can rely on this. We have to act as if we did not have the money'. He pointed to the necessity of reducing short- and medium-term loans and continuing the policy of reducing imports and increasing exports. Honecker was fully aware that the prolongation of the extreme foreign trade strategy would face opposition in the West: 'Countries like France, Great Britain and Belgium, with whom we have an active balance, also want to sell and not only buy'. However, at that time there was still no alternative to reducing imports and selling oil on the world market. Nevertheless, pointing to developments in the other socialist countries, Honecker stated, 'I want to put on record that our economic system is altogether in best order. It just depends on using the advantages of socialism properly. I am saying this because there is talk about reforms in many countries' ${ }^{110}$ Indeed, despite and because of its own reform experiment in the 1960s, the East German leadership had always been highly sceptical about reform attempts by other socialist states. 
Although the preceding statements leave few doubts that Honecker's dealing with the 'necessary evil' was primarily aimed at securing power by continuing his economic policy, his critics saw it differently and so did Moscow. ${ }^{111}$ In 1984, immediately after the second Strauß loan and with preparations for a visit by Honecker to the FRG in full swing, the East German leadership was called to the Kremlin. The CPSU leaders harshly criticised Honecker's policy towards the FRG and pressed him to cancel his visit. ${ }^{112}$ However, the question remains: were Honecker's opponents right when they denounced him in Moscow, claiming that he did not believe in socialism anymore and only reached out for cooperation with the West and especially with West Germany? Indeed, not least because of economic needs, relations with the FRG intensified and demanded concessions in return, but their development was a visible proof of the existence of an independent GDR under SED rule, which Honecker's politics aimed to make permanent. ${ }^{113}$ However, the economic foundations of the second German state had further weakened and the shortcomings of socialist integration were frustrating. Permanently facing the more functional West changed perceptions of it.

Despite continually deploring EEC protectionism, the East German view of Western European integration had altered profoundly since the mid-1970s. First came academics, followed by officials in the ministries involved (although at different levels), and somehow this knowledge also made it up to the top level of the party. Regarding the EEC, the Institute of International Politics and Economics (IPW) was the most important academic institution. Founded in 1971, it primarily focused on West Germany, but right from the start European integration was also on its research agenda. Because of scientific contacts with the West and analyses based on Western materials, the IPW was something special within the GDR, although at least in the first few years it remained an ideological think tank presenting results according to the official party line. ${ }^{114}$ Over the years, the IPW's analyses improved and the image of the EEC as a growing and more integrated community underwent a change. Despite still playing on the 'irreconcilable antagonisms of capitalism', the EEC member states' ability to compromise in decision-making processes was gradually recognised. ${ }^{115}$

This became visible in 1976 when the IPW analysed the Tindemans Report for the politburo. It was perceived as an attempt to overcome the crisis of Western Europe and the 'so far severest crisis' in its integration. Instead of predicting a foreseeable failure, the analysis acknowledged the will and the ability of the EEC to overcome crises. The conclusion stated:

Altogether, it can be expected that due to the mentioned contradictions the proposals of the 'Tindemans report' will be subject to multiple trade-offs and in most cases only compromises on the least common denominator will materialise. However, in the basic direction, certain enhancements of West European integration will take place. ${ }^{116}$

The Foreign Ministry was a little more cautious in its assessment, considering 'agreements on certain aspects' possible. ${ }^{117}$ However, the prospect of a 'European 
Union' constituted a nightmare, and the foreign policy goal was still to 'make use of all contradictions in order to delay or obstruct integration processes especially in the political and military field'. ${ }^{118}$ The analyses produced in the following years show that the basic assessments on the prospects for integration were stable. Furthermore, the EEC was explicitly recognised as the core of the Western European 'imperialist power centre', which especially economically had gained 'weight, importance and influence in the capitalist world'. Through its internal development, enlargement and the expansion of its economic sphere of influence, the EEC had become a 'considerable competitor of the USA'.119 The approaching second enlargement of the EEC was primarily seen as 'politically motivated' and the candidate countries (Greece, Spain and Portugal) were qualified as 'politically unstable and economically less developed capitalist states', yet the consequences for GDR trade were foreseeable. ${ }^{120}$ Interestingly, despite the decried protectionism of the Common Market and non-recognition of the EEC, the example of Western European integration was increasingly regarded as something to strive for in the CMEA.

Not least, Honecker started to regard the EEC as a desirable model for the CMEA. Against the background of the first elections to the European parliament in 1979, he told CMEA Secretary Nikolai Faddeev that this Western step must be an incentive for closer integration in the East, and one should not allow Romania to obstruct it. ${ }^{121}$ In 1982, Honecker told Soviet Foreign Minister Andrei Gromyko that 'despite the contradictions in the EC', the economic integration of the West 'is further developed than in the CMEA'. ${ }^{122}$ In March 1983, in a conversation with Hungarian politburo member Görgy Aczél, Honecker openly spoke about the differences between the CMEA and the EEC. He pointed to the fact that

despite unemployment, the EC functions better than the CMEA. In principle, the CMEA is based on bilateral relations and does not fulfil the tasks which the EC accomplishes. The EC has a council of ministers, commissions, a parliament, that indeed has not much say, while the socialist world is separated into single states.

Towards the end of his remarks he frustratedly stated that in the CMEA

not even the transport of goods works smoothly. Recently, there was a traffic jam at one of the stations on the Soviet border in which trains with 650 wagons were caught. There was a tailback to the factories. There are no such incidents in the EC. North-south traffic does not run smoothly either. Fruit from Bulgaria is stopped en route at closed frontiers and then arrives in Berlin rotten. ${ }^{123}$

\section{Conclusion}

Certainly, many SED leaders still believed that capitalism was doomed, but by the years of the debt crisis there was a certainty that even the crisis-ridden West functioned better, something that became evident in assessments of the EEC. From 


\section{Maximilian Graf}

a capitalist stillbirth, Western European integration had turned into a role model for the CMEA. Despite this, the GDR still refused to recognise the EEC. East Berlin stuck with Moscow's line and had to face the consequences. Even though access to the Common Market was decisively privileged due to the unique intraGerman trade, in its economic relations with the rest of the West the GDR was no less affected by the progress of European integration than the other socialist states. The CCP also applied to the GDR, and EEC protectionism impaired its economic interests. This became clear already in the first half of the 1970 s, a time when politics dominated over economics in East Berlin's rationale in dealing with the West.

At the beginning of the 1970s, the long-isolated East German regime gained international recognition. The SED leadership celebrated this development and aimed at a diversification of its relations with the West, not least (as ever since) to reduce dependence on the FRG. Their increase had been one of the reasons for the abortion of the economic reforms (which had included an import-financed technology offensive) and the change in the party leadership in 1971. Nevertheless, regarding foreign trade and indebtedness to the West, continuities from the 1960s predominated. Basic economic reasons were the driving factor. As in the case of Czechoslovakia, regardless of political decisions certain components and raw materials had to be bought in the West to keep the comparatively welldeveloped industrial production afloat. Additionally, loan-financed investments seemed to be the only possible way to modernise the economy and to improve its competitiveness. The consumerist turn in the Honecker era reduced the financial leeway in this regard. Growing debt immediately led to internal criticism by economic experts, but it fell on deaf ears and the course was not changed. In the hopeful years, stability mattered more and the downside seemed far away. As in Poland, there was hope that investments would pay back and time would work in the direction of socialism. Throughout the 1970s, cheap Soviet crude oil allowed hard currency to be earned by selling refined products. Additionally, various nontrade-related economic exchanges, or more precisely West German subsidies for the GDR, eased the life of the SED leadership, but it had to make concessions in return. In order to avoid them, other Western countries gained importance. Attempts to diversify Western trade intensified but in the end remained limited to several loan-financed large-scale orders and the respective countertrades. Apart from international recognition, no real breakthrough in relations with the West was achieved during the 1970s, and the development of economic relations was additionally impaired by the progress of European integration. A real counterbalance to dependence on the FRG was out of reach.

Because of costly consumer socialism and continual trade deficits with the West (similar to Poland and Hungary), the East German balance of payments crisis worsened towards the end of the 1970s. Despite all internal warnings and massive Soviet complaints about dependence on the West, the concept of the Unity of Economic and Social Policy remained unchanged, and all the measures taken to reach a favourable trade balance proved insufficient. On the one hand, the much-needed cooperation with the West had caused financial dependence and conflict with the Soviets. On the other hand, the developments in neighbouring Poland once again 
showed that any change in social policy was too risky. ${ }^{124}$ Declining Soviet support (raw materials) and the financial turbulence in other socialist states (Poland, Romania) made the situation even worse. In spring 1982, the GDR faced a Western credit boycott, and bankruptcy seemed unavoidable. By implementing several emergency measures, ironically still financed with Western money, solvency was secured in the short term. In the years of the debt crisis, East Berlin's leeway was more limited than ever. Within the limits Honecker perceived as tolerable for the infinite existence of two German states, he turned to the FRG until Moscow showed the red light. However, this outcome was not the result of a political westward drift aiming at closer bonds with the FRG; it was rooted in the particularity of the GDR and reflected the unresolvable paradoxes in the existence of the second German state. The East German economy had drifted westward ever since and, indeed, since progress in CEMA integration never materialised, only increasing economic cooperation with the West seemed to have the potential to lay the foundations of a stable and independent GDR. Although the result was the opposite, the aims of the economic strategy clearly indicate that in a political sense no westward drift took place. The desired but deceiving financial salvation came in the form of the Strauß loans in 1983-84. Regardless of potential Western intentions behind them, it was their unintended consequences that contributed to the demise of the GDR, namely allowing the leadership to proceed with its failed economic policy. ${ }^{125}$ The SED rule survived a severe economic crisis and secured the existence of a socialist Germany in the short term. However, surviving the debt crisis in 1982-83 proved to be a Pyrrhic victory. The measures taken caused growing dependence on the FRG, continuing economic decline and lowered East German living standards. Against the background of a changed international environment, these factors decisively contributed to the collapse of the GDR in $1989 . .^{126}$

\section{Notes}

1 Note by Werner Krolikowski on the internal situation of the GDR, 30 March 1983, in Przybylski, Tatort Politbüro, 349-56, 351.

2 Malycha, Die SED in der Ära Honecker, 243-56. On the internal conflicts about Germany policy, see Amos, SED-Deutschlandpolitik, 347-62.

3 Selvage and Süß, Staatssicherheit und KSZE-Prozess, 222-31, 397-421.

4 Malycha, Die SED in der Ära Honecker, 177-322; Steiner, The plans that failed; Steiner, Überholen ohne einzuholen; Berghoff and Balbier, The East German Economy, 1945-2010; Hoffmann, Die zentrale Wirtschaftsverwaltung in der SBZ/DDR; Zatlin, The currency of socialism; Ahrens, Gegenseitige Wirtschaftshilfe?; Hertle, "Die Diskussion der ökonomischen Krisen," 309-45.

5 For the best accounts, see Wentker, Außenpolitik in engen Grenzen; Siebs, Die Außenpolitik der DDR 1976-1989.

6 Especially the neutrals Austria and Finland as well as Japan played an important role exceeding that played by smaller EEC states. Maximilian Graf, Österreich und die DDR.

7 For the most recent studies on bilateral relations regarding the countries under discussion and addressing the 1970s, see Wenkel, Auf der Suche nach einem "anderen Deutschland"; Pfeil, Die "anderen" deutsch-französischen Beziehungen; Fasanaro, La DDR e l'Italia; Berger and LaPorte, Friendly enemies; Pekelder, Die Niederlande und die DDR; Pfeil, Die DDR und der Westen. 
8 Wüstenhagen, "Blick durch den Vorhang”; Schmidt, Europäische Gemeinschaft; Müller, "Ex oriente luxus?," 187-212.

9 Fäßler, Durch den "Eisernen Vorhang"; Kruse, Politik und deutsch-deutsche Wirtschaftsbeziehungen.

10 Through intra-German trade the GDR had some sort of 'freeway' into the Common Market, but the FRG had to inform the EEC about the imports. According to Bonn, less than $1 \%$ of the volume of intra-German trade was re-exported into the Common Market, amounting to only $0.02 \%$ of overall West German exports. Thus, in comparison to the economic benefits resulting from intra-German trade, the additional benefits of exporting via West Germany were negligible. Nakath, "Die DDR - "heimliches Mitglied'," 451-73. For a detailed discussion of this issue, see Graf, "Die DDR und die EWG 1957-1990," 21-35; Graf, "Nichtanerkennung zu eigenen Lasten?," 225-38.

11 Wenkel, Auf der Suche nach einem "anderen Deutschland," 148-61; Pfeil, Die "anderen" deutsch-französischen Beziehungen, 393-413. Bundesarchiv, Abteilung DDR (BArch-DDR), DL 2/6235, Information über Verlängerung der Kreditlaufzeiten von 5 auf 8 Jahre beim Import aus EWG-Ländern, Berlin, 14 August 1970.

12 Ahrens, "Außenwirtschaft zwischen Ostintegration und Westverschuldung," 510-90, for the figures see 561; and Ahrens, "Debt, cooperation, and collapse," 161-76, for the quote see 176 .

13 Steiner, Die DDR-Wirtschaftsreform der sechziger Jahre.

14 For details, see Steiner, The plans that failed, 141-69; Hertle, "Die Diskussion der ökonomischen Krisen," 311-19; Ahrens, Gegenseitige Wirtschaftshilfe?, 268-9; Malycha, Die SED in der Ära Honecker, 186-95.

15 According to a recent biography, distrust of his own people was one of the most determining imprints on Honecker, who had witnessed the people's support for the Nazi regime. Sabrow, Erich Honecker, 504-5.

16 Ahrens, Gegenseitige Wirtschaftshilfe?, 250-1.

17 Schürer, Gewagt und verloren, 114-17.

18 Judt, Der Bereich Kommerzielle Koordinierung.

19 BArch-DDR, DE 1/58539, B1. 88-100, Memorandum on the discussion of the plan 1971-75 in the Council of Ministers, 21 July 1971.

20 BArch-DDR, DE 1/58539, B1. 233-247, Memorandum on a meeting by the Deputy Heads of the State Planning Commission, 15 February 1972.

21 Already in 1970, the total debts of the GDR in the West had amounted to $50 \%$ of the annual East German exports to the West. Ahrens, Gegenseitige Wirtschaftshilfe?, 235-6, 239, for the quote 269.

22 Stiftung Archiv der Parteien und Massenorganisationen der ehemaligen DDR im Bundesarchiv (SAPMO-BArch), DY 30/J IV 2/2J/4555, "Information über die aktuelle Lage der Entwicklung der kapitalistischen Währungskrise für das SED-Politbüro" (information for the politburo on the current situation and development of the capitalist monetary crisis), 12 February 1973; SAPMO-BArch, DY 30/J IV 2/2J/5319, "Information für das SED-Politbüro. Zur gegenwärtigen Lage der Wirtschaft in den kapitalistischen Hauptländern" (information for the politburo on the current situation of the economy in the main capitalist countries), May 1974.

23 SAPMO-BArch, DY 30/17790, "Information Nr. 9/I" (information on the economic development of France 1973/74).

24 On rising oil prices and the repercussions, see Steiner, "Common sense is necessary'," 231-50.

25 Stokes, "From schadenfreude to going-out-of-business sale," 131-43, 142.

26 Judt, Der Bereich Kommerzielle Koordinierung, 62-6, 105-12, 183-4.

27 Ahrens, Gegenseitige Wirtschaftshilfe?, 275-6. On the origins of this tendency, see Hoffmann and Malycha, Erdöl, Mais und Devisen.

28 BArch-DDR, DE 1/58507, Memcon Schürer - Baibakov, Moscow, 21 May 1973.

29 BArch-DDR, DE 1/58507, Memcon Stoph - Kosygin, Moscow, 20 August 1973. 
30 Sarotte, Dealing with the devil.

31 SAPMO-BArch, DY 30/J IV 2/2/1420, Bl. 6-10, Directive approved by the politburo on 31 October 1972.

32 BArch-DDR, DL 2/6283a, "Erste prognostische Einschätzung der Entwicklung der Außenwirtschaftsbeziehungen der DDR mit der BRD und der selbständigen politischen Einheit Westberlin bis zum Jahre 1990" (first projection of the development of the GDR's economic relations with the FRG and West Berlin until 1990), Berlin, 28 August 1970.

33 BArch-DDR, DE 1/58719, Bl. 212-227, Assessment of the status of the GDR's economic relations with the FRG and West Berlin, 12 January 1973.

34 On German-German relations and the "swing" negotiations, see Dokumente zur Deutschlandpolitik, series VI: 21. Oktober 1969 bis 1. Oktober 1982, vol. 3: 1. Januar 1973 bis 31. Dezember 1974 (DzD VI/3). Munich: Oldenbourg, 2005.

35 Wentker, Außenpolitik in engen Grenzen, 410-11.

36 BArch-DDR, DL 226/1319, B1. 186-194, Information on questions regarding economic relations between the GDR and the FRG, Berlin, 2 December 1975.

37 Amos, SED-Deutschlandpolitik, 273-329.

38 Hanisch, Die DDR im KSZE-Prozess 1972-1985; Selvage and Süß, Staatssicherheit und KSZE-Prozess.

39 Wentker, Außenpolitik in engen Grenzen, 449-59.

40 Due to the limited validity of East German statistics (resulting among other things from the permanent undervaluation of the DM in relation to the GDR mark), no exact figures exist. These are the 'least bad figures'. Ahrens, "Außenwirtschaft zwischen Ostintegration und Westverschuldung," 568.

41 On the example of Austria but with an eye on the other neutrals, see Graf, Österreich und die $D D R$.

42 SAPMO-BArch, DY 30/J IV 2/2A/1849, B1. 55-125, Conception or the development of the GDR's relations with France, Great Britain and Italy until 1977-78, approved by the politburo on 14 January 1975.

43 Wüstenhagen, "Blick durch den Vorhang," 107-41; Schmidt, Europäische Gemeinschaft, 101-47.

44 Müller, "Ex oriente luxus?," 201.

45 SAPMO-BArch, DY 30/J IV 2/2A/1578, B1. 4, 113-122 and 1579, Bl. 1-29, Brief assessment of the EEC, approved by the politburo on 29 February 1972.

46 Kansikas, Socialist countries face the European Community.

47 SAPMO-BArch, DY 30/J IV 2/2A/1601, Bl. 1-36, Meeting of the politburo, 6 June 1972.

48 Wüstenhagen, "RGW und EWG," 135-49, 139.

49 BArch-DDR, DL 2/6290, "Information Nr. 19/4" (information on the EEC's trade policy toward the GDR), Berlin, 31 May 1973; BArch-DDR, DL 2/6287, "Information Nr. 19/ VII" (information on the EEC Commisson's efforts to enforce treatment of the GDR as a 'third country'), Berlin, 23 July 1974. See Chapter 2 by Angela Romano in this book.

50 SAPMO-BArch, DY 30/J IV 2/2A/1845, Bl. 8, 54-67, Meeting of the politburo, 17 December 1974.

51 BArch-DDR, DL 2/11774, "Die Notwendigkeit von technischen Kontakten von Betrieben und Institutionen der DDR zu EWG-Organen zur Sicherung des Exports der DDR sowie Abwendung von ökonomischen Verlusten" (memorandum on the necessity of technical contacts of companies and institutions of the GDR with EEC organs to secure the GDR's exports and to prevent economic losses), Berlin, 25 February 1975; Wüstenhagen, "Blick durch den Vorhang," 284-5.

52 SAPMO-BArch, DY 30/J IV 2/2A/1864, Bl. 65-75, Meeting of the politburo, 7 March 1975.

53 BArch-DDR, DL 2/16751, "Standpunkt der DDR zur Weiterführung der Verhandlungen des RGW mit der EWG" (GDR standpoint on the continuation of negotiations between CMEA and EEC). 
54 BArch-DDR, DL 2/16751, "Bemerkungen zu den vorliegenden Ausarbeitungen RGW-EWG" (remarks on the present papers CMEA-EEC), signed H.v.B. Berlin, 23 February 1977. Von Berg was an academic with a history as secret negotiator who later became a persona non grata because of leaking criticism on the GDR's economic situation to the West German magazine Der Spiegel. See Malycha, Die SED in der Ära Honecker, 219.

55 Angela Romano, "Untying Cold War Knots," 169-70.

56 SAPMO-BArch, DY 30/J IV 2/2A/2047, Bl. 138-146, Meeting of the politburo, 1 March 1977.

57 For the drafts and reports on the negotiations, see Politisches Archiv des Auswärtigen Amts, Ministerium für Auswärtige Angelegenheiten der DDR (PA/AA-MfAA), M 1 C 7135, B1. 1-191; and BArch-DDR, DC 20/4320, Bl. 1-35.

58 This assumption is based on a review of the SED's daily Neues Deutschland and other print media.

59 The Economic Commission was not a decision-making body, but it served as Mittag's tool for the top-down management of the economy. For the Commission's protocols 1976-83, see SAPMO-BArch, DY 30/70615-70676. On the institutional context, see Malycha, Die SED in der Ära Honecker, 92-3, 99-103, 190-1.

60 BArch-DDR, DE 1/58633, Schürer to Honecker, "Information über Grundfragen der Planzahlungsbilanz 1976 mit dem nichtsozialistischen Wirtschaftsgebiet" (information on basic questions of the planned balance of payments with the non-socialist economic area 1976), Berlin, 24 November 1975.

61 BArch-DDR, DE 1/58633, Schürer to Honecker, "Zusammengefaßte Einschätzung zum Entwurf des Fünfjahrplanes 1976-1980" (summarised assessment of the draft of the five-year plan), Berlin, 6 October 1976.

62 BArch-DDR, DE 1/58633, "Niederschrift über eine Beratung zum Entwurf des Fünfjahrplanes 1976-1980 unter Leitung des Generalsekretärs des ZK der SED Genossen Erich Honecker" (memorandum on the discussion of the draft of the five-year plan 1976-1980 presided by Honecker), 5 November 1976.

63 Memcon Honecker - Brezhnev, Berlin, 20 August 1976, in Hertle and Jarausch, Risse im Bruderbund, 113-35, 130.

64 Hertle, "Die Diskussion der ökonomischen Krisen," 314-15.

65 BArch-DDR, DE 1/58719, B1. 482-514, Memorandum on a meeting discussing the 1977 and 1978 plans at Honecker's office, 2 June 1977.

66 In this chapter I use the figures on which internal assessments and decisions were based. On the problem of the actual value of the 'divided' VM and the amount of debt, see Volze, "Zur Devisenverschuldung der DDR," 151-83.

67 BArch-DDR, DL 226/1248, B1. 220-238, Current status of the GDR's balance of payments with the West in 1978/79, Berlin, 1 February 1979.

68 Archiv des Bundesbeauftragten für die Unterlagen des Staatssicherheitsdienstes der ehemaligen DDR (BStU), MfS, HA XVIII, Nr. 4692, B1. 13-38, Recommendations and proposals for solutions in the interest of a further stable growth of the output of the GDR's national economy, 24 November 1980.

69 SAPMO-BArch, DY 3023/1271, Bl. 129-133, Information on Beil's meetings with representatives of the French government and economy in Paris, Berlin, 25 November 1976.

70 SAPMO-BArch, DY 30/17796, "Information über die 4. Tagung der Gemischten Regierungskommission DDR-Italien" (information on the fourth meeting of the mixed governmental commission GDR-Italy), Berlin, 20 May 1977. Fasanaro, $L a$ DDR e l'Italia, $135-54$.

71 SAPMO-BArch, DY 30/17791, "Information über den Aufenthalt einer Staatsdelegation der DDR unter Leitung des Mitgliedes des Politbüros und Sekretär des Zentralkomitees der SED, Genosse Günter Mittag, in Frankreich" (information on the visit by Mittag in France), 5-8 June 1978. 
72 Judt, "Kompensationsgeschäfte der DDR," 117-38.

73 SAPMO-BArch, DY 3023/1302, B1. 299-300, Memorandum on available funds for compensation projects, Berlin, 25 April 1978.

74 SAPMO-BArch, DY 3023/1304, Bl. 180, Information by Beil, Berlin, 13 June 1979; SAPMO-BArch, DY 30/J IV 2/2/1781-1783, Meeting of the politburo, 12 June 1979.

75 BArch-DDR, DE 1/58719, B1. 409-433, Memorandum of the joint meeting of the politburo and the Council of Ministers on the draft plan 1980, Berlin, 4 December 1979.

76 SAPMO-BArch, DY 30/25758, Bl. 19-27, Memorandum by Krolikowski, 24 October 1980.

77 Romano, "Untying Cold War Knots," 167.

78 SAPMO-BArch, DY 3023/1276, B1. 77-80, Information on the impact of the EEC measures in the metallurgy field for the GDR, Berlin, 5 January 1978.

79 SAPMO-BArch, DY 3023/1276, B1. 199-203, Information on a meeting of the ministers during the fifty-first session of the Standing Commission on Foreign Trade, Berlin, 4 April 1978.

80 BArch-DDR, DL 2/20070, "Bericht über die Tagung der Leiter der handelspolitischen Verwaltungen der Ministerien für Außenhandel der ML/RGW" (report on the meeting of the heads of the commercial administrations of the CMEA members' Ministries of Foreign Trade), Warsaw, 18-20 April 1978.

81 SAPMO-BArch, DY 3023/1277, B1. 249-250, Tautenhahn to Mittag, 21 September 1979.

82 Beil managed to secure the import contingents needed for the refinancing of compensation deals with Italy, not least because the Italian Foreign Trade Minister Rinaldo Ossola was lobbying for another big steel plant order by the GDR. SAPMO-BArch, DY 3023/1279, B1. 58-59, Beil to Mittag, Berlin, 1 March 1979; SAPMO-BArch, DY 3023/1279, B1. 113-115, Memcon Mittag - Ossola, Leipzig, 12 March 1979; SAPMO-BArch, DY 3023/1281, Bl. 144-148, Information on the visit by Beil to Italy, 1-3 October 1979.

83 SAPMO-BArch, DY 3023/1281, B1. 278-279, Relations CMEA members - EEC, Brussels, 5 December 1979.

84 SAPMO-BArch, DY 3023/1287, B1. 40, Information on additional anti-dumping procedures by the EEC, 13 September 1982; BArch-DDR, DL 2/6380, Bl. 296-298, Information on anti-dumping procedures against GDR foreign trade companies, 16 September 1981.

85 BArch-DDR, DL 2/16754, "Einschätzung des Standes der Schaffung handelspolitischer Voraussetzungen für die Erfüllung des Planes 1979 gegenüber KIL, BRD/WB und ausgewählten EL" (assessment on anti-dumping procedures and consequences for the export plan), 5 January 1979; BArch-DDR, DL 2/6365a, "Information Nr. 178/1980" (assessment on anti-dumping procedures), 27 June 1980.

86 SAPMO-BArch, DY 30/IV 2/2.036/71, B1. 93-94, Tschanter to Verner, 30 January 1979.

87 BArch-DDR, DL 2/16749, "Einschätzung der Selbstbeschränkungsabkommen und -vereinbarungen im Rahmen der protektionistischen Politik der KIL, insbesondere der EWG" (memorandum), Brussels, 5 March 1981.

88 Wenkel, Auf der Suche nach einem "anderen Deutschland", 173-5; Pfeil, Die "anderen" deutsch-französischen Beziehungen, 451-3, 571-9.

89 SAPMO-BArch, DY 3023/1282, Bl. 20-32, Memcon Krolikowski - Patolichev, 21 January 1980.

90 SAPMO-BArch, DY 3023/1554, B1. 191-196, Information on the conclusion of the agreement on economic, industrial and technical relations between the GDR and France 1980-1985, Berlin, 12 February 1980.

91 Hertle and Jarausch, Risse im Bruderbund, 188-97.

92 BStU, MfS HA XVIII Nr. 26078, B1. 162-164, Information, Berlin, 23 August 1980. 
93 Wentker, Außenpolitik in engen Grenzen, 420; BArch-DDR, DL 226/1319, B1. 255275, Conception for relations to the FRG and West Berlin in 1976, Berlin, 6 February 1975.

94 Wölbern, Der Häftlingsfreikauf aus der DDR 1962/63-1989.

95 Hertle, "Die Diskussion der ökonomischen Krisen," 319 (footnote 36).

96 SAPMO-BArch, DY 3023/1347, Bl. 284-286, Memcon Behrendt - Rohwedder, 17 January 1978; SAPMO-BArch, DY 3023/1347, B1. 292-299, Memcon Sölle Rohwedder, 14 March 1978.

97 BArch-DDR, DL 226/1319, B1. 79-109, Memcon Mittag - Lambsdorff, 23 February 1979; BArch-DDR, DL 226/1319, B1. 44-52, Memcon Sölle - Lambsdorff, 12 March 1979; SAPMO-BArch, DY 3023/1347, B1. 82-93, Memcon Mittag - Lambsdorff, 13 March 1979; also see Akten zur Auswärtigen Politik Deutschlands (AAPD) 1979, vol. 1, 367-72.

98 See the documentation in SAPMO-BArch, DY 30/IV 2/2.035/85, B1. 123-35.

99 Memcon Gaus - Honecker, East Berlin, 12 October 1979, in AAPD 1979, vol. 2, 1441-51.

100 Already in April 1980, the FRG voiced doubts that a long-term agreement would be compatible with the EEC's acceptance of intra-German trade. SAPMO-BArch, DY 3023/1345, B1. 99-100, Memorandum for Beil on the preparation for the visit by Schmidt, Berlin, 20 August 1980.

101 Wentker, Außenpolitik in engen Grenzen, 421-7; DzD VI/7, 423-522; AAPD 1981, vol. 2, 1935-63.

102 SAPMO-BArch, DY 3023/1359, B1. 198-204, Schalck to Mittag, Berlin, 10 April 1980.

103 Report by Bölling on a conversation with Schalck, Berlin, 14 April 1982, in $D z D$ VI/7. 685-8, 686.

104 SAPMO-BArch DY 30/25759, B1. 47-62, Memorandum by Krolikowski, 3 December 1981.

105 For details on the debt crisis, see Graf, "Before Strauß"; Judt, Der Bereich Kommerzielle Koordinierung, 142-74.

106 BStU, MfS HA XVIII 26566, B1. 257-263, Information, 20 May 1982.

107 For details on this issue in a comparative perspective, see Steiner, "The globalisation process and the Eastern Bloc," 172-6.

108 Graf, "Before Strauß."

109 Kieninger, "Freer movement in return for cash," 117-37.

110 BArch-DDR, DE 1/58704, B1. 272-277, Memorandum by Klopfer on the politburo consultations, Berlin, 9 August 1983.

111 SAPMO-BArch DY 30/25759, B1. 129-144, Memorandum by Krolikowski, 16 May 1984.

112 Memcon Honecker - Chernenko, Moscow, 14 June 1984, in DzD VII/1 670-80.

113 Amos, SED-Deutschlandpolitik, 612-13.

114 Klein, Das Institut für Internationale Politik und Wirtschaft.

115 Schwarz, "Das Verhältnis der DDR zur westeuropäischen Integration," 140-57; Schmidt, Europäische Gemeinschaft, 309-403.

116 SAPMO-BArch, DY 30/J IV 2/2J/7124, "Information für das SED-Politbüro. Zum'Tindemans-Bericht' über die Entwicklung der 'Europäischen Gemeinschaft' zur 'Europäischen Union'" (information for the politburo on the 'Tindemans report'), February 1976.

117 PA/AA-MfAA, M 1 C 3525, B1. 7-11, Memorandum by the policy planning department of the foreign ministry on the 'Tindemans report' about the 'European Union'.

118 PA/AA-MfAA, M 1 C 3525, Bl. 22-35, Draft: Assessment on the prospect of the creation of a 'European Union' in Western Europe and conclusions.

119 PA/AA-MfAA, M 1 C 1002/78, Bl. 1-27, Development trends of the 'European Communities,' 1977. 
120 BArch-DDR, DL 2/16735, “Thesen und Probleme zur Erweiterung der 'Europäischen Gemeinschaften' durch Griechenland, Portugal und Spanien" (theses on the enlargement of the 'European Communities' through Greece, Portugal and Spain), 23 January 1979.

121 SAPMO-BArch, DY 30/IV 2/2.036/71, B1. 199-204, Memcon Honecker - Faddeev, 19 March 1979.

122 SAPMO-BArch, DY 30/J IV 2/2A/2457, Bl. 1-21, Report on Gromyko's visit to the GDR, 27/28 January 1982.

123 SAPMO-BArch, DY 30/J IV 2/2A/2551, B1. 192-212, Memcon Honecker - Aczél, 10 March 1983.

124 On the example of state price policy, see Steiner, "State price policy in the German Democratic Republic," 169-89.

125 Zatlin, The currency of socialism, 125-48.

126 The further consequences of the East German effort to avoid bankruptcy for the economic demise of the GDR have been assessed in a similar way by Steiner in The plans that failed.

\section{Bibliography}

\section{Published primary sources}

Akten zur Auswärtigen Politik Deutschlands (AAPD), 1979 and 1981.

Dokumente zur Deutschlandpolitik (DzD), series VI, vols. 3, 7 and series VII, vol. 1.

Hertle, Hans-Hermann and Konrad H. Jarausch, eds. Risse im Bruderbund. Die Gespräche Honecker-Breshnew 1974 bis 1982. Berlin: Ch. Links, 2006.

Hoffmann, Dierk and Andreas Malycha, eds. Erdöl, Mais und Devisen. Die ostdeutschsowjetischen Wirtschaftsbeziehungen 1951-1967. Eine Dokumentation. Berlin: De Gruyter, 2016.

\section{Secondary sources}

Ahrens, Ralf. Gegenseitige Wirtschaftshilfe? Die DDR im RGW. Strukturen und handelspolitische Strategien 1963-1976. Cologne: Böhlau, 2000.

Ahrens, Ralf. "Debt, cooperation, and collapse. East German foreign trade in the Honecker years." In The East German Economy, 1945-2010. Falling behind or catching up?, edited by Hartmut Berghoff and Uta Andrea Balbier, 161-76. New York: Cambridge University Press, 2013.

Ahrens, Ralf. "Außenwirtschaft zwischen Ostintegration und Westverschuldung." In Die zentrale Wirtschaftsverwaltung in der SBZ/DDR. Akteure, Strukturen, Verwaltungspraxis, edited by Dierk Hoffmann, 510-90. Berlin: De Gruyter, 2016.

Amos, Heike. Die SED-Deutschlandpolitik 1961-1989. Ziele, Aktivitäten und Konflikte. Göttingen: Vandenhoeck \& Ruprecht, 2016.

Berger, Stefan and Norman LaPorte. Friendly enemies: Britain and the GDR, 1949-1990. Oxford: Berghahn, 2010.

Berghoff, Hartmut and Uta Andrea Balbier, eds. The East German economy, 1945-2010: falling behind or catching up? New York: Cambridge University Press, 2013.

Fäßler, Peter E. Durch den "Eisernen Vorhang". Die deutsch-deutschen Wirtschaftsbeziehungen 1949-1969. Köln: Böhlau, 2006.

Fasanaro, Laura. La DDR e l'Italia. Politica, commercio e ideologia nell'Europa del cambiamento (1973-1985). Rome: Carocci, 2016. 


\section{Maximilian Graf}

Graf, Maximilian. Österreich und die DDR 1949-1990. Politik und Wirtschaft im Schatten der deutschen Teilung. Vienna: Verlag der Österreichischen Akademie der Wissenschaften, 2016.

Graf, Maximilian. "Before Strauß: the East German struggle to avoid bankruptcy during the debt crisis revisited." The International History Review (2019): 1-18. Accessed 31 March 2020. https://doi.org/10.1080/07075332.2019.1641542.

Graf, Maximilian. "Die DDR und die EWG 1957-1990." Revue d'Allemagne et des pays de langue allemande 51:1 (2019): 21-35.

Graf, Maximilian. "Nichtanerkennung zu eigenen Lasten? Die DDR und die Europäische Wirtschaftsgemeinschaft in den 'langen 1970er-Jahren'." Jahrbuch für historische Kommunismusforschung (2020): 225-38.

Hanisch, Anja. Die DDR im KSZE-Prozess 1972-1985. Zwischen Ostabhängigkeit, Westabgrenzung und Ausreisebewegung. Munich: Oldenbourg, 2012.

Hertle, Hans-Hermann. "Die Diskussion der ökonomischen Krisen in der Führungsspitze der SED." In Der Plan als Befehl und Fiktion. Wirtschaftsführung in der DDR. Gespräche und Analysen, edited by Theo Pirker, M. Rainer Lepsius, Rainer Weinert and Hans-Hermann Hertle, 309-45. Opladen: Westdeutscher Verlag, 1995.

Hoffmann, Dierk, ed. Die zentrale Wirtschaftsverwaltung in der SBZ/DDR. Akteure, Strukturen, Verwaltungspraxis. Berlin: De Gruyter, 2016.

Judt, Matthias. "Kompensationsgeschäfte der DDR - Instrumente einer europäischen OstWest-Wirtschaftsintegration?” Jahrbuch für Wirtschaftsgeschichte 49:2 (2008): 117-38.

Judt, Matthias. Der Bereich Kommerzielle Koordinierung. Das DDR-Wirtschaftsimperium des Alexander Schalck-Golodkowski - Mythos und Realität. Berlin: Ch. Links, 2013.

Kansikas, Suvi. Socialist countries face the European Community: Soviet-bloc controversies over East-West trade. Brussels: Peter Lang, 2014.

Kieninger, Stephan. "Freer movement in return for cash. Franz Josef Strauß, Alexander Schalck-Golodkowski, and the Milliardenkredit for the GDR, 1983-1984." In New perspectives on the end of the Cold War: unexpected transformations?, edited by Bernhard Blumenau, Jussi M. Hanhimäki and Barbara Zanchetta, 117-37. London: Routledge, 2018.

Klein, Michael B. Das Institut für Internationale Politik und Wirtschaft der DDR in seiner Gründungsphase 1971 bis 1974. Berlin: Duncker\&Humblot, 1999.

Kruse, Michael. Politik und deutsch-deutsche Wirtschaftsbeziehungen von 1945 bis 1989. Berlin: Köster, 2005.

Malycha, Andreas. Die SED in der Ära Honecker, Machtstrukturen, Entscheidungsmechanismen und Konfliktfelder in der Staatspartei 1971-1989. Munich: Oldenbourg, 2014.

Müller, Werner. "Ex oriente luxus? - Supranationale Verflechtung der DDR in der Sicht des SED-Politbüros." Jahrbuch für historische Kommunismusforschung (2000/2001): 187-212.

Nakath, Detlef. "Die DDR - 'heimliches Mitglied' der Europäischen Gemeinschaft? Zur Entwicklung des innerdeutschen Handels vor dem Hintergrund der westeuropäischen Integration." In Aufbruch zum Europa der zweiten Generation. Die europäische Einigung 1969-1984, edited by Franz Knipping and Matthias Schönwald, 451-73. Trier: Wissenschaftlicher Verlag, 2004.

Pekelder, Jacco. Die Niederlande und die DDR. Bildformung und Beziehungen 1949-1989. Munster: Agenda, 2002.

Pfeil, Ulrich, ed. Die DDR und der Westen. Transnationale Beziehungen 1949-1989. Berlin: Ch. Links, 2001.

Pfeil, Ulrich. Die “anderen” deutsch-französischen Beziehungen. Die DDR und Frankreich 1949-1990. Cologne: Böhlau, 2004.

Przybylski, Peter. Tatort Politbüro. Die Akte Honecker. Berlin: Rowohlt, 1991. 
Sabrow, Martin. Erich Honecker. Das Leben davor 1912-1945. Munich: C.H. Beck, 2016. Sarotte, Mary E. Dealing with the devil: East Germany, détente, and Ostpolitik, 19691973. Chapel Hill: University of North Carolina Press, 2001.

Schmidt, Klaus-Peter. Die Europäische Gemeinschaft aus Sicht der DDR (1957-1989). Hamburg: Kovač, 1995.

Schürer, Gerhard. Gewagt und verloren. Eine deutsche Biografie. Berlin: Frankfurt Oder Editionen, 1998.

Schwarz, Siegfried. "Das Verhältnis der DDR zur westeuropäischen Integration. Phasen der Wahrnehmung - Umdenken - Annäherung an die Realität (1950-1990)." In Die DDR in Deutschland. Ein Rückblick auf 50 Jahre, edited by Heiner Timmermann, 14057. Berlin: Duncker \& Humblot, 2001.

Selvage, Douglas and Walter Süß. Staatssicherheit und KSZE-Prozess. MfS zwischen SED und KGB (1972-1989). Göttingen: Vandenhoeck \& Ruprecht, 2019.

Siebs, Benno-Eide. Die Außenpolitik der DDR 1976-1989. Strategien und Grenzen. Paderborn: Schöningh, 1999.

Steiner, André. Die DDR-Wirtschaftsreform der sechziger Jahre. Konflikt zwischen Effizienzund Machtkalkül. Berlin: Akademie Verlag, 1999.

Steiner, André, ed. Überholen ohne einzuholen. Die DDR-Wirtschaft als Fußnote der deutschen Geschichte? Berlin: Ch. Links, 2006.

Steiner, André. The plans that failed: An economic history of the GDR. New York: Berghahn, 2010.

Steiner, André. “'Common sense is necessary:' East German reactions to the oil crises of the 1970s." Historical Social Research 39:4 (2014): 231-50.

Steiner, André. "The globalisation process and the Eastern Bloc countries in the 1970s and 1980s." European Review of History 21:2 (2014): 165-81.

Steiner, André. "State price policy in the German Democratic Republic in the 1970s and 1980s." In Calmer les prix. L'inflation en Europe dans les années 1970, edited by MichelPierre Chélini and Laurent Warlouzet, 169-89. Paris: Presse de Sciences Po, 2016.

Stokes, Ray. "From schadenfreude to going-out-of-business sale: East Germany and the oil crises of the 1970s." In The East German economy, 1945-2010: falling behind or catching up?, edited by Hartmut Berghoff and Uta Andrea Balbier, 131-43. New York: Cambridge University Press, 2013.

Volze, Armin. "Zur Devisenverschuldung der DDR - Entstehung, Bewältigung und Folgen." In Die Endzeit der DDR-Wirtschaft - Analysen zur Wirtschafts-, Sozial- und Umweltpolitik, edited by Eberhard Kuhrt, 151-83. Opladen: Leske + Budrich, 1999.

Wenkel, Christian. Auf der Suche nach einem "anderen Deutschland." Das Verhältnis Frankreichs zur DDR im Spannungsfeld von Perzeption und Diplomatie. Munich: Oldenbourg, 2014.

Wentker, Hermann. Außenpolitik in engen Grenzen. Die DDR im internationalen System 1949-1989. Munich: Oldenbourg, 2007.

Wölbern, Jan Philipp. Der Häftlingsfreikauf aus der DDR 1962/63-1989. Zwischen Menschenhandel und humanitären Aktionen. Göttingen: Vandenhoeck \& Ruprecht, 2014.

Wüstenhagen, Jana. "Blick durch den Vorhang”: Die SBZ/DDR und die Integration Westeuropas (1946-1972). Baden-Baden: Nomos, 2001.

Wüstenhagen, Jana. "RGW und EWG. Die DDR zwischen Ost- und Westintegration." In Die DDR und der Westen. Transnationale Beziehungen 1949-1989, edited by Ulrich Pfeil, 135-49. Berlin: Ch. Links, 2001.

Zatlin, Jonathan R. The currency of socialism: money and political culture in East Germany. Cambridge: Cambridge University Press, 2007. 


\title{
6 Czechoslovakia's Pan-European Relations During the "Long 1970s"
}

\author{
Pavel Szobi
}

The "long 1970s" in Czechoslovakia marked their start with the beginning of a normalisation process in 1969 and their end with overcoming economic stagnation in 1982. While the first half of the 1970s can be designated a consolidation process during which the state regained its grip on previously de-centralised economic planning and used extensive growth to increase the gross national product, the second half of the 1970s was a period of broader opening towards cooperation with the West, investment and consideration of reforms. This is why Czechoslovakia had the lowest level of indebtedness among the CMEA countries. It only became higher towards the end of the 1970s. With no investment in the first half of the decade, Czechoslovakia was risking losing its competitiveness in global markets in the long run, but the strategy eventually paid off at the end of the decade when East German and Polish hopes of investment returns and export revenue from new production lines failed to materialise. However, Czechoslovak industry gradually became outdated with growing competitiveness problems in Western markets, which were aggravated by expanding EEC competences and EEC enlargement. An active balance of payments was progressively achieved thanks to exports of food, raw materials and consumer goods instead of machinery products. This stabilised the economy for the remaining decade but warned economists of the fustiness of the system and its growing technological backwardness.

This chapter contributes to existing historiography, which has dealt with the role of Czechoslovakia in pan-European relations and its foreign trade in the long 1970s rather marginally, the main focus being on political aspects of international relations. ${ }^{1}$ The most notable work on the subject has been done by a team of Czech and Slovak historians under the leadership of Václav Průcha in the second volume of their extensive Economic and Social History of Czechoslovakia, 1918-1992. ${ }^{2}$ Particular aspects of Czechoslovak relations with Western Europe have been discussed in studies and articles by Karel Svoboda, Oldřich Tůma and Tomáš Vilímek, which will be specifically discussed later in the chapter.

\section{The consolidation process and credit policies}

The 1970 document 'Lessons Drawn from the Crisis Development in the Party and Society after the 13th Congress of the Communist Party of Czechoslovakia' 
by the party's Central Committee counts as the main document which set out the normalisation process characterising the late period of state socialism in Czechoslovakia. ${ }^{3}$ However, the economic strike back against the 1968 reform initiative started much earlier than that. After the suppression of the Prague Spring, the Czechoslovak economy and foreign trade had to undergo specific changes regarding ideological requirements. Deliveries of British Vickers VC-10 aircrafts for the Czechoslovak airlines were suspended, construction contracts for Czechoslovak construction teams to work in West Berlin were cancelled and thoughts of an automobile factory built by a French-Italian consortium in Slovakia were abandoned. ${ }^{4}$ Although the Dubček administration was considering a credit from the International Monetary Fund in 1968, this plan was also quickly buried. ${ }^{5}$ A month after Gustáv Husák became the new first secretary of the party, in May 1969 the Central Committee adopted the document 'Realisation Direction for the Party Strategy Until the 14th Congress', which effectively enforced state control over the national economy. The half-started reform connected to the Prague Spring was condemned as chaotic and contradicting the rules of the socialist way of life. ${ }^{6}$ In June, so-called stabilisation measures stopped increases of nominal wages and stabilised consumer prices in order to control inflation. The progressive passive balance of payments and the private consumption boost of the late 1960s were to be fought with a strong pro-export policy, an autarky programme and limitation of foreign debt. This consolidation strategy was intended to endure for a short period of two years, but it eventually defined the whole first half of the 1970s. In order to re-centralise economic planning, the conservative communist leadership argued from experience of earlier years in which a conservative interpretation of central planning had proven to be useful. This approach would certainly not provide any economic miracles but it would guarantee modest but stable economic growth.

The Czechoslovak federal and republican elite set the paradigm of the economic consolidation process which would endure until 1975-76. The main keynotes of the policy were 'stability' and 'a calm environment for work'. The only significant investment plans were realised in Slovakia as part of a long-term policy of equalising the two parts of the federation and involved financial transfers from the Czech part of the federation to the Slovak part. ${ }^{7}$ The fast economic growth in Slovakia and the preference for investing in this part of the federation were a source of hidden national tension between the Czech and Slovak elites and also between common citizens. ${ }^{8}$ The conservative investment policy, an emphasis on autarky in grocery and consumer good production ${ }^{9}$ and reinforcement of the energy base were crucial in the consolidation process. Many technological innovations were sold to Western companies instead of being implemented in Czechoslovak industry. ${ }^{10}$ One well-known and telling example was the invention of soft contact lenses by Czechoslovak chemist Otto Wichterle. This could have been a success story for Czechoslovakia, but the invention was sold to the US. In 1971, the Bausch + Lomb company started to sell Wichterle's lenses, launching a revolution in the field of optical aids. ${ }^{11}$

In the mid-1960s, other CMEA member countries followed the traditional ideological extensive fast-growth policy but had to fight increasing trade deficits. 
The exports which were expected to pay for the credits did not manifest. State socialism found itself in a hole but could not stop digging. In the next decade, most CMEA members decided to take advantage of the financial market, which was flooded with cheap oil dollars with favourable credit conditions. The situation convinced many socialist countries that they could use credits for imports of consumer goods to keep the citizens calm, which meant abandoning the policy of self-sufficiency and economic independence from the West. ${ }^{12}$ However, the Czechoslovak political and economic elite, shaken by the events of 1968, turned in the exact opposite direction. In particular, Prime Minister Lubomír Štrougal and Chairman Stanislav Potáč of the Czechoslovak State Bank were eager to limit imports, to stop inflation and to re-establish a balance between supply and demand in the domestic market - all this with an accent on autarky. The social contract with citizens used other social policy tools, like housing, leisure at the state's expense and pensions. This worked out rather well all through the normalisation period because the citizens were not dissatisfied enough with the situation. As Czech journalist Petr Honzejk has stated in a commentary on the Czech mentality in this historical context, 'If there is something here, even when we know that it is horrible and it badgers us, we learn to live with it very fast and make it bearable. And if it is bearable why should we change it?'13

Eventually, the relatively high level of economic growth and the good results from the fifth five-year plan (1971-75) convinced the high level of the party that the return to fully centralised planning was the right decision and the system should be maintained with eventual amendments which would merely bring the system closer to perfection. The belief in continuing growth convinced the State Planning Committee and economic ministries to consider the possibility of an ambitious investment wave in the sixth five-year plan (1976-80). Observers in the West German Foreign Office saw the success of the first half of the decade as evidence for the Czechoslovak leaders that growth and development were possible without the 1968 reform attempts and the success silenced any remaining liberal thinking within the Communist Party of Czechoslovakia (CPC).${ }^{14}$ The remaining latent liberals would not raise their voices until changes in the Soviet Union in 1985.

The investment plan, which included projects like the construction of a highway between Bratislava and Prague, a metro system in Prague and a steel mill in Košice, required imports of technologies, materials and licenses. This required an amount of free convertible currency which the foreign trade was not able to generate. Therefore, it was at this time that Czechoslovakia jumped on the "credit train" to finance the new investment projects. The first large credits from Western European bank consortia were only received in 1975 and 1976, amounting to 60 million dollars and 200 million dollars, respectively. ${ }^{15}$ The debt to the West then slowly began rising but remained relatively small in comparison to the other CMEA countries. At a Bundesbank board meeting in December 1982, it was stated that Czechoslovakia and Bulgaria were able to keep their foreign indebtedness very low. ${ }^{16}$ When the Western states reacted to martial law in Poland in December 1981 with credit sanctions, Czechoslovakia did not seek the solution 
of joining the International Monetary Fund like the other CMEA countries but instead reduced imports and followed an export 'at any cost' policy. ${ }^{17}$

The high investment rate and the renewed growth in private consumption resulted in cyclic development with phases of acceleration and deceleration. While in the first half of the 1970s acceleration was notable, the results in the years 1976-78 pushed economic growth into a deceleration phase. ${ }^{18}$ This unexpected development urged the economic authorities in the federal government to think about changes. In 1979, several programmes in the investment plan were halted and the government introduced new prices for consumer goods to stop private spending and to decrease the need for imports. Chairman Stanislav Potáč of the Czechoslovak State Bank strongly defended the autarky policy and rejected requests from enterprises across the country for free currency. He was able to back his stand with the unique position of the State Bank as the final controller of the state budget and finances, which made the bank a strong voice in the national economy, unlike in the other CMEA countries. ${ }^{19}$ At the same time, Potáč opposed suggestions from some CPC Central Committee Presidium members who would have preferred to take out a loan to continue with the investment programmes. ${ }^{20} \mathrm{~A}$ modest liberalisation of foreign trade conditions for Czechoslovak enterprises as a means to achieve an active balance of trade with Western countries was followed by the first reform attempt since 1968. Strongly advocated by federal Prime Minister Lubomír Štrougal, it was introduced with the document 'Series of Policies for Improving the System of Central Planning in the National Economy after $1980{ }^{\prime} .{ }^{21}$ It would be a simplification to state that this was a repetition of the unsuccessful 1959 economic reform, but at the same time the 'Series of Policies', as it was commonly referred to in public institutions, shared many of the 1959 reform's aims. The strategy was to intensify production and to improve the efficiency of planning, the effects of economic inputs, the level of management and workers' participation in it. The Series of Policies is generally dismissed as having been unsuccessful. The original tasks in the five-year plan could not be completed and the first three years were planned individually. Between 1980 and 1982, economic growth was close to zero, and Western sources calculated it as negative: $-0.1 \%$ in 1981 and $-0.3 \%$ in $1982 .{ }^{22}$ Nevertheless, it can be argued that the implementation of the Series of Policies stopped the stagnation/negative growth of the Czechoslovak economy, and from 1983 it started to grow modestly.

The second half of the 1970s was also marked by a significant decrease in Czechoslovak competitiveness in foreign trade, with the terms of trade hitting the bottom in 1984. One of the reasons for this trend was the late effect of the oil crisis in the West, as the Soviet Union demanded price increases for its oil deliveries within the CMEA. ${ }^{23}$ The higher energy expenditure increased the cost of Czechoslovak industrial production and therefore the final product prices. The negative impact of the bad terms of trade was not resolved with any systematic changes. The federal government used short-term tactics like decreasing imports, as mentioned earlier. At the same time, it pushed for additional exports of consumer goods, which had originally been meant for the domestic market. On the 
one hand, these decisions helped to achieve an active balance of foreign trade and successful discipline in paying Western creditors. On the other hand, they repeatedly caused shortages of goods for the Czechoslovak population. Moreover, the increasing amounts of groceries, raw materials such as brown coal and lumber, and semi-finished products like plywood in the export portfolio were a warning sign of technological backwardness and an inability to sell high-quality industrial goods to Western customers.

\section{The 'normalised' elite}

Economic, financial and foreign-trade policy decision-making was done by a new political and economic elite which emerged from the purges in the normalisation process. A series of committee hearings at all levels in the hierarchy of public organisations, enterprises and agencies led to the firing of $30 \%$ of party members. ${ }^{24}$ This is generally well known and it has been relatively well analysed. More penalties for supporting the 1968 reforms were applied in the Czech part of the federation. The positions freed in state institutions, academia and state enterprises were mostly filled by a 'second league' of less experienced but loyal party members. Among the successful Czech professionals able to deal with the complex issues arising in foreign trade and international relations who rose to higher levels were the federal prime minister, Lubomír Štrougal; the federal minister of finance, Leopold Lér; the federal minister of technology and innovation, Ladislav Šupka; the federal vice minister of foreign trade, Jaroslav Jakubec; and the chairman of the Czechoslovak State Bank, Stanislav Potáč. These men created a closed think tank which achieved a consensus on how to develop the Czechoslovak economy in the years to come. Attached to them, a large Slovak cohort emerged in the higher political levels, mainly due to the fact that the normalisation process and sacking of elite members in Slovakia was much less harsh than in the Czech lands. Among the Slovaks most influential in decision-making, we should name the first secretary of the Central Committee of the Communist Party of Slovakia (CPS), Jozef Lenárt; the prime minister of the Slovak Socialist Republic, Peter Colotka; and the federal minister of foreign trade, Andrej Barčák. I do not include the first/general secretary, Gustáv Husák, in this group as he concentrated on political matters and particularly relied on Lubomír Štrougal and Peter Colotka in the economic and investments areas. Both of them originally supported the 1968 reform process but pragmatically withdrew from their reformist positions. This helped Gustáv Husák save them from the purges, as he considered both to be close allies.

Their knowledge, experience and business thinking made managers of state enterprises a regular choice for political posts in the respective economic ministries. The federal and republican governments had numerous specialised ministries for individual industries. Prime Minister Štrougal identified promising young managers and either actively promoted their professional careers in state enterprises or appointed them as ministers, vice ministers or ministerial state secretaries. Among these success stories, that of František Čuba is the most spectacular. Čuba was an 
agronomist who took over an average cooperative farm in Slušovice in 1963 and turned it into a thriving business with a turnover of 7 billion crowns by 1989. Cuba used the location of the farm in the relative periphery of the Gottwaldow region and started to implement specific methods reminiscent of capitalist business. Thanks to his good connections with the region's political elite, he was not invited to the committee hearings after 1968 and survived the purges. His achievements during the 1970s attracted the attention of high-level politicians, who suspected Čuba of anti-socialist ideas. As a businessman who felt that his success could be a reason for firing him, Čuba entered regional politics, and as a member of the system sealed his position as the Slušovice chairman. As an advocate of cooperation with Western partners, he created cooperation projects with companies in Canada, Italy and West Germany. The peak of Čuba's managerial career was to come after 1985, when his cooperative farm was taken as an example of a successful socialist business by the first secretary of the Communist Party of Ukraine, Volodymyr Shcherbytsky. ${ }^{25}$ Although Čuba may be an extreme case among the Czechoslovak managerial elite, a "capitalist" approach among successful Czechoslovak enterprises was taken by many other managers. Miroslav Zapadlo, who between 1969 and 1979 was the director of AZNP Mladá Boleslav, which produced the popular Skoda cars, was a manager who went to the limits of the existing laws to acquire more convertible currency for the company and tried to involve Western European automobile companies in cooperation talks. Although he led the Skoda factory through a massive expansion in his ten years in charge, his actions eventually led to a decision to remove him from office. ${ }^{26}$

\section{The specific case of academia}

The academic elite was not a consistent group and has to be defined on the basis of specialisations. Particularly economists were kept close to political decisions and participated in creating economic policy in the long 1970s. The initial purge among academic economists affected all those who had collaborated with the main representatives of the 1968 economic reform. In a critical article in the main academic economic journal in Czechoslovakia, Politická ekonomie, the 1960s reform process was interpreted as counter-socialist and revisionist. ${ }^{27}$ The main author, Felix Oliva, was an old-school Stalinist economist who had always been a loud opponent of the 1968 reforms. The normalisation process at the University of Economics in Prague which, together with the Czechoslovak Academy of Science, was the centre of Czechoslovak economic thinking, was led by Chancellor Stanislav Hradecký. In the first normalisation years, Soviet textbooks on economic theory were hastily translated into Czech and Slovak. However, the situation in academia could not be wound back to the 1950s. Academics who formally agreed with the Soviet invasion and the subsequent normalisation process started to release their own textbooks, like one on credit and monetary policies by Jiří Petřivalský, who based his argumentation on capitalist examples and authors. ${ }^{28}$ František Vencovský, who had been active at the University of Economics and had held an important role as a consultant to the chairman of the Czechoslovak 
State Bank since 1970, stated that research into the usefulness and possibilities of monetary policy in a centrally planned economy should not be limited at all, as long it did not doubt the re-centralisation of economic planning back in 1970 . The research was based on the most recent findings in the West, along with the most important scientific books and journals which were accessible in university and department libraries. ${ }^{29}$ Thanks to this, the next generation of economic graduates was not only not affected by the purges but was training with knowledge of Western economic models and policies. The works on Czechoslovak foreign trade by another prominent economist, Karel Dyba, show the same picture. ${ }^{30}$ This was an important element in creating a managerial elite with a realistic vision of the West and able to do business with partners in foreign private enterprises. After all, many members of this managerial elite went on to transfer into the private sector in the Czech and Slovak economies in the 1990s.

It is not necessary to name other branches of academia individually. In all the specialisations, the generation of scientists who had held positions in 1968 was subject to committee hearings and could only keep their posts if they expressed their 'agreement with official Party policy' following the Soviet military invasion. Together with the upcoming young generation of scientists, Czech and Slovak academics in all fields were eager to work with technologies they read about in foreign research papers. Their attitude to contacts with the West was therefore very stable: the more conferences with foreign scientists they could attend or fellowships at Western European universities they obtained, the more contacts they could establish, hopefully with significant research outcomes and patents for Czechoslovak industry. Among historians, Miroslav Hroch became the doyen of Czechoslovak academics, attending conferences abroad and publishing in Western European journals. His work on nations and nationalism became crucial in narratives on the creation of national states. ${ }^{31}$ Among molecular biologists, Jiří Bártek was one of the most successful Czechoslovak scientists working on cancer treatment. He was allowed to take up fellowships in the UK and to conduct research which eventually brought him into the position of being the only Czech scientist considered for a Nobel Prize. Nevertheless, both scientists were able to internationalise their research thanks to deals with Czechoslovak State Security (StB). ${ }^{32}$ The scientists' wish to get travel permits to the West went along with a willingness to report or deliver. The State Security hoped for information that would be valuable either in negotiating with Western countries or in competing with them. Economic espionage was among the key tasks of the service, and its attempts to gain know-how concerned both military and civil technology. ${ }^{33}$ Bártek was allowed to travel to the West in exchange for doing technological espionage. Smuggling biological cultures and devices from top British laboratories helped Czechoslovak cancer research and generic drug development. Bártek later stated in a newspaper interview, 'Young people are lucky that nowadays nothing like that can happen to them. They do not have to go through the choice. For me, it was about my job. I learnt so much in the West'.${ }^{34}$ Bártek is a symbol of a period when not only scientists but broad parts of the Czechoslovak population compromised moral principles to achieve their professional or personal goals. 


\section{The impact of global changes on Czechoslovak economic relations with the West}

At the beginning of the 1970s, the CMEA European members were receiving between $80 \%$ and $90 \%$ of their oil imports from the Soviet Union. Measured even with today's criteria, the Soviet oil reserves were seemingly endless. And although statistically the Soviet Union/Russian Federation has been floating on an oil basin, already by the mid-1960s extraction had to be moved to remote regions of Siberia so the Soviets could meet the demand in the world market. Exploration and extraction costs in these regions due to the harsh climate were considerably higher. Costs were further increased by the long-distance transportation of the oil, which grew from an average of 80 kilometres in 1970 to 1910 kilometres in 1980 - only within the Soviet Union. ${ }^{35}$ Oleg Bogomolov, the director of the Institute for the World Socialist Economic System at the Soviet Academy of Sciences, openly expressed the Soviet discontent. Bogomolov pointed to three main problems that aggravated the situation for the Soviet Union: the high costs of raw material extraction, the lack of incentives on the part of allies to compensate the USSR for these high costs, and the relative unprofitability of oil exports. Therefore, the Soviet Union wanted either a major increase in the prices paid for its raw material exports or much greater Czechoslovak participation in investments in new mining installations. The Czechoslovak government needed to start benefiting the 'underdeveloped and exploited' USSR. ${ }^{36}$

The year 1973 brought a big change for Czechoslovakia and the other small CMEA countries which lacked their own oil reserves. At the beginning, it seemed to be a very promising year, as the socialist camp had the big advantage of cheap Soviet oil, unlike the Western competitors. The input to Czechoslovak industry was therefore bargain-priced and accordingly contributed to Czechoslovak competitiveness. This was one of the reasons for the high levels of economic growth in the first half of the decade. However, the seemingly advantageous situation had a dark side: the West's ability to absorb CMEA goods was diminished due to the enduring economic crisis. Moreover, the Soviets were not happy to sell their oil to socialist allies at dumping prices. From 1975 onwards, the five-year moving average of prices for this particular commodity would be valid for one year only. For 1975, the average for a shorter period (1972-74) was calculated. The Soviet Union was able to achieve a $32 \%$ change in its favour in the terms of trade with the other CMEA members. ${ }^{37}$ Notwithstanding this achievement, the price change did not diminish the Soviet requirement for its customers to contribute their share to the costs of raw material extraction before it would consent to increase its deliveries. In this respect, Czechoslovakia had an advantage in comparison to other CMEA members. The country had participated in a broad Soviet oil industry modernisation project since 1966. In exchange, Czechoslovakia was granted 5 million tons of crude oil for a fixed price of 15.8 transferable roubles (approximately 25 dollars per ton). ${ }^{38}$ The Soviets were not happy about the terms of the agreement as the deliveries were guaranteed until 1984. The pressure they put on their Czechoslovak partners eventually led to shortening the delivery period 
until 1979, when the Czechoslovak investment credit would be paid back. ${ }^{39}$ These missing oil deliveries became a matter requiring a diplomatic solution. In 1977, Czechoslovakia decided to lend 200 million US dollars to Iran in exchange for the necessary oil deliveries at acceptable prices and a similar deal was done with Turkey. ${ }^{40}$ However, Czechoslovakia continued to search for other partners among the oil exporting countries, for two reasons. First, during a visit to Czechoslovakia in June 1979, Brezhnev warned that the Soviet Union could not guarantee continued oil deliveries. The Soviet production levels were dependent on declining reserves. ${ }^{41}$ Second, as at the beginning of the 1980s, the world market price for oil was dropping but the CMEA countries still paid at prices based on a five-year moving average. This meant a long-lasting burden for energy-demanding industrial economies like Czechoslovakia. The country needed to diversify its export portfolio with items such as agricultural crops, food and lumber in order to keep its energy consumption at affordable levels.

\section{The rules on Czechoslovak trade with the West}

Unlike the other CMEA members, Czechoslovakia was a founding member of both the International Monetary Fund and the General Agreement on Tariffs and Trade (GATT). In 1947, the Soviet Union refused to participate in the GATT on the ground that it was simply a tool in the hands of the Americans to implement their economic expansion and dominance of the world economy. The Soviet rejection crystallised the growing tension between the USSR and the Western allies and can be explained by Moscow's apprehension that participation in a multilateral trading system dominated by the capitalist countries might threaten its centrally planned economy and its aspiration to implement a system of bilateral trading arrangements with the countries in its sphere of influence. Therefore, when the USSR refused to become a member of the GATT, the Eastern European countries were not allowed to join either. The only exception was Czechoslovakia, as it had been an original contracting party from the time before the communist takeover. ${ }^{42}$ Although its IMF membership was cancelled due to the unacceptable circumstance of the Czechoslovak currency reform in 1953, the country continued to be an active GATT member throughout the whole period of state socialism. This had a particular benefit for Czechoslovakia. Foreign trade did not depend on bilateral agreements with Western European countries and it automatically had the status of most favourite nation (MFN). ${ }^{43}$ With the exception of the US, the GATT contracting parties continued to grant MFN treatment to Czechoslovakia and did not want to disrupt their trade relations. However, the discriminatory quantitative restrictions introduced or retained by numerous contracting parties against products originating from socialist countries applied to Czechoslovak products too. ${ }^{44}$

Unlike its socialist neighbours Poland and Hungary, Czechoslovakia did not establish any legislative conditions for opening its economy to foreign investment. The institution of joint ventures, which was creating a thriving business in Hungary, was only enabled in the late $1980 \mathrm{~s} .{ }^{45}$ Nevertheless, small steps were taken in the second part of the 1970s, as Czechoslovak officials recognised that the momentum 
of extensive economic growth was exhausted and export results were becoming fragile. In 1976, foreign businesses were allowed to open representations in Czechoslovakia. ${ }^{46}$ At the same time, the Federal Ministry of Foreign Trade started an offensive policy in the Czechoslovak diplomatic representations and at international industry fairs promoting Czechoslovak exports and licence agreements with Western companies. At this time, Czechoslovakia was far behind the other socialist countries in the matter of licenses. By 1980, in the CMEA area over 2000 cooperation or licence agreements were signed. ${ }^{47}$ Compared to this cumulative number, Czechoslovakia rated poorly and had not even reached fifty agreements. ${ }^{48}$

The late opening of the Czechoslovak economy to the West was observed by the Czechoslovak State Bank as an example of the gradually deteriorating export position of the CSSR among the CMEA countries. By the end of the 1970s, Czechoslovak per capita participation in world trade put it in eighteenth position, while Bulgaria was fifteenth and East Germany sixteenth. ${ }^{49}$ To support exports, in 1980 the Czechoslovak government issued a new law which allowed state companies to go by themselves into foreign trade up to a value of 10 million crowns, or 30 million crowns if the overseeing government institution did not object. ${ }^{50}$ However, it took three more years before four renowned state companies were selected for experimental autonomy regarding direct trade relations with partners in the West. ${ }^{51}$

\section{Czechoslovakia, the CMEA and the global South}

Czechoslovakia had a traditionally strong position in the markets in Latin America, Southeast Asia and Africa. It had one particular advantage in its competition with socialist exporters in the global South markets and in particular in newly established African national states following the dynamic but often chaotic and uncoordinated decolonisation process. The African independence movements which eventually became the governments of the former African colonies showed more trust in Czechoslovakia than in the USSR. They understood that Czechoslovakia was a fledgling country that had never occupied others and had its own history of being subject to the multinational Habsburg Empire until 1918 and to occupation by Nazi Germany between 1939 and 1945. ${ }^{52}$ In this context, there was a natural prospect for mutual understanding. By contrast, the Africans saw Czechoslovakia's East German competitors in an ambivalent way. First, even if they were a socialist country, they were still Germans, and Germany was a colonial power in Africa until 1918. However, at the same time, as Germans they were expected to deliver high-quality products but at cheaper prices because they were in the socialist camp. Nevertheless, Czechoslovakia also faced competition from recently industrialised countries which started to influence the world machinery market. Countries like Brazil, South Korea, Taiwan, Yugoslavia, Hong Kong, Mexico and Singapore more than doubled their share in the world market, from $3.3 \%$ in 1970 to $8.5 \%$ in 1982 . These countries offered relatively cheap machinery goods compared to the Czechoslovak portfolio. Therefore, they were more effective competitors than the socialist allies. ${ }^{53}$ 
Although the debt crisis was deeply connected to the credits which the socialist countries had received from the West, credits by socialist regimes to the global South should also be emphasised. In particular, the Soviet Union and East Germany, which was finally recognised as a sovereign country by the UN, invested large amounts of resources to help allies in Africa and Southeast Asia, such as Ethiopia, Angola, Mozambique and Vietnam. The East Germans were hoping for both economic revenue and a high profile in world politics.

Credits in convertible currency played an important part in this help, but the financial solvency to pay back these credits was a liability. Although Czechoslovakia played its part in the global South, the Czechoslovak Trade Bank advocated a strictly conservative approach regarding any financial aid to developing countries, even those which were on a socialist course. The Czechoslovak State Bank was also lukewarm about the possibility of providing African countries such as Angola with new credits in general. ${ }^{54}$ The Czechoslovak bank elite had a strong negotiation position with the federal government and expressed concerns regarding the credibility of the comrades in Luanda. ${ }^{55}$ The Czechoslovak Trade Bank and the Czechoslovak State Bank were even able to stop a 100-tractor contract for a credit of 1 million US dollars from being realised despite efforts by the Czechoslovak Ministry of Foreign Affairs and the embassy in Luanda. ${ }^{56}$ There was not much enthusiasm for African credits among high ministry and party officials either. Secretary Vasil Bil'ak, who was responsible for international relations, stated in a private discussion with Angolan officials that Czechoslovakia lacked US dollar reserves and could not risk increasing its debt to the West. ${ }^{57}$ All in all, on the Czechoslovak side business thinking clearly prevailed over ideological solidarity in this matter.

However, in the 1970s two developing countries which had observer status in the CMEA, Cuba and Vietnam, became full members of the organisation in 1972 and 1978, respectively. The admission of these states to the organisation was based on purely political motives. It was the Soviets in particular who advocated the expansion of the territorial scope of the CMEA outside Europe. One of the motives for this was that with CMEA membership USSR would get an important tool to even more closely politically connect Cuba and Vietnam with Moscow. This supports the view that the USSR perceived the CMEA as a tool for its own foreign policy purposes. ${ }^{58}$ This explanation seems to be even more plausible in the light of repeated reports of opposition from Hungary and Czechoslovakia to developing states becoming CMEA members. Czechoslovakia particularly opposed the admission of Vietnam, as the other developing member states Mongolia and Cuba were already a considerable burden on the limited resources of the CMEA. The Czechoslovak opposition may have contributed to the fact that for the rest of the CMEA's existence no other candidates, such as Ethiopia or Mozambique, were accepted as members. This confirms that the Czechoslovak elite preferred a business-driven approach in relations with developing countries. ${ }^{59}$

\section{The perception of the EEC in Czechoslovakia}

Understanding of the CMEA as an evident outcome of the socialist countries' partnership was a natural perception in the Czechoslovak public space. This was 
not the case with the European Economic Community, which was perceived as an ideological and economic counterpart to the CMEA in the West. The Czechoslovak elite's approach was restrained in both communication and politics at the beginning of the EEC. In the late years of state socialism in Czechoslovakia, newspaper articles were still embedded with propagandistic terms of anti-capitalist rejection. ${ }^{60}$ The tone of academic texts was never openly hostile but remained passive-aggressive. Nevertheless, Western economic development and the development of the Community were studied with rising interest. Otto Klička, deputy minister of foreign affairs, proclaimed already at a conference in December 1962 that the integration of the EEC had become faster and had recently acquired new features: 'Therefore it is important to eliminate the superficiality of our interest and the fragmentation of research on this important symbol of the third phase in the general crisis of capitalism' ${ }^{61}$ In a speech repleted with Marxist-Leninist terms, he added that the Common Market of six countries in Western Europe was evidence of the fact that capitalist enterprise would inevitably grow beyond the limits of town, region and eventually even country. ${ }^{62}$ He summed up EEC integration as an action of the Bonn-Paris axis which was only a temporary power marriage used by revanchist West German politicians and businesses. ${ }^{63}$ In 1963 , Vladimír Landa from the Research Institute for National Economic Planning in Prague stated that the creation of imperialist international organisations would be a natural outcome of the conditions in state monopolistic capitalism. According to Landa, the EEC was one of them. ${ }^{64}$ Some Czechoslovak academics like Vladisav Pavlát from the University of Economics in Prague proposed an interesting explanation for the acceleration of the EEC integration process, namely that the capitalist world felt the necessity to fortify itself against the growing socialist camp, ${ }^{65}$ yet he also argued that the CMEA countries were only able to react to increasing EEC integration with single countermeasures in foreign trade directives and lacked a theoretical base regarding the EEC as such: 'The CMEA countries are actually at the very beginnings of a unified approach to the EEC. And here, unsolved theoretical issues make practical measures nearly impossible'. ${ }^{66}$ In the second part of the 1960s, Czechoslovak academia attempted to promote a less politicised approach in research on the EEC. One of the outcomes was a collective work led by Vladislav Pavlát (EEC. Today and Tomorrow) which brought objective economic reasons for EEC integration into the light and recognised its usefulness. ${ }^{67}$ Research papers and studies released in the 1970s and 1980s no longer questioned the existence of the EEC and instead concentrated on specific branches of the integration process, like the agricultural market, or discussed the benefits and possible difficulties of EEC enlargement. ${ }^{68}$ Academic circles closely observed the new member countries and analysed the differences which had arisen between the original Six and the new members since the enlargement, especially the UK's perpetual attempts to change the Community's agricultural policy. ${ }^{69}$ Agricultural experts in the Czechoslovak government were looking at the UK with great interest also because the country was trying to satisfy demand for food with its own resources to strengthen its negotiating position at EEC summits, but at the end of the 1970 s it still had to import $30 \%$ to accommodate the domestic market. ${ }^{70}$ Although Czechoslovakia concentrated mostly on industrial exports to the EEC 
countries, it counted on a rise in crop exports in the future. The shortfall in the UK's production hinted at a possible market for Czechoslovak grain or meat surpluses.

Czechoslovak newspapers and television mostly copied statements in Soviet articles about the EEC, ${ }^{71}$ but sometimes Czechoslovak press and TV editors did their own pieces on the topic. František Šulc wrote an article in which he asked rhetorically whether the Common Market existed, criticising the fact that despite the official line of the Brussels Eurocrats each member country was doing what was in its best interests. He used the French monetary decision to float the exchange rate of the franc as evidence of this. ${ }^{72}$ According to him, the 1973 Copenhagen meeting was a fiasco demonstrating that the member states were not able to find any common ground regarding common fiscal and energy policies. However, Šulc acknowledged that the new members from the EFTA group were relatively successful in harmonising their policies with the original Six. ${ }^{73}$ His final statement can be interpreted as an official statement from the Czechoslovak government as Rudé právo was the main press agency of the CPC: 'This does not mean that the EEC stands in front of an imminent collapse, but it is merely clear that the reality of world economic development is more powerful than the hopes and wishes of the Brussels "Europeans". ${ }^{74}$ All in all, the Czechoslovak press informed on the integration process and the functions of the EEC, even citing the reactions of the Western European press following the results of the Norwegian referendum on EEC membership in $1972 .{ }^{75}$ At the same time, Czechoslovak journalists regularly added bittersweet comments about a 'so-called parliament of the Communities' or about the prevalence of West German, French and NATO and global capitalist interests over the wishes of small member states. ${ }^{76}$ When in 1982 the EEC celebrated the 25th anniversary of the Treaties of Rome, Rudé právo described it as 'a celebration with a wormwood aftertaste', claiming that there was not much to celebrate, as economic crisis and unemployment were spreading in the EEC member states. ${ }^{77}$

\section{Czechoslovak diplomatic contacts with EEC officials}

At the diplomatic level, the Czechoslovak Ministry of Foreign Affairs tried to figure out the state of the European Community and its possible future. In a report to Prague in 1970, the Czechoslovak chargé d'affaires in Brussels, František Rajman, wrote that political union of the EEC would be very difficult. He argued that the Community would have problems in adding the economies of the prospective new members to the highly integrated economies of the older members. ${ }^{78}$ However, although the future integration of the Community was observed with some scepticism, Czechoslovak officials gradually took the organisation more and more seriously, as is demonstrated by the growing numbers of reports on the EEC found in the archives of the Czech Ministry of Foreign Affairs. This is also supported by the fact that a relatively high-ranking party official, Vladimír Koucký, was appointed as Czechoslovakia's ambassador to Belgium for nine years running, from 1970 to 1978. In 1975, the growing importance of issues related to the EEC 
even led Koucký to request an additional employee for the embassy in Brussels who would be specifically responsible for Community matters. ${ }^{79}$

During his years in service, Koucký created good relations with officials in the Belgian Ministry of Foreign Affairs, and especially with the director of the Political Section, Andre Forthomme. In his meetings with Koucký, Forthomme was quite open about his opinions regarding relations with the Eastern European regimes. In a meeting on 20 November 1970, he mentioned that Western European politicians were perplexed about the interest in enhancing trade and other relations among European countries which had been expressed by the socialist regimes at the meeting of the UN Economic Commission for Europe earlier that month. He made it clear to Koucký that if the only interest of the socialist countries was to question the sense of the Common Market, the Belgians would not have any interest in such discussions at all, as they were fully satisfied with the EEC in its recent form and with its further evolution. ${ }^{80}$ Koucký responded that the latest developments in the EEC created a problem for economic relations with other European countries, which would need to be discussed and resolved, eventually at the European security and cooperation conference. ${ }^{81}$ Koucký also regularly met Étienne Davignon, who was the director general of the Belgian Ministry of Foreign Affairs in the early 1970s. Over lunch on 3 May 1972, they had an animated discussion about the relations of the EEC with the socialist countries. Davignon stated that there was no sense in the EEC insisting on it being recognised by the Eastern European countries because that would mean that the organisation was depending on it or would be inferior without it. It was furthermore important for the socialist regimes to abandon their public notion of the EEC being only a NATO agency. In response, Koucký argued that it was the EEC and the ultimatums from the 'Europe' agency to the socialist countries which were not helping to improve the climate in mutual relations. ${ }^{82} \mathrm{He}$ claimed that the Western Europeans underestimated the importance of the CMEA and were over-confident about improvements within the EEC. Davignon responded ironically that he was not aware of the CMEA already behaving as a spokesperson for its members and acting on their behalf. If that became a fact, it would be a most interesting one. ${ }^{83}$

The Czechoslovak embassy in Brussels maintained relatively intensive relations with EEC insiders like the long-time socialist member of the European parliament, Lucien Radoux, who Ambassador Koucký used to get information about future EEC member trade policies towards the socialist countries after 1 January 1975 as, because of their non-recognition policy, the CMEA countries were not able to get any official information. Radoux responded that he was not aware of the details, but he was wondering why the Czechoslovak authorities, unlike the other socialist governments, did not have at least technical contacts with EEC officials. He mentioned the Romanians and Poles as good examples: their technical contacts with the EEC Commission would certainly make some deal possible. As he wrote in his report, Koucký reacted in a very cold way. ${ }^{84}$ Even Jürgen von Alten, a highly placed West German diplomat who helped to negotiate the establishment of official diplomatic relations between Bonn and Prague, suggested that Czechoslovakia should have these contacts. He used the example of the Soviet 
embassy consul Vladimir A. Gnevashev and his meetings with the FRG's ambassador to the EEC, which were essential for the further Soviet approach to the EEC. Von Alten even offered Koucký his assistance in creating such contacts. ${ }^{85}$ One of the important contacts for the Czechoslovak diplomats was the deputy director of the EEC Directorate-General for External Relations, Wolfgang Ernst. He was used to dealing with the Eastern Europeans and told Ambassador Koucký during their first accidental meeting at the Japanese embassy in September 1972 that he was happy to finally meet a Czechoslovak official in Brussels. He stated that 'the ČSSR is one of the few socialist countries not maintaining regular technical relations with the EEC Commission. Just in the last week, several diplomats from socialist countries visited our department. I can remember officials from the Polish and Romanian embassies' ${ }^{86}$ Ernst proposed establishing casual relations and talks. He mentioned that the problem of official relations between the EEC and the Eastern European countries had not been dealt with at the highest level yet, as the socialist countries had more imminent problems to resolve, particularly exports of agricultural goods to the EEC market. ${ }^{87}$ Ernst's proposal led to an informal lunch meeting in May 1974 with the first secretary of the Czechoslovak embassy, Jan Stehno, who referred to it as almost conspiratorial. Ernst commenced the meeting with a statement that in the time of détente it was important to maintain personal contacts and exchange ideas to resolve small issues in order to move the contacts between the CMEA and the EEC to the next level. He expressed his surprise that recently all the socialist countries had maintained contacts with the EEC except Czechoslovakia and Albania. Ernst reassured his interlocutor that these 'meetings do not bind the participants to anything and are not understood in any way by the Commission as recognition of the EC ${ }^{88}$ Ernst's initiative brought results: unofficial meetings with EEC officials started to be a regular part of the work at the Czechoslovak embassy in Brussels. After a meeting in March 1974 with the head of the EEC department for socialist countries, Friedrich Klein, chargé d'affaires Vasil' Choma wrote in a report to Prague:

Our meetings with Mr. Klein and the experience of our friends in Brussels show so far that the European Commission does not avoid contacts with embassies of the socialist countries. For the last two years approximately, these relations have been fully ordinary while being considered by both sides as being of a strictly technical nature. ${ }^{89}$

\section{Czechoslovak official policy towards the EEC in the 1970s and 1980s}

The intensive diplomatic contacts show that high-ranking party and government members took the EEC seriously, not as an institution but rather as a threat to Czechoslovak foreign trade interests. Already in December 1969, a summit of CMEA leaders convened in Moscow to adopt a common strategy for approaching the EEC. A policy of 'controlled bilateralism' emerged at this meeting as the guiding principle behind the Soviet Union's bloc diplomacy. According to this policy, 
individual Eastern European initiatives were to be consistent with the pace of the entire bloc towards the EEC. Regular consultations with Moscow would ensure that no state was out of step with the group. ${ }^{90}$ At the top party level, Czechoslovakia supported the Soviet stance that the question of relations with the EEC was first and foremost a political one. ${ }^{91}$ However, during a lead-up session to the meeting of the Political Consultative Committee of the Warsaw Pact in January 1972, Czechoslovakia, along with Hungary and Poland, did not rule out the possibility of establishing some kind of contacts with the EEC. ${ }^{92}$ Prime Minister Strougal confirmed this stance three years later when he acknowledged the importance of CMEA-EEC contacts: 'As we are two different economic groups, the first contacts cannot be more than probes. .. . We do not wish to disturb EEC quests, but we would like to talk with the EEC about mutual goals in multilateral affairs.' 93

Nonetheless, the EEC started to have a significant impact on the CMEA countries and their export policies. It is no surprise that the socialist regime in Czechoslovakia perceived the EEC as an obstacle to foreign trade. The EEC was a protectionist organisation adopting limits on imports of certain goods, import duties and contingent amounts, protecting French farmers as much as West German steel mills or Danish pork breeders. Since 1 January 1975, countries interested in doing business with an EEC member had to enter into complex negotiations with the Community to get the desired import rights. Based on the CPC Central Committee Presidium records from throughout the 1970s, it is more than obvious that the high political levels misunderstood and disdained the EEC as a purely economic organisation which created problems for Czechoslovak steel or textile exports to countries like West Germany. Apart from this view, there is hardly a record of serious discussions in Presidium sessions regarding the EEC and how to handle relations with it. If any, the discussion was very short and vague, even though the Presidium was supposed to discuss such serious matters as a dossier on EEC antidumping procedures against Czechoslovakia.

The attitude of the top party and government levels to the EEC does not mean it was not closely observed by the ministerial, party, academic and diplomatic operatives at the middle level, and by trade organisation experts. Already in May 1967, the University of Economics in Prague organised an international colloquium titled 'Actual Situation and Perspectives on EEC Development', which was attended by two EEC officials, the director of the cabinet of the vice president of the Commission, Sicco Mansholt, and a functionary from EUROSTAT. ${ }^{94}$ With the acceleration in East-West trade relations in the second half of the 1960s, Czechoslovak politicians feared the implementation of the EEC's common tariff policy. However, not all Czechoslovak export specialists considered the EEC's common tariff policy to be a problem. The foreign trade corporation Strojimport considered tariffs to be only a marginal element in the final price of machinery products for customers in EEC countries. Ján Janšta from the Department of International Economic Organisations argued that the real problem was the competition among CMEA countries to access Western markets and the complicated decision-making between foreign trade organisations and production factories regarding suitable offers to Western costumers. ${ }^{95}$ The EEC's common external tariffs would only be imposed 
on products from sectors the member states wished to protect, such as agricultural and manufactured goods. On the one hand, these were exactly the type of goods the Eastern Europeans wanted to export, and they would have to face import quotas and higher customs duties. On the other hand, the Community would not restrict imports of raw materials that were in high demand, like fossil fuels. The common tariffs did not scare exporters of natural resources, especially of coal. ${ }^{96} \mathrm{It}$ was general knowledge that the EEC countries needed Eastern European natural resources and would not impose high tariffs on them. ${ }^{97} \mathrm{~A}$ more considerable issue were tariffs on glass, textile and steel, which would make Czechoslovak products less competitive against West German and Italian goods, as the EEC institutions would continue with protectionist policies for domestic enterprises. ${ }^{98}$

The Czechoslovak Ministry of Foreign Trade recognised the growing dualism of the economic/trade competences of the EEC institutions and the national governments of the member states. In the mid-1970s, the loss of individual EEC member state rights regarding the liberalisation of import contingents from the socialist states created much concern in the CMEA. From January 1975, the EEC member states were no longer allowed to negotiate bilateral agreements. The socialist countries were not appeased by a resolution of the EEC Council on 12 November 1974 which assured them that the CMEA countries would continue to have MFN status. ${ }^{99}$ Czechoslovak diplomats complained about small Belgian and Dutch import contingents for the years 1975 and 1976, which were the result of decisions by the Commission and were not in accordance with the high volumes of Czechoslovak and other socialist countries' exports to Belgium and Netherlands. Commission officials blamed the continuing economic crisis in the EEC member states for the small contingents. The truth is that the problem was both economic and political. Czechoslovakia and the other CMEA members faced a political barrier hindering their access to the EEC market: in order to be able to continue trading with EEC member states they had to acknowledge the competence of the EEC Commission in trade policy. This was a challenge to the non-recognition policy, which the CMEA had adhered to since the very beginning. ${ }^{100}$ The EEC's expanding competence and prestige was becoming an issue for the unity of the CMEA and the Soviet leadership in it. The EEC was becoming an attractive trade partner for some CMEA countries which had strong economic motives to take up negotiations. Czechoslovakia, the Soviet Union and East Germany feared the protectionist EEC policy regarding some very traditional export items, such as steel. Czechoslovakia put pressure on the CMEA to start formulating a policy towards the EEC which would secure the members' foreign trade interests.

As long as there was no institutional framework to negotiate trade agreements with the EEC, Prague had to negotiate with the EEC individually, using other channels. Although Czechoslovak diplomats in Brussels feared that the latest protests by Western Europeans against the denial of human rights in Czechoslovakia following the publication of Charter 77 could be an issue, communication went smoothly. ${ }^{101}$ To resolve problems with metallurgy exports, in April 1978 Czechoslovakia used the GATT platform to sign a self-limiting sector agreement regarding trade in metallurgy goods with the EEC. This agreement was the very 
first steel arrangement between a CMEA country and the EEC, and also the very first official document signed between the ČSSR and the EEC. The deal proved to be very beneficial: in exchange for respecting a given EEC minimum price, the steel agreement allowed $90 \%$ of Czechoslovak steel to be sold on the EEC market. ${ }^{102}$ This benefited all the Czechoslovak steel mills, especially the one in Košice, which was extending its production and depended on rolling product exports. The steel deal was therefore followed by a similar agreement on textiles in 1982. By contrast, the Czechoslovak diplomats were not able to push some agricultural products through a negotiation process with the Commission. This led to a refusal of certificates for Czech hops, a traditional Czechoslovak high-quality export item. ${ }^{103}$ Even though agricultural products and groceries had never played big roles in Czechoslovak exports, the growing self-sufficiency of Czechoslovak food production brought an expectation of higher levels of meat, dairy, fruit and vegetable exports in the 1980s. ${ }^{104}$ However, only one agreement on more mutton, vine and seed exports was negotiated between the EEC and Czechoslovakia. The three sector agreements mentioned in this paragraph covered merely $20 \%$ of Czechoslovak exports to the EEC market and limited Czechoslovak possibilities until a sector agreement on industrial goods and a general trade agreement between the CSSR and the EEC were signed in late $1988 .{ }^{105}$ However, already in the mid-1980s Czechoslovakia needed to establish intensive contacts with the EEC institutions, the banks had to apply the new European standardised systems and computing, research institutions had to collaborate with intergovernmental platforms like EUREKA and foreign trade corporations needed to use the European Currency Unit in business deals with Western European partners. ${ }^{106}$ In simple terms, Czechoslovak enterprises and institutions had to adapt to EEC standards in order to sustain and boost business contacts with the EEC countries. When the moderator of the main news panel on Czechoslovak Television, Rastislav Bajer, invited Deputy Minister of Foreign Trade Jiři Němec to the studio in August 1988 shortly after the establishment of official relations between the CMEA and the EEC, his question was remarkably open: 'How is it possible that the normalisation of mutual relations took all of fifteen years?' Němec replied that what was not possible in the previous fifteen years had been resolved relatively easily now due to the broader context of East-West relations. ${ }^{107}$

\section{Conclusion}

This chapter has shown that the socialist camp was not a consistent group of like-minded regimes with similar economic and foreign trade policies. Strongly affected by the 1968 Warsaw Pact invasion and its aftermath, Czechoslovakia quickly diverted from its economic reform plans to the safe waters of re-centralised economic planning, autarky and an active balance of payments. The consolidation programme, which became the economic companion of political normalisation, safeguarded the stabilisation of the Czechoslovak economy and fast economic growth during the fifth five-year plan (1970-75). Unlike the other CMEA countries, Czechoslovak citizens were not promised a supply of consumer goods but 


\section{2}

were appeased by a generous social policy. An important ingredient in the growth in exports was favourable circumstances in the world market following the rise in oil prices. The mixed blessing of bargain-price oil deliveries from the Soviet Union secured cheap machinery production and made Czechoslovak products more competitive on Western markets in the short term. However, as the economic crisis in the West took root, the Western market's absorption capacity was eventually exhausted, which created problems for Czechoslovak export targets in the second half of the decade. Together with an ambitious investment policy and large amounts of credit taken under the sixth five-year plan (1976-80), this was the reason for a deceleration in economic growth, eventually leading to stagnation in 1982. The economic problems were intensified by Soviet attempts to sell their natural resources, crude oil in particular, at higher prices based on the moving average world prices over the previous five years. This meant that, while at the beginning of 1980 the world market prices for oil were dropping, Czechoslovakia still had to pay the higher market price from the period of the 1979 oil crisis.

The second part of the long 1970s saw a late re-opening by Czechoslovakia towards the West. The country was trying to catch up with fellow socialist allies in signing cooperation agreements and buying industrial licenses, but it had to face difficulties due to the economic crisis in the Western European countries and the EEC's expanding competences and membership. In the process of negotiating with the Community, Czechoslovakia backed Soviet positions and did not come up with its own initiatives. In comparison to other CMEA partners, Czechoslovakia was late in developing contacts and sectoral agreements with the Community. Nevertheless, it was the first CMEA country to sign a steel agreement with the EEC after its individual members had lost the authority to sign bilateral trade agreements with other countries. As Czechoslovak exports were mainly industrial products, and not crops as in the case of some other CMEA members, this was an important step to spur the volume of exports to the EEC market, especially to the Federal Republic of Germany.

The end of the long 1970s was marked by a recovery of economic growth in 1983. For the rest of the decade, the economy was able to produce modest but stable growth, although industrial modernisation efforts had been partly abandoned due to the previous stagnation. In order to achieve an active balance of payments, Czechoslovakia diverted its export portfolio from uncompetitive machinery goods towards raw materials and semi-products. In other words, the conservative economic strategy secured the stability of the economy and the regime itself, but in the long term it put the country on a course towards backwardness and the position of a developing country. But the fear of the political, economic and social consequences that reforms could bring prevailed until the very end of state socialism in Czechoslovakia. As the common Czech sayings have it, 'If it works, don't mess with it' and 'All changes can only make things worse'.

\section{Notes}

1 For example, Dejmek, Československo, jeho sousedé a velmoci ve 20. století.

2 Průcha, Hospodářské a sociální dějiny Československa. 
3 Slouka, Poučení z krizového vývoje ve straně a společnosti.

4 Slovenský národný archív (SNA), fond Predsedníctvo ÚV KSS, box 1217; Hill, Industrial Co-operation and Technology Transfer, 105.

5 "Prag erwägt IWF-Kredit," Handelsblatt, 22 April 1968.

6 The continuing discussions among Czech and Slovak economists since 1989 have not found common ground regarding evaluation of the reform yet. See, for example, Šulc, Stručné dějiny ekonomických reforem v Československu.

7 For specifics regarding the development of the Slovak economy, see Štefániková, "Ekonomicé aspekty normalizácie," 84-200.

8 Das Politische Archiv des Auswärtigen Amts (PA/AA), fond: Zwischenarchiv, room Tresorebene B - Zwischenarchiv, shelf 113, parcel 6968, ordering number 117.644, "Vergleich der wirtschaftlichen Entwicklung in den beiden Teilrepubliken der CSSR," 13 November 1974.

9 In this matter, Czechoslovak policies contrasted with the boosts of consumer goods imports in other CMEA countries. Party officials understood that Czechoslovakia could not compete with the West in consumption, so they created a theory about socialist lifestyle in which people could reach things which were not accessible in the West. See Bren, "Mirror, mirror, on the wall," 854.

10 Gerle, "Zastavení první: Vzpomíná Ladislav Gerle," 36-48.

11 "Bausch + Lomb," accessed 12 March 2020, https://bauschandlomb.com.au/history/.

12 Berend, From the Soviet bloc to the European Union, 33.

13 Petr Honzejk, "Varianta pštros. Česko se na budoucnost nechystá, většina věří, že všechno může být "jako vždycky," Hospodářské noviny, 7 June 2019, 22.

14 PA/AA, fond Zwischenarchiv, Raum Tresorebene B - Zwischenarchiv, shelf 113, parcel 6968, ordering number 117.644, "Wirtschaftliches Jahresbericht 1975. Tschechoslowakische Sozialistische Republik."

15 Historisches Archiv der Deutschen Bundesbank (HUBABA), fond B 330, number 10496/2, “Angaben zur Westverschuldung der Tschechoslowakei,” April 7, 1978.

16 HABUBA, fond B 330, number 11604, "Protokoll der 619. Sitzung des Zentralbankrates der Deutschen Bundesbank in Frankfurt am Main am 16. Dezember 1982/2."

17 Steiner, "The decline of Soviet-type economies," 202.

18 Průcha, Hospodářské a sociální dějiny Československa, 854.

19 Paragraph 4 of the Act on the State Bank of Czechoslovakia no. 144/1970 specifically ordered the bank to present and defend a proposal for a monetary (credit, cash-desk and foreign currency) plan. For further arguments, see Půlpán, Měnové plánování v reálném socialism, 5 .

20 HABUBA, fond B 330, number 10496/2, "Notiz über den Empfang bei der tschechoslowakischen Zentralbank (Státní Banka Československá) am 17. April 1978, 10:3011:45 Uhr., Handakte Dieter Schmölling vom Büro des Präsidenten (Dr. Emminger) Enthält: Besuch des Präsidenten bei der tschechoslowakischen Zentralbank (Státní Banka Československá), April 1978."

21 Handlír, Soubor opatření.

22 Höhmann and Meier, Wirtschaftslage, Außenwirtschaft und Außenpolitik, 11.

23 Jansen, "Energiepolitik unter dem Eindruck," 15.

24 Maňák, Čistky v Komunistické straně Československa. 42.

25 Archiv a programové fondy ČT (APF Praha), Sedláček, Robert, František Čuba: Slušovický zázrak, Česká televize, Tvůrčí skupina Karla Hynie 1999.

26 Vilímek, "Mladoboleslavská Škodovka v období normalizace," 98-9.

27 “Analýza vývoje ekonomické teorie v Československu v šedesátých letech,” 793-860.

28 Petřivalský, Úvěrová a měnová politika, 230-32.

29 Vencovský, Vzestupy a propady československé koruny, 154.

30 See, for example, Dyba, Československé vnějši ekonomické vztahy.

31 Hroch, Social preconditions of national revival in Europe.

32 The State Security collaborator registers are available online. For Miroslav Hroch, see the register, last accessed 12 March 2020, www.abscr.cz/data/knihy/C88/36/ C88_36_35.jpg. 


\section{Pavel Szobi}

33 Domnitz, "National separation, controlled co-operation," 207.

34 Held, Roman and Jaroslav Klementa, Jaroslav, "Tu minulost bych nejraději vymazal z paměti. Neudával jsem," Mladá fronta Dnes, 7 July 2011, 4.

35 Beckmann and Fidrmuc, "Oil price shock and structural changes in CMEA trade," 35.

36 Kansikas, "Calculating the burden of empire," 348-9.

37 Svoboda, "Vliv vnějších podmínek na zahraniční obchod Československa," 336.

38 HABUBA, fond B 330, number 10496/2, "Notiz über den Empfang bei der tschechoslowakischen Zentralbank (Státní Banka Československá) am 17. April 1978, 10:30 11:45 Uhr. Handakte Dieter Schmölling vom Büro des Präsidenten (Dr. Emminger) Enthält: Besuch des Präsidenten bei der tschechoslowakischen Zentralbank (Státní Banka Československá)" April 1978.

39 Svoboda, "Vliv vnějších podmínek na zahraniční obchod Československa," 336.

40 HABUBA, fond B 330, number 10496/2, "Notiz über den Empfang."

41 Lüthi, "Drifting apart," 380.

42 Coppolaro, "East-West trade." 78.

43 PA/AA, fond Zwischenarchiv, room Tresorebene B - Zwischenarchiv, shelf 113, parcel 6968, ordering number 117.644, "Sachstand: Deutsch-tschechoslowakische Wirtschaftsbeziehungen," 16 February 1976.

44 Maresceau, The political and legal framework, 271.

45 Bundesarchiv (BArch, fond B/102, signature 240369, localisation 10, magazine I 5 A 2.2.03, order 243, "Interne Auskunft, 1. August 1977, Betr. ČSSR-Klagen über Wirtschaftsbeziehungen; hier: Strougal gegenüber Botschafter Diesel vom 20. Juli 1977," 1 August 1977.

46 Stiftung Rheinisch-Westfälisches Wirtschaftsarchiv zu Köln (RWWA), signature 175-10-1, "Programm der gemeinsamen Vorstandsitzung reziproker Organe am 25.5.1978, Anlage 3a1: Deutsch- tschechoslowakische Wirtschaftsbeziehungen."

47 Průcha, Hospodářské a sociálni dějiny Československa, 854.

48 BArch, fond B/102/, signature 240369, localisation 10, magazine I 5 A 2.2.03, order 243, "Übersicht der Kooperationsprojekte, September 1978"; RWWA, signature 175-13-2, "Kooperationsabkommen zwischen der Industrie der CSSR und ausländischen Unternehmen (Messebeobachtung Brünn 1970)."

49 Archiv České národni banky (AČNB), fond SBČS, box Investice, KGMF, KSČ Národohospodářská komise ÚV KSČ, Kovy drahé 1982, "Státní plánovací komise, Hlavní úkoly 7. Pětiletého plánu, a jejich zabezpečení."

50 Průcha, Hospodářské a sociální déjiny Československa, 855.

51 The selected companies were from the fields of machinery and military equipment but also musical instruments. Průcha, Hospodářské a sociální dějiny Československa, 855.

52 Archiv Ministerstva zahrančních věcí Č eské republiky (AMZV), fond TO-T Angola, 19751979, box 1, folder 3, "Informace o průběhu a výsledcích návštěvy ministra zahraničníhc věcí ČSSR s. B. Chňoupka v Angolské lidové republice,” September 25, 1978.

53 Svoboda, "Vliv vnějších podmínek na zahraniční obchod Československa." 334.

54 AMZV, fond TO-T Angola, 1980-1989, box 1, folder 2, "Zaměření a hlavní úkoly čs. zahraniční politiky vůči Angolské lidové republice," 18 February 1986.

55 AMZV, fond TO-T Angola, 1980-1989, box 2, folder 24, "Hodnotenie plnenia //Zamerania a hlavných úloh čs. zahraničnej politiky voči Angolskej l'udovej republike//," 14 March 1988.

56 AMZV, fond TO-T Angola, 1980-1989, box 5, folder 33, "Hodnocení plnění "Plánu práce čs. ZÚ Luanda na rok 1987,” 29 December 1987.

57 Sieber, "Angola "zemí přednostního zájmu," 293.

58 Bloed, The external relations, 63.

59 Bloed, The external relations, 63.

60 Domnitz, "National separation, controlled co-operation," 204.

61 Klička, "Západoevropská integrace," 7.

62 Klička, "Západoevropská integrace," 8. 
63 Klička, "Západoevropská integrace," 12.

64 Landa, "Západoeurópska integrácia a EHS," 26.

65 Pavlát, "Vývoj marxistického hodnocení integračních procesů," 35-6.

66 Pavlát, "Vývoj marxistického hodnocení integračních procesů," 46-7.

67 Pavlát, EHS. Dnešek a budoucnost, 7-8.

68 Bednařík, Integrace zemédělství Evropského hospodářského společenství.

69 Kadeřábková, "Některé problémy společné zemědělské politiky," 1112.

70 Národní archiv České republiky (NA), fond 1261/0/7, folder 101, agenda point 1e, "Ústav vědeckotechnických informací pro zemědělství, Postavení československého zemědělství ve světě (srovnání se státy RVHP, EHS a dalšími). Praha, 1979,” internal document.

71 For example, the article by Leonid Zamjatin, "Competititve fight in the EEC" in Sovetskaya Rossya was simply translated and printed in Rudé právo on 15 December $1972,6$.

72 František Šulc, "Je EHS ještě," společným trhem, Rudé právo, 11 February 1974, 4.

73 František Šulc, "Je EHS ještě," společným trhem, Rudé právo, 11 February 1974,

74 František Šulc, “Je EHS ještě,” společným trhem, Rudé právo, 11 February 1974,

75 "Rozčarování z referenda. Výsledky norského hlasování o vstupu do EHS středem pozornosti," Rudé právo, 28 September 1972, 7.

76 Zdeněk Porybný, "Zájem silných. K snahám o vytvoření měnového systému EHS," Rudé právo, 12 December 1978, 6.

77 "Oslavy s příchutí pelyňku. Črvrtstoletí Evropského hospodářského společenství," Rudé právo, 25 March 1982, 6.

78 AMZV, fond TO Belgie 1970-1974, box 1, "Davignonův výbor. Politická zpráva č. 15.”

79 AMZV, fond TO-T Belgie 1975-1979, box 1, "Předběžné hodnocení práce ZÚ Brusel v roce 1975," 29 October 1975.

80 AMZV, fond TO Belgie 1970-1974, box 1, "Záznam o návštěvě velvyslance s. Kouckého u pana Forthomma na belgickém MZV dne 20. 11. 1970."

81 See Chapter 2 by Angela Romano in this book for details.

82 AMZV, fond TO Belgie 1970-1974, box 1, "Oběd soudruha Kocukého s generálním ředitelem MZV vikomtem Davignonem. Záznam z rozhovoru č. 18," 4 May 1972.

83 AMZV, "Oběd soudruha Kocukého s generálním ředitelem MZV vikomtem Davignonem. Záznam z rozhovoru č. 18."

84 AMZV, fond TO Belgie 1970-1974, box 1, "Oběd s. velvyslance Kouckého s poslancem PSB L. Radouxem. Záznam z rozhovoru č. 37,” 6 December 1972.

85 AMZV, f. TO Belgie 19701974, kr. 1, "Setkání s rady ZÚ NSR v Bruselu. Záznam z rozhovoru č. 23, 28. února 1974."

86 AMZV, f. TO Belgie 1970-1974, kr. 1, “Záznam o seznámení se zástupcem generálního ředitele odboru mezinárodních vztahů Komise EHS prof. Wolfgangem Ernestem dne 29.3.1973. Záznam z rozhovoru č. 15, 30. března 1973."

87 AMZV, fond TO Belgie 1970-1974, box 1, "Záznam o seznámení se zástupcem generálního ředitele odboru mezinárodních vztahů Komise EHS prof. Wolfgangem Ernestem dne 29.3.1973. Záznam z rozhovoru č. 15, "March 30, 1973; Historical Archives of the European Union (HAEU), EUI Interview Collections, Interview with Wolfgang Ernst, 20, accessed 30 October 2017, archives.eui.eu/en/files/transcript/15182. pdf. For more about EEC protection against cheap agricultural imports from socialist countries, see Kansikas, "Acknowledging economic realities," 314.

88 AMZV, fond TO Belgie 1970-1974, box 1, "Setkání s vedoucími pracovníky ředitelství pro mezinárodní záležitosti Komise EHS. Záznam rozhovoru č. 31," 18 May 1973.

89 AMZV, fond TO Belgie 1970-1974, box 1, "Setkání s pracovníky Komise EHS. Záznam č. 30," 15 March 1974.

90 Ouimet, The rise and fall of the Brezhnev Doctrine, 70.

91 Kansikas, Socialist countries face the European Community, 96.

92 Kansikas, Socialist countries face the European Community, 99. 
93 PA/AA, fond Zwischenarchiv, room Tresorebene B - Zwischenarchiv, shelf 113, box 6968, ordering number 117.644, "Deutsch-tschechoslowakische Außenministerkonsultationen, 26. März 1975."

94 AMZV, fond OMEO 1966-1970, box 18, "Kolokvium o vývoji a perspektivách EHS," 26 May 1967.

95 AMZV, fond OMEO 1966-1970, box 18, "Informace k material o důsledcích Západoevropské integrace," 15 November 1967.

96 Kansikas, "Calculating the burden of empire," 352.

97 AMZV, fond OMEO 1966-1970, box 18, "Informace k material o důsledcích Západoevropské integrace," 15 November 1967.

98 AMZV, "Informace k material o důsledcích Západoevropské integrace."

99 PA/AA, fond Zwischenarchiv, room Tresorebene B - Zwischenarchiv, shelf 113, box 6969, ordering number 117.646, "Höfflichkeitsbesuch des Außenhandelsministers Barčák un des Ministers für technische und industrielle Investitionsentwicklung der CSSR Šupka und Unterzeichnung des deutsch-tschechoslowakischen Kooperationsabkommens am 22. Januar 1975," 17 January 1975.

100 Kansikas, "Calculating the burden of empire," 352.

101 AMZV, fond TO Belgie 1975-1979, box 2, "Záznam z porady diplomatických pracovníkủ konané na ZÚ Brusel 8.10. 1979.”

102 Romano, "Untying Cold War knots," 15.

103 AMZV, fond TO Belgie 1975-1979, box 2, “Záznam z porady diplomatických pracovníků konané na ZÚ Brusel dne 18.9.1978."

104 Průcha, Hospodářské a sociální dějiny Československa, 867.

105 CSSR-EEC relations were well reflected by the membership of the Research Institute of External Economic Relations in Prague. Zemanová, Analýza hospodářských vztahů evropských států RVHP s EHS, 56.

106 As a matter of fact, FTC Merkuria had been using the ECU as a reference currency for tbusiness deals since the mid-1980s. Zemanová, Analýza hospodárských vztahů evropských států RVHP s EHS, 65.

107 APF Praha, signature IDEC 288451 90992, "Rozhovor s náměstkem ministra zahraničního obchodu Jiřím Němcem o ekonomické spolupráci RVHP a Československa s EHS, Televizní noviny," 3 August 1988.

\section{Bibliography}

Beckmann, Elisabeth and Jarko Fidrmuc. "Oil price shock and structural changes in CMEA trade: pouring oil on troubled waters?" European Journal of Comparative Economics 9 (2012): 31-49.

Bednařík, Zdeněk, ed. Integrace zemědělství Evropského hospodářského společenství. Ekonomický růst, státní intervence, společný trh. Praha: Academia, 1970.

Berend, Ivan. From the Soviet bloc to the European Union. Cambridge: Cambridge University Press, 2009.

Bloed, Arie. The external relations of the Council for Mutual Economic Assistance. Dordrecht: Martinus Nijhoff, 1988.

Bren, Paulina. "Mirror, mirror, on the wall . . . is the West the fairest of them all?: Czechoslovak normalization and its (dis)contents." Kritika: Explorations in Russian and Eurasian History 9 (2008): 831-54.

Coppolaro, Lucia. "East-West trade, the General Agreement on Tariffs and Trade (GATT), and the Cold War: Poland's accession to GATT, 1957-1967." In East-West trade and the Cold War, edited by Jari Eloranta and Jari Ojala, 77-93. Jyväskylä: University of Jyväskylä, 2005. 
Dejmek, Jindřich. Československo, jeho sousedé a velmoci ve 20. století (1918 až 1992): vybrané kapitoly z dějin československé zahranični politiky. Prague: Centrum pro ekonomiku a politiku, 2002.

Domnitz, Christian. "National separation, controlled co-operation: how state-socialist elites communicated economic openings." European Review of History: Revue européenne d'histoire 21 (2014): 201-17.

Dyba, Karel. Československé vnějši ekonomické vztahy. Praha: Academia, 1980.

Gerle, Ladislav. "Zastavení první: Vzpomíná Ladislav Gerle.” In Ještě pár odpovědí, edited by Lubomír Štrougal, 36-48. Praha: Epocha, 2001.

Handliřr, Josef. Soubor opatřeni ke zdokonaleni soustavy plánovitého řizení národního hospodářství. Praha: Oddělení propagandy a výchovy ÚRO, 1980.

Höhmann, Hans-Hermann and Christian Meier. Wirtschaftslage, Außenwirtschaft und Außenpolitik in Osteuropa: Zur Politischen Ökonomie der RGW-Gipfelkonferenz. Köln: Bundesinstitut für Ostwissenschaftliche und Internationale Studien, 1984.

Hroch, Miroslav. Social preconditions of national revival in Europe: a comparative analysis of the social composition of patriotic groups among the smaller European nations. Cambridge: Cambridge University Press, 1985.

Jansen, Paul. "Energiepolitik unter dem Eindruck der beiden Ölpreiskrisen - Die Beispiele der ČSSR, der DDR, Polens und Ungarns." In Das Energieproblem in Ostmitteleuropa. Teil II: Energiepolitik und Energieverbund in den mitteleuropäischen RGW-Staaten, edited by Gernot Gutmann, Karl C. Thalheim and Wilhelm Wöhlke, 11-33. Marburg/ Lahn: Herder-Institut, 1984.

Kadeřábková, Božena. "Některé problémy společné zemědělské politiky zemí Evropského hospodářského společenství." Politická ekonomie 33 (1985): 1109-15.

Kansikas, Suvi. "Acknowledging economic realities. The CMEA policy change visà-vis the European Community, 1970-1973." European Review of History 21 (2014): 311-28.

Kansikas, Suvi. Socialist countries face the European Community: Soviet-bloc controversies over East-West trade. Frankfurt: Peter Lang, 2014.

Kansikas, Suvi. "Calculating the burden of empire: Soviet oil, East - West trade, and the end of the socialist bloc." In Cold War energy, edited by Jeronim Perovic, 345-69. Cham: Springer International, Imprint: Palgrave Macmillan, 2017.

Klička, Otto. “Západoevropská integrace a československá zahraniční politika.” In Západoevropská integrace. Sborník př́spěvků přednesených na poradě o západoevropské integraci 18. a 19. prosince 1962, edited by Ústav pro mezinárodní politiku a ekonomii, 7-19. Praha: Nakladatelství politické literatury, 1963.

Landa, Vladimír. Západoeurópska integrácia a EHS. Dôsledky integračných procesov na priemysel krajín EHS. Bratislava: Vydavatel'stvo politickej literatúry, 1963.

Lüthi, Lorenz M. "Drifting apart: Soviet energy and the cohesion of the communist bloc in the 1970s and 1980s." In Cold War energy, edited by Jeronim Perovic, 371-99. Cham: Springer International, Imprint: Palgrave Macmillan, 2017.

Maňák, Jiří. Čistky v Komunistické straně Československa v letech 1969-1970. Praha: Ústav soudobých dějin, 1997.

Maresceau, Marc, ed. The political and legal framework of trade relations netween the European Community and Eastern Europe. Dordrecht: Martinus, 1987.

Ouimet, Matthew J. The rise and fall of the Brezhnev Doctrine in Soviet foreign policy. London: UNC Press, 2003.

Pavlát, Vladislav. "Vývoj marxistického hodnocení integračních procesů.” In Západoevropská integrace. Sborník př́spěvků prednesených na poradě o západoevropské integraci 


\section{Pavel Szobi}

18. a 19. prosince 1962, edited by Ústav pro mezinárodní politiku a ekonomii, 32-48. Praha: Nakladatelství politické literatury, 1963.

Pavlát, Vladislav. EHS. Dnešek a budoucnost. Praha: Svoboda, 1967.

Petřivalský, Jiří. Úvěrová a měnová politika. Praha: SNTL, 1973.

Průcha, Václav. Hospodářrské a sociální dějiny Československa 1918-1992, vol. 2: 19451992. Brno: Doplněk, 2009.

Půlpán, Karel. Měnové plánování v reálném socialism. Praha: Working Papers UK FSVIES, 2004.

Romano, Angela. "Untying Cold War knots: the EEC and Eastern Europe in the long 1970s." Cold War History 14:2 (2014): 153-73.

Sieber, Karel. “Angola 'zemí přednostního zájmu' (1975-1982).” In Dějiny Angoly, edited by Jan Klíma, 289-93. Praha: NLN, 2008.

Slouka, Tomáš, ed. Poučení z krizového vývoje ve straně a společnosti po 13. sjezdu KSČ. Praha: SPN, 1982.

Štefániková, Anónia. "Ekonomicé aspekty normalizácie (1969-1989).” In Slovensko a režim normalizácie, edited by Norbert Kmet' and Juraj Marušiak, 184-200. Prešov: Vydavatel'stvo Michala Vaška, 2003.

Steiner, André. "The decline of Soviet-type economies." In The Cambridge history of communism, vol. 3, Endgames? Late communism in global perspective, 1968 to the present, edited by Juliane Fürst, Silvio Pons and Mark Selden, 178-202. Cambridge: Cambridge University Press, 2017.

Šulc, Zdislav. Stručné dějiny ekonomických reforem v Československu (České republice) 1945-1995. Brno: Doplněk, 1998.

Svoboda, Karel. "Vliv vnějších podmínek na zahraniční obchod Československa v letech 1971-1980.” Slovanský přehled 99 (2013): 323-38.

Vědecké kolegium eknomie ČSAV. "K vývoji ekonomické teorie v šedesátých letech v Československu (revizionismus v ekonomické teorii v ČSSR).” Politická ekonomie 20 (1972): 799-838.

Vencovský, František. Vzestupy a propady československé koruny. Praha: Oeconomica, 2003.

Vilímek, Tomáš. "Mladoboleslavská Škodovka v období normalizace." In Česká společnost v 70. a 80. letech, edited by Oldřich Tůma and Tomáš Vílímek, 66-275. Praha, Ústav soudobých dějin, 2012.

Zemanová, Rudolfina. Vytváření jednotného vnitřního trhu EHS, popojováni EHS a ESVO a možné vlivy na vnějši ekonomické vztahy ČSSR. Praha: Výzkumný ústav vnějších ekonomických vztahů, 1988. 


\title{
7 Balancing Between Socialist Internationalism and Economic Internationalisation
}

\author{
Bulgaria's economic contacts \\ with the EEC
}

Elitza Stanoeva

During his first visit to Bonn in 1975, Todor Zhivkov, Bulgaria's party leader and head of state for nearly two decades, met an assembly of West German entrepreneurs, and not just any, but the top management of powerful concerns such as Krupp and Daimler-Benz - 'the monopolies and firms which control $50 \%$ of the economic potential of the country', as argued in the lauding report on the visit afterwards submitted to the politburo of the Bulgarian Communist Party (Balgarska komunisticheska partiya [BKP]). ${ }^{1}$ Five pages later, the same report highlighted Zhivkov's witty retort to an SPD politician: 'Regardless of whether the elections are won by the social democrats or the Christian democrats, Beitz, the boss of Krupp, who represents capitalism in Germany, will remain in place'. ${ }^{2}$ The irony of criticising West German politicians for being in cahoots with the corporate world while trying to strike a deal with the very same corporations passed unnoticed. After all, Zhivkov went to Bonn to do business, namely to give a boost to the strained Bulgarian economy by securing a long-term loan from the West German government. In this mission, which ultimately failed, he did not shy away from reaching out to the corporate milieu with promises of high profits in the Bulgarian market. Neither did he shy away from depicting his native socialist economy as one overpowered by 'trade unions, party organisations and the like whom even we cannot cope with' - in order to divert West German requests for direct investment options. ${ }^{3}$

Rather than being an anecdote on political duplicity, Zhivkov's conflicting statements, admittedly aimed at different audiences, illustrate the duality in Bulgaria's policy of doing business with the West as a balancing act between socialist internationalism and economic internationalisation. This was particularly the case with regard to Bulgaria's interactions with the European Economic Community (EEC), where separating political and economic issues became increasingly difficult in the 1970s. And while a political compromise would have been a step too far, the economic benefits were indispensable. From the 1960s onwards, purchases from EEC members provided technology and manufactured inputs that were essential for the modernisation of Bulgarian industry. The party perceived this as a prerequisite for participation in the international division of labour, 
which would be evidence of the growing international prestige of socialist Bulgaria. As the country was devoid of raw materials that could generate demand in world markets, it was in dire need of state-of-the-art factory production that could be competitive in international trade. Although Bulgarian industry repeatedly failed to optimise the benefits of costly technological transfers, it grew ever more dependent on Western imports and craftier in requesting their delivery from the state leadership.

To expand exports was therefore a primary aim of all purchases from the capitalist economies, while improving domestic consumption was relegated to domestic manufacturers. Unlike Poland, Bulgaria, which was still running a predominantly agricultural economy, never experienced food shortages and price spikes of foodstuff, so direct imports for domestic consumption never became urgent. ${ }^{4}$ As in the rest of the bloc, the Bulgarian regime attached priority to consumption from the 1960s onwards but improving it was pursued through domestic economic reforms aimed at raising quality and increasing variety. ${ }^{5}$ Therefore, the share of imported consumer goods remained negligible up until 1989. In 1956, 'means of production' accounted for $93 \%$ of Bulgaria's imports (against $7 \%$ for consumer goods) and they never dropped below $86 \%$ in the decades to come. ${ }^{6}$ Moreover, imported consumer goods were sold mainly through hard-currency shops, Corecom, and the international tourism system so they were not bound to the social policy of raising standards of living for the population at large but to the needs of Bulgarian foreign trade. ${ }^{7}$

In the literature on the Eastern bloc, the People's Republic of Bulgaria (Narodna republika Balgariya [NRB]) is usually portrayed as the most loyal follower of the Soviet line (or even as a 'Soviet locum tenens'), ${ }^{8}$ an orthodox satellite that in the Cold War gave up any autonomous pursuits on the international stage. In the perspective of its foreign economic pursuits, what is more remarkable about Bulgaria's standing within the bloc, however, is its internalised perception of having secondary importance in the eyes of the West. This frustrated self-image as a provincialised periphery no doubt had deeper historical roots than state socialism. But in the post-war period, Bulgaria's new geopolitical position in the Soviet sphere of influence put it at a more pronounced disadvantage vis-à-vis the Central European states than previously within its region. This gave new urgency to its catching-up endeavour on the European stage.

While arguably all the socialist regimes were in one way or another torn between fraternal solidarity and mutual competition in their opening up to the West, for Bulgaria this rivalry, from a position of recognised weakness, was a determining dimension in its foreign policy. And Bulgaria's competitive weakness prompted the regime to cover all bases: on the one hand it provided incentives for expanding and diversifying bilateral partnerships with the West and on the other hand for maintaining tight bonds with the Soviet Union. Regarding the latter, Bulgaria could always rely on economic benefits in exchange for political loyalty. While these benefits seemingly came for free, they further hampered Bulgaria's outreach to the West.

Exacerbating its competitive disadvantage was the fact that unlike the rest of the bloc, Bulgaria had very few traditional partnerships with Western Europe that 
it could easily reactivate once opening up was possible after de-Stalinisation. With a low level of industrialisation and agricultural mechanisation and scarce natural resources, its feeble economy was doomed to fare worse than the others in the Eastern bloc. Ultimately, it lacked both geopolitical importance and substantial economic resources to increase its attractiveness to potential Western partners. But its fledgling economy matched the needs of Soviet commerce better than others and so added economic rationale to Bulgaria's heavy dependency on the Soviet Union. Being the most export-oriented country in the bloc (relative to its GDP), Bulgaria was also the one bloc member that relied the most on the Council for Mutual Economic Assistance (CMEA) market, and primarily on the Soviet Union. ${ }^{9}$ Economic transfers with the latter notwithstanding, Bulgarian industry gradually developed a strong dependency on high-tech inputs from capitalist countries. In this regard, trade with the EEC was vital, despite sporadic attempts to reduce costly imports from its members in order to keep the balance of payments in check. Throughout the period, Bulgaria suffered from endemic trade deficits in the free market, and although it strove to offset this by prioritising sales of machinery and other heavy industry outputs, its agricultural production dominated the composition of its exports. Ultimately, this led the regime into a debt spiral due to its constant demand for credits from foreign banks and firms. ${ }^{10}$

Against this backdrop, from the early 1960s onwards opening up to the West was an imperative for the Bulgarian regime that at no point diminished regardless of Cold War geopolitics. Naturally, the socialist establishment did not use the phrase "opening up to the West" to describe its policy of cooperation with capitalist countries. While this was certainly a catchphrase in the writings of Western commentators at the time, the socialist rhetoric depicted the process in terms of peaceful coexistence. Both phrases were politically charged and with normative connotations: while the former conveyed the West's self-understanding as the centre of gravity in the process, the latter expressed the socialist camp's selfconfidence in leading initiatives securing world peace. This interpretative split goes a long way to explaining why the Bulgarian establishment had neither ideological problems in pursuing a course of "opening up" nor serious discords with Moscow over the scope of its openness (as Romania did). ${ }^{11}$ Any milestone in that regard served the regime's self-legitimation as proof of the country's growing international prestige. Domestic propaganda along these lines was framed by the party dogma that the Cold War was the sole responsibility of the West due to its antagonism towards the socialist bloc over its being at the forefront in the struggle for world peace.

In tackling Bulgaria's opening up to the West in the "long 1970s", this chapter breaks away from several fundamental assumptions pervading much of the post1989 national historiography of the socialist era where the totalitarian paradigm still occupies central place. First and foremost, it contests the notion of a partystate monolith which takes for granted that the party top made all the important decisions and the state institutions had a passive role in their execution with no policy initiative. The role of a few individuals (mainly Zhivkov) is often exaggerated along with their capacity for comprehensive oversight. The same applies 


\section{2}

to Zhivkov's closest circle, the politburo, which de facto constituted the party apex. Nevertheless, its concentration of powers did not necessarily translate into decision-making initiatives: much of the policymaking discussed in this chapter was done in the state ministries despite it requiring formal authorisation by the politburo. With nine to twelve members throughout the period, the party top brass could have only partial oversight and, moreover, it had limited economic competence for more active involvement in steering the foreign-economic course of the country. Therefore, this chapter shifts the focus from the actors who held power to those who forged policies - concerning general strategies, long-term plans, priorities in foreign policy and economic cooperation. And its point of departure is to decouple the party-state entity and approach the different institutional levels as having their own logics, stakes and interests - in other words, institutional rationality.

\section{First steps in opening up to the West in the 1960s: main trends and actors}

Initial contacts with Western European countries in the 1960s, including with EEC members, evolved at the economic level and were administered in a rather horizontal fashion without much top-down interference from the party leadership. The Bulgarian economic services, particularly foreign-trade envoys stationed abroad, were to a great extent emissaries of the post-Stalinist doctrine of peaceful coexistence. Moreover, the trade envoys were still the only actors in direct contact with foreign partners and with first-hand knowledge of both the efficiency and systemic setbacks in economic cooperation in the concrete conditions in each EEC country. However, they were also people who were excluded from policymaking and lacked inside knowledge of broader policy deliberations. These deliberations took place at the top levels of the economic ministries, which at times coordinated their policies in a cross-sectoral manner but often pursued incompatible agendas: for example by securing high-tech imports (industrial ministries), by maintaining the trade balance by reducing costly imports and securing commercial credits from foreign banks (the Ministry of Foreign Trade [MFT]) and by preserving financial discipline and avoiding indebtedness (the Ministry of Finance, the Bulgarian National Bank). ${ }^{12}$

In many Western countries, the trade envoys forged contacts ahead of diplomats, and foreign trade missions were often set up prior to (and independently of) embassies. This was the case in the Federal Republic of Germany (FRG), Bulgaria's largest economic partner in the West, as long as the Warsaw Pact refused diplomatic normalisation..$^{13}$ But it was also the case in Denmark, for example, where Bulgaria simply lacked any solid relations from previous times and its trade representatives enjoyed easier entry than party functionaries. ${ }^{14}$ Trade thus became instrumental in opening channels for intergovernmental contacts with Western states.

The significance of foreign trade in the Bulgarian planned economy, on the other hand, had been on the rise ever since the late 1950s. The early phase of 
reviving commercial contacts with the West also witnessed an escalation of the trade deficit into the first debt crisis in the Bulgarian socialist economy, the peak of which was between 1959 and $1963 .{ }^{15}$ The ensuing financial shock was overcome thanks to 'palliative emergency support by the Soviet Union' - what Roumen Avramov describes as a conventional tool for solving any runaway hard-currency debt in the decades to come until Gorbachev shut down this emergency exit. ${ }^{16}$ Given its easy solution, this crisis did nothing to shake the Bulgarian resolve to expand commercial links with the West. Moreover, national economic reforms, which were undertaken between 1963 and 1968 under the New Economic System heading, were from the onset dependent on both increases in costly imports of production equipment, inputs and know-how from technologically advanced Western economies and increases in high-value exports to Western markets that could replenish the hard-currency reserves of the country.

The 1960s were a particularly dynamic period in Bulgaria's interactions with the West as various forms of economic cooperation were tested, centralised control over the economic envoys was still rudimentary and the bureaucratic ground rules were subject to negotiation. Ministries and other government branches founded special sections dedicated to economic relations with capitalist countries, and the Bulgarian Foreign Trade Bank was established. The most controversial organisations for fostering economic cooperation with the West were the so-called trans-border firms, which mushroomed from 1960 onwards. These were private companies set up with Bulgarian capital abroad to circumvent embargoes or other trade barriers (and sometimes to facilitate illicit arms trading). ${ }^{17}$ They were loosely affiliated to the MFT and often went rogue by withholding profits, falsifying their accounts or engaging in unauthorised economic activities. Despite regular audits and closures, the number of trans-border firms multiplied to over 450 by 1989 , with the highest number being based in the FRG. ${ }^{18}$ Another instrument for circumventing trade barriers was mixed firms, joint ventures with foreign and Bulgarian capital, similar to the trans-border firms except that they operated in open cooperation instead of hiding Bulgarian involvement. The legal provisions for establishing such companies were passed in the mid-1960s and were continually amended to make them more accommodating to the foreign partners.

Since in the 1960s foreign policy towards Western Europe was to a great extent implemented by economic agencies, Bulgaria's opening up to the West evolved first and foremost as economic cooperation. The first bilateral treaties with EEC countries consisted of trade protocols and agreements together with other documents ascertaining the mutual will for economic cooperation. Cultural exchanges, conversely, were an area where the regime would take a conservative turn when some retreat from openness to the West was expedient, be it as a show of loyalty to the Soviet line or in response to domestic concerns over Western influences. ${ }^{19}$ However, in the mindset of the party leadership, increasing the number of economic deals retained high priority, as it did at the managerial level where this imperative was additionally conditioned by an institutional path dependency: for the operatives in the foreign service, expanding partnerships with Western entities meant increasing their organisation's weight within the sectoral administration, 
successfully meeting their annual targets and ultimately protecting their personal positions. Such micro-institutional stakes enhanced the bottom-up commitment to opening up to the West. ${ }^{20}$

Another pillar in the Bulgarian strategy of economic cooperation with the West was international tourism, which was responsible for most of Bulgaria's invisible earnings from the mid-1960s onwards. In the tourism business, Bulgaria enjoyed competitive advantages over the other CMEA members that it lacked in trade due to its geographical and climatic conditions. The "sun-and-sea" became the trademark of its tourism as the first resorts for foreigners were built on the Black Sea in the late 1950s. Providing much-needed hard currency, the development of international tourism was from the onset closely linked to the foreign-trade strategy towards the West. ${ }^{21}$ The authorities in charge of the sector presented its fundamental economic service as being 'export in situ', a form of trade that not only complemented the conventional exchange of goods but substantially ameliorated the country's balance of payments. ${ }^{22}$

Another path for Bulgaria's economic outreach to the West, which was embarked upon in the 1960s and followed throughout the 1970s, was multilateral cooperation within the frameworks of international organisations. ${ }^{23}$ All the state institutions were encouraged to participate in as many such fora as they were eligible to. ${ }^{24}$ However, to advance its commercial interests and particularly to negotiate better terms of trade with its capitalist partners in the EEC, Bulgaria set its hopes mainly on the United Nations Conference on Trade and Development (UNCTAD) and the General Agreement on Tariffs and Trade (GATT). While it was an enthusiastic member of the UNCTAD ever since its establishment in 1964, Bulgaria initially had a more ambivalent attitude towards the GATT because of its profile as an organisation of rich countries imbued with the economic logic of capitalism and thus not entirely accommodating the specificities of a socialist state with central economic planning and a state monopoly over trade.

Bulgaria's approach to international organisations was elaborated under the auspices of the economic branches of the state apparatus, and only key decisions such as membership applications were forwarded to the politburo for approval. The Ministry of Foreign Affairs (MFA) oversaw the relevant activities of all national and local institutions on a day-to-day basis through its International Organisations Section. ${ }^{25}$ A similar unit was also set up at the MFT to manage ministerial affiliation to international trade organisations. Further up the chain of command, the Commission for Economic and Scientific-Technical Cooperation (CESTC) at the Council of Ministers (CM) was the body which reviewed and eventually authorised any policy proposals in this field.

In December 1966, the CESTC approved probing contacts with the GATT and a year later Bulgaria acquired observer status and started considering full membership. ${ }^{26}$ To this end, a special Inter-institutional Section on Issues of Capitalist Integration and the GATT (ISICI) was set up, which was modelled on a similar body focused on the UNCTAD. ${ }^{27}$ The ISICI dispatched an envoy to Bulgaria's Permanent Representation in Geneva and soon afterwards an entire Trade Section was formed there to monitor the GATT's activities. ${ }^{28}$ 


\section{First concerns about the EEC}

In the 1960s, the overall pragmatic agenda of economic cooperation with the West was rarely coloured by ideological issues and was shielded as much as possible from the demagoguery of Cold War politics. Bulgaria was quite active in fostering economic relations with all the EEC members on a bilateral basis. By 1968, the FRG, Italy and France together accounted for almost half of Bulgaria's exports to capitalist countries and for more than half of its imports from such countries. Bulgaria's exchanges with the Common Market might have been at nowhere near the level of its commerce within the CMEA, yet the bloc countries' share of total turnover was steadily decreasing: from $82 \%$ in 1956 and $81 \%$ in 1960 down to $74 \%$ by $1970 .{ }^{29}$ While the EEC market area held the lion's share of Bulgaria's commercial exchanges outside its geopolitical bloc, it was also responsible for the bulk of its trade deficit. Bulgaria did not maintain a positive trade balance with a single member state. ${ }^{30}$ All the government's attempts at tackling this problem were concentrated in bilateral negotiations. The EEC as such was a matter of interest for trade envoys stationed in the member states and academics specialising in capitalist economic groupings at home but not yet an issue in the policymaking arena.

The EEC entered the party top's political agenda for the first time at the beginning of 1968, although the deliberation did not concern the EEC as a supranational organisation but its member states as a distinct group of countries. At this point, the politburo endorsed a rather concise document titled 'Considerations for the Directions of NRB's Foreign-Economic Relations with the Countries in the EEC (Common Market)', which set the baseline for the regime's approach to the EEC for years to come. Although it emphasised the need to expand economic ties with its members for purchases of machines, licenses and synthetic materials, the blueprint was motivated by Bulgaria's growing deficit with the Common Market due to existing agricultural protectionism and also by further anticipated discrimination. Amid this mix of incentives and challenges, the document called for coordinated actions with the other socialist countries and bilateral negotiations with individual EEC members. ${ }^{31}$ The details of how to carry through these two approaches, however, were left entirely in the hands of the relevant state institutions, mainly the MFA and the MFT. The general aim, as defined by the politburo, was simply to 'take advantage of political and economic disagreements among the EEC members'. ${ }^{32}$ A cornerstone of the general strategy was a differential approach to individual countries, which would remain a keyword in all further policy papers concerning the EEC.

With this resolution, the politburo also gave the green light to attempting technical contacts with the EEC bodies and full membership of the GATT, again delegating decisions on timing and procedure to the state administration. A final item in the resolution, which was deemed a technical issue of secondary importance but in the next years would prove quite intricate, concerned amending the Bulgarian customs system. The introduction of multiple import tariffs was specifically for the purpose of bargaining with the EEC countries: to counter discrimination with discrimination and lay the ground for positive reciprocity. 
To this brief blueprint was appended a much lengthier memorandum by politburo member Tano Tsolov, who was Bulgaria's permanent representative at the CMEA and head of the CESTC until the mid-1970s. The latter post effectively made him the person overseeing not only all cooperation activities with Western countries but also all advances towards Western economic organisations, including the EEC. In this capacity he maintained party oversight of state policies while the politburo focused on other issues. Explaining the nature of the EEC, Tsolov's memorandum underlined the growing share of this group of countries in Bulgarian trade (a fourfold increase between 1961 and 1966 compared to a twofold increase in the total volume), also pointing out that the value of imports was twice that of exports. Given Bulgaria's import dependency on the EEC for complex machinery and manufactured production inputs, Tsolov recommended improving the national export capacity rather than reducing purchases. ${ }^{33}$

Discussing EEC protectionism, the document emphasised its differentiated application to third countries with a strong bias against the socialist states. Despite reiterating the cliché of 'inevitable disagreements between EEC members', Tsolov warned that clashes of interests among them would not impede further economic integration in the long run. Therefore, he argued for a 'realistic policy' towards the EEC that would factor in future enlargement and a deepening of integration. ${ }^{34}$ Arguing that Bulgaria was the worst affected socialist country, Tsolov highlighted the high share of agricultural goods in the composition of Bulgarian exports: 53\% compared to $41 \%-43 \%$ for Hungary, Poland and Romania and only $13 \%$ for Czechoslovakia. In light of this, the 'realistic policy' he proposed underscored a need not only for technical contacts with the EEC but also for the CMEA's position to be revised in the near future and for official contacts to be established. ${ }^{35}$

By 1968, cooperation with the West had become a firm dimension in Bulgarian economic planning. The invasion of Czechoslovakia, however, disrupted established contacts and economic cooperation hit an abrupt low after a previous peak in 1966-67. Many partnerships were hurt by the diplomatic repercussions of the Bulgarian military participation in the invasion. Other commercial exchanges, however, were reduced under the pressure of pragmatic concerns over the trade deficit among the Bulgarian economic authorities. Indeed, in the next three years (1969-72) they succeeded in improving the balance of payments, ending each fiscal year with a trade surplus. ${ }^{36}$ Simultaneously, at home the party leadership was wary of losing control over its economic reforms, which had often been depicted by outside observers as having 'great affinities with the Czechoslovak model', and so tightened its reins over the economic sectors. ${ }^{37}$ This led to serious reshuffles in many economic institutions and a re-composition of the cabinet. ${ }^{38}$ Within the Bulgarian leadership, the Prague Spring stirred internal rather than external political concerns - a fear of the growing influence and institutional autonomy of the managerial elite. Foreign trade experienced the harshest backlash because of unchecked activities in the West. For Bulgaria, therefore, the party's dilemma regarding opening up to the West was not between exposure and retreat but between technocratic efficiency and centralised oversight. 


\section{In the aftermath of the 1968 crisis: new strategies with old guidelines}

With the hard-line shift, reinforcing centralised control cut across all levels of management of the foreign-trade sector. The prerogatives of the foreign-trade operatives, which previously had been continually broadened, were now narrowed down to their main activities. In addition, the post-1968 overhaul involved purges of middle-level managers and top-level technocrats, although they were nowhere as severe or sweeping as in Czechoslovakia. ${ }^{39}$ Five directors of foreigntrade organisations were indicted for selling commercial secrets to West Germany along with three department heads in the ministry. ${ }^{40}$ Even more impactful was a trial of the entire managerial board of the largest trans-border company, Texim, which by 1968 had grown into a true corporate empire in control, among other things, of the entire Bulgarian merchant fleet. ${ }^{41}$ This was the first massively publicised corruption trial in socialist Bulgaria, and one that hit the socialist regime's most ever successful business venture. Finally, at the very top of the MFT, two consecutive ministers were reassigned and thus demoted: Ivan Budinov in December 1968 and his successor Luchezar Avramov in April 1971, both of whom were particularly active in expanding cooperation with capitalist countries.

Just like all the moves to enhance centralisation, the repressive wave was neither a signal to cut off economic ties with the West nor a trigger for any substantial modification of the general course vis-à-vis the EEC. On the contrary, the blueprint for Bulgaria's foreign policy, which had been rubber-stamped by the politburo in May 1969, determined economic relations to be the fundamental objective of all diplomatic missions worldwide. It urged better coordination between the MFA and the economic ministries and between the embassies and the trade representations in order to improve economic performance abroad. Within the EEC area, this meant reducing the alarming trade deficit, especially vis-à-vis the FRG, and mitigating the impact of discriminatory policies. ${ }^{42} \mathrm{~A}$ lengthy statement of the motivation for the politburo's resolution further highlighted MFA's foreign-economic functions with an underlying definition of national interests on the international stage in economic terms: "[the MFA sections] should not only deal with "pure" politics . . but at the centre of their attention should stand, in a more determined way and in closer coordination with political matters, foreigneconomic, commercial and scientific-technological questions' ${ }^{43}$ In economic planning, in turn, industrial production was to be subordinated to the goal of foreign trade being required to "take into consideration the demands of international markets when organising production activity'. ${ }^{44}$

Following this greater prioritisation of commerce in Bulgaria's foreign affairs, the network of trade missions continued to expand ahead of the diplomatic corps. By 1972, Bulgaria had trade representations in eighty-two countries. Unsurprisingly, the largest was that in the Soviet Union with seventy-two operatives, but it was followed in size by that in the FRG, which employed thirty-one people, thus overshadowing the missions in the largest CMEA economies (the GDR, Poland and Czechoslovakia). Next in line came those in Italy and France, Bulgaria's other 
two main partners in the EEC, which exceeded the size of the Bulgarian missions in Hungary and Romania. ${ }^{45}$

At the same time that the economic aspects of foreign policy assumed centrality, the particulars of the economic policy towards the West were spared any profound revision. In the mind of the central bureaucracy, enhancing financial discipline was a typical remedy for the growing trade deficit, yet it was one that worked out on paper, in the annual plan, but quickly fell apart in the process of implementation. Keeping a lid on the trade deficit with any Western country was nearly impossible for the trade envoys who negotiated the sales and purchases on the ground. Along with a constant under-fulfilment of export contracts by producers and suppliers, manufacturers often sent urgent requests for imports beyond the set limits, with the argument that 'the factory is brought to a standstill' ${ }^{46}$ Producers' hunger for Western technology and their continual reluctance to adopt higher standards in export-bound production was a bad match that undermined Bulgaria's competitiveness in international markets.

Another typical measure imbued with wishful thinking that was hardly new was to decrease the predominance of agricultural exports in favour of machinery and industrial goods by binding imports of factory machinery and production facilities to compensatory exports of finished produce. In 1969, machinery in the structure of Bulgarian exports to capitalist countries accounted for as little as $1.8 \% .{ }^{47}$ While the MFT's blueprint forecast that by 1975 it would rise to $25.5 \%$, from the viewpoint of the trade officials abroad this was simply impossible considering the many returns of defunct items. Most of the increases in machinery exports highlighted in annual reports hinged on one-off deals, and many such deals were short-lived, often falling apart because of negligence on the part of the producer. ${ }^{48}$ Because of their unpredictability, such failures caused by structural problems in the planned economy were a greater problem for the foreign trade representatives in the West than trade discrimination. ${ }^{49}$

With regard to the EEC, two consecutive general strategies in the foreigntrade sector, which were authored under the guidance of two freshly appointed ministers, simply reiterated previous guidelines. The one by Lachezar Avramov in 1969 did not require any reduction in hard-currency imports, which by then were in permanent demand in all industrial areas. Instead, it stipulated the usual adjustment in export structure (a shift from agriculture to machinery) alongside a modification of the geographical distribution of imports - a shift from the EEC to the European Free Trade Association (EFTA), which was currently estimated to represent $32 \%$ of Bulgaria's trade volume with capitalist countries, compared with $55 \%$ for the EEC..$^{50}$ All these changes were relative given the backdrop of an absolute increase across the board. Moreover, the importance of the EEC countries to Bulgaria's commerce was reconfirmed. At the same time, internal reforms which were aimed at improving Bulgaria's trade position in the Common Market, like the new customs system, were assessed less optimistically than before. While reiterating the need for technical contacts with the EEC and full membership of the GATT, the document admitted that Bulgaria could not have much sway alone 'so we should make efforts to secure efficient coordinated counter-measures by the CMEA member states, both in the sphere of production and mutual trade and in their commercial policy and activity towards the EEC countries'. ${ }^{51}$ 
Little changed in the blueprint compiled after Avramov's removal in 1971, although the MFT's new leadership claimed that it had been reworked in light of the CMEA's Comprehensive Integration Programme of $1971 .^{52}$ The policy line towards the EEC was narrowed down to coordinated actions by CMEA members, yet actions defined broadly enough to not delegate the initiative exclusively to the CMEA bodies. Refusal of official recognition of the EEC was explicitly added, but its uncompromising resolve was undermined one paragraph later with the condition that 'if later the right situation emerges for establishing official contacts with the EEC, then the best path will be negotiation led by the CMEA in order to obtain better results' ${ }^{53}$ Technical contacts, however, remained a national prerogative, not a matter of collective endeavour.

Indeed, the earlier decisions about launching contacts with Western organisations, specifically the EEC and the GATT, had gone into implementation already in 1969. At this point, the CESTC mandated the MFT to approach the EEC Commission for technical contacts. ${ }^{54}$ The first talks in October 1969 were considered exploratory and were followed by a second phase of negotiations a year later when the two parties signed agreements concerning crucial Bulgarian export items such as pork, sheep, cheese and wine. The EEC exempted these products from any additional customs duties while the Bulgarian government committed to complying with certain standards, including anti-dumping rules. The Bulgarian delegation also expressed interest in continuing negotiations and expanding these arrangements towards other agricultural goods. ${ }^{55}$ Simultaneously, in September 1969 the CESTC decided to start negotiations for membership of the GATT and authorised preliminary unofficial contacts with its secretariat and bilateral consultations with the main members. ${ }^{56}$

All these diplomatic advances built on the 1968 politburo resolution on relations with the EEC and were conducted with ministerial discretion. Few subsequent Western-oriented policies implemented by the MFA and the MFT were scrutinised by the party organs. Instead, they were reported to the CESTC chairman, Tano Tsolov, who by way of his position in the politburo guaranteed their compliance with the party line. It was not the economic approach to the West but the positions of the Bulgarian delegations at CMEA sessions that invariably required politburo sanctions, even if they were just formal endorsements - still more items that passed through Tsolov. Whereas in internal policy deliberations he was quite vocal about the national interest in stabilising relations with the EEC, within the CMEA forum he maintained a more restrained stance and took his cues from Soviet statements. Moreover, in the CMEA context he gave more weight to the political aspects of potential approaches to the EEC, while in debates at home he discussed the EEC mainly in economic terms.

Reporting to the politburo on CMEA deliberations regarding its Comprehensive Integration Programme in 1972, Tsolov once again discussed establishing official contacts with the EEC, yet this time he refrained from voicing his support and instead made reference to the favourable Hungarian and Romanian positions. While Bulgaria certainly shared the Romanian concerns over EEC barriers against agricultural exports, Tsolov's report stressed the political repercussions, namely granting recognition of the EEC's supranational authority, and criticised 
the Romanians for underestimating them. This understanding then shaped the official Bulgarian position: the political aspect outweighed the economic benefits, so the question of official relations with the EEC should not be rushed. ${ }^{57}$ Such declarations paid lip service to the Soviet position and contradicted the pragmatic position at home. As an example of this, at a ministerial meeting with the trade representatives in capitalist countries two months later, Boris Velchev, a member of the politburo and Zhivkov's right-hand man at the time, described the link between the political and economic aspects of cooperation with the West in the opposite way: 'Our trade and mutual ties with the developed capitalist countries also have a political side. The capitalist countries are in Europe. [Therefore] we should pursue politics of détente in Europe'. ${ }^{58}$

Even though the EEC was becoming an issue of growing concern, there was no discernible spike in the propaganda against it in the post-1968 period. Reports on EEC summits invariably mentioned 'sharp contradictions among the members', which were evident to the socialist commentator. While news reports remained truthful about events, their narratives gave more weight to confrontational aspects and added a touch of scepticism about any resolution of outstanding issues as a matter of unstable and transient compromise. When delving into such internal disagreements, correspondents highlighted member states' positions that were in synchrony with the grievances of the socialist bloc, for example France's desire for a Western European union outside of American tutelage or West German opposition to agrarian protectionism. ${ }^{59}$

In short, post-1968 policy changes regarding Bulgarian interactions with the West took place internally, through enhanced centralised control inside the state institutions in charge of these interactions. In contrast, the external aspects concerning the scope of permitted contacts and the breadth of cooperation remained the same. While economic relations with the West were streamlined under the supervision of the CESTC, the MFT and the MFA, and the party abstained from direct intervention, on the international stage its top brass took a more visible, though largely ceremonial, role. Bulgaria's new constitution, adopted in 1971 and nicknamed 'Zhivkov's Constitution', was a means of international (self-)promotion of the general secretary. It introduced a new supreme body, the State Council, the leadership of which was reserved for Zhivkov, thereby bestowing on him a status in state affairs equivalent to president, instead of his previous title of prime minister. ${ }^{60}$ The new post granted him entry into the diplomatic arena outside the socialist camp. In economic matters, however, any advances would still be in the competence of the state apparatus, although Zhivkov did not abstain from pursuing economic objectives during his state visits abroad.

\section{In pursuit of preferential conditions: Bulgaria's participation in international economic fora}

In the early $1970 \mathrm{~s}$, the state administration took several steps to improve the terms of trade with the EEC. Although they were pursued in various fora, these efforts were all aimed at securing preferential treatment for Bulgarian exports under the 
provisions of international trade organisations. As the Bulgarian authorities soon realised, a key bargaining tool was the customs system approved in 1968 as a punitive measure in response to the Common Market trade discrimination that Bulgarian exports encountered. It had been rushed into implementation for political reasons without being given much thought economically. ${ }^{61}$ While initially the Bulgarian leadership had hoped that the threat of higher duties for entry into its import-hungry market might motivate Western countries to ease their own restrictions against Bulgarian products, it now discovered the usefulness of a tariff system as a legal instrument. It gave Bulgarian foreign trade a semblance of market rationality and thus qualified the country to apply for various preference schemes that were averse to the planned economies.$^{62}$ However, the Bulgarian government seemed at a loss as to the details of the new customs system and its differential tariffs. It tried to resolve these issues through consultations with the other two CMEA members that applied tariffs, Czechoslovakia and Hungary, and ultimately by mechanically emulating their approach. ${ }^{63}$

In the pursuit of better terms for East-West trade, the UNCTAD aspired to be a friendlier multilateral forum for the socialist bloc than the GATT. In the early 1970s, Bulgaria's activity within the UNCTAD was additionally motivated by the organisation's Generalized Scheme of Preferences (GSP), which was designed to aid developing countries. Following the example of Romania, which claimed developing country status, Bulgaria adopted a similar approach but one different enough to not be at odds with the socialist bloc's dogma of the superiority of its socio-economic system. In particular, Bulgaria claimed an intermediate position on the scale of economic development. This was a relational argument: claiming to have reached a more advanced stage than the developing countries, an accomplishment thanks solely to socialist economic overhaul, yet admitting that it was just as far behind the developed capitalist economies as it was ahead of the "third world" as a result of historical reasons and external challenges. ${ }^{64}$

Within the UNCTAD, the Bulgarian regime committed to granting developing countries preferential access to its national market but made this conditional, although with the necessary diplomatic subtlety, on being itself considered for inclusion in the systems of preferences adopted by the developed countries. The Bulgarian delegates at the UNCTAD presented this conditionality as a positive thing - evidence that they were attempting to become not only recipients (like Romania) but also providers of preferences. ${ }^{65}$ To this end, the newly inaugurated customs tariffs were instrumentalised as an 'important economic weapon'. The tariff system also served to advance additional demands for preferential treatment on a reciprocal basis, with regard to both the EEC members and the countries in the global South. ${ }^{66}$

In the early 1970s, when Bulgaria was still recovering from the economic cooloff in the aftermath of the events in Czechoslovakia and facing the new challenge of deepening Western European integration, its bid for better terms of trade within the UNCTAD became a priority on the agenda of the MFT. For this purpose, Minister Lachezar Avramov invited Manuel Pérez-Guerrero, secretary-general of the UNCTAD, to visit Bulgaria in July $1970 .{ }^{67}$ During his stay, Pérez-Guerrero 
held meetings not only with Avramov but also with Foreign Minister Ivan Bashev and the chairman of the Committee for Economic Coordination, which were complemented with broader discussions with state experts, academics and journalists. In all the talks, the statements of the Bulgarian representatives were closely synchronised, aiming on the one hand to achieve better terms of trade with the organisation's Western members and on the other hand to strengthen Bulgaria's participation in the international division of labour by taking a more prominent role in the UNCTAD. ${ }^{68}$

In light of the upcoming EEC Common Commercial Policy (CCP), Bulgaria put more hope on its request for preferential treatment under the UNCTAD provisions than on its demand for most favoured nation (MFN) treatment, the instrument for liberalising trade backed by the GATT. While in the previous years, requests for MFN status were a standard item on the Bulgarian agenda in any bilateral trade negotiation with Western countries, now the MFT concentrated its efforts on obtaining tariff preferences. ${ }^{69}$ The MFA also became mobilised in this endeavour once the EEC Council of Ministers embraced the UNCTAD's GSP in March 1971. The MFA assigned its economic advisors the task of approaching the ambassadors of member states (and other capitalist countries) stationed in Sofia in order to directly submit official requests for reciprocal GSP application. ${ }^{70}$ While most states reacted favourably (especially Italy), their envoys also urged the Bulgarian government to forward its request straight to the EEC Commission for an all-encompassing multilateral solution. This was still a step too far for the Bulgarian regime, which was bent on keeping the issue within the safe bounds of bilateral relations and reducing all contacts with the EEC supranational bodies to the accepted minimum. ${ }^{71}$ Consequently, it was non-EEC members (Austria and Japan) that not only reacted benevolently but indeed fulfilled the Bulgarian requests. ${ }^{72}$

Apart from the direct economic benefits of its system of preferences, the UNCTAD offered less direct political benefits too, namely advantageous opportunities to discuss the pressing problems of East-West trade on the broadest international basis and to co-opt the support of developing countries in the process. Speaking on their behalf and arguing that Western economic groupings like the EEC damaged the fledgling decolonised economies made the "third world" a sort of proxy for the socialist bloc's agenda. ${ }^{73}$ This was especially convenient when the bloc wished to criticise the EEC without being suspected of hollow ideological antagonism. ${ }^{74}$ At the same time, the socialist bloc was wary of any special benefits and exemptions designed exclusively for the needs of the developing countries. Such exclusivity was even more alarming given the additional preferences that EEC association agreements gave north African and Mediterranean countries in the Common Market. ${ }^{75}$ Exclusive benefits were feared to give developing countries a competitive edge over the socialist bloc in trade with the West, a concern that ran deep in the Bulgarian case given the similarity in the types of goods Bulgaria exported westward. ${ }^{76}$

After the third UNCTAD session in 1972, when Bulgaria acted as official spokesman for the CMEA, the Bulgarian delegation noted that the group of developing 
countries was becoming ever more internally diversified. While some were on the side of the socialist camp, 'upholding distinct anti-imperialist positions', others were gravitating closer to the Western alliance, seduced by the promised benefits of cooperation. Last but not least, the West was putting up less of a united front. As the EEC was becoming more integrated and discriminatory towards nonmembers, the interests of the socialist countries converged with those of capitalist countries outside of Europe. ${ }^{77}$ This realisation pushed more active engagement with the GATT up the Bulgarian foreign-trade agenda in light of its upcoming trade round, which was scheduled to start in 1973 and focus on non-tariff barriers and problems of trade in agricultural goods. ${ }^{78}$

Shortly before the launch of the GATT's Tokyo round, the ongoing Hungarian negotiations over membership made the experts in the ISICI more optimistic about the price Bulgaria might need to pay for entry. So far, they had reviewed the accession process undergone by Poland and Romania and concluded that the conditions they had been offered were quite harsh and overall disadvantageous. Hungary, however, used a very different negotiating strategy, stressing the market aspects of its new economic mechanism (in both price-setting and customs tariffs) and thereby under-playing the impact of the state's central planning on foreign trade. ${ }^{79}$ As Bulgaria was in the process of enacting its own "new economic mechanism", the state-affiliated experts on capitalist integration felt that the Hungarian precedent could serve them well, especially in arguments bearing on the tariff system. ${ }^{80}$ Accordingly, the Bulgarian bargaining position was optimistically defined as 'deriving from the possibility of adapting the General Agreement to the particularities of the economic structure of the socialist countries by not allowing the opposite - the adaptation of our foreign-trade policy to the GATT's order' ${ }^{81}$

At the same time, the Bulgarian experts assessed GATT membership as a prerequisite, more important than ever before, for economic normalisation with the "first world", not least because it would facilitate contacts with the EEC organs without any pressure for recognition of their authority. ${ }^{82}$ As at the UNCTAD, the deliberation style at the GATT was conducive to geopolitical alliances. In contrast with UNCTAD, however, it encouraged alliances with developed capitalist countries outside the EEC instead of developing countries. This opportunity to unite forces was something that 'for our country, whose opportunities for bilateral influence over larger trade partners are understandably limited . . . is of particular significance' ${ }^{83}$ However, Bulgaria's prospective membership application would not advance any further by the end of the 1970s as many aspects of its tariff system still remained unclear and GATT's evaluation procedures were quite demanding. Prior to the launch of the Tokyo round, the GATT's directorship had invited Bulgaria to take part in talks under its observer status, guaranteeing that this form of participation was sufficient to qualify the country for negotiated concessions, and this took away the urgency of pursuing full membership at any cost. ${ }^{84}$

With the Conference on Security and Cooperation in Europe (CSCE) in Helsinki approaching, the Bulgarian economic advisors also highlighted the growing importance of the United Nations Economic Commission for Europe (UNECE) in 'eliminating the obstacles in trade between socialist and capitalist countries' and 


\section{4}

argued for more active involvement with it. ${ }^{85}$ In short, they lobbied for increased participation by Bulgaria in all international organisations focused on economic issues, counting on continuing adjustment and reformulation of national demands for better terms of trade with reference to instruments specific to each organisation.

\section{'Capitalists of the world, integrate!' ${ }^{86}$ Assessing the challenges of EEC enlargement and deepening integration}

Bulgaria's stepping up of its participation in international organisations - and in the international division of labour - was motivated mainly by the integration processes in Western Europe, and especially the widening and deepening of the EEC with the ensuing aggravation of trade discrimination. So far, both in deliberations on macro-policies at the top level of the ministries and in pragmatic discussions on policy implementation at the level of the managerial elite, the relevant Bulgarian institutions viewed European integration through the lens of its economic repercussions (i.e. with a narrow focus on the Common Market). The political dimensions of European integration were noted in passing and usually in terms of their linkages with economic prospects. Some political implications were even positively construed, particularly signs of a rift between the US and Western Europe over clashing commercial interests.

While 'conflicts among capitalist countries' was a cliché in all reports on European integration, the officials at the MFT and the MFA who authored these reports never failed to add that conflicts could not be expected to weaken the overall trend of deepening integration. ${ }^{87}$ Accordingly, the state apparatus adhered to a realistic policy of improving economic relations with the West and particularly with the EEC by way of increasing cooperation instead of reducing exposure. The first wave of EEC enlargement in 1973 unsurprisingly stirred much commotion within the state administration. The party's politburo, in contrast, seemed to have withdrawn to a passive role: relegating policy initiatives to the state branches on the one hand and to the CMEA's collective organs on the other hand. (This passivity on a key economic issue was not unusual. As Vachkov and Ivanov argue, the politburo similarly dealt only 'peripherally' with the problems of Bulgaria's debt. $)^{88}$ Indeed, 1973 was the last time the EEC was on the politburo's agenda, and only for formal ratification of the CMEA's draft guidelines on the scope and forms of acceptable contacts with it, which were circulated a month earlier. ${ }^{89}$ These guidelines stipulated that the CMEA members should refrain from establishing diplomatic relations bilaterally and limit interactions to technical contacts while at the same time deciding on their content in consultation with each other and keeping in close mutual coordination. An additional tenet allowed for official recognition if relations could be forged between the EEC and the CMEA as 'two equal economic organisations'. ${ }^{90}$

The MFA and the MFT, and sometimes jointly with the Ministry of Finance, commissioned their experts to prepare an avalanche of evaluations, analyses and forecasts of the impact of the EEC's enlargement on Bulgaria. The fact that incoming diplomatic reports relayed contradictory messages on what the entry of 
the new members entailed did little to offset pessimistic expectations. During a meeting at the MFA, for example, the UK's ambassador in Sofia attested to his government's commitment to open trade:

England, as you know, is a country with ideas for much more open foreigneconomic relations with all countries in the world. It is only natural that with its presence the UK will exert influence over the EEC, especially with regard to settling relations with third countries. I can already state that once the UK enters the EEC, the Community will certainly change its outlook. It cannot remain as tightly closed as it has been so far. ${ }^{91}$

In the Bulgarian assessment, however, the EEC accession of the UK along with Ireland and Denmark was harmful at many levels. Despite cuts in tariffs with regard to some goods as a result of tariff harmonisation, Bulgarian economic interests were strongly hurt because of the expansion of the customs union and the subsequent intensification of intra-EEC trade. ${ }^{92}$ Furthermore, the EEC preferences towards associated third countries, among them Bulgaria's neighbours Turkey and Greece, and agreements with the EFTA members further damaged the competitiveness of Bulgarian goods, and to a far greater extent than tariffs. ${ }^{93}$ Additional trade complications resulted from what the Bulgarian trade services perceived as 'para-tariff taxation' in the form of compensational and antidumping fees and standards and quality norms that increased customs formalities. ${ }^{94}$

Nevertheless, not all the dimensions of integration were seen in a critical light. The prospects for a monetary union, for example, were evaluated as a measure that would have a positive impact on East-West trade because currency stabilisation could only contribute to economic normalisation after the abandonment of the Bretton Woods system. ${ }^{95}$ Despite substantiated concerns, the EEC's integration was not presented to the domestic public as a capitalist 'evil plan', not even in the mouthpiece of party propaganda, the daily Rabotnichesko Delo (Workers' Cause). The year of the first EEC enlargement was the point when issues related to the Common Market gained most coverage in the BKP's daily. Apart from subordinating the EEC's development to the interests of the capitalist monopolies in Western Europe, the newspaper noted the impressive success of integration, which turned the alliance into the largest economic actor worldwide. It also emphasised its potential counterweight to the American superpower and the expected mitigation of its anti-socialist thrust thanks to the Helsinki process: 'The closeness of this economic grouping shows the conservativism of the principles that it is built upon. Now, more and more people on our continent see that all economic and social problems can be solved best on the basis of pan-European economic cooperation. ${ }^{96}$

Furthermore, the EEC's ongoing consolidation was seen as a model for successful socialist integration, although proposals for such emulation never left the internal institutional channels. Analysing the new phase in European integration from Bonn, Todor Matanov, a secretary at the Bulgarian embassy, highlighted the prospective monetary union as an idea worth exploring in the CMEA, even though 
not one to be mechanically replicated. ${ }^{97}$ And an MFT report on 'new forms of mutually beneficial cooperation with the EEC' suggested free trade zones similar to the Common Market between socialist and neutral capitalist countries in Europe under the auspices of the CMEA. ${ }^{98}$

The most detailed proposal along these lines came from influential economist Evgeny Mateev, who held leading positions in various economic branches of the state apparatus. In 1973, he submitted to the MFT some chapters from a broader study of his which dealt specifically with socialist economic integration and included an evaluation comparing it with the Common Market. Marking dogmatically the EEC's lack of coordinated economic planning as a weakness compared to the CMEA, he argued that it nonetheless compensated well for this deficiency with successful harmonisation of policies, institutions and regulatory mechanisms in agriculture and customs and potentially in taxation, social welfare, trade law, transport, energy and monetary policies. In contrast, he went on, 'in many of these areas, the CMEA does not manifest enough dynamism and initiative for unification'. 99

Further on, Mateev emphasised the greater turnover in internal EEC trade compared to CMEA trade, the EEC's higher level of internationalisation of capital and its more advanced preparation to be a supranational organisation. He also added a point regarding 'integration and the ordinary man', where he went as far as to claim that

although capitalist integration mainly serves monopolistic capital, in the EEC the ordinary man in his everyday life feels more directly and strongly the growing ties to the other countries in the Community (through the mass supply of imported consumer goods, intensive mobility of people across borders, etc.) than in the CMEA member states. ${ }^{100}$

The bottom line of his comparison tacitly suggested taking the EEC as a model for reforming the CMEA: 'Some of the above-mentioned tendencies and characteristics of integration are typically capitalist so it is not necessary to emulate them, but others, regardless of their social system, constitute real achievements'. ${ }^{101}$

The Common Market also received more attention in Bulgarian economics literature. In the 1960s, Bulgarian scholarly works had dealt with it very rarely and within the study of alternative economic systems, a rather theoretical academic pursuit. Once the EEC's deepening integration started affecting Bulgaria's external economic activities more tangibly, the academic approach expanded beyond the idiosyncrasies of the Common Market to analysing its interrelations with the CMEA, or even, albeit more rarely, the consequences of the integration processes for Bulgarian trade. ${ }^{102}$ Additionally, in 1976 a statistical periodical dedicated exclusively to exchanges between the CMEA and the EEC went into circulation. ${ }^{103}$

All these assessments, however, did not shift Bulgarian foreign-trade policy vis-à-vis the EEC in a different direction. The non-recognition policy, despite admittedly being a political matter forged at the CMEA level, also made sense 
economically in the mind of state officials. To yield on this, they thought, would only aggravate Bulgaria's position in relation to the Common Market, especially since the bulk of its exports were still agricultural and therefore, 'even if they wished to, the Common Market could not grant us any substantial relief'. ${ }^{104}$ Accordingly, the state apparatus favoured expanding technical contacts while still refraining from official advances. ${ }^{105}$

The Bulgarian institutions, however, realised that their approaches bypassing the Commission or reducing negotiations with it to technical contacts were hitting a wall. During the third round of technical contacts, the Bulgarian delegation failed to secure new preferences and found itself under strong pressure to raise the level of the talks, thus making an official approach to the Commission. Moreover, as the embassy in Brussels reported, the head of the Bulgarian delegation was told in private that a refusal to keep the talks going under such conditions would have negative repercussions in the forthcoming negotiations on a Bulgarian-Benelux trade agreement, a threat that soon came true. ${ }^{106}$

\section{After Helsinki: Bulgaria's foreign policy of 'reasonable compromise'}

Bulgaria's lobbying for better treatment did not yield any significant results, at least not from the EEC members, which refused to apply the UNCTAD's GSP on a bilateral basis and referred the Bulgarian envoys to the EEC organs. ${ }^{107}$ Instead, Bulgaria obtained preferences from non-European capitalist countries like Japan, Canada, Australia and New Zealand simultaneously with signing trade agreements with them, and also from neutral capitalist countries in Europe like Sweden, Austria and Finland, with which it had enjoyed stable trade relations since the 1960s. ${ }^{108}$ The shortcomings in their approach to the EEC and the implementation of the CCP led the Bulgarian economic services to refocus discussions with EEC members from trade issues in the narrow sense to options for economic cooperation involving licenses, transfers of technology, joint production and joint ownership. They hoped that exports of cooperative production would enter the Common Market more easily. None of these mechanisms was new to Bulgarian economic strategy, but in the mid-1970s they all underwent further elaboration and came to the fore as main vehicles of economic relations with developed capitalist countries.

The Helsinki Final Act additionally encouraged this strategy. While the Bulgarian leadership was aware of the uncomfortable concessions it had accepted regarding civil rights, it was quite optimistic about the commitments in the Accords for increased contacts and exchange between East and West in the areas of scientific-technological progress and industrial cooperation. This trade-off was indeed described by Andrey Lukanov, Tano Tsolov's successor at the helm of the CESTC, as a 'reasonable compromise'. ${ }^{109}$ Economic issues had been at the centre of the Bulgarian position at the CSCE from the very beginning: 'The surge in prosperity of the population of the European continent and the preservation of Europe's role as one of the most important centres of world civilisation 
hinges to a great extent on such developments [expansion of commercial, economic and scientific-technical links on an equal footing].' ${ }^{110}$ Expecting a peak in pan-European cooperation, some state experts even envisaged an 'all-European programme for trade liberalisation' modelled on that of the Organisation for Economic Co-operation and Development (OECD) but covering equally capitalist and socialist states. ${ }^{111}$ While the humanitarian clauses were seen as an instrument for slandering the socialist system, in turn the regime did not shy away from instrumentalising aspects of the Accords concerning economic rapprochement to accuse Western European governments of acting 'completely at odds with the constructive spirit of Helsinki' when they abstained from closer partnerships. ${ }^{112}$ Accordingly, the Bulgarian embassies across Western Europe were instructed to closely follow how the Helsinki provisions were being implemented and to notify the government of instances in which they were disrespected or violated in national policymaking or EEC policy resolutions. ${ }^{113}$

In light of the anticipated new opportunities, in early 1974 the politburo adopted a resolution on production-technological cooperation with non-socialist countries. As the resolution boasted, this was an entirely new approach compared to the 'classical way of industrial cooperation', one that encompassed the complete process from factory equipment to market placement. Manoeuvring between opening up to the West and staying firmly in the Soviet orbit, the party defined this new form of cooperation as being at the service of the principal path of Bulgaria's foreigneconomic activity: creating greater cohesion between the national and Soviet economies and facilitating socialist integration in general. ${ }^{114}$ For the economic agencies, however, this seemingly key point remained an ideological pledge with little bearing on their actual practice of contracting cooperation deals with Western companies.

Now, their efforts were legislatively bolstered by giving broader rights to foreign partners. The terms improved so much that the Financial Times stated that Bulgaria offered the best conditions for foreign investors in the Eastern bloc. ${ }^{115}$ By the end of 1975, Bulgaria had concluded a total of around one hundred cooperation contracts in machine building, electronics, industrial agriculture and food processing. As with the trans-border firms, the highest number of joint production contracts outside the bloc was with the FRG, accounting for a quarter of all the partnerships with the capitalist world, followed by Italy and France. ${ }^{116}$ Once the Community's CCP put an end to bilateral trade agreements, the Bulgarian government delegations in economic negotiations shifted their focus to treaties on economic, industrial and scientific-technical cooperation with a ten-year term, which had not yet come under the supranational authority of the EEC. ${ }^{117}$

The post-Helsinki era brought not only a new emphasis on cooperation but also a specific focus on economic cooperation within the Balkan region and mainly with the Balkan capitalist countries: Greece, Turkey and Cyprus. ${ }^{118}$ The end of the reign of the junta in Greece in 1974 enabled normalisation of diplomatic relations after years in which the Bulgarian regime had clandestinely supported the underground communist opposition. The renewal of inter-governmental contacts immediately led to economic activity across the border with joint industrial projects and 
intensified trade. ${ }^{119}$ The year 1975 witnessed a diplomatic stir in Bulgaria's relations with both Greece and Turkey as Todor Zhivkov separately met their prime ministers, Konstantinos Karamanlis and Süleyman Demirel, and even proposed mediating between them in the conflict over Cyprus. ${ }^{120}$ Bridge-building initiatives in the Balkans were promoted by the Bulgarian leadership as an 'important contribution, in accordance with the capacities of our country, to the strengthening and deepening of the overall process of easing of tensions in Europe'. ${ }^{121}$

The economic dimension of Balkan cooperation was quite impressive. While in 1975 total exports to the EEC members dropped by 35 million lev compared to the year before, exports to Greece increased by exactly the same amount and to Turkey by 21 million. ${ }^{122}$ As a result, that year Bulgaria's two southern neighbours were responsible for a $211 \%$ spike in exports, which contrasted sharply with the stagnation in overall trade with capitalist countries. Moreover, Bulgaria scored huge trade surpluses with both countries. ${ }^{123}$

While the association agreements of the two countries with the EEC had bothered the Bulgarian government for reasons of competitiveness, in the second half of the 1970s Greece's impending membership worried them for its negative impact on bilateral cooperation. ${ }^{124}$ Driven by this anxiety, the Bulgarian trade representative in Athens pushed for an acceleration of all projects under discussion that concerned assembled factories so that the contracts could be sealed prior to Greece's accession and the expected shift in its foreign-economic activity towards the Common Market. ${ }^{125}$ The largest joint project, an agreement to connect the energy systems of Greece and Bulgaria, was signed in 1977..$^{126}$

Regarding the EEC itself, the immediate post-Helsinki period did not witness much progress in negotiations on concessions despite the high expectations among Bulgarian technocrats during the early phases of the CSCE. At the same time, Bulgaria's non-member participation in the GATT's Tokyo Round opened up a chance for bargaining with the EEC without extending official recognition through the mechanism of bilateral GATT consultations. ${ }^{127}$ By then, however, the MFT was all but optimistic about its chances of achieving better terms of trade with the Common Market, and the incentive to engage in such talks was purely bureaucratic. The minister was concerned that if they did not carry out any consultations in the Tokyo Round, it might provide evidence that its participation was limited to being a passive observer and therefore justification for denying Bulgaria the right to benefit from negotiated concessions. In the consultations with the EEC that the Bulgarian delegation initiated at the end of 1976, exports of agricultural goods were a central topic. In response, the EEC underscored its members' reciprocal difficulties in exporting agricultural produce into the Bulgarian market because of the lack of reliable statistical data on national production and consumption and on trade policies and the balance of payments. For the Bulgarians, this counter-request had the ring of a ruse to obtain confidential information about the national economy and was therefore rejected. ${ }^{128}$ Thus, the consultations reached a dead end, which was reported back home as having been caused by the 'non-constructive position of the Community'. ${ }^{129}$ 


\section{The end of Bulgaria's "long 1970s": foreign debt, growing trade barriers and diplomatic predicaments}

Despite ambitious ideas and general optimism stirred up by the Helsinki process, the second half of the 1970s turned out to be a difficult period for the Bulgarian economy, especially in its international dimension. The travails that it faced resulted from both internal factors, namely the rigidity of planning and production undermining the competitiveness of national production and the global impacts of the two oil shocks in 1973 and 1979. While Bulgaria was shielded from the immediate impact of the oil crises by its flow of subsidised Soviet oil, its trade nevertheless suffered from the limits on imports imposed across Western Europe. The Bulgarian state was therefore attentively and sympathetically looking at Western efforts at recovery. Against the gloomy background of the drop in total commerce with the Western countries in the second half of the 1970s, the Balkan capitalist countries as a sub-group of economic partners in the other camp were on the rise in Bulgaria's trade relations. The dynamism in economic relations within the region was the only positive development in trade with capitalist Europe in the difficult years between the two oil crises. ${ }^{130}$

Moreover, Bulgaria's planning system could not adjust quickly enough to the changing conjuncture and minimise the losses incurred. In 1974, Bulgarian foreign trade was badly hit due to a sharp disbalance in the rising values of exports and imports to and from non-socialist countries, which immediately led to a doubling of the country's foreign debt. ${ }^{131}$ As it went into a spiral of borrowing to pay off outstanding loans, already in 1975-76 Bulgaria entered a debt crisis ahead of all the other socialist countries. As Vachkov and Ivanov argue, the earlier exacerbation of Bulgarian financial troubles compared to the rest of the bloc was actually Bulgaria's lucky chance to get out of the debt trap more easily and faster than the others as the regime did not face fraternal competition when asking for Soviet help. Thanks to direct Soviet aid and re-exports of cheap Soviet oil, by 1979, when the Central European members of the CMEA hit the bottom, Bulgaria not only had left the worst behind but also managed to achieve a trade surplus and accumulate hard-currency reserves that would facilitate restructuring and even early acquittal of its foreign loans. ${ }^{132}$ This exogeneous solution delayed Bulgaria's economic travails until the Soviets refused to keep subsidising its unreformed and underperforming economy.

Once Bulgaria embarked on the path to financial recovery in 1978, the CESTC renewed technical contacts with the EEC to update the existing agreements and test the ground for further exemptions regarding textile and metallurgy products. The initial talks with the Commission were construed by the Bulgarian delegation as an attempt to shift the conversation from the practicalities of commercial relations to the intricacies of diplomatic recognition. The Commission reminded the negotiating party about its outstanding proposal for a bilateral trade agreement made back in November 1974 and announced that Bulgaria's export problems 'could be solved only in the context of comprehensive negotiations between Bulgaria and the Community'. ${ }^{133}$ Throughout the follow-up meetings, the Bulgarian 
delegation desperately tried to reduce its contacts with the Commission, which it viewed as non-compromising and pursuing its own political objectives, and to conduct most of the talks with the representatives of the industrial sectors of interest, but to no avail. The delegates felt repeatedly blackmailed into granting the EEC official recognition in order to trade on its markets on a par with others. This boosted Bulgaria's suspicions of the Commission as opposed to the member states and their economic experts, who were perceived as more pragmatically minded:

\begin{abstract}
At present, when a number of socialist countries have established contacts with the EEC's Commission and conduct talks on concrete issues and sectors, certain circles in the Commission intensify their efforts to extort within the frames of these contacts political concessions from the socialist countries, and to this end they resort to any means. One can see in these actions a desire to bring an element of distrust into the bilateral relations between socialist countries and EEC member states. Apparently, the level reached in the development of our bilateral relations with the EEC member states is a substantial obstacle for the Commission to carry out its foreign-policy ambitions and goals. ${ }^{134}$
\end{abstract}

Despite its doubts about the potential usefulness of the negotiations, the Bulgarian delegation persisted well into 1979 , when it finally managed to renew the agreements on some agricultural goods, ferrous metallurgy and textile products. ${ }^{135} \mathrm{At}$ the same time, the GATT's Tokyo Round ended and Bulgaria recommenced its probes into full membership of the organisation, although it would eventually submit an official application only in 1986. ${ }^{136}$

The early 1980s were marked by the boldest campaign of popularising the country worldwide - an exuberant celebration of ' 1,300 Years of Bulgaria' in 1981. ${ }^{137}$ But this period also witnessed the gravest tarnishing of the regime in the eyes of the world, first when it was implicated in the assassination attempt on Pope John Paul II in 1980 and later when it launched an aggressive assimilation campaign against the national Muslim minority in 1984-89. The international outcry against the alleged state sponsorship of terrorism and later against the gross human rights violations under BKP rule damaged many of the previously developed amicable relations and forms of cooperation with the West, and specifically with EEC members. ${ }^{138}$ In effect, it was only in 1989 that Bulgaria started and completed negotiations for a diplomatic agreement with the EEC and its application for GATT membership was finally accepted - shortly before Zhivkov's demise a day after the fall of the Berlin Wall. ${ }^{139}$

\title{
Conclusion
}

Ever since the 1960s, for Bulgaria economic cooperation with the capitalist countries of Europe served both the pragmatic objective of industrial modernisation in an endeavour to catch up with the Central European countries in its camp and the symbolic purpose of bolstering the regime's international reputation. Despite its decisive opening up to the West in the 1960s and modest progress in expanding 


\section{2}

cooperation with the European capitalist states throughout the 1970s, Bulgaria certainly fell behind its allies in economic bridge-building towards Western Europe and specifically the EEC members. The reasons were both economic and political. On the one hand, Bulgaria's relentless efforts to find a diplomatic solution to trade obstacles did nothing to ameliorate the structure or quality of its westbound exports, a systemic failure which even the Soviet Union under Gorbachev would soon lose its tolerance for. On the other hand, Bulgaria's opening up to the West, as ambitious as it was, inevitably seemed cautious and hesitant to prospective partners on the other side of the Cold War divide, thus diminishing their political incentives to make transactions more beneficial to the Bulgarian economic agencies. ${ }^{140}$

Many of the intricacies of this opening up can be described as a balancing act between socialist internationalism and economic internationalisation. Ironically, whereas both provided the Bulgarian regime with easy remedies for the shortcomings of its planned economy - in the form of Western imports of state-of-the-art production technology and regular injections of generous Soviet subsidies - in the long run these two paths of economic interactions would ensure the doom of Bulgaria's socialist economy.

Purchases from the West inevitably led to insurmountable trade deficits and growing debts. Soon the main purpose of imports became to improve production in such a way as to prop up the quality, structure and ultimately the value of Bulgarian exports. ${ }^{141}$ This vicious circle, which never worked out as planned, was maintained by the growing hunger of Bulgarian industry for high-tech transfers, despite the fact that overall industry failed to optimise the benefits they brought. At the same time that economic dependency on the West was growing, diplomatic negotiations on more beneficial forms of cooperation stalled and ultimately faced uncompromising conditions by the EEC that the Bulgarian regime could not accept without jeopardising Soviet protectionism.

The Bulgarian strategy for dealing with the EEC proved less flexible and hence less successful than those of its allies in the socialist camp and especially Romania or Hungary. It relied rigidly on a twofold approach: state institutions bargaining for exemptions bilaterally with the EEC members, thereby ignoring the supranational authority of the Commission, and socialist countries coordinating their national approaches through the CMEA and responding jointly to the EEC. As this dual course did not yield the desired results, the Bulgarian state institutions pursued better terms of trade simultaneously at the UNCTAD and the GATT, adjusting the general strategy to the instruments available in the two organisations. Within their fora, the Bulgarian foreign services also took advantage, with more or less success, of different options for building coalitions - with the global South under the umbrella of the UNCTAD and with non-European capitalist countries under the GATT. These twofold efforts demonstrated both the limits of socialist solidarity with the so-called third world and the breadth of ideological compromise vis-à-vis the "first world". At times, the "third world" was used as a proxy to advance the socialist position in trade negotiations; at times it was seen as a potential competitor with the socialist bloc on Western markets. On the other hand, while the capitalist 
West was imperialist in the view of Marxist-Leninist ideology, in commerce there were interesting convergences of interests, especially with non-European states once the protectionism of the Common Market was the topic of discussion.

Regardless of the coalitions it forged internationally, Bulgarian foreign trade remained plagued by internal problems of low quality, low flexibility and few incentives for reform. Its failure became irreversible towards the end of the 1970s, when balancing between expanding cooperation with Western Europe and political pressure to tow the Soviet line (and also between costly imports and the growing difficulties in exporting) became an impossible predicament.

\section{Notes}

1 Tsentralen darzhaven arhiv (TsDA), f.1B, op.35, a.e.5557, 1.145, Information about Todor Zhivkov's official visit to the FRG, 24-28 November 1975. See also Baev, "The establishment of Bulgarian-West German diplomatic relations," 174-5.

2 TsDA, f.1B, op. 35 , a.e.5557, 1.151, Information.

3 TsDA, f.1B, op.35, a.e.5557, 1.183, Todor Zhivkov's meeting with representatives of FRG's business circles.

4 See Chapter 4 by Aleksandra Komornicka in this book.

5 Guentcheva, "Material harmony"; Stanoeva, "Inventing the socialist consumer."

6 Statisticheski Godishnik na NRB 1965, 299; Statisticheski Godishnik na NRB 1968, 308; Statisticheski Godishnik na NRB 1974, 302; Statisticheski Godishnik na NRB 1979, 369; Statisticheski Godishnik na NRB 1985, 362.

7 See Guentcheva, "Mobile objects"; Ivanova, Turizam pod nadzor; and Stanoeva, "Exporting holidays."

8 Pedaliu, "The US, the Balkans and détente," 198.

9 Lampe, The Bulgarian economy, 177-84.

10 Vachkov and Ivanov, Balgarskiyat vanshen dalg, 140.

11 Mavrodin, Romania and the Cold War, ch. 5.

12 Avramov, Pari i de/stabilizatsiya, 124-47.

13 TsDA, f. 1477 , op. 25 , a.e.761, 1.15; Information regarding trade relations between Bulgaria and the FRG and the trade mission's operation, May 1969.

14 Stanoeva, "Squeezed between external trade barriers and internal economic problems."

15 Vachkov and Ivanov, Balgarskiyat vanshen dalg, ch. 4; Avramov, Pari i de/stabilizatsiya, $123-4$.

16 Avramov, Pari i de/stabilizatsiya, 8-9.

17 Vachkov and Ivanov, Balgarskiyat vanshen dalg, 147-8.

18 Hristov, Imperiyata na zadgranichnite firmi, 12-14.

19 On Bulgaria's cultural diplomacy in the 1970s, see Dragostinova, "The East in the West."

20 Stanoeva, "The imperative of opening to the West."

21 Stanoeva, "Exporting holidays."

22 TsDA, f.310, op.5, a.e.6, 1.4; Report by Petko Todorov, Chairman of the Committee on Tourism, on the conception of development of the "International and internal tourism" sector in the sixth five-year plan 1971-75, 8 August 1970.

23 TsDA, f.259, op.36, a.e.460, 1.185, "NRB's participation in international trade-economic organisations," 1 August 1972.

24 TsDA, f.1B, op.81, a.e.171, 1.2-6, Report by Tenyu Petrov, Director of the MFA's Economic Section, 12 December 1968.

25 Arhiv na Ministerstvoto na vanshnite raboti (AMVnR), op.32, a.e.67, Materials related to the Economic Department's report on the work of the "International Organisations" sector in 1971. 
26 TsDA, f.259, op.36, a.e.460, 1.187, "NRB's participation"; TsDA, f.1B, op.35, a.e.12, 1.32, Report on further activisation of Bulgaria's work in international organisations, 18 November 1967.

27 TsDA, f.259, op.36, a.e.61, 1.112, Information by Penko Penkov, Deputy Minister of Foreign Trade, on UNCTAD's third session and our country's preparation, 1972.

28 TsDA, f.259, op.36, a.e.460, 1.148-9, Report on NRB's accession to GATT, September 1972.

29 Statisticheski Godishnik na NRB 1971, 320-2.

30 TsDA, f.259, op.36, a.e.88, 1.53, Report on the state's additional considerations regarding the position towards the EEC, 19 February 1972; TsDA, f.259, op.44, a.e.173, 1.62, the MFT's conception of the role and significance of foreign trade for NRB's economic development, 1971.

31 TsDA, f.1B, op. 35 , a.e.12, 1.12, Considerations for the direction of NRB's foreigneconomic relations with the countries in the EEC (Common Market), November 1968.

32 TsDA, f.1B, op. 35 , a.e. $12,1.13$, Considerations.

33 TsDA, f.1B, op.35, a.e.12, 1.17-18, Report on NRB's position towards the EEC (Common Market), 16 November 1967.

34 TsDA, f.1B, op.35, a.e.12, 20, Report on NRB's position towards the EEC.

35 TsDA, f.1B, op.35, a.e.12, 23, Report on NRB's position towards the EEC.

36 Vachkov and Ivanov, Balgarskiyat vanshen dalg, 157-8.

37 Vera and Donald Blinken Open Society Archive (HU OSA), 300-8-3-676, f-112, Curt - Bulgaria's Economic Reform, 9 December 1965.

38 HU OSA 300-8-3-776, RFE Research East Europe: Structural and Personnel Changes in Bulgaria, 3 January 1969; HU OSA 300-8-3-770, RFE Research East Europe: Reshuffle at the Deputy Level in Economic Ministries, 29 January 1969.

39 See Chapter 6 by Pavel Szobi in this book.

40 HU OSA 300-8-47-25-72, 6, RFE Research East Europe: Situation Report, Bulgaria 26 November 1969.

41 Slavova, Georgi Naydenovi Teksim-Imekstrakom.

42 TsDA, f.1A, op.35, a.e.704, 1.2-39, Resolution of politburo on elevating MFA's role and responsibility in elaborating and implementing NRB's foreign policy and its further activisation, 27 May 1969.

43 TsDA, f.1A, op.35, a.e.704, 1.81-82, Letter to politburo by Boris Velchev, Ivan Bashev, K. Tellalov, Gero Grozev, Boris Tsvetkov, 12 May 1969.

44 TsDA, f.259, op.44, a.e.173, 1.19, MFT's conception.

45 TsDA, f.259, op.36, a.e.142, 1.177-8, Report by Ivan Ivanov, Deputy Minister of Foreign Trade, 13 January 1972.

46 TsDA, f.1477, op.25, a.e.761, 1.24, Bulgarian trade representation - Frankfurt: Information regarding trade relations between NRB and FRG and the trade representation's work, May 1969.

47 TsDA, f.259, op.36, a.e.61, 1.24, Report by Ivan Ivanov, Deputy Minister of Foreign Trade, on fulfilment of the export-import plan for 1971 and the 1972 plan's main aim.

48 TsDA, f.259, op.36, a.e.88, 1.55, Report by Ivan Nedev.

49 Stanoeva, "Squeezed between external trade barriers and internal economic problems."

50 TsDA, f.1B, op.35, a.e.1202, 1.186-7, Conception of the strategy and tactics of NRB's foreign trade: Appendix 8, 1969.

51 TsDA, f.1B, op.35, a.e.1202, 189, Conception.

52 TsDA, f.1B, op.35, a.e.3079, 1.42-3, Report on the endorsement of the strategy and tactics of NRB's foreign trade, March 1972.

53 TsDA, f.1B, op.35, a.e.3079, 1.108, Strategy and tactics of NRB's foreign trade, 1972.

54 On the first round of technical contacts with the EEC, see Grigorova, "Kolebaniya i reshitelnost."

55 TsDA, f.259, op.36, a.e.89, 1.188-90, Report by Ivan Nedev, Minister of Foreign Trade, 15 March 1972; TsDA, f.259, op.36, a.e.357, 1.81-2, Letter by I. Dimitrov, 
Director of Section "International Organisations" to H. Sheinov, Chief Director of "Hranexport," 27 January 1972.

56 TsDA, f.259, op.36, a.e.460, 1.71, Report of Section "International Organisations" on NRB's position towards GATT, 1972.

57 TsDA, f.1B, op.35, a.e.2828, 1.121-2, Information about the 56th session of CMEA's Executive Committee, 27 January 1972.

58 TsDA, f.259, op.36, a.e.168, 1.19, Protocol of meeting with trade representatives in developed capitalist countries, 25 July 1972.

59 For example, the following articles published in 1969 in the BKP's daily, Rabotnichesko delo: Ivan Dimitrov, "Koy finansira agrarnata politika na Obstiya pazar?," 9 January 1969, 4; "Otnovo seriozni protivorechiya," 28 January 1969, 5; Georgi Konstantinov, "Pred konferentsiyata na shestte v Haga," 1 December 1969, 6; Ivan Slavkov, "Golemiyat pazarlak zapochva edva sega," 12 December 1969, 5; Pavel Pisarev, "Zapadnoevropeyski problem," 18 December 1969, 4-5.

60 Vezenkov, "Institutsiyata na darzhavnia glava."

61 TsDA, f.259, op.36, a.e.460, 1.59-66, Information about some new elements in NRB's customs policy in view of questions that foreign experts might ask, 25 February 1972.

62 TsDA, f.259, op.36, a.e.460, 1.79-80, 123, Report.

63 TsDA, f.259, op.36, a.e.459, 1.356-370, Report by Simeon Enchev, economist in the "International Organisations" section, on consultation between Bulgarian, Hungarian and Czechoslovak experts on tariff preferences for developing countries, 4 June 1971.

64 TsDA, f.259, op.36, a.e.459, 1.43, Report on the visit to Bulgaria by the SecretaryGeneral of UNCTAD, Mr. Pérez-Guerrero, 12-16 July 1970; TsDA, f.259, op.36, a.e.459, 1.320, Verbal note, 5 May 1971.

65 TsDA, f.259, op.36, a.e.459, 1.357, Report by Simeon Enchev.

66 TsDA, f.259, op.36, a.e.459, 1.44, Report on the visit; TsDA, f.259, op.36, a.e.61, 1.121, Information by Penko Penkov.

67 TsDA, f.259, op.36, a.e.61, 1.104-6, Report by Penko Penkov, Deputy Minister of Foreign Trade, on a meeting with UNCTAD Secretary-General, 20 September 1969.

68 TsDA, f.259, op.36, a.e.61, 1.7-14, Report by Penko Penkov, Deputy Minister of Foreign Trade, on meetings in Bulgaria with UNCTAD Secretary-General, Mr. Guerrero, 20 July 1970.

69 TsDA, f.259, op.44, a.e.173, 1.59, MFT's conception.

70 TsDA, f.259, op.36, a.e.459, 1.341-383, Reports by Mihail Paskalev, Deputy Director of MFA's Economic Section, 29 April - 7 May 1971.

71 TsDA, Reports by Mihail Paskalev, 342-3.

72 TsDA, f.259, op.36, a.e.100, 1.145, Report by Ivan Nedev, Minister of Foreign Trade, on the work and results of UNCTAD's third session, 18 June 1972.

73 TsDA, f.259, op.36, a.e.100, 1.138, Report by Ivan Nedev Minister of Foreign Trade, on the work and results of UNCTAD's third session, 18 June 1972; TsDA, f.259, op.36, a.e.459, 1.3, "UN Conference on Trade and Development (UNCTAD)," 10 February 1972; TsDA, f.259, op.36, a.e.61, 1.150, Information by Penko Penkov.

74 TsDA, f.259, op.36, a.e.459, 1.3, "UN Conference on Trade and Development (UNCTAD)," 10 February 1972; TsDA, f.259, op.36, a.e.61, 1.150, Information by Penko Penkov, 126.

75 TsDA, f.259, op.36, a.e.459, 1.332, unnamed document [1971].

76 TsDA, f.259, op.36, a.e.459, 1.336-7; TsDA, f.259, op.36, a.e.61, 1.140, Information by Penko Penkov.

77 TsDA, f.259, op.36, a.e.100, 1.154, Report by Ivan Nedev.

78 TsDA, f.259, op.36, a.e.460, 1.72, Report by "International Organisations" section; TsDA, f.259, op.36, a.e.110, 1.182, Report by Ivan Nedev, Minister of Foreign Trade, Petar Mladenov, Minister of Foreign Affairs, on NRB's position towards GATT's new multilateral negotiations, 23 August 1973.

79 See Chapter 3 by Pàl Germuska in this book. 
80 TsDA, f.259, op.36, a.e.460, 1.71-81, Report on NRB's attitude towards GATT, 1972.

81 TsDA, f.259, op.36, a.e.460, 1.47, Information by Petko Baev.

82 TsDA, f.259, op.36, a.e.460, 1.78, Report on NRB's attitude.

83 TsDA, f.259, op.36, a.e.460, 1.154, Report on NRB's accession.

84 TsDA, f.259, op.36, a.e.110, 1.181, Report by Ivan Nedev.

85 AMVnR, op.32, a.e.5172, 1.30, Information on the implementation of the CSCE's Final Act and preparation for the Belgrade meeting, 23 November 1976; TsDA, f.259, op.36, a.e.174, 1.62, "Abolishing restrictions and discrimination in international trade, seeking new forms of mutually beneficial cooperation with the EEC," April 1973.

86 An MFT report from April 1973 opened by qualifying developments in the West this way. TsDA, f.259, op.36, a.e.174, 1.32. "Abolishing."

87 TsDA, f.259, op.32, a.e.18, 1.97a-98, "Building economic and monetary union - a new phase in West European integration" (T. Matanov, Bonn), 18 October 1973; TsDA, f.259, op.36, a.e.88, 1.65-66, Report by Ivan Nedev; TsDA, f.259, op.36, a.e.174, 1.34 36, "Abolishing"; TsDA, f.1477, op.30, a.e.549, 1.52, Information about some new elements in the relations between Western countries manifested during their meetings in Brussels and Copenhagen (A. Yankov, Ambassador in London), 28 December 1973.

88 Vachkov and Ivanov, Balgarskiyat vanshen dalg, 185.

89 TsDA, f.1B, op.35, a.e.4142, Protocol A-342 of politburo session, 15 May 1973.

90 TsDA, f.1B, op.35, a.e.4142, 1.20, Proposals on the permitted order, forms and content of CMEA contacts with the EEC.

91 TsDA, f.259, op.36, a.e.459, 1.392, Report by Mihail Paskalev, Deputy Director of MFA's Economic Section, 20 May 1971.

92 TsDA, f.259, op.36, a.e.460, 1.126, Information by Petar Mladenov, Minister of Foreign Affairs, Ivan Nedev, Minister of Foreign Trade, on the impact of the Common Market's expansion and EEC's free-trade treaties with Sweden, Switzerland, Austria, Finland, Iceland and Portugal on NRB's economic relations with these countries, 20 October 1972.

93 TsDA, f.259, op.36, a.e.88, 1.62, Report by Ivan Nedev.

94 TsDA, f.259, op.36, a.e.174, 1.46-8, Abolishing.

95 TsDA, f.259, op.32, a.e.25, 1.10, Monetary-financial problems in economic relations between member states of the CMEA and the EEC (Prof. Nesho Tsarevski, Scientific Institute on Problems of Socialist Economic Integration), 12 January 1974.

96 Volen Butashkov, "Predizvikatelstvoto na Obshtiya pazar," Rabotnichesko delo, 2 January 1973, 5.

97 TsDA, f.259, op.32, a.e. $18,1.98$, Building.

98 TsDA, f.259, op.36, a.e.174, 1.54-63, Abolishing.

99 TsDA, f.259, op.36, a.e.174, 1.8, Exploration of some problems concerning the operation of state and public bodies under contemporary conditions (E. Mateev, Chairman of the Council on Reproduction of Material Resources), 11 April 1973.

100 TsDA, f.259, op.36, a.e.174, 1.9, Exploration of some problems.

101 TsDA, f.259, op.36, a.e.174, 1.10, Exploration of some problems.

102 For example, Lalov, Vanshnotargovskata politika na stranite ot "Obshtiya pazar" and the works of Nacho Nachev: Agrarniyat protektsionizam v EIO; Targovska politika na EIO; Otnosheniyata mezhdu SIV i EIO.

103 SIV i Obshtiyat Pazar: Statisticheski spravochnik (published in 1976, 1977 and 1980).

104 TsDA, f.259, op.36, a.e.88, 1.68, Report by Nedev.

105 TsDA, f.259, op.36, a.e.88, 1.63, Report by Nedev.

106 TsDA f.1B, op.81A, a.e.171, 1.13-14, Information by Petar Avramov, third secretary at Bulgarian Embassy in Brussels, on technical contacts conducted between representatives of Bulgarian foreign trade organisations and experts at the EEC Commission 18-19 April 1972, Brussels, 28 April 1972.

107 TsDA f.1B, op.81A, a.e.171, 1.18, Information from the MFT's "International Organisations" section on a conversation with a representative of the EEC Commission, 19 September 1972. 
108 TsDA, f.259, op.39, a.e.49, 1.51, 67, Information on the meeting with the heads of trade-economic missions in developed capitalist countries, 18 February 1976.

109 TsDA, f.259, op.39, a.e.49, 1.86, Information on the meeting with the heads of tradeeconomic missions.

110 TsDA, f.1477, op.27, a.e.4371, 1.70, Information on NRB's standpoints on matters of European security, 21 August 1971.

111 AMVnR, op.32, a.e.6312, 1.1, Some ideas, 1969.

112 TsDA, f.259, op.39, a.e.49, 1.66, Information on the meeting.

113 AMVnR, op.32, a.e.5172, 1.27, Information; AMVnR, op.32, a.e.5175, 1.39, Tasks for NRB's embassies in implementation of the Final Act's resolutions and recommendations, 4 February 1976.

114 TsDA, f.259, op.39, a.e.49, 1.84-5, Information on the meeting.

115 Financial Times 8 September 1979, cit. in Bell, The Bulgarian Communist Party, 146.

116 TsDA, f.259, op.39, a.e.49, 1.62-3, Information on the meeting.

117 TsDA, f.259, op.39, a.e.49, 1.47-8, Information on the meeting.

118 On the "Balkan micro-détente," see Pedaliu, "The US, the Balkans and détente," 206-11.

119 TsDA, f.259, op.39, a.e.49, 1.95-8, Information on the meeting.

120 AMVnR, op.33, a.e.5172, 1.15, Information on the implementation.

121 AMVnR, op.33, a.e.5172, 1.16, Information on the implementation.

122 TsDA, f.259, op.39, a.e.49, 1.55-8, Information on the meeting.

123 TsDA, f.259, op.44, a.e.181, 1.16, Information on the activity of the "Economic Cooperation with Developed Capitalist Countries" department in 1977.

124 TsDA, f.259, op.36, a.e.174, 66, Abolishing.

125 AMVnR, op.33, a.e.918, 1.28, NRB's Embassy in FRG: Some trends in EEC's development and positions of FRG authorities regarding the anticipated reply by EEC's Council of Ministers to the letter from the CMEA Executive Committee, September 1976.

126 TsDA, f.259, op.44, a.e.181, 1.18, Information on the activity.

127 TsDA, f.259, op.44, a.e.181, 1.21, Information on the activity.

128 TsDA, f.259, op.44, a.e.921, 1.93, Report by Hristo Hristov, Minister of Foreign Trade, on implementation of the bilateral meeting between NRB and EEC representatives within GATT's multilateral trade negotiations, 1 April 1977.

129 TsDA, f.259, op.44, a.e.922, 1.150, Report by Hristo Hristov, Minister of Foreign Trade, on GATT's multilateral trade negotiations and NRB participation, 24 October 1978.

130 TsDA, f.259, op.39, a.e.49, 1.33,79, Information on the meeting; TsDA, f.259, op.44, a.e. $181,1.1$, Information on the activity.

131 Vachkov and Ivanov, Balgarskiyat vanshen dalg, 159.

132 Vachkov and Ivanov, Balgarskiyat vanshen dalg, 176-84.

133 TsDA, f.259, op.44, a.e.922, 1.9-11, Report by Hristo Hristov, Minister of Foreign Trade, on implemented talks with representatives of EEC Commission, 28 June 1978.

134 TsDA, f.259, op.44, a.e.922, 1.8, Report by Hristo Hristov.

135 TsDA, f.259, op.44, a.e.922, 1.60-7, Report by Hristo Hristov, Minister of Foreign Trade, on the conclusion of negotiations and the long-term treaty for commerce with textile products between NRB and EEC Commission, 28 February 1979.

136 TsDA, f.259, op.45, a.e.1336, 1.1, Information on NRB's negotiations with GATT, 13 May 1987.

137 Stanoeva, "Bulgaria's 1,300 Years and East Berlin's 750 Years."

138 Iakimova, "Ustanovyavane na ofitsialni otnosheniya," 178; Mihaylov, "Targoviyata mezhdu Balgariya i Evropeyskata ikonomicheska obshtnost," 199.

139 TsDA, f.259, op.45, a.e.1332, 1.8-11, Report by Atanas Paparizov, Director of "Developed Capitalist Countries and Multilateral Trade Policy" bureau, on talks in Brussels on 26 June in preparation for the agreement between NRB and the EEC, 26 June 1989, on diplomatic negotiations with the EEC in the late 1980s. See Marcheva, "Parvi stapki na Balgariya." 
140 Grigorova, "Kolebaniya i reshitelnost."

141 A similar argument is made with regard to the GDR in Chapter 5 by Maximilian Graf in this book (i.e. modernisation through economic cooperation with the West aimed at reducing East German economic dependency on the West).

\section{Bibliography}

Avramov, Roumen. Pari i de/stabilizatsiya v Balgariya 1948-1989. Sofia: Ciela, 2008.

Baev, Jordan. "The establishment of Bulgarian-West German diplomatic relations within the coordinating framework of the Warsaw Pact." Journal of Cold War Studies 18:3 (2016): 158-80.

Bell, John. The Bulgarian Communist Party from Blagoev to Zhivkov. Stanford: Hoover Press, 1986.

Dragostinova, Theodora. "The East in the West: Bulgarian culture in the United States of America during the global 1970s." Journal of Contemporary History 53:1 (2018): 212-39.

Grigorova, Irina. "Kolebaniya i reshitelnost: tehnicheskite kontakti na Balgariya s EIO v kraya na 60-te i nachaloto na 70-te godini na XX vek." Historical Review 5-6 (2012): 127-44.

Guentcheva, Rossitza. "Mobile objects: Corecom and the selling of Western goods in socialist Bulgaria." Études Balkaniques 1 (2009): 3-28.

Guentcheva, Rossitza. "Material harmony: the quest for quality in socialist Bulgaria, 1960s-1980s." In Communism unwrapped: consumption in Cold War Europe, edited by Paulina Bren and Mary Neuburger, 140-63. Oxford: Oxford University Press, 2012.

Hristov, Hristo. Imperiyata na zadgranichnite firmi: Sazdavane, deynost i iztochvane na druzhestvata s balgarsko uchastie zad granitsa 1961-2007. Sofia: Ciela, 2009.

Iakimova, Irina. "Ustanovyavane na ofitsialni otnosheniya mezhdu Balgariya i zapadnoevropeyskiya Obsht pazar." In Integratsiya i dezintegratsiya v Evropa prez 80-te godini na XX vek, edited by Iskra Baeva, 152-81. Sofia: Sofia University Press, 2016.

Ivanova, Maya. Turizam pod nadzor: Balkanturist - nachaloto na mezhdunarodniya $i$ masov turizam v Balgariya. Sofia: Ciela, 2018.

Lalov, Lalo. Vanshnotargovskata politika na stranite ot "Obshtiya pazar" $i$ ikonomicheskite im vrazki sas stranite ot SIV. Leningrad, 1975.

Lampe, John. The Bulgarian economy in the twentieth century. London: Croom Helm, 1986.

Marcheva, Iliana. "Parvi stapki na Balgariya kam obedinyavashta se Evropa v kraya na 80-te I nachaloto na 90-te godini na XX vek." Bulgarian Historical Review 1-2 (2006): 348-64.

Mavrodin, Corina. Romania and the Cold War: the roots of exceptionalism, 1953-63. London: Palgrave Macmillan, forthcoming.

Mihaylov, Venelin. "Targoviyata mezhdu Balgariya i Evropeyskata ikonomicheska obshtnost prez 80-te godini." In Integratsiya i dezintegratsiya $v$ Evropa prez 80-te godini na XX vek, edited by Iskra Baeva, 197-213. Sofia: Sofia University Press, 2016.

Nachev, Nacho. Agrarniyat protektsionizam v EIO i iznosat na balgarski selskostopanski stoki. Sofia: Balgarska targovsko-promishlena palata, 1974.

Nachev, Nacho. Targovska politika na EIO kam sotsialisticheskite strani. Sofia: BTPP, 1977.

Nachev, Nacho. Otnosheniyata mezhdu SIV i EIO - vazhen faktor na evropeyskoto satrudnichestvo. Sofia: Partizdat, 1980.

Pedaliu, Effie G.H. "The US, the Balkans and détente, 1963-73." In The Balkans in the Cold War, edited by Svetozar Rajak, Konstantina E. Botsiou, Eirini Karamouzi and Evanthis Hatzivassiliou, 197-218. London: Palgrave Macmillan, 2017. 
Slavova, Petya. Georgi Naydenov i Teksim-Imekstrakom: "Komisionerska" ikonomika $i$ stopanska avtonomia prez sotsializma ot 60-te. Sofia: Ciela, 2017.

Stanoeva, Elitza. "Bulgaria's 1,300 years and East Berlin's 750 years: comparing national and international objectives of socialist anniversaries in the 1980s." CAS Working Paper Series 9 (2017): 3-40.

Stanoeva, Elitza. "Inventing the socialist consumer: worker, citizen or customer? Politics of mass consumption in Bulgaria, 1954-1960." In New perspectives in transnational history of communism in East Central Europe, edited by Krzysztof Brzechczyn, 171-98. Berlin: Peter Lang, 2019.

Stanoeva, Elitza. "Squeezed between external trade barriers and internal economic problems: Bulgaria's trade with Denmark in the 1970s." European Review of History: Revue européenne d'histoire (2019): 1-23. Accessed 7 April 2020. https://doi.org/10.1080/13 507486.2019 .1663796$.

Stanoeva, Elitza. "Exporting holidays: Bulgarian international tourism and the Scandinavian market in the 1960s and 1970s." In Tourism and travel during the Cold War: negotiating tourist experiences across the Iron Curtain, edited by Sune Bechmann Pedersen and Christian Noack, 23-46. London: Routledge, 2020.

Stanoeva, Elitza. "The imperative of opening to the West and the impact of the 1968 crisis: Bulgaria's cooperation with Denmark and West Germany in the 1960s." Margins for manoeuvre in Cold War Europe: the influence of smaller powers, edited by Susanna Erlandsson and Laurien Crump-Gabreëls, 110-29. London: Routledge, 2020.

Statisticheski Godishnik na NRB 1965. Sofia: Tsentralno statistichesko upravlenie pri MS, 1965.

Statisticheski Godishnik na NRB 1968. Sofia: Tsentralno statistichesko upravlenie pri MS, 1968.

Statisticheski Godishnik na NRB 1974. Sofia: Ministerstvo na informatsiyata i saobshteniyata, 1974.

Statisticheski Godishnik na NRB 1979. Sofia: Komitet po edinna sistema za sotsialna informatsiya pri MS, 1979.

Statisticheski Godishnik na NRB 1985. Sofia: Komitet za sotsialna informatsiya, 1985.

Vachkov, Daniel and Ivanov, Martin. Balgarskiyat vanshen dalg 1944-1989: Bankrutat na komunisticheskata ikonomika. Sofia: Ciela, 2008.

Vezenkov, Aleksander. "Institutsiyata na darzhavnia glava v Bulgaria (1944-1990). Sravnitelno predstavyane." Istorichesko badeshte 1 (2001): 129-43. 


\title{
8 Romania Turns West \\ National and international rationales
}

\author{
Elena Dragomir
}

From the late 1960s, the Romanian authorities intensified their struggle to increase exports to Western Europe, aiming to improve the state's balance of payments by accumulating hard currency. However, reducing the country's trade deficit was not an easy objective as the foreign trade sector was affected by a series of both domestic and foreign difficulties. Among the latter, the intensification of the Western integration process was perceived in Bucharest as one of the major threats to Romania's commercial interests. Different institutions and specialists were given the tasks of studying the impact of EEC protectionism on Romania's economic interests and of recommending solutions. Based on the proposals received, in the late 1960s and early 1970s Romania defined its approach to the EEC, an approach that guided its relations with the Western European states during the 1970s and beyond.

This chapter investigates Romania's openness to the West in the "long 1970s" and focuses on how the Romanian authorities prepared for the consequences of EEC integration and enlargement and the overall results of the endeavour. It addresses the period between 1968, when the Romanian authorities began to put together a strategy towards the EEC, and 1980, when for the first time since 1961 Romania registered a positive balance of trade in its relations with the EEC member states.

The subject of Romania's relations with the West is much overlooked by scholarship, which tends to focus instead on the country's relations with the Soviet Union or its so-called maverick position within the CMEA and the Warsaw Pact. ${ }^{1}$ Petre Opriş has examined specific micro-case studies of how Romania obtained industrial (civil and military) licences from various Western firms, but not the question of how the Romanian leadership conceptualised cooperation with Western states. ${ }^{2}$ Despite some progress, studies on the country's bilateral relations with different Western states ${ }^{3}$ and Western-based international organisations ${ }^{4}$ are also rather scarce, and even scarcer when it comes to Romania's approach to the Common Market. ${ }^{5}$ This chapter appraises Romania's economic approach to the EEC and the West in general in the long 1970s, a time of East-West mutual rediscovery, détente and cooperation.

\section{The foreign trade sector reconsidered in the late 1960s}

Having been defined by the communist leadership in the late 1940s, Romania's post-war national economic strategy was refined during the next decades, without, 
however, changing much in terms of its ultimate goals and main conception. Throughout the post-war era, industrialisation remained the concept at the centre of this strategy, deriving in equal measure from the leaders' ideological view of socialism and from their desire to improve people's living standard. Following Marxist-Leninist teachings, the Romanian communist leadership wanted to build a socialist state based on a dictatorship of the proletariat, 'the supreme principle of which was the alliance of the working class with the working peasantry'. It was argued that 'socialist industry and, first of all, heavy industry' constituted the main mandatory condition for building the economic base of socialism, the ultimate aim of which was to create welfare and a high standard of living for the people. ${ }^{6}$ In defining the main lines of Romania's economic development for the next five-year plan (1961-65) and for the next fifteen-year prospects programme (1961-75), the third Congress of the Romanian Workers' Party (RWP) in June 1960 envisioned 'the development of the technical-material base of socialism' and 'the continuation of the industrialisation of the country, giving priority to heavy industry and its hub - the machine-building industry'. A sixfold increase in industrial production was expected by 1975 . By the mid-1970s, Romania was to become 'a developed industrialised country with diversified and highly productive agriculture', 'ensuring living conditions for the entire people worthy of the era of socialism'?

In July 1965, the ninth Congress of the Romanian Communist Party (RCP) elected the members of the Permanent Praesidium (PP) and Nicolae Ceaușescu as secretary general of the Central Committee (CC). However, the new party leadership did not differ much from the previous one as most of its members, Ceaușescu included, had held high party and state positions during the previous leadership of Gheorghe Gheorghiu-Dej. Therefore, the general stance of the national economic strategy did not change much either, and neither did Romania's foreign policy line in general. Instead, what the new leadership proposed was better management of all economic sectors and an increase in their efficiency. ${ }^{8}$ The foreign trade sector was given special attention in the process, as it was seen as a field of 'vital importance' in the country's economic development. ${ }^{9}$ To secure industrialisation of the country, machinery and technology had to be imported and the leadership gave directives to 'create supplementary currency means in order to cover the imports necessary for the long-term development of our economy'. ${ }^{10}$ The Ministry of Foreign Trade and the Ministry of Foreign Affairs were called on not only to take measures to diversify and enlarge the country's relations with the Western European states but also to study possible membership of the GATT, the IMF and the International Bank for Reconstruction and Development (IBRD) for Romania. More specifically, they were to establish whether participation in the GATT would help overcome various export barriers and whether membership of the IMF and the IBRD would secure credits to pay for Western imports of machinery and technology. ${ }^{11}$

Confirming the party's commitment to industrialisation, the 1965 congress envisioned an increase of $40 \%$ in the volume of the country's foreign trade by 1970 together with improvement in the quality of exported goods and changes in the export structure aiming at increases in machinery, equipment and chemical 


\section{2}

product exports. ${ }^{12}$ According to Ceauşescu, foreign trade was 'one of the problems of vital importance for the economic and social development of our country' because 'most new enterprises are built with imported machinery, installations and licences'. Observing that Romania's imports exceeded its exports and that its commerce was insufficiently developed - lagging not only behind Western European states but behind all the other Eastern European states too - Ceaușescu stressed that 'evidently, things cannot continue like this' and a reform of the entire sector was needed. ${ }^{13}$

Publicly, the leadership always stressed that Romania's central foreign policy objective was friendship and collaboration with the Soviet Union and the socialist states, and criticism of the capitalist system was constant. At the same time, however, it stated that Romania was in favour of expanding its economic, technical, scientific, cultural and political relations with Western European states specifically and all the states in the world in general. ${ }^{14}$ Observing the emergence of a new global economy - a system that in the Romanian conception should be free from protectionist or discriminatory policies - the Romanian leadership considered that extending cooperation with countries in Europe, Asia, Africa and Latin America regardless of their social systems was an objective necessity in order to obtain products and raw materials Romania could not produce domestically. To raise profitability, Ceaușescu further argued, Romania had to export more highly manufactured industrial products to both capitalist and socialist states capable of providing the country with the foreign currency needed to pay for necessary imports. ${ }^{15}$

Behind the scenes, however, the Romanian authorities defined their commercial interest in the Western European states in more concrete terms, and especially their interest in the EEC members, which were seen as a main source of machinery, installations and licences and major importers of Romanian agricultural products and raw materials, and therefore sources of foreign currency.

\section{Assessing the impact of the EEC's increased protectionism}

The decision to improve the foreign trade sector coincided with a deepening of integration in the EEC, the protectionist policies of which were expected to negatively impact Romania's commercial interests and economic development. A group of experts from the Institute for Economic Research, the Institute for the Study of the International Economic Situation, the Ministry of Foreign Trade (MFT), the Ministry of Foreign Affairs (MFA), the Ministry of Finance, the State Planning Committee, and the Government Commission on Economic and Technical-Scientific Cooperation was called on to draw up solutions. In January 1968, this group of specialists issued a joint study titled 'The Common Market' on Romania's future position regarding the EEC. ${ }^{16}$

Its recommendations were based on two types of assessment. On the one hand, it observed that the EEC members were 'the most important European exporters of machinery, equipment, installations and modern technology' and that these countries 'are and will continue to be suppliers of first importance for our country'. In 1966, 30\% of Romania's imports of industrial products originated in the 
EEC, and $51 \%$ of these imports were investment goods and means of transport. Moreover, at the time Romania's exchanges with the EEC represented $20 \%$ of its total foreign trade and $51.5 \%$ of its trade with capitalist states. On the other hand, the study argued that due to the forthcoming implementation of the EEC's Common Commercial Policy (CCP), 'the negative effects of the discriminatory policy of the Common Market on non-members, including on those with developed economies, will become increasingly bigger', creating barriers and discrimination against Romania's exports to the Western European states. Looking at how other countries prepared to respond to further EEC integration, the joint study observed that Yugoslavia, Poland and Czechoslovakia were using their membership of GATT to 'decrease discrimination by the Common Market'. ${ }^{17}$

Arguing that increasing economic and technical-scientific relations with the EEC member states was mandatory for Romania's economic development, the study formulated a series of proposals structured at three main levels. The first level envisioned direct contacts with EEC institutions in parallel with bilateral negotiations with each EEC member state. However, direct contacts with the EEC might imply diplomatic recognition, which was seen as a delicate political matter, since 'until now, the socialist states have formally declared that they do not recognise the Common Market'. This led to the second level of how the CMEA would affect Romania's EEC-related interests and how Romania's approach to the EEC would affect its relations with the other socialist states, and especially with the Soviet Union. The third level envisioned using other international organisations and particularly the GATT to obtain better conditions for Romania's trade with capitalist states. $^{18}$

The study also proposed concrete measures to secure the country's commercial interests in the EEC. Observing that $85 \%$ of Romania's exports to the EEC consisted in raw materials, fuels, foodstuffs and non-manufactured goods, it recommended an increase in exports of industrial products and manufactured goods. However, a handwritten annotation by the State Planning Committee emphasised that these products were not qualitatively fit for the EEC market. ${ }^{19}$ Exporting more industrial goods to Western states (or even to other CMEA states) was a task often mentioned by Romanian officials, ${ }^{20}$ but given the inferior quality of these products the results of Romania's intensified industrialisation were mainly exported to "third-world" developing countries and not to industrialised capitalist countries.

Other measures envisioned establishing official technical contacts with EEC institutions following the examples of Poland and Yugoslavia, agreements on agricultural products and sending Romanian experts to Brussels to gather information on how the EEC worked and how other third countries were dealing with it. ${ }^{21}$

Following the guidelines drawn up in the 1968 joint study, the MFA, the MFT, the Ministry of Finance and the State Planning Committee recommended Romania participating in the GATT on the ground that it would facilitate exports of 'Romanian products to the capitalist developed countries, especially to those participating in economic groupings' ${ }^{22}$ The PP approved this recommendation on 26 February, and in July Romania applied to the GATT. ${ }^{23}$ The same month, the MFT 
appointed Andrei Șerban as delegate to the Romanian commercial agency in Brussels and instructed him to "carry out frequent unofficial contacts of a technicalinformative character with officials in various competent bodies of the Executive Commission of the Common Market'. ${ }^{24}$

Furthermore, in connection with a series of proposals advanced by the Romanian embassy in Rome, the MFA tackled and solved the problem of whether establishing direct contacts with EEC institutions would imply official recognition of the EEC and what the political implications would be for Romania. In a note to the MFA in June 1968, Romania's ambassador in Rome, Cornel Burtică, ${ }^{25}$ observed that given the way the EEC worked, concluding bilateral agreements with EEC members would no longer be possible. Burtică further argued that a solution for Romania could be to conclude technical agreements on products with the EEC Commission, as Poland and Bulgaria had already done. ${ }^{26}$ In response to Burtică's suggestion, the MFT studied the agreement that Poland had concluded on 24 April 1968 with the EEC Commission regarding the non-fixing of an additional amount of imports of live swine and pig carcasses from Poland. Worrying that concluding this type of agreement with the EEC Commission could have political implications and could involve official recognition of the EEC, the MFT asked the MFA for its opinion on the matter. ${ }^{27}$ Responding, the MFA provided the main arguments that Romania would use during the next decades to explain its decision to carry out direct contacts with the EEC to its CMEA partners. Observing that the Common Market was 'an entity, an objective reality' with specific competences in terms of foreign trade, the MFA argued that 'establishing relations with the institutions of the Common Market only targets the commercial field and not the political field and even less so the ideological one'. Considering the imminent implementation of the EEC Common Commercial Policy, the MFA further argued that 'third countries cannot avoid contacts with the institutions of the Common Market' - where contacts were defined in terms of commercial relations - unless they were willing to risk stopping their trade with the EEC zone completely. Therefore, the MFA recommended concluding agreements with the EEC on various agricultural products following the Polish example. ${ }^{28}$ The proposal was approved by the PP and agreements on eggs, swine, pork, cheese, beef, sunflower oil and wine were discussed and concluded. ${ }^{29}$ These agreements followed the examples set by Poland and Hungary and took the form of exchanges of letters. They were concluded by the Ministry of Agriculture and Forestry and the Ministry of the Food Industry, not by the MFT or the local embassy, in order to keep them at the level of 'technical unofficial contacts'. 30

In preparing its approach to the EEC, Romania paid special attention to the position of the CMEA. In 1963, the CMEA member states had agreed that establishing contacts with the EEC was not timely and that the question of recognising the EEC could be re-analysed in the future if necessary. ${ }^{31}$ The Romanian authorities now questioned whether this position would prevent them from establishing direct contacts with the EEC institutions. The Government Commission on Economic and Technical-Scientific Cooperation argued that the CMEA's position involved simple mentions and not official resolutions and so could not constitute 
an obstacle of a juridical nature able to prevent Romania from adopting whatever approach it considered appropriate to the EEC. ${ }^{32}$

Formulated in November 1970, the approach drew heavily on Romania's general strategy for economic development and foreign trade. The tenth Congress of the RCP (6-12 August 1969) stated that socialist industrialisation and particularly the development of heavy industry remained the basis for the general progress of society and the welfare of the people. Romania planned to reach production of 10 million tons of steel and 2.4 million tons of chemical fertilisers by 1975 . Improving foreign trade was conceived as a condition for achieving industrialisation, while the development of relations between countries with different social systems was seen as an expression of the economic and social reality of the time, in which 'the world is in full transformation'. ${ }^{33}$

These party directives were followed by new legislation, procedures and rules aimed at securing Romania's transformation into an advanced industrialised country with an efficient foreign trade sector able to provide imports of Western machinery and technology without creating a deficit in the country's balance of payments. Exporting more Romanian products to foreign (including Western) markets and obtaining foreign credits were two key pillars of Romania's economic strategy at the time. ${ }^{34}$ However, by the end of 1969 , Romania saw all these plans potentially jeopardised by the imminent implementation of the EEC Common Commercial Policy and EEC enlargement.

\section{Romania's strategy towards the EEC: expectations}

Romania's strategy towards the EEC was officially adopted in February 1971. The EEC allowed its member states to negotiate bilateral agreements valid until 31 December 1974 with third countries before the end of 1972. Romania responded to the EEC policy in three main steps. First, it designed a strategy that encompassed practical measures to deal with the EEC and its member states until 31 December 1972. Then, it adopted a policy that dealt with Romania-EEC relations until 31 December 1974. Finally, in late 1974 it defined its stance towards the EEC for the period after 1 January 1975. The differences between these three stages lay in some very pragmatic actions taken in response to EEC policies. What gave them consistency was that they all derived from the same general conception of Romania's approach to the EEC.

\section{The 1970 to 1972 period}

In early 1970, the MFT asked the Romanian embassy in Brussels and its Economic Agency to draft a note on the negative effects of EEC policy on Romania's trade and to propose solutions. Drawn up by Ștefan Niţă, the chief of the agency, and S,erban Andrei, the economic secretary, the note reflected 'the point of view of the entire operative staff of the embassy and agency'. ${ }^{35}$ In fact, it was a very detailed study on the matter. It observed that the EEC member states had lost their commercial competences in relation to third countries, which reacted by 
concluding with the EEC association agreements (Greece and Turkey), partial association agreements (Morocco and Tunisia), preferential commercial agreements (Spain and Israel) and agreements on products or commercial agreements (Yugoslavia). Therefore, it argued that Romania's foreign trade was affected not only by EEC protectionist measures but also by the network of agreements and arrangements it had established with other third countries which now benefited in one way or another from preferential treatment. The EEC enlargement to the UK, Ireland and Denmark was also perceived as a threat to Romania's interests. ${ }^{36}$

The study suggested a series of practical measures to secure the export of Romanian goods, such as adapting to EEC demands, improving the quality of goods, establishing joint production units with EEC-based firms, increasing technical and industrial cooperation with EEC countries, searching for other markets for Romanian products that were not in demand in the EEC, establishing production units in countries that had association agreements with the EEC, concluding new agreements on agricultural products (particularly beef) and studying the possibility of concluding a government agreement with the EEC and its political implications. These measures, the study contended, could reduce the negative impact of EEC policies on Romania's trade to some extent but would not eliminate it completely. ${ }^{37}$

As Ceauşescu publicly and repeatedly admitted, Romania had taken measures to reduce its balance of payments deficit, but despite some improvements the value of imports still surpassed the value of exports. ${ }^{38}$ Therefore, Romania began taking credits from the West. Visiting Moscow in May 1970, the Romanian leadership was harshly criticised for 'reorienting Romania's economic relations towards the West', as Ceaușescu narrated it. Brezhnev tried to convince Ceaușescu to revise his foreign trade policy, to limit imports from capitalist states and to be more careful about taking Western loans. The Soviet leader reasoned that Romania would not be able to pay back its loans, would suffer an increase in the deficit of its balance of payments and would end up asking the Soviet Union for financial and economic support. Ceauşescu rejected such pessimistic interpretations and remained committed to the idea of increasing commercial and financial relations with the Western states. ${ }^{39}$ The same year, the General Secretariat of the Council of Ministers asked the MFA, the MFT and the National Bank to study possible Romanian adherence to the IMF and the IBRD. ${ }^{40}$

In July 1970, another study on the EEC by the embassy in Brussels signed by Niță, Andrei and ambassador Alexandru Lăzăreanu observed that most third countries were not focusing on whether the EEC should be diplomatically recognised but on convincing the EEC to accept commercial negotiations and grant export concessions. It suggested that Romania should follow the same path. Analysing the CMEA dimension, it stressed that the socialist states were not affected equally by EEC protectionism. Regarding Romania's possible juridical framework for relations, the study argued that concluding technical agreements on products was a limited solution, as they could only address a limited number of products which was almost exhausted and that a non-preferential agreement like the one concluded by Yugoslavia could be the solution. ${ }^{41}$ Noting that the "Common Market 
tends to evolve towards consolidation and not towards weakening' and that its protectionist measures had 'an irreversible character', the Romanian embassy in Brussels argued that Romania should approach the EEC at two levels: through bilateral contacts with EEC member states and through direct contacts with its institutions. ${ }^{42}$

Synthesising information, reports and studies gathered through different channels during the previous years, in November 1970 the MFT and the MFA drew up an eight-page joint document on 'Our Country's Strategy in its Economic Relations with the Common Market'. ${ }^{43}$ The document was signed by Cornel Burtică, now minister of foreign trade, Corneliu Mănescu, minister of foreign affairs, ${ }^{44}$ and Ion Pățan, vice president of the Council of Ministers. ${ }^{45}$

Romania's strategy towards the EEC derived from the party's general conception of its national economic development. Aiming to increase commercial relations between Romania and the Western states, the strategy envisioned three main points: direct relations with the EEC institutions in parallel with bilateral relations with EEC member states; using other international organisations to support Romania's EEC-related objectives; and preventing the CMEA from having a negative impact on Romania's objectives regarding the EEC. Thus the strategy was that establishing contacts with the EEC institutions did not require recognition of the organisation; that Romania should use the GATT and the UNCTAD to obtain better trade conditions with the EEC member states; and that Romania needed to inform the CMEA of its approach to the EEC (as previously agreed at the CMEA level) and to abstain in the future from accepting any CMEA policy that might affect Romania's EEC-related interests, such as agreeing not to conclude commercial agreements with the EEC or not to recognise the EEC. The practical measures identified in the 1970 strategy envisioned bilateral consultation with EEC member states and institutions; unofficial visits by EEC officials to Romania; authorising Romanian diplomats in Brussels to establish unofficial contacts with representatives of the EEC Commission; increasing the quality of the goods exported to the EEC; creating joint production units with EEC-based firms; adapting exports to EEC demand; concluding agreements on agricultural products; acting within the UNCTAD to obtain customs preferences from the EEC; and drawing up studies on the EEC and recommendations on Romania's approach to it. ${ }^{46}$

After being approved by the Permanent Praesidium of the party on 22 February 1971 , the strategy was rapidly put into practice. ${ }^{47}$ Unofficial bilateral consultations with representatives of the EEC Commission were organised both in Romania and in Brussels to discuss better conditions for Romania's exports. ${ }^{48}$ One of the questions addressed during these talks was Romania's admission to the EEC's Generalized Scheme of Preferences (GSP). ${ }^{49}$ The MFA continued to ask its representatives abroad to gather information and report on EEC evolution and its relations with third countries 'in order to substantiate possible actions that might be taken' by the Romanian side. ${ }^{50}$ The MFA argued that the EEC had become 'the first commercial power and the second economic power' in the world. As other states were likely to join the EEC, its influence and role as a world power were expected to grow, not only economically but also politically. ${ }^{51}$ 
In a study in July 1971, the MFT identified concrete problems that Romania needed to solve: obtaining better trade conditions and being accepted in the EEC's GSP; designing a programme of cooperation with the EEC; and creating a joint Romania-EEC commission to address problems of mutual interest. The study concluded that Romania needed to start negotiating with the EEC as an entity. ${ }^{52}$

Measures were also taken to prevent the CMEA from frustrating Romania's EEC-related goals. Therefore, Romania blocked a proposal to include a stipulation regarding official non-recognition of the EEC in the CMEA's 'Comprehensive Programme' adopted in July $1971 .{ }^{53}$ Its opposition was grounded on the fact that the 'Comprehensive Programme' 'is long-term and it is not excluded that in the future our interests will require another tactic'. ${ }^{54}$ In October 1971, Romania put the problem of CMEA-EEC relations on the Council's agenda. Contending that the commercial aspects of relations could no longer be addressed bilaterally and that EEC protectionism was negatively impacting the commercial interests of the socialist states, Gheorghe (Gogu) Rădulescu, Romania's permanent representative at the CMEA, argued that the EEC as an entity had to be approached at two levels: by each individual CMEA member state on the one hand and by the Secretariat of the Council on the other. The latter should address general aspects of relations in order to create a favourable framework for the improvement of relations between the CMEA member states and the EEC institutions. ${ }^{55}$

As Suvi Kansikas has demonstrated, this proposal resulted in considerable contradictory debates at the CMEA level. The problem was even referred to the Political Consultative Committee of the Warsaw Pact in January 1972, but there were no results. ${ }^{56}$ As the controversy continued, Romania's representative insisted that contacts with the EEC institutions would not imply official recognition of the EEC as they only occurred at the level of economic-commercial relations. Romania insisted that exchanges between the CMEA member states and the EEC should be increased. ${ }^{57}$ Instead, the Soviet Union proposed reducing them, arguing that in this way the economic vulnerability of the socialist states to EEC protectionism would decrease. ${ }^{58}$

Being committed to the national objective of increasing foreign trade in general, and observing that 'the Common Market is a reality', following previous recommendations by specialists and diplomats the Romanian leadership decided that 'some problems, such as that regarding generalised customs preferences, should be discussed with the [EEC] institutions that can make a decision on the matter' as Ceaușescu publicly acknowledged. ${ }^{59}$ According to the Romanian leader, 'we consider it necessary to develop commercial contacts with the EEC in order to favour an increase in exchanges and cooperation with all countries that are members of this organisation' ${ }^{60}$

On 31 January 1972, in a letter addressed by Foreign Trade Minister Cornel Burtică to Gaston Thorn, the president of the EEC Council of Ministers, Romania requested admittance to the EEC's GSP. ${ }^{61}$ To support its request, Romania presented statistical data regarding its economic development. ${ }^{62}$ Initially, France opposed, arguing that Romania was not a developing country and that granting it generalised preferences could create a dangerous precedent. ${ }^{63}$ Gradually, however, 
France reviewed its position. ${ }^{64}$ Moreover, Romanian officials intended to use the GATT framework to obtain better trade relations with the EEC members and compensation for the damage that EEC enlargement did to its trade interests. Romania had been a member of the GATT since October 1971, a mandatory preliminary condition for qualifying for the EEC's GSP. ${ }^{65}$ According to Ion Gheorghe Maurer, Romania's prime minister, ${ }^{66}$ benefiting from the EEC's GSP 'with the same conditions as the other developing countries in the Group of 77' was 'one of the major problems for the future orientation of Romania's commercial exchanges' and had 'major political-economic importance'. ${ }^{67}$ In November 1971, the MFA was instructed to take diplomatic actions to secure Romania's membership of the G-77, the largest intergovernmental organisation of developing countries in the UN. ${ }^{68}$

Romanian adherence to the IMF and the World Bank was further explored as another route to solving foreign trade and economic development problems. According to the Ministry of Finance, the foreign currency collected from exports was mostly used to pay for the amortisation of loans contracted in the West for buying Western equipment and installations on credit, "which restricts our import possibilities, forcing us to take new credits'. The reimbursement difficulties originated in the fact that Romania had contracted mostly short-term loans. Contracting long-term loans from the IMF and the IBRD was thought to be the solution. ${ }^{69}$ In December 1972, Romania joined the IMF and the IBRD, from which the Romanian authorities hoped to obtain advantageous loans to support imports of Western machinery and technologies. ${ }^{70}$

Brezhnev continued to warn Ceauşescu that importing and taking credits from the West would create major economic problems for Romania: 'I want to tell you as a friend, so you will pay attention. You will have to pay a lot of interest for this money'. Ceaușescu argued that 'we will manage because we took measures'. At the same time, Brezhnev insisted that the USSR could no longer supply the increasing quantities of raw materials and fuels requested by the Eastern European states. Ceaușescu reiterated that Romania would find them in other countries. ${ }^{71}$ Needing large quantities of oil (especially for its chemical industry), Romania had started to import from Iraq, Lebanon, Syria and Iran. ${ }^{72}$ According to Ceaușescu, the shortage of energy resources was a fundamental problem for Romania's economic and social development not only in the short term but also in the long term. ${ }^{73}$ In the aftermath of the October 1973 oil crisis, Romania adopted legislation designed to rationalise the consumption of fuels and primary energy resources. Industry and particularly the chemical industry were given priority, while all economic sectors (industry, agriculture, transportation and construction) were requested to use all energy sources more judiciously. However, the population was the most affected. ${ }^{74}$

\section{The 1973-74 period}

In 1973, in another study on the Common Market, MFT experts identified four objectives for Romania's relations with the EEC: to receive generalised 
preferences; to obtain the elimination of the quantitative restrictions applied to its exports; to be granted concessions for its exports of agricultural products; and to be compensated for the losses it incurred after the enlargement of the EEC. ${ }^{75} \mathrm{On}$ the basis of this study, the MFA and the MFT elaborated a concise 'Note on Proposals Regarding Romania's Strategy in Its Relations with the Common Market (EEC)', which was signed by Ion Pățan, vice president of the Council of Ministers and minister of foreign trade, and George Macovescu, ${ }^{76}$ minister of foreign affairs. ${ }^{77}$ The note confirmed previous Romanian analyses and argued that, with a $36 \%$ share of world commerce, the EEC was 'the biggest commercial entity' and an increasing number of third countries adopted active policies towards it, either by concluding association agreements, commercial agreements or free trade agreements or by asking for generalised preferences. Thus, 'an enlarged system of preferential relations' was created, from which only the developed capitalist states (the US, Japan, Canada, Australia, New Zealand and South Africa) and the socialist states with the exception of Yugoslavia were excluded. It was expected that new EEC common policies would produce even greater negative effects on Romania's trade interests. New solutions were needed to secure generalised preferences and a juridical framework to allow commercial exchanges between Romania and the EEC members after 31 December 1974, when the existing bilateral agreements expired. The note recommended continuing diplomatic actions to obtain generalised preferences, asking for preferences from other donating countries (Finland, Norway, Sweden and Switzerland), obtaining better trade conditions for products excluded from the GSP (i.e. chemical fertilisers, footwear, textiles, clothing, petroleum and steel products), obtaining through the GATT compensation for losses suffered as a result of EEC enlargement and acting to attract more advantageous credits. ${ }^{78}$

The Permanent Praesidium approved this proposed strategy with two indications: 'to act' and 'to insist' on obtaining generalised preferences and to conclude long-term commercial agreements with the EEC member states with the possibility of prolonging them. ${ }^{79}$ In accordance, the Romanian representatives abroad approached representatives of the EEC member states and proposed long-term bilateral agreements on economic, industrial and scientific collaboration on the one hand, and bilateral commercial protocols regarding Romania's exports for the year 1974 on the other. This approach was based on the observation that agreements on economic cooperation were still in the competence of the EEC member states. It was hoped that commercial stipulations could be included in long-term agreements on economic, scientific and technical cooperation, thus bypassing the authority of the EEC, ${ }^{80}$ an approach common to that of other Eastern European states.

The Romanian officials in Brussels, and especially the group responsible for EEC problems, were instructed to draw up monthly and quarterly analyses of the EEC's evolution, procedures, policies, relations with third countries and positions in different international organisations such as the GATT, the UNCTAD and the IMF, and also on 'the experience of other countries' in dealing with the EEC. They were asked to formulate concrete proposals to establish a 'juridical framework 
necessary to achieve our programmes regarding the development of commercial exchanges and economic cooperation with the member countries of the Common Market'. 81

The 1973 strategy did not propose a new general conception of EEC relations but only new concrete actions. In an interview with a group of British journalists in November 1973 which was also published in Romania, Ceaușescu presented Romania's approach to the EEC as follows:

We start from the fact that the existence of the Common Market is a reality and, therefore, we develop relations with its countries. We also try to solve some problems directly with the Common Market, especially regarding obtaining tariff preferences and the elimination of some restrictions that are established and applied by the Common Market in its relations with other states. . . . We would like the Common Market to practise an open policy, to lift the barriers and restrictions that prevent free collaboration, at least in Europe. Romania has reached some agreements [with the Common Market] and we hope that they will be applied with the best conditions, especially with regard to granting generalised tariff preferences, which will contribute to the broadening of economic collaboration with the countries of the Common Market. ${ }^{82}$

The March 1973 strategy guided Romania's relations with the EEC until the end of 1974. It derived from the observation that commercial relations with Western European states - deemed absolutely necessary for Romania's general development could only be established through direct contacts with the EEC Commission. Therefore, a remarkable diplomatic effort was made to convince the EEC member states to support Romania's request to be included in the GSP. ${ }^{83}$ These efforts paid off. On 4 July 1973, the EEC Council of Ministers decided to grant Romania generalised preferences. ${ }^{84}$ This led to the creation in July 1973 of a 'Party and State Commission Regarding Problems in Economic Relations between Romania and the Common Market' under the leadership of Ion Pățan, the new minister of foreign trade, and George Macovescu, minister of foreign affairs. ${ }^{85}$ In the following months, technical discussions between experts from the two sides confirmed that products such as chemical fertilisers, footwear, textiles and clothing, petroleum and steel products would not be included in the GSP. The EEC Commission argued that special arrangements regarding exports of Romanian textiles, oil and steel products could be addressed separately. ${ }^{86}$ According to estimations in Bucharest, if such 'sensitive' products were left out of the GSP, then only $11 \%$ of Romania's exports to the EEC would benefit from customs preferences, which meant that the facilitations thus received would be 'insignificant' ${ }^{87}$ Although the country was included in the GSP as of 1 January 1974, the agreement was only applied to a limited number of agricultural products. During the next years, Romania would try in vain to obtain the inclusion of new products in the scheme. ${ }^{88}$

Romania also tried to receive tariff compensation for losses due to EEC enlargement. In July 1973, it joined the group of other third countries that were 
negotiating on this matter with the EEC in the GATT framework. ${ }^{89}$ In December 1973, the EEC delegation made a global offer of tariff reductions, which Romania accepted in April 1974. Moreover, as a result of negotiations with the EEC member states, it obtained prorogation of the 1973 commercial protocols for another year. It also signed long-term agreements on economic, industrial and technical cooperation with Italy and France. ${ }^{90}$

The March 1973 note also suggested that Romania should not agree with the idea that the problem of the juridical framework for commercial exchanges between the CMEA member states and the EEC should be solved through a CMEA-EEC agreement. Romania wanted to solve its problems through direct contacts with the EEC..$^{91}$

At the CMEA level, the Romanian officials took two approaches: first, they acted to prevent the adoption of any EEC-related policies that might prevent Romania from acting as it saw fit in its relations with the EEC; second, they tried to use the CMEA to create a more favourable general framework for direct contacts between the CMEA member states and the EEC as an entity. Romania's representatives argued that, in parallel with CMEA-EEC contacts, each CMEA state had the right to contact the EEC independently and to negotiate and conclude agreements with it, that the CMEA could only address matters in its competence with the EEC and not matters in the competence of its member states, and that a CMEA common commercial policy towards the EEC could not be adopted as the CMEA member states had different national conditions and different trade interests. ${ }^{92}$ These positions were also made clear to the EEC members, emphasising that any CMEA-EEC agreement that might be reached could not affect relations that Romania might decide to have with the Community. ${ }^{93}$

\section{The strategy for after 1 January 1975}

All the measures Romania took to improve its commercial relations with the EEC produced positive results, but the overall impact was not what the Romanian authorities had hoped for. Romania continued to export mainly agricultural products, foodstuffs and light industry products to the EEC, which increased its vulnerability to EEC protectionist policies. The GSP was applied to a reduced list of goods. Negotiations carried out with France, Benelux and the UK exposed their reluctance to include commercial stipulations in long-term agreements on economic, scientific and technical cooperation. ${ }^{94}$

Thus, as the date of 31 December 1974 was approaching, the MFA and the MFT drew up yet another document regarding strategy towards the EEC on the basis of a June 1974 study by the MFT called 'New Forms of Romania's Commercial Relations with the Countries of the Common Market'. The previous general line was maintained, but more careful attention was paid to the CMEA's attitude to the EEC, observing that the EEC's proposal regarding the conclusion of trade agreements between the Community as an entity and each CMEA member state had been rejected, and that despite Romania's different position the CMEA member states had decided that the Secretariat of the Council should seek to negotiate 
a commercial agreement with the EEC. Instead, Romania wanted to be able to address its commercial problems directly with the EEC. The 1975 policy towards the EEC was a confirmation of the previous strategy. It proposed exploratory talks with experts from the EEC Commission in parallel with bilateral consultations with the EEC member states and using GATT to promote Romania's interests in the EEC, a special emphasis being placed on negotiating a textile agreement with the EEC within the multi-fibre GATT agreement. ${ }^{95}$ This strategy was to guide Romania's relations with the EEC until the end of the 1970s and beyond.

It was also consistent with the directives that the 11th Congress of the RCP of 25 November 1974 drew up for Romania's economic development in the next five-year plan (1976-80) and the next fifteen-year prospects program (1976-90). At the centre of the RCP's economic policy remained the development of industry, and especially of the machine-building and chemical industries, two sectors that were required to produce half of the country's global industrial production by 1980. In the party's conception, the economic development of the country would raise the living standard of the whole population and was based on accomplishing socialist industrialisation on the one hand and on developing economic relations with other states on the other. It contended that Romania's 'external economic relations and its cooperation with other states represent a significant factor in the economic progress of the country'. Moreover:

In the development of its foreign trade and international economic cooperation, Romania starts from the imperative of its participation as actively as possible in the world economic circuit as an objective necessity of the accelerated increase in the national economy for the progress of Romanian society. The 1976-1980 plan will target an increase in foreign trade, an improvement of its structure and an enlargement of international cooperation in production, technology and science. We will act with determination so that, in parallel with increasing the volume of foreign trade, an equilibrated balance of payments can be realised, simultaneously increasing the foreign currency reserves of the country. ${ }^{96}$

Special attention was paid to the country's relations with capitalist developed states. By 1980, exports of the products of the machine-building and chemical industries had to increase to $50 \%$ of the country's total exports. Romania was still interested in importing fuel, raw materials, machines, equipment and installations. The measures envisioned to achieve these goals involved increasing the quality of the goods produced for export to make them competitive in foreign markets, concluding long-term contracts with foreign partners, adapting exports to the demand in foreign markets and reducing the volume of imports to what was 'strictly necessary, on the basis of judicious use of foreign currency funds'. Economic units and ministries were instructed to take measures to secure from their exports the foreign currency funds necessary to cover their import needs. ${ }^{97}$

The general conception was that the economic and social progress of the country depended to a great extent on the 'objective necessity' of the enlargement 
of its economic exchanges and cooperation with other states, including Western states. ${ }^{98}$ However, the EEC's exclusive competence in relation to trade with third countries and the CMEA attempt to adopt a common commercial policy towards the EEC were seen in Bucharest as threats to Romania's trade interests and economic development in general.

In June 1975, at the 44th session of the CMEA's Foreign Trade Permanent Commission, all the members except Romania proposed to conclude a commercial agreement between the CMEA and the EEC as entities. ${ }^{99}$ The Romanian authorities considered that the proposal was unacceptable for two main reasons: it was based on an 'intention to prove' that CMEA integration 'was a reality', and it aimed to 'give the CMEA - deviating from the CMEA statute - competences in the commercial field similar to those given to the Common Market through the Treaty of Rome'. ${ }^{100}$ The RCP confirmed Romania's 'position of principle' towards the conclusion of a CMEA-EEC agreement as previously defined. Ceauşescu insisted that the Romanian delegates at the CMEA should inform the other participants of Romania's intention to establish immediate and direct contacts with the EEC institutions. ${ }^{101}$ A similar declaration had already been made by the Romanian delegation at the CMEA meeting mentioned earlier, when the other participants had been informed that Romania would contact the EEC institutions 'in the next period' to 'analyse concrete ways to eliminate discrimination and other obstacles against Romanian exports, and problems regarding the juridical framework for commercial exchanges'. ${ }^{102}$ The CMEA's Executive Committee was also notified in writing of Romania's intention to establish contacts with the EEC institutions. ${ }^{103}$

During the next years, Romania continued to hold its position vis-à-vis the CMEA. ${ }^{104}$ Throughout the 1970 s, Romania acted to prevent the adoption of any CMEA decision or any CMEA-EEC agreement that had the potential to affect the national trade competences of CMEA member states regarding the EEC. The Romanian authorities did not trust the CMEA allies or the CMEA as an entity to made decisions on their behalf. They feared that a CMEA-EEC agreement would secure the interests of the great powers to the detriment of the interests of the small states. Therefore, Romania put much effort into solving its EECrelated problems through direct negotiations with the EEC institutions. In 1979, Ceaușescu publicly confirmed Romania's interest in concluding direct agreements with the EEC. ${ }^{105}$

\section{Key achievements and failures}

From 1975 onwards, trade between the Eastern European states and the EEC states took place within a juridical framework consisting of three main sets of rules: those stipulated in international and bilateral agreements; those adopted unilaterally by the EEC; and those included in bilateral cooperation agreements. While not being commercial in themselves, these arrangements were used to some extent to circumvent EEC trade policy, stipulating, for instance, the lifting of quantitative restrictions on specific goods, preferential arrangements for imports and exports and customs clearance in connection with their implementation. ${ }^{106}$ In 
this general framework, Romania's relations with the EEC followed the position established in the previous years along three main lines: conducting direct negotiations with the EEC institutions on matters in its competence in parallel with bilateral relations with the EEC member states; using various international organisations (such as the IMF, the IBRD, the UNCTAD and especially the GATT) to obtain better trade conditions and loans; and preventing the CMEA from having a negative impact on its EEC-related objectives.

As bilateral trade agreements with EEC states expired and could not be renewed, from 1975 onwards Romania signed long-term cooperation agreements on economic, scientific, industrial and technical cooperation. In some cases, such as those with Italy, West Germany, the Netherlands and the Belgium-Luxembourg Economic Union, these agreements granted Romania most favoured nation status. ${ }^{107}$

In matters that were in the EEC's competence, the Romanian authorities continued to deepen their contacts with the EEC institutions. The EEC member states were still considered an important source of industrial imports, technology and foreign loans, and an outlet for Romania's exports of agricultural products, foodstuffs and raw materials. ${ }^{108}$ Romania continued to export foodstuffs under provisions in the technical agreements negotiated with the EEC Commission on products such as pork, beef, cheese and wine, and annually asked for improved export conditions, which were often granted. ${ }^{109}$ Participation in the EEC's GSP also had a positive impact on Romania's exports. In 1975, the EEC had a share of $71.7 \%$ in the exports that Romania made via the preferential system. The remaining $28.3 \%$ represented exports to other developed capitalist states that had granted Romania customs preferences prior to $1975 .{ }^{110}$ A 1978 MFA and MFT joint note appreciated that being granted customs preferences 'had a favourable influence on Romania's exports, resulting first of all in additional foreign currency for our country'. As a member of the G-77 since 1976, Romania asked the EEC for the same type of trade concessions that were granted to any other developing countries and the extension of customs preferences to a series of Romanian products that were excluded from the GSP (textiles, chemicals and furniture). These requests were denied, mostly due to opposition from the UK, France and Italy. ${ }^{111}$

During 'official exploratory talks' with representatives of the EEC Commission in July 1977, Romania proposed concluding sectoral agreements regarding its exports of industrial products (including steel) and agricultural products, an agreement on fishing and another on access to loans from the European Investment Bank. The EEC representatives responded that agreements on fishing and agricultural products were not possible, and neither was Romanian access to loans. Contending that 'sectoral agreements would not solve all the problems of mutual interest in a unitary way', they argued in favour of a general commercial agreement as in the EEC's 1974 proposal. ${ }^{112}$ However, Ceaușescu was of the opinion that 'there is no question now of a general agreement' with the EEC. ${ }^{113}$

Negotiations with the EEC were unsuccessful with regard to sectoral agreements on agricultural products and arrangements for fishing, transport and financial cooperation, but successful with regard to sectoral agreements on textiles, steel and industrial products. In 1976, Romania was the first Eastern European 
country to conclude an agreement with the EEC regarding its exports of textiles on the basis of the GATT multi-fibre agreement. This one-year sectoral agreement was followed in 1978 by another long-term arrangement covering the period up to 1982. ${ }^{114}$ On 31 May 1978, an agreement on Romania's exports of steel products to the EEC market entered into force. Renewed annually, it provided the conditions on which Romanian steel products had access to the EEC market in terms of prices and quantities. According to a joint MFT and MFA note in December 1978, concluding sectoral agreements with the EEC was Romania's solution to the problem of the juridical framework for its commercial relations with the EEC member states. ${ }^{115}$ In July 1978, Romania proposed to conclude an agreement on industrial products (other than textiles and steel) with the EEC and another regarding the creation of a Joint Romania-EEC Commission to address the problems of trade relations. The two proposed agreements were signed on 28 July 1980 and entered into force on 1 January $1981 .{ }^{116}$ Until the end of the decade, Romania remained the only Eastern European country with an industrial agreement and a Joint Commission with the EEC.

In this context, the value of Romania's commercial exchanges with the EEC constantly increased throughout the 1970s, with a slight decrease in 1975 when the CCP entered into force (Table 8.1) ${ }^{117}$ In 1976, the main group of imported goods was machinery and equipment. Fuels, raw materials, metals, industrial consumer goods and agricultural raw materials represented $84 \%$ of Romania's total exports to the EEC. ${ }^{118}$ Exporting petroleum products to the EEC member states was important in the 1970s (Table 8.2). ${ }^{119}$ However, these exports depended on imports of crude oil. From 1976, Romania was a net importer of oil and by the end of the decade it relied heavily on Middle Eastern oil, especially from Iran. ${ }^{120}$

Table 8.1 The evolution of Romania-EEC commercial exchanges, 1970-1984 (in million US dollars)

\begin{tabular}{lcccl}
\hline Year & Total & Exports & Imports & Trade balance \\
\hline 1970 & 938 & 449 & 487 & -38 \\
1971 & 1084 & 513 & 551 & -38 \\
1972 & 1334 & 630 & 704 & -74 \\
1973 & 1797 & 842 & 955 & -113 \\
1974 & 2369 & 1026 & 1343 & -317 \\
1975 & 2330 & 1060 & 1270 & -210 \\
1976 & 2546 & 1286 & 1278 & +8 \\
1977 & 2611 & 1204 & 1407 & -203 \\
1978 & 3315 & 1441 & 1874 & -433 \\
1979 & 4654 & 2214 & 2440 & -226 \\
1980 & 4838 & 2460 & 2378 & +82 \\
1981 & 3937 & 2041 & 1896 & +145 \\
1982 & 2773 & 1734 & 1039 & +695 \\
1983 & 2410 & 1621 & 789 & +832 \\
1984 (9 months) & 2702 & 2129 & 573 & +1556 \\
\hline
\end{tabular}

Source: ANIC, CC of RCP, Economic Section, File 387/1984, 16. 
Table 8.2 The evolution of Romania's exports to the EEC, 1973-1983 (in million US dollars and percentages)

\begin{tabular}{lcclll}
\hline Year & $\begin{array}{l}\text { Total } \\
\text { exports }\end{array}$ & $\begin{array}{l}\text { Exports of } \\
\text { petroleum } \\
\text { products }\end{array}$ & $\begin{array}{l}\text { Exports of } \\
\text { non-petroleum } \\
\text { products }\end{array}$ & $\begin{array}{l}\text { Share of exports } \\
\text { of non-petroleum } \\
\text { products in total } \\
\text { trade (\%) }\end{array}$ & $\begin{array}{l}\text { Share of exports } \\
\text { of petroleum } \\
\text { products in total } \\
\text { exports (\%) }\end{array}$ \\
\hline 1973 & 842 & 52 & 790 & 93.8 & 6.2 \\
1974 & 1026 & 191 & 832 & 81.0 & 19.0 \\
1975 & 1060 & 198 & 862 & 71.1 & 28.9 \\
1976 & 1286 & 307 & 979 & 76.1 & 23.9 \\
1977 & 1204 & 203 & 1001 & 83.1 & 16.9 \\
1978 & 1441 & 281 & 1160 & 80.4 & 19.6 \\
1979 & 2214 & 850 & 1364 & 61.6 & 39.4 \\
1980 & 2460 & 1030 & 1430 & 58.1 & 41.9 \\
1981 & 2041 & 929 & 1112 & 54.4 & 45.6 \\
1982 & 1734 & 637 & 1097 & 63.2 & 36.8 \\
1983 & 1621 & 633 & 988 & 60.9 & 39.1 \\
\hline
\end{tabular}

Source: ANIC, CC of RCP, Economic Section, File 387/1984, 16.

Despite the increase in the value of commercial exchanges, Romania's trade balance with the EEC remained negative throughout the 1970s (Table 8.1). ${ }^{121}$ According to Ceaușescu, the trade deficit was mostly explained by the protectionist policies of the EEC against the socialist states. To secure the country's 'equilibrium in the balance of payments', Ceaușescu envisioned 'not a reduction of economic exchanges' with the Western European states but 'an intensification of Romanian exports'. ${ }^{122}$ The Romanian authorities believed that increasing exports would provide the foreign currency necessary to pay for previous and future Western imports. ${ }^{123}$

In December 1977, the National Conference of the RCP established the main lines of the next five-year plan (1980-85). Industrialisation was still acknowledged as a major national objective. However, it stressed that the process of industrialisation and Romania's economic development in general had entered a new phase, moving from the stage of quantitative accumulation to the stage of qualitative improvement. Special attention was paid to foreign trade, and all the institutions and cadres involved in foreign exchanges were instructed to 'strictly respect the equilibrium of the balance of trade and the balance of foreign payments'. Ceaușescu appreciated Romania's commercial relations with the capitalist developed states but considered that better results could still be obtained if 'a series of obstacles' in the way of free international trade were overcome. ${ }^{124}$

In December 1978, Ceaușescu expressed concern with regard to the 'world crisis of raw materials and energy', which would create 'increasing difficulties' for all countries, Romania included. All responsible institutions and cadres were asked to take measures to reduce consumption and imports to what was strictly necessary. ${ }^{125}$ The first measure, Ceaușescu stated, was to secure raw materials and energy from domestic sources and substantially reduce imports. Provisions were 
made for a $50 \%$ increase in the volume of foreign trade, with a more accentuated increase in exports to 'secure the necessary means for imports and amortisation of due payments for credits taken in the past in order to achieve an equilibrated balance of foreign payments' and 'the consolidation of currency reserves'. ${ }^{126}$

Towards the end of the decade Romania's imports from the EEC decreased while exports increased, with the balance of trade improving significantly. For the first time since 1961, in 1980 Romania had a positive balance of trade with the EEC as a whole, a trend that continued in the next years too (Table 8.1). ${ }^{127}$ However, the impact of the oil crisis was worrisome. According to Ceaușescu, in 1979 Romania was importing more oil than it produced domestically. Facing the rapid growth in oil prices, Romania responded with new measures reducing oil imports and domestic consumption, and by developing coal-fuelled industries and technologies. ${ }^{128}$ The Romanian authorities were also increasingly worried that the country's access to foreign loans might soon be limited. ${ }^{129}$ An excessive increase in the cost of foreign loans was another source of concern, which prompted discussions with Western bankers, but the situation did not look promising. ${ }^{130}$ In October 1979, the US Federal Reserve Bank adopted new policy procedures leading to a rise in interest rates and in the cost of energy supplies, creating a macroeconomic context in which Romania and Poland were no longer able to meet their hard-currency obligations. ${ }^{131}$

By 31 October 1979, Romania had contracted from Western developed states (France, the UK, Italy, Belgium, West Germany, Norway, Spain, Austria, Finland, Switzerland, the US, Canada and Japan) lines of credits for over 9.7 billion lei valută, which were to be used exclusively to finance imports of machinery, equipment and installations from the respective countries. The interest rate ranged from $4.5 \%$ (Switzerland) to $9.5 \%$ (West Germany), while the terms varied from five years (France, Finland, Belgium, the FRG and Italy) to eight years (the US, Norway and Austria) and even twenty-eight years (Canada). ${ }^{132}$ Not all these lines of credits were used, however, as between 1980 and 1984 Romania's decision to pay back its foreign debt resulted in a $70 \%$ decrease in its imports of machinery and equipment. ${ }^{133} \mathrm{~A}$ significant decrease in the foreign debt also occurred in Romania's relations with the EEC Ten, Portugal and Spain, from 4735.6 million US dollars in 1981 to 2734.5 million US dollars in 1984. However, the interest payments remained considerably high, increasing from 296.5 million US dollars in 1981 to about 350 million US dollars in 1982 and 1983 and 366.4 million US dollars in 1984. ${ }^{134}$ Despite the improvements in Romania's balance of trade, Ceaușescu was constantly dissatisfied with the overall results, asking for an increase in exports and for continual improvement of the trade balance and the balance of payments. ${ }^{135}$ However, neither ministries nor production and trade managers could comply with Ceaușescu's unrealistic indications and they could not meet the objectives set in the country's export plan. ${ }^{136}$

\section{Conclusion}

Romania's approach to Western Europe in the long 1970s derived from the country's national strategy for economic development and its interpretations and 
perceptions of the EEC's impact on its commercial interests, and by extension on its economic development. Industrialisation was conceived as a mandatory base for building a socialist (and ultimately a communist) society and was to provide the people with a high standard of living. In Romania's striving for industrialisation, the West was seen as an important source of technology and know-how as well as credits to pay for these imports. Besides loans, another source of hard currency was Romania's exports of raw materials and foodstuffs. Despite Romania's efforts to increase exports of highly manufactured goods, raw materials and foodstuffs represented the largest share of its exports to the Western European market throughout the period discussed. From the late 1960s onwards, the EEC was seen in Bucharest as a threat to Romania's interests but also as a fact of life, an economic reality that needed to be dealt with pragmatically so that its negative impact on Romania's commercial interests and national economic development in general would be limited as much as possible.

This chapter has confirmed that decisions were made by Secretary General Nicolae Ceaușescu and a handful of his closest collaborators who were members of the executive bodies of the Central Committee and held high-level positions in the state apparatus. However, in addressing Romania's stance towards the EEC, the study has evidenced that the decisions of the leadership were greatly influenced by input provided by officials at different party and state levels, such as ministers, deputy ministers, experts in different fields, researchers in research institutes, diplomats abroad and economists. These officials were explicitly invited to identify problems and propose solutions in their areas of work and expertise. As opposed to the Hungarian case, however, in Romania there were no contradictory debates with regard to the country's approach to the EEC, the West in general or its economic development at large. Within the general economic conception of the party leadership, professionals advanced proposals, which were then submitted for approval to the leadership, which in many cases accepted them.

Romania's approach to the EEC was at two main levels. At the base was a general conception, a position of principle decided in 1971 that did not change in the subsequent years. This position encompassed three main elements: direct relations with the EEC institutions in parallel with bilateral relations with the EEC member states; using various international trade or financial organisations to reach its EEC-related goals; and preventing the CMEA from impacting the country's policy towards the EEC in a way that was incompatible with Romania's interests. The second level of the approach consisted in very pragmatic measures in response to EEC policies, which were therefore continually adjusted. Each time the EEC finalised or adopted new regulations or measures impacting third countries, the Romanian authorities responded with their own set of actions designed to reduce the expected negative impact.

This chapter has also found that in Romania's case ideology did not override national interests, as happened in Hungary, for instance. Theoretically and publicly, Romania's openness to the West was mainly explained with arguments related to the peaceful coexistence doctrine, international détente or increasing globalisation. Behind the scenes, however, reasons involving very pragmatic commercial considerations were often invoked. Romania's openness to the West 
provides us with another example of its ability to oppose its allies and the Soviet Union. Nevertheless, its political disloyalty to Moscow could only go so far and the Romanian leadership avoided taunting the Soviets more than was absolutely necessary. To avoid Soviet susceptibility and anger, and despite numerous Romanian studies on the matter (and EEC prompting), the 1970s ended without Romania making the decision to start talks on a general agreement with the EEC.

In the end, Romania's approach to the West and the EEC in particular proved to be a double-edged sword: a success in the short run and a failure in the long run. Romania-EEC exchanges constantly increased throughout the 1970s, giving the country access to Western technology, machinery and loans and an outlet for its exports of raw materials and foodstuffs, which provided the country with a flow of hard currency. The end of the decade brought Romania a positive trade balance, and it remained the only Eastern European state with a joint commission and an industrial agreement with the EEC.

However, in the long run, Romania's strategy for economic development failed and its openness to the West created additional problems. Industrialisation had been deemed the foundation for building a better society and for raising the people's living standard, while foreign economic relations were called on to contribute to reaching this ultimate goal. However, lacking the necessary domestic resources, the country's forced industrialisation was to a great extent based on imports of technology and raw materials and on foreign loans - which made the country very vulnerable to the global energy and debt crises in the late 1970s and early 1980s.

Romania's failure to fulfil its debt obligations and its request for debt rescheduling were followed in 1982 by a cessation of export credits guarantees to Romania by EEC governments. ${ }^{137}$ In June 1982 and May 1983, Romania concluded rescheduling agreements with the Paris Club. Rescheduling agreements with individual Western states followed, but Romania's financial situation remained very difficult and it could not fully meet its rescheduling obligations. ${ }^{138}$

In closed meetings, Ceaușescu admitted that Romania's import and credit policies in the 1970s had negatively impacted the country's economy and foreign indebtedness, but he denied any personal or party responsibility - not that anybody dared to blame him or the party. The culprits were, he held, the Ministry of Finance and the National Bank, which had contracted credits to support imports without the approval of the party leadership and against its directives. ${ }^{139}$

At the National Conference of the RCP in December 1982, Ceaușescu announced the decision to pay back the country's foreign debt by the end of the decade and to adopt severe measures to reduce consumption in general and the consumption of energy resources in particular. Ceaușescu held that Romania should react to the world economic crisis not by diminishing but by 'intensifying and developing the exchanges, collaboration and cooperation in production' with all countries - capitalist countries included - which translated into increasing Romanian exports and decreasing imports. Publicly, Ceaușescu argued that the decision to pay back the foreign debt was driven by the world economic crisis. ${ }^{140}$ However, the decision was also greatly influenced by his refusal to bargain on political issues touching upon sovereignty. 
In March 1989, Bucharest announced that Romania's foreign debt had been paid back in full. However, in taking measures to reach this end, the Romanian leadership, and particularly Ceaușescu himself, had lost sight of the primary goal of the national economic development strategy (i.e. the welfare of the people), and this was one of the main factors that by the end of the year brought his regime to its end.

\section{Notes}

1 For instance, Țăranu, România în Consiliul de Ajutor Economic Reciproc; Opriș, România în Organizația Pactului de la Varșovia; Buga, Pe muchie de cuțit; Buga, Lumini și umbre.

2 Opriș, Licențe străine; Opriș, Aspecte ale economiei românești.

3 Harrington and Courtney, Tweaking the nose of the Russians; Sitaru, British-Romanian relations; Pechlivanis, America and Romania.

4 Miloiu, "Consideraţii pe marginea procesului"; Alexandrescu, "Oportunităţi economice și bariere politice"; Nistor, Admiterea României comuniste în ONU.

5 Aioanei, "Atitudinea unor partide comuniste"; Bottoni, 'Unrequited love? ... '

6 "Raportul de activitate al Comitetului Central al Partidului Muncitoresc Român. Raport prezentat de tovarăşul Gheorghe Gheorghiu-Dej" (Gheorghe Gheorghiu-Dej's Report at the Second Congress of the RWP), 23-28 December 1955, in Congresul al II-lea al Partidului Muncitoresc Român, 36-83.

7 "Raportul CC al PMR cu privire la activitatea partidului în perioada dintre Congresul al II-lea şi Congresul al III-lea cu privire la Planul de dezvoltare a economiei naționale pe anii 1960-1965 și la Schița planului economic de perspectivă pe 15 ani" (Gheorghe Gheorghiu-Dej's Report at the Third Congress of the RWP), 20 June 1960, in Gheorghiu-Dej, Raport la cel de-al III-lea Congres al Partidului Muncitoresc Român, 21-9, 78-85.

8 For instance, "Raportul Comitetului Central al Partidului Comunist Român cu privire la activitatea partidului în perioada dintre Congresul al VIII-lea și Congresul al IX-lea al PCR. Raportor tovarășul Nicolae Ceaușescu” (Nicolae Ceaușescu's Report at the 9th Congress of the RCP), 19 July 1965, in Congresul al IX-lea al Partidului Comunist Român, 64.

9 “Cuvântare la Consfătuirea privind activitatea în domeniul comerțului exterior, 23 februarie 1967" (Ceaușescu's speech at the conference on foreign trade, 23 February 1967), in Ceaușescu, vol. 2, 214-34.

10 "Raport asupra directivelor Congresului al IX-lea al Partidului Comunist Român privind planul de dezvoltare a economiei naţionale pe perioada 1966-1970. Raportor tovarășul Ion Gheorghe Maurer" (Ion Gheorghe Maurer's Report at the 9th Congress of the RCP), 19 July 1965, in Congresul al IX-lea al Partidului Communist Român, 188-9.

11 Arhivele Naționale Istorice Centrale (The National Historical Central Archive, Bucharest, hereinafter ANIC), CC of RCP, Office, File 4/1967, Note by V. Vlad on the activity of the Ministry of Foreign Affairs in 1966 and its plan of objectives for 1967," 18 January 1967; Note by C. Mănescu on the activity of the Ministry of Foreign Affairs (MFA) in 1966 and its plan of objectives for 1967," 6 January 1967; "Planul de obiective al Ministerului Afacerilor Externe pe anul 1967" (the MFA's plan of objectives for the year of 1967), 6 January 1967, 13-29.

12 "Raportul Comitetului Central al Partidului Comunist Român cu privire la activitatea partidului în perioada dintre Congresul al VIII-lea și Congresul al IX-lea al PCR. Raportor tovarășul Nicolae Ceaușescu” (Nicolae Ceaușescu's Report at the 9th Congress of the RCP), 19 July 1965, in Congresul al IX-lea al Partidului Comunist Român, 32-66, 100-1. 


\section{Elena Dragomir}

13 "Cuvântare la Consfătuirea privind activitatea în domeniul comerțului exterior, 23 februarie 1967" (Ceaușescu's speech at the conference on foreign trade, 23 February 1967), in Ceaușescu, vol. 2, 214-34.

14 "Expunere cu privire la politica externă a Partidului și Guvernului, prezentată la sesiunea Marii Adunări Naționale din 24-26 iulie 1967" (Nicolae Ceaușescu's speech at the session of the Great National Assembly, 24-26 July 1967), in Ceaușescu, vol. 2, 412-64.

15 "Cuvântare la Consfătuirea privind activitatea în domeniul comerțului exterior, 23 februarie 1967" (Ceaușescu's speech at the conference on foreign trade, 23 February 1967), in Ceaușescu, vol. 2, 214-34.

16 Arhivele Diplomatice ale Ministerului Afacerilor Externe (The Diplomatic Archives of the Ministry of Foreign Affairs, Bucharest, hereinafter AMAE), Problem 241/2C52/1968, Common Market, vol. 1, "Studiu: Piața Comună" (Study: The Common Market), 23 January 1968, 16-81.

17 AMAE, Common Market, vol. 1, "Studiu: Piața Comună," 23 January 1968, 16-81.

18 AMAE, Common Market, vol. 1, "Studiu: Piața Comună," 23 January 1968, 16-81.

19 AMAE, Common Market, vol. 1, "Studiu: Piața Comună," 23 January 1968, 16-81.

20 For instance, "Cuvântare la Consfătuirea privind activitatea în domeniul comerțului exterior, 23 februarie 1967" (Ceaușescu's speech at the conference on foreign trade, 23 February 1967), in Ceaușescu, vol. 2, 217-18.

21 AMAE, Common Market, vol. 1, "Studiu: Piața Comună," 23 January 1968, 16-81.

22 ANIC, CC of RCP, Office, File 28/1968, "Notă de siteză asupra lucrării Interesul și condițiile unei eventuale participări a RSR la GATT' (note regarding Romania's possible participation in GATT), February 1968, 10-20.

23 ANIC, CC of RCP, Office, File 28/1968, Protocol no 10 of the meeting of the PP of the CC of the RCP, 26 February 1968, 2-4.

24 ANIC, CMEA, Foreign Trade Permanent Commission (FTPC), I, File 78/1968, "Studiu: Piața Comună" (Study: Common Market), July 1971, 249.

25 Born in 1931, Burtică was an electromechanical engineer. He joined the party in March 1956. In the 1960s he was a councillor at Romania's embassy in France. Between 1966 and 1969 he served as Romania's ambassador to Italy (February 1966April 1969), Morocco (September 1966-April 1969) and Malta (November 1968April 1969). In April 1969, he was appointed minister of foreign trade, serving in this position until February 1972. Burtică was president of the National Council of the Romanian Radio Broadcasting Company (1973-77), vice prime minister (1977-82) and minister of foreign trade and international economic cooperation (7 March 197821 May 1982). In the party, Burtică was a member of the CC of the RCP (August 1969-October 1982), an alternate member of the Executive Committee of the CC of the RCP (July 1972-November 1974) and a member of the Executive Political Committee of the CC of the RCP (November 1974-October 1982).

26 AMAE, Problem 241/2C52/1968, Common Market, vol. 1, Cornel Burtică to the MFA, 15 June 1968, 228-32.

27 AMAE, Problem 241/2C52/1968, Common Market, vol. 1, Gheorghe Cioară to Ilie Verdeț, 5 July 1968; V. Răuță to Mircea Malița, 19 July 1968, 147-54, 164-75.

28 AMAE, Problem 241/2C52/1968, Common Market, vol. 1, Vasile Șandru to Vasile Răuță, 7 August 1968, 156-63.

29 AMAE, Problem 241/2C52/1970, Belgium, Note by Cornel Burtică, 5 January 1970; The Office of the CC of the RCP to C. Burtică, 19 January 1970; The Office of the CC of the RCP to C. Mănescu, 16 July 1970, 1-4, 92.

30 AMAE, Problem 241/ 2C52/1971, Regional Economic Organizations, vol. 2, A. Lăzăreanu, St. Niță to C. Mănescu: The advantages and disadvantages of a possible conclusion of a commercial agreement between Romania and the EEC, 30 July 1970, 122-4.

31 ANIC, CMEA, Executive Committee, General, File 81/1964, "Raport" (report regarding the Prague Program), 27-29 May 1964, 202. 
32 ANIC, CMEA, FTPC, I, File 101/1968, Radu Negru to Ion Stoian: Points of view formulated and documents concluded in the CMEA regarding the attitude of the CMEA member states towards the bodies of the Common Market and its member countries, 19 January $1968,143-5$.

33 "Raportul Comitetului Central al Partidului Comunist Român cu privire la activitatea PCR în perioada dintre Congresul al IX-lea şi Congresul al X-lea şi sarcinile de viitor ale Partidului. Raportor tovarășul Nicolae Ceaușescu" (Ceaușescu's Report at the 10th Congress of the RCP), 6 August 1969 in Congresul al X-lea al Partidului Comunist Român, 6-12 august 1969, 19-89.

34 For instance, "Raportul cu privire la dezvoltarea economico-socială a României în următorii ani și în perspectivă, la perfecționarea conducerii planificate a societății și dezvoltarea democrației socialiste, la creșterea rolului conducător al partidului în edificarea socialismului și comunismului, la activitatea internațională a partidului și statului, prezentat de tovarășul Nicolae Ceaușescu" (Ceaușescu's Report at the National Conference of the RCP), in Conferința Națională a Partidului Comunist Român, 19-21 iulie 1972, 13-107.

35 AMAE, Problem 241/2C52/1971, Regional Economic Organizations, vol. 2, A. Lăzăreanu to Cornel Vladu: The implications of the Common Market over the economic exchanges of the Socialist Republic of Romania with the EEC countries and proposals regarding measures to counteract unfavourable effects of this economic grouping, 31 March 1970, 40-1.

36 AMAE, Problem 241/ 2C52/1971, Regional Economic Organizations, vol. 2, A. Lăzăreanu to Cornel Vladu, The implications of the Common Market over the economic exchanges of the Socialist Republic of Romania with the EEC countries and proposals regarding measures to counteract unfavourable effects of this economic grouping, 31 March 1970, 42-98.

37 AMAE, Lăzăreanu to Cornel Vladu: The implications of the Common Market, 31 March 1970, 42-98.

38 "Cuvântare la Consfătuirea privind activitatea de comerț exterior, 5 februarie 1971" (Ceaușescu's speech at the conference on foreign trade), 5 February 1971, in Ceaușescu, vol. 5, 417-53.

39 ANIC, CC of RCP, Office, File 59/1970, The minutes of the meeting of the Executive Committee from 20 May 1970, regarding the talks between the Romanian and the Soviet leaderships in Moscow from 17-18 May 1970, 5-19.

40 Alexandrescu, Oportunități economice, 29.

41 AMAE, Problem 241/2C52/1971, Regional Economic Organizations, vol. 2, A. Lăzăreanu, St. Niță to C. Mănescu: The advantages and disadvantages of a possible conclusion of a commercial agreement between Romania and the EEC, 30 July 1970, 101-33.

42 AMAE, Problem 241/2C52/1970, Belgium, Gh. Elian to Vasile Gliga, 16 October 1970, 114-21.

43 ANIC, CC of RCP, Office, File 24/1971, "Notă privind strategia țării noastre în relațiile economice cu Piața Comună" (Note on Romania's Strategy Regarding Economic Relations with the Common Market), 26 November 1970, 149-58.

44 Born in 1916, Corneliu Mănescu was a lawyer. A party member since October 1944, Mănescu was a member of the CC of the RCP between 1965 and 1980. He was vice president of the State Planning Committee (1955-60), ambassador to Hungary (196061), minister of Foreign Affairs (1961-72) and ambassador to France (1977-82).

45 Born in 1926, Ion Pățan was an accountant and an economist specialised in foreign trade. A party member since 1955, Pățan was an alternate member of the CC of the RCP (1965-69), a member of the CC of the RCP (1969-87), an alternate member of the Executive Committee of the CC of the RCP (1972-74), a member of the Executive Political Committee (1974-87), a director in the Ministry of the Consumer Goods Industry (1956-62), a secretary general in the Ministry of Light Industry (1962-64), deputy minister of light industry (1964-65), minister of domestic trade (1968-69), 


\section{Elena Dragomir}

vice president of the Council of Ministers (1969-75), vice prime minister (1975-82), and minister of foreign trade (1972-78).

46 ANIC, "Notă privind strategia țării noastre în relațiile economice cu Piața Comună," 26 November $1970,149-58$.

47 ANIC, CC of RCP, Office, File 23/1971, The Office of the CC of the RCP to P. Niculescu-Mizil, I. Verdeț, M. Mănescu, V. Vlad, C. Mănescu, I. Pățan, 22 February 1971, 236.

48 AMAE, Problem 241/2C52/1971, Regional Economic Organizations, vol. 1, "Notă de propuneri" (Note of proposals) 21 July 1971; "Raport privind discuțiile purtate cu o delegație de experți ai Comisiei Comune, București, 15-16 iulie 1971" (report on talks with a delegation of experts of the EEC Commission in Bucharest, 15-16 July 1971); C. Vladu, P. Burleanu cu C. Mănescu, 28 August 1971, 106-8, 118-25, 128-9.

49 AMAE, Problems 241/2C52/1971, Note by Corneliu Mănescu, 3 December 1971; The Office of the CC of the RCP to C. Mănescu, 14 December 1971, 1-9.

50 AMAE, Problem 241/2C52/1971, Regional Economic Organizations, vol. 3, C. Vladu to Romanian Embassies in Helsinki, Copenhagen, Stockholm, Vienna, Paris, Bonn, Rome, The Hague, London, Current aspects regarding the evolution of the Common Market's relations with third countries, 29 June-17 July 1971, 147.

51 AMAE, C. Vladu to Romanian Embassies, 29 June-17 July 1971, 125-47.

52 ANIC, CMEA, FTPC I, File 78/1968, "Studiu: Piața Comună” (Study: The Common Market), July 1971, 228-328.

53 ANIC, CC of RCP, Foreign Relations, File 182/1972, "Informare cu privire la examinarea în cadrul CAER a poziției țărilor member față de Comunitatea Economică Europeană (Piața Comună)" (report regarding the examination in the CMEA of the position of the member states towards the EEC), 31 March 1972, 17.

54 ANIC, "Studiu: Piața Comună," 228-328.

55 ANIC, CMEA, Executive Committee, General, File 267/1971, Gheorghe Rădulescu to Mikhail Lesechko, 6 October 1971, 324-6.

56 Kansikas, Socialist countries face the European Community, 93-107.

57 ANIC, CMEA, Executive Committee, General, File 282/1972, "Intervenție" (Gheorghe Rădulescu's speech at the 58th meeting of the Executive Committee of the CMEA, 26-27 May 1972), 1-4.

58 ANIC, CMEA, Executive Committee, General, File 283/1972, N. Faddeev to G. Rădulescu: The expositions of the other participants at the 58th meeting of the Executive Committee of the CMEA, 26-27 May 1972, 23 July 1972, 1-24.

59 ANIC, CC of RCP, Economic Section, File 62/1972, "Comunitatea Economică Europeană (Documentar)" (The European Economic Community (Documentary)), 1972,145 verso.

60 "Raportul cu privire la dezvoltarea economico-socială a României în următorii ani şi în perspectivă, la perfecționarea conducerii planificate a societăţii şi dezvoltarea democrației socialiste, la creșterea rolului conducător al partidului în edificarea socialismului și comunismului, la activitatea internațională a partidului și statului, prezentat de tovarășul Nicolae Ceaușescu" (Ceaușescu's Report at the National Conference of the RCP from 19-21 July 1972), in Conferința Națională a Partidului Comunist Român, 19-21 iulie 1972, 29-31.

61 ANIC, CC of RCP, Economic Section, File 18/1972, "Notă referitor la continuarea demersurilor României pentru obținerea de preferințe vamale de la CEE" (note regarding the actions taken by Romania to receive generalised preferences from the EEC), 11 March 1972, 96-100.

62 AMAE, Fond 1972, File 3002/1972, "Relațiile României cu CEE" (Romania's relations with the EEC), 26 April 1972, 14-17.

63 HAEU, BAC 48/1984, File 678, Memorandum: Romania-EEC (Project), 6 May 1973, 68-71. 
64 ANIC, CC of RCP, Foreign Relations, File 19/1973, "Notă de convorbire" (note regarding the talks between Maurice Schumann and Nicolae Ceaușescu), 30 January 1973, 14.

65 AMAE, Fond, 1973, File 4977/1973, "Studiu: Piața Comună” (Study: Common Market, first draft), January 1973, 58-61.

66 Born in 1902, Ion Gheorghe Maurer studied law. A party member since 1937, Maurer was under-secretary of state in the Ministry of Industry and Commerce (1946-48), minister of foreign affairs (1957-58), president of the Council of Ministers (196174). Maurer was a member of the CC of the RWP/RCP (1945-55, 1955-74), an alternate member of the CC of the RWP (1955-58), a member of the politburo (1960-65), a member of the Executive Committee of the CC of the RCP (1965-74) and a member of the Permanent Praesidium of the CC of the RCP (1965-74).

67 AMAE, Fond 1972, File 3008/1972, Ion Gheorghe Maurer to Willy Brandt, May 1972, 7-8.

68 ANIC, CC of RCP, Foreign Relations, File 182/1972, Note by C. Mănescu, 4 March $1972,38-40$.

69 "Considerations on Romania's position towards the IMF and IBRD, July 1972," in Alexandrescu, România între Est și Vest, 153-9.

70 Alexandrescu, Oportunități economice, 29.

71 ANIC, CC of RCP, Foreign relations, File 141/1973, Minutes of the talks between Ceaussescu and Brezhnev, Crimea, 1 August 1973, 1-55.

72 ANIC, CC of RCP, Foreign Relations, File 85/1973, "Notă de convorbire" (Note regarding the talks between Ceaușescu and Mohammad Reza Pahlavi Aryamehr (Shahanshah of Iran), 2 June 1973), 2-22.

73 "Cuvântare la plenara comună a Comitetului Central al Partidului Comunist Român și Consiliului Suprem al Dezvoltării Economice și Sociale a României” (Ceaușescu's speech at the common plenary session of the CC of the RCP and of the Supreme Council of Romania's Economic and Social Development), 28 November 1973, in Ceaușescu, vol. 9, 618-23.

74 "Decretul nr. 620/18 noiembrie 1973" (Decree no 620, 18 November 1973), in Buletinul Oficial, no 181, November 1973, 18.

75 AMAE, Fond 1973, File 4977/1973, "Studiu: Piața Comună, variant a II-a" (Study: Common Market, Second version), March 1973, 112-74.

76 Born in 1913, George Macovescu studied law. A party member since 1936, Macovescu served as deputy foreign affairs minister (1961-67), first deputy foreign affairs minister (1967-72) and minister of foreign affairs (1972-78). He was a member of the CC of the RCP between 1969 and 1984.

77 AMAE, Fond 1973, File 4977/1973, "Notă de propuneri privind strategia României în relațiile cu Piața Comună (CEE)” (Note of proposals regarding Romania's strategy in its relations with the Common Market), 20 March 1973, 105-11.

78 AMAE, "Notă de propuneri privind strategia României în relațiile cu Piața Comună (CEE)," 20 March 1973, 105-11.

79 AMAE, Fond 1973, File 4977/1973, The Office of the CC of the RCP to George Macovescu, 27 March 1973, 214.

80 AMAE, Fond 1973, File 4953, "Notă privind asigurarea cadrului juridico-economic extern pentru realizarea planului de comerț pe anul 1974 în relațiile cu țările membre ale Pieței Comune" (Note regarding the creation of the external juridical economic framework for achieving the 1974 foreign trade plan in Romania's relations with the Common Market member countries), 1973, 1-5.

81 AMAE, Fond 1974, File 5845, MFA to A. Lăzăreanu, December 1973, 1-6.

82 "Inteviu acordat unor ziariști britanici" (Interview by Ceaușescu with a group of British journalists), 29 November 1973, in Ceaușescu, vol. 9, 681-2.

83 For instance, AMAE, Fond 1973, File 4978/1973, Note by Mircea Zara, 24 October 1973, 131-3. 


\section{Elena Dragomir}

84 ANIC, CMEA, FTPC, I, File 130/1972, R. Van Elslande to Ion Pățan, 27 June 1973, 197.

85 ANIC, CMEA, FTPC, I, File 130/1972, "Notă privind instituirea Comisiei de partid și de stat pentru problemele relațiilor economice ale României cu Piața Comună" (note on establishing the Party and State Commission regarding problems in economic relations between Romania and the Common Market), 6 July 1973, 186-94.

86 AMAE, Fond 1973, File 4976/1973, "Notă referitor la preferințele vamale" (note concerning the customs preferences), July 1973; Nicolae Ghenea to George Macovescu: Report on the technical talks with EEC experts, 12-20 July 1973, 77-82, 91-3.

87 AMAE, Fond 1973, File 4976/1973, N. Ghenea to the Romanian Embassy in Paris, 13 October 1973, 100-1.

88 AMAE, Fond 1975, File 5815/1975, Mircea Zara to C. Oancea, 19 May 1975, 8-9.

89 AMAE, Fond 1973, File 4983/1973, Note by C. Stanciu and N. Ghenea, 22 May 1973; C. Stanciu and N. Ghenea to C. Ene, Romania's ambassador in Geneva, 26 June 1973; C. Ene to C. Stanciu and N. Ghenea, 16 July 1973, 3-6, 8-10, 17-19.

90 AMAE, Fond 1974, File 5845/1974, Note by Ion Pățan and George Macovescu cu C. Pacoste, March 1974, 14-17.

91 AMAE, Fond 1973, File 4977/1973, "Notă de propuneri privind strategia României în relațiile cu Piața Comună (CEE)" (note of proposals regarding Romania's strategy in its relations with the Common Market), 20 March 1973, 110.

92 For instance, ANIC, CMEA, FTPC, I, File 57/1967, The Protocol of the CMEA working group on the problems of the CMEA-EEC contacts, 28-29 November 1973, 137-50; AMAE, Fond 1974, File 5836/1974, "Notă privind lucrările consfătuirii conducătorilor direcțiilor de relații din ministerele comerțului exterior ale țările membre ale CAER (19-22 noiembrie 1974, Varșovia)" (note concerning the meeting of the foreign trade directors from the CMEA member states, 19-22 November 1974), 45-51.

93 The National Archives, FCO, File 30/1728, W.M. Marsden to P.E. Hall, 24 September 1973.

94 AMAE, Fond 1974, File 5845/1974, Note by Ion Pățan and George Macovescu cu C. Pacoste, March 1974, 14-22.

95 AMAE, Fond 1974, File 5845/1974, "Studiu privind noi forme ale relațiilor comerciale ale RS România cu țările Pieței Comune" (study on new forms of Romania's commercial relations with the countries of the Common Market), June 1974, 67-202.

96 Directivele Congresului al XI-lea al Partidului Comunist Român, 5-31, 68.

97 Directivele Congresului al XI-lea al Partidului Comunist Român, 68-70.

98 Programul Partidului Comunist Român de făurire a societății socialiste multilateral dezvoltate și înaintare a României spre communism, 174.

99 ANIC, CC of RCP, Office, File 80/1975, "Notă explicativă prezentată de celelalte delegații CAER în ședința CPCE din 3-5 iunie 1975" (explanatory note of the other CMEA delegations at the session of the FTPC, 3-5 June 1975), 186-7.

100 ANIC, CC of RCP, Office, File 80/1975, "Notă" (note), 13 June 1975, 179-81.

101 ANIC, CC of RCP, Office, File 80/1975, Minutes of the meeting of the Permanent Bureau of the Executive Political Committee, 21 June 1975, 9.

102 ANIC, CC of RCP, Office, File 80/1975, "Punctul de vedere al Părții române în problema contactelor viitoare dintre CAER și Piața Comună (CEE)" (Romania's point of view regarding the problem of future contacts between the CMEA and the EEC), 13 June 1975, 182.

103 ANIC, CC of RCP, Office, File 80/1975, The Office of the CC of RCP to M. Mănescu, S. Andrei, C. Burtică, G. Macovescu, 25 June 1975, 234.

104 For instance, ANIC, CMEA, Executive Committee, General, File 421/1978, "Interventie" (the intervention of the Romanian representative at the 32nd session of the CMEA), 27-29 June 1978, 104-7.

105 "Interviu acordat ziarului suedez Svenska Dagbladet" (interview by Ceaușescu with the Swedish newspaper Svenska Dagbladet), 24 January 1979; "Interviu acordat 
ziarului Il Giornale Nuovo" (interview by Ceaușescu with Il Giornale Nuovo), 21 February 1979, in Ceaușescu, vol. 17, 455-6, 534-6.

106 "Report drawn up on behalf of the Committee on External Economic Relations on the state of relations between the EEC and East European state-trading countries and COMECON," EP Working Documents 1978-79, Document 89/78, 11 May 1978, 1-33, accessed 1 March 2020, http://aei.pitt.edu/95625/1/1978-79.78.89.pdf.

107 ANIC, CC of RCP, Economic Section, File 50/1975, 97, "Notă” (note), July 1976, 94; "Acord pe termen lung de colaborare economică, industrială și tehnică între Republica Socialistă România și Uniunea Economică Belgo-Luxemburgheză, 27 mai 1976" (long-term cooperation, industrial and technical agreement between Romania and the Belgium-Luxembourg Economic Union, 27 May 1976), in Buletinul Oficial, no 93, 4 November 1976.

108 AMAE, Fond 1978, File 3307/1978, "Notă referitor la perfecționarea cadrului juridic al relatiiilor economice România-CEE" (note regarding the perfecting of the juridical framework of the economic relations between Romania and the EEC), 18 November 1978, 54; ANIC, CC of RCP, Economic Section, File 62/1972, vol. 2, "Notă" (note), 31 May 1977, 126.

109 AMAE, Fond 1978, File 3309/1978, C. Stanciu, C. Oancea to A. Lăzăreanu, 20 January $1978,1$.

110 Australia, Japan, New Zealand and Austria in 1972; Finland in 1973; the EEC, Canada and Sweden in 1974; the US and Switzerland in 1976; and Norway in 1977.

111 AMAE, Fond 1978, File 3316/1978, "Notă referitor la aspecte ale beneficierii şi folosirii de către România a preferințelor vamale acordate de țările dezvoltate" (note regarding aspects of benefiting from and using by Romania of customs preferences granted by the developed countries), 1978, 1-4; AMAE, Fond 1978, File 3307/1978, "Poziția Comisiei CEE și a țărilor membre ale Pieței Comune față de cererea Republicii Socialiste România de extindere a preferințelor vamale generalizate" (the position of the EEC Commission and of the EEC states towards Romania's request for the enlargement of generalised customs preferences), November 1978, 61-2.

112 ANIC, CMEA, FTPC, I, File 196/1977, "Notă" (Note), 4 August 1977; "Rapoarte" (reports regarding the official exploratory talks between Romania and EEC representatives from 26-27 July 1977), August 1977, 3-21, 123-35.

113 ANIC, CC of RCP, Foreign Relations, File 137/1977, Minutes of the talks between Ceauşescu and Mario Zagari, vice-president of the European Parliament, 10 August 1977, 7.

114 AMAE, Fond 1978, File 3307/1978, "Notă referitor la asigurarea cadrului juridic pentru dezvoltarea relațiilor economice ale României cu țările membre ale Pieței Comune" (note regarding the development of the juridical system for Romania's economic relations with the EEC), 30 December 1978, 73-9.

115 AMAE, Fond 1978, File 3307/1978, "Notă referitor la perfecționarea cadrului juridic al relațiilor economice România-CEE" (note regarding the perfecting of the juridical framework of the economic relations between Romania and the EEC), 18 November 1978, 54-8.

116 ANIC, GCETCC, Contacts of the CMEA with international organisations, File 12/1985-1986, "Relațiile RS România cu CEE" (Romania's relations with the EEC), 25 October 1985, 149-52.

117 ANIC, CC of RCP, Economic Section, File 387/1984, "Notă privind punctul de vedere al delegației române la sesiunea a IV-a a Comisiei Mixte România-CEE" (note regarding the point of view of the Romanian delegation at the 4th session of Romania-EEC Joint Commission, 8-9 November 1984), 16.

118 AMAE, Fond 1978, File 3306/1978, "Notă referitor la comerțul României cu țările membre ale Pieței Comune" (note on Romania's trade with the EEC countries), February $1978,61-2$. 


\section{Elena Dragomir}

119 ANIC, "Notă privind punctul de vedere al delegației române la sesiunea a IV-a a Comisiei Mixte România-CEE," 16.

120 Opriș, Aspecte ale economiei românești, 119-21.

121 ANIC, "Notă privind punctul de vedere al delegației române la sesiunea a IV-a a Comisiei Mixte România-CEE," 16.

122 "Interviu acordat Radiodifuziunii italiene RAI-TV" (interview by Ceaușescu with RAI-TV, Italy, 2 September 1976), in Ceaușescu, vol. 13, 324-5.

123 AMAE, Fond 1981, File 2409, A. Mărgăritescu, G. Dolgu to Romania's embassies in The Hague, Koln, Paris, Rome, London, Athens, Copenhagen, 11 November 1981, no page number.

124 "Raportul cu privire la realizarea hotărârilor Congresului al XI-lea, a programului Partidului Comunist Român și la sarcinile de viitor, prezentat de tovarășul Nicolae Ceaușescu, Secretar General al Partidului Comunist Român" (Ceaușescu's speech at the RCP's national conference, 7 December 1977), in Conferința Națională a Partidului Comunist Român, 7-9 decembrie 1977, 21-9.

125 "Expunere la sesiunea solemnă comună a Comitetului Central al Partidului Comunist Român, Consiliului Naţional al Frontului Unității Socialiste și Marii Adunări Naționale consacrată sărbătoririi a șase decenii de la făurirea statului național unitar roman" (Ceaușescu's speech at the common session of the CC of the RCP, National Council of the Front of Socialist Unity and Grand National Assembly), 1 December 1978, in Ceaușescu, vol. 17, 292-3.

126 "Raportul Comitetului Central al Partidului Comunist Român în perioada dintre Congresul al XI-lea și Congresul al XII-lea şi sarcinile de viitor al partidului”" (Ceauşescu's report at the 12th Congress of the RCP), 19 November 1979, in Ceaușescu, vol. 19, 194-220.

127 ANIC, "Notă privind punctul de vedere al delegației române la sesiunea a IV-a a Comisiei Mixte România-CEE," 16.

128 “Cuvântare la consfătuirea cu cadrele de conducere din industrie, construcții, transporturi și agricultură" (Ceaușescu's speech at the meeting with the management cadres from industry, construction, transportation and agriculture), 6 March 1979, in Ceaușescu, vol. 17, 570.

129 AMAE, Fond 1979, File 2501/1979, “Considerente ale țării noastre privind criteriile pentru acordarea de împrumuturi de către BIRD în decada 1980-1990 și demersul pentru sprijinirea cu credite de către BIRD în cincinalul viitor" (Romania's considerations regarding the IBRD criteria for granting loans in the decade 1980-90 and Romania's approach to taking credits from the IBRD in the next five-year period), September 1979, 59-61.

130 ANIC, CC of RCP, Foreign relations, File 6/1980, Minutes of the talks between Ceauşescu and Evelyn de Rothschild, president of the Bank NM Rothschild and Sons Ltd, UK, 22 January 1980, 3-18.

131 See Chapter 1 by Federico Romero in this book.

132 ANIC, CC of RCP, Economic Section, File 76/1979, "Situațiile liniilor de credit: Raport" (The situation of the lines of credits: Report), 31 December 1979, 158-60.

133 ANIC, "Notă privind punctul de vedere al delegației române la sesiunea a IV-a a Comisiei Mixte România-CEE," 16.

134 AMAE, Fond 1986, File 1498/1986, Petre Gigea to Iulian Văcărel, 13 February 1986, 95.

135 ANIC, CC of RCP, Office, File 34/1983, "Cuvântarea lui Nicolae Ceaușescu la Plenara CC al PCR din 29-30 iunie 1983" (Ceaușescu's speech at the plenary session of the CC of the RCP, 29-30 June 1983), 94.

136 ANIC, CC of RCP, Office, File 7/1984, Minutes of the working meeting on foreign trade problems, 9 February 1984, 2-85.

137 AMAE, Fond 1983, File 2399/1983, Iulian Văcărel to Aurel Duma: Report on Romania's relations with the EEC, 13 January 1983, 35. 
138 Quarterly Report by the Congress and the Trade Policy Committee on trade between the United States and the non-market economy countries during 1983, 93-4; ZlochChristy, Debt problems of Eastern Europe, 114.

139 For instance, ANIC, CC of RCP, Office, File 7/1984, Minutes of the working meeting on foreign trade problems, 9 February 1984, 14.

140 "Raport cu privire la stadiul actual al edificării socialismului, la realizarea Planului național unic de dezvoltare economico-socială, la programele speciale și la măsurile pentru îndeplinirea cu succes a cincinalului, a hotărârilor Congresului al XII-lea al partidului" (Ceauşescu's Report at the National Conference of the RCP), 16 December 1982; "Cuvântare la încheierea lucrărilor Conferinței Naţionale" (speech at the final session of the National Conference), 18 December 1982, in Ceaușescu, Raport la Conferința Națională a Partidului Comunist Român, 16-18 decembrie 1982, 31-2, 79-89.

\section{Bibliography}

\section{Published primary sources}

Alexandrescu, Ion. România între Est și Vest. Aderarea la FMI și BIRD. Târgoviște: Cetatea de Scaun, 2012.

Ceaușescu, Nicolae. România pe drumul desăvârșirii construcției socialiste, vol. 2. București: Politică, 1968.

Ceaușescu, Nicolae. România pe drumul construirii societății socialiste multilateral dezvoltate, vol. 5. București: Politică, 1971.

Ceaușescu, Nicolae. România pe drumul construirii societății socialiste multilateral dezvoltate, vol. 9. București: Politică, 1974.

Ceaușescu, Nicolae. România pe drumul construirii societății socialiste multilateral dezvoltate, vol. 13. București: Politică, 1976.

Ceaușescu, Nicolae. Romania pe drumul construirii societății socialiste multilateral dezvoltate, vol. 17. București: Politică, 1979.

Ceaușescu, Nicolae. România pe drumul construirii societăţii socialiste multilateral dezvoltate, vol. 19. București: Politică, 1980.

Ceaușescu, Nicolae. Raport la Conferința Națională a Partidului Comunist Român, 16-18 decembrie 1982. București: Politică, 1982.

Conferința Națională a Partidului Comunist Român, 19-21 iulie 1972. București: Politică, 1972.

Conferința Națională a Partidului Comunist Român, 7-9 decembrie 1977. București: Politică, 1978.

Congresul al II-lea al Partidului Muncitoresc Român. București: Editura de Stat pentru Literatură Politică, 1956.

Congresul al IX-lea al Partidului Comunist Român. București: Politică, 1965.

Congresul al X-lea al Partidului Comunist Român, 6-12 august 1969. București: Politică, 1969.

Directivele Congresului al XI-lea al Partidului Comunist Român. București: Politică, 1974.

Gheorghiu-Dej, Gheorghe. Raport la cel de-al III-lea Congres al Partidului Muncitoresc Român. București: Politică, 1960.

Programul Partidului Comunist Român de fãurire a societății socialiste multilateral dezvoltate și înaintare a României spre comunism. București: Politică, 1975.

Quarterly Report by the Congress and the Trade Policy Committee on trade between the United States and the non-market economy countries during 1983, vol. 37. Washington, DC: United States International Trade Commission, March 1984. 


\section{Secondary sources}

Aioanei, Alexandru. "Atitudinea unor partide comuniste din Europa față de Piaţa Comună, la începutul anilor '60.” East European Journal of Diplomatic History 2 (2015): 155-65.

Alexandrescu, Ion. "Oportunități economice și bariere politice.” In România între Est și Vest. Aderarea la FMI și BIRD, edited by Ion Alexandrescu, 26-84. Târgoviște: Cetatea de Scaun, 2012.

Bottoni, Stefano. "Unrequited love? The Romanian Communist Party and the EEC in the 1960s and 1970s." In Kommunismus und Europa: Vorstellungen und Politik europäischer kommunistischer Parteien im Kalten Krieg, edited by Francesco di Palma and Wolfgang Mueller, 118-37. Paderborn: Schöningh, 2015.

Buga, Vasile. Pe muchie de cuțit. Relații româno-sovietice, 1965-1989. București: Institutul Național pentru Studiul Totalitarismului, 2013.

Buga, Vasile. Lumini și umbre. Relații economice româno-sovietice. București: Institutul Naţional pentru Studiul Totalitarismului, 2019.

Harrington, Joseph F. and Bruce J. Courtney. Tweaking the nose of the Russians: fifty years of American-Romanian relations, 1940-1990. Boulder, CO: East European Monographs, 1991.

Kansikas, Suvi. Socialist countries face the European Community: Soviet-bloc controversies over East-West trade. New York: Peter Lang, 2014.

Miloiu, Silviu-Marian. "Consideraţii pe marginea procesului de decizie britanic cu privire la aderarea României la FMI şi BIRD în decembrie 1972.” Studii și Materiale de Istorie Contemporană 5 (2006): 209-16.

Nistor, Paul. Admiterea României comuniste în ONU. Între negocieri diplomatice și discreditare simbolică. Iași: Institutul European, 2014.

Opriș, Petre. România în Organizația Pactului de la Varşovia. București: Militară, 2008.

Opriș, Petre. Licențe străine pentru produse civile și militare fabricate în România, 19461989. București: Militară, 2018.

Opriș, Petre. Aspecte ale economiei românești în timpul Războiului Rece, 1946-1991. București: Trei, 2019.

Pechlivanis, Paschalis. America and Romania in the Cold War: a differentiated détente, 1969-1980. London: Routledge, 2019.

Sitaru, Mihaela. British-Romanian relations during the Cold War. PhD diss., University of Western Ontario, 2014.

Țăranu, Liviu. România în Consiliul de Ajutor Economic Reciproc, 1949-1965. București: Enciclopedică, 2007.

Zloch-Christy, Iliana. Debt problems of Eastern Europe. Cambridge: Cambridge University Press, 1987. 


\title{
9 From Liberalism to Underdevelopment
}

\author{
The Yugoslav elites facing Western \\ European economic integration in the \\ "long 1970s"
}

\section{Benedetto Zaccaria}

During the 1970s, Yugoslavia's stance towards the process of Western European economic integration, and the EEC (European Economic Community) in particular, was affected by the country's sui generis internal and international stance. Despite retaining a one-party communist political regime, the Yugoslav federation distinguished itself from the Soviet bloc countries by virtue of its autonomous course grounded on a self-management system ${ }^{1}$ and a non-aligned foreign policy. ${ }^{2}$ However, Yugoslavia was not immune from the political dynamics of the Soviet bloc due to the unresolved relationship with Moscow after the TitoStalin split (1948) ${ }^{3}$ and solid economic ties with the CMEA (Council of Mutual Economic Assistance). At the same time, Yugoslavia nurtured a realistic attitude towards the EEC. Unlike the Soviet bloc countries, which regarded the Common Market as an imperialist enterprise, Belgrade established direct diplomatic relations with the Community in 1968. These would lead to the conclusion of two trade agreements (in 1970 and 1973) and a cooperation agreement in $1980 .{ }^{4}$ During the decade under consideration, Yugoslavia was therefore at the edge of European regional economic integration processes. This specificity was further complicated by its internal configuration. Yugoslavia's status as a federal union of six republics (Slovenia, Croatia, Bosnia and Herzegovina, Serbia, Montenegro and Macedonia) and two autonomous provinces (Vojvodina and Kosovo) with different levels of economic development and dynamics of regional integration with the Common Market area resulted in a gradual process of decentralisation of political and economic competences, which was sanctioned by the adoption of a confederal constitution in 1974.

The aim of this chapter is to address the Yugoslav elites' views and predicaments regarding economic integration in Western Europe against this multi-faceted background. Overall, scholarly works on Yugoslavia's internal and international dynamics have largely neglected the Western European integration question. Famously, historians have focused on the country's early opening to the West in the immediate aftermath of the Tito-Stalin split ${ }^{5}$ and the successive deterioration of relations with the USSR and the Soviet bloc countries. ${ }^{6}$ Historical analysis has also broadly focused on the 1950s, when the self-management system, based on the social ownership of the means of production, was first introduced, 
and in parallel with this the country's economy started its early integration with the international economic system. ${ }^{7}$ As is highlighted in recent literature, during the early 1960s the Yugoslav political leadership was divided between conservatives and so-called liberals, who pushed for Yugoslavia's further integration in the world market and a closer relationship with its Western European partners. ${ }^{8}$ The eventual adoption of economic reforms in 1965 meant a success of the party's liberal reformers and resulted in a consequent acceleration of economic ties with the West. ${ }^{9}$ While literature on Yugoslavia during the 1960s has broadly illustrated the rationale and internal debates leading to this reform process, the effects of the process in the following decade are still to be systematically explored. ${ }^{10}$ Several reports and studies on Yugoslavia and the EEC, quoted in this study, were published in the 1970s, 1980s and 1990s. However, they were not based on archival research and did not dig into the internal debates on how to deal with the European integration question, which is what makes this study new. Archive-based studies focusing on EEC-Yugoslav relations during the 1970s have mainly focused on the EEC's viewpoint. ${ }^{11}$ The few historical accounts of Yugoslavia's stance in the international economy of the 1970s have addressed the federation's early relations with international financial institutions such as the International Monetary Fund (IMF) and World Bank and the rising dependence of the country on Western credits leading up to the debt-service crisis of $1982 .{ }^{12}$ In general, agreement exists among historians that relations with the West were crucial in the evolution of Yugoslavia's internal and external balance during the decade under consideration: the unresolved questions of the trade deficit and international debt after the energy crises of 1973 and 1979 were to affect the stability of the federation and the political leadership of the League of Communists of Yugoslavia (Savez Komunista Jugoslavije [SKJ], or the League). ${ }^{13}$

However the West, towards which Yugoslavia leaned during the 1970s, has been only vaguely addressed. It has sometimes been considered to be the international financial institutions ${ }^{14}$ or Yugoslavia's main Western partners, namely the US, ${ }^{15}$ West Germany, ${ }^{16}$ and Italy. ${ }^{17}$ But the picture of Yugoslavia's stance within the international political economy of the 1970s is still blurred and vague. While limited attention has been devoted to its relationship with the Organisation for European Economic Co-operation (OEEC) ${ }^{18}$ and the Council of Europe, ${ }^{19}$ the historical understanding of Belgrade's relations with its Western partners suffers from an overall neglect of its relationship with the EEC, which during the 1970s accounted for more than $40 \%$ of the country's foreign trade. Common Market countries were also the principal recipients of the Yugoslav migrant force and the main source of workers' remittances and foreign tourism. ${ }^{20}$ Finally, the EEC has only been considered within the context of the disintegration of the Yugoslav federation in the early 1990s, as if Yugoslavia had only passively dealt with the European integration question in previous years. ${ }^{21}$

This chapter re-assesses the political and economic rationale for Yugoslavia's relations with the EEC during the long 1970s, illustrating the internal debates among the country's elite at all levels (political, economic, academic) on the European integration question and the question's importance for the country's internal 
and external developments. The chapter's argument is that internal debates on the EEC were profoundly shaped by the internal evolution of the Yugoslav federation during the 1970s. The marked process of confederalisation that was initiated after the adoption of the 1974 constitution resulted in diverging economic interests between the individual republics and autonomous provinces. Internal contradictions within the federation, amplified by the centrifugal tendencies of the northern republics of Slovenia and Croatia, affected the elaboration of a comprehensive federal strategy towards the Community. This chapter illustrates the divergence between a political-diplomatic interpretation of the EEC by the federal centre (in particular the SKJ and the Federal Secretariat for Foreign Affairs) and an economic view of the Common Market as a source of hard currency, industrial technology and know-how, particularly among the republican leaderships. This divergence developed against a background of international economic recession and energy crises (1973 and 1979), which exposed the Yugoslav federation to unrestrained external borrowing and to the rise of a balance of trade deficit. The chapter considers how elite debates and inter-republican confrontation - a direct consequence of the 1974 reform - developed at the federal level. The internal policymaking of each individual republic and autonomous province is beyond the scope of this study. ${ }^{22}$

This work is structured in three chronological sections. The first explores Yugoslavia's internal debates on the EEC from the establishment of diplomatic relations between the parties (1968) to the signing of the first trade agreement in 1970. The second section addresses Yugoslav views of the EEC against the background of a rapidly evolving internal framework, characterised by the end of the liberal reforms launched in the mid-1960s and the adoption of the 1974 constitution. In this section, the economic consequences of the 1973 oil shock and the suspension of the trade provisions in Yugoslavia's agreement with the EEC are considered. Finally, the chapter focuses on the period 1975-80, addressing the deterioration in the balance of trade, centrifugal economic tendencies, the rise in foreign borrowing and the internal debates over the economic orientation of the country. In conclusion, this chapter depicts a declining trajectory from the enthusiastic prospects of an 'industrial' future in the 1960s to the disillusion of the late 1970s, when the country's elites focused on the 'underdevelopment question' to cover both the shortcomings of the self-management system and the centrifugal tendencies at the federal level.

A terminological disclaimer is needed. In this chapter, the 'republican' affiliations of the leading actors involved in internal debates on the EEC are highlighted. This is not to offer a post-1989 reading of the political dynamics of socialist Yugoslavia. The author is aware that the disintegration of the federation was the outcome of complex internal and international dynamics which will not be dealt with here. He is also aware that republican leanings were in most cases blended with ideological adhesion to the 'brotherhood and unity' principle - which the SKJ had espoused since 1945 to overcome the troubled legacy of the 'first' Yugoslavia (1918-41) and World War II - and that labels when applied to human beings by their nature offer a simplified historical reading. However, to make sense of the 
economic competences of the individual republics - the clear-cut economic prerogatives of which were discussed at the federal level throughout the 1970s, as is shown in minutes of federal government meetings quoted in this chapter - and how they shaped the way Western European economic integration was perceived in Yugoslavia, republican inputs at the federal level are deliberately emphasised. It is argued that, especially after the adoption of the 1974 constitution, dealing with Yugoslavia's foreign economic policy without considering the republican factor would overlook a constitutive element of Yugoslavia as it was in the late Cold War years.

\section{A liberal opening towards the EEC}

In September 1968, Yugoslavia became the first socialist country to enter into official diplomatic relations with the EEC. ${ }^{23}$ The decision to establish direct relations with the Community was the result of a foreign policy orientation which went back to the mid-1950s. Due to its dependence on Western technology and industrial equipment, Yugoslavia had manifested profound interest in early Western European post-war integration efforts and had therefore applied to the OEEC for observer status in December 1954, becoming an associate member of the organisation the following year. The Yugoslav authorities expected that associating with the OEEC would enhance exports to Western markets and integrate the country in intra-European trade. Indeed, already in the mid-1950s, the Yugoslav leadership regarded the country's external commercial imbalance as a pressing concern. ${ }^{24}$ The same economic rationale shaped Yugoslavia's early approaches to the European Coal and Steel Community (ECSC) and later the EEC. The goal was to preserve economic ties with the six founding members of the Community (the Six) and avoid economic isolation between the two regional economic blocs. Indeed, Yugoslavia did not ignore the economic weaknesses of the federation and its entanglement between the two European blocs. Its active participation in the official establishment of the Non-Aligned Movement (Belgrade, 1961) went hand in hand with a careful diplomatic balance between the Soviet Union and the Western partners.

As for the former, after the death of Stalin (1953) relations between Tito and the new Soviet leadership led by Nikita Khrushchev had fluctuated between moments of 'reconciliation, comradeship and confrontation'. ${ }^{25}$ The normalisation of diplomatic relations favoured the development of economic ties after Yugoslavia's post-1948 isolation. Economic relations with the CMEA area were grounded on a clearing system based on agreements on the exchange of goods and bilateral cooperation in the industrial field. ${ }^{26}$ The development of economic ties with the Soviet bloc countries, which represented the privileged market for Yugoslavia's industrial output, resulted in Belgrade's association with the CMEA in 1964. ${ }^{27}$

From the late 1950s, Yugoslavia's relationship with its Western European partners and the newly established EEC also followed a clear-cut economic rationale which reflected contemporary debates within the SKJ on the process of internal economic liberalisation. The establishment of the Community indeed coincided 
with a rise of internal divergences within the country's political leadership about the integration of Yugoslavia in the international economy. The party's liberal wing - which advocated an introduction of market mechanisms in the economic system and opening to the international market through attracting foreign investments - prevailed over the resistance of the party conservatives, who feared the political consequences of economic liberalisation. Famously, in December 1964 the League's Central Committee approved a first set of liberal economic reforms (which began to be implemented in 1965) with the goal of strengthening the technological basis of Yugoslav industry and increasing the country's participation in the 'international division of labour' ${ }^{28}$ The introduction of liberal reforms was paralleled by enhanced relations with the EEC. The leading actors in the 1965 economic reforms were indeed deeply interested in rising to the commercial challenge stemming from the constitution of the customs union and the launch of the Common Agricultural Policy (CAP) in the early 1960s. The first official exploratory talks with representatives of the European Commission took place in Brussels in 1965 and led to an official request for the conclusion of a trade agreement with the Community. Between 1967 and 1968, the goal of Yugoslavia's political leadership - led by the president of the Federal Executive Council (Savezno izvršno veće [SIV]); the Croatian Mika Špiljak, the secretary for foreign affairs; the Serb Marko Nikezić; 29 and the Serb Milentije Popović, the president of the Federal Assembly ${ }^{30}$ - was to secure access for its external output to the Common Market in order to strengthen the process of internal economic reform.

All in all, during the early and mid-1960s, the Yugoslav leadership followed a cautious and pragmatic course which resulted in a balanced relationship with the two leading regional economic blocs. ${ }^{31}$ This attitude reflected the structure of Yugoslavia's external trade, which was based on importing technology and industrial equipment from the Western European market and exporting industrial goods to the CMEA area. However, this equilibrium was precarious and uncertain, as it depended on the delicate balance of relations with Moscow. This balance started to change after the appointment of Leonid Brezhnev as secretary general of the Communist Party of the Soviet Union in 1964. With an orthodox turn impressed on Soviet foreign policy, ideological controversies with Yugoslavia resurfaced, and they exploded after the Warsaw Pact intervention in Prague in August 1968. Yugoslavia's open condemnation of the military intervention in Czechoslovakia and the brutal suppression of the Prague Spring marked a deterioration in relations with Moscow. ${ }^{32}$ The Yugoslav leadership feared that the Soviet decision to invade Czechoslovakia could herald a new phase of aggressive foreign policy which would soon involve the Yugoslav 'heresy'. The consequences of the Czechoslovak crisis primarily concerned fear of renewed economic isolation from the Soviet bloc area. ${ }^{33}$ In Moscow, Yugoslav diplomatic representatives were blamed for playing a 'double game' between the CMEA and the EEC. ${ }^{34}$

The Prague events marked a first step towards the politicisation of relations with the Community. On the commercial dimension, they acquired a broader political meaning which was openly manifested by Yugoslav representatives in Brussels (in particular, the Slovenian Miloš Oprešnik, Yugoslavia's first ambassador to 
the EEC from September 1968) and the capitals of the EEC member states. The Czechoslovak crisis was indeed a leitmotiv during the preparatory phases of trade talks on a commercial agreement with the EEC, which opened in October 1968. ${ }^{35}$ An overall agreement emerged on a deepening of relations with the Community, and no opposition arose in this regard within the League or the SIV. Indeed, the Czechoslovak events were only one of multiple factors determining the choice to accelerate negotiations with the Community; they were used as a political tool to convince the EEC member states to respond to commercial requests which had been made well before August 1968. The launch of the market-oriented reforms indeed resulted in massive imports of Western industrial equipment. At the same time, Yugoslavia's exports to the EEC (mostly agricultural products) had stagnated as a consequence of the CAP regulations. ${ }^{36}$ This resulted in an increase in the country's trade deficit (from 58 million US dollars in 1965 to 364 million US dollars in 1969), and a continual search for import credits from its Western European partners, particularly West Germany, Italy and France. ${ }^{37}$ Within this framework, republic-level banks played a prominent role in investment finance operations. ${ }^{38}$ Yugoslavia's economic reforms were also followed by a search for increased economic autonomy of the republics and autonomous provinces vis-à-vis the federal centre. This was particularly the case of Slovenia and Croatia, whose business elites advocated an expansion of relations with the Common Market countries, in particular West Germany (which in the late 1960s included Yugoslavia in its Neue Ostpolitik) and Italy. ${ }^{39}$

The opening towards the EEC was therefore a combination of liberal and republican interests. It was not by chance that the leading actor in commercial negotiations was the Slovenian Toma Granfil, a member of the SIV who had been in charge of relations with the EEC since 1968. Granfil was assisted by Boriš Šnuderl, also a Slovenian and a deputy secretary at the Federal Secretariat for External Trade (Savezni Sekretarijat za Spoljnu Trgovinu [SSST]). Both Granfil and Šnuderl were in close contact with Yugoslav industrial enterprises (particularly in Slovenia, Croatia and Serbia) and acted as links between them and the federal centre. What these enterprises requested through the republican chambers of commerce was an expansion of commercial and industrial relations with Italy and West Germany, an improvement of industrial relations with firms in Italy's northern regions (Lombardy, Veneto and Friuli-Venezia Giulia) ${ }^{40}$ and an expansion of technical cooperation and joint investments with West German firms. ${ }^{41}$ The idea that Yugoslavia's enterprises should benefit from closer contacts with the Common Market was widespread among liberal reformers in the country, among whom were Špiljak and Granfil. Within the SIV, the prevalent opinion was that Yugoslavia's first need was to resolve its trade deficit and expand exports of agricultural products (beef in particular), which accounted for about $40 \%$ of the country's total exports to Western Europe. ${ }^{42}$ Accordingly, during the negotiations with the European Commission representatives, Yugoslavia insisted on including an agricultural chapter in the future commercial agreement. ${ }^{43}$

The negotiations led to the conclusion of a three-year trade agreement in March 1970, the first between the EEC and a socialist country. It was based on 
a non-preferential approach, as Belgrade deemed that a discriminatory agreement with the Community would affect the federation's political stance within the NonAligned Movement. ${ }^{44}$ The Yugoslav negotiators linked this treaty to the success of the market-oriented reform process. The public discourse developed in the League's official newspaper, Borba, and the bulletin of the Chamber of Commerce of Yugoslavia, Export Journal, focused on the economic and commercial aspects of the negotiations and the need to overcome the EEC commercial barriers to favour the development of the country's industrial base and agricultural production. ${ }^{45}$ The link between the liberal reforms and the Western European integration question was also constantly underlined by Granfil to his Community counterparts, who he urged to respond to Yugoslavia's requests to defend its particular path to socialism and resist alleged pressure from Moscow. During a meeting in November 1968 with Jean-François Deniau, the European commissioner in charge of external economic relations, Granfil argued: 'It is important for reciprocal economic relations for Yugoslavia to be treated like other market-economy countries, to eliminate any [commercial] clause identifying Yugoslavia as a state economy, which would be wrong and politically and economically unjustified' ${ }^{46}$

\section{The end of the liberal narrative}

The liberal narrative which had characterised Yugoslavia's policy towards the EEC started to change when the post-1965 economic reforms were followed by a gradual crisis. Famously, between 1970 and 1971 an economic recession was followed by an uncontrolled rise in investment and inter-republican acrimony over the allocation of federal resources and contributions to the federal budget. ${ }^{47}$ What followed was a move from economic to political confrontation among the republics. The emergence of nationalist and separatist trends, especially in Croatia, seemed to indicate that the process of economic liberalisation was the agent responsible for centrifugal tendencies in the federation. Purges started in Croatia in December 1971 and widened to all the republics, taking in a broad spectrum of party leaders in Slovenia and Serbia who were accused of liberalism, 'managerialism' and 'technocratic bureaucratism' ${ }^{48}$ Within this context, the party's leading ideologue, the Slovenian Edvard Kardelj, launched an anti-liberal and anti-reform discourse reaffirming that self-management and democratic centralism were the cornerstones of Yugoslavia. ${ }^{49}$

In July 1971, some of the leading actors involved in negotiating the first trade agreement with the EEC were replaced with the setting up of a new Federal Executive Council led by Bosnian Džemal Bijedić. Šnuderl, Granfil's successor, confirmed Belgrade's interest in carrying out negotiations to renew the 1970 trade agreement (which was to expire in 1973). He was in close contact with the Executive Council of Slovenia and was always receptive to input from Ljubljana. ${ }^{50}$ Šnuderl followed the path previously set by Granfil, insisting on the need for Yugoslavia to develop relations with the Community according to a twofold logic: economic, given the EEC's commercial importance for Yugoslavia; and political, as the Community was emerging as a balancing factor between the two superpowers. ${ }^{51}$ 
Šnuderl's activism was facilitated by Tito's views on the Western European integration question, which had been clearly manifested during a diplomatic tour of Western European capitals (Paris, Bonn, Brussels and Rome) between 1970 and 1971. These diplomatic missions were conceived as the Yugoslav response to the process of international détente between the superpowers and the parallel proposal for a pan-European Conference on Security and Cooperation in Europe (CSCE) by the Warsaw Pact countries in March 1969. Tito nurtured ambivalent feelings towards the unfolding of international détente. On the one hand, he was in favour of a relaxation of international tension which would result in expanded possibilities for Yugoslavia's economic relations with both regional blocs. On the other hand, he feared that the bloc-to-bloc dialogue, which seemed to be confirmed by the CMEA's early attempts to enter into direct relations with the European Community, ${ }^{52}$ would result in economic isolation of Yugoslavia. ${ }^{53}$

After an intergovernmental summit held at The Hague in December 1969, the EEC underwent its first enlargement with three new member states and launched a programme of deepening and completion which, among other goals, aimed to make the Community an international actor able to speak 'with one voice' in the international arena. ${ }^{54}$ To avoid isolation from the enlarging EEC, Yugoslav diplomacy reframed its approach to the Community, insisting on the developing status of the federation. This was a propitious juncture, as the EEC was looking for a new relationship with the members of the Group of 77 (G-77) developing countries through its launch of the Generalized Scheme of Preferences (GSP) in July 1971, and at the same time the Non-Aligned Movement was becoming increasingly interested in the issue of economic progress for underdeveloped countries, as emerged during the Lusaka conference in September of the same year. ${ }^{55}$ Yugoslavia successfully requested to be included in the list of the GSP beneficiaries by stressing its economic underdevelopment and its need to benefit from the same trade preferences as the other members of the G-77. The "development" discourse also originated from a widespread awareness within the League that the post-1945 bipolar equilibrium was being challenged by the political weight of the developing countries. ${ }^{56}$

Linked to this development issue was renewed propaganda on self-management in Western Europe. Although the re-launch of self-management was based on strict criticism of the alleged negative effects of the liberal reforms (i.e. bureaucratisation and marketisation of the economy) and on internal economic dynamics (which will not be addressed here), self-management was nevertheless depicted in SKJ international propaganda as an innovative system able to overcome the contradictions of both capitalism and socialism. A clear-cut political nexus linked non-alignment, underdevelopment and self-management. These labels were all intended to attract the attention of progressive Catholic, socialist and social-democratic political leaderships, intellectuals and trade unions in Western Europe. Indeed, in the late 1960s and early 1970s, the issue of industrial democracy acquired new momentum in Western European public discourse after the rapid decline of the les trentes glorieuses. ${ }^{57}$ The SKJ was aware of this and tried to emphasise its particular social and economic system, financing publications, 
scientific symposia and international conferences with the participation of leading politicians and intellectuals from Western Europe. ${ }^{58}$

A close link was also established between self-management and non-alignment in propaganda, and the northern republics made parallel calls for further economic relations with the Common Market. This was particularly the case on the occasion of a visit by the president of the European Commission, Sicco Mansholt, to Belgrade in December 1972. Mansholt, a Dutch social-democrat who had been deeply involved in the Community's relations with the developing world, ${ }^{59}$ was an ideal interlocutor for Yugoslavia. Indeed, Šnuderl, who had planned the European Commission president's visit, ${ }^{60}$ openly advised Tito's head of cabinet, his Slovenian comrade Marko Vrhunec, that self-management should be at the very core of Tito's conversation with Mansholt, given the latter's interest as a socialdemocratic leader in Yugoslavia's self-managed economy. ${ }^{61}$ Šnuderl's suggestion was accepted, and both Tito and Kardelj discussed the issue of Yugoslavia's 'modernity label' of self-management during Mansholt's visit. ${ }^{62}$

As the SIV member in charge of relations with the EEC, Šnuderl was also in direct contact with the SSST, the senior officials of which - in particular deputy federal secretary Milica Žiberna - represented a continuity factor in Belgrade's stance towards the EEC (she had been involved in the negotiations on the 1970 agreement with the Community). Šnuderl and Žiberna were aware of increasing pressures from the republican chambers of commerce and individual enterprises, in particular in the federal republics of Slovenia and Croatia, for closer links with the Western European markets to be established. Žiberna was in direct contact with the directors of enterprises and constantly informed them about the export/ import regime with the Community and the working of the GSP. She and her deputy, Petar Tomić, were veritable links between the business world and the state apparatus. ${ }^{63}$ Together with a number of officials from the SSST, Žiberna authored one of the first major publications explicitly dealing with the issue of Western European economic integration. ${ }^{64}$ In this book, the authors underlined Yugoslavia's dependency on Western European technology and know-how and related problems concerning the country's balance of payments. The book, as its authors explicitly stated, was intended to be a guide for Yugoslav enterprises, chambers of commerce and regional banks to better integrate with the Western European economic system.

The volume had symbolic importance as it inaugurated a series of contributions from the Yugoslav academic world on the question of European integration that paid prominent attention to individual policies and initiatives of the EEC, such as the CAP, the development of regional policy and monetary integration. ${ }^{65}$ However, given their specialised nature these studies did not develop into a true public debate ${ }^{66}$ Yugoslavia's academic elite's contribution on the country's stance towards Western European integration during the 1970s was therefore limited. Unlike what had happened during the 1960s, when studies on the EEC had contributed to political decision-making in dealing with the Community, politicaleconomic analyses concerning economic integration in Western Europe during the 1970 s were mostly carried out by the very people who were actually involved in 
official policymaking towards the EEC, or who collaborated with state-led organisations and agencies, such as the Institut za Medjunarodnu Politiku i Privredu (Institute for International Politics and Economy). This was particularly the case of articles published during the 1970s in Medjunarodna Politika (International Politics). ${ }^{67}$ As Ljubiša Adamović, chair of international economic relations at the University of Belgrade between 1972 and 1992, retrospectively argued, only in the late 1980s did Yugoslav scientific circles resume interest in the European integration question by virtue of the deep interest of Yugoslav society and the economic and political elite in the single market project. ${ }^{68}$

The prominent role of the state apparatus in dealing with the question of Western European economic integration confirmed the SIV as the main forum of debate. As the minutes of its meetings between 1972 and 1973 reveal, confrontation on this issue involved two alternative views. Šnuderl and his fellow representatives from Slovenia (Anton Vratuša and Janko Smole) advocated a qualitative step towards expanding commercial and economic cooperation relations with the Community. ${ }^{69}$ Šnuderl favoured direct relations with the European Commission, which had proved to prefer a more comprehensive approach to Yugoslavia according to an extensive interpretation of the Community's common commercial policy. However, Slovenia's proactive stance was not welcomed within the SIV, and in June 1972 Vratuša complained of an absence of a definite federal platform for enhancing relations with the EEC and of the ambivalent attitude of the Federal Secretariat for Foreign Affairs (Savezni Sekretarijat za Inostrane Poslove [SSIP]) on this matter. ${ }^{70}$ Indeed, a more conservative faction, headed by Bijedić, was sceptical about strengthening the supranational dimension of European integration and favoured the preservation of Yugoslavia's balance between the Community and the CMEA. ${ }^{71}$ Bijedić's stance was also linked to a parallel reshuffling of Yugoslavia's relations with the Soviet Union, sanctioned by a visit by Brezhnev to Belgrade in September 1971, against the backdrop of centrifugal tendencies in the federation and the purge of Croatia's leadership. ${ }^{72}$

However, the importance of the Common Market for Yugoslavia's external commerce was not questioned. In late 1973, Western European countries (the EEC plus the EFTA) represented Yugoslavia's main partner (accounting for $47 \%$ of its exports and $54 \%$ of its imports). Conversely, commerce with the CMEA countries lagged behind (34\% of its exports and $25 \%$ of its imports). ${ }^{73}$ The confrontation between Šnuderl and Bijedić did not result in an overt clash, and in the following months no clear-cut opposition to Šnuderl's initiatives emerged within the SIV. The Slovenian representative successfully insisted on including economic cooperation provisions in the fields of industry and agriculture in the new commercial agreement with the EEC, which was signed in June 1973. In parallel, on 18 April 1973 a non-preferential agreement on textile exports from Yugoslavia to the Common Market was also concluded. Prominent input in this direction had come from Yugoslav textile producers, mostly based in Slovenia. ${ }^{74}$

The period 1971-73 was marked by overall continuity in terms of Yugoslavia's relations with Western Europe and the EEC in particular. When the trade agreement with the Community was renewed in June 1973, Medjunarodna Politika reported 
that the SIV had succeeded in securing the Community's support for the country's internal and international status. However, beyond the official propaganda, the making of the 1973 agreement manifested profound differences from the previous one. The liberal discourse on the modernisation drive which had accompanied the negotiations on the 1970 agreement had faded, and with it efforts by Yugoslavia's leadership to enhance the country's competitiveness in the international market. As a consequence, the development discourse was promoted. It emphasised the need for Yugoslavia to be assisted economically through commercial concessions and the GSP. Moreover, the preparation of the 1973 trade agreement highlighted the emergence of specific republican interests in the EEC. However, contradictions in Yugoslavia's approach to the Community were to surface rapidly in the aftermath of the post-1973 economic recession in Western Europe.

\section{Playing the underdevelopment card}

The year 1974 marked the approval of a new constitution which confirmed the self-management system, later strengthened by the Associated Labour Act of 1976, as the cornerstone of the country's economic organisation. This reform process attributed a high degree of independence to the newly established 'organisations of associated labour' in all their business dealings and transactions with foreign partners. Enterprises were free to engage in operations involving the transfer of goods and capital and involving production and financial cooperation with foreign firms. Self-management provisions also assigned greater room for manoeuvre to the federal republics, which were now given broad exclusive competences in the fields of income distribution, taxation, employment, welfare policy and foreign trade. Instead, foreign policy and relations with international organisations, including the EEC, remained within the federal domain. However, according to the newly approved constitution, decision-making was based on negotiation and agreement among the republics and autonomous provinces. ${ }^{75}$ After 1974, the SIV became a clearing house for inter-republican confrontation and the major task of preserving the unity of the Yugoslav market (Art. 381 of the 1974 constitution) was subject to such confrontation.

The growing weakness of the SIV coincided with the explosion of a global economic recession in the aftermath of the 1973 oil shock. On a proposal by Italy and France, the EEC issued protectionist measures suspending the provisions of the 1973 trade agreement to face competition from Yugoslavia's agricultural exports. ${ }^{76}$ At the same time, the rising cost of oil made imports from Western Europe more expensive. From 1968 to 1972, imports of mineral fuels accounted for about $5.5 \%$ of the country's total imports. In 1974, this percentage rose to $12.6 \%$, heralding a growing trend which would culminate at $23.5 \%$ in 1980 in the immediate aftermath of the second oil shock. ${ }^{77}$ At the same time, a decrease in internal demand in the Community meant restrictions in the labour market. A massive return of Yugoslav guest workers from West Germany exacerbated the balance of payments problems. After the oil shock, the country was also hit by the availability of international credit. Like the vast majority of developing 


\section{2}

countries in Eastern Europe, it was 'kissed' by debt. ${ }^{78}$ Aiming to expand domestic credit, Yugoslav banks started the practice of borrowing abroad and converting the credits into dinars. Constitutional provisions limited the capacity of the SIV to manage the balance of payment problems, impose any kind of strategic pattern on the flood of foreign borrowing and foster a homogeneous import policy. Successive reforms in the foreign trade system, later sanctioned by a 1977 Law on the Turnover of Goods and Services with Other Countries, ${ }^{79}$ created a complex interest network, based on self-management planning of foreign economic relations, which put workers in organisations of associated labour in the focus of economic decision-making in the sphere of foreign exchange operations. ${ }^{80}$ This had a clear impact on the country's export policy and, in turn, on relations with the EEC.

The individual republics - Slovenia and Croatia in particular - stepped up pressure to get the maximum advantage from negotiations with the European Commission to improve access to the Common Market (in particular to West Germany and Italy). ${ }^{81}$ The Republican Secretariat for Agriculture and Forests in Ljubljana in particular manifested attention to the development of agricultural relations with the Common Market, ${ }^{82}$ whereas the decorative fabrics factory in Ljubljana (Tovarna Dekorativnih Tkanin) ${ }^{83}$ and the Textil company based in Zagreb insisted on broader concessions for the textile industry. ${ }^{84}$ At the business association level, the Association of Yugoslav Iron Workers in Belgrade (Udruženje Jugoslovenskih Železara) paid particular attention to the EEC's preferential scheme, ${ }^{85}$ openly insisting on closer cooperation between Yugoslavia and the Community in the industrial domain. ${ }^{86}$ These calls were results of the industrialisation process which, to face international competition during the 1960s, had turned Yugoslavia from an agricultural into an industrial country. The agricultural population had decreased from 51\% to 38\% of Yugoslav workers between 1961 and 1971, and over the same period the share of agriculture in Yugoslavia's total exports had fallen from $38.1 \%$ to $19.6 \%{ }^{87}$ This process would characterise the Yugoslav federation's patterns of trade throughout the 1970s: in 1980 agricultural exports would only represent $11.39 \%$ of the country's exports. ${ }^{88}$

The huge impetus for increased relations with the EEC was confirmed by the pressure exerted by the Slovenian and Croatian economic elites for settlement of the border issue with Italy. The two republics' chambers of commerce promoted a joint action which called for increased border cooperation with Italy's northeastern region as a doorway into the Common Market. In direct contacts with the Slovenian leadership, Šnuderl himself conducted secret negotiations which were to lead to the Osimo agreements between Rome and Belgrade signed in November 1975. ${ }^{89}$ This agreement solved the border problem between the two countries, a troubled legacy of World War II. It envisaged the creation of a cross-border industrial zone between Italy and Yugoslavia from which Slovenian and Croatian industrial produce could enter the Community without tariff restrictions. After the signing of the Osimo agreements, and on the basis of the confederal provisions in the 1974 constitution, Slovenia and Croatia fostered bilateral cooperation with bordering regions. In November 1978, this led to the constitution of the AlpsAdriatic Working Community as a means to foster regional cooperation with Italy 
(Friuli-Venezia Giulia and Veneto) and Austria (Carinthia, Upper Austria and Styria) in the fields of culture, science, transport and tourism. ${ }^{90}$

Given the pressure from the northern republics and the parallel crisis in commercial relations with the EEC, debates on the Western European integration question acquired new momentum. Yugoslavia's unbalanced dependency on the Common Market was highlighted within the SIV. While the Federal Secretary for Finance, Montenegrin Momčilo Čemović, openly accused Italy (which had first proposed the Community ban on beef imports from Yugoslavia) of 'stabbing Yugoslavia in the back', Šnuderl insisted on a less emotional approach to their Western European partners and on the need to expand cooperation well beyond the commercial sphere to avoid dependence on the nine members of the EEC (the Nine). ${ }^{91}$ Conversely, the political side of relations with the EEC was underlined by the League's leadership (particularly Tito and Kardelj) and the SSIP, which after the 1972 purges of the liberals in Serbia was led by Serb Miloš Minić, a veteran member of the League and one of Tito's closest comrades. The party elite was mostly interested in the EEC's role in foreign policy as an international actor and how it could match the country's non-aligned stance. The launch of an intergovernmental scheme for foreign policy cooperation (EPC) among the EEC member states in 1970 and the Nine's proactive stance during the CSCE preparatory phase confirmed the Community's ambitions in the international arena. ${ }^{92}$ In addition, the SSIP closely monitored the development of direct relations between the EEC and the People's Republic of China, depicting them as a demonstration of the Community's increasing international weight. ${ }^{93}$ At the same time, the SKJ and the SSIP were concerned about the effects of the balance of trade disequilibrium on the financial stability of the federation. In this regard, they were also supported by Bijedić, who strove to balance competing republican interests. The Slovenian and Croatian activism towards the EEC, which had clearly emerged during the negotiations on the Osimo agreements, indeed arose the concerns of the Federal Secretariat for the Economy, led by the Serb Boško Dimitrijević, that a privileged border regime with Italy - based on finished products drawing on raw materials or semi-finished goods coming from the central or southern republics which could not, in turn, enjoy the economic advantages of the northern republics - would enhance economic disparities within the federation. ${ }^{94}$

Minić advanced requests for the relaunch of commercial relations with the Community during an official visit to Brussels in November 1974. Once back in Belgrade, Minić reported his personal apprehensions during a meeting of the SIV on 30 December 1974. He underlined the payment problems which Yugoslavia would face should the deterioration of the trade balance in relations with Western Europe continue. ${ }^{95}$ For his part, Bijedić agreed on the importance of closely examining the evolution of the balance of payments. ${ }^{96}$ In the following weeks, appeals for enhanced cooperation with the EEC partners were also issued by Ivo Kuštrak, the president of the Federal Committee for Agriculture and formerly the vice president of the Chamber of Commerce of Croatia. In January 1975, he argued: 'The ratio between imports and exports is 1 to 3 . This is not negligible. I am saying this because we are severely hit in the agricultural sector and we must look for a way out, not only for agriculture but for the country as a whole' ${ }^{97}$ 
Kuštrak's inputs were supported by the Federal Secretary for External Commerce, the Croatian Emil Ludviger, who insisted on a pragmatic approach towards the Community based on a step-by-step policy. He was against an overall strategy encompassing 'economy, finance, social policy, monetary policy. . . . this would be pretentious on our part. ... We must be realistic about what to expect from this [European] Community'. ${ }^{98}$ Following Ludviger's appeal, a pragmatic initiative started to develop to enlarge financial cooperation with the European Investment Bank (EIB).

This initiative was once again an outcome of lobbying by Slovenia. Indeed, already in 1973 the Federal Secretariat for Finance under the leadership of Secretary Janko Smole had explored the possibility of Yugoslavia having access to EIB loans. ${ }^{99}$ Smole had been fully supported by his Slovenian comrade Šnuderl as both regarded financial cooperation with the Community on infrastructure projects as a fundamental means for further integrating the Yugoslav federation, and Slovenia in particular, with the Common Market. ${ }^{100}$ Appeals for financial cooperation were reiterated during a ministerial meeting of the EEC-Yugoslavia Mixed Commission in July $1975 .{ }^{101}$ In this instance, the initiative was taken by Smole himself, who had meanwhile replaced Šnuderl, due to the latter's divergences with Bijedić over the EEC question, ${ }^{102}$ as the SIV member in charge of relations between Yugoslavia and the Community.

After the aforementioned preliminary approaches in the financial field, Smole realised that a broader political mandate from the SIV was needed to foster his initiative. On 23 October 1975, he clearly stated to his peers that a federal strategy should be inaugurated to convey an external image of Yugoslavia as a reliable partner. ${ }^{103}$ 'The EEC member states', Smole argued, 'believe that the issue of commercial deficit only depends on us, that this is a question of Yugoslavia's political economy'. ${ }^{104}$ Smole therefore did not present financial cooperation as a Slovenian project but, being aware that the political aspect of the EEC question was of primary importance for the SIV presidency and the SKJ, he argued that Yugoslavia should demonstrate its interest in taking initiatives to overcome the present impasse. The political battle for financial cooperation was to be the starting point for extended collaboration in the field of commerce, tourism and joint ventures. Čemović argued that Smole's initiative should be followed up and that concrete proposals for financing joint projects should be made. Čemović also claimed during the debate that increasing republican competences in the field of logistics investment were hindering the creation of genuinely federal infrastructure networks. He stressed that Yugoslavia's major aim was to get financing for the creation of a highway linking Slovenia (Ljubljana) to Macedonia (Djevdjelija). Such financial support would have a political meaning. By investing in the unity of the country as a whole, Yugoslavia (as a federal and homogeneous entity) could be recognised as a strategic partner by the EEC member states as a bridge towards Greece and the Arab world. Thanks to Čemović's support, based on a federal perspective which, however, did not challenge the Slovenian requests, Smole's proposal for enhanced financial cooperation with the Community was approved by the SIV. The appeals by the federal government for the establishment of financial 
cooperation were finally accepted by the Council of Ministers of the EEC in January 1976, paving the way for the launch of projects of joint interest from 1977 onwards, including the financing of five sections of the future trans-Yugoslavia motorway. ${ }^{105}$

Beyond the financial sphere, a political initiative to face the question of trade relations with Western Europe was reappraised by Bijedić during a meeting of the SIV on 3 December 1975. The SIV met to review the state of the federal balance of payments, as the dreadful situation depicted by Minic the previous year had not improved. The growing trade deficit was threatening Yugoslavia's economic links with the West, a situation which, in Bijedić's words, could not be passively accepted: 'We cannot detach from the West so easily. Neither will we have to because this is our traditional market for imports and exports and we need to plan an organised economic strategy'. ${ }^{106}$ Bijedić therefore called for increased diplomatic pressure on Western European partners to invest in Yugoslavia. He insisted, however, that such assistance should be based on direct pressure from the directors of Yugoslavia's major enterprises. Western partners should be literally urged to buy Yugoslav goods. This was the case, for example, of relations with Italy. Bijedic stated that, by virtue of traditional links in the automobile sector established by FIAT and ZASTAVA in Kragujevac, the influential president of FIAT, Giovanni Agnelli, should urge the Italian government to adopt a more liberalised commercial stance towards Yugoslavia: 'Let's make Agnelli help us sell 20,000 tons of meat and that would already be a good deal. Let's make him fight with the Italian government in order to make it buy [meat]'. ${ }^{107}$ According to the president of the SIV, Yugoslavia could hardly compete on economic grounds: 'It is capitalism: they tend to preserve their own interests'. ${ }^{108}$

The relationship with the Community was therefore increasingly intertwining with the trade deficit problem. During a meeting of the SIV in early January 1976, Minić defined the country's commercial imbalance as Yugoslavia's 'most important foreign policy issue'. At the same time, he noted a stark increase in trade relations with Eastern Europe: 'The question arises as to where we are actually going'. ${ }^{109}$ Minić's attitude was marked by profound pessimism, which echoed Bijedić's previous statements: 'In our economy . . . there is not the capacity to compete within the markets of developing countries, whereas all our weaknesses can be sold in the East'. He defined the CMEA area as a second-ranking market which was ready to accept low-quality technology, 'something which the Western market cannot tolerate'. 'We must import', Minić continued: 'This is the real state of our economy and we must find ways . . . to increase exports. . . . This issue is linked to our political independence, to our position in the international political scene. The state of our exports to the Western market is unbearable'. ${ }^{110}$ Minić therefore called for new diplomatic initiatives towards the Western European partners and the European Community to overcome commercial barriers. Similar concerns were echoed by Milorad Birovljev, a Serb from Vojvodina who chaired the Federal Committee for Social Planning. Birovljev expressed his alarm at the federal weakness in managing import and export strategies due to the direct competence of the republics and autonomous provinces in this field. At the same 
time, he underlined a need for a political action towards Western European governments. The Serb Berislav Šefer, a vice president of the SIV, spoke of the bad situation of the balance of payments and the 'politically dangerous' reflection of this situation on the country's international image. He agreed with Minic that the penetration of Yugoslavia's exports in the Common Market should be increased. However, beyond general statements on the need to foster exports, this debate was characterised by an overall disillusionment about the possibility of changing the course of Yugoslavia's economic policy. This was explicitly manifested by Bosnian Gojko Ubiparip, who argued: 'We are debating about exports . . . to the Western markets. . . . we are debating and finding reasons for our economic recession. However, we are not considering our internal disorganisation and the lack of planning. There are no plans in the country and we do not know what our strategy is'. Šefer agreed with Ubiparip and underlined the need for the federal authorities to find a way to manage the uncontrolled flow of financial credits to finance imports. ${ }^{111}$

After this disconsolate debate, the SIV paid increasing attention to the evolution of a federal posture towards the Common Market. In February 1976, Bijedić made a diplomatic tour to Paris, Luxembourg and Brussels. During the visits, he spoke of the political importance of relations with the Community and the need to solve the trade deficit question. The decision to make the EEC a political partner to face the question of the country's internal stability led to the conceptualisation of a joint declaration to be signed by Yugoslavia and the EEC. As the archival sources reveal, negotiations on this were entirely dealt with at the federal level and were strongly supported by Bijedić. The tightly knit inter-ministerial group which was set up to prepare the draft text to be submitted to the Community counterparts was made up of members of the SSIP (Božidar Frangeš), the SSST (Milica Žiberna) and two diplomats in the Yugoslav mission to the EEC in Brussels (Žarko Tomašević and Časlav Djermanović). ${ }^{112}$ The declaration was signed on 2 December 1976 by Bijedić and Max Van der Stoel, the Dutch foreign minister and president of the Council of Ministers of the EEC. ${ }^{113}$ The 1976 Joint Declaration affirmed Yugoslavia's non-alignment and developing status as the cornerstone of bilateral relations between the two parties. This was a clear input coming from the SSIP. ${ }^{114}$ Publicly, the 1976 declaration was presented as a success for the Yugoslav federation, as it reaffirmed the principles and character of its foreign policy and particularly the country's standing as a 'non-aligned, socialist and developing country with a distinctive socio-economic system based on the principles of self-management socialism' ${ }^{115}$

The rationale behind the Yugoslav stance towards the EEC after the signing of the joint declaration confirmed the foreign policy dimension of Yugoslavia's opening towards the Community. Yugoslav representatives from the SKJ and the SIV - which was now led by the Montenegrin Veselin Djuranović after the premature death of Bijedić in January 1977 - were increasingly aware that the high investment rate which had characterised the country throughout the 1970s was not sustainable. A sort of 'prisoner's dilemma' was emerging within the federation, with each republic benefiting from autonomous import regimes to the detriment 
of the federal balance of trade. In fact, a 'Resolution on the Realisation of Yugoslavia's Social Plan for 1978', which was approved by the parliament on 28 December 1977, provided that import substitution programmes should be adopted in the course of 1978. However, unfavourable market conditions in the Western countries and the orientation of domestic producers towards the internal market, in which high prices in comparison with the world market could be obtained, compromised this effort. To face the trade deficit, a change in Yugoslavia's policy towards the Community was agreed and the traditional non-preferential commercial approach had therefore to be overcome. This policy change was manifested by Djuranović during a meeting in Belgrade with the vice president of the European Commission, Wilhelm Haferkamp, in June 1978. ${ }^{116}$ On this occasion, the SIV president stated that the Nine should defend Yugoslavia's non-aligned status, and that to do so a new sui generis commercial regime should be set up to assist the federation with unilateral trade concessions well beyond the GSP. ${ }^{117}$ This policy change modified the non-discriminatory approach endorsed by the Yugoslav leadership since the negotiations for the 1970 agreement. All in all, this was the consequence of the incapacity of the SIV to impose a working import substitution policy. ${ }^{118}$ The aforementioned 1977 foreign trade reform had even deteriorated the coordinating role of the SIV. Retrospectively, improving relations with the EEC was a way to solve the trade deficit situation while avoiding internal reforms.

Djuranović's move was openly sponsored by the SKJ leadership. In December 1978, Tito explicitly declared his country's weakness and dependency on the West while meeting with the secretary general of the Organisation for Economic Co-operation and Development (OECD), Emiel van Lennep. In 1977 the OECD countries represented $51 \%$ of Yugoslavia's total trade, $77 \%$ of its commercial deficit and $87 \%$ of its foreign debt. Tito therefore made an appeal for economic assistance on the basis of Yugoslavia's status as a developing country. In particular, he made it clear that in the long run Yugoslavia could not stand a policy of high investment and foreign indebtedness. He therefore asked for Western understanding of Yugoslavia's precarious state. Referring to the debt question, Tito argued, 'We are continuing to buy goods in Western Europe which are necessary for our development. I do not know for how long this may go on' ${ }^{119}$ Tito's statements were frequently raised by senior representatives of the SKJ, particularly Vladimir Bakarić, in bilateral contacts with West German representatives. ${ }^{120}$ According to Bakarić, relations between the EEC and Yugoslavia should mainly comprise and be understood within the broader context of north-south relations and the EEC's development policy. ${ }^{121}$ It was not by chance that at the level of the League's International Commission, discussions centred on topics such as the new international economic order and the critical role of Western Europe in it - indeed, criticism of EEC protectionism had been clearly made in the final conclusions of the Fourth Non-aligned Summit in Algiers in September $1973^{122}$ - rather than on the actual dimension of economic relations between the Community and Yugoslavia or the federation's internal plans to face the rising commercial deficit. ${ }^{123}$ This attitude also reflected the stance adopted by SKJ representatives during the preparatory phases of the Conference of European Communist Parties held in Berlin in June 
1976. On an initiative of the Italian Communist Party, representatives of several Western and Eastern European communist parties had gathered in Rome on 19-20 April 1975 to review the 'contemporary status, possibilities and prospects for economic cooperation in Europe'. While the representatives of the Eastern European parties limited themselves to blaming the discriminatory nature of the Common Market, Milan Aleksić, a member of the SKJ Presidency and director of the Belgrade-based Institute for Foreign Trade (Institut za Spoljnu Trgovinu), stated that economic cooperation in Europe should not neglect the broader necessity of reforming the international division of labour and relations with developing countries. ${ }^{124}$

However, the north-south issue and the coordination among developing countries had less impact on Yugoslavia's relations with Western Europe than the continual deterioration of the trade balance and the increasing foreign indebtedness. The lack of a federal economic strategy was even emphasised by the sheer absence of communication between the SIV and the republics and autonomous provinces of statistics on the actual flow of financial credits from the West, as emerged during a meeting of the SIV on 19 March 1979. ${ }^{125}$ Macedonian Stojan Andov, who replaced Smole as the person in charge of the SIV Commission for Relations with the EEC in May 1978, worked towards a politicisation of relations with the Community. During a meeting of the SIV on 10 May 1979 he argued, 'It is important to regulate our relations with the EEC for the economic stability of the country, as the economic stability of the country is important for its overall position in international relations'. ${ }^{126}$ Negotiations between Belgrade and the European Commission concerned the conclusion of a sui generis cooperation agreement. On the Yugoslav side, they were carried out by Andov on the basis of this clear-cut political rationale, which was later underlined by the Soviet invasion of Afghanistan in December 1979 and the rapid deterioration of Tito's health in January 1980. ${ }^{127}$ Croatian Josip Vrhovec, who had replaced Minić as foreign minister in 1978, was instead de facto excluded from the negotiations between Belgrade and Brussels. The SIV as a whole was only consulted when the guidelines for the platform for negotiations were discussed in spring 1979 and when the treaty was ready to be signed in February 1980. Communication with the members of the federal government was therefore kept to a minimum level and the question was treated as a state secret. During the final negotiating phases, many of the SIV members, including Vrhovec, lamented the overall lack of information about the whole process. ${ }^{128}$ All in all, the conclusion of the 1980 agreement developed without comprehensive economic and political debate within the federation and the republics.

The 1980 cooperation agreement with the EEC was finally signed on 2 April, a few weeks before the death of Tito on 4 May 1980. Belgrade was granted unilateral and non-reciprocal commercial concessions in both the agricultural and industrial fields. ${ }^{129}$ Provisions on economic cooperation in the fields of tourism, environment, finance and industrial cooperation were also included. However, beyond the commercial sphere, the provisions of the agreement were general and indicative. As Andov himself stressed in Medjunarodna Politika, Yugoslavia's opening 
to the Community was primarily linked to the country's status as a developing country which had to depend on Western European commercial concessions. ${ }^{130}$ The rise in the trade deficit and the growth of Yugoslav overall foreign indebtedness (from 3.5 billion US dollars in 1972 to 18.4 billion US dollars in 1980) ) $^{131}$ against a backdrop of sky-high oil prices and rapidly escalating rates of interest on international credit bore witness to such dependency. However, relying on a policy of assistance and concessions was exposing Yugoslavia to increasing dependency on the Common Market and the goodwill of Western European leaders. It seems that the Yugoslav leadership artificially separated the European integration question from its internal economic dimension. The preconditions for the link between Yugoslavia's performance at home and abroad, which hugely impacted the country's economic balance at the end of the decade, were definitively set, as was its entry into the financial spiral which would lead to the debt-service crisis and successive IMF restructuring programmes from 1982 onwards. ${ }^{132}$

\section{Conclusions}

During the long 1970s, Yugoslavia's policy towards the EEC was the result of a complex set of diverging dynamics. The establishment of relations with the Community and the making of the first trade agreement in 1970 were outcomes of a process of liberal reforms. The "realistic" opening towards the EEC, which distinguished Yugoslavia from the Soviet bloc countries, was therefore grounded on economic considerations which pointed at the need to avoid the negative consequences of the customs union established by the Six and foster economic relations with the Common Market. While the Warsaw Pact intervention in Prague and its international repercussions highlighted the political dimension of EEC-Yugoslav relations, the liberal rationale of the commercial negotiations which officially opened after October 1968 did not change. However, also as a consequence of the market-oriented reforms and political opening to the Community - which was then experiencing a triple process of enlargement, deepening and completion - during the negotiations on the first trade agreement (1968-1970), specific economic interests of the economic elites of Slovenia and Croatia began to take shape. As was highlighted in the second section of this chapter, the crisis resulting from the liberal reforms also involved the course of Yugoslavia's opening towards the EEC. This opening was conditioned by the emergence of inter-republican competition and the successive confederalisation of the country with the adoption of the 1974 constitution. Within this framework, competing views between the federal approach adopted by the SKJ and the SIV presidency and the republican prerogatives of Slovenia and Croatia emerged. While the former advocated a political reading of relations with the EEC - based on Yugoslavia's status as a non-aligned and developing country and the rising international role of the Community within the framework of the CSCE - the latter were instead interested in the economic advantages which the republics would draw from closer ties with the Common Market. The two views became irreconcilable after the economic recession which hit Western Europe in the aftermath of the 1973 oil shock and the 
adoption of the 1974 constitution. While the commercial and economic dimension of relations with the EEC was sponsored by the republican leadership, the political view of relations with the Community endorsed by the SKJ, SSIP and SIV presidency (Bijedić and from 1977 onwards Djuranović) gradually prevailed. The view of the EEC as a political rather than economic partner suited the foreign policy orientation of the League's leadership - as it focused on the Western European attempt to prevent a superpower condominium in Europe - and was functional in maximising the strategic value of a united Yugoslavia in Western eyes. Overall, the opening to the EEC, which had started within the framework of the reformist policies of the 1960s in order to integrate Yugoslavia in the international economy, turned into a conservative policy to preserve the federation's internal and external status quo. From the viewpoint of the Yugoslav federal leadership, the EEC member states had to assist Yugoslavia's policy of high investment and exports to the Common Market. The short-term aims were to get convertible currency from the West, solve the trade deficit and sustain the confidence of Western creditors. To justify this policy internally and abroad, Yugoslavia's official narrative was that of an underdeveloped country assisted by developed economies. Indeed, the negotiation of the 1980 cooperation agreement with the EEC was the outcome of a pessimistic outlook on the capacity of the country to stand integration in the international economy and balance internal investment with foreign exports. Once the political aspect of the negotiation prevailed over its economic rationale, Yugoslavia condemned itself to a policy of dependency on Western Europe, confirming its isolation at the periphery of the Common Market. At the turn of the decade from the late 1960s to the late 1970s, the Yugoslav federal elite had thus moved from the illusion of an industrial future to an apologetic description of the federation as an underdeveloped country which hid its growing structural disparities.

While this study has not addressed the origins of the collapse of Yugoslavia in the early 1990s, which took place in a different international context, it has addressed the lack of a veritable federal strategy vis-à-vis the EEC, and the impossibility for the federal government to shape the country's foreign economic policy, which was considered an object, rather than a subject, of the globalised economy of the 1970s. We can see here the long-term roots of Yugoslavia's uncontrolled spiral of commercial and credit imports and the ever-declining role of the federal government vis-à-vis the federal republics, which Ante Marković's reforms in the late 1980s were not able to correct.

Comparatively, the sui generis character of Yugoslavia's relations with the EEC proved to be nominal rather than substantial. Yugoslavia's official recognition of the Community and the conclusion of official agreements with it - a unicum in relations between the Community and the socialist world which would only be followed by the People's Republic of China in the late 1970s - did not mean the country was actually included in the integration path of Western Europe, nor did it imply a process of EEC-inspired political and economic liberalisation in the country. Internal political dynamics shaped the rapprochement to the EEC rather than vice versa. Instead, the story told in this chapter shows the impressive 
similarity of the Yugoslav case with those of the other socialist states addressed in this book, in that unbalanced trade relations, determined by an import hunger for high-quality machinery and equipment in the absence of an endogenous drive for exports, and a chronic deficit of the balance of payments were concerned (as in the case of Bulgaria in the late 1970s and Poland, Romania and the GDR at the beginning of the 1980s). ${ }^{133}$ Equally similar to the dynamics experienced by the CMEA member states were Yugoslavia's attempts to move to less centralised market socialism (Hungary), to play the development card to obtain commercial concessions (Romania) and to rely on Western financial credits to foster internal investment (in particular, the GDR, Hungary, Poland and Romania). Finally, this work has highlighted the internal effects of Yugoslavia's inclusion in the global economy in terms of import-based investment, uncontrolled access to foreign credits after the 1973 oil shock and dependency on fluctuations in interest rates, which made the country part of the broader group of underdeveloped countries in Eastern Europe and Latin America which later underwent the global debt crisis of the 1980s. ${ }^{134}$

\section{Notes}

1 On the origins of self-management, see Unkovski-Korica, The economic struggle for power in Tito's Yugoslavia.

2 Rajak, "From regional role to global undertakings," 65-86; Jakovina, Treća Strana.

3 See Perović, "The Tito-Stalin split," 32-63; Rajak, Yugoslavia and the Soviet Union in the early Cold War.

4 Zaccaria, The EEC's Yugoslav Policy.

5 Lees, Keeping Tito afloat; Heuser, Western 'containment'policies; Bekić, Jugoslavija u Hladnom ratu.

6 Kramer, "Stalin, the split with Yugoslavia," 29-63.

7 Uvalić, Investment and property rights in Yugoslavia.

8 Obadić, "A troubled relationship," 337-39.

9 Obadić, In pursuit of stability; Bianchini, La diversità socialista in Jugoslavia, 57-70.

10 The most recent studies on Yugoslavia's views on the EEC based on Yugoslav archival sources have addressed the 1970s only tangentially, and in view of the consequences of the reforms launched in the 1960s. See Obadić, "A troubled relationship," 329-48; Dragišić, "Jugoslovenski pogledi," 147-60; Ruzicic Kessler and Dragišić, "Zwischen Chance und Bedrohung," 138-56. This offers an analysis of YugoslavEEC relations at the institutional level without systematically investigating internal debates among the Yugoslav elite.

11 Zaccaria, The EEC's Yugoslav Policy.

12 Woodward, Socialist unemployment; Ramet, The three Yugoslavias, 325-40; Dyker, Yugoslavia.

13 Calic, "The beginning of the end," 66-86.

14 Woodward, Socialist unemployment.

15 Lampe, Prickett, and Adamović, Yugoslav-American economic relations.

16 Kosanović, "Brandt and Tito," 232-43.

17 Zaccaria, La strada per Osimo; Mišić, Pomirenje na Jadranu; Bucarelli, Micheletta, Monzali, and Riccardi, Italy and Tito's Yugoslavia; Škorjanec, Osimska pogajanja; Pirjevec, Klabjan, and Bajc Osimska Meja.

18 Marković and Obadić, "A socialist developing country," 89-111.

19 Milikić, Između Evrope i Nesvrstanosti. 


\section{Benedetto Zaccaria}

20 Artisien and Holt, "Yugoslavia and the E.E.C. in the 1970s," 355-69. On tourism, see Grandits and Taylor, Yugoslavia's sunny side.

21 Rafael Biermann, "Back to the roots," 29-50; Radeljić, Europe and the collapse of Yugoslavia.

22 This chapter is mostly based on archival sources in the Archives of Yugoslavia (Arhiv Jugoslavije) in Belgrade related to the Federal Executive Council, Federal Secretariat for External Trade, Cabinet of the President of the Republic and the SKJ. It also benefits from archival sources in the Diplomatic Archives of the Republic of Serbia.

23 Zaccaria, The EEC's Yugoslav Policy, 33.

24 Marković and Obadić, "A socialist developing country," 91.

25 Rajak, Yugoslavia and the Soviet Union in the early Cold War.

26 Arhiv Jugoslavije (AJ), Kabinet Predsednika Republike (KPR), 837, III-b-2-a, Naši odnosi sa Savetom za Uzajamnu ekonomsku pomoć (SEV), April 1962, Beograd.

27 AJ, KPR, 837, III-b-2-a, "Referat i ratifikaciji Sporazuma izmedju Vlade SFRJ i SEV," 16 December 1964.

28 Obadić, "A troubled relationship," 329-48.

29 AJ, Fond 751, File 115, "Informacija o poseti predsednika SIVa SFRJ Mike Špiljaka Italiji," 18 January 1968.

30 AJ, A-CK SKJ, IX, 48/I - 392-426, Komisija za medjunarodne odnose i veze, Italija, K. 9, Report of meeting between Popović and Trabalza, 12 February 1968.

31 Jakovina, Treća Strana, 34.

32 Banac, "We Did Not Quarrel, We Did Not Curse," 173-96.

33 AJ, KPR, II-5-c-2/197, "Predlog zaključaka Saveznog izvršnog veća o nekim ekonomskim pitanjima u vezi sa dogadjajima u Čehoslovačkoj," 2 September 1968.

34 AJ, KPR, III-b-2-a, "Izvod iz izlaganja Aleksadra Griličkova na sednici SIVa," 5 December 1968.

35 Arhiv Ministarstva za inostrane poslove Republike Srbije, Belgrade (AMIP), PA, R, 1968, f 141: b 434938, Brisel, 27 September 1968.

36 AJ, Fond 751, File 234, "Efekti pojedinih varijanti za rešenje problema izvoza goveda, govedjeg mesa i kukuruza u pregovorima sa EEZ," Beograd, 2 October 1969.

37 AJ, "Efekti pojedinih varijanti za rešenje problema izvoza goveda, govedjeg mesa i kukuruza u pregovorima sa EEZ," Beograd, 2 October 1969.

38 Dyker, Yugoslavia, 63-5.

39 Zaccaria, "Yugoslavia, Italy."

40 AJ, Fond 751, File 277, Pov. 57/2-69, L. Cukala to P. Tomić [SSST], 22 December 1969.

41 AJ, Fond 751, File 340, "Savezna Privredna Komora, Sekretarijat za privredne odnose sa inostranstvom, broj. 1732, Poseta delegacije BDI," Beograd, 16 October 1969.

42 AJ, KPR, III-b-2-a, "Informacija o EEZ i saradnji Jugoslavije sa ovom multilateralnom organizacijom," Beograd, 5 October 1970.

43 AJ, KPR, III-b-2-a, "Informacija o diskusiji Saveznog izvršnog veća po pitanju sredjivanja naših odnosa sa EEZ i stava Francuske,” Beograd, 31 January 1969.

44 Obadić, "A troubled relationship," 329-48.

45 "Jugoslovenska delegacija otputovala na pregovore sa ZET," Borba, 14 October 1968, 1; "European Economic Community will negotiate with Yugoslavia," Export Journal 13 (1968): 1.

46 AJ, KPR, III-b-2-a, "Izveštaj o održanim razgovorima šefova delegacija SFRJ i EEZ," 17 November 1968.

47 Dyker, Yugoslavia, 76-7.

48 Cohen, "Partisans, professionals, and proletarians," 446-78; Mencinger, "Uneasy symbiosis," 118-44.

49 Singleton, Twentieth-century Yugoslavia, 273.

50 Zaccaria, "Yugoslavia, Italy," 6-9.

51 AJ, KPR, I-3-b/42, "Kabinet B. Šnuderla, Informacija o odnosima SFRJ-EEZ," 6 December 1972. 
52 Angela Romano, "Behind closed doors," 107-22; Kansikas, “Acknowledging economic realities," 311-28.

53 Ljubodrag Dimić, "Josip Broz Tito," 183-204.

54 See Chapter 2 by Angela Romano in this book.

55 See Pustaj, Ekonomski odnosi SFRJ.

56 AJ, A CK SKJ, Komisija za medjunarodne odnose i veze, Italija, IX, 48/I - 490-525, K. 12, Report of meeting between SKJ and Italian Communist Party, 3-4 February 1972, 28 February 1972.

57 Zaccaria, "Learning from Yugoslavia?," 213-35; Johanna Bockman, Markets in the name of socialism.

58 Zaccaria, "Blowing up the self-management bubble," 125-42.

59 On Mansholt's attention to the "third world," see Garavini, After empires, 141-52.

60 AJ, Fond 130, File 1304, Stenographic notes of the 104th meeting of the SIV, 16 November 1972.

61 AJ, KPR, I-3-b/42, "Beleška u vezi prijema S. Mansholta," 16 December 1972.

62 AJ, KPR, I-3-b/42, Report of meeting between Kardelj and Mansholt, 17 December 1972.

63 See the vast documentation on direct contacts between the SSST and Yugoslav enterprises in AJ, Fond 751, File 615 (1971).

64 Žiberna, Mijalković, Rajković, and Stojković, Evropska ekonomska.

65 See, for example, Zdenko Rajh, "Smisao i opasnosti Mansholtovog plana za reformu poljoprivrede EEZ," Medjunarodna Politika, 16 May 1972, 25-7; Ladjević, "O monetarnoj integraciji," 83-105; Mileta, "Ekonomski odnosi," 142-60.

66 Maja Kovačević, "Medjunarodi problem," 147-80.

67 Toma Granfil, "Jugoslavija i EEZ," Medjunarodna Politika, 4 January 1970, 1-3; Boris Šnuderl, "Razvoj ekonomskih odnosa Jugoslavije i EEZ," Medjunarodna Politika, 1 January 1973, 5-6; Božidar Frangeš, "Jugoslavija i regionalna suradnja razvijenih zemalja. Poslije potpisivanja Zajedničke izjave SFRJ-EEZ," Medjunarodna Politika, 16 December 1976, 9-10; Žarko Tomašević, "Sporazum o ekonomskoj saradnji Jugoslavije i Evropske ekonomske zajednice," Medjunarodna Politika, 16 March 1980, 6-9; Stojan Andov, "Jugoslavija i EEZ," Medjunarodna Politika, 1 December 1980, 1-4.

68 Adamović, Jugoslavija i Evropska Ekonomska Zajednica, 252.

69 AJ, KPR, III-b-2-a, Pov.br. 117/1/73, "Informacija o prvoj fazi pregovora izmedju SFRJ i EEZ za zaključene novog trgovinskog sporazuma," Beograd, 17 May 1973.

70 AJ, Fond 130, File 1301, Stenographic notes of the 68th meeting of the SIV, 8 June 1972.

71 AJ, Stenographic notes of the 68th meeting of the SIV, 8 June 1972.

72 Banac, "We Did Not Quarrel," 182-91.

73 AJ, Fond 751, File 1047, "Godišnji izveštaj o spoljnoj trgovini i politici razvoja Jugoslavije," 16 May 1974.

74 AJ, Fond 751, File 894, "Odeljenje za medjunarodne organizacije to Poslovno udruženje tekstilne konfekcije Jugoslavije,” Beograd, 20 July 1973.

75 Korošić, "Economic system and economic policy," 261-72.

76 Zaccaria, The EEC's Yugoslav Policy, 73-98.

77 The statistics are drawn from OECD (Organisation for Economic Co-operation and Development) Economic Surveys, Yugoslavia 1981, 58, accessed 27 December 2019, www.oecd-ilibrary.org/economics/oecd-economic-surveys-yugoslavia-1981_eco_ surveys-yucs-1981-en.

78 Kotkin, "The kiss of debt," 80-93. On the rise of the debt question in Eastern Europe, see in particular Chapter 3 by Pal Germuska, Chapter 4 by Aleksandra Komornicka and Chapter 5 by Maximilian Graf in this book.

79 Official Gazzette of the SFRY, No. 15/1977.

80 Čolanović, Commercial guide to the economic system of Yugoslavia, 91-100. 


\section{Benedetto Zaccaria}

81 AJ, Fond 751, File 1047, "Privredna Komora Jugoslavije, Sekretarijat za metalnu i elektroindustriju, Broj. 1931/3," Beograd, 3 January 1974; AJ, Fond 751, File 1047, Privredna Komora Jugoslavije, Sekretarijat za hemijsku i gumarsku industriju, Broj. 2013/12, 31 January 1974.

82 AJ, Fond 751, File 1119, SSST (V. Mijalković) to Republican Secretariat for Agriculture and Forests in Ljubljana, 6 August 1975.

83 AJ, Fond 751, File 1119, "Tovarna Dekorativnih Tkanin, Bezcarinski izvoz u Zapadnu Njemačku," 5 March 1975.

84 AJ, Fond 751, File 1119, "Produzeće za uvoz i izvoz tekstilnih sirovina i gotovih proizvoda," 7 July 1975.

85 AJ, Fond 751, File 1119, "Udruženje Jugoslovenskih Železara, Broj. 021/JLj-206," 8 February 1974.

86 AJ, Fond 751, File 1119, Udruženje Jugoslovenskih Železara, 014/RP-882, "Saradnja sa EEZ-om u oblasti crne metalurgije," 28 August 1974.

87 Vinski, "Dugoročna kretanja stanovništva," 112.

88 OECD Economic Surveys, Yugoslavia 1981, 58, accessed 27 December 2019, www. oecd-ilibrary.org/economics/oecd-economic-surveys-yugoslavia-1981_eco_surveysyucs-1981-en.

89 Zaccaria, "Yugoslavia, Italy," 13-16.

90 Ruzicic Kessler, "Regional cooperation in Europe," 91-110.

91 AJ, Fond 130, File 2040, Stenographic notes of the 207th meeting of the SIV, 13 March 1974.

92 AMIP, PA, R, 1975, f 187: b 45293, Report from Brussels on relations between EEC and CMEA; AMIP, PA, R, 1976, f 181: b 494114, Brussels Delegation to SSIP, 21 June 1976.

93 AMIP, PA, R, 1975, f 187: b 45293, Note by P. Miljević, Brussels, 31 January 1975.

94 AJ, Fond 751, File 776, N. Filipović (Federal Secretariat for Economy) to M. Hadžić, 21 February 1973.

95 AJ, Fond 130, File 2045, Stenographic notes of the 45th meeting of the SIV, 30 December 1974.

96 AJ, Stenographic notes of the 45th meeting of SIV, 30 December 1974.

97 AJ, Fond 130, File 2317, Stenographic notes of the 50th meeting of the SIV, 30 January 1975.

98 AJ, Stenographic notes of the 50th meeting of the SIV, 30 January 1975.

99 AJ, Fond 751, File 894, Report of meeting with Luca Rosania, Vice-President of the EIB, 9 November 1973.

100 AJ, Fond 751, File 894, Note by the Cabinet of Boris Šnuderl, 19 November 1973.

101 AMIP, PA, R, 1975, f 188: b 436810, Report from Brussels Delegation, 26 July 1975. The EEC-Yugoslavia Mixed Commission was established in the 1970 trade agreement.

102 See "Pismo Borisa Šnuderla Sergeju Kraigherju, Ljubljana, junij 1974 - Doc. 80," VIRI 23 (2006): 241-2.

103 AJ, Fond 130, File 2321, Stenographic notes of the 207th meeting of the SIV, 23 October 1975.

104 AJ, Stenographic notes of the 207th meeting of the SIV, 23 October 1975.

105 AJ, KPR, III-b-2-a, Report on EIB mission, 15 February 1977.

106 AJ, Fond 130, File 2322, Stenographic notes of the 111th meeting of the SIV, 3 December 1975.

107 AJ, Stenographic notes of the 111th meeting of the SIV, 3 December 1975.

108 AJ, Stenographic notes of the 111th meeting of the SIV, 3 December 1975.

109 AJ, Fond 130, File 2916, Stenographic notes of the 209th meeting of the SIV, 23 January 1976.

110 AJ, Stenographic notes of the 209th meeting of the SIV, 23 January 1976. 
111 AJ, Stenographic notes of the 209th meeting of the SIV, 23 January 1976.

112 AJ, KPR, I-3-b/50, Report from SSIP, Pov. Br. 461732, 27 November 1976.

113 On the EEC's viewpoint on the 1976 Joint Declaration, see Zaccaria, The EEC's Yugoslav Policy, 99-128.

114 AJ, KPR, I-3-b/50, SSIP report on meeting with Van der Stoel, 28 November 1976.

115 Frangeš, "Jugoslavija i regionalna suradnja," 9-10.

116 On the European Community's perceptions of this change, see Zaccaria, The EEC's Yugoslav Policy, 139-43.

117 AJ, KPR, III-b-2-a, 72a, "Služba za spoljnopoltička pitanja, Beleška," 29 June 1978.

118 AJ, Fond 130, File 3768, Stenographic notes of the 6th meeting of the SIV, 29 June 1978.

119 AJ, KPR, I-3-b/55, Note on meeting between Tito and Emiel van Lennep, 14 December 1978 .

120 AJ, KPR, I-5-b/82-14, Report of Bakarić's mission in the Federal Republic of Germany, 16-18 January 1978.

121 AJ, Report of Bakarić's mission in the Federal Republic of Germany, 16-18 January 1978.

122 Vladimir Djuro Degan, "Institucionalni aspekti ekonomske suradnje," Medjunarodna Politika, 1 December 1976, $24-8$.

123 See the documentation in AJ, SKJ, 507, IX, S/q-325-329, K 23, D 324.

124 AJ, A CK SKJ, Komisija medjnunarodne odnose i veze, Italija, IX, 48, I - 526-571, K 13, "Etat actuel, possibilités et perspectives de la cooperation economique en Europe, Réunion des partis communists et ouvriers d'Europe," 19-20 April 1975.

125 AJ, Fond 130, File 4211, Stenographic notes of the 63th meeting of the SIV, 19 March 1979.

126 AJ, Fond 130, File 4212, Stenographic notes of the 79th meeting of the SIV, 10 May 1979.

127 Tvrtko Jakovina, "Sovjetska intervencija u Afganistanu," 295-320.

128 AJ, Fond 130, File 4627, Stenographic notes of the 185th meeting of the SIV,19 February 1980.

129 ADMIP, PA, R, 1980, f 240: b 410729, "Informacija o novom sporazum o ekonomskoj saradnji SFRJ-EEZ,” 3 March 1980.

130 Andov, "Jugoslavija i EEZ," 1-4.

131 Dyker, Yugoslavia, 120.

132 Dyker, Yugoslavia, 114-27.

133 See Zloch-Christy, Debt problems of Eastern Europe, 13-23.

134 On the global character of the 1980s debt crisis, see Bartel, "The power of omission," 200-20.

\section{Bibliography}

Adamović, Ljubiša S., ed. Jugoslavija i Evropska Ekonomska Zajednica. Beograd: Institut za Medjunarodnu Politiku i Privredu, 1988.

Artisien, Patrick F. R. and Stephen Holt. "Yugoslavia and the E.E.C. in the 1970s." Journal of Common Market Studies 18 (1980): 355-69.

Banac, Ivo. “'We Did Not Quarrel, We Did Not Curse': the price of Yugoslav independence after the Soviet intervention in Czechoslovakia." In The Balkans in the Cold War, edited by Svetozar Rajak, Evanthis Hatzivassiliou, Eirini Karamouzi and Konstantina E. Botsiu, 173-96. London: Palgrave Macmillan, 2017.

Bartel, Fritz. "The power of omission: the IMF and the democratic transitions in Poland and Hungary." In New perspectives on the end of the Cold War: unexpected transformations? edited by Bernhard Blumenau, Jussi M. Hanimäki and Barbara Zanchetta, 200-20. New York: Routledge, 2018. 
Bekić, Darko. Jugoslavija u Hladnom ratu. Odnosi s velikim silama 1949-1955. Zagreb: Globus, 1988.

Bianchini, Stefano. La diversità socialista in Jugoslavia: modernizzazione, autogestione e sviluppo democratico dal 1965 ad oggi. Trieste: Stampa Triestina, 1984.

Biermann, Rafael. "Back to the roots. The European Community and the dissolution of Yugoslavia - policies under the impact of global sea-change." Journal of European Integration History 10 (2004): 29-50.

Bockman, Johanna. Markets in the name of socialism: the left-wing origins of neoliberalism. Stanford: Stanford University Press, 2011.

Bucarelli, Massimo, Luca Micheletta, Luciano Monzali and Luca Riccardi, eds. Italy and Tito's Yugoslavia in the age of international détente. Brussels: Peter Lang, 2016.

Calic, Marie-Janine. "The beginning of the end: the 1970s as a historical turning point in Yugoslavia." In The crisis of socialist modernity: the Soviet Union and Yugoslavia in the 1970s, edited by Marie-Janine Calic, Dietmar Neutatz and Julia Obertreis, 66-86. Göttingen: Vandenhoeck \& Ruprecht, 2011.

Cohen, Lenard J. "Partisans, professionals, and proletarians: elite change in Yugoslavia, 1952-78." Canadian Slavonic Papers 21 (1979): 446-78.

Članović, Branko. Commercial guide to the economic system of Yugoslavia. Belgrade: YugoslaviaPublic, 1978.

Dimić, Ljubodrag. “Josip Broz Tito i 'Jugoslovenski pogled na Evropu'.” In Jugoslavija u Hladnom Ratu, edited by Aleksandar Životić, 183-204. Institut za noviji istoriju Srbije: Beograd, 2010.

Dragišić, Petar. "Jugoslovenski pogledi na evropsku ekonomsku zajednicu 1957-1973." Istorija 20. veka 36 (2018): 147-60.

Dyker, David A. Yugoslavia: socialism, development and debt. London: Routledge, 1990.

Garavini, Giuliano. After empires: European integration, decolonization, and the challenge from the global South 1957-1986. Oxford: Oxford University Press, 2012.

Grandits, Hannes and Karin Taylor, eds. Yugoslavia's sunny side: a history of tourism in socialism (1950s-1980s). Budapest: Central European University Press, 2010.

Heuser, Beatrice. Western 'containment' policies in the Cold War: the Yugoslav case, 1948-1953. London: Routledge, 1989.

Jakovina, Tvrtko. "Sovjetska intervencija u Afganistanu 1979. i Titova smrt." Historijski zbornik 60 (2007): 295-320.

Jakovina, Tvrtko. Treća Strana Hladnog Rata. Zaprešić: Fraktura, 2011.

Kansikas, Suvi. "Acknowledging economic realities. The CMEA policy change vis-à-vis the European Community, 1970-3." European Review of History 21 (2014): 311-28.

Korošić, Marijan. "Economic system and economic policy." In Essays on the political economy of Yugoslavia, edited by Rikard Lang, George Macesich and Dragomir Vojnić, 261-72. Zagreb: Informator, 1982.

Kosanović, Milan. "Brandt and Tito: between Ostpolitik and nonalignment." In Ostpolitik, 1969-1974: European and global responses, edited by Carole Fink and Bernd Schäfer, 232-43. Cambridge: Cambridge University Press, 2009.

Kotkin, Stephen. "The kiss of debt. The East bloc goes borrowing." In The shock of the global: the 1970s in perspective, edited by Niall Ferguson, Charles S. Maier, Erez Manela and Daniel J. Sargent, 80-93. Cambridge, MA: Belknap Press of Harvard University Press, 2010.

Kovačević, Maja. "Medjunarodi problemi i izučavanje procesa evropske integracije od osnivanja zajednica do Jedinstvenog evropskog akta." Medjunarodni problemi 70 (2018): 147-80. 
Kramer, Mark. "Stalin, the split with Yugoslavia, and Soviet-East European efforts to reassert control, 1948-53." In The Balkans in the Cold War, edited by Svetozar Rajak, Evanthis Hatzivassiliou, Eirini Karamouzi and Konstantina E. Botsiu, 29-63. London: Palgrave Macmillan, 2017.

Ladjević, Djordje. “O monetarnoj integraciji u Evropskoj Ekonomskoj Zajednici.” Medjunarodni problemi 25 (1973): 83-105.

Lampe, John R., Russell O. Prickett and Ljubiša S. Adamović. Yugoslav-American economic relations since World War II. Durham: Duke University Press, 1990.

Lees, Lorraine M. Keeping Tito afloat: The United States, Yugoslavia and the Cold War. University Park: Pennsylvania State University Press, 1997.

Marković, Andrej and Ivan Obadić. "A socialist developing country in a Western capitalist club: Yugoslavia and the OEEC/OECD, 1955-1980." In The OECD and the International Political Economy Since 1948, edited by Matthieu Leimgruber and Matthias Schmelzer, 89-111. London: Palgrave Macmillan, 2017.

Mencinger, Jože. "Uneasy symbiosis of a market economy and democratic centralism: emergence and disappearance of market socialism in Yugoslavia." In Equality, participation, transition - essays in honour of Branko Horvat, edited by Vojmir Franičević and Milica Uvalić, 118-44. London: Palgrave Macmillan, 2000.

Mileta, Vlatko. "Ekonomski odnosi izmedju država članica evropske ekonomske zajednice od osnivanja do danas." Politička Misao 11 (1974): 142-60.

Milikić, Ratomir. Između Evrope i Nesvrstanosti. Jugoslavija i Savet Evrope 1960-1980. Beograd: Institut za savremenu istoriju, 2017.

Mišić, Saša. Pomirenje na Jadranu. Jugoslavija i Italija na putu ka Osimskim sporazumima iz 1975. Beograd: Univerzitet u Beogradu, Fakultet političkih nauka, 2018.

Obadić, Ivan. "A troubled relationship: Yugoslavia and the European Economic Community in détente." European Review of History 21 (2014): 329-48.

Obadić, Ivan. In pursuit of stability: Yugoslavia and Western European economic integration, 1948-1970. PhD diss., European University Institute, 2017.

Perović, Jeronim. “The Tito-Stalin split: a reassessment in light of new evidence." Journal of Cold War Studies 9 (2007): 32-63.

Pirjevec, Jože, Borut Klabjan and Gorazd Bajc, eds. Osimska Meja. Jugoslovanskoitalijanska pogajanja in razmejitev leta 1975. Koper: Založba Annales, 2006.

Pustaj, Marko. Ekonomski odnosi SFRJ i nesvrstanih zemalja Afrike 1973-1981. Master's diss., University of Zagreb, 2016.

Radeljić, Branislav. Europe and the collapse of Yugoslavia: the role of non-state actors and European diplomacy. London: I. B. Tauris, 2012.

Rajak, Svetozar. Yugoslavia and the Soviet Union in the early Cold War: reconciliation, comradeship, confrontation, 1953-1957. London: Routledge, 2010.

Rajak, Svetozar. "From regional role to global undertakings: Yugoslavia in the early Cold War." In The Balkans in the Cold War, edited by Svetozar Rajak, Evanthis Hatzivassiliou, Eirini Karamouzi and Konstantina E. Botsiu, 65-86. London: Palgrave Macmillan, 2017.

Ramet, Sabrina P. The three Yugoslavias: state building and legitimation, 1918-2005. Washington, DC: Woodrow Wilson Center Press, 2006.

Romano, Angela. "Behind closed doors. Contacts between EEC and CMEA in the early 70s." In The Helsinki Process: a historical reappraisal, edited by Carla Meneguzzi Rostagni, 107-22. Padova: Casa Editrice Dott. Antonio Milani, 2005.

Ruzicic Kessler, Karlo. "Regional cooperation in Europe: Austria, Italy, Yugoslavia and the ‘Alps-Adriatic' region.” Europske studije - European Studies 2 (2015): 91-110. 


\section{Benedetto Zaccaria}

Ruzicic Kessler, Karlo and Petar Dragišić. "Zwischen Chance und Bedrohung: Die jugoslawischen Kommunisten und die westeuropäische Integration.” In Kommunismus und Europa. Europapolitik und vorstellung kommunistischer Parteien im Kalten Krieg, edited by Franscesco di Palma and Wolfgang Mueller, 138-56. Paderborn: Ferdinand Schöningh, 2016.

Singleton, Fred. Twentieth-century Yugoslavia. London: Macmillan Press, 1976.

Škorjanec, Viljenka. Osimska pogajanja. Koper: Založba Annales, 2007.

Unkovski-Korica, Vladimir. The economic struggle for power in Tito's Yugoslavia: from World War II to non-alignment. New York: I.B. Tauris, 2016.

Uvalić, Milica. Investment and property rights in Yugoslavia: the long transition to a market economy. Cambridge: Cambridge University Press, 1992.

Vinski, Ivo. "Dugoročna kretanja stanovništva i društvenog proizvoda Jugoslavije." In Aktuelni problemi privrednih kretanja i ekonomske politike Jugoslavije, edited by Dragomir Vojnić, 111-17. Zagreb: Informator, 1974.

Woodward, Susan L. Socialist unemployment: the political economy of Yugoslavia, 19451990. Princeton: Princeton University Press, 1995.

Zaccaria, Benedetto. The EEC's Yugoslav Policy in Cold War Europe, 1968-1980. London: Palgrave Macmillan, 2016.

Zaccaria, Benedetto. La strada per Osimo. Italia e Jugoslavia allo specchio (1968-1975). Milano: FrancoAngeli, 2018.

Zaccaria, Benedetto. "Learning from Yugoslavia? Western Europe and the myth of selfmanagement (1968-1975)." In Planning in Cold War Europe: competition, cooperation, circulations (1950s-1970s), edited by Sandrine Kott, Michel Christian and Ondrej Matejka, 213-35. Berlin: De Gruyter, 2018.

Zaccaria, Benedetto. "Blowing up the self-management bubble: Yugoslav propaganda and Italian reception in the early 1970s." Acta Histriae 27 (2019): 125-42.

Zaccaria, Benedetto. "Yugoslavia, Italy and European integration: was Osimo 1975 a Pyrrhic victory?" Cold War History (2019): 1-18. Accessed 26 December 2019. https://doi. org/10.1080/14682745.2019.1657094.

Žiberna, Milica, Vera Mijalković, Blagoje Rajković and Djordje Stojković. Evropska ekonomska zajednica i položaj Jugoslavije. Beograd: Privredni pregled, 1969.

Zloch-Christy, Iliana. Debt problems of Eastern Europe. Cambridge: Cambridge University Press, 1987. 


\title{
10 Conclusions
}

\author{
Angela Romano and Federico Romero
}

This book has focused on a particular historical moment when the socialist regimes of Europe banked their hopes for prosperity and stability on enhanced relations with the West, and more specifically Western Europe. Our specific intent was to explore, and hence reveal, the debate in each country among and within the elites involved in policymaking as they elaborated this strategic view and coped with shortcomings and unexpected turns. A comparative analysis of national cases reveals a shared logic and common patterns, together with national variations and a plurality of views on the desirability of exchanges with the capitalist neighbours and the ways to promote them.

Our first interest was to investigate the European socialist regimes' expectations with regard to East-West relations in the 1970s. Our findings confirm that all the socialist regimes read European détente and the ensuing emergence of a pan-European space for cooperation as an opportunity to quickly and effectively modernise their economies, catch up with the capitalist West and hopefully leap forward, ultimately achieving better living standards for their people. Party leaders and officials did not abandon notions of socialism as a more progressive system, inherently different from and opposed to capitalism. Neither did they subscribe to reformist views of a liberalised and democratised socialism. Instead, they aimed at consolidating their single-party domestic rule and making socialism stronger and more influential on a global scale. To achieve these goals, the socialist economies had to become more productive, efficient, internationally competitive and more responsive to the material needs of their citizens. Among them, the Polish leadership stands out for its ambition and confidence, which was epitomised in the regime's slogan 'Poland, the 10th global industrial power'. ${ }^{1}$

The policy all the socialist regimes pursued at the time was one of import-led growth, which relied on increased imports of advanced technology and investment goods from advanced capitalist economies, particularly those of Western Europe, in order to upgrade their industrial structures. These massive purchases required substantial loans, which Western banks and governments were eager to provide at cheap rates for most of the 1970s. The assumption was that the new investments would spur economic growth and expand export capacities. International loans would then be gradually repaid with the increased earnings expected 
from this virtuous cycle. In short, a modernised industrial structure would reduce the gap that separated the socialist countries from the most advanced economies and provide socialism with the means to take the best advantage of a fast-growing global economy.

Some regimes also planned to import consumer goods from Western Europe in order to raise living standards before this could be done via domestic production. Yugoslavia stands out for its policies of openness in this respect. In the socialist bloc, the most impressive case was Poland, whose political elite was confident that the country's quality of life could soon equal that of the capitalist European countries. The Hungarian elite was also thinking along these lines but was less bold in its rhetoric. By contrast, the governments of Czechoslovakia and the GDR were more cautious. They tackled the problem of popular satisfaction not only with imports from the West but primarily by means of social policy (e.g. housing, services, holiday programmes). The Bulgarian leadership pursued increased consumption through domestic economic reforms, and imports of consumer goods remained negligible until 1989. Although improvement of the standard of living was considered the ultimate goal of socialism in Romania, the ruling elite gave predominant emphasis to investments in new plants and infrastructure for fully fledged industrialisation.

Appraisal of the opportunities offered by détente was not limited to economic aspects. The prominence of security and foreign policy motivations was apparent in Yugoslavia's cautious yet steady path towards closer relations with Western Europe and the EEC in particular. In Yugoslavia, Western Europe and the US, the question of safely anchoring socialist Yugoslavia to the West, or at least of protecting it from any possible direct or indirect Soviet takeover and meddling after Tito's death, was high on the political agenda. For the GDR and Poland, the most important aspects of détente were the securing of borders and the international political recognition of East Germany. As Europe increasingly became a space for rapprochement, recombination and convergence, the socialist bloc countries also viewed connections with Western Europe as levers for reconfiguring hierarchies within the socialist bloc and vis-à-vis Moscow. In two cases, this policy was pursued with determination and a distinctive streak of nationalism. The new Polish leadership in the early 1970s believed that their country should (and had the right to) play a central role in European affairs and aimed to be the second most influential socialist country after the Soviet Union. Romania boldly asserted its political autonomy from the 1960s onwards, earning the label of "maverick" of the socialist bloc. Our research shows the fundamental importance that the conceptualisation of national sovereignty had in shaping the Romanian ruling elite's economic visions and strategy, and its determination to go against CMEA common positions and Soviet advice alike on a series of issues. Romanian nationalism went hand in hand with serious distrust of the willingness of the other socialist countries to consider Romanian interests. The most interesting case, though, is Bulgaria, the elite of which conceived of trade as an instrument to open political relations with Western European states and hence to overcome the long-term peripheral condition of the country that it deeply resented. This, however, was done in the name of the 
socialist doctrine of peaceful coexistence and hence caused no serious discords with the USSR.

The chapters in this book show the limited extent of Soviet control over the other socialist bloc countries' pursuit of their Western strategies. On several occasions, the Soviets tried to reverse their allies' foreign trade policies. Brezhnev personally, and sometimes harshly, warned his allies of the perils of becoming too dependent on Western markets and loans, but to little avail. Both Honecker and Ceausescu, for instance, actually blamed the Soviets for not satisfying their allies' needs and presented increased exchanges with the West as unavoidable. The Polish leadership avoided confrontation but covered up statistics to prove to the Soviets that the country was not so dependent on the West as they claimed. In Hungary, Kádár and his older generation comrades restrained bolder moves suggested by experts and some ministerial officials for fear that Moscow might withdraw its energy supplies or even decide on political intervention. Nonetheless, Hungary gradually supplemented the idea of socialist integration with rapprochement to Western Europe.

Indeed, a further conclusion that the research behind these chapters validates is that in pursuing their Western strategies, the European socialist regimes developed increasingly national outlooks and goals. Romania openly challenged bloc discipline, to the point of internationally presenting itself as a developing country in order to extract preferential treatment on trade and credit. Although less outspoken, most of the other regimes were no less keen to carve out for themselves a more advantageous position in international relations, and often tried to out-compete their socialist partners. Above all, they pinned their hopes on expanding their trade outside the socialist bloc and on multiplying their partners and options. Even the GDR, which was the most committed to improving CMEA cooperation, viewed trade with capitalist countries as a necessity so as to compensate for the shortcomings of intraCMEA trade. As a result, the bloc was not undone but certainly loosened, and became an even less cohesive coalition.

This is particularly evident when it came to how to deal with the EEC. Its policies, tariffs and expanding membership badly hit the export component of the socialist countries' strategies. No regime considered the Soviet proposal that they should reduce trade with Western Europe so as to diminish their economic vulnerability vis-à-vis EEC protectionism. All, however, bowed to bloc unity by respecting the policy of non-recognition and supporting the idea of EEC-CMEA negotiations. However, what they understood by this varied greatly. Romania constantly refused to release foreign trade policy up to the CMEA level. While Hungary, Poland, Czechoslovakia and Bulgaria initially supported negotiations with the EEC as a group so as to have a stronger bargaining position, they did not give up the possibility of also dealing bilaterally with the EEC. Pending recognition, they devised various strategies to cope with EEC protectionist policies. All tried to insist on bilateral trade relations with EEC member states. With the sole exception of the GDR, European socialist regimes also tried to use international fora to build coalitions against EEC tariffs and barriers - mainly the GATT but 
also the UNCTAD in the case of Bulgaria and the G-77 for Romania. This strategy of bypassing the EEC, however, often reached a dead end. With the exception of the GDR, direct contacts with the EEC Commission became inevitable. The socialist countries upgraded their embassy staff in Brussels with officials specifically responsible for Community contacts. In this process, emulation played an important role. Hungary, Romania and Bulgaria explicitly looked at the Polish example when deciding to enter into technical contacts and agreement with the EEC on agricultural exports. Bulgaria imitated Hungary in turning to GATT and Romania in requesting access to the EEC's preferential scheme for developing countries. In this case, both Bulgaria and Romania had the Yugoslav example in mind.

In the first half of the 1970s, all the European socialist countries pursued new trade arrangements, signed license agreements with Western partners and took up loans to finance technology imports. The noticeable exception was Czechoslovakia, where the political normalisation process went hand in hand with economic consolidation and fiscal prudence. The initial results were encouraging for all. In the early 1970s, Poland and Romania experienced record economic growth; Bulgaria, the GDR and Hungary also performed very well. The planners' expectations of a stronger and more prosperous socialism therefore seemed to be borne out, thus stimulating further loans and investments.

Ironically, the import-led growth strategy to prompt socialist modernisation and prosperity relied, at least in the short to medium term, on the dynamism of the capitalist economies. Western Europe's recession in the mid-1970s was a serious blow to the socialist regimes' economic strategies because it led to protectionist measures to preserve the worst-hit sectors of the economy. Moreover, they faced growing competition from newly rampant East Asian economies and from African countries that had privileged access to the EEC market. The limited possibility of exporting, and hence gaining hard currency to repay debts combined with the availability of cheaper loans - thanks to the petrodollars flooding Western banks - to create the preconditions for the debt trap. The West's triumphalist narrative has long depicted the socialist ruling elites as unable to understand finance and therefore blindly walking into spiralling indebtedness. Our research proves this to be a misconceived view. For starters, the peril of getting into heavy debt was known and accurately understood. The Czechoslovak elites, for instance, were highly sensitive to the risk of indebtedness and took very cautious decisions. The Bulgarian government was also less risk-prone. Even in the GDR the dilemma of import needs and growing indebtedness was omnipresent. More crucially, the problem of the countries that got into the debt trap was that the party leadership chose not to listen to warnings by experts, central bankers, branches of the state apparatus and Moscow. In Hungary, Romania and Poland (at least initially), the leadership had faith in the strategy adopted and was optimistic about the country's capacity to repay debts through exports. In Poland and the GDR, Gierek and Honecker personally silenced internal opposition (notably from the ministers of defence and of finance) because they knew their regimes' 
existence rested on popular satisfaction and hence considered a U-turn too politically costly.

Indeed, another important conclusion that our research brings to the fore is the plurality of voices in the policymaking process in the socialist countries in the 1970s. With the single exception of the GDR, where foreign trade and finance remained under the strict control of the top political leadership, national strategies towards the West opened room for the agency and even some autonomy of ministries and government organisations, the experts they employed or consulted, trade associations and their officials, and managers in key sectors. In Ceausescu's Romania, most surprisingly, ministerial staff, experts and diplomats in Brussels were constantly asked by the party leadership to provide information and solutions, which were then approved in most cases. With the exception of Hungary, where the party was involved throughout, the top leadership usually signed up to the broad guidelines of the strategy and was occasionally involved at the level of crucial symbolic decisions, but the definition and implementation of the strategy's tenets, the actual pursuit of agreements and the search for new venues and means was in the hands of mid- to high-level government officials, managers and experts. Thus, the party's grip became looser and the internal structure of the regimes less cohesive (a process most apparent in Yugoslavia's creeping confederalisation of economic decisions), new areas of expertise were cultivated in the extended networking with international institutions and Western firms, and the socialist elite grew more differentiated by task, training and exposure to foreign experiences. Notably, academics and foreign trade organisation managers had better knowledge and understanding of international economic dynamics together with a direct stake in more contacts with the West, and were usually keen advocates of the Western strategy and of direct relations with the EEC. As the cases of Poland, Czechoslovakia and Hungary reveal, the generational shift was also a key factor in the growing support for these policy lines. In Hungary, the party's young reformist wing even called for a demonstrative political agreement with the EEC to prove Hungary's commitment to its most important European commercial partners. Indeed, in some cases, like Hungary, the EEC question caused sharp debates among the elites; in others, like Romania, there were almost unanimous views on how the country should approach the EEC (and the CMEA). Overall, the chapters in this book shed light on how the socialist elites envisioned and debated the coexistence and interaction between adjacent and overlapping spaces shaped by contrasting logics: the socialist bloc and Western European integration; ideological rivalry and a new cooperative stance; important bilateral relations; and emerging multilateral frameworks.

Taken together, this book's chapters give us a detailed historical catalogue of the various factors that contributed both to the early achievements and to the subsequent setbacks and failures of socialism's Western strategy. The insertion of new technologies and procedures without substantial alterations to the overall planning system did not kick the entire economy into higher gear. Slow and shoddy supplies hampered the new production lines. Existing working practices 
prevented or hindered the deep restructuring that was common practice in Western factories, thus forestalling the expected productivity boom. Investments decisions often remained hostage to political lobbying by the well-connected traditional heavy industry sectors. By the middle of the decade the balance of trade turned negative for Poland, Yugoslavia, the GDR and even Hungary (see Tables A.1 and A.2). In spite of new technology inputs, socialist manufactured goods made few inroads in world markets. On both quality and price, they were most often outcompeted by Western products and, most crucially, by the aggressive competition from fast-rising East Asian economies.

However, the impact of external factors was of great importance in determining the failure of the socialist countries. Their domestic difficulties were crucially compounded by a rapidly evolving international environment. The Western economic crisis deeply changed the premises on which the socialist regimes' import-led strategies were founded. No less relevant was the protected nature of their most obvious export markets, those regulated by the EEC agricultural and tariff policies. Overcoming the EEC protectionist structure would have been hard in any case but was made extremely difficult by adherence to the socialist bloc policy of non-recognition of the EEC, which prevented the negotiation of comprehensive trade agreements. The socialist regimes had to make do with ad hoc sectoral trade arrangements with the EEC. Even a government like Hungary's, despite being very keen to penetrate EEC markets, felt restrained by its strategic and energy dependency on the USSR. And even "maverick" Romania, which obtained access to the EEC's preferential scheme for developing countries - and in 1980 discussed a larger agreement with the EEC Commission - stopped short of granting official recognition to the Community.

The result was that the hard-currency gains the socialist regimes envisioned in order to balance their increasing financial exposure to the West never acquired sufficient mass. The inevitable consequence was a steep rise in debt to Western banks and governments, a dynamic further deepened by ongoing transformations in the international context. The ascending cost of energy supplies and other raw materials exacerbated inflationary pressures. Larger and freer capital flows pressured governments to impose fiscal discipline on their societies and spurred firms towards more flexible modes of production and distribution. Adaptation to these new conditions of tighter interdependence was problematic for Western countries - as was evidenced by the financial crises experienced by the UK and Italy in 1976 and the deep restructuring of the steel industry in Europe and North America - but positively painful, if not impossible, for the socialist ones. Socialist firms could not keep pace with the Western move towards leaner and more flexible industrial practices. When the Polish government tried to contain consumers' expectations of rising prosperity in 1976, social protests forced the authorities to privilege consumption at the expense of investment, thus further deepening the country's long-term financial predicament.

By 1979, when energy prices rose steeply and a new US monetary policy pushed interest rates sharply up, the costs of socialism's Western strategies became 
unsustainable. The burden of foreign debt skyrocketed (see Appendix, Table A.5), and most of central-eastern Europe (even though with substantial national variations) joined the ranks of economies that, like in Latin America, precipitated into a most serious debt crisis. Poland experienced a systemic convulsion, with economic grievances sparking an outright social and political challenge to the regime. The other socialist countries had to devise defensive strategies pivoted on a variable mix of domestic austerity, a reduction in investments and renegotiations of their debts. Economic growth faltered and dependence on the West did not altogether diminish, but the previous delusions of an upgraded participation in the international economy faded away.

Overall, by the early 1980 s the Western strategy of the socialist regimes was far from the projected success and instead mired in a deep crisis of indebtedness, deteriorating socio-economic conditions and, more crucially, lack of prospects. Rather than reviving socialism in a modernising and competitive fashion, this Western strategy eventually magnified the limitations and shortcomings of the system, evidencing its subordinate and increasingly feeble position in the international economy. Quite revealingly, the proportion of manufactured goods among the socialist countries' total exports declined by the early 1980s (see Appendix, Table A.4). European socialism's attempt to climb up in the transformative whirlwind of incipient globalisation had not worked. Rather than sustained progress, it had brought to the fore an entrenched subordinate dependency on the most advanced Western economies. Steeped in a far more adverse economic and fiscal environment and financially burdened by their own failures, the socialist regimes had to settle for the more peripheral and dependent position that their early 1970s Western strategies had boldly tried to transcend.

Our research also casts a rather oblique light on notions of alternative nonWestern paths to globalism and particularly on the kind of engagement socialism looked for in, and with, the global South. Socialist economic strategies came to rely less and less on global exchanges and focused instead on Western capital, technologies and markets, with a particular emphasis on a privileged space for interaction between Eastern and Western Europe. While not abandoning discourses (and occasionally strategic options) of alternative globalism, socialist regimes did not really see trade with the South as the solution to their predicaments. Markets in the developing world were not rich, deep and dynamic enough to attract many exports. Moreover, competition from the West and from East Asia was fierce and most often victorious. In addition, trade expansion would usually require substantial financing via long-term credit, aid and subsidies. In short, it required capital, the most precious resource that the socialist countries lacked and were borrowing in large quantities from the West. Here, once again, the area's condition of dependency comes to the fore and explains the limited options the socialist regimes could select among on their chosen path towards industrial modernisation. In the rapidly evolving global division of labour, the scarce resources of their economies, and the political and institutional constraints they operated in, made the Western and European option the only feasible one. This, in turn, further deepened a path 
dependency determined not only by growing financial exposure but also by the fading away of other imagined paths and the corresponding strengthening of a single conception of the future.

In their increasingly composite assortment, the socialist elites - be they of a technocratic persuasion, modernisers, mildly or more radically reformist, or gradually even in opposition roles, as in Poland - discarded notions of alternative global alignments pivoted on anti-imperial positions. Instead, they came to see their path towards Europe and the West, which had meanwhile grown far more familiar by means of multiple and persistent international networking, first as the most preferable and then as their only conceivable horizon. The decisions of Hungary, Poland and Romania to apply for membership of the IMF proves that their socialist elites were left in no doubt that the remedy to their predicaments lay in the West. The same applies to the GDR: while IMF membership was never an option, its avoidance of bankruptcy in 1982 owed much more to West German loans than to scarce Soviet support, prompting some economic experts in the government to argue that the future existence of the GDR 'depended solely on the West'. ${ }^{2}$ Our research therefore highlights a long-term path - which started well before the fall of socialist regimes - towards the recombination of Europe according to Western institutions and influence. By 1989, even the core communist party leaderships could no longer envision, much less credibly propose, a different prospect.

Of course, several other factors that have remained at the margins of our enquiry contributed to this ending. By the late 1970s, a language of human rights focused on their civic and individual dimension had become predominant in international discourse. It was sustained by an odd but very influential combination of the conservative liberalism preached by Ronald Reagan and Margaret Thatcher on the one hand and the progressive transnationalism of human rights non-governmental organisations on the other. It eclipsed notions of collective socio-economic improvement; it delegitimised the state as an agent of progress; and it erected freedom of choice as the paragon of (post-)modernity. While it affected politics and culture in the West and put Western social democrats on the defensive, it had a far more potent impact on socialist regimes, which were cornered into a very difficult position - first, because it turned their Helsinki commitments against them, and second, because it joined the ongoing discussion on market mechanisms to the notion of democracy and freedom as prerequisites for economic growth.

Whether these transformative influences could have been withstood, rejected or even suppressed by the communist leaderships in the absence of the Gorbachev factor remains a purely speculative question. It certainly mattered, though, that the regimes' economic strategies had internalised an assumption of Western superiority, had opened their societies up to unfavourable comparisons with Western goods and technologies, had linked the assessment of socialism's effectiveness to the metrics of productivity and consumption, and had nurtured a diffused familiarity with the West among key elements in the economic technocracy. This long-held attitude of engaging with the West coupled with the heavy burden of 
indebtedness eroded the foundations of the regimes' self-confidence, fractured their solidity, and facilitated the peoples' revolutions. The dynamics analysed in this book were at the roots of the 1989 collapse.

\section{Notes}

1 See Chapter 4 by Aleksandra Komornicka in this book.

2 See Chapter 5 by Maximilian Graf in this book. 


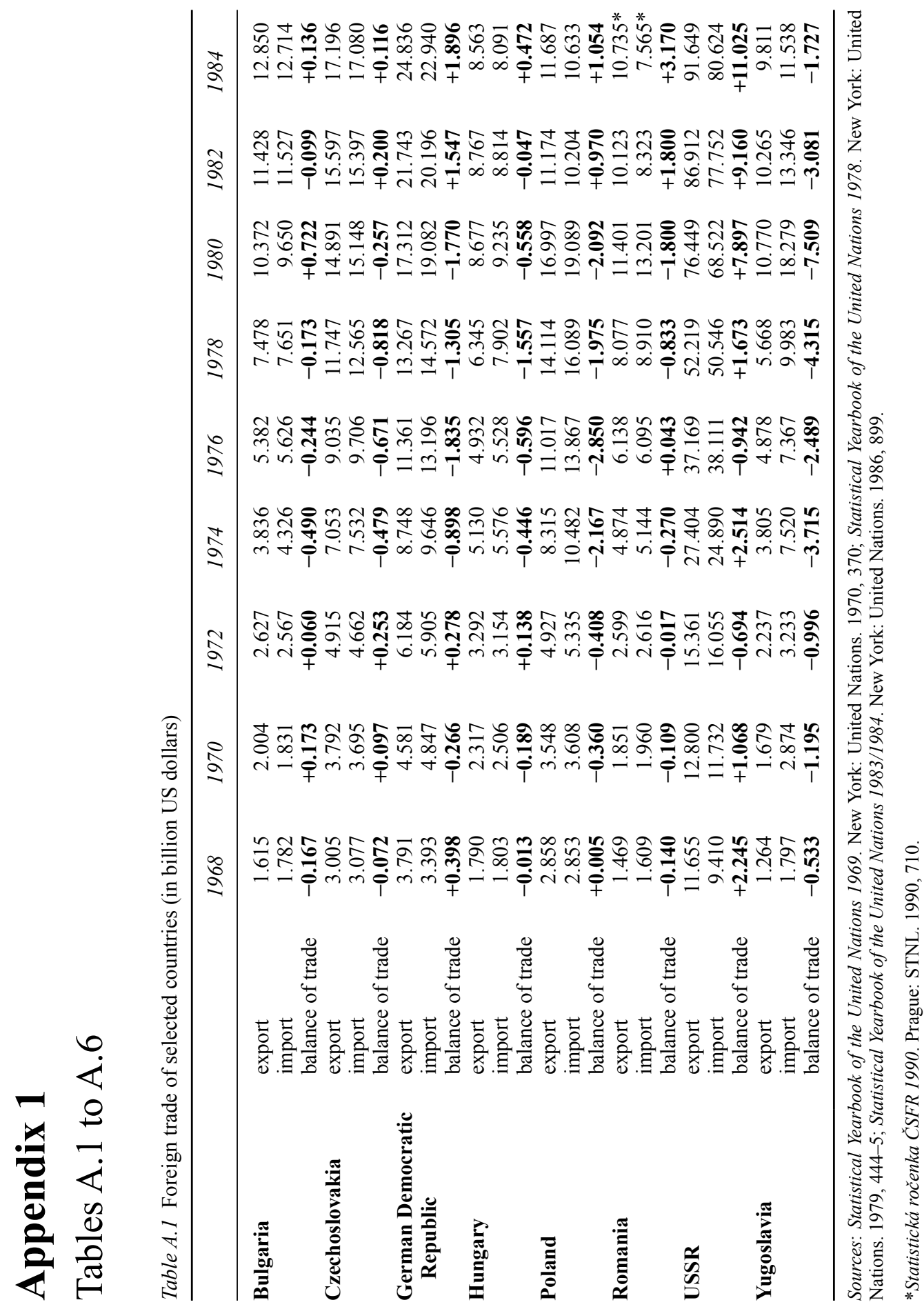


Table A.2 European centrally planned economies' trade with the EEC (without the USSR, in billion US dollars)

\begin{tabular}{lrrrrrrrr}
\hline & 1970 & 1972 & 1974 & 1976 & 1978 & 1980 & 1982 & \multicolumn{1}{l}{1984} \\
\hline Export & 2.444 & 3.330 & 6.120 & 6.511 & 8.172 & 18.922 & 19.710 & 19.549 \\
Import & 2.395 & 3.650 & 7.730 & 8.251 & 9.937 & 12.735 & 8.127 & 7.311 \\
Balance & $\mathbf{- 0 . 0 4 9}$ & $\mathbf{- 0 . 3 2 0}$ & $\mathbf{- 1 . 6 1 0}$ & $\mathbf{- 1 . 7 4 0}$ & $-\mathbf{1 . 7 6 5}$ & $\mathbf{+ 6 . 1 8 7}$ & $\mathbf{+ 1 1 . 5 8 3}$ & $\mathbf{+ 1 2 . 2 3 8}$ \\
\hline
\end{tabular}

Sources: Statistical Yearbook of the United Nations 1975. New York: United Nations, 1976, 439, 441; Statistical Yearbook of the United Nations 1979/1980. New York: United Nations, 1981, 449, 453; Statistical Yearbook of the United Nations 1983/1984. New York: United Nations, 1986, 905-6.

Note: The European centrally planned economies included here are Albania, Bulgaria, Czechoslovakia, the German Democratic Republic, Hungary, Poland and Romania. The EEC's membership expanded in 1973 to the UK, Ireland and Denmark and in 1981 to Greece. The quick rise of the export numbers in 1980 was caused by Romania's massive export policy. 


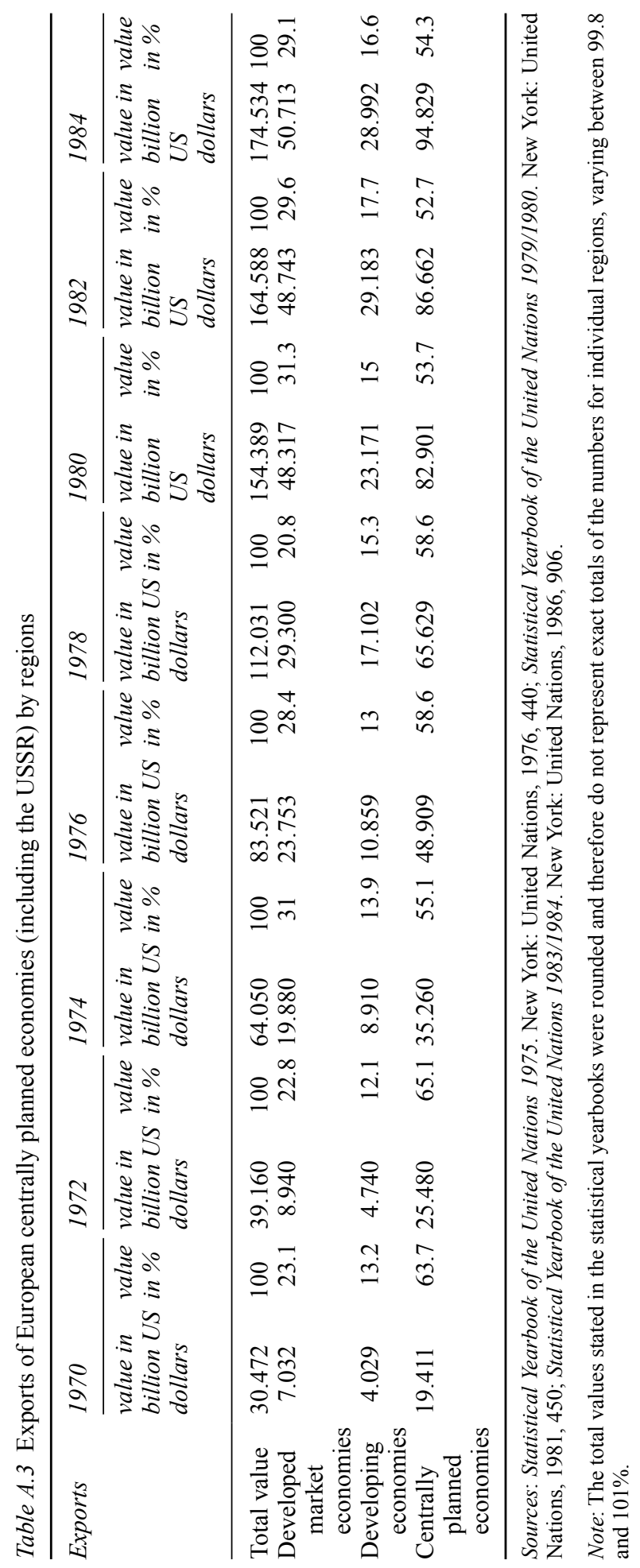


Table A.4 Export structure of European centrally planned economies (including the USSR, in percentages)

\begin{tabular}{lrrrrrrrr}
\hline European CMEA countries & 1970 & 1972 & 1974 & 1976 & 1978 & 1980 & 1982 & 1984 \\
\hline $\begin{array}{l}\text { Food, live animals, beverages } \\
\text { and tobacco }\end{array}$ & 10.1 & 9.4 & 9.6 & 7.5 & 6.6 & 6.2 & 5.7 & 5.0 \\
$\begin{array}{l}\text { Crude materials, oils and fats, } \\
\quad \text { fuel excluded }\end{array}$ & 10.0 & 9.1 & 9.9 & 8.3 & 7.3 & 7.2 & 5.6 & 5.2 \\
$\begin{array}{l}\text { Mineral fuels, lubricants and } \\
\quad \text { related material }\end{array}$ & 9.6 & 9.8 & 14.5 & 19.6 & 20.2 & 27.2 & 31.3 & 32.9 \\
$\begin{array}{l}\text { Chemicals } \\
\begin{array}{l}\text { Machinery and transport } \\
\quad \text { equipment }\end{array}\end{array}$ & 5.0 & 5.2 & 5.4 & 4.9 & 4.6 & 5.0 & 5.5 & 5.7 \\
\begin{tabular}{l} 
Other manufactured goods \\
\hline
\end{tabular} & 25.3 & 25.2 & 22.7 & 20.8 & 19.9 & 18.2 & 14.1 & 14.3 \\
\hline
\end{tabular}

Sources: Statistical Yearbook of the United Nations 1977. New York: United Nations, 1978, 510; Statistical Yearbook of the United Nations 1979/1980, New York: United Nations, 1981, 480; Statistical Yearbook of the United Nations 1983/1984, New York: United Nations, 1986, 937. 


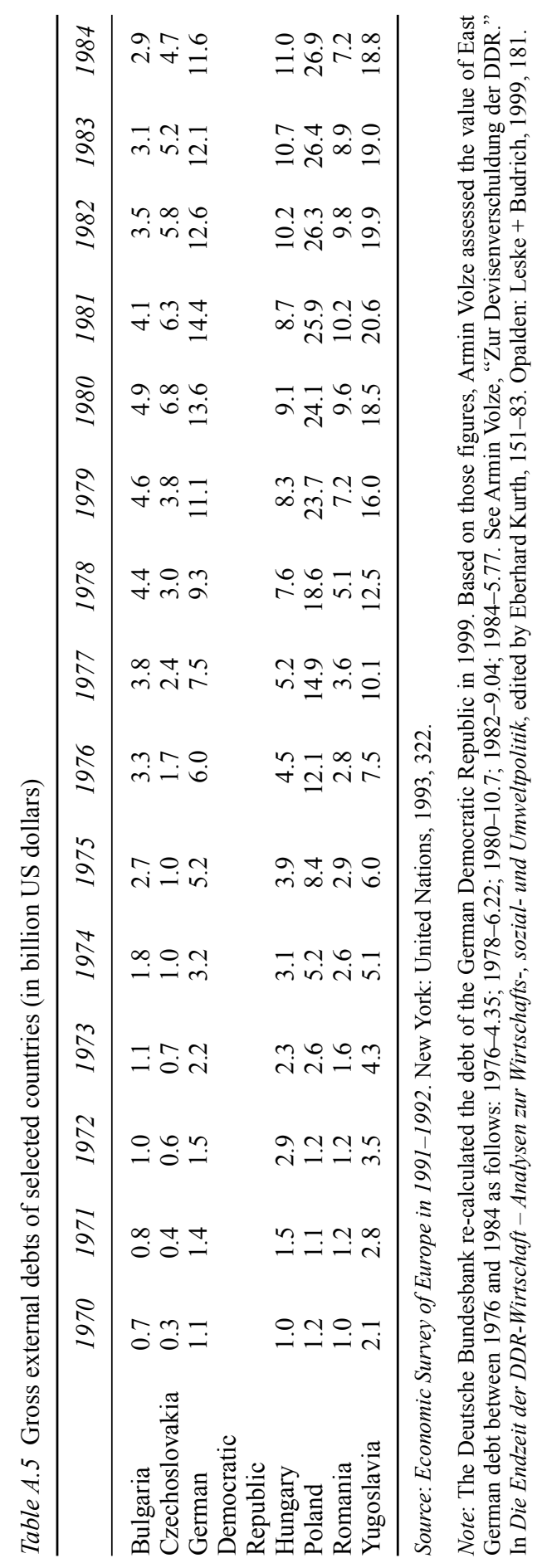


Table A.6 Average annual growth of GDP in selected countries

\begin{tabular}{llrrr}
\hline & & $1970-75$ & $1975-80$ & $1980-83$ \\
\hline Bulgaria & Growth of GDP & $7.8 \%$ & $6.0 \%$ & $4.1 \%$ \\
Czechoslovakia & Growth per capita of GDP & $7.3 \%$ & $5.7 \%$ & $3.8 \%$ \\
& Growth of GDP & $5.4 \%$ & $3.7 \%$ & $0.7 \%$ \\
German Democratic & Growth per capita of GDP & $4.7 \%$ & $3.0 \%$ & $0.5 \%$ \\
Republic & Growth of GDP & $5.2 \%$ & $3.3 \%$ & $-0.9 \%$ \\
Hungary & Growth per capita of GDP & $5.4 \%$ & $3.4 \%$ & $-0.8 \%$ \\
& Growth of GDP & $6.6 \%$ & $3.2 \%$ & $1.9 \%$ \\
Poland & Growth per capita of GDP & $6.2 \%$ & $2.8 \%$ & $2.0 \%$ \\
& Growth of GDP & $10.0 \%$ & $1.4 \%$ & $-4.3 \%$ \\
Romania & Growth per capita of GDP & $9.0 \%$ & $0.5 \%$ & $-5.1 \%$ \\
& Growth of GDP & $11.2 \%$ & $7.2 \%$ & $2.8 \%$ \\
Yugoslavia & Growth per capita of GDP & $10.2 \%$ & $6.3 \%$ & $2.3 \%$ \\
& Growth of GDP & $5.9 \%$ & $6.1 \%$ & $0.2 \%$ \\
& Growth per capita of GDP & $4.9 \%$ & $5.2 \%$ & $-0.5 \%$ \\
\hline
\end{tabular}

Sources: Statistical Yearbook of the United Nations 1983/1984. New York: United Nations, 1986, 95-9. 


\section{Appendix 2}

\section{List of Archival Collections}

\section{Bulgaria}

AMVnR

TsDA

\section{Czechoslovakia}

AČNB

AMZV

APF

NAČR

SNA

\section{Germany}

BArch

BArch-DDR

BStU

HABUBA

PA/AA
Arhiv na Ministerstvoto na Vanshnite Raboti (Archives of the Ministry of Foreign Affairs), Sofia, Bulgaria

Tsentralen Darzhaven Arhiv (Central State Archives), Sofia, Bulgaria

Archiv České národní banky (Archive of the Czech National Bank), Prague, Czech Republic

Archiv Ministerstva zahraničních věcí (Archive of the Ministry of Foreign Affairs), Prague, Czech Republic Česká televize, Archiv a programové fondy Praha (Czech Television, Archive and Program Funds Prague), Prague, Czech Republic

Národní archiv (National Archives), Prague, Czech Republic Slovenský národný archív (Slovak National Archives), Bratislava, Slovakia

\section{Bundesarchiv (Federal Archives), Koblenz, Germany}

Bundesarchiv, Abteilung DDR (Federal Archives, Department GDR), Berlin - Lichterfelde, Germany Archiv des Bundesbeauftragten für die Unterlagen des Staatssicherheitsdienstes der ehemaligen Deutschen Demokratischen Republik (Archives of the Federal Commissioner for the Records of the State Security Service of the former German Democratic Republic), Berlin, Germany Historisches Archiv der Deutschen Bundesbank (Historical Archive of the German Federal Bank), Frankfurt/Main, Germany

Politisches Archiv des Auswärtigen Amts (Political Archive of the German Foreign Office), Berlin, Germany 
PA/AA-MfAA Politisches Archiv des Auswärtigen Amts, Bestand Ministerium für Auswärtige Angelegenheiten der Deutschen Demokratischen Republik (Political Archive of the German Foreign Office, Holdings of the Ministry for Foreign Affairs of the German Democratic Republic), Berlin, Germany

RWWA Rheinisch-Westfälisches Wirtschaftsarchiv zu Köln (Foundation Economic Archive of Reinhland-Westfalen in Cologne) Cologne, Germany

SAPMO-BArch Stiftung Archiv der Parteien und Massenorganisation der ehemaligen DDR im Bundesarchiv Berlin (Foundation Archive of Parties and Mass Organisations of the former GDR in the Federal Archives), Berlin - Lichterfelde, Germany

\section{Hungary}

BFL

Budapest Föváros Levéltára (Budapest City Archives), Budapest, Hungary

MNL OL Magyar Nemzeti Levéltár (National Archive of Hungary), Budapest, Hungary

\section{Poland}

AAN

AMSZ

\section{Romania}

AMAE

ANIC

\section{Yugoslavia}

AJ

AMIP
Archiwum Akt Nowych w Warszawie (Central Archives of Modern Records), Warsaw, Poland Archiwum Ministerstwa Spraw Zagranicznych (Archive of the Ministry of Foreign Affairs), Warsaw, Poland

Arhiva diplomatică - Ministerul Afacerilor Externe (Diplomatic Archives of the Ministry of Foreign Affairs), Bucharest, Romania Arhivele Naționale ale României (National Historical Central Archives), Bucharest, Romania

Arhiv Jugoslavije (Archives of Yugoslavia), Belgrade, Serbia Diplomatski arhiv Ministarstva spoljnih poslova Republike Srbije (Diplomatic Archives of the Ministry of Foreign Affairs of Serbia), Belgrade, Serbia

\section{Other}

AEI

DNA
Archive on European Integration, University of Pittsburgh

Rigsarkivets (Danish National Archives), Copenhagen, Denmark 
266 Appendix 2

HAEU Historical Archives of the European Union, Florence, Italy

OSA The Vera and Donald Blinken Open Society Archives at

Central European University, Budapest, Hungary

TNA The National Archives, London, UK

WTO/GATT World Trade Organization GATT documents collection 


\section{Index}

Note: Page numbers in bold indicate tables.

1968 Non-proliferation Treaty 16

1972 SALT agreement 16

1977 Davignon Plan for Europe's Steel 118

Aczél, Görgy 123

Adamovič, Ljubiša 230

Afghanistan 22, 33-4, 95, 238

Africa 143-4, 192

Agnelli, Giovanni 235

Ahrens, Ralf 110

Aleksič, Milan 238

Alps-Adriatic Working Community 232

Alten, Jürgen von 147-8

Andov, Stojan 238

Angola 144

Apró, Antal 56

Association of Yugoslav Iron Workers 232

Atlantic Alliance 37

Austria 233

autarky policy $13,22,135-7,151$

Avramov, Luchezar 167-9, 171-2

Avramov, Roumen 163

Baibakov, Nikolai 112

Bajer, Ratislav 151

Bakarič, Vladimir 237

Balázs, Péter 66, 69

Balkan region 178-9

Bange, Oliver 31

Bank for International Settlements (BIS) 66

Barčák, Andrej 138

Bártek, Jiří 140

Bartel, Fritz 51

Bashev, Ivan 172

Basic Treaty of 1972 109, 113
Beil, Gerhard 118

Békés, Csaba 70

Belgium 32

Bereich Kommerzielle Koordinierung (KoKo) 111, 121

Bijedič, Džemal 227, 230, 233-6

Bil'ak, Vasil 144

Bíró, József 54

Birovljev, Milorad 235-6

Bogomolov, Oleg 141

Böhm, Siegfried 111, 117

Boleslav, Mladá 139

Borba 227

Borhi, László 70

Bosnia and Herzegovina 221, 227

Bożyk, Paweł 91, 93, 95

Brandt, Willy 6, 16, 33, 82

Bratkowski, Stefan 82, 96

Bretton Woods monetary system 11, 18, 36, 39, 90, 112

Brezhnev, Leonid: call for EEC-CMEA negotiations 39; Ceauşescu and 196, 199; CSCE and 40; on East-West exchange 95, 251; Honecker and 116, 119; Polish gestures of alliance with 92; on Soviet oil production 142; stabilisation ideology of 15; Yugoslavia and 225, 230

Brezhnev doctrine 35, 38, 87

Budapest appeal 34, 82

Budinov, Ivan 167

Bulgaria: agricultural exports and 166, 168-9, 177; average annual growth of GDP 263; CCP and 42-3, 172; centralised planning and 167; CESTC and 164, 169; CMEA and 161, 169; competitive disadvantage of 160-1; 
consumption and 160, 250; corruption trials in 167; cultural exchange and 163; debt crisis and 163, 180; dependence on the Soviet Union 160-1, 167; economic internationalism and 159, 161, 163, 170, 182; on EEC expansion 174-6; EEC protectionism and 165-6; EEC relations and $159,163-4,168-71,176-7$, 179-82; expansion of exports 160; Final Act (CSCE) and 177-8; foreign debt and 136, 180; foreign investment in 178 ; foreign policy and $167-8$; foreign trade and 161-3, 165, 167-72, 174, 177, 180, 182-3, 258; foreign-trade envoys and 162, 167-8; FRG relations and 162, 167; GATT and 164, 173, 179, 181; Greece and 178-9; gross external debt 262; human rights violations in 181; industrial cooperation and 178-9; international organisations and 164, 170-4, 182; international tourism and 164; Ministry of Finance 162, 174; Ministry of Foreign Affairs (MFA) 164-5, 167, 169, 174; Ministry of Foreign Trade (MFT) 162-5, 167-9, 174; most favourite nation (MFN) status and 172; New Economic System 163; oil crisis and 180; preferential export treatment and 170-2, 175, 177, 179; socialist internationalism and 159, 182; Soviet protectionism and 182; trade deficit and 161, 163, 165-8, 182; transborder firms in 163; Turkey and 178-9; UNCTAD and 164, 171-3; Western relations and 161-70, 181-2; Western technology and 159-61, 163, 166, 168, 180, 182

Bulgarian Communist Party (BKP) 159

Bulgarian Foreign Trade Bank 163

Bunce, Valerie 2

Burtică, Cornel 194, 197, 198, 212n25

capitalism: crisis predictions $18,114,123$, 145; economic integration and 37-8; neo-liberalism and 22; polycentrism and 39 ; socialist encroachment of 17

Carter, Jimmy 34

Catholic Church 88, 95-6

Ceauşescu, Nicolae: Brezhnev and 196, 199; EEC negotiations and 201, 204-5; on energy resources 199, 207-8; on foreign debt 210-11; foreign trade and 192, 196, 198, 207; industrialisation and 192; national economic policy and
191, 209, 211; policy of prestige and 89; trade deficit and 196, 207-8; on Western economic integration 251

Čemovič, Momčilo 233-4

Central Statistical Office (Hungary) 60

CESTC see Commission for Economic and Scientific-Technical Cooperation (Bulgaria)

China, People's Republic of 22, 42, 233, 240

Choma, Vasil' 148

Churchill, Winston 32

CMEA see Council for Mutual Economic Assistance (CMEA)

Cold War: division of Germany and 109; East-West exchange and 32; historiography of $3,13,31,43$; Iron Curtain 1, 32-3, 41, 52, 79; isolation of socialist economies in 12-13; panEuropean cooperation and 5, 31-2; peaceful coexistence $2,33,53-5,82,88$, 96, 161-2, 209, 251; see also European détente

Colotka, Peter 138

Commission for Economic and ScientificTechnical Cooperation (Bulgaria) 164, 166, 169-70, 177, 180

Commission for the Modernisation of the Economy and State Functioning (Poland) 84, 87, 92

Committee for International Economic Relations (Hungary) 56-7, 59

Common Market see European Economic Community (EEC)

communism 7, 12, 14

Communist Party of Czechoslovakia (CPC) 136

Communist Party of Slovakia (CPS) 138

Communist Party of the Soviet Union (CPSU) 14, 107

Communist Party of Yugoslavia (SKJ) 222-4, 228, 233-4, 236-8

Conference of European Communist Parties 237

Conference on Security and Cooperation in Europe (CSCE): Bulgaria and 173; East-West exchange and 17; economic consequences of 59-60; EEC and 1, 32, 38, 40; European détente and 31, 43; Final Act and 34-6, 40, 78, 92; Hungary and 59; multilateral cooperation and 36, 40, 43; Mutual and Balanced Force Reduction in Europe (MBFR) and 34; pan-European cooperation and 35-6; Poland and 87; Yugoslavia and 228 
Council for Mutual Economic Assistance (CMEA): Bulgaria and 161, 169; Comprehensive Integration Programme 169; Cuba and 144; division of labour and 13, 15, 37-8; East German exports and 110; economic integration and $15,38-9$; economic relations and 36-7, 63; EEC as model for 123-4, 175-6; EEC imports/exports and 3; EEC protectionism and 114; Hungary and 50, 58-9, 65; non-recognition of the EEC 56, 90, 114, 194-5; oil prices and 20; Poland and 80; Romania and 198, 202, 204; Soviet oil and 137, 141-2; Soviet Union and 144; steel exports and 118; Vietnam and 144; Yugoslavia and 221, 225; see also EEC-CMEA relations

Council of Europe 222

Croatia 221, 223, 225-7, 229, 232; see also Yugoslavia

CSCE see Conference on Security and Cooperation in Europe (CSCE)

Csizmadia, Ervin 51

Cuba 144

Čuba, František 138-9

Cyprus 178-9

Czechoslovakia: academic elite in 139-40, 145; agricultural exports and 41, 151; autarky policy $135-7,151$; average annual growth of GDP 263; balance of payments in 134; capitalist enterprises in 139; CCP and 43; centralised planning and 135-6, 140; consumer goods and $135,153 \mathrm{n} 9$; diplomatic contact with the EEC 146-8; economic growth and 135-7, 141-3, 151-2; economic reform and 137-40; EEC protectionism and 149-50; foreign debt and 136; foreign trade and 137-8, 142-3, 258; GATT and 40, 80, 142; global South and 143-4; gross external debt 262; IMF and 142; import limitations in 136-7; inflation in 135-6; investment plan in 136-7; licence agreements and 143; Ministry of Foreign Affairs 144, 146; Ministry of Foreign Trade 143, 150; most favourite nation (MFN) status and 142, 150; national strategies in 23; normalisation process and 134-5, 138, 151, 252; normalised elite in 138-9; official EEC policy $148-52$; oil imports and 137 , 141-2, 152; pan-European relations and 134; perceptions of the EEC in 144-6; Series of Policies and 137; social policies and 136, 152, 250; Soviet raw materials for 141; steel exports and 118,151 ; Western sale of technological innovations 135; see also Prague Spring Czechoslovak State Bank 136-8, 143-4 Czechoslovak State Security (StB) 140

Czechoslovak Trade Bank 144

Daimler-Benz 159

Davignon, Étienne 147

de Gaulle, Charles 32

Demirel, Süleyman 179

Dencker, Norman 69

Deniau, Jean-François 57, 227

Denmark 6, 32, 38, 41, 162, 175, 196

détente 6, 16-18, 22, 31; see also

European détente

Dietrich, Helmut 111

Dimitrijevič, Boşko 233

Djermanovič, Časlav 236

Djuranovič, Veselin 236-7

Dubček administration 135

Duchâteau, Pierre 57

Dyba, Karel 140

East Asia 252, 254

Eastern Europe: consumption in 19; economic growth and 2, 12, 19; EEC-CMEA relations and 41-3; export opportunities and 20; external economic factors and 2-3; foreign trade and 17, 32; national strategies and 16, 19 ; see also European détente; socialist regimes; specific country names

East Germany see German Democratic Republic (GDR)

East-West exchange: détente and 6, 16-18, 22 ; economic growth and 16; foreign trade and 32-3; modernisation strategy in 249-50; post-Stalin 32; socialist elites and 1-4, 15; technological innovation and 14; see also European Economic Community (EEC)

ECE see United Nations Economic Commission for Europe (ECE)

Economic and Social History of Czechoslovakia, 1918-1992134

economic growth: CMEA and 15; Czechoslovakia and 135-7, 141-3, 151-2; Eastern Europe and 2, 12, 19; East-West exchange and 16; foreign trade and 38; Japanese development model for 86; Poland and 19, 82, 85-6, 252; Romania and 19, 252; socialist 
economies and 6, 17, 19, 42; Soviet Union and 14; Western technology and 4, 249

economic integration: acceleration of 145; bilateralism and 32; Bulgaria and 164, 166, 169, 174-6; capitalism and 37-8; CMEA and 13, 15, 37-9, 43; CSCE and 40; Czech attitudes towards 146; East German attitudes towards 108, 114, 122-4; EEC and 38-9; Hungarian attitudes towards 50-1, 60, 71-2; multilateralism and 32; Poland and 80, 87-91, 97; Romania and 190, 192-3, 204; socialist regimes and $37-9,43$; state sovereignty and 38-9; supranational institutions and 38-9; Western European 15, 36-41, 43; Yugoslavia and 221-2, 224, 229-30; see also Council for Mutual Economic Assistance (CMEA); EastWest exchange; European Economic Community (EEC)

Economic Research Institute (Hungary) 60 EEC see European Economic Community (EEC)

EEC-CMEA relations: Brezhnev call for negotiations in 39; Common Commercial Policy (CCP) and 41, 58; common policy and 41-2; contractual relationship between 55 ; economic policy and 63; Hungary and 55-61; individual state relations and $41-3$; intra-German trade and 115; long-term trade and 58, 61-2, 64; negotiations between 50, 62-4, 68, 119; Romania and 202, 204, 209; socialist regimes and 4, 251; Soviet stance on 149

EEC Common Agricultural Policy (CAP) $37,41,89,225-6$

EEC Common Commercial Policy (CCP): Bulgaria and 42-3, 172; GDR and 114, 124; Hungary and 43, 58; impact on socialist exports 41-3; Poland and 43, 89-90, 94; Romania and 43, 193-4

EEC Common Fisheries Policy 42

EEC Generalized Scheme of Preferences (GSP): products excluded from 200, 202, 205; relations with the Group of 77 and 228; Romania and 42, 197-202, 205; UNCTAD and 171-2, 177;

Yugoslavia and 228

EEC protectionism: Bulgaria and 182; GDR and 114-15, 119, 122-4; Hungary and 50, 55, 65, 70; oil crisis and 231; Romania and 190, 192-3, 195-7; socialist regimes and 3, 40-3, 150, 251-2, 254

Ehrensperger, Günter 121

Ernst, Wolfgang 57, 148

Euratom 36

Europe 31, 34, 36; see also Eastern Europe; Western Europe

European Coal and Steel Community (ECSC) 36-7, 224

European détente: cultural exchange and 33, 88; economic growth and 249-50; Final Act (CSCE) and 34-5; financial relations and 33; foreign policy and 250 ; multilateral cooperation and 31-2, 34-6, 43; pan-European cooperation and 31-4, 43, 249; security and 250; socialist liberalisation and 43; trade and 32-3

European Economic Community (EEC): agricultural imports and 41; bilateral trade agreements with socialist countries 41; Bulgaria and 42, 159, 163, 165-6, 168-70, 174-5, 180-2; CAP and 37, $41,89,225-6$; CCP and 41-3, 90, 94, 114, 172, 193-4; centrally-planned economies trade with 259; China and 233, 240; CMEA trade and 149-51; common fisheries policy and 42,115 ; CSCE and 40; Czechoslovakia and 144-51; East Germany and 108; economic integration and 38-9; enlargement of $6,41,43,58,61$, $89,114,123,145,166,174-6,190$, 195-6, 199-201, 228, 239; European Monetary System (EMS) and 39; Final Act (CSCE) and 59-60; foreign policy and 233; GATT and 40; GSP and 42-3, 197-200, 202, 205, 228; Hungary and $42,50-5,61-71$; as international actor 1, 6; as model for CMEA 123-4, 175-6; pan-European cooperation and 32, 175; Poland and 42, 90; recognition by socialist countries $3-4,36,39-41$, 114-15; recognition of East Germany 113; Romania and 42, 50, 71, 193-206; Romanian commercial exchange and 206, 206; Romanian exports to 207; Soviet Union and 3, 39; steel exports and 118-19; Treaties of Rome 36-7; Yugoslavia and 32, 41-2, 71, 221-8, 230-41; see also EEC-CMEA relations; EEC protectionism 
European Free Trade Association (EFTA) 54, 168

European Investment Bank (EIB) 234

European Political Cooperation 38

European Research Council 1

Export Journal 227

Faddeev, Nikolai 123

Federal Republic of Germany (FRG): Basic Treaty of 1972 109, 113; Bulgarian relations with 162, 167; East German relations with 108-10, 113, 119-20, 122; economic exchange and 6; economic growth and 37; intra-German trade and 109, 113-15, 119-20, 126n10; Polish relations with $80,82,87-8$; socialist regime trade and 33; US relations with 82

Fekete, János 66

FIAT 85, 92, 235

Final Act (CSCE): balanced progress in European security and 35; Bulgaria and 177-8; citizen rights and 35, 92, 177; East German recognition and 113; ECE and 36; economic/scientific cooperation and 35; EEC and 40; humanitarian cooperation and 35; pan-European cooperation and 34-5, 92, 177; trade and 59-60; see also Conference on Security and Cooperation in Europe (CSCE)

Fischer, Oskar 115

Fock, Jenő 56

foreign debt: Bulgaria and 136, 180; Czechoslovakia and 136; Poland and 87, 94, 96; Romania and 208, 210-11; socialist economies and 20-2, 255, 262; Yugoslavia and 232, 234, 237, 239

Forthomme, Andre 147

France 32

free market ideology 11-12

FRG see Federal Republic of Germany (FRG)

GATT see General Agreement on Tariffs and Trade (GATT)

GDR see German Democratic Republic (GDR)

General Agreement on Tariffs and Trade (GATT): Bulgaria and 164, 173, 179, 181; Czechoslovakia and 40, 80, 142; EEC and 40; Hungary and 50-1, 56-8, 61-2; Poland and 40, 80, 90; Romania and 40, 193; socialist regimes and 40; Soviet rejection of 142
German Democratic Republic (GDR): average annual growth of GDP 263; balance of payments in 111-12, 117-18, 124-5; bankruptcy and 107, 116, 120-1, 125; Basic Treaty of 1972 109, 113; bilateralism and EEC members 108, 114-15, 119; CCP and 114, 124; collapse in 1989 125; common fisheries policy and 42, 115; consumption in 19; debt crisis and 120-1, 123, 125; economic policy and 107-12; economic reform and 110-11; EEC protectionism and $115,119,122-4$; exports to CMEA countries 110; exports to EEC countries 114; foreign relations and 107-8, 115; foreign trade and 116, 121, 258; gross external debt 262; impact of EEC on 108, 113-15, 118-19, 123; import needs and 112, 115-20; indebtedness and 111-12, 115-17, 120; intra-German trade and 109, 113-15, 119-20, 126n10; living conditions in 111; loan-financed countertrades and 111, 113, 117-18; New Economic System 110; nonrecognition of the EEC 114-15, 123-4; oil crisis and 112; productivity gains in 20; relations with the West 107-10, 113-25; social policies and 250;

Soviet oil and 120-1, 124; Soviet raw materials for 112, 117, 119; Soviet trade and 108, 125; steel exports and 119; Störfreimachung policy 109; "swing" and 109, 113, 120; Unity of Economic and Social Policy in 110-11; Western technology and 110; West German relations and 108-10, 113, 119-20, 122

Germany 37, 108-9; see also Federal Republic of Germany (FRG); German Democratic Republic (GDR)

Gheorghiu-Dej, Gheorghe 191

Gierek, Edward: appointment of 82-3; consumption model and 85 ; economic reform and 78, 84-5, 91-3, 95, 97; on end of Cold War 88; policy of prestige and 89; political formation of 81; relations with Western leaders 89; removal of 96

Giscard d'Estaing, Valéry 95

globalisation 11-13, 19, 23, 255

global South: Czechoslovakia and 143-4; developing economies in 20; Eastern engagement with 16; foreign trade and 2; socialist model for 13,15 ; socialist regimes and 144, 255 
Gnevashev, Vladimir A. 148

Gomułka, Władysław 78-83, 86

Gorbachev, Mikhail 6, 23-4, 50

Granfil, Toma 226-7

Greece 43, 116, 175, 178-9

Gromyko, Andrei 123

Group of 7 (G-7) 22

Group of 77 (G-77) 228

Gulyás, Pál 54

Gyovai, Gyula 67

Haferkamp, Wilhelm 68-9, 237

Hallstein Doctrine 33

Harmel, Pierre 32

Havasi, Ferenc 64-5

Honecker, Erich: appointment of 110; consumerism and 111, 124; distrust of inner circle 111, 126n15; economic policy and 107-8, 111-12, 116-17, 119-22; EEC negotiations and 115; small circle of advisors 107, 117; Soviet criticism of 119-20, 122, 125; on Western economic integration 123, 251; westward drift and 107-8, 116, 120-2, 125

Honzejk, Petr 136

Horizon 20201

Horn, Gyula 65, 67

Horváth, István 64-5

Hradecký, Stanislav 139

Hroch, Miroslav 140

HSWP see Hungarian Socialist Workers' Party (HSWP)

HSWP Political Committee (PC) 56, 61

human rights: in Bulgaria 181; in Czechoslovakia 150; Final Act (CSCE) and 35, 78; international discourse and 256; Polish strikes and 78; socialist regimes and 17-18, 23; Western loans and 94

Hungarian Academy of Sciences (HAS) 60,62

Hungarian National Bank (HNB) 63-4, 66

Hungarian Socialist Workers' Party (HSWP) 51, 53, 59, 64, 68

Hungary: agricultural exports and 41, 52, 56-8; attitudes toward European integration in 50-1, 60, 71-2; average annual growth of GDP 263; avoidance of Soviet intervention 50, 64-71;

Budapest-Brussels relations 57, 61-2, 64-72; CCP and 43, 58; CMEA and $50,58-9,65$; criticism of the EEC by $54-5,67$; debt crisis and 63,71 ; détente and 60; dual dependency of 51; economic motivation for opening up 52; economic policy and 60-2; EEC negotiations and $38,42,50-8,61-6$, 68-71; EEC protectionism and 50, 55, 65,70 ; energy safety and 50 ; foreign policy and 51-5, 67, 70; foreign trade and 56-7, 59, 61-4, 258; foreign trade deficit in 52; GATT and 40, 50-1, 56-8, 61-2; gross external debt 262; IMF entry and 22, 66; industrial cooperation and 19; modernisation strategy in 52; most favourite nation (MFN) status and 54,62 ; open economy and 51-2; panEuropean cooperation initiatives and 53, 59-60; political risk of EEC connections 65; productivity gains in 20; Soviet Union and 50-1, 68-9; steel exports and 118; technology imports and 56; US relations and 52, 70; Western relations and 251

Husák, Gustáv 135, 138

IMF see International Monetary Fund (IMF)

inflation 18-19, 21, 90, 135-6

Inotai, András 63

Institute for Economic and Market Research (Hungary) 60

Institute for Foreign Affairs (Hungary) 67

Institute for International Economy and Politics (Czechoslovakia) 37

Institute for the World Socialist Economic System (Soviet Union) 141

Institute for World Economics (Hungary) 60,62

Institute of International Politics and Economics (IPW) (GDR) 122

Institute of World Economy and International Relations (IMEMO) (Soviet Union) 37

International Bank for Economic Cooperation (CMEA) 37

International Bank for Reconstruction and Development (IBRD) 191, 199

International Monetary Fund (IMF) 22, 51, $66,95,142,199,222,256$

Iran 142

Iranian revolution 94

Ireland 6, 38, 41, 115, 175, 196

Italian Communist Party 238

Italy $32,232-3$

Ivanov, Martin 174, 180

Ízikné Hedri, Gabriella 61 
Jakubec, Jaroslav 138

Janšta, Ján 149

Japan 19, 82, 86

Jaroszewicz, Piotr 83, 87, 91, 93, 96

Jaruzelski, Wojciech 83, 91, 96

Jędrychowski, Stefan 83, 91

John Paul II, Pope 95-6, 181

Kádár, János 50-1, 54-5, 64-5

Kaminsky, Horst 111, 117, 120

Kania, Stanisław 95-6

Kansikas, Suvi 198

Karamanlis, Konstantinos 179

Kardelj, Edvard 227, 229, 233

Kawan, Louis 69

Khrushchev, Nikita 14, 33, 37-8, 224

Kisiel, Henryk 84

Klein, Friedrich 148

Klička, Otto 145

Klopfer, Heinz 112

Kohl, Helmut 121

KoKo see Bereich Kommerzielle Koordinierung (KoKo)

Kosovo 221

Kostikow, Piotr 86, 89

Kosygin, Aleksei 112, 117

Koucký, Vladimír 146-8

Közgazdasági Szemle 61

Koziolek, Helmut 111

Kozma, Ferenc 60

Krolikowski, Werner 107, 120

Külpolitika 60-1

Kuštrak, Ivo 233-4

Landa, Vladimír 145

Larosière, Jacques de 66

László, Andor 63

Lázár, György 66

Lăzăreanu, Alexandru 196

League of Communists of Yugoslavia (SKJ) 222

Lenárt, Jozef 138

Lennep, Emiel van 237

Lér, Leopold 138

Life and Modernity 82, 91

Ludlow, Piers N. 32

Ludviger, Emil 234

Lukanov, Andrey 177

Macedonia 221, 234

Macovescu, George 200-1, 215n76

Mănescu, Corneliu 197, 213n44

Mansholt, Sicco 149, 229

Marjai, József 66-9
Marrese, Michael 52

Marshall Plan 12, 37

Marxist-Leninist ideology 7, 14

Matanov, T. 175

Mateev, Evgeny 176

Maurer, Ion Gheorghe 199, 215n66

Medjunarodna Politika 230

Melega, Tibor 69, 72

Mielke, Erich 107

Minič, Miloš 233, 235-6, 238

Mittag, Günter 107, 110, 116-17, 119, 121

Moczar, Mieczysław 81, 83

Montenegro 221

Moro, Aldo 40

Mutual and Balanced Force Reduction in Europe (MBFR) 34

NATO 34, 36

Němec, Jiři 151

neo-liberalism 12-13, 22

Népszabadság (Peoples' Freedom) 53, 54

Neue Ostpolitik 16, 33-4, 81, 113

Nikezič, Marko 225

Niţă, Ştefan 195-6

Nixon, Richard 6

non-aligned movement $6,35,221,224$, 227-9, 236

Nowe Drogi 82, 85

Nyerges, János 57, 61-2

Nyers, Rezső 54

oil crisis: Bulgaria and 180;

Czechoslovakia and 137, 152; demand

for Soviet fuels and 19; global monetary crisis and 94, 112; Hungary and 62;

inflation and 18; international trade and 11; Iranian revolution and 94; OPEC and 18-19; Poland and 90-1, 94, 97; Romania and 199, 208; Soviet prices within CMEA 137; Western recession and 18; Yugoslavia and 231

Olechowski, Tadeusz 84

Oliva, Felix 139

Olszowski, Stefan 83, 95

OPEC 18-19

Oprešnik, Miloš 225

Opriş, Petre 190

Organisation for Economic Co-operation and Development (OECD) 178, 237

Organisation for European Economic Cooperation (OEEC) 222

Organization for Security and Co-operation in Europe (OSCE) 34 
Osimo agreements between Italy and Yugoslavia 232-3

Ostpolitik see Neue Ostpolitik

Pajestka, Józef 82, 84, 96

PanEur1970s research project 1

pan-European cooperation: Balkan region and 178-9; challenges of 1; Cold War partition and 5; cultural exchange and 59; EEC and 32, 175; European détente and 31-4, 249; financial relations and 33; Hungarian initiatives and 53, 59-60; multilateral cooperation and 31-2, 34-6, 43; OSCE and 34; socialist regimes and 4; trade and 32-3; see also economic integration; European détente

Păţan, Ion 197, 200-1, 213n45

Patolichev, Nikolai 119

Pavlát, Vladislav 145

People's Republic of Bulgaria (NRB) see Bulgaria

Pérez-Guerrero, Manuel 171

Péter, János 53, 59

Petřivalský, Jiř́i 139

Poland: agricultural exports and 41, 80, 89; anti-Semitic campaign in 81 ; average annual growth of GDP 263; Catholic Church and 95-6, 99; CCP and 43, 89-90, 94; CMEA and 80; common fisheries policy and 42, 94, 115; consumption model in 85-6, 89, 96; CSCE and 87, 92; cultural liberalisation in 88,97 ; debt crisis and 21-2, 94-6; December 1970 strikes in 15; dissident activity in 93-5; economic crisis in 78-9, 96-7; economic growth and 19, 82, 85-6, 252; economic reform and 93-5; EEC and 42, 90; emigration and 79 ; exchange with capitalist countries 78-81; five-year plan (1971-75) 85-8; foreign debt and 87, 94, 96; foreign policy and 87-8; foreign relations and 91, 96; foreign trade and 83, 86-7, 89, 92-4, 258; GATT and 40, 80, 90; Gierek leadership and 78, 82-96; Gomułka leadership and 78-83; gross external debt 262; industrial investment in 86; Main School of Planning and Statistics $81,83,91$; martial law in 22, 34, 96; Ministry of Finance 95; Ministry of Foreign Affairs 83, 87-8, 90-1, 95; Ministry of Foreign Trade 84, 90; motorisation battle in $81-2$; oil crisis and 90-1, 94, 97; political crisis in
$78-9$; productivity gains in 20 ; quality of life improvements 84-6, 96, 250; relations with the FRG $80,82,87-8$; relations with the West 79-83, 87-94, 96; rise of civil society in 96 ; socialist elites and 78-9, 83-6, 96-7; Solidarnosc and 21, 96; Soviet Union and 92, 94-5; steel exports and 118; technocratic government in 83-6; Western credit and 86, 95; Western technology and 81-2, 86 ; worker strikes in $21,78,82$

Polish United Workers' Party (PUWP) 78-9, 82, 86, 88-9, 96

Politická ekonomie 139

Polityka 82

Polze, Werner 111, 117

Popovič, Milentije 225

Potáč, Stanislav 136-8

Prague Spring: Bulgarian concerns and 166; suppression of 2, 6, 15, 33, 70, 87, 135; Yugoslav condemnation of 225

Průcha, Václav 134

Puja, Frigyes 55

\section{Rabotnichesko Delo 175}

Radoux, Lucien 147

Rădulescu, Gheorghe (Gogu) 198

Rajman, František 146

Rakowski, Mieczysław 82, 94-5

Reagan, Ronald 34, 256

Reinhold, Otto 111

Research Institute for National Economic Planning (Czechoslovakia) 145

Romania: agricultural exports and 41, 194, 202, 205; average annual growth of GDP 263; balance of payments in 196; bilateral trade agreements and 190, 193-5, 197-8, 200, 203-5; CCP and 43, 193-4; CMEA and 198, 202, 204; economic development planning in 191, 203, 207-11; economic growth and 19, 252; EEC commercial exchange and 206, 206; EEC exports and 193-5, 207, 207, 208; EEC GSP and 198-9, 201, 205; EEC imports and 208, 210; EEC negotiations and 42, 50, 71, 193-206, 209; EEC protectionism and 190, 192-3, 195-7; energy resources and 199, 207-8; foreign debt and 208, 210-11; foreign policy and 192; foreign trade and 190-204, 206-7, 258; GATT and 40, 193; gross external debt 262; IMF and 199; impact of EEC expansion on 196, 200-2; industrial cooperation 
and 19; industrialisation and 191-3, 195, 207, 209, 250; long-term trade agreements and 205; most favourite nation (MFN) status and 205; national economic policy and 38-9; oil crisis and 199, 208; opposition to EEC-CMEA relations 202, 204; resistance to division of labour 38; Soviet raw materials for 199; State Planning Committee 192-3; steel exports and 118; trade balance and 208, 210; trade deficit and 190, 206; Western relations and 190-2, 209-10; Western technology and 191-3, 209-10; World Bank and 199

Romanian Communist Party (RCP) 191

Romanian Workers' Party (RWP) 191

Rudé právo 146

Rurarz, Zdzisław 84-5, 91, 95-6

Schalck-Golodkowski, Alexander 111, 120

Schmidt, Helmut 22, 65, 71, 120

Schürer, Gerhard 107, 111, 116-17, 119

Šefer, Berislav 236

Şerban, Andrei 194-6

Serbia 221, 226-7

Shcherbytsky, Volodymyr 139

SKJ see Communist Party of Yugoslavia (SKJ)

Skoda 139

Slovenia 221, 223, 226-7, 229-30, 232, 234; see also Yugoslavia

Smole, Janko 230, 234

Šnuderl, Boriš 226-30, 232-4

Social Democratic Party of Germany (SPD) 82

socialist economies: Cold War isolation of 12; division of labour and 37-8; economic growth and $6,15,17,19$, 42; export opportunities and 20; foreign debt and 20-2, 255; foreign trade and 33; free market ideology and 11-12; globalisation and 11-12, 19,23 ; isolation and 12; oil prices and 20-1; per-capita income in 12; systemic inadequacies and 19-20, 23; trade deficit and 19

socialist regimes: academic experts and 5-6; average annual growth of GDP 263; consumption policies and 15; CSCE and 40; decentralisation and 33; East-West exchange and 4, 15, 249-50; EEC bilateral trade agreements 41; EEC-CMEA relations and 251; EEC protectionism and 3, 40-3, 150,
251-2, 254; EEC recognition and 3-4, 36, 39-41, 114-15; Europeanness and 5 ; exports of 260; export structure of 261; foreign debt and 249, 254-5; foreign trade and 2, 250-1, 258; global South and 144, 255; gross external debt 262; IMF and 256; import-led growth and 249 ; integration process 38 ; national strategies and 4-6, 16, 22; non-aligned movement and 35; plurality in policymaking 253; public welfare and 15; quality of life improvements and 250; relationships with the Soviet Union 4-5, 13, 23-4, 251; Soviet raw materials for 19-20, 112, 117, 119, 199; trade within 13; trade with the EEC 259; Western strategies and 249-56; Western technology and 114, 249; see also Eastern Europe; specific country names Socialist Unity Party of Germany (SED) $107-8,110-11,113-15$

Solidarnosc 21, 96

Sölle, Horst 118

Soviet Academy of Sciences 141

Soviet Union: bloc discipline and 44, 251; Bulgaria and 160-1, 167; CMEA and 144; CMEA oil deliveries and 137, 141-2; common fisheries policy and 42, 115; concern with Polish economy 92, 94-5; economic growth and 14-15; EEC and 3, 39-40; foreign trade and 32, 258; German Democratic Republic (GDR) and 108; Hungary and 50-1, 68-9; impact of EEC on 32; invasion of Afghanistan 22, 33-4, 95, 238; nonrecognition of the EEC 114-15; oil deliveries to socialist regimes $69,120-1$, 124; oil sales and 20, 141-2; opposition to EEC-CMEA relations 41-2; raw material supply for socialist regimes 19-20, 112, 117, 119, 141, 199; socialist regimes and 4-5, 13, 23-4; steel exports and 118; technological innovation and 14; Tito-Stalin split and 221; Yugoslavia and 230

Sozialdemokratische Partei Deutschlands (SPD) 64

Špiljak, Mika 225

Stalin, Joseph 37, 224

Stalinist industrialisation 12, 14

steel industry 118-19, 151

Stehno, Jan 148

Steiner, André 110

Stoph, Willi 107, 112, 116-17, 120 
Störfreimachung policy 109

strategic arms control 16

Strauß, Franz-Josef 121-2

Strojimport (Czechoslovakia) 149

Štrougal, Lubomír 136-8, 149

Šulc, František 146

Šupka, Ladislav 138

Svoboda, Karel 134

Szalai, Béla 54, 56

Szilágyi, Gábor 53

Szita, János 59-60

Szlachcic, Franciszek 83, 91

Szydlak, Jan 84, 87, 96

Szydlak's Commission 84

Talyzin, Nikolai 68

Texim (Bulgaria) 167

Thatcher, Margaret 256

Thorn, Gaston 198

Tikhonov, Nikolai Aleksandrovich 66

Tímár, Mátyás 63

Tindemans Report 122

Tito, Josip Broz 224, 228-9, 233, 237

Tomaševič, Žarko 236

Tomič, Petar 229

Treaties of Rome 36, 109

Trepczyński, Stanisław 87

Tschanter, Horst 119

Tsolov, Tano 166, 169, 177

Tůma, Oldřich 134

Turkey 175, 178-9

Ubiparip, Gojko 236

Ulbricht, Walter 110

Union of Polish Youth 83

United Kingdom: Eastern European trade and 32; EEC entry and 6, 38, 41, 175, 196; multilateral détente and 34; threat to Polish agricultural exports 89

United Nations Conference on Trade and Development (UNCTAD) 54, 84, 164, 171-3

United Nations Economic Commission for Europe (ECE) 36, 59, 90, 147, 173

United States: Eastern European trade and 17; EEC conflict and 55, 123; foreign loans and 208; foreign policy and 18, 34; human rights concerns and 94; Hungary and 52, 70; purchase of Czech technology 135; relations with the FRG 82; relations with the GDR 116; strategic arms control 16; trade embargos 22; Yugoslavia and 222, 250
University of Economics in Prague 139, 145,149

US Federal Reserve Bank 21, 208

Vachkov, Daniel 174, 180

Van der Stoel, Max 236

Velchev, Boris 170

Vencovský, František 139

Veress, Péter 66-8, 70

Vietnam 144

Vilímek, Tomáš 134

Villaume, Poul 31

Vojvodina 221

von Berg, Hermann 115

Vratuša, Anton 230

Vrhovec, Josip 238

Vrhunec, Marko 229

Warsaw Pact: 1968 NATO appeal to 34; Budapest appeal and 34; CESTC 15; CSCE and 35, 228; diplomatic normalisation and 162; economic reform and 87; Prague Spring suppression and 6, 151, 225, 239; Romania and 190; socialist regimes and 5; threat of Polish interventions by 96

Wellenstein, Edmund 57

West see East-West exchange; United States; Western Europe

Western banks 20-2, 86, 95, 136, 159; see also foreign debt

Western Europe: détente and 17, 22, 33; Eastern European trade and 17-18, 32; economic growth and 12,33; economic integration and $36-9,41$; foreign policy and 18; recession in 252; see also EastWest exchange; European Economic Community (EEC)

Western technology: Bulgaria and 159-61, 163, 166, 168, 180, 182; economic growth and 4; GDR and 110; Hungary and 56; Poland and 81-2, 86; Romania and 191-3, 209-10; socialist regimes and 2, 114; Yugoslavia and 224, 229

West Germany see Federal Republic of Germany (FRG)

Wichterle, Otto 135

Wittkowski, Grete 111

Wojtyła, Karol 95

Workers Defence Committee (KOR) 94

World Bank 95, 199, 222

Wrzaszczyk, Tadeusz 81, 84, 92, 96 
Yugoslavia: 1973 trade agreement 230-1; academic elite in 229-30; agricultural exports and 226; Associated Labour Act (1976) 231; average annual growth of GDP 263; CAP and 226; CMEA and 221, 225; confederalisation and 221-3; cooperation agreement with EEC 221, 238, 240; Croatian elites and 226, 229, 232-3; debt crisis and 22; decentralisation and 221; developing country status and 20, 231, 235-40; economic liberalisation and 225-7; economic recession in 227; economic ties with socialist countries 224; economic view of the EEC 223; EEC GSP and 228; EEC relations and 32, 412, 71, 221-8, 230-41; elites and 221; Federal Executive Council (SIV) 225-6, 229-34, 236-8; Federal Secretariat for External Trade (SSST) 226; Federal Secretariat for Foreign Affairs (SSIP) 230, 233, 236; as federal union 221 ; foreign debt and 232, 234, 237, 239; foreign investment and 235; foreign policy and 233; foreign trade and $\mathbf{2 5 8}$; gross external debt 262; Group of 77 and 228; industrial cooperation and 19; industrialisation and 232; non-alignment and $6,221,224,227-9,236$; oil crisis and 231; Osimo agreements 232; political-diplomatic view of the EEC 223; Prague Spring and 225-6; regional cooperation and 232-3; republican affiliations and 223-4, 226-7, 232, 239; self-management system in 221-2, 228-9, 231; SKJ and 222-4, 228, 233-4, 236-8; Slovenian elites and 226-7, 229-30, 232-4; Soviet Union and 230; SSIP and 230, 233, 236; Tito-Stalin split and 221; trade deficit and 223, 226, 235-7; Western relations and 222, 224-6, 228, 230-8; Western technology and 224, 229

Zapadlo, Miroslav 139

ZASTAVA 235

Zhivkov, Todor 159, 161-2, 170, 179, 181

Žiberna, Milica 229, 236 


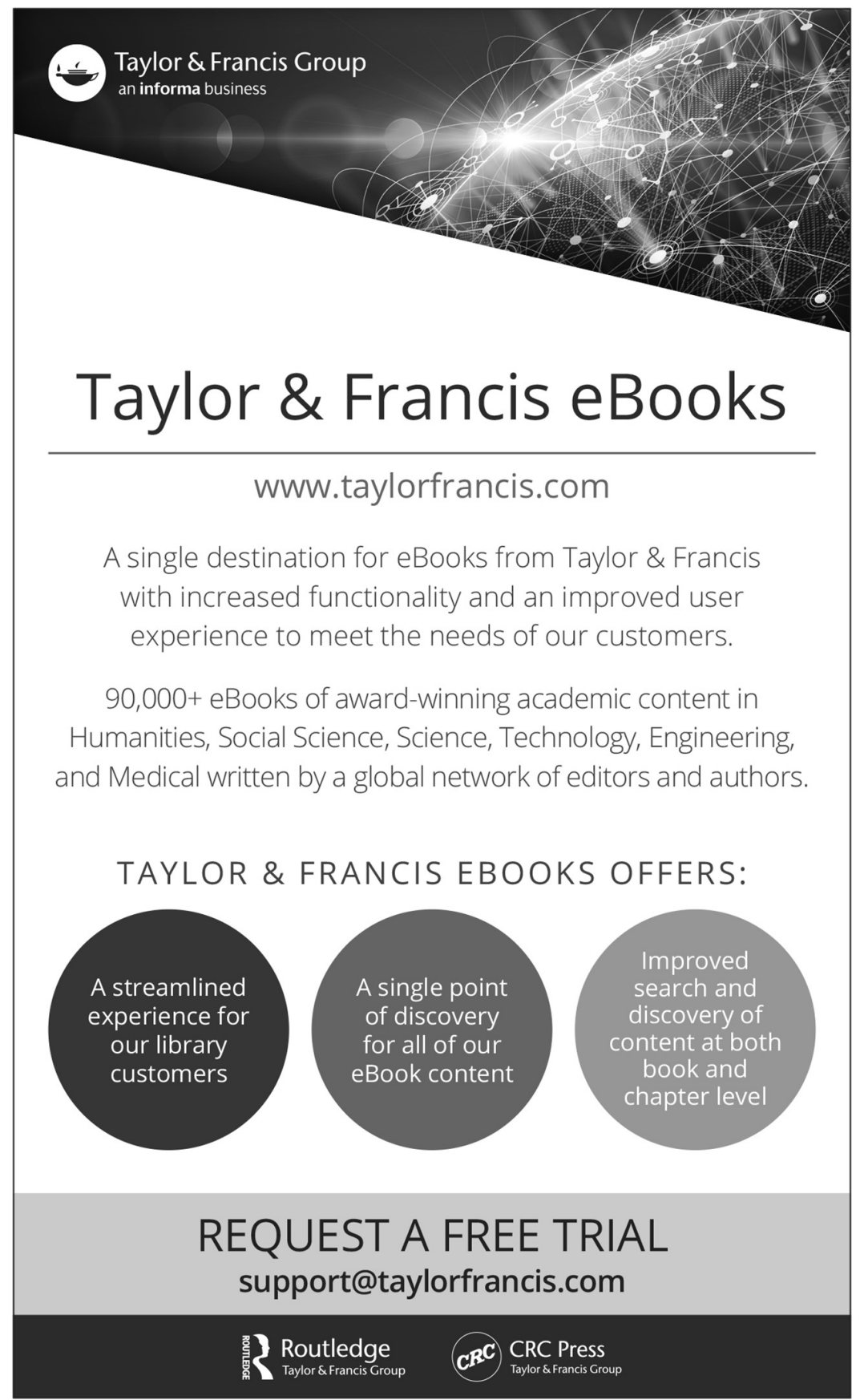

